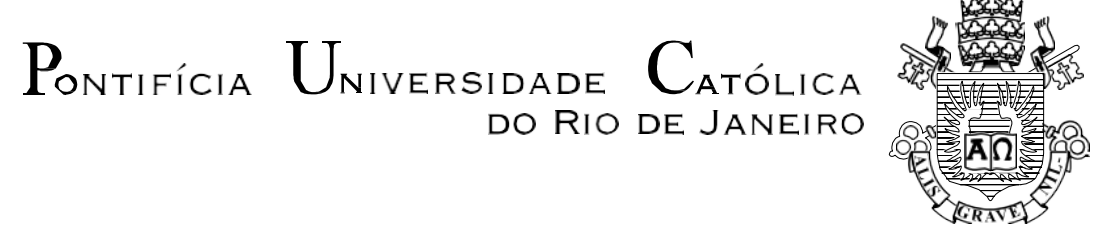

Cristiano Mahaut de Barros Barreto

Translation and Metalanguage in Laozi: a Perspectivist Approach

Tese de Doutorado

Dissertation presented to PUC-Rio's Graduate Program in Language Studies as one of the requisites for being conferred the degree of Doctor in Letters/Language Studies.

Adivisor: Profa. Helena Franco Martins Co-adivisor: Prof. Hans-Georg Moeller

VOLUME I

Rio de Janeiro

March 2015 


\section{Pontifícia Universidade C atólica $_{\text {a }}$ DO RIO DE JANEIRO

Cristiano Mahaut de Barros Barreto

\section{Translation and Metalanguage in Laozi: a Perspectivist Approach}

Dissertation presented as one of the requisites for being conferred a doctoral degree by PUC-Rio's Graduate Program in Language Studies. Dissertation approved by the undersigned members of the Dissertation Committee.

Profa. Helena Franco Martins

Advisior

Departamento de Letras - PUC-Rio

Prof. Hans-Georg Moeller Co-Advisor University of Macau

Prof. Paulo Fernando Henriques Britto Departamento de Letras - PUC-Rio

Prof. Danilo Marcondes de Souza Filho Departamento de Filosofia - PUC-Rio

Prof. Caetano Waldrigues Galindo UFPR

Profa. Ana Paula Grillo El-Jaick UFJF

Profa. Denise Berruezo Portinari Coordenador Setorial do Centro de Teologia e Ciências Humanas - PUC-Rio

Rio de Janeiro, 31 de março de 2015 
All rights reserved

\section{Cristiano Mahaut de Barros Barreto}

Graduated in Economics at Pontifícia Universidade Católica do Rio de Janeiro (1990), with a Master (2011) and Doctorate (2015) in Language Studies at Pontifícia Universidade Católica do Rio de Janeiro, doing research mainly in the following areas: semantics, writing studies, history of the language ideas, philosophy of language, Chinese poetry, translation of poetry and Chinese.

Ficha Catalográfica

Barros Barreto, Cristiano Mahaut de.

Translation and metalanguage in Laozi: a perspectivist approach / Cristiano Mahaut de Barros Barreto ; adivisor: Helena Franco Martins; co-adivisor: Hans-Georg Moeller. - 2015.

$$
2 \text { v. } ; 30 \mathrm{~cm}
$$

Tese (doutorado)-Pontifícia Universidade Católica do Rio de Janeiro, Departamento de Letras, 2015. Inclui bibliografia

1. Letras - Teses. 2. Laozi. 3. Perspectivismo. $4 . \quad$ Wittgenstein. 5. Metalinguagem. 6. Chinês. 7. Etimologia. I. Martins, Helena Franco. II. Moeller, HansGeorg. III. Pontifícia Universidade Católica do Rio de Janeiro. Departamento de Letras. IV. Título. 


\section{Acknowledgments}

À minha orientadora, professora Helena Franco Martins e meu co-orientador, professor Hans-Georg Moeller.

Aos professores que me acompanharam e me ajudaram nessa jornada desde o mestrado, em particular aos participantes da minha banca do doutorado e do mestrado.

Àminha esposa Paulinha e minha filha Nicole, luzes da minha vida.

Aos meus pais e minhas irmã̃ . 


\section{Abstract}

Barros Barreto, Cristiano Mahaut de; Martins, Helena Franco (Advisor). Translation and Metalanguage in Laozi: a Perspectivist Approach. Rio de Janeiro, 2015. 425p. Doctoral dissertation - Departamento de Letras, Pontifícia Universidade Católica do Rio de Janeiro.

This dissertation identifies and discusses the use of metalanguage in the classical Chinese text of the Laozi. Taking language as a form of life, in a Wittgensteinian - perspectivist rather than relativist - sense, it assumes that encounters between different forms of life/languages do not correspond to mere clashes between incommensurable conceptual schemes or modes of existence. They are, rather, instances where these forms of life may be brought to glimpse, however precariously, at their own unfounded, non-intellectual bases, and furthermore, occasions with potential for transformation, prone to dislocate not only discernible ideologies, but also highly entrenched pre-conceptual convictions. The study presented here elaborates and investigates the premise - called the Metalinguistic Perspectivism Hypothesis (MPH) - that different metalinguistic repertoires do not get to name universal, language independent entities. On the contrary, they testify to cultural and historical circumstances, and ultimately to forms of being in the world that encompass subterraneous propensities and preconceptual certainties, thus having a direct and coercive effect on how we conceive and experience what language "is." To advance the investigation of the MPH, we examine a selection of metalinguistic passages in the Laozi, by adopting a comparative approach along two main paths: etymology and translation. The etymological comparative analysis between Chinese metalinguistic terms and their counterparts in the Greco-Western tradition shows ample evidence of the stark contrast between their deep-rooted visions of language and historically motivated categories, reinforced by the alterity of the grapho-etymological activity of the Chinese tradition. Additionally, the comparison of translations/commentaries of contextualized metalinguistic uses in the Laozi (into English, Portuguese, French and modern Mandarin) confirms that the authors are motivated by significantly different underlying metalinguistic repertoires, tacitly 
at work in their interactions with the Chinese text: they often employ sharply diverse strategies which testify to how the authors strive to accept and/or reject the practices they construe from the original text. The evidence for the MPH is shown to manifest in the following central axes: the relationship between speech and writing; the role of language in the civilization/nature nexus; the question of the centrality of meaning in language; the relation between metaphor, literality and image; and the problem of names.

\section{Keywords}

Laozi; Perspectivism; Wittgenstein; Metalanguage; Chinese; Etymology. 


\section{Resumo}

Barros Barreto, Cristiano Mahaut de; Martins, Helena Franco. Tradução e Metalinguagem no Laozi: uma Abordagem Perspectivista. Rio de Janeiro, 2015. 425p. Tese de Doutorado - Departamento de Letras, Pontifícia Universidade Católica do Rio de Janeiro.

A presente dissertação assinala e discute o uso da metalinguagem no texto em chinês clássico do Laozi. Ao tomar a linguagem como uma forma de vida, no sentido Wittgensteiniano - perspectivista em vez de relativista - assumimos que os encontros entre diferentes formas de vida / línguas não correspondem a meros confrontos entre esquemas conceituais ou modos de existência incomensuráveis entre si. Referem-se, ao contrário, a oportunidades em que essas formas de vida podem ser trazidas a vislumbrar, ainda que de forma precária, suas próprias bases infundadas e não intelectuais e, além disso, ocasiões com um potencial de transformação, prestes a deslocar não apenas marcas ideológicas visíveis, mas também convicções pré-conceituais fortemente arraigadas. O estudo apresentado aqui elabora e investiga a premissa - chamada de Hipótese do Perspectivismo Metalinguístico (HPM) - em que diferentes repertórios metalinguísticos não nomeiam entidades universais e independentes da linguagem. Pelo contrário, eles dão testemunho a circunstâncias culturais e históricas e, em última instância, a formas de estar no mundo que carregam propensões subterrâneas e certezas préconceituais, exercendo assim uma força direta e coerciva sobre a forma como concebemos e experimentamos o que língua "é". Na investigação da HPM, analisamos uma seleção de passagens metalinguísticas do Laozi, por meio da adoção de uma abordagem comparativa bipartida, orientada pela etimologia e pela tradução. A análise comparativa etimológica entre termos metalinguísticos chineses e seus homólogos na tradição ocidental dá ampla evidência do profundo contraste entre suas visões da linguagem e categorias historicamente motivadas, $o$ que é reforçado pela alteridade da atividade grafo-etimológica da tradição chinesa. Ademais, a comparação das traduções/comentários dos usos contextualizados da metalinguagem no Laozi (para o inglês, português, francês e mandarim moderno) confirma que a prática de seus autores é guiada por diferentes repertórios 
metalinguísticos subjacentes, agindo de forma tácita no processo interativo junto ao texto chinês: a grande variedade de estratégias empregadas pelos tradutores testemunha como os autores se esforçam para aceitar e / ou rejeitar as práticas que constroem no texto original. Evidências para a HPM manifestam-se principalmente ao longo dos seguintes temas: a relação entre fala e escrita; o papel da linguagem na nexo entre civilização e natureza; a questão da centralidade do significado da linguagem; a relação entre metáfora, literalidade e imagem; e o problema dos nomes.

\section{Palavras-chave}

Laozi; Perspectivismo; Wittgenstein; Metalinguagem; Chinês; Etimologia. 


\section{Summary}

$\begin{array}{ll}\text { Introduction } & 18\end{array}$

1. Theoretical framework 26

1.1. Wittgenstein's Language as Form of Life 26

1.1.1. Introduction 26

1.1.2. Wittgenstein's language 28

1.1.3. The essence of language 30

1.1.4. Language and meaning 35

1.1.5. Language-games, rules and regularity 38

1.1.6. Relativism and perspectivism 45

1.1.7. Epistemology 47

1.1.8. Naming and names 51

1.1.9. Consequences 53

1.2. Metalinguistic Perspectivism 56

1.2.1. Introduction 56

1.2.2. A tripartite sketch of perspectivism 60

1.2.3. Metalanguage and perspectivism: Taylor and Harris 72

1.2.4. Wittgenstein and perspectivism 84

1.2.5. Etymology 94

1.2.6. Translation 96

2. The metalinguistic terms 100

2.1. Language as a system of representation: 102 etymological drifts in Western metalanguage Classical World

2.1.2. Etymological analysis of Western metalinguistic 113 terms

2.1.2.1. On the general phenomenon or faculty of language 114

$\begin{array}{ll}\text { 2.1.2.2. Action terms } & 116\end{array}$

$\begin{array}{ll}\text { 2.1.2.3. Units or parts } & 121\end{array}$ 
2.1.2.4 The visual dimension 124

2.2. The case of Chinese 127

2.2.1. Dào 道: to say, to speak, speakable, to guide 129

2.2.2. Míng 名: name, (to be) called 140

2.2.3. Yán 言: speech, word, to say, talk, language, 150 phrase, sentence

2.2.4. Zi 字: writing, (Chinese) character, letter, word, 159 courtesy name

2.2.4.1. Yán 言, zì 字and writing 162

2.2.5. Wén 文: writing, language, literature, culture 168

2.2.5.1. Wén 文 as the patterns of the world, culture and 172 writing

2.2.6. Yì 義: meaning, sense, significance 178

2.2.7. Xiàng 象: image, figure 186

2.2.7.1. Xiàng 象and Chinese representation 189

2.3. Overview of the chapter 200

3. Metalanguage in translations in the Lăozi 204

3.1. The selection of translations 205

3.2. The unlanguaged dào 道? 211

3.3. Wordless teaching 235

3.4. Creating Words for dào 道 250

3.5. Righteousness and Ornaments 262

3.6. The "true essence" and image 278

3.7. "I style it 'Dao'” 293

3.8. The emergence of names 305

3.9. "Right words in reverse" 317

3.10. Overview of this chapter 328

4. Conclusion 335

5. Bibliography 352

$\begin{array}{ll}\text { 6. } & \text { Appendix }\end{array}$ 


\section{List of Tables}

Table 1- Selected Chinese metalanguage comparison 177

Table 2- The unlanguaged dào 道? - list of translations 211

Table 3- The unlanguaged dà $O$ 道? - summary of the 230 metalanguage's translations $(A)$

Table 4- The unlanguaged dà o 道? - summary of the metalanguage's translations $(B)$

Table 5- The unlanguaged dà o 道? - summary of the metalanguage's translations $(\mathrm{C})$

Table 6- Wordless teaching - list of translations

Table 7- Wordless teaching - summary of the metalanguage's translations

Table 8- Creating Words for dà o 道- list of translations

Table 9- Creating Words for dà o 道 - summary of the metalanguage's translations

Table 10- Righteousness and Ornaments - list of translations

Table 11- Righteousness and Ornaments - qualities to be avoided and to be sought

Table 12- Righteousness and Ornaments - summary of the metalanguage's translations

Table 13- The "true essence" and image - list of translations

Table 14- The "true essence" and image - summary of the metalanguage's translations 
Table 15- "I style it 'Dao”" - list of translations 293

Table 16- "I style it 'Dao”" - summary of the 301 metalanguage's translations

Table 17- The emergence of names - list of translations 305

Table 18- The emergence of names - summary of the 314 metalanguage's translations

Table 19- "Right words in reverse" - list of translations 317

Table 20- "Right words in reverse" - summary of the 326 metalanguage's translations 


\section{List of Boxes}

Box 1- Dào 道's network of allusions 136

Box 2- Ming 名's network of allusions 147

Box 3- Yán 言's network of allusions 155

Box 4- Zi 字's network of allusions 166

Box 5- Wén 文's network of allusions 175

Box 6- Yi 義's network of allusions 184

Box 7- Xiàng 象's network of allusions 198 


\section{List of abbreviations and conventions}

Unless otherwise indicated, all references are to the pages of the edition cited. I refer to the primary and secondary sources for the grapho- and etymological data and for the seven main translations selected for this work. Henceforth, references to the major grapho- and etymological sources will be noted by the abbreviations below.

\section{Etymological and Grapho-etymological sources}

HU HU Qiguang \& FANG Huanhai 胡奇光, 方环海 ([2004]2007) Ěryă yìzhù 尔雅译注.上海：上海书籍出版社 (Shanghai, Shanghai Shuji chubanshe) (Е̌ryă's reference).

Shuōwén XU Shen (Han) 許慎（漢）/ XU Xuan (Song) 徐鉉（宋）Shuōwén jiězì 說文解字。上海：上海古籍出版社 (Shanghai, Shanghai Guji chubanshe) (2004) (Shuōwén's main reference).

YL YANG Liu (ed) 杨柳 (2011) xīnbiān Shuōwén jiězì dàquánjí 新编说文解 字 大全集．北京：中国华侨出版社 (Beijing, Zhongguo Huaqiao chubanshe) (Shuōwén's based commentary and grapho-etymological work).

\section{Contemporary dictionaries:}

GH Gǔhànyǔ dà cídiǎn ( 古汉语大辞典) (from www.pleco.com, originally from 上海辞书出版社-Shanghai, Cishu chubanshe).

GD CHEN Fuhua 陈复华 (ed) (1998) Gǔdài hànyǔ cídiăn 古代汉语词典. 北京 : 商务印书店(Beijing, Shangwuyin Shudian).

GU GU Yankui 谷衍奎 (ed) (2003) Hànzi yuánliú zìdiăn 汉字源流字典. 北京: 华夏出版社(Beijing, Huaxia chubanshe).

CT CHEN Tao 陈涛 (者) (2011) Chángyòng hànzì qiănshì. 常用汉字浅释。北 京：新界出版社(Beijing, New World Press) 
TH TANG Han 唐汉 (2012) Hánzìde àomì. 汉字的奥秘. 北京: 新世界出 版社.

(Beijing: Xinshijie Chubanshe)

Schuessler SCHUESSLER, Axel (2007). ABC Etymological Dictionary of Old Chinese. Honolulu: University of Hawai'i Press.

CUHK $<$ http://humanum.arts.cuhk.edu.hk/Lexis/lexi-mf/>, "Multi-function Chinese Character Database," Chinese University of Hong Kong, accessed in 2014-5.

The four main classical Chinese dictionaries used in this work are the $\check{E} r y a ̆$ 爾雅, the Shuōwén jiězi 說文解字, the Shìmíng 釋名 and the Fāngyán 方言. In this dissertation they are respectively referred as Ěryă, Shuōwén, Shiming and Fāngyán except when the reference specifically regards the books above.

The script styles of the Chinese writing are referred per the abbreviations below:

- The oldest writing style in Chinese is traditionally named "Oracle Bones" script (jiăgǔwén 甲骨文), since it was found primarily in inscriptions carved into the bones of animals for divinatory purposes. First samples of this script are dated from the Shāng 商 dynasty (c. 1766-1122 BC).

Henceforth, OB.

- The subsequent "Bronze script" (jīnwén 金文) style was used since the end of the Shāng 商 period until the $4^{\text {th }}$ century BC, into the Zhōu 周 dynasty period (1122-256 BC). It is a term that creates some measure of confusion because it was also used later to refer to the "large seal script" (see below) when referred to bronze vessels, but also in contrast to $L \check{\imath} S \vec{\imath}$ s reformation and the introduction of the "small seal script." It is often restricted to the writing on bronze vessels, thus distinct from writing on paper and silk and the older writing on oracle bones. Henceforth, BS.

- The "Large seal script" (dà zhuàn 大管 ), as mentioned above, is sometimes confused with the Bronze Inscriptions, the major difference being the media used in writing, paper or bamboo stems. It was also used 
throughout the Zhōu 周 dynasty up to the radical reform of the Qín 秦 dynasty (221-206 BC) by $L \grave{l} S \bar{l}$ 李斯, who (traditionally) developed the new style, called "Small seal script" (xiăo zhuàn 小管) as a new symbol of the unification of China under the Qin 秦. It is the style that heads the glosses of the Shuōwén and was later substituted by the "Clerical writing," lìsh $\bar{u}$ 隸書, under the Hàn 漢 dynasty (206 BC-220 AD). Henceforth, respectively, LS, SS and CW.

The passages in Chinese are presented as follows:

- The first line in Chinese characters (with the simplified orthography for the texts produced in the People's Republic of China after the reformation of 1956 and the traditional orthography for all the other texts);

- the second line with the phonetic transliteration in pinyin 拼音 for the pronunciation in the contemporary Mandarin standard. The pinyin method is the official system for transcribing the Mandarin pronunciations of Chinese characters into the Latin alphabet in the People's Republic of China, Taiwan and Singapore, having four diacritics to represent the four tones of Mandarin, high, rising, low/dipping and falling (respectively $\bar{a}, \dot{a}$, $\check{a}$ and $\grave{a}$, for $/ \mathrm{a} /)$;

- the third line for the translation into English. Characters that are particularly polysemous and whose translations are especially disputable will be glossed with additional footnotes.

Furthermore, to help readers unfamiliar with Chinese, along the text of the English translation, Chinese key words have been inserted between brackets.

Punctuation marks did not exist in the Lăož̆, the Shuōwén or the Ěryă, as well as in the overwhelming majority of the texts in Classical Chinese, being a concept imported from the West. They are shown here as conventional guides to the reading of the Chinese texts, following the most generally accepted interpretation. However, it must be made clear that these punctuation marks are only provisional and that some authors use different sets of punctuation marks. All references throughout the dissertation to chapters from the Lăož refer to the Wáng Bì received version of the text. 
I have provided the texts in English from the translations that were written in other languages (namely, French, Portuguese and Chinese). The original translation/commentaries will be presented before my own text in English and I will make use of footnotes whenever necessary to underscore the major questions in this re-translation. All translations from the Greek are from the authors quoted, unless otherwise noted. The vernacular languages are thus abbreviated: English Eng.; French - Fr.; Portuguese - Port. All words in past languages are in italics and the theoretical non-attested forms are initiated by a “*”. The major etymological sources are listed in the dissertation's bibliography section entitled Western etymological sources.

As for the transliteration of the Indo-European words, I have employed the ALA-LC 1997 system (American Library Association - Library of Congress, 1997) for the Greek words, with an added polytonic orthography which marks the pitch accent of Ancient Greek and the presence or absence of word-initial $/ \mathrm{h} /$. For Indo-European I will borrow the transliterations used by the author mentioned.

All references to the sections of Wittgenstein's Philosophical Investigations (henceforth, P.I.) are indicated only with a "P.I.§" before the number of the paragraph. Other works by the author are shown in the abbreviated form, referring to the abbreviation section in the bibliography of this work, with no further indication. All other authors are indicated per the conventions of this dissertation. 


\section{Introduction}

《老子》之書, 其幾乎可一言而蔽之。噫! [...] 解其一言而蔽之, 則無幽而不識。每 事各 為意,則雖辯而愈惑。Wáng Bì: Lăozǐ Zhìlüè

As a book, the Laozi can be almost covered completely in a single phrase: Ah! [...] If one understands how the above single phrase covers it, nothing hidden in it will fail to yield to recognition. But if each matter is taken to involve a separate concept, no matter how much argument there is about them, more and more confusion will result. (Lynn, 1999,p.37)

All arguments consist in proceeding from the known to the unknown, in persuading people that the new thing you want them to think is not essentially different from [...] the old thing they think already. This is the method of science, just as much as it is a method of rhetoric and poetry $[\ldots]$

Poetry and rhetoric are also concerned with bridging the gap between the new and the old; but they do not need to build a formal bridge. What they fling across the intervening space is a mere filament such as no sober foot would dare to thread. But it is not with the sober that poetry and eloquence have to deal. Their tê, their essential power, consists in so intoxicating us that, endowed with the recklessness of drunken men, we dance across a chasm, hardly aware how we reached the other side.

The appeal of the Tao Tê Ching is entirely of this second kind. "What others have taught", says the author, "I too will teach." We are not, he promises, to be tempted across any chasm. Our feet are firmly planted on the safe, familiar shore. Yet long before we have closed the book we find to our astonishment that the chasm is behind us. Magically, without bridge or ferry, we have been transported to the other shore. (Waley, 1958, p. 96-7)

When I first read the Lăož́, I was struck by its enigmatic language, its meandering and apparently disconnected chapters, and its arresting metaphors. The extreme concision of its language - even compared to other seminal texts of the Chinese canon - held a fascination over me, and encouraged me to explore it further with the aid of a few translations. Soon, it seemed to me as if there were as many translations to choose from as there are lines in the text. Furthermore, the translations offered a variety of interpretations that was likewise remarkable, each serving the purposes and objectives of its respective translator and commentator, each evincing traces of their own cultural and historical contexts of production.

Later on, having made contact with the earth-shaking writings of Wittgenstein and the (Wittgensteinian) iconoclastic texts of Roy Harris and Talbot Taylor on Western linguistic myths, I went back to the Lăož̆, now paying special attention to the question of language. For I sensed the possibility of an intensive 
and potentially fruitful dialogue between that old Chinese text compiled 25 centuries ago and the Wittgensteinian reflections on language I was getting acquainted with, with comparable awe.

In this process, one of the issues that caught my eye was that of the statute of metalinguistic practices. What places do they hold within human affairs? How do they migrate across different languages and cultures? Why has the research in linguistics, with which I was beginning to get familiarized, usually downplayed their importance? I noticed, for instance, that some important lines of the Lăož were rendered in Western languages with an intriguingly varied (and somewhat hesitant) range of metalinguistic terms - and was even more surprised by the fact that, in some cases, these same lines had been translated without the use of any metalinguistic vocabulary whatsoever. Here is a conspicuous example, extracted from the first lines of the ancient text:

Original: 道可道, 非

常道。dào kè dào, fēi

cháng dào

La voie that peut être exprimée par la parole n'est pas la Voie éternelle (Julien, 1842 , p. 2)

Waying wayable: no common waying; Naming nameable: no common naming. (Boodberg, 1957, p. 607)

O curso que se pode discorrer não é o eterno curso (Sproviero, 2007, p.43)

Ways can be guided; they are not fixed ways (Hansen, 2009, p. 38)

A brief look at these different versions is enough to raise a number of thought-provoking questions. We notice first that the same (key) word in the short excerpt above - dào 道, - is used with respect to something that is consensually non-metalinguistic (the first and third instances), a reference to aspects of the way of Daoism and the Lăož́. However, the second instance of dào 道 straddles between the linguistic and the non-linguistic realms. Julien and Sproviero, respectively translating as exprimée and discorrer, implicitly considered it metalanguage, while Boodberg and Hansen, respectively wayable and guided, did 
not. However, as we will see in chapter III, the guidance referred to by these last two authors (Boodberg's wayable can possibly be considered as such) could arguably be called metalanguage within the context of the Lăož́. Therefore, we are led to consider the possibility that the metalinguistic terms are not universal notions, but rather should be considered in their historicity and contextuality.

This dissertation responds to these provocations. In the pages ahead, I intend to show that the Lăož̆, together with a number of its different translations, may be taken as an especially favorable occasion to address the issue of metalanguage from a Wittgensteinian point of view of language as a form of life (P.I. $\S \S 19,23,241)$.

This is a point of view that entails, among many other things, that language is itself irreducible to any full-fledged universal theory: it cannot be abstracted away from the flow of life, it cannot be grasped as an autonomous object - the verbal and the non verbal maintain mutually constitutive bonds. From this angle, intriguingly, metalinguistic terms - such as, in English, "syllable," "word," "metaphor"... and even "language" - do not get to name universal, languageindependent entities. Rather, as much as any other kind of term, they testify to cultural and historical circumstances, and ultimately to forms of being in the world that encompass subterraneous propensities and pre-conceptual certainties, which are themselves characteristically elusive and refractory to intellectual apprehension and description. If language is heterogeneous and discontinuous historical praxis, with no defining telos and no fixed foundations, then so are any metalinguistic gestures that might take place therein.

Now, the encounter of different (meta)languages can be conceived of in a Wittgensteinian spirit along at least two main lines: relativistic or perspectivistic. This dissertation follows the latter, striving to adopt a reading of Wittgenstein informed by the motto "perspectivism without relativism.” (Prado Jr., 2004, p. 55)

To assume the Wittgensteinian viewpoint of (meta)language with a perspectivist rather than relativist persuasion is, very roughly, to accept that encounters between different forms of life/languages do not correspond to mere (mis)interpretations between incommensurable conceptual schemes or modes of existence, set apart by supposedly unsurpassable historical and anthropological 
boundaries. It is to accept, rather, that such encounters are occasions where these forms of life/languages may be brought to glimpse, however precariously, at their own unfounded, non intellectual foundations - circumstances where, in other words, they may be brought to sense that, appearances notwithstanding, they are, so to speak, already different from themselves. It is to accept, rather, that such encounters are occasions upon which we may catch a glimpse, however precariously, at the unfounded, non-intellectual foundations of these forms of life/languages. In other words, circumstances when, such forms of life may be understood, appearances notwithstanding, as already different from themselves.

This amounts to saying that such encounters may bring about the possibility of radical transformation and otherness, the chance of dislocating not only discernible ideologies, but also highly entrenched pre-conceptual convictions. It is worth adding parenthetically that, under this view, transformation, if it happens, is not to be thought of as good or bad in itself - no fixed, transcending value ever presides over it, be it ethical, logical, aesthetical or any other kind of absolute value. As the famous dictum goes, perspectivism has nothing to do with progressing to a final/ideal destination, but everything to do with the possibility of moving somewhere else.

With specific respect to metalinguistic practices, the main consequence of this line of thinking is that we should expect that the metalanguage we are currently using may have a direct and coercive effect on how we conceive of and experience language. While relativism implies incommunicability due to the absence of common (rationally-based) truth criteria, perspectivism embraces the inevitability of the relative. The eye that privileges the relation over the end nodes of the relationships (subject/object, observer/observed, etc.) calls our attention to the importance of the metalinguistic apparatuses that linguistically mediate these contacts. The importance, the historicity and the coerciveness of metalinguistic practices are central aspects in what will be investigated and explored here as the metalinguistic perspectivism hypothesis (henceforth $\mathrm{MPH}$ ).

The main objective of this dissertation is thus to identify and discuss, from a Wittgensteinian standpoint, the use of metalinguistic expressions in the classical 
Chinese text, the Lăožr. The investigation is guided by the following research questions:

1) When compared with Western metalinguistic practices, does the use of metalinguistic expressions in the Lăož̀ give support to the MPH and favor a perspectivist view of language as a form of life?

2) Are there affinities between the Daoist thought in the Lăož̀ and the ideas associated with the perspectivist view of (meta) language as form of life?

3) Does the confrontation between different readings and translations of the Lăož̆, informed by Chinese and Western metalinguistic practices, reveal differences and specificities with the potential to disturb and dislocate our own metalinguistic repertory? Does this confrontation give support to the MPH?

The methodology of the study is compatible with its ambitions and theoretical stance. I adopt a comparative strategy along two main paths: (i) a contrastive analysis of relevant sections of Western and Chinese metalinguistic repertoires, through the examination of their (grapho)etymologies; and (ii) a contrastive analysis of different translations of contextualized metalinguistic use in the Lăozĭ.

While the pertinence of comparing translations may be quite obvious here, the same cannot be said of the proposed (grapho)etymological investigations. This will become clearer later, but, for now, it is sufficient to say that, given the interest of the present study in comparing historically-conditioned metalinguistic practices, one cannot overlook the enormous importance of grapho-etymological considerations within the context of the Chinese linguistic tradition. In this tradition, graphic motivations and relationships between hànzì (漢字) are often taken as key factors bearing on discussions about the semantics of the Chinese words/characters, a fact that is fully imbricated in the semantically motivated 
character of Chinese writing. ${ }^{1}$ Any analysis of the kind suggested in this research cannot abstain from taking into account the grapho-etymological history of the terms under scrutiny. Therefore, it should be naturally expected that the exploration of the characters' histories would shed some light on the use of the metalinguistic terms in the Lăož̀ and on their relation to other terms from the Chinese tradition. Such analyses are particularly adequate in addressing the research question (1) above. The methodological adequacy of grapho-etymology is further reinforced in the face of the intimate relationship between metalinguistic practices and the advent writing systems, notably explored in the works of Sylvain Auroux [1992, 1995] 2000.

As for the contrastive analysis of translations, there seems to be little doubt that it offers an outstanding opportunity to compare and analyze different historical and cultural milieus. As we shall see, this proves to be the case also when, as in this study, one wishes to compare different sets of metalinguistic practices. Contemporary theories of translation have thoroughly questioned the representationalist conception of translation as the transport of meaning between languages - although this is still very much a part of our common sense and everyday discourses. This scenario has caused a complete reassessment of the position of the translator and the object of the translation, and the radical dislocation of previously stable poles of relationship, such as subject and language, language and world. The consequences of this reassessment of the activity of translation and its evaluation have been severe. Roughly speaking, theorists have found themselves struggling with the dilemma that is illustrated by the radical opposition between two assertions: "there is no such a thing as translation" vs. "everything is translation." On the other hand, the possibility to regard translation as the re-writing of a new text (original and, at the same time,

\footnotetext{
${ }^{1}$ The semantic motivation and the graphical iconicity of the Chinese characters are a matter of heated debates among Sinologists and Chinese scholars. Some of the authors aligned with the theoretical viewpoints defended in this work see the hànzi as a somewhat natural manifestation of the Chinese worldview, therefore justifying the importance of the etymological analyses. For further details, see Jullien (2008, 2013), Hansen (1985, 1992), Owen (1992) and Hutton (2006[2013]).
} 
translated), and the translator as an authentic author, has tremendously empowered this activity and widened the horizons of its possibilities. ${ }^{2}$

These on-going debates are a testimony on how the apparently untenable position of the translator - stretched over the abyss between languages - in fact provides him with an insight into two worldviews. The situation obviously cannot be different in the case of translations between English and Chinese. The translators of the Lăož enjoy the benefits (and the risks!) of their position as privileged non-native speakers of classical Chinese, who are given the opportunity to be faced with the strangeness of a new language and the uneasiness to deal with scenarios that question some of our most deeply entrenched common-sense ideas and practices. The difficulty we confront, in dealing with this (to us) new language/form of life, inevitably leads to the self-questioning of our own practices and metalinguistic reflections. As Blanchot aptly puts it, "every translator lives on the difference between languages; every translation is founded on such difference, even when chasing, or appearing to do so, the evil design of its suppression." (1997, p. 58)

For our purposes here, I will specifically focus on how the translators and commentators deal with the metalinguistic terms in the Lăož̆, and on the discussions of the Daoist view on language that are subjacent to these texts, aiming to respond to, but not limited to, the research questions (2) and (3) above.

With the support of the (meta)linguistic reflections offered by the translations and grapho-etymological analyses, I will attempt to gauge the differences in the translators' metalinguistic presuppositions and suggest possible criteria to evaluate each translation within a perspectivist view of language as form of life. I will show that the contrast between the different translations underscores not only the different strategies used by each translator when dealing with moments of alterity, but also, as expected within the context of the MPH, different metalinguistic repertoires whose influence will be pervasive beyond their translational practices.

\footnotetext{
${ }^{2}$ The impact of the recent translation studies will be further explored along this dissertation. For more details on the subject, see Barthes (2004), Borges (1972), Britto (1996), Eco (2007), Fish (1980), Mounin ([1963]1975), Bassnet (1998) and others.
} 
The dissertation outline is motivated by the objectives and methodology shown above. It consists of an explanation of perspectivism and the MPH in chapter I, followed, in chapter II, by a comparative (grapho)-etymological study of the metalinguistic terms in the Lăož̆ and their translations, offering us evidence to support the MPH. Finally, in chapter III, I will show, through a comparative analysis of different translations of the Lăož̆, that a contrast between Chinese and Indo-European metalinguistic practices adds evidence of radical otherness in these practices, as expected within the framework of the MPH. Furthermore, I will gauge the adequateness of the translations in light of such a framework. The dissertation is completed by a summary of its main findings in the Conclusion, which also will show possible affinities between the Daoist philosophy of the Lăož̌ and some of tenets related to the MPH and perspectivism. 


\section{Theoretical framework}

\section{1. Wittgenstein's Language as Form of Life}

\subsection{1. Introduction}

Wittgenstein's later philosophical work is inextricably linked to his discussion on language and his views on the matter are one of the touchstones of this dissertation. His philosophy is strictly non-dogmatic and therefore does not seek to impose a new "correct" way of thinking, but rather to broaden the horizon with his commitment to question our deepest-rooted beliefs. Wittgenstein might even be called an anti-philosopher, a thinker who argued against the ontological drive that fueled the ambitions of many fellow philosophers to accomplish the ultimate task of a full understanding of reality and the infinite. ${ }^{3}$ In Wittgenstein's reflection on language, he did not seek to build a firmer basis to it, but, on the contrary, strived to disclose its shaky foundations. ${ }^{4}$

The present work is guided by the influential Wittgensteinian concept of language as a form of life (P.I. $\S 19,23,241)$, which, in its most general terms, entails that language itself is irreducible and ever changing (P.I.§18), that is, it can neither be grasped as an autonomous object nor reduced to a mere tool of representation of entities from the "outside" of language. This is a form of life

\footnotetext{
3 "In philosophy no inferences are drawn. 'But it must be like this!' is not a philosophical proposition. Philosophy only states what everyone concedes to it” (P.I.§599).

4 "Perhaps we feel the foundations of language to be shaky when we look for, and miss, foundations of a particular sort [...]" (Cavell, 1979, p.179) Wittgenstein insists, however, that ordinary language works "just fine."
} 
constituted by a plethora of language-games (P.I.§66), ${ }^{5}$ as will be discussed in more detail below.

It is through a series of examples of these language-games that Wittgenstein attempted to disclose to his reader the contradictions and uncomfortable situations provoked by what he considered a "one-sided diet" that was "the main cause of philosophical diseases" (P.I.§593). 6 It is an inability to look closely and attentively (P.I.§52) that prevents us from questioning our most entrenched beliefs and, worse still, pastes an ontological coating to such beliefs. ${ }^{7}$ This thrust to interrogate is at the root of the radical anti-dogmatism of Wittgenstein's thoughts, particularly in his later writings. By placing these deeply ingrained dogmas under scrutiny, we are led to glimpse the fragile basis upon which we construct our theories of language, knowledge and reality.

This chapter addresses the aspects of Wittgenstein's later writings on language that are most relevant to this dissertation. What are his thoughts on language and on the relationship between language and thought and the world? How does he approach the questions of meaning, learning, understanding and naming? How does his language philosophy relate to (meta)linguistic perspectivism?

What Wittgenstein wished to convey in the expression form of life can be interpreted in a number of ways. ${ }^{8}$ Biological - or; naturalistic - and ethnological readings are common, each emphasizing, respectively, an analogy of the living forms of life in contrast to other (natural) forms of life, and the social nature of

\footnotetext{
5 "I shall also call the whole, consisting of language and the activities into which it is woven, a 'language-game"” (P.I.§7).

${ }^{6}$ Some examples are: the constructor's language (P.I. $\left.\S 2,8\right)$; Theaetetus' simples (P.I. $\left.\$ 48\right)$ and the numbering games (P.I. $\S 143-146)$.

${ }^{7}$ John Dewey is a philosopher who warned against this most pervasive danger in philosophy, as the "conversion of eventual functions into antecedent existence: a conversion that may be said to be the "philosophic fallacy' [...]" (Dewey, 1929, p.29)

8 "Although the term occurs only half a dozen times in Wittgenstein's published work, it has given rise to a multitude of misinterpretations, partly due to his nonchalant use." (Glock, 1996,p.124).

Glock also comments that the term intertwines ideas of "culture, world-view and language." Since this whole chapter is but a discussion on Wittgenstein's form of life, the multifaceted ramifications of the term should become apparent along its reading.
} 
language and human behavior. ${ }^{9}$ Such variety of interpretations of Wittgenstein's form of life and the need to address its multifarious ramifications shows that this is a particularly rich field of study on the philosopher's writings.

The present dissertation offers only a brief introduction to Wittgenstein's philosophy and the specifics of his interpretations. This study will more precisely focus on the presentation of my own chosen line of interpretation, one that refutes overly hierarchizing interpretations, and which probes a theme that is crucial to both the philosopher's inquiries and my own: language. My reading is predominantly supported by Martins (2012a, 2012b), Cavell (1979), Prado Jr. (2004), and Baker \& Hacker's monumental exegesis of the Philosophical Investigations (1990, 2005, 2009, 2014).

Wittgenstein's texts are particularly receptive to a rich variety of interpretations (in a way, much like the Chinese texts that will be discussed later in this dissertation) and some of the scholars' works that attempt to analyze it are frequently faced with the frustrating task of attempting to solve its irreducible ambiguities. I believe that Wittgenstein's latter texts are much like language:

maybe the very ambiguity of ordinary language, though sometimes, some places, a liability, is just what gives it the power, of illumination, of enriching perception, its partisans are partial to. (Cavell, 1979, p. 180)

\subsection{2. \\ Wittgenstein's language}

Wittgenstein's language, in his latest writings, often leads itself to enigmatic excerpts and a collage-like collection of passages and aphorisms without a clear discernable direction. ${ }^{10} \mathrm{He}$ arguably uses his own language as testimony to the

\footnotetext{
${ }^{9}$ For instance, when Wittgenstein settles a scene where one sees a chair and discusses the certainty that there is a chair, he writes: "Now I would like to regard this certainty, not as something akin to hastiness or superficiality, but as a form of life. [...] But that means I want to conceive it as something that lies beyond being justified or unjustified; as it were, as something animal." (OC $\S 358-9$, my emphasis)

10 "The best that I could write would never be more than philosophical remarks; my thoughts soon grew feeble if I tried to force them along a single track against their natural inclination. - And this
} 
fractured and irrational characteristics of language, those being constitutive of what Wittgenstein calls forms of life. In his writing style the philosopher seems to be using the form of his text, as one that is explicitly non-technical and ordinary ${ }^{11}$ and at the same time almost poetical and "odd," to convey his ideas and to provoke a shock in the reader that is apt to dismantle their preconceived ideas about what language "is" or "is not." The apparently non-connected passages and superficial lack of cohesion of the text leads the reader to ponder on the "missing links" and to construct the text together with its writer in a dialogic process that is alive and dynamic. ${ }^{12}$ It is therefore a reading that involves the non-negligible possibility of a double-sided risk: on the one hand, once the fragments are organized, ordered and dissected (as I am presently attempting to do here!), there is always the possibility to slip into representationalism, into forced dogmatism. On the other hand, with risk there is always the possibility of new and unexpected opportunities and surprises. I believe that by having us experience this possibility as readers, Wittgenstein's text is working as a meta-commentary on the inevitable perils (and opportunities) we run in the context of the language-games and as an exposition of the unavoidable circularities in which he seeks to call attention.

I consider that Wittgenstein's attempts to deal with these circularities are shown by what might be called his "blurred expressions," concepts that have particularly hazy contours and open exiguous and unexpected interstices. These

\footnotetext{
was, of course, connected with the very nature of the investigation. [...] a number of sketches of landscapes which were made in the course of these long and meandering journeys." (P.I., Preface) As it happens, the in-depth exegetical work of the scholars on the Philosophical Investigations lays out complex structures and relationships along the text and gives to it the scholar's interpretation of an apparent "super-structure." This is a naturally a valid form of reading, but, as per Wittgenstein's own philosophy, I do not believe it should be considered the only one.

11 The characterization of Wittgenstein's writing style as one which employs ordinary (gewöhnlichen) language is a controversial matter. Although he explicitly mentions his predilection for it (P.I. $\S 98,105,116,243)$, especially in its opposition to an "ideal" language, his vocabulary inevitably employs words not in their ordinary (common) uses. In some ways, the "discomfort" one often feels when reading his texts is mirrored in the philosopher's own struggle to call attention to the perils of ordinary language uses while at the same time he endeavors to use words in their ordinary ways.

In some way we might recognize in Wittgenstein's "ordinary language" an attempt to reach some "pre-philosophical language," such as the one used by the earliest Greeks (and, most likely, earliest Chinese, Indians, Mayans, etc..): "At first they [the early Greeks] did nothing since they did not know, fortunately perhaps, that they were philosophers and so continued to use words in their common acceptance [...]" (Peters, 1967, p. xi)

${ }^{12}$ Wittgenstein writes about the related concept of the "intermediary links" (Zwischengliede) in his "Remarks on Frazer's The Golden Bough" and their importance to "perspicuous representation" (übersichtliche Darstellung). This will be further discussed below.
} 
are terms such as: affinity (Verwandtschaft, P.I. $\S 65,76)$, similarities and family resemblances (Ähnlichkeiten, P.I.§66; Familienähnlichkeiten, P.I.§67), regularity (Regelmäßigkeit, P.I.§208), blurred edges (unscharfes Bild, P.I.§§71, 77) and reasonable man (vernünftige Mensch, P.I. §§402, O.C. §§19, 208, 219, 220, 252, $254,323,334)$. As the reader will see throughout this dissertation, Wittgenstein's concepts of meaning, rules and games are inherent to the ideas coalescing around some of the terms above. ${ }^{13}$ These "features" might be motivated by naturalistic limitations, without the necessary implication of Nature being explained by these regularities. It is important to note here, that it is a balance of regularities, affinities and blurred edges which empowers language and enables Wittgenstein to circumvent the futile endless dialectic opposition between relativism and universalism and its fruitless discussions on the essence of language.

\subsection{3. The essence of language}

Wittgenstein's text in the Philosophical Investigations begins with a wellknown excerpt from Augustine's Confessions. ${ }^{14}$ The philosopher claims that Augustine's words (and indeed, the mainstream vision of our Western GraecoChristian heritage) portray a quite clear view on the essence of language:

P.I. 1 . In diesen Worten erhalten wir, so scheint es mir, ein bestimmtes Bild von dem Wesen der menschlichen Sprache. Nämlich dieses: Die Wörter der Sprache

\footnotetext{
${ }^{13}$ In other texts Wittgenstein, however, wrote that "The goal of philosophy, [...], is 'transparency of arguments' (BT 414) and the 'clarification of the use of language' (BT 422) in order to dissolve philosophical problems." (Baker \& Hacker, vol. 1, part I, p. 308) We would have to interpret that this "clarification" and "transparency" are not achieved through the elimination of the haziness and lack of borders that is so crucial in the author's characterization of language.

${ }^{14}$ Since Plato, the Western tradition considers that there are idealized forms "behind" what we can access in the concrete reality through our senses. Aristotle added that in conjunction to such abstracted and perfect forms lies human reason, which is likewise perfect, as well as being stable, universal and objective. Reason and perfect forms constitute a basis that is isolated from the imperfect empirical reality, where we find our human bodies. Augustine and Christian theology were directly influenced by the body/mind duality, delegating to the divine sphere the perfectly abstracted forms.

Wittgenstein is a force that seeks to refrain us from abstraction, from the urge to idolize the perfect abstract forms that Plato wrote about. His is a philosophy that accepts the enormous task of dealing with infinitude without striving to reduce it to man-made abstract concepts.
} 
benennen Gegenstände - Sätze sind Verbindungen von solchen Benennungen. In diesem Bild von der Sprache finden wir die Wurzeln der Idee: Jedes Wort hat eine Bedeutung. Diese Bedeutung ist dem Wort zugeordnet. Sie ist der Gegenstand, für welchen das Wort steht.

P.I. 1 . These words, it seems to me, give us a particular picture of the essence of human language. It is this: the words in language name objects - sentences are combinations of such names. - In this picture of language we find the roots of the following idea: Every word has a meaning. This meaning is correlated with the word. It is the object for which the word stands. ${ }^{15}$

In this view, Wittgenstein argues, there are no differences among the classes of words in language; each and every one would have a represented counterpart in the world. ${ }^{16}$ As a corollary, to learn a language would mean to acquire words that stand for each new "thing" we experience in the world, the mind passively reflecting the external world's state of affairs. ${ }^{17}$ Furthermore, meaning becomes the object represented by a linguistic unit and there would not be a discernable difference between learning language as L1 or as L2. ${ }^{18}$

Aristotle was responsible for restructuring the representation axis between things in the world and language by interposing reason (logos) as the principle that organized this system of representation. In the dualistic worldview where the body (and physical world) stands in direct opposition to the mind, it is logic and reason that are the perfect mirror congruent to the abstracted order of the world, one that must be "utterly simple" and of the purest crystal, free from tainted experience (P.I.§97). Logic must be precise and free from vagueness (P.I.§101).

With the Cartesian elaboration of the mind, it acquires an even greater importance as the justification of what differentiates us from other animal forms

\footnotetext{
${ }^{15}$ Whenever available, references will be given firstly in the original language of the text followed by the translation into English. The Philosophical Investigations' bilingual versions is provided by Anscombe et al (2009); translation of Observations on the Golden Bough by Almeida (2007); and all other translations of Wittgenstein by myself.

16 "Augustinus, in his description of child language-learning, did not speak of there being different kinds of word (or parts of speech, as W[ittgenstein] preferred to say in English), although he was evidently thinking primarily of common nouns and proper names." (Baker \& Hacker, v. 1, part II, p. 70)

17 "Perception is a process by which we receive information from the world. Cognition is then a matter of performing operations - computations - on a static inner rendition of such information." (Love, 2004, p. 526)

${ }^{18}$ In this state of affairs, translation can be considered just another process of coding/decoding pairs of meaning/form between two languages. The question of meaning will be discussed more carefully in the next section of this chapter.
} 
of life: reason is uniquely human. ${ }^{19}$ Descartes does not show us why or what this distinction is, he simply postulates it, based on what he believed to be an obvious truth that mirrors another obvious fact: that humans are the only species to have language. (Harris, 2004, p. 731) Because language reflects our perfect reason to the point that they are conflated in the Greek lógos, its essence must be likewise perfect and totally transparent in order not to obscure or cloud our reach, via the intellect, into reality. This perfection and definitiveness must encompass all language; involve even the most vague of the propositions (P.I.§99). In his discussion on the "Augustinian picture of language", ${ }^{20}$ Wittgenstein claims that we are bound by this need for the ideal: "You can't step outside it. You must always turn back. There is no outside; outside you cannot breathe" (P.I.§103). ${ }^{21}$

A fatal mistake from previous language theorists, Wittgenstein argues, happens when the philosophers seize words like understanding from their contexts within the language-games and put them "on holiday," as if the words would remain frozen as mental concepts which could systematically be applied to whatever different situation one desires (P.I.§38). Wittgenstein writes:

P.I.§116. Wenn die Philosophen ein Wort gebrauchen - "Wissen", "Sein", "Gegenstand", "Ich", "Satz", "Name" - und das Wesen des Dings zu erfassen trachten, muß man sich immer fragen: Wird denn dieses Wort in der Sprache, in der es seine Heimat hat, je tatsächlich so gebraucht?

Wir führen die Wö rter von ihrer metaphysischen, wieder auf ihre alltägliche Verwendung zurück.

P.I.§116. When philosophers use a word - "knowledge", "being”, "object", "I", "proposition/sentence", "name" - and try to grasp the essence of the thing, one must always ask oneself: is the word ever actually used in this way in the language in which it is at home?

What we do is to bring words back from their metaphysical to their everyday use.

${ }^{19}$ In the relationship between humans and animals, we see ourselves as physically contiguous animals (possessing a body) and metaphysically discontinuous non-animals (possessing a $\mathrm{mind} /$ soul). It is the spirit (soul, reason, language) that is the great Differentiator, which makes us human and individualizes our bodies. (see also Viveiros de Castro, 2004, p. 241)

${ }^{20}$ See also Glock, 1995, p. 41-45.

${ }^{21}$ Taylor (1997, p. 178) describes a likewise bleak picture when we attempt to step completely out of our most deeply entrenched ideas and risk opening ourselves to radical questioning: "My answer, in short, is that if we gave into a wholesale skeptical rejection of that picture, we would not be able to live." 
There is an obvious conundrum here because when writing his text (as with any text), Wittgenstein is clearly using words in a specific context outside of their "everyday" uses and is arguably using them in a "metaphysical" sense, or at least in a metalinguistic sense. ${ }^{22}$ Even more, he seems, enigmatically, to be seeking to "clarify the essence of language" 23 and insists that grammar "tell us the essence of a thing" (P.I. §371, 373).

However, it is crucial to understand how and why Wittgenstein employs the word essence (Wesen). It is used not as an ontological, objective grounding principle that is described by grammar (language), but as exactly that which is called by grammar essence.

Grammar tells us the essence of a thing, not because it reflects the objective, language-independent, essential nature of what is represented, but because it determines essence. [...] Grammar does not describe the essential nature of . . ., it determines what is called.... (Baker \& Hacker, v. 1, part II, p.252)

Moreover, neither is grammar a prerequisite to learn or even to have a language:

The grammar of a language isn't recorded and doesn't come into existence until the language has already been spoken by human beings for a long time. (PG, p. 62-3) $)^{24}$

The "metaphysical uses" mentioned in P.I. $\$ 116$ above refer to this quite specific philosophical endeavor where what is described by physics is explained by metaphysics, as a "super-science of reality." 25 Wittgenstein's de-

\footnotetext{
${ }^{22}$ See for instance, Taylor (1997, p. 76): "Wittgenstein himself usually speaks of language as if it consisted of invariant formal entities. Words and sentences are pictured as instruments which we 'make use of' when we speak." I have already briefly discussed about the circularity of language on the section above on Wittgenstein's language.

23“" $[\ldots]$ we, in our investigations, are trying to understand the nature of language [...]"(P.I.§92)

${ }^{24}$ Harris (1988, p. 71) speculates that what comes into existence after "a long time" is the codification of grammar. However, this would only cause further questions about what form exactly this "codification" could take. It might be that Wittgenstein here is just stressing the point of the non-antecedence of grammar as a prerequisite to language.

25 "When this quest [for the essence of language] is pursued under the misconception of the sublimity of logic, then the essence of language appears to be something hidden beneath the surface of ordinary language, to be revealed only by depth analysis. [...] The quest for the essence of language, understood as an investigation into the function and structure of language, is here endorsed." (Baker \& Hacker, v. 1, part II, p.206)
} 
metaphysicalization of words, and especially of metalinguistic terms, is a crucial aspect that links the philosopher's reflections in the Philosophical Investigations with what will be presented below as metalinguistic perspectivism. Words are not describing the ontological reality of objects, but rather are determining how we call them. Likewise, that is what metalanguage (and linguistics) does in regard to language.

In his analysis of communicational situations and examples of "reduced language-games", Wittgenstein dealt directly with practical scenarios of language use and postulated the impossibility of abstracting the language from praxis, the reciprocity between the verbal and the nonverbal and the irreducibility of verbal practices to any telos or essence. ${ }^{26}$ In the moment one tries to extract an essence from language, one inevitably must give away some constituent part of the language. Indeed, the very idea of completeness of the language does not make sense for the philosopher: "Ask yourself whether our language is complete" (P.I.§18). ${ }^{27}$

Language is not contiguous to anything (it is not bounded by borders), so it should not to be taken as a sealed off and isolated object, which could be described and explained by progressively chopping it up into smaller and more basic units, up to the limit of the minimum constituent units (its atoms). ${ }^{28}$ Likewise, language cannot be defined chronologically, it is not suspended in the story; instead, it drags a history and has no origin. ${ }^{29}$

${ }^{26}$ When Harris $(1988$, p. 97) writes "Neither Saussure nor Wittgenstein questions the lay assumption that language is primarily a form of communication and that languages are to be viewed as communication systems," it seems that the author is ascribing some sort of telos to language, that is, as a communication system. I would prefer to modalize such affirmation, even if recognizing that Wittgenstein's examples might all be called "communication games." However, Wittgenstein himself leaves that open to question when he writes that "[...] the concept of language is contained in the concept of communication." (PG, p.193) Because Philosophical Grammar was a transitional work (written between 1930 and 1933), it might have shown aspects of the "early" Wittgenstein (see also Miller, 1977).

${ }^{27}$ In the discussion of the definition of a game in P.I.\$69, Wittgenstein writes: "We don't know the boundaries because none have been drawn," and that is equally valid for language.

${ }^{28}$ In P.I. $\$ 46-59$, Wittgenstein analyzes the idea of the "simples" in the context of naming and questions the hazy frontiers between simples and composites, demystifying two claims from Plato's Theatetus: 1) that simples can only be named, not described, and 2) that simples are beyond existence and inexistence (see Baker \& Hacker, vol 1, part II,p.95).

${ }^{29}$ See also Auroux (2004, chap. 1) on the question of the origin of language. 
Language and language-games do not have an external motivation or an invariable internal system; they are not based on any discernable fundaments:

The concept of language is not defined by specification of necessary and sufficient conditions in virtue of which something qualifies as language or a part of language. It is not sharply circumscribed at all. For language is a motley of language-games, none of which is essential. (Baker \& Hacker, v. 1, part II, p.146)

We practice language unknowingly: it seems that we all share one and the same system of representation, but this is but a false comfort. We must take the risks because the language-games are not versions of implicit or explicit underlying formal relations. For this reason, there is no intrinsical guarantee of mutual understanding between the speaker and hearer. Understanding is not provided by any shared meaning between different parties in the language-games.

\subsection{4.}

\section{Language and meaning}

Wittgenstein dared to question what few had questioned before, and which lies at the basis of our Western cultural heritage: the predominance of logic and reason, the imperialism of the scientific method. ${ }^{30}$

P.I.§81. Während die Logik doch nicht von der Sprache - bzw. vom Denken handelt in dem Sinne, wie eine Naturwissenschaft von einer Naturerscheinung

P.I. $\S 1$. Whereas logic does not treat of language - or of thought - in the sense in which a natural science treats of a natural phenomenon

P.I.§89. Wir stehen mit diesen Überlegungen an dem Ort, wo das Problem steht: Inwiefern ist die Logik etwas Sublimes?

Denn es schien, daß ihr eine besondere Tiefe - allgemeine Bedeutung - zukomme. Sie liege, so schien es, am Grunde aller Wissenschaften.

P.I.§89. With these considerations we find ourselves facing the problem: In what way is logic something sublime?

\footnotetext{
${ }^{30}$ This is what Campos (1977, p. 76) calls "the tyranny of the logic."
} 
For logic seemed to have a peculiar depth - a universal significance. Logic lay, it seemed, at the foundation of all the sciences.

We take for granted that the "scientific method", based on logical inference and deduction, is the (only) one that can produce knowledge, without asking ourselves exactly why. On this supposition scholars built "ideal languages" that would mirror the logical structure of reality and consider them as better or more exact than everyday languages (P.I. $\$ 81),{ }^{31}$ implicitly accepting hierarchies guided by the rule of a supposedly objective, eternal and constant logic. ${ }^{32}$ Wittgenstein could not see any justification for the primacy of the rational:

I want to regard man here as an animal; as a primitive being to which one grants instinct but not ratiocination. As a creature in a primitive state. Any logic good enough for a primitive means of communication needs no apology from us. Language did not emerge from some kind of ratiocination. (O.C, §475, my emphasis)

The philosopher noticed the inevitable circularity of a philosophy which is ultimately based on the concept of meaning:

Wittgenstein's most important strategy maneuver was to have given the notions of understanding and explanation priority over the notion of meaning. This contradicts the outlook of the semantic tradition descending from Plato. (Taylor, 1997, p. 63, my emphases)

By focusing on understanding and acting, Wittgenstein downplays the central role that meaning has played since the Greeks. If meaning ceases to be a transcendent and mysterious entity, then mutual understanding likewise ceases to be an identification of the correct meaning by two or more parties, and instead becomes intrinsical to the linguistic practices involved in the use of an expression.

\footnotetext{
31 'It is another facet of the illusion of an 'ideal language' where, as envisaged in the Tractatus, expression would be pictorial of that which is expressed." (Harris, 1981, p.110)

The role played by the writing dimension of language in the idealization of language is discussed at length by Taylor (1997, chapt. 2) and other like-minded writers.

${ }^{32}$ For an account of the attempts made by scholars to read in Wittgenstein the objective of a "ideal and final language-game", see Prado Jr (2004, p. 38).
} 
${ }^{33}$ Therefore one can argue that there is no "theory of meaning" in Wittgenstein's latter works, but rather an account of meaning: "what is at issue here is the ordinary concept of meaning, not technical notions which formal semanticists might devise." (Glock, 1995, p. 377) Meaning remains nothing but the use of each word in their praxis:

P.I.§10. Was bezeichnen nun die Wö rter dieser Sprache? - Was sie bezeichnen, wie soll sich das zeigen, es sei denn in der Art ihres Gebrauchs?

P.I.§10. Now what do the words of this language signify? - How is what they signify supposed to come out other than in the kind of use they have?

Whether a sign is meaningful depends on whether there is an established use, whether it can be employed to perform meaningful linguistic acts; what meaning it has depends on how it can be used. (Glock, 1996, p. 376-7)

As commented, the devaluation of the concept of meaning obviously does not entail its complete absence from Wittgenstein's philosophy. Quite the contrary, meaning still plays a central role in his investigations, but once it loses its position as the main source of philosophical questions (and problems!), it becomes a natural consequence of the praxis of language, unencumbered by the heavy anchors of logic and idealism and the necessity that language be the perfectly transparent mirror into nature. Meaning acquires hazy contours but the use of the signs within the context of the language-games - that is, the way meaning is generated - is not a completely unrestricted and unregulated practice. Signs become meaningful "through having a rule-governed use" (Glock, 1995, p. 376) and it is a combination of these rules (grammar) and regularity that will characterize the language-games.

\footnotetext{
${ }^{33}$ This is the opposite of strategies adopted in most of the formal lines of research in linguistics, such as Gerativism. As Werry (2005, p.382) comments:

This naturalization and internalization of knowledge in part explains why Chomsky is so dismissive of the idea of analyzing how knowledge is produced, disseminated and legitimized. In much of Chomsky's writings one can identify a tendency to dismiss or define as 'uninteresting' issues that involve reflection on how knowledge is produced.
} 
1.1.5.

\section{Language-games, rules and regularity}

By transposing the axis of exploration of understanding from the ontological meaning into the context of uses, showing us practical daily examples of uses of language, and dismantling the theoretical possibility of abstract language as an isolated object of study, Wittgenstein leads us to contemplate the idea of the language-games.

Moreover, we may ask, what it is that we can grasp from the Wittgenstein's conception of language-games? First, it serves to bring to our attention that language is an activity, ${ }^{34}$ or, in another term that stresses its dynamism, a form of life. It is a multiple-sided activity with an incredible richness of facets (P.I.§23).

Second, it is also a game, and therefore we are led to believe that it must share some similarities with other games. ${ }^{35}$ However, as the passage below shows us, we are faced with insurmountable obstacles when attempting to find out what exactly such similitudes are:

P.I.§66. Und das Ergebnis dieser Betrachtung lautet nun: Wir sehen ein kompliziertes Netz von Ähnlichkeiten, die einander übergreifen und kreuzen. Ähnlichkeiten im Großen und Kleinen.

P.I.§66. And the upshot of these considerations is: we see a complicated network of similarities overlapping and criss-crossing: similarities in the large and in the small.

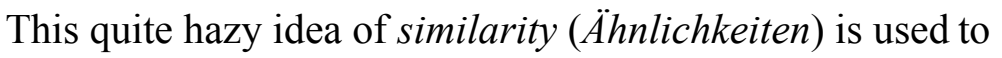

Refute the preconception that a concept-word (such as 'language' (\$65)) is correctly applied to each of a set of objects only if these share some common property in virtue of which they fall under this concept. (Baker \& Hacker, v. 1, part II, p. 153)

\footnotetext{
${ }^{34}$ In this aspect, similarly to speech-act theory.

${ }^{35}$ There is a question related to the translation of the term Spiel from German into game in English. As noted in Baker \& Hacker (v.1, part II, p. 153): "the activities characterized as Spiele in German are perhaps a wider set than those called 'games' in English." This would give a broader range to the German term in comparison to the English word. Although Baker \& Hacker conclude that this difference does not affect Wittgenstein's point, I consider it a point worth mentioning that would help us refrain from taking too hasty conclusions based on the term game in English.
} 
In the end, we can see that there are no common properties between games such that would justify our calling these activities games, nor are there common traces that we use when we explain the term game other than the fact that they are called games! As Baker \& Hacker elucidate, this is the argument that serves as a hint on what Wittgenstein means when he writes that there is nothing in common to all the phenomena pertaining to language, except "many different kinds of affinity [Verwandtschaft] between them" (P.I.§65). His idea is that it is possible to

P.I.§68. kann es [Begriff] auch so gebrauchen, daß der Umfang des Begriffs nicht durch eine Grenze abgeschlossen ist. Und so verwenden wir ja das Wort "Spiel". Wie ist denn der Begriff des Spiels abgeschlossen?

P.I.§68. use it [concept] so that the extension of the concept is not closed by a boundary. And this is how we do use the word "game". For how is the concept of a game bounded?

This speculation on the difficulty of tracing clear boundaries that delineate the space of concepts also led the philosopher to the aforementioned idea of "blurred edges" (P.I.§71). This is an affirmation, contra Frege, that vague concepts are valid concepts, which, in the end, excludes the possibility of vagueness as a category. Wittgenstein suggests the hopelessness of a task where one attempts to "draw a sharp picture 'corresponding' to a blurred one" (P.I.§77), calling attention to the distortion of imposing artificial sharp-edged abstractions over the blurred nature of things. In addition, how sharp should a "sharp picture" be (P.I.§77)? There are no a priori limits to this kind of idealization, he argues: "No single ideal of exactness has been envisaged; we do not know what we are to make of this idea" (P.I.§88).

Third, and finally, games have a close affinity to the idea of rules. ${ }^{36}$ Wittgenstein is obviously not talking about a fixed set of rules that must be learned by members of a community, because that would bring us back to the external, stable and extra-linguistic factors structuring language. What we call rule might play widely different roles in the language-games (P.I.§§53-4) and the

\footnotetext{
36 "The concept 'rule' is one of the main links in the analogy between languages and games." (Harris, 1988, p. 69)
} 
rules themselves are inevitably open to different interpretations. ${ }^{37} \mathrm{~A}$ rule is valid in a way that those taking part in the language-game in question are in mutual agreement that the rule is being enforced.

When Wittgenstein discusses how the language-games could be characterized (P.I.§65ff), and, therefore, what could be considered the "essence" of language, he engages a "dialog" with his interlocutor about family resemblances and how to apply the rules of the language games. ${ }^{38} \mathrm{He}$ uses one of his many analogies, that of a tennis game: "no more are there any rules for how high one may throw the ball in tennis, or how hard, yet tennis is a game for all that, and has rules too" (P.I. $\$ 68) .{ }^{39}$ Another analogy that calls the attention to the complex relationship between the playing of a game and its rules is to be found in the games where we "[make] up the rules as we go along" (P.I.§83).

37، A rule stands there like a signpost. - Does the signpost leave no doubt about the way I have to go?” (P.I.§85)

${ }^{38}$ The family resemblance concept is an alternative to an otherwise ontological status of language and is introduced in P.I. $\S \S 65-88$. According to Glock (1996, p. 120):

the notion is part of Wittgenstein's general resistance to dogmatism (BT 259-60; EPB 158), and linked to the idea that an OVERVIEW constructs connecting links between the phenomena it describes. [...] The notion is crucial to Wittgenstein's attack on essentialism [...].

The family resemblances, argues Cavell, can be taken in their very trivial sense, but their importance lies in them showing that:

concepts do not usually have, and do not need "rigid limits", so that universals are neither necessary nor even useful in explaining how words and concepts apply to different things (cf. §68); and again, see that the grasping of a universal cannot perform the function it is imagined to have, for a new application of a word or concept will still have to be made out, explained, in the particular case, and then the explanations themselves will be sufficient to explain the projection; and see, finally, that I know no more about the application of a word or concept than the explanations I can give, so that no universal or definition would, as it were, represent my knowledge (cf. §73) (Cavell, p. 188)

${ }^{39}$ This metaphor alludes to the token/type relation that will be discussed at length in the chapter II of this dissertation. Very briefly, as it happens in language, in the game of tennis one could concoct an "idealized" ("essentialized") form that regulates some of its aspects but not others. For instance, the ball must pass over the net, but the height over it is unregulated. Whatever height the ball passes (the different tokens), we can recognize that it all falls in the "over the net" (one) type and this consists of a valid move. This relation is incredibly more complex in language, where the distinction between token/type is one of the weaknesses of the formal models oflanguage.

There is a technical commentary to be made specifically about the tennis game analogy. Harris (1988, p. 70) comments that it is not correct to say that "there is no rule for how high one throws the ball in tennis" because in fact there is a rule, namely that one can throw the ball at any height. What is lacking is a rule-formulation for that. However, this comment does not seem to alter the comparison above. 
Games might be played without knowledge of their rules and somehow we do follow a set of rules in the language-games, ${ }^{40}$ rules that are habits pertaining to a technique:

P.I.§199. Einer Regel folgen, eine Mitteilung machen, einen Befehl geben, eine Schachpartie spielen sind Gepflogenheiten (Gebräuche, Institutionen). Einen Satz verstehen, heißt, eine Sprache verstehen. Eine Sprache verstehen, heißt eine Technik beherrschen.

P.I.§199. To follow a rule, to make a report, to give an order, to play a game of chess, are customs (usages, institutions). To understand a sentence means to understand a language. To understand a language means to have mastered a technique.

All these observations from Wittgenstein's writings drawn a complex picture, where language-games' rules are constantly being updated and contextualized in every language interaction and, at the same time, languagegames follow customs and traditions that have a temporal dimension and import. As we will see below, I cannot justify the way I act by rules and rules cannot explain how I act:

P.I.§201. Unser Paradox war dies: eine Regel könnte keine Handlungsweise bestimmen, da jede Handlungsweise mit der Regel in Übereinstimmung zu bringen sei. Die Antwort war: Ist jede mit der Regel in Übereinstimmung zu bringen, dann auch zum Widerspruch. Daher gä be es hier weder Übereinstimmung noch Widerspruch.

Daß da ein Mißverstä ndnis ist, zeigt sich schon darin, daß wir in diesem Gedankengang Deutung hinter Deutung setzen; als beruhige uns eine jede wenigstens fü $r$ einen Augenblick, bis wir an eine Deutung denken, die wieder hinter dieser liegt. Dadurch zeigen wir nä mlich, daß es eine Auffassung einer Regel gibt, die nicht eine Deutung ist; sondern sich, von Fall zu Fall der Anwendung, in dem ä ußert, was wir "der Regel folgen", und was wir "ihr entgegenhandeln" nennen.

P.I.§201. This was our paradox: no course of action could be determined by a rule, because every course of action can be brought into accord with the rule. The answer was: if every course of action can be brought into accord with the rule, then it can also be brought into conflict with it. And so there would be neither accord nor conflict here.

40 “The propositions describing this world-picture might be part of a kind of mythology. And their role is like that of rules of a game; and the game can be learned purely practically, without learning any explicit rules" (OC, $\S 95$, my emphasis); or "[...] there's certainly such a thing as learning the game without explicit rules" (PG, p. 62). 
That there is a misunderstanding here is shown by the mere fact that in this chain of reasoning we place one interpretation behind another, as if each one contented us at least for a moment, until we thought of yet another lying behind it. For what we thereby show is that there is a way of grasping a rule which is not an interpretation, but which, from case to case of application, is exhibited in what we call "following the rule" and "going against it".

When asked by his "interlocutor" how one would be able to follow a rule, Wittgenstein replies: "Then I am inclined to say: "This is simply what I do" (P.I.§217). One just cannot elucidate what rules "are": "Knowing the language is not a question of being able to explain what the rules are if asked [...] Knowing the language is also exhibited in speaking it." (Harris, 1988, p. 71)

It seems that a rule cannot determine the correct course of action, because every course of action can be made compatible with any rule "by means of some interpretation." However, isn't it in the nature of rules to determine what is correct and what is not? In that case, any course of action can also be interpreted as being in contradiction with the rule. "Hence the very notions of being in accord with and being in conflict with are deprived of any meaning." (Baker \& Hacker, v. 2, p. 125-5) This conundrum arises from thinking of each interpretation in a chain of interpretations, one surpassing the other directly before it: each interpretation can be re-interpreted. The paradox lies with "the idea that it is interpretations which determine the correct application of rules. How one understands a rule is also shown by what one does in following it [...] It is a matter of acting." (Ibidem) Therefore, in Wittgenstein's terms to go against the rule should not be conceived of as a misinterpretation of the rule, but as an action not in accordance to (what we expect from) the rules. In other words, to understand a rule does not entail its correct interpretation, but rather just involves the act of following or going against this rule (P.I.§202):

\footnotetext{
"What counts as following a given rule is exhibited in those actions that are called 'following the rule'. 'Following a rule' designates a normative practice. It is that practice that forges the internal relation between the rule and what counts as accord with it." (Ibidem, p.130)
}

There is arguably an inevitable social dimension to its practice and technique: when one follows a rule, one is being guided by one's previous 
practices, experience in past language-games and interactions within one's social context. This instantiates a (normative) "regularity of conduct and a mastery of a technique" (Ibidem), a sort of savoir-faire.

This regularity is crucial to the language-games. We see it in the example of a researcher coming to an unknown country where there is no "regular connection" between sounds and actions, and therefore "there is not enough regularity for us to call it 'language"' (P.I.§207).

The notion of regularity is crucial to the proper functioning of language, as Prado Jr (2004) comments:

Sem regularidade natural, não poderíamos falar, mas não poderíamos sequer sobreviver. Mas isto não pressupõe harmonia preestabelecida entre pensamento e realidade [...] Não é necessário que o mundo seja bem comportado [...] para que eu não caia do cavalo, para usar a metáfora de Wittgenstein. O mundo sabe empinar, pular ou mesmo bolear. No pior dos casos, mudo de sela ou transformo meu jogo de linguagem. Mas, para que haja verdade (ou erro), certeza (ou dúvida), razão (ou loucura), nenhuma harmonia precisa ser estipulada: deve-se apenas aceitar que até agora, pelo menos, tudo ou quase tudo ocorreu bem [...] Basta aceitar algo como a ideia vaga $[. .$.$] da regularidade da natureza. (p.33)$

Without natural regularity, we could not talk, but we could not even survive. However that does no presuppose a pre-established harmony between thought and reality $[\ldots]$ It is not necessary for the world to be well behaved [...] so that I do not fall from the horse, to use Wittgenstein's metaphor. The world knows how to prance, jump or even to picket. In the worst of cases, I change my saddle or modify my language-game. However, so that there is truth (or error), certainty (or doubt), reason (or madness), no harmony must be stipulated: one should only accept that so far, at least, everything, or mostly everything, has happened well [...] It is sufficient to accept something like the vague idea $[\ldots]$ of nature's regularity.

In other words, Prado Jr affirms that regularity is somehow ("vaguely") perceived as a trait of nature. Wittgenstein also indirectly remarks on this connection by calling attention to the importance of nature to what we can (and cannot) know:

O.C. §505. It is always by favor of Nature that one knows something.

This regularity is not - cannot be - exact and this fact mirrors itself in the indefiniteness of language and the word: 
P.I.§211. If a pattern of life is the basis for the use of a word then the word must contain some amount of indefiniteness. The pattern of life, after all, is not one of exact regularity. (Preliminary Studies for Part II of Philosophical Investigations)

There is neither explaining power nor ontological reason for this regularity - it just is. In addition, it is the adaptation and friction between language and world that fuels the dynamics of the language-games. The famous river analogy from On Certainty is also apt to convey this idea of regularity and change:

O.C $\S 97$. The mythology may change back into a state of flux, the river-bed of thoughts may shift. But I distinguish between the movement of the waters on the river-bed and the shift of the bed itself; though there is not a sharp division of the one from the other.

Prado Jr.'s analysis of this metaphor is quite instructive:

Um jogo de linguagem permanece o mesmo, mesmo se as proposições [inicialmente] nele consideradas verdadeiras, passam a ser consideradas falsas e vice-versa. Mas se o bloco ou o aglomerado das proposições polares - a mitologia de base - muda, não mais se pode dizer que jogamos o mesmo jogo e que nos banhamos no mesmo rio. Não é o mundo que se revela volúvel [...] nós mudamos as regras do jogo e, com elas, nossa forma de vida, isto é, nós mudamos. (Prado Jr., 2004, p. 35)

A language-game remains the same, even if its propositions [initially] considered truthful, turn out to be considered false, and vice-versa. However, if the block or agglomerate of opposing propositions - the base mythology - changes, we can no longer claim that we play the same game and bathe ourselves in the same river. It is not the world that is revealed volatile $[\ldots]$ we change the game rules and, with them, our forms of life, that is, we change ourselves.

One can notice in Prado Jr's words an introduction to the possibility of alterity, a situation where the ground mythology changes as we consistently change our forms of life. This analysis will be pursued later in the discussion on perspectivism. For the moment, if suffices to say that the language-games conceived in articulation with the ideas of rules and regularity will constitute Wittgenstein's arguments against a purely relativistic reading of the Philosophical Investigations and his later writings. 


\subsection{6. \\ Relativism and perspectivism}

The ideas related to rules and regularity, as discussed above, have a crucial bearing in a matter that is central to the present work: the question of relativism and universalism in Wittgenstein. This subject will be readdressed later with the discussion of the particularities of Perspectivist philosophy; however, it deserves some reflections here within the context of Wittgenstein's thought.

When he imposes his radical reassessment of all dogmas, Wittgenstein shares a risk that is common to all relativistic thinking, that is, to have his arguments criticized as self-refuting, as committed to the claim that, if correct, the argument would reject itself. Glock argues that the philosopher might have a reply for that. Wittgenstein's self-questioning does "not apply epistemic terms in a way limited by the practice concerned. They [the epistemic terms] are grammatical remarks, reminders of the way these words are used in this practice." (Glock, 1996, p. 127) He dislocates the question of the meaning (in the Augustinian sense) of his assertions to the manner in which they are used. Wittgenstein's statements do aspire to be correct in transcending different practices, but they are not transcendental (necessary) in a way that they apply to all language-games. Different practices have different priorities and we cannot abstract from all of them without losing something in the process. Wittgenstein's text gives testimony to the philosopher's own praxis, embedded within his concerns and priorities, his own perspective.

As a norm in relativistic persuasions, meaning (in the Augustinian sense) plays a pivotal role in understanding language and in the evaluation of the success or failure of a communicational instance. Being considered a "mysterious" entity, in this worldview it is not understood how meaning could ever be shared or transmitted between people, communities and cultures. It is possible to argue that those who defend a skeptical stance also believe in the existence of meaning as entity (as well as other metaphysical concepts), but doubt that one would ever be able to fully understand what it is. The contrast between the skeptic and the universalist's positions could be, very roughly, distributed along the axis oriented 
by the antinomy of the necessary and the contingent. Whatever that is necessary would be of the order of the universal, the fixed and the ontological, while the contingent is contrariwise related to the conventional, the changing and the relative. $^{41}$

Wittgenstein's view of the necessary is "internal to his view of what philosophy is" (Cavell, 1979, p. 119), but it cannot obviously imply a universalist outlook. The philosopher's necessary rests not on the grounding or explaining of reality (or language), but rather, that

[...] something can be necessary whatever we happen to take as, or believe to be, necessary. - But that only says that we have a (the) concept of necessity - for it is part of the meaning of that concept that the thing called necessary is beyond our control. (Ibidem)

The necessary is therefore what lies beyond our control, what we take as not depending on our decisions and needs, what is (believed to be) external. We do not know a priori what will be accepted as such, but once we admit it, it becomes necessary. And while very little on human matters is strictly/merely conventional, on the other hand "it can seem that really all the rules of a game, each act it consists of, is conventional." (Ibidem) The rules are the necessary guidelines (necessary conventions) to the language-games that are not known (nor explained) a priori; we recognize them as such and start to act by them, behaving as if abiding by necessary conditions. Once we master the technique of the languagegame, we become slaves to such convention, and it is only in that condition that we are able to know how to change it and fight the internal tyranny of convention, thereby re-starting the process.

Therefore, what is contingent (relative) and what is necessary (universal) are merely what we call so in each instance of the language-games. The languagegames are always following necessary rules, however, these rules are themselves

\footnotetext{
${ }^{41}$ One could argue that here is a healthy skepticism in the perspectivist theoretical viewpoint, in the commonsensical use of the word skepticism, as a moderation of ambition and a refusal to accept truths at face value. There are also skeptical approaches which see as alternatives against the suspension of disbelief a negotiated, political and pragmatic process. The complexities regarding the philosophical question of skepticism are not the focus of this dissertation, which uses the term with hesitation.
} 
changeable, guided by our use and the fuzzy notions of regularity. How we know about the rules and the language-games is directly related to this dynamic.

\title{
1.1.7. Epistemology
}

The worldview that is criticized by Wittgenstein is one that entails a strict separation between observer and observed, with what one might call an “objectivist epistemology.” In Castro's words, “to know is to objectify”:

\begin{abstract}
A categoria do objeto fornece o telos: conhecer é objetivar; é poder distinguir no objeto o que lhe é intrínseco do que pertence ao sujeito cognoscente, e que, como tal, foi indevida e/ou inevitavelmente projetado no objeto. Conhecer, assim, é dessubjetivar, explicitar a parte do sujeito presente no objeto, de modo a reduzi-la a um mínimo ideal. (Castro, 2004, p. 231)

the object's category provides its telos: to know is to objectify; it is to be able to distinguish in the object what is intrinsic in itself from what belongs to the cognizant subject, and which, as such, was improperly and/or inevitably projected onto the object. Knowing is thus to "un-subjectify", to explicate the part of the subject that is present in the object, in order to reduce it to an ideally minimum.
\end{abstract}

This divide is primarily a mirror of the divide between mind and body, reason and the empirical senses that has already been the subject of discussion above. As we have seen, in this worldview, language is the channel that crosses these chasms, but in order not to taint the original perfection of the ideal hemisphere, it should remain inert, a mere appendix of the human cognitive apparatus. ${ }^{42}$ Because the object is supposedly not influenced by the subject, language is considered a mere passive instrument of representation, one that should be considered non-temporal and non-contextual. Furthermore, this

\footnotetext{
${ }^{42}$ Whenever we use expressions such as "I cannot put my thoughts into words" or "this is not what I had in mind," we are unknowingly perpetuating the commonsensical notion that there is thought preceding language (the "mentalese" hypothesis). Here I refer to the well-known statement from Chomsky: "Language, it is argued, is 'essentially' a system for the expression of thought.." (Chomsky, 1975b, In: Allan, 2003, p. 556). The problematic relation between language and thought is extensively discussed in Wittgenstein's Philosophical Investigations, introduced in P.I.§§19-20 and discussed at length in P.I.§243-315, in what Baker \& Hacker (v. 3, part II) call "the private language arguments."
} 
movement is taken as an attempt to create an artificially inert, stable and observable object of inquiry, which could be scrutinized by the human lógos, without being affected by it.

The act of learning a language in an objectivist epistemology scenario would entail, at its core: the memorization of the conventional relations between linguistic forms (words) and the represented object and/or its mental representation (meaning); ${ }^{43}$ the mutual understanding that occurs as a result of a successful coding/decoding transmission process between speaker and hearer; and some sort of "alignment" between each party's mental states. ${ }^{44}$

Wittgenstein's language as form of life stands in direct opposition to these well-entrenched views. ${ }^{45}$ His philosophy, as we have seen above, cannot justify such a strict separation. He argues that this picture, exactly because it separates observer and observed, abstracts out of the process the crucial role of the teacher and the relationship between the teacher and the pupil. Furthermore, to say that a child/pupil learns to master names by "attaching labels to things" is to describe the children as if they were adults. If we say that a child, while learning a language, is actually just learning the names of things, we are failing to recognize that the child is not learning out of thin air, but rather that children learn language from us. Moreover, it is clear that a child does not learn labels, but gradually grasps what things "are" (in their understanding):

In "learning language" you learn not merely what the names of things are, but what a name is [...] In learning language, you do not merely learn the pronunciation of sounds, and their grammatical orders, but the "forms of life" which make those sounds the words they are, do what they do [...] (Cavell, 1979, p. 177-178)

\footnotetext{
${ }^{43}$ Very roughly, in a psychological-biased view of language (Gerativism, for instance), there are innate structures in our minds that are responsible for the capacity to generate grammatical sentences (syntax). Semantics are usually restricted to a secondary role and, mostly, theoretically incorporated into syntax.

44 "That is to say, we are so much accustomed to communicating in speech, in conversation, that it looks to us as if the whole point of communicating lay in this: that someone else grasps the sense of my words - which is something mental - that he, as it were, takes it into his own mind." (P.I.§363) How this alignment could be achieved is a central problem of linguistics, addressed by luminaries in the history of language philosophy, such as John Locke.

45"We're talking about the spatial and temporal phenomenon of language, not about some nonspatial, atemporal non-entity.” (P.I.§108)
} 
This interactive process is not just a smooth one-sided transmission of knowledge and often we find ourselves frustrated when the learning side seems not to grasp what is being taught. Wittgenstein presents to us several cases where this bafflement occurs, as in the language games of P.I.§§143-146. We cannot systematize exactly what is being taught and underestimate the "gaps" in the learning process. The teaching/learning process, according to Wittgenstein, is also a language-game and as such bears its marks as an activity that is, at some point, irreducible and ever incomplete and without a definite telos. As we have seen in the discussion on language, it is also an activity that involves guessing and thus risks - something that is reflected in the inherent difficulties of any learning process. $^{46}$

Because, as we have already seen, to understand a language is considered by Wittgenstein as mastering a technique (P.I.§199), to teach a language is naturally akin to training a student, initiating them in language's practices, ${ }^{47}$ so that the child is able to follow their teacher naturally and actually wants to follow them. (Cavell, 1979, p. 178)

As we have seen above, once we master the rules of the language-games we are empowered to change them, despite not intellectually knowing how. Wittgenstein says that this change is intimately related to the meaning of a word: "to know the meaning of a word, to have the concept titled by the word, is to be able to go on with it into new contexts" (Cavell, 1979, p. 122) without knowing any formula. The teaching and learning activities (learning "how to continue") are directly linked to this on-going process where, according to Cavell, the idea of normality is seen as possessing a naturalness. For Wittgenstein the "naturalness" in the acquiring and changing of the rules is a result of considering these rules as evident (selbstverständlich):

P.I.§238. Damit es mir erscheinen kann, als hätte die Regel alle ihre Folgesätze zum Voraus erzeugt, müssen sie mir selbstverständlich sein.

\footnotetext{
46 "He guesses what I mean would amount to: "various interpretations of my explanation come to his mind, and he picks one of them."” (P.I.\$210)

47" A child uses such primitive forms of language when he learns to talk. Here the teaching of language is not explaining, but training."(P.I.§5)
} 
P.I.§238. The rule can only seem to me to produce all its consequences in advance if I draw them as a matter of course.

For the rules to be evident (a matter of course), I must know the continuation of my language-game before I know the specific series: "In the series of words we call sentences, the words I will need meet me half way. They speak for me. I give them control over me.” (Cavell, 1979, p. 122) Language takes control over me, as the pupils take control once they master the technique of language. This "matter of course" is obviously not an ontological "matter of course," but rather what we consider as being one. ${ }^{48}$

What is evident also carries a history: ideas and concepts are evident for a while, then they are taken as necessary rules or conventions by those who live by them. To create and subsequently transform breakthrough concepts, one needs first to consider things as evident. There would be no revolution in science or any true advance in knowledge if our immovable (essential) a priori ideas, crystallized as commonsensical concepts, were truly unchangeable. Once the revolution is set in motion, we become acquainted with new sets of (newly) evident concepts, of new necessary rules we learn to live by and "an idea of a new (human) nature" (Cavell, 1979, p.121). To experience a revolution is to be like a child, a moment when we construct a new reality, with no a priori concepts and nothing that is too evident to be questioned. When faced by questions proposed by great philosophers, "we are children; we do not know how to go on with them, what ground we may occupy. In this light, philosophy becomes the education of grownups." (Cavell, 1979, p. 125).

\footnotetext{
${ }^{48}$ See also above how the discussion of the necessary in Wittgenstein is tied up with the loss of control of language. Here we are faced with another aspect of the same process: the pupil becomes initiated in the language-games by learning its practice and, at that point, relinquishes their control and becomes subservient to the tyranny of the necessary: the rules that they must follow in order for them to communicate with their fellows.
} 
1.1.8.

Naming and names

If meaning is nothing more than language in praxis and learning is the acquisition of technique to master this praxis, what can be said about the act of naming?

It should be clear by now that, as with all other activities pertaining to language, naming is first and foremost an activity as well. However, the act of naming is of central importance to the illusion that language is a system of representation, since names are perceived as the "labels" that link linguistic forms with objects in reality. Wittgenstein noted an implicit and important hierarchical structure in the Augustinian picture of language, between definable expressions and indefinables; the first being explained through lexical definitions, until we eventually reach the terminus of this chain where the indefinables are found. The end of the chain, according to Wittgenstein, inevitably concludes in what he calls an "ostensive definition" (hinweisende Definition), the explanation of a meaning of an expression that typically involves three elements: a demonstrative, a deictic gesture and a sample object being pointed at. (Glock, 1996, p. 274) If the Augustinian concept of meaning pertains to the object a word stands for, naming things in the world (ostensive definition, in Wittgensteinian terms) in this worldview is an act that defines meaning.

This confusion between naming and meaning is part of the "mystifying power of language" according to Wittgenstein:

The power of language to make everything look the same which appears in its crassest form in the dictionary \& which makes it possible to personify time, something which is no less remarkable than would have been making divinities of the logical constants. (C.V., p. 19)

Identifizierung der eigenen Gö tter mit Gö ttern andrer Völker. Man überzeugt sich davon, dass die Namen die gleiche Bedeutung haben. (Wittgenstein's Type Script $n$. 211, p. 321, In: Almeida, 2007, p. 200)

Identification of the Gods themselves with Gods from other people. One is convinced that the names have the same meaning. 
The result of the naming act can be interpreted in many different ways (P.I.§28) and therefore may need some explanation, which can only be achieved with the use of language and other definitions (P.I.§29), along the chain up to the ostensive definition. However, nothing guarantees a correct (desired) understanding of the explanation. Nevertheless, it is a hopeless task, according to Wittgenstein, to try to look for meaning in the act of an ostensive definition:

P.I.§30. Man könnte also sagen: Die hinweisende Definition erklärt den Gebrauch - die Bedeutung - des Wortes, wenn es schon klar ist, welche Rolle das Wort in der Sprache überhaupt spielen soll.

P.I.§30. So, one could say: an ostensive definition explains the use - the meaning of a word if the role the word is supposed to play in the language is alreadyclear.

Ostensive definitions do not connect language with reality; they are a rule to use a word, but only one rule among others for the use of a word. (Baker \& Hacker, v.1, part II, p. 94) This makes sense in the overall Wittgensteinian picture of language: being an activity which requires non-intellectual acceptance and support, the moment one learns the language-games is the moment one loses control over them. Therefore naming things in the world cannot "create" meaning, but rather names are marks of how language creates its meanings for us: they become rules that we subscribe to if we are willing to be effective in the languagegames.

Against the dominant Empiricism, where we are told about word meanings through ostensive definitions, Wittgenstein says that to be told about what a word means, we need to know how to ask what a word means. Consequently, we need first to know how to play the language-games in order to use names and to negotiate our own uses of names, which are in constant actualization in each instance of use. Naming itself should not be reduced to a mere denominating activity. ${ }^{49}$

The act of naming in itself provides no explanation (no description):

\footnotetext{
49 “"...] we call very different things 'names'; the word 'name' serves to characterize many
} different, variously related, kinds of use of a word [...]” (P.I.§38) 
P.I.§49. Benennen und Beschreiben stehen ja nicht auf einer Ebene: Das Benennen ist eine Vorbereitung zur Beschreibung. Das Benennen ist noch gar kein Zug im Sprachspiel - so wenig, wie das Aufstellen einer Schachfigur ein Zug im Schachspiel. Man kann sagen: Mit dem Benennen eines Dings ist noch nichts getan.

P.I.§49. For naming and describing do not stand on the same level: naming is a preparation for describing. Naming is not yet a move in a language-game - any more than putting a piece in its place on the board is a move in chess. One may say: with the mere naming of a thing, nothing has yet been done.

That is, a decontextualized name means nothing, and the ostensive definitions do not add to our capacity to play the language-games. ${ }^{50}$ This is what Wittgenstein said about the risk of taking the words (names) "on holiday," as discussed above, and, additionally, it also has bearings on the innocuousness of the Platonic idea that the meaning of something exists independently of the existence of this thing. Wittgenstein argues that any expression of the form " $\mathrm{X}$ exists" is not an ontological statement about " $\mathrm{X}$," but an expression that merely says that the word " $\mathrm{X}$ " has a meaning, that is present whenever we pronounce or write this word (P.I.§58). By disentangling X from (the word) "X", the whole representational edifice is put under severe attack. Substituting $X$, in an example, with red, we can see in Baker \& Hacker's analysis the anti-essentialist thrust of Wittgenstein's Philosophical Investigations:

So 'red exists' is not an attempt to state an ineffable truth about red, but an innocuous proposition about the word 'red'. Consequently, the metaphysical thesis that red necessarily exists and is indestructible boils down to the trivial claim that the word 'red' has a meaning. (Baker \& Hacker, v.1, part II, p.138)

\subsection{9.}

\section{Consequences}

In this last section of the chapter on Wittgenstein's language as form of life, I present a very brief summary on the consequences of adopting the view of language as a form of life to the analyses of metalanguage that will constitute the

\footnotetext{
${ }^{50}$ In P.I. $\$ 50$ Wittgenstein provides an enlightening analogy with the standard meter bar kept in Paris. One cannot say that the meter has one meter of length nor that it hasn't, exactly because as it stands by itself, it has no use (yet) in the game of measuring.
} 
main body of the present work. I follow this path treading with care, knowing that there is always the danger in summarizing Wittgenstein's work of losing that which is most precious in it.

Language (Sprache): language is an irreducible and unbounded activity, which has neither telos nor grounding on intellectual reason. It is a collection of uncountable rule-based language-games that contextually determine the world, creating meaning in every situation of use. These language-games have shifting patterns of regularity, which enable us to identify and subscribe to them. In short, they are a form of life.

Meaning (Bedeutung): meaning is found in the praxis of language. There is some regularity in this praxis, but meaning, being inherently hazy and blurred, is not bound by precise limits. It is perpetually contextual, always political, forever changeable, and because it is updated in every language exchange, cannot have an ontological basis. The motivations for the convergence of meaning among language parties lie in the vitality of the forms of life and similarities of the language-games played by different people, in the apparent naturalness of the evident rules that coerce us towards similar uses. But this stability can be deceiving, because once we master the rules, nothing guarantees that they cannot be subverted, and "old" meanings changed, loaned, borrowed, aggregated, separated and renovated.

Understanding (Verständnis): to understand (language) is to join, to subscribe and accept the play of the language-games; to know how to play the next hand in the linguistic interaction. To understand a sentence is to understand a language, a non-intellectual epiphany that stirs the spirit: an instantaneous process of the (re)actualization of meaning simultaneous to the reading (or hearing) of what is being enunciated. Understanding is not a result that is triggered by the decoding of the language's meaning pairs, but rather it is an act that abides by rules. It is fleeting and contingent: the language-games are contextually ever changing and infinitely varied and likewise our capacity to play the different language-games. Because "mutual understanding, and hence language, depends upon nothing more and nothing less than shared forms of life [...]" (Cavell, 1979, 
p. 168), there can be no systematic way or method to share my form of life with yours or anybody else's.

Name, naming (Name, benennen): naming is a linguistic activity like all others and it is related to its use. Ostensive naming, the mere attachment of a "label" to a thing, decontextualized, is not a language-game, but it provokes the powerful illusion to us that it creates and crystallizes meaning. Deprived of the metaphysical power it has in our representationalist tradition, naming has a potency along the tension between the necessary/contingent that crosses Wittgenstein's latter writings: it is coercive and, at the same time, innocuous.

Translation (Übersetzung): Contrary to Quine \& Davidson's Principle of Charity, Wittgenstein does not prioritize agreement in opinion, ${ }^{51}$ but rather a convergence of patterns of behavior, like perceptual capacities, needs and emotions:

P.I.§206. Die gemeinsame menschliche Handlungsweise ist das Bezugssystem, mittels welches wir uns eine fremde Sprache deuten.

P.I. $\$ 206$. Shared human behavior is the system of reference by means of which we interpret an unknown language.

This explains P.I., part II, $\S 327 /$ p. 223, “If a lion could talk, we wouldn’t be able to understand it," because the lion has a form of life (patterns of behavior) so alien to us, so detached from the regularity one needs in human life. ${ }^{52}$ This prerequisite does not explain nor justify whether translation is possible or not among human beings. Translation's activity, as well as other linguistic practices, also involves risks. It is neither necessarily perfect nor impossible; it is not motivated by universal principles of cooperation or charity; it is simply an activity that is describable by its own praxis. Translation is what we call translation, although disagreements between conversational parties on what exactly should be called translation in each context are also part of the language-games

\footnotetext{
51 Although he partly concurs with both theorists when he writes that in successful language practices (translation among them) "it is not only agreement in definitions, but also (odd as it may sound) agreement in judgments that is required for communication by means of language." (P.I.§242)

52 See Glock (1996, p. 128) and Baker \& Hacker (v. 2, p. 173). This comparison of human and animal language is explored in detail in the Amerindian perspective of the world in Viveiros de Castro's work and will be addressed in the section on Perspectivism.
} 
Learning (Lernen): to learn a language is to be initiated in linguistic practices, to master a technique that is neither grounded on an intellectual basis nor in an expressively non-intellectual one, in a process that involves trial, error, guesswork, desires, frustrations, etc. Once initiated, the pupil sees ideas as "evident" and commences to abide by them; the pupil learns to play the next step in the language-games by following rules that become necessary for them. This "crystallization" of rules however is but fleeting, because after the pupil acquires language they are able to play with the rules of language (grammar) as is any adult.

\section{2. \\ Metalinguistic Perspectivism}

Once equipped with the invaluable insights provided by the later writings of Wittgenstein, we should be better prepared to develop in some more detail the "metalinguistic perspectivist" theoretical viewpoint that motivates the present dissertation, and elucidate how one could benefit from its intercourse with the Wittgensteinian ideas presented above.

Very succinctly, the purpose of the present chapter is to introduce to us the manner that a "Wittgensteinian metalinguistic perspectivism" could provide the necessary theoretical background in order to suggest strategies and a methodology to address and analyze the metalanguage and related passages in the Lăož that will form the main body of the present dissertation.

\subsection{1.}

\section{Introduction}

The term Perspectivism, according to Ferrater Mora (2009, p. 2767-9), has been coined by Gustav Teichmüller (Die wirkliche und die scheibare Welt, 1882) to refer to the possibility to consider something (and, in general, the world) from 
various points of view, all of them justifiable, in such a way that every point of view would offer a unique, and at the same time, indispensable, perspective over what is under scrutiny.

In this sense, we might call Leibniz Monadologie (1714) a precursor of perspectivism, as we read on $\S 57$ :

Et comme une même ville regardée de différents côtés paraît toute autre et est comme multipliée perspectivement [...] il y a comme autant de différents univers, qui ne sont pourtant que les perspectives d'un seul selon les différents points de vue de chaque Monade.

And like the same city viewed from different sides appears completely different as if multiplied in perspectives [...] there seems to be so many different universes, which are not, however, but perspectives for each [universe] according to the different points of view of each Monad.

Nietzsche, in turn, justifies perspectivism (or phenomenalism) with his observation that the animal consciousness of man only manages to perceive the world in a superficial and generalized manner and that knowledge can never lay claim to a total objectivity.

Perspectivism, in its most simplified (and almost trivial) version, is directly related to the idea that we always have an individual and partial view of the whole and are able to grasp only a fragment of any observed object. Ortega y Gasset developed this perspectivism, not only in (psycho)biological terms, but also historically, where every moment and historical context motivates its own perspectival context. (Ferrater Mora, 2009, p. 2768) However, the same authors believed that through the "juxtaposition of partial views of all, one would be successful in weaving a total and absolute truth" (Ibidem), an ultimate truth which is only available to God, who in His omniscience would see the total sum of the particular (perspectival) views. Other approaches still, according to Ferrater Mora, are more radical, such as AP Ushenko's "perspectival theory of truth," in which the idea of truth is not exhausted by the mere existence of different perspectives.

As writes Ferrater Mora (Ibidem): "many are the perspectival doctrines in contemporary thought." Some lines of study proposed more practical "perspectival methods" of apprehending reality and many authors whom are 
called perspectivists propose that, at least from a theoretical point of view, truth or reality is ultimately achievable and liable to be understood. These lines of research will not be of particular interest to the present dissertation, as might have already become clear by the author's affinity with the later Wittgenstein.

The relevant varieties of perspectivism here are the most radical readings of a so-called Nietzschean propensity. In transcending the question of truth itself, the Deleuzian (1988) reading of Leibniz's Monadologie and the anthropological research of Viveiros de Castro $(2002,2004 a, 2004 b, 2007,2009,2011)$ are also both inestimable sources that will inform what I mean to call perspectivism in the present dissertation. ${ }^{53} \mathrm{An}$ important argument presented in this section lies on the affinities between what has been discussed on Wittgenstein's reflections from his later writings and these authors.

As with other philosophical tendencies, perspectivism is particularly interested in the questions related to language. Another central theme to this section is the perspectivist approach to the questions of language as an object of study and metalanguage as the language that examines language. In the discussion throughout this chapter, we will see that perspectivism considers the passage (translation) into a new language (and even the first contact with our own native language) as a process of initiation and of adherence and support rather than as the final result of intellectual considerations or a reasoning process. ${ }^{54}$ The very impossibility of a complete analysis and dissection of language that was defended by Wittgenstein has ample dialogue with the Nietzschean and Deleuzean approaches mentioned above.

Deprived from any inherent logic, language leads us to engage in the use of words motivated by their effectiveness, based on the past experience of our own dialogic intercourses. However, the conviction that we will attain our original desired outcome is essentially not based on intellectual reasoning, but rather stems

\footnotetext{
${ }^{53}$ Henceforth all mentions of the word perspectivism with no further qualifications will refer to the particular perspectivist views that are informed by the authors discussed in this section of the present dissertation.

${ }^{54}$ Here "adherence and support" is an attempt to translate the Portuguese word adesão, which is arguably a difficult term to translate in English. It connotes the idea of a non-intellectual support. Adesão comes from Latin adhaerēre, "to cling, to adhere to", constituted by ad-, to, and haerēre, "to stick together". (De Vann, 2008, p. 278)
} 
from a heritage from which we ourselves are unable to disengage, without even understanding exactly why. It is a usage, so to speak, "without knowledge of the facts":

The notion that knowing is only to reduce what is strange to what is known - that to know is [the same as] to recognize - here is something that Nietzsche's perspectivism wants, as far as possible, to avoid. ${ }^{55}$ (Martins, 2012b,np)

Knowledge is not gained through the rational deciphering of the fundamental and founding dichotomies upon which our epistemology is grounded. ${ }^{56}$ However, the desired destabilization and problematization does not occur because we subvert such oppositions, but only through the annulment and refusal of their fundamental ability as ontological entities that structure the world, and thus ultimately by the questioning of the universality of the dichotomy concept itself and the dualistic frame of mind. Perspectivism believes that there is a history, culture and ideology (Weltbild) ${ }^{57}$ behind the apprehension of each oppositional pair as builders of dichotomous relationships that could "explain" the world. One way to isolate and identify these forces - that are so intimately responsible for the way we talk and think - is to consider situations of radical alterity. These are the ones we might consider as those of confrontations between adults and children, the sane and the crazy, humans and animals, natives and foreigners. I will suggest that the confrontation between east and west is also a

\footnotetext{
${ }^{55}$ The human urge to transform the foreign and inexplicable into the familiar and known is clear in this excerpt from Nietzsche's The Gay Science:

The origin of our concept of 'knowledge.' - I take this explanation from the street; I heard one of the common people say 'he knew me right away' - and I asked myself: what do people actually take knowledge to be? What do they want when they want 'knowledge'? Nothing more than this: something unfamiliar is to be traced back to something familiar. And we philosophers - have we really meant anything more by knowledge? (\$355)

${ }^{56}$ We have already scratched the surface of the founding dichotomies of the Western tradition in the previous sections on Wittgenstein in the discussion of the Platonic (and Christian) duality of mind and matter, of soul and body.

${ }^{57}$ It is important to keep in mind the crucial difference between Weltbild and Weltanschauung in the later Wittgenstein. Weltbilder are roughly the irreducible world-pictures that each one of us negotiates with each other through persuasion. They are certainties which belong to the sphere of acting and doing, thus are non intellectual in nature. Weltbild compares with Weltanschauung, the term more usually associated with relativism, a "representational form", or world vision. For more details, see Glock (1996, p.129) and Prado Jr. (2004, p. 49).
} 
powerful source of potential situations of alterity that will offer outstanding and unexpected results when studied through the lenses of perspectivism. ${ }^{58}$

Perspectivism, as I hope to make clearer along this dissertation, is particularly amiable to Wittgensteinian thoughts on language and his view of language as a form of life. Some linguistic theorists appropriated ideas from Wittgenstein and other perspectivists' ideas to develop what Martins (2012a, np) christened "metalinguistic perspectivism." I intend to give evidence in this section to the hypothesis that the adoption of metalinguistic perspectivism is a necessary and natural consequence of espousing the view of language as form of life.

\subsection{2.}

\section{A tripartite sketch of perspectivism}

It is obviously not my intention here to present anything more than a concise sketch of the three authors that have been very influential for Perspectivism in their areas of activity. These authors are Friedrich Nietzsche, Gilles Deleuze and Eduardo Viveiros de Castro. This very brief discussion of their works should allow for a more detailed qualification of the perspectivist ideas that will serve as a basis to address the theoretical question of metalanguage in the present dissertation and, at the same time, to build a working dialogue with Wittgenstein's ideas brought forward in the last sections. Of the three authors under discussion here, two might be subcategorized (in an heuristic manner) as writers of philosophical perspectivism, Nietzsche and Deleuze, while one is focused on what we may call anthropological perspectivism, Castro. (See Martins, 2012a, np)

\footnotetext{
${ }^{58}$ This dissertation uses the words West and China (East) without any intention to oversimplify or to essentialize the lives, histories and cultures of either of the areas roughly corresponding to the Indo-European languages and the Far East region of influence of the Chinese culture. China has for long proven to be a source of admiration and curiosity to the European and the tendency to treat it as a monolythical entity has been overwhelming. The same word could apply to Europe and "Western" world. For more information, see also Nancy (1998, p. 6), Norman (1988, p. 16), Zhang (1998), Casacchia (In Auroux, 1995) and Porter(2001).
} 
Although working in totally different contexts, Deleuze is an attentive reader of Nietzsche (Deleuze, [1962] 1976), while Viveiros de Castro is an avid reader of Deleuze (Viveiros de Castro, 2007). Their inclusion in the present work does not mean that they are ideal examples of perspectivist theorists, but rather it offers an opportunity to "perspectively" sketch an impressionist panorama of ideas, or what could be called a bricolage in Viveiros de Castro's terms. ${ }^{59} \mathrm{I}$ expect that the convergence of their ideas will become clear along the discussion here and will justify their inclusion together in this section.

Leibniz Monadologie is again a useful starting point to approach the authors being referred to in this section. Leibniz's Monads stand for the multiple incommensurable perspectives over the object under scrutiny. ${ }^{60}$ However, the German philosopher still recognizes an absolute point of view, that of God's whom is able to unite in Himself everyone else's perspectives. ${ }^{61}$ Nietzsche and Deleuze, on the other hand, although writing in entirely different contexts, will somehow mention or recourse to the idea of different perspectives that eventually manage to cancel the possibility of any absolute background. I draw particular attention to Deleuze (2007) perspectival reading of Leibniz's texts, which is especially useful for the subsequent analysis of metalanguage. His is the concept of the "variation of the point of view":

Si l'objet change profondément de statut, le sujet aussi [...] Partant d'une branche de l'inflexion, nous déterminons un point qui n'est plus celui qui parcourt l'inflexion, ni le point d'inflexion même, mais celui où se rencontrent les perpendiculaires aux tangentes dans un état de la variation. Ce n'est pas exactement un point, mais un lieu, une position, un site, un « foyer linéaire », ligne issue de lignes. On l'appelle

${ }^{59}$ See Viveiros de Castro (2009, p.2).

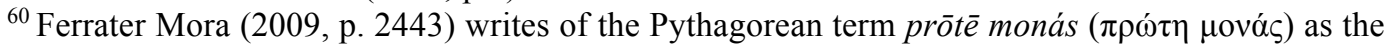
"first mónad" or the "first unity," as some sort of fundamental unity. The ancient Greek term monás, according to Liddell \& Scott (1996), stands for the feminine form of the adjective solitary, but also has a philosophical use as unit and principle. Ferrater Mora also writes that sometimes Plato used the term to call what is usually translated as his famous forms or ideas (the Greek idea $(1 \delta \varepsilon \bar{\alpha})$ ), however the same author also writes that monad was only used as a "central philosophical concept" in the beginning of the Modern Age.

${ }^{61}$ As written in the Stanford Encyclopedia of Philosophy (entry: Gottfried Wilhelm Leibniz, 2013): $[\ldots]$ central to Leibniz's philosophy was the view that God freely chose the best world from an infinite number of possible worlds and that a person could be said to act freely when the contrary of And: that action does not imply a contradiction. (p. 10)

[...] each finite substance is the result of a different perspective that God can take of the universe and that each created substance is an emanation of God [...] God's omniscience entails knowledge of the world from every perspective simultaneously, and the infinite perspectives of the world originating from God's nature simply are monads. (p. 35-6) 
point de vue pour autant qu'il représente la variation ou inflexion. Tel est le fondement du perspectivisme. Celui-ci ne signifie pas une dépendance à l'égard d'un sujet défini au préalable : au contraire, sera sujet ce qui vient au point de vue, ou plutôt ce qui demeure au point de vue. [...] Entre la variation et le point de vue il y a un rapport nécessaire : non pas simplement en raison de la variété des points de vue (bien qu'il y ait une telle variété, nous le verrons), mais en premier lieu parce que tout point de vue est point de vue sur une variation. Ce n'est pas le point de vue qui varie avec le sujet, du moins en premier lieu ; il est au contraire la condition sous laquelle un éventuel sujet saisit une variation (métamorphose), ou quelque chose $=\mathrm{x}$ (anamorphose). Le perspectivisme chez Leibniz, et aussi chez Nietzsche, chez William et chez Henry James, chez Whitehead, est bien un relativisme, mais ce n'est pas le relativisme qu'on croit. Ce n'est pas une variation de la vérité d'après le sujet, mais la condition sous laquelle apparaît au sujet la vérité d'une variation. C'est l'idée même de la perspective baroque. (Deleuze, 2007, p. 27)

If the object changes dramatically its status, so does the subject [...] Starting from a branch of inflection, we determine a point that is not the one which runs through the inflection, or even the inflection point itself, but rather it is the one where the perpendiculars to the tangents meet in a state of variation. It is not exactly a point, but a place, a position, a site, a "linear home," line born out of lines. It is called a point of view as far as it represents the change or inflection. Such is the foundation of perspectivism. This does not mean to be dependent on a subject previously defined: on the contrary, the subject will be the one who comes to the point of view, or rather, who resides in the point of view. [...] Between the variation and the point of view there is a necessary relationship: not just because of the variety of points of view (although there is such a variety, as we will see), but in the first place because every point of view is the point of view on a variation. This is not the point of view which varies along with the subject, at least in the first place; rather it is quite the opposite: the condition under which a fortuitous subject grasps a variation (metamorphosis), or something $=\mathrm{x}$ (anamorphosis). Leibniz's perspectivism, and also Nietzsche's, William, Henry James's and Whitehead's, it is really a relativism, but this is not the relativism which we are thinking. This is not a variation of truth according to the subject, but the condition under which the truth of a variation appears to the subject. This is the very idea of the Baroque perspective.

This long passage endeavors to draw a graphic picture where one could visualize perspectivism, not only in terms of lines, tangents and perpendiculars, but also particularly in terms of the variations of these lines, in what could be called a "second order perspectivism." From the changing (graphically moving) subject(s) it seems that these lines (perspectives) emanate in tangents, but this picture must not be perceived, claims Deleuze, as the "foundation" of perspectivism. A Deleuzean perspectivist "foundation" seems to be an articulation of perpendiculars from all the points in the curve, constantly meeting themselves "in a state of variation." Variation is a crucial aspect of the whole picture and an inversion that is hinted by the play of tangents and perpendiculars: the truth is simply not "out there" - in any multifaceted space where an infinitude of 
perspectives converge from different (unrelatable) positions, each seeing a different aspect of it - but rather what we call truth lies in how this variation appears to the subject. ${ }^{62}$

The Baroque space, where we find the Monads, according to Deleuze, is a reality that cannot be separated into a finite number of discrete parts. It is a space which is curved, with no straight lines, where the inner and outer (façade) spaces are partitioned into two infinite sets, an interior which lacks the exterior, like a sheet of paper that has only one side. This is where one finds the objects of one's studies:

L'objet ne se définit plus par une forme essentielle, mais atteint à une fonctionnalité pure, comme déclinant une famille de courbes encadrées par des paramètres, inséparable d'une série de déclinaisons possibles ou d'une surface à courbure variable qu'il décrit lui-même. [...] C'est un objet maniériste, et non plus essentialiste : il devient évènement. (Deleuze,2007, p.26-7)

The object is not definable through an essential form, but rather it reaches a pure functionality, as declining a family of curves framed by parameters, inseparable from a series of possible declensions or from a surface of variable curvature that it itself describes [...] It is a mannerist object and not essentialist anymore: it becomes an event.

In the Baroque space one does not analyze and does not find the fundamental through the dissection of its minimal parts. It is not constituted of parts, but rather of events, of change and changing of change. It is in this space that the radical alterity becomes possible in Deleuze's reassessment of the other within his idea of the autrui.

Deleuze's philosophy stands far beyond the scope and focus of the present dissertation, however. What is relevant here is the interplay of the ideas of variation, perspectives and the theoretical possibility of other(ness).

Nietzsche's writings become of particular interest to the present dissertation when around 1872-74 language starts to take a prominent role in his philosophical speculations, and art and music are relegated to a secondary role. This is the period to which I will limit Nietzsche's contributions, focusing on two of his texts,

\footnotetext{
${ }^{62}$ The articulation of the Deleuzean (or rather, perspectivist) condition of truth with Wittgenstein's reflections on the matter will be briefly discussed below.
} 
Darstellung der antiken Rhetorik and Über Wahrheit und Lüge im außermoralischen Sinn.

From 1872, Nietzsche starts to investigate the artifices (Kunstmittel) that ground language when word is present in the world (Suarez, 2011, pp. 71-85). The rhetorical source of language is offered as a hypothesis which constitutes a dislocation of the art of rhetoric from its usual confined and specialized realm of activity where it has long been relegated by the Greeks in their attempt to properly place language in a "total universe." 63 As Nietzsche wrote:

\begin{abstract}
Mas não é difícil provar [...] que a retórica é um aperfeiçoamento (Fortbildung) dos artifícios já presentes na linguagem. Não existe de maneira nenhuma a "naturalidade" não-retórica da linguagem à qual se pudesse apelar: a linguagem é ela mesma o resultado de artes puramente retóricas. (Darstellung der antiken Rhetorik, In: Cardoso e Cunha, 1995, p.44-5)

It is not difficult to prove [...] that rhetoric is an improvement (Fortbildung) of the artifices already existent in language. There is absolutely no non-rhetorical "naturality" of language to which one can resort to: language is itself the result of purely rhetorical arts.
\end{abstract}

According to Nietzsche, language is intuitive, transmitting opinions (dóxa) and not knowledge (epistemê); language does not aim to instruct, but to convey to the other subjective emotions and apprehensions. (Cardoso e Cunha, 1995, pp. 456) The distinction between truth and falsehood lies in its use, unsupported by any "outside" reason. One of Nietzsche's major contributions to the present work is perhaps his pioneering radical aversion of an absolute concept of truth, coupled with his singular thoughts on language:

It is only by means of forgetfulness that man can ever reach the point of fancying himself to possess a "truth" of the grade just indicated. (Über Wahrheit und Lüge im außermoralischen Sinn, [1873]1993, p. 81)

What then is truth? A movable host of metaphors, metonymies, and anthropomorphisms: in short, a sum of human relations which have been poetically and rhetorically intensified, transferred, and embellished, and which, after long usage, seem to a people to be fixed, canonical, and binding. Truths are illusions

\footnotetext{
${ }^{63}$ Nietzsche himself wrote on how the mainstays of the Greek thinkers were ardent adversaries against the malaises of rhetoric in the collection of one of his courses, "Darstellung der antiken Rhetorik" (1872). (Cardoso e Cunha, 1995)
} 
which we have forgotten are illusions. (Über Wahrheit und Lüge im außermoralischen Sinn, [1873]1993, p. 84)

Truth, as one reads in Nietzsche's 1873 paper, is born in language, when one employs it in a "correct" manner, as a successful move in the social game: it is what people recognize as being true, the consensual but unstable result of a (rhetorical) debate. What the philosopher writes in his discussion on figures in language is valid to language as a whole: "a figure (tropo) that is not met with acceptation becomes an error. An error resumed by an usus [use] becomes a figure." (Cardoso \& Cunha, p. 48) Nietzsche will place a high value on figurative language and the "adornment" that is characteristic of the metaphoric use of language (which, for him, is the only use of language).

The same radical opposition of the philosopher is directed against the idea of the concept as an ontological entity:

\begin{abstract}
Every word instantly becomes a concept precisely insofar as it is not supposed to serve as a reminder of the unique and entirely individual original experience to which it owes its origin; but rather, a word becomes a concept insofar as it simultaneously has to fit countless more or less similar cases - which means, purely and simply, cases which are never equal and thus altogether unequal. Every concept arises from the equation of unequal things. (Über Wahrheit und Lüge im außermoralischen Sinn, [1873]1993, p. 83)
\end{abstract}

We see here in Nietzsche's writings clear reflexes of an anti-essentialism that was also present in Wittgenstein and Deleuze, which translates into an aversion to metaphysical concepts that would be justified as an external grounding to language. For the German philosopher, "the full essence of things is never apprehended" (Cardoso \& Cunha, 1995, p. 44) and "language never expresses something in a complete way but only exhibits the most prominent mark." (Ibidem, p. 75) We might end this brief exposition on the aspects of Nietzsche's perspectivism with an excerpt from the author's The Will to Power:

\footnotetext{
Against positivism, which halts at phenomena - "There are only facts" - I would say: No, facts is precisely what there is not, only interpretations. We cannot establish any fact "in itself": perhaps it is folly to want to do such a thing.

"Everything is subjective," you say; but even this is interpretation. The "subject" is not something given, it is something added and invented and projected behind what
} 
there is. - Finally, is it necessary to posit an interpreter behind the interpretation? Even this is invention, hypothesis.

In so far as the word "knowledge" has any meaning, the world is knowable; but it is interpretable otherwise, it has no meaning behind it, but countless meanings. "Perspectivism." (Nietzsche, 1968, §481)

These are the traits of Nietzsche's "perspectivism" that will inform this dissertation.

From the writings of Brazilian anthropologist Eduardo Viveiros de Castro, it is of particular interest to the present dissertation how the author made use of the Western perspectivist tradition to guide his anthropological research on Amerindian thought, in the identification of common features that substantiates the coinage of the terms "Amerindian perspectivism" and "perspectival multinaturalism" and that prompted a radical reassessment by the anthropologist of his own field of work.

Traditional anthropology, Viveiros de Castro claims, seeks specific (culturally based) solutions for generic and universal problems. Therefore, it often happens that behind the façade of a relativist or pragmatist agenda lurks a disguised, all-powerful paradigm of a universalist Truth:

It is true that pragmatism does indeed uphold an intersubjective, consensual, and ethnocentric conception of truth; but this truth is still One. This leads us to conclude that what lies outside the "conversational" sphere of the pragmatic community of similars is the very essence of non-truth in all its proteic monstrosity. (Viveiros de Castro, 2009, p.5)

As Viveiros de Castro himself explains, although the "other" (aboriginal) cultural perspectives are reputed objects of research interest and are nominally respected by the academia, under the guise of pragmatism the natives are simply not taken in earnest. In other words, to the pragmatist eyes their (the others') visions are ultimately impenetrable, or are just regarded as disenfranchised beliefs. ${ }^{64}$

\footnotetext{
${ }^{64}$ Belief is an important and polysemic term is discussed in some more detail below. Viveiros de Castro's critic of Pragmatism is specifically aimed at Richard Rorty.
} 
In traditional anthropology, the researchers bring their tools from their own academic milieu into the research field to dissect and categorize the native forms of knowledge, without cogitating its epistemic value, in a unilateral relation where the native's culture stands as passive objects of inspection. In this multiculturalist framework, anthropology runs the risk of losing its bearings in the relativistic sea of misunderstandings and miscommunications, where the researchers are simply unable to find a two-way dialogue of other cultures with their own traditions. The skeptic trap of relativism is a gloomy, dead-ended result, which is a natural reaction to the explicit ethnocentrism and evolutionism of the early anthropology of Tylor and Frazer.

Viveiros de Castro seeks, in typical Wittgensteinian fashion, to subvert the commonsensical foundations of his field of study. If the Austrian philosopher may be called an anti-philosopher, the Brazilian anthropologist could in his turn be called an anti-anthropologist. Viveiros de Castro relies on the radical antidogmatism of perspectivism to question the foundations of his field of study by postulating that the procedures (tools, techniques) that characterize the anthropologist's investigation are epistemologically of the same order as the procedures of the natives. (Viveiros de Castro, 2002, p. 116-7) In this context, the anthropologist's investigation should attempt to assess the radically dissimilar questions the natives pose themselves, consequently contrasting anthropological (Western) and indigenous modes of making distinctions. This constitutes the art of questioning, not of answering - the will to embrace the specific problems and concerns of the indigenous cultures. Hence Viveiros de Castro's redefinition of anthropology as "a theory of people's ontological auto determination, and of a practice of permanent decolonization of thought." (Viveiros de Castro, 2009, p. $1)^{65}$

Viveiros de Castro's maneuver is not to confront relativism in the usual way, as an "epistemological puzzle, but as an anthropological subject [...] where it can be effectively analyzed in its "relationship-ness." (Ibidem) In his 2009 paper

\footnotetext{
${ }^{65}$ Viveiros de Castro seems to be more willing to take an overtly political stance than what might be expected from the philosophical perspectivism of scholars such as Wittgenstein. However, the sheer fact that he is suggesting a new "theory" of anthropology should not lead us to believe that he is trying to impose a new dogmatic field of study in place of the "old anthropology," as I intend to make clear along this short presentation of his work.
} 
written in English, the Brazilian anthropologist calls his new model of anthropology comparative relativism, an eloquent oxymoron which gives prominence to the seemingly paradoxical task of the perspectivist anthropologist: the embrace of the non-(common)sensical Amerindian practices in their own terms: ${ }^{66}$

That which Rorty [pragmatism] declares as being impossible to take seriously turns out to be exactly anthropology's subject matter. [...] anthropology is the endeavor which takes dead seriously the question of how to take seriously lots of "visions" - not in the sense of "beliefs", that is consensual views, but in the sense of worlds seen objectively; not other world views, but other worlds of vision. (Viveiros de Castro, 2009, p. 5)

What then does he mean by the expression take the other on its own terms?

Viveiros de Castro himself argues (2009, p. 8) that it would be naïve to consider that the Amerindian's express a literal truth about the world. Moreover, it is neither a matter of a psychological account of belief, ${ }^{67}$ nor - true to the tenets of Wittgenstein - should we employ the "logicist language of truthvalues." He writes that "alien thoughts cannot be taken as opinions (the only possible object of belief or disbelief), or as collections of propositions, (the only possible object of truth judgments)" (Ibidem), lest beliefs would just be considered mental states assessed via cultural practices - instead of the "effect of the relation between people" - and these propositions would create an "epistemological teratology."

As an alternative, Viveiros de Castro suggests that we borrow Deleuze's concept of the other (autrui) which, as we have seen above, is the expression of a

\footnotetext{
${ }^{66} \mathrm{We}$ are so embedded in a tradition with Greek forefathers that we sometimes forget that the ancient Greek realities were chronologically situated in a past incredibly distant from us and that the Greeks themselves are also, in some way, "Amerindians" to us. Etymological dictionaries of ancient Greek strive to discard the subsequent avalanche of connotations (especially from Christianism) that have since loaded and informed the lexicon of modern Indo-European languages. As Peters (1967, p. v) wrote: in this context "it is an obvious necessity to make some sort of attempt at coming to the Greeks on their own terms." It is not an entirely different effort that the Castrian anthropologist has to embrace when dealing with natives'cultures.

${ }^{67}$ Viveiros de Castro's approach to Amerindian knowledge is, like Wittgenstein's and the perspectivist lines presented here, not cognitive nor psychological, because it is not "concerned with the empirical possibility to know another culture. It is epistemological, that is, political." (Viveiros de Castro, 2002, p. 119) For a further discussion on the brief history of the word belief in the West, see Cassin (2014, p. 97-102).
} 
possible world and of life. ${ }^{68}$ The reality of the worlds that each self is constantly implementing and revising is validated or refused by the other(s) around them in a constant process of its re-assessment and verification. To accept the other's world as true or to discard it as false introduces the element of belief and rejects the possibility of the other. Deleuze, in Viveiros de Castro's reading, maintains what he calls

Special conditions of experience, however artificial — namely the moment at which the expressed has (for us) no existence apart from that which expresses it; the Other as the expression of a possible world. (Deleuze, 1968, In: Viveiros de Castro, 2009, p. 9)

The others' worlds, in Viveiros de Castro's anthropology, should be sustained as virtual possibilities, as possible and inexplicable expressions of many worlds, eternally changing within their expression:

If there is one thing that it falls to anthropology to accomplish, it certainly is not to explicate the worlds of Others, but to multiply our world, peopling it with "all those expresseds which do not exist apart from their expressions." (Viveiros de Castro, 2009, p. 10)

The other is not a source of profound mysteries that unveil the ultimate nature of reality, rather theirs is their reality, ever possible, never actualized to us, always suspended as possibilities and, therefore, in tranquil theoretical coexistence (if we could call it "existing") with many worlds. This is the philosophical stance that Viveiros de Castro calls multinaturalism in his study on the Amerindians, in opposition with relativism's multiculturalism:

O perspectivismo não é um relativismo, mas um multinaturalismo. O relativismo cultural, um 'multiculturalismo', supõe uma diversidade de representações subjetivas e parciais, incidentes sobre uma natureza externa, una e total, indiferente à representaçao. (Viveiros de Castro, 2004a, p. 239)

Perspectivism is not a relativism, but a multinaturalism. Cultural relativism, a "multiculturalism," presupposes a variety of subjective and partial representations that falls upon a single and totalizing external nature, indifferent to representation.

\footnotetext{
${ }^{68}$ It is not a coincidence that life is crucial to the Wittgensteinian vision of language discussed above.
} 
todos os seres veem ('representam') o mundo da mesma maneira - o que muda é o mundo que eles veem. (Ibidem)

[..] every being sees ('represents') the world in the same way - what changes is the world that they see.

The appropriation of the Deleuzean concept of the other as the expression of possible worlds must be qualified. These are worlds that cannot be validated with the truth-value methods which constitute the basis of our "science," and we likewise should not attempt to "explicate oneself too much with the other, [nor] to explicate the other too much" - that is, we should avoid the introduction of the element of belief and should try to limit the ambitions of our analyses.

When Deleuze (quoted by Viveiros de Castro) wrote that these are multiple worlds populated "with all those expresseds that do not exist apart from their expressions," we can interpret it as saying that these are worlds that exist within each other's language. In Viveiros de Castro's Amerindian perspectivism, all language is "relative" and nouns are transmuted into pronouns, from the substantive to the perspective. In this context, all words are used as if they were kinship terms (father, son, cousin, etc). This opens the possibility of a language that has no ontological ground, where concepts are not entities, but relations, lines that asymptotically link two (or more) empty sets, whose extremes are never reached, and not because they are beyond our reach, but rather because they simply are not there. However, these relations are not merely conventional, but rather necessary relations within the context of each specific world-culture. These are live relations. The one culture, which in relativism represents the mark of incommensurability, mediates all with necessary intentionalities and personalities. This marks the culture as a space of alterity, which has precedence over the many natures, therefore empowering it as an epistemological space to construct objects.

Viveiros de Castro's discourse is one that perilously balances itself on the verge of the paradoxical and the inconceivable. Quoting from Rodney Needham: "There is only one method in social anthropology, the comparative method - and that is impossible." (Viveiros de Castro, 2009, p. 14) However, the mark of the paradox is constitutive of his thought and it is not to be avoided, but rather embraced, as the sign of how precarious meaning is in language: 
The caricatural, (auto-)deconstructive form of doxa is, precisely, paradox, which exposes the radical impossibility of univocal meanings and the precariousness of every identification, a predicament (or a power) that is immanent to language. (Ibidem, p. 16-7)

These lines — which could perfectly have been written by Nietzsche show us that even if paradox effectively calls our attention to the precariousness of language, juggling with our concerns about truth and falseness, Viveiros de Castro proposes to us to risk even more, passing further to the realm beyond paradox. The anthropologist in his 2009 paper elects Henri Michaux's formula as a telling example of a meta-paradox: "Even if it is true, it is false." (Mê me si c'est vrai, c'est faux) It is a formula not concerned with truth, or even with the doxa that might suspect or subvert truth, but with effect. It does not say anything, but it rather does something. It is not that paradox is inherent to language, it is that there is no paradox and that is precisely the (meta)paradox.

The fact that Viveiros de Castro accepts that we only have our own intellectual tradition from which to start does not discourage him from attempting to "distort" his (our) epistemological tools in order to glimpse at the other worlds. (Viveiros de Castro and Sztutman, 2008, p.112, In: Martins, 2012a.) This represents an optimism that is reflected in the present dissertation's own attempts to articulate a dialog with the radical alterity of Chinese thought, with the confidence that there are ways to glimpse through the cracks that are created when we, like Viveiros de Castro, attempt to distort the self-reinforcing circle of language and its own image (metalanguage):

If there is one place, therefore, at which "we Western intellectuals" have to start, because in the end we never manage to leave it, it is precisely at this "vision" of Zeno's immobile arrow [...] exactly equidistant between the two poles of meaning and nonsense [...]. And we do get to the far side, with a little help from anthropology. (Viveiros de Castro, 2009, p. 15)

If anthropology's challenges stem from the turbulent relation of cultures and its reflexive aspect of using culture's methods to research culture, linguistics' challenges are not completely distinct and may be even more prominent due to the particularities of linguistic activity. 
Viveiros de Castro's program is mirrored in the theoretical stance supported by the present dissertation - only, naturally, exchanging anthropology for linguistics. The necessary reassessment of linguistics away from its own selfimage as a formal(ist) science - achieved through the rationalization of linguistic patterns and activities - is an inevitable consequence of this theoretical viewpoint. In this perspectivist linguistics, the possibility of alterity is not menaced by the ghost of relativism, since language creates uncountable worlds as virtual possibilities and each linguistic tradition has its own epistemologically valid tools whose effectiveness lasts as long as they "count as" valid tools, that is, while we keep using them. Viveiros de Castro's reflections, as well as their fundamental sources of inspiration in authors such as Deleuze and Nietzsche, set an almost perfect initial departure point to discuss the destabilization and dislocation of the science of language that is suggested by metalinguistic perspectivism.

\subsection{3. Metalanguage and perspectivism: Taylor and Harris}

So far I have only very briefly mentioned one of the most central issues of this dissertation - one that together with translation stands in its title: metalanguage. Metalinguistic terms are those expressions that are similarly (in Wittgensteinian terms) used to refer to language, that is, they have a reflexive effect. In the Western linguistic tradition, metalanguage usually does not play a prominent role: "normative metadiscourse has typically been misrepresented as inessential, peripheral, and supplemental to language." (Taylor 2007, p. 13) ${ }^{69}$ The thesis defended by Talbot Taylor and others in the context of metalinguistic perspectivism is that this misrepresentation is "a theoretical blindness towards the NORMATIVE function of much reflexive discourse," (Ibidem, p. 11) and that metalanguage ultimately informs, at least partially, how we do linguistics and postulate what language is.

\footnotetext{
${ }^{69}$ See also Werry's (2005) critique on the lack of attention on metalanguage and the reflexive nature of language, especially towards the Gerativist and Cognitivist schools of thought.
} 
We may consider that one of the major aspects of Wittgenstein's later philosophy is the demise of reason (or mind, or thought, or even language in its "restricted aspect") as the privileged (for some, even monopolistic) way to gauge reality. However, reason is not substituted with another ontology or guiding rule, it is only discarded, as any other candidate, as the tool of understanding. The key term here is tool, usually conceived as a neutral standard of measure in the onedirectional relationship between subject and object. The major problem with this use of tool, it seems, is its abhorrence of reflexivity, not only between subject and object, but also between both of them and the medium of their relationship.

Formal (scientific) models of nature and language thrive on tools. Actually, they cannot do without them: language is the tool of representation of the world while anthropologists' (and other scientists') concepts and models are their tools in the description and explanation of our cultural and physical reality. When linguistics was aiming at being recognized as a science (and that was explicitly one of Saussure's motivations), the linguists needed to possess some sort of toolkit of analysis, as enjoyed by the other scientists. However, here lies a major obstacle: the only tool available to analyze language belongs to language itself, therefore it inevitably must possess this "reflexive" effect and that is precisely why we call it metalanguage. ${ }^{70}$ That might be the reason that it is arguable to say that language is the most complicated - and possibly fascinating - subject of study and, maybe, why for Wittgenstein philosophy is language-philosophy: language is metaphilosophy. When language is the object of study, the impossibility of a neutral set of tools becomes most ostensible and inevitable.

The hopelessness of a neutral and privileged viewpoint on a subject is at the core of perspectivism. We have already seen how Wittgenstein and other authors such as Nietzsche and Viveiros de Castro drew our attention to the dangerous process of the "truification" of the commonsensical ideas, which gradually and inevitably acquired an undue epistemological validity. This same approach, when

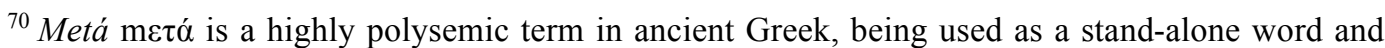
also as a prefix. Chantraine $(2009$, p. 664) writes that it is a very productive prefix with many effects, all alluding to a reflexive idea of participating or being in the middle of something: "pour exprimer une idée de participation [...] d'action en commun [...] de situation au milieu [...] de succession dans le temps [...et] souvent avec le notion de changement." The author says that it has an obscure etymology.
} 
applied to the study of language, is what we are calling here the MPH: the image of language that is at least partially regulated by the metalanguage we are (currently) employing becomes enmeshed and indiscernible from our tradition and surfaces to us as evident and commonsensical truth.

A perspectivist approach, with a Wittgensteinian inspiration, on how to approach the metalanguage conundrum is discernably found in the iconoclastic works of Roy Harris and Talbot Taylor. In this section, I will introduce their most relevant conclusions and ideas that will help to guide the analyses in the main part of this dissertation. But first, I will revisit once more the Platonic-Aristotelian scene at the dawn of Western linguistic speculation. ${ }^{71}$

\section{The old Greek scene}

Ever since the Greeks' initial philosophical speculations, one perceives a certain discomfort about language and an anxiety, which contaminated the foundations of the representational building. ${ }^{72}$ As we have already seen in Nietzsche's critique, Plato intentionally isolated the laws of rhetoric (persuasion) from the laws of logic (or dialectic) with the intent to purge the philosophical study (and its all-important interest on the Truth) from what was variable and contextual, which was then relegated to the field of persuasion and the unpredictable nature of opinion, doxa. Logic could only then be treated as fixed systematization, mirrored on the natural relationship between signified/signifier. In looking for more solid bases for this relationship, the Greeks often sought justification on the origin of words (etymology, as notoriously shown in the Cratylus).

Natural linguistic forms eventually proved unsustainable and, as we have already seen, Aristotle added to Platonic realism a third vector, the mental representation, where the conventional relationship between words and things in the world became possible by the intervention of the affections of the soul (psyche pathèmátōn). (Aristotle, De Interpretatione, 16 3 ) With Aristotelian mentalism,

\footnotetext{
71 What Wittgenstein calls the "Augustinian picture of language", as the traditional mode of thinking language that he intends to question, is, in general lines, what Talbot Taylor calls the "commonsense picture of language." (Taylor, 1997, p. 170)

72 See Peters (1967, p.ix)
} 
another problem imposed itself: how can people communicate? Or rather, how can they exchange their mental affections? The question of understanding still gravitated around the entity of meaning, the conjugated pairs of words and represented objects and the parallel situation of linguistic form and substance. ${ }^{73}$

Hence, argues Taylor and other advocates of metalinguistic perspectivism, linguistic speculation has been trapped around the question of meaning and the attempt to avoid the skeptical/relativist trap:

\begin{abstract}
All linguistic theory, he [Taylor] argues, is motivated by a desire to counter a threatening skepticism about the possibility of linguistic communication. And this common desire or cause gives apparently divergent theories a shared rhetorical shape. Skepticism thus sets the rhetorical terms of the debate: every theory is driven to repeat the same moves because it is implicitly controlled by its desire to avoid skepticism. (Schalkwyk, 2005, p. 99)
\end{abstract}

The language of linguistics, under this view, is eminently motivated by issues that were born as the inaugural debate of the Greeks favored meaning as the entity that guides and enables communication, understanding and language. ${ }^{74}$ Over the cornerstone of meaning was built the metalinguistic edifice that subsequently will inform the debates about language: signifier, word, sentence, understanding, communication, writing, etc. This repertory was driven by a

\footnotetext{
${ }^{73}$ The dual-sided nature of language is a recurrent question of linguistics and maybe it was best first explicitly proposed as a question of linguistics in Saussure's structuralism, where language as the object of study of linguistics was recognized as form (or "structure"), while substance was stripped of its influence and let loose to the unregulated realm of use and parole.

In Saussure's language as a semiotic system, the whole structure of language was to be dualized:

In order to account for how (realist) communication occurs, languages must, for instance, be both individual and supraindividual [...]. For this essential condition to be possible, languages must consist of signs composed of two internally-related "sides," signifiant and signifié, which are not subject to the voluntary control of sign•users. For signs to be independent of their users' control, Saussure argues, they must be arbitrary. And this in turn means that the identity of any given sign [...] must be determined not by substantive properties but by the differential relations between its signifiant and other signifiants in the language and between its signifié and other signifiés in the language. (Taylor, 1997, p. 188)
}

${ }^{74}$ McDonough (2000) lists what he recognizes in Harris (1996) as the "metalinguistic illusions" which have "hampered study of language in the West for over two thousand years":

the use-mention doctrine, the type-token doctrine, the doctrine of parts of speech, the doctrine of sentences and propositions, the doctrine of telementation, the doctrine of fixed codes and the doctrine of plain representation [...] (p. 203)

All these "doctrines" are in one way or another related to the founding moment of Greek thought on language and meaning.

For a specific article on the theory of language as a fixed-code, see Love (1985). 
rhetorical strategy linked to an unstated transcendental logic necessary to guarantee that communication does occur.

It is this prevention against the risk of loss of understanding that motivated and still motivates what Taylor (1997, chapter 9) calls the "rhetorical source" of the theory(ies) of language. The discourse of linguistics has repeatedly engaged in the attempt to provide a theoretical framework where the skeptical trap could be avoided:

[...] the "synchronic" origin of the Western linguistic tradition may be found: an origin, that is, located not in Ancient Athens or 17th•century Europe but in what, if asked, we might simply call “ordinary commonsense." (Taylor, 1997, 170)

For the discursive continuity of Western linguistic thought can be seen as the inevitable legacy of its rhetorical origins: that is, of the interpretation of commonsense claims about language and communication as empirical truths. (Taylor, 1997, p. 172)

This commonsense encourages a compulsion that inevitably leads us to subscribe to what Taylor (and others that are like-minded) call the "myth of western linguistics." What happens then, he argues, is a perverse and inverted relationship between the layman's and the scholar's discourse, in which the former is treated by linguists and philosophers as providing empirical a priori forms of language that are subsequently intellectualized and that become the research object of the linguistic theories:

[...] intellectual metadiscourse emerges, I believe, by means of the decontextualization of contingently functional, commonplace expressions of practical metadiscourse and their recontextualization within intellectual discourse. (Taylor, 1997, p. 185)

Language theorists see it as their task to show what facts would have to obtain for our ordinary talk about language to make sense, and then, to invoke theoretical arguments to show that they do, or indeed, must, obtain. (Schalkwyk, 2005, p. 101).

In other words, through our daily (lay) use of language we exercise an unconscious authority that limits the scope and range of the research of philosophy of language. Moreover, the lay discourse is in turn, as we have seen above, attempting to answer questions proposed by our Greek forefathers. 
These are the "truisms" to which we are accustomed: that we usually understand what has been said to us; that in order to achieve this understanding, we need to understand the meaning of the language form that is transmitted to us; that for understanding to be possible all words must have a shared and stable meaning; etc. A "skeptical" questioning of these assumptions would be perceived as clashing against common sense. However, we do not take notice that when accepting these affirmations as commonsensical we are implicitly considering them to be TRUE, and more, we are believing that they are true because they correspond to FACTS. (Taylor, 1997, p. 171) Taylor invokes Wittgenstein to this most radical of all self-questionings:

Here we need to invoke the contrast which Wittgenstein emphasized between "understanding the subject and what most people want to see." Because the distinction between these two is so rarely recognized "the very things which are most obvious may become the hardest of all to understand." (Taylor, 1997, p. 9)

Taylor shows us that the underlying assumptions of common sense lead to a rich and complex figure of the communicational reality where the factors that cannot be directly observed - such as meaning or state of understanding - need to be "explained." When we make replies such as "he did not understand the meaning of my letter" or complain that "she didn't get my meaning," the linguistic theorists find themselves forced to explain how exactly this "meaning" failed (in this case) to be transferred between people and why it has been misunderstood (or understood).

The "image creation" of common sense is highly efficient in crafting an ontological coating that leads us to forget its initial motivations. Thus, Harris (1996, In: McDonough, 2000) warns us that metalanguage has a perverse effect when it is used to reinforce the language-as-object concept through the reification of linguistic forms, rather than a second order reflection on language. The doctrine of the use-mention distinction ${ }^{75}$ sanctions an illusion that creates the linguistic

\footnotetext{
75 "that there is a parallel between using a word to mention a (generally) non-linguistic object and using a quotational device to mention a word" (McDonough, 2000, p. 204)
} 
objects being mentioned (named) in the discourse. ${ }^{76}$ This is the same danger to which Wittgenstein calls our attention when he argues that names are not just labels on "objects," but rather have many uses (P.I.§§38-39); or when he argues against the risk of the decontextualization of words (P.I.§38), when "one gets the sublimed conception of names, in which the name-relation appears to be distinct from any of its specific manifestations [...].” (McDonough, 2000, p. 206)

Formalist linguistics' ominous search for unobservable "deep structures" is a consequence of the representational model of language in what Taylor and Harris call the type-token doctrine:

Orthodox language theory embodies [...] a metaphysical premise: If I am able to understand what you say to me, I must be able to identify the phonemes, word, sentences, speech acts, etc., of which your utterance consists in token instances. (Taylor, 1997 p.5)

Harris shows in his analysis of the Philosophical Investigations (§§87-8) that, when taken in the surrogationalist model, language falls into a never-ending regressive pattern when it attempts to reach a degree of "exactness" that is expected in the realm of meaning:

[...] the problem of showing exactly what one means is shown to be regressive and in which, moreover, the problem is treated not simply as a problem for the descriptive analysis, but intrinsically as a participant's problem. (Harris, 1981, p. 202)

The regressive chain of semantic description has an "exactly analogous problem" in the identification of the linguistic forms. ${ }^{77}$ In Wittgenstein's example, this is the process whereupon hearing the phonological form [Moses] one is supposed to have enough evidence that one is referring to the word Moses. This

\footnotetext{
${ }^{76}$ This reification is directly tied to the speech/writing distinction (in speech one is not able to distinguish between when words are used to mention words - with the use of quotation marks and the general use of words) that is also discussed by Harris (2001) and Barros Barreto (2011).

${ }^{77}$ For example, when faced with a question like "how can I explain what the name Moses is referring to?" we might answer: "the man who led the Israelites out of the Egypt, etc." However, this provokes another round of questions: "What are you calling Egypt or Israelites?" and so on... Harris (and Wittgenstein) calls our attention to this endless recursivity and to the even greater difficulties when dealing with words such as red, dark or sweet.
} 
type/token link is commonsensical to representational linguistics as well as the assumption that we recognize right away that the phonological form [Moses] is a token of the word type Moses and not only refers to "the man who led the Israelites out of the Egypt," but also that it is a proper name that follows certain conventions and collocational restrictions in one's language syntax. However, these links are far from following any systematic procedure: for any utterance $[\mathrm{X}]$ there is an unending repertoire of meanings available and

In order to determine which sentence of language $L$ is actually represented by $X$ in any given case $[\ldots]$ he [the speaker-hearer] already needs to know what the utterance means in order to find out which sentence it represents. (Harris, 1981, p. 203-204)

In one way this leads us to Wittgenstein's own conclusion (P.I.§30): an ostensive definition (the final step in the semantic chain) of a word only explains something once we know the role this word plays in language. There simply is no self-explicable "dead" link in the end of the semantic chain because the sign is a form of life:

But if we had to name anything which is the life of the sign, we should have to say that it was its use. (B.B., p. 4)

Taking the "truisms" of language as if they were empirical truths engenders issues that are notoriously hard to answer (Taylor, 1997, p. 172), such as: What are the necessary conditions for an understanding between two speakers? Are these conditions related to communicational circumstances or the mental states of speakers, social structures or behavior patterns? How can we justify the occurrence of these facts? These and other related questions constitute the basis of the research of most of the Western linguistics tradition. Thus the various theories and models of language and the philosophy of language repeatedly seek to answer the same questions over and over. ${ }^{78}$

\footnotetext{
${ }^{78}$ Auroux (2004, p. 12) presents his own abstract of the concerns of Western philosophy of language:

- [What is] the nature of language: do animals speak it? Is language based in intentional entities (ideas, meaning), linked to a specific property(ies) of the human spirit (the intentionality)? What is
} 


\section{The Perspectivist alternative}

Perspectivism begins by questioning the "ontological" bases of ontological worldviews (Weltanschauungen) and therefore approaches the unsolved problems above without expecting to provide solutions within a given commonsensical model of language. It sees the "unsolved problems" as signs of an ultimately incomplete view of language and of the fissures in whatever model of language we manage to fabricate. In its metalinguistic persuasion, it cannot but assume that metalanguage is also a form of life and, as such, is comprised of life forms that are irreducible, contextual and political. ${ }^{79}$ Metalanguage "is part of the scientific object that they [linguists] are studying," (Taylor, 1997, p. 15) conceived not as a tool to describe language, as written above, but as a never neutral(ized) second order phenomenon which shapes the way we construe language:

If language has form, it is precisely because it is a normative action, an activity that matters to its participants because they make it do so. The perspective from which linguistic form appears is not statistical, biological, abstract, chronological, logical or psychological: it is a moral and political perspective. (Taylor, 1997, p. 140)

This process of creation of an "image" of language is what Taylor (2008) and others call Reflexive Enculturation, the interaction of the discursive processes that refer to language using metalanguage with its embedded tradition/culture. Taylor argues that this is also the process through which we see the

\footnotetext{
the origin of language? Where does it come from? [... What is] the nature of writing and its relationship to [spoken] language?

- language and thought: can we think without language? Is thought an "inner language"? Are general concepts nothing more that words?

- language and reality: what do the different elements of our languages mean? An isolated term can be true? The truth about what we say depends on the words we possess to say it?
}

It is not by chance that the French author divides its questions exactly into the three vertices of the Aristotelian triangle: language in the relation to itself (the words in Aristotle), in the relation to thought (the Aristotelian "affections of the soul") and in the relation with reality.

Another telling example that gives eloquent signs of the fact that we are still trying to answer Greek problems in Greek ways is the layout of chapters of a collection of classical articles in language called Philosophy of Language: the Big Questions, (ed. by Andrea Nye, 1998). The book's six parts are: 1) Language: what is it?; 2) Meaning: how do words get their sense?; 3) Speaking: what is it to say something?; 4) Reference: what do we talk about?; 5) Truth: what is the relation between language and reality?; 6) Other minds and foreign tongues: how is it possible to understand what someone else says?

79 “[...] intellectual metadiscourse can be given a sociopolitical explanation [justification]." (Taylor, 1997, p. 185) 
Developing child bridge the ontological gap from the empirical, measurable world [...] to the world of the linguistic phenomena referred to by the expressions of commonsense metalinguistic discourse [...] (Taylor, 2010, abstract)

As it has been noted above, the linguists approach their object of study, language, loaded with their own cultural-historical prejudices and submerged in the dialogical daily situations where the questions on meaning and understanding (among other subjects) are discussed in lay terms, according to the commonsense practices of their community and culture. Furthermore, language is likewise loaded with such commonsensical concepts: "the language-using population is already in possession of a highly sophisticated, vigorous, multi•dimensional, and robust linguistic-cultural 'civilization." (Taylor, 1997, p. 24) This linguistic heritage is as important (if not more) as the intellectual abstractions of the language models that are suggested by different language theories, exactly because it does not count as a theory, but as an ontology. And this process is not static but

\begin{abstract}
A continuously on-going, creative activity [...] socially contested, differentially valued, variable, and inseparable from its participants' purposes, prejudices, and desires. (Taylor, 1997, p. 25)
\end{abstract}

In conclusion:

What matters to us in verbal behavior is not an independent property of that behavior itself but is determined by how we in our culture talk about verbal behavior and about the contextual circumstances of which we make that behavior a part. By this means language is enculturated (Taylor, 2007, p. 23).

Perspectivism recognizes that, in spite of its complexities, communicational skepticism is not normally part of our experience. One must therefore, as per a perspectivist view, accept that understanding occurs because people affirm so when they are communicating, without any need for further assumptions. Understanding is neither made possible nor encumbered by issues related to meaning, but it is seen as a process negotiated with the inestimable use of metalanguage. 
When we act prescriptively through metalanguage ("you do not understand me!") we state judgments where the measure of understanding is given by the negotiated use of our metalanguage, coercively guiding the other towards an(other) accepted form of expression. ${ }^{80}$ To evaluate language we need some measurement or evaluation scale that is (at least precariously and partially) "independent" of language. The way to achieve a shared system of measurement is through its discussion and negotiation, until we find what the majority judge to be an "efficient", "regular", "stable" system. (Taylor, 1997, p. 19) This is an eminently political process, devoid of further justifications other that the fact that the "winning methods" are those that slowly acquire acceptance and understanding within the context of the metalinguistic-games. Likewise, to inquire about the (a)grammaticality of a sentence does not mean to gauge the intrinsic properties of that sentence, but rather to ask how we could reflexively evaluate it according to our currently considered best metalinguistic practices.

We have in principle freedom as individuals, but we do not live "in principle" but rather under constant guidance and repositioning. The same principle guides, as we have seen, the historical ways in which is forged language's identity and, often in the West, its essence.

The importance of metalanguage is so prominent, as writes Taylor (2000), that the absence of a meta-reflection would imply the impossibility to create and negotiate concepts like meaning, word, true and false. Without the metalinguistic practice, we could never learn the written language or transfer from one media to another. ${ }^{81}$ Without metalanguage there also could not exist a standard language, or standard forms; there would be no language planning, prescription or language teaching. Hence, the point of view that creates the "language" as an object of study for us

Is that which, at least in part, we adopt by speaking of language in certain ways [...] The viewpoint creates the semiotic object and creates it as having particular properties: those that we intuitively "know" (assume, take, intuit) our vocalizations, gestures, and writing to have. (Taylor, 2000, p. 493-494)

80 “" $[.$.$] language is taught, explained, justified, and corrected with remarks which we also treat as$ carrying a normative force." (Taylor, 1997, p. 12)

${ }^{81}$ Writing is learned from the exercise of metalanguage, nothing in it indicates that it is innate, but rather a cultural product. See also Auroux (2004, 2009) and Barros Barreto (2011). 
We take support from previous discussions on perspectivism to remain at safe distance from the no man's land of relativism. These practices are not entirely conventional and one cannot simply start inventing ludicrous new parts of speech because they will not be accepted and recognized as such by others. ${ }^{82}$ The interplay of the contingent and the necessary is a central aspect of Wittgenstein's latter thought, providing an important linkage to metalinguistic perspectivism and it will be discussed in more detail in the next section.

On the other hand, to assume one's privileged way to see language as grounded in some ontological truth is what Viveiros de Castro calls - as applied to anthropology - "epistemocide." This principle also lies behind Auroux's historically moderate position:

We do not wish to renounce anything, not Derrida, Heidegger and Lacan, and neither Carnap nor Chomsky, certainly, not Plato and Aristotle. Our goal is to somehow offer a topography of the whole territory. (Auroux, 2004, p. 14)

The approach of metalinguistic perspectivism, it seems, uses Auroux's "purely descriptive and not teleological moderate historicism" in considering such linguistic knowledge grounded in the ability of any linguistic tradition to produce valid knowledge. ${ }^{83}$ It is not the disenfranchisement of (Western) linguistics as a science that is being suggested here, and that is precisely because the term science itself needs to be perspectively addressed within its social, historical and cultural contexts. ${ }^{84}$ The "scientific method" is no longer a monopoly-holding exclusivity to the Graeco-Western civilization. Again, it seems that we may be hearing Wittgenstein's words resonating in our eardrums...

\footnotetext{
${ }^{82}$ Barring the notable exceptions of the most creative works of literature and poetry, where the coinage of hitherto unheard of vocabulary and even grammatical structures is not rare and an accepted and sometimes highly valued practice.

${ }^{83}$ The ambitious project of History of the Linguistic Ideas edited by Sylvain Auroux that started in 1982 seeks to build a non-teleological history and, insofar as possible, purely descriptive metalinguistic knowledge, guided by a common thread that delegates to writing a protagonist role in this history.

${ }^{84}$ Viveiros de Castro (2009, p. 16) writes: "Science, as classically conceived, is based in the principle $[\ldots]$ that it is possible and necessary to distinguish between true and false propositions, separating everything that is affirmed about Being into truths and falsities." This is exactly what perspectivism puts into question.
} 
The emphasis on the "rhetorical source" of linguistics as well as the recognition of the coercion exercised by the metalanguage arising from our commonsensical non-ontological roots points to the inescapable political and ethical dimension of linguistics. (Taylor, 1997, p. 13-16) It is clear that the theoreticians of metalinguistic perspectivism are also subject to the same political dimension and, at least for one of them, Roy Harris, his skillful use of rhetoric is particularly well known by friends and foes alike (see Wolf and Love, 1997). Metalinguistic perspectivist theoreticians may fall into the trap of attempting to build their own archetheories, that is, to envelop their arguments with an omniscient gloss that verges on the very same universalism they so strongly fight against (see: Joseph, In: Wolf and Love, 1997, chapter 1); or, on the other end of the spectrum, they can be criticized for their failure in presenting any positive theory.

However I do believe that once we recognize and embrace the nonontological and political side of linguistics, we must also accept its limitations, not as a shortcoming of the linguistic theories, for their formal models are still capable of presenting outstanding results in their different areas of study (such as in the acquisition of language and in cognitive disorders), but as a sensible limitation of the ambitions of such theories. Similarly, metalinguistic perspectivism drinks from its relational roots in Wittgenstein and other perspectivisms and should learn from the Austrian philosopher that to guard against universalism does not necessarily incur rampant relativism. We then revisit Wittgenstein to provide further support of his dialogue with perspectivism.

\subsection{4.}

Wittgenstein and perspectivism

The suggestion of connections and affinities between Wittgenstein and perspectivism is not unprecedented and has already been proposed by some authors (see: Martins, 2012; Prado Jr 2004). Here I intend to call attention to some arguments and passages in Wittgenstein's later writings where one finds arguable vestiges of the kinship with these traditions and to add a "metalinguistic" 
dimension to the discussion. ${ }^{85}$ We may take this section as a conjecture on what might have been Wittgenstein's reading of the authors quoted in the above sections and how we should construe a speculative term like "Wittgensteinian metalinguistic perspectivism" and the bases of a MPH.

As in Perspectivism, Wittgenstein does not intend to impose a new correct model of thinking, a new theory, but rather he seeks to open one's mind and vision into all directions and to all possibilities. Although his thinking clearly points to a non-universalist stance, we have argued elsewhere in the present work that Wittgenstein can also be read as a non-relativist. This is why "some of his readers have attributed to him a singular manifestation of perspectivism," (Martins, 2012a, np) which, as presented above, attempts to avoid the unproductive dichotomy of universalism/relativism.

\section{Regularity against the universal/relative dichotomy}

Prado Jr (2004) is an author who emphasizes particularly the affinities between Wittgenstein and perspectivism along the lines of their anti-universalism and anti-relativism. We have already seen the Brazilian philosopher's comments on regularity (Regelmäßigkeit), a term that is so dear to his Viennese counterpart. He goes much further in reverberating Wittgenstein's as a philosophical work that is outspokenly non-philosophical:

\footnotetext{
Há que acrescentar que pertence à essência do vernünftige Mensch [...], justamente, não perguntar pelo fundamento, não ser filósofo. A análise filosófica [...] percorre à contracorrente o movimento espontâneo da Vernünftigkeit, definida como o bom senso comum. (Prado Jr, 2004, p.36)
}

One has to add that it belongs to the essence of the vernünftige Mensch [...], exactly, not to inquire about the fundament, not to be a philosopher. Philosophical analysis [...] strives along the countercurrent of the spontaneity of Vernünftigkeit, defined as the good common sense.

\footnotetext{
${ }^{85}$ Schalkwyk (2005, p. 102) refers to the direct and profound influence of Wittgenstein in Talbot Taylor's linguistics, especially in his 1997 book, Theorizing Language: "he [Taylor] uses Wittgenstein to play a much more positive role in the latter [1997 book]." It is less usual to find traces of some "proto-metalinguistic perspectivism" in Wittgenstein's works, as I shall attempt to do here.
} 
The expression "reasonable men" (vernünftige Mensch) can be interpreted as a sign of Wittgenstein's attempting to work with the blurred concepts that dangerously balance perched on the tenuous cords stretched between the edges of universalism and relativism. Moreover, the "good" common sense that Prado Jr writes about is exactly the opposite of the concept of commonsensical truths that is liable, as the philosopher repeatedly warns us against, to fabricate ontological illusions. Wittgenstein criticized the epistemological value of the truisms, which fail when they are employed in the defense of either side of the "philosophical battleground":

No fundo, aponta Wittgenstein, [estas] são as mesmas razões que cancelam o sentido possível de relativismo e de idealismo, que mostram que a aparente oposição entre essas metafísicas é meramente efeito de superfície, que ambas partilham do mesmo equívoco filosófico de base. (Ibidem, p. 41)

Deep down, indicates Wittgenstein, [these] are the same reasons that cancel the possible sense of relativism and idealism, which show that the apparent opposition between such metaphysics is merely a superficial effect, and that each share the same basic philosophical mistake.

According to Prado Jr, ontological or epistemological efforts cannot rescue us from relativism (or pragmatism, for that matter). It merely suffices for us to recognize that once we are initiated in one language-game, we are able to understand all language-games of a language, even if, as we have seen in the chapter on Wittgenstein, the language-games do not partake in a common history and our own Weltbilder are irreducible against each other. For Wittgenstein, we only need to share:

O.C. $§ 70$. We might speak of fundamental principles of human enquiry (my emphasis).

What we notice here is a dislocation of the axis of inquiry, from questioning the conditions of truth to the suggestion of imprecise patterns that (somehow) include humanity in its "regularities." There is a limit to the justification of (rational) evidence: 
O.C. §204. Giving grounds, however, justifying the evidence, comes to an end; but the end is not certain propositions' striking us immediately as true, i.e. it is not a kind of seeing on our part; it is our acting, which lies at the bottom of the language-game.

O.C. $\$ 205$. If the true is what is grounded, then the ground is not true, nor yet false.

However, one will be disappointed if expecting to find a substitute for rationality as another standard of measure in some kind of "reasonableness," because Wittgenstein also refutes that later in the same book:

O.C. $\$ 559$. You must bear in mind that the language-game is so to say something unpredictable. I mean: it is not based on grounds. It is not reasonable (or unreasonable).

It is there - like our life.

One is likewise to be disappointed in their search for the sources of Wittgensteinian regularities among structures in formal or pragmatic models of language. As the last section tried to show, the argument that regularities in language somehow emanate from underlying regularities in a universal language structure lacks any theoretical support.

We could, however, resort to alternative approaches, as in the Gricean and Hallidayan ethnomethodology. Conversation analysis treats the unending variation of utterances in speech as "consisting of something like token-instances of particular types of events, occurring and reoccurring in regular types of sequences." (Taylor, 1997, p. 111) Taylor's argument line is that ethnomethodologists and (traditional) linguists still share the same motivations and obsession for meaning that has characterized the so-called Augustinian picture of language. This is a further indication that Wittgenstein's ideas on regularity should not be sought in linguistic practices that are unwittingly subscribing to the commonsensical picture of language, which are extremely prevalent in the Western tradition.

However, as one might have noticed from the discussion of metalinguistic perspectivism presented above, there is a force that (at least partially) justifies and 
explains why language appears to be like a formal system: ${ }^{86}$ the normative effect of our language practices mediated by metalanguage. ${ }^{87}$ If we can construe Wittgensteinian rules as meta-game activities on metalanguage-games, these rules have a similar normative effect (self-regulating, non-intellectual) to the one that metalanguage has in metalinguistic perspectivism.

In any case, the reflexive aspect of language, as an envelope which folds unto itself, should prevent us from attempting to inspect language "from outside" and entice us to take a closer look, in its (language's) own terms:

P.I. §51. Um klarer zu sehen, müssen wir hier, wie in unzähligen ähnlichen Fällen, die Einzelheiten der Vorgänge ins Auge fassen; was vorgeht aus der Nähe betrachten.

P.I. §51. In order to see more clearly, here as in countless similar cases, we must look at what really happens in detail, as it were from close up.

These are ideas that by now must surely be familiar to the reader and might recall to us what has already been discussed in the previous chapters. Prado Jr.'s exposition on the later Wittgenstein is particularly relevant here because it focuses on a reading of the philosopher that offers us the possibility of escaping from the universal/relative duality in its reductionist effect.

\section{Wittgenstein writing about metalanguage}

Wittgenstein's approach to metalanguage is mostly indirect and sometimes idiosyncratic. For instance, he "made use of grammatical terminology in novel ways," (Harris, 1988, p. 66) incorporating terms that otherwise would not be included by grammarians as parts of speech, such as "shape words" or "sound words." It seems, argues Harris, that the philosopher is calling attention to the inevitable oversights (or excessive generalizations) on the part of the grammarians

86 Taylor (1997, p. 164) argues that there appears to be a differentiation between "externally motivated" regularities in language ("why does everyone in the speech community pronounces 'nurse' [nois]?") compared to "internally motivated" regularities ("why classes of words almost always appear before/after other classes of words?"). It is this last category that lends to language the appearance of a formal system.

87 "If we want to explain the formal regularity of what we produce in language, then we must recognize the normative character of the situated events of linguistic production." (Taylor, 1997, p.165) 
or, more importantly, to the fruitlessness of the task of fitting the words in language into definitive categories.

In addition, although Wittgenstein does not make an explicit study of the metalinguistic repertoire in language, his view in the Philosophical Investigations seems clearly to point to what we are calling here metalinguistic perspectivism:

P.I. §97. [...] Wir sind in der Täuschung, das Besondere, Tiefe, das uns Wesentliche unserer Untersuchung liege darin, daß sie das unvergleichliche Wesen der Sprache zu begreifen trachtet. D. i., die Ordnung, die zwischen den Begriffen des Satzes, Wortes, Schließens, der Wahrheit, der Erfahrung, u. s. w. besteht. Diese Ordnung ist eine Über-Ordnung zwischen - sozusagen - Über-Begriffen. Während doch die Worte "Sprache", "Erfahrung", "Welt", wenn sie eine Verwendung haben, eine so niedrige haben müssen, wie die Worte "Tisch", "Lampe", "Tür".

P.I. §97. [...] We are under the illusion that what is peculiar, profound and essential to us in our investigation resides in its trying to grasp the incomparable essence of language. That is, the order existing between the concepts of proposition, word, inference, truth, experience, and so forth. This order is a super-order between - so to speak - super-concepts. Whereas, in fact, if the words "language", "experience", "world" have a use, it must be as humble a one as that of the words "table", "lamp", "door".

This section of the Philosophical Investigations calls our attention to the ordinariness of the use of all words in language, to the fact that there is no language "outside" of language, no "super-language" which stands independently of the "rest" of language and that might follow a different set of external criteria (such as Reason). Although Wittgenstein writes about words that refer to conceivable metaphysical entities (in his examples, "language", "experience", "world"), the same is valid for meta-words in language. The corollary is inescapable: metalinguistic terms are nothing but words, not "super-concepts" that exist "on holiday" (P.I. §116), decontextualized from their situations of use.

On the other side of the spectrum from ordinary, lies what we usually call special, but that is often also recognized as perfect or ideal. Wittgenstein writes that "we misunderstand the role played by the ideal in our language" (P.I.§100), the incredibly strong drive towards perfection, where vagueness can only reach the surface. Therefore, when we study language we strive to look for the desired perfection in it. The words that describe language must be, within this worldview, super-concepts, because they are describing what is likewise perfect, superlative. 
However, Wittgenstein argues that these words are not "concepts" giving an essential structure to language, but rather are words like any other, whose value resides solely in their use. Hence they can be manipulated, can be loaned to myriad contexts, can be deformed in situations of alterity, and their fate cannot be different from the fate of all words in language.

The philosopher wants to shatter the illusion that there is a "special type" of language to talk about language (or to talk about philosophy): "The sense in which philosophy of logic speaks of sentences and words is no different from that in which we speak of them in ordinary life" (P.I. $\S \S 108,120)$. And the way we categorize and rank word groups is also contingent on our motivations: "how we group words into kinds will depend on the aim of the classification - and on our own inclination" (P.I. §17). ${ }^{88}$

It is inevitable to see clear patterns of similarities between Wittgenstein's "ordinary language" and what Taylor and Harris write about metalanguage: its political use; its ordinary (lay) uses; its inseparability from language; its coercive effect on how we understand language; the dangerous reification effect on our commonsensical picture of language. These similarities add strong support to the hypothesis of a Wittgensteinian metalinguistic perspectivism.

\section{The need for metalanguage}

In writing about language, Wittgenstein argues that there are no complete explanations, and because the moment we use language it is already fully developed, we can only adduce (quote, exemplify, present reasons) exterior facts about language:

P.I. §120. Daß ich bei meinen Erklärungen, die Sprache betreffend, schon die volle Sprache (nicht etwa eine vorbereitende, vorläufige) anwenden muß, zeigt schon, daß ich nur Äußerliches über die Sprache vorbringen kann.

P.I. §120. In giving explanations, I already have to use language full-blown (not some sort of preparatory, provisional one); this is enough to show that I can come up only with externalities about language.

\footnotetext{
${ }^{88}$ One clear instance is the discussion on the expression "Slab!" on (P.I. §19) about whether this is a sentence or a word.
} 
This is valid for explaining words, citing rules for the game, justifying the use of a word or teaching words to a child. If you are explaining a direction to reach a place, you can elucidate it by using examples of things in the world ("pass that house," "take the right in the next corner," etc.), but you cannot explain what direction or right is. The interlocutors must be previously acquainted with these games of language that you are using with them.

When language is represented in language, that is, when we talk or write about it and therefore make use of metalanguage, there are no "external references" to be made or to be pointed at because metalinguistic discourse is filled with words such as direction and right. This knowledge must be had in advance, and the fact that we manage to understand each other in metalinguistic discourse is a sign of the (unstable?) stability of language and of the knowledge we have about how to use it: "To know how to use the word 'anger' is to know what anger is." (Cavell, 1979, p. 185) We are reminded of Taylor's discussion above that there could not even be language if metalanguage did not exist: there would be no way to learn language. This evaluation is supported by Cavell:

\begin{abstract}
You can't give someone a piece of information unless he knows how to ask for that (or comparable) information. [...] You can't tell a child what a word means when the child has yet to learn what "asking for a meaning" is (i.e., how to ask for a meaning), in the way you can't lend a rattle to a child who has yet to learn what "being lent (or borrowing) something" means. (Cavell, 1979, p. 170-171)
\end{abstract}

Cavell's activity of "asking for a meaning" is, in a way, the metalinguistic activity that Taylor writes about. The correspondences again are visible: to use language and to participate in the language-games one must know the rules, that is, one must know how to ask (among other metalinguistic activities). In other words, you must know the metalanguage, which, like the language it is part of, is also "born" whole, and to which only exterior information can be adduced.

I can build further the parallel between Wittgenstein's rules and (Taylor's) metalanguage. The rules are sometimes referred to as grammar of the language- 
games $^{89}$ and its normative aspect suggests a direct connection to perspectivism's normative metalanguage, one that is debatable but already alluded to in Taylor:

To my mind, normative metadiscourse is the most appropriate referent for Wittgenstein's idiosyncratic use of the term "grammar," although this would be a highly controversial interpretation [...] (Taylor, 1997, p. 17)

Either way, the point that Taylor drives at is that grammar (in a Wittgensteinian sense and sometimes equated with rules) should not be regarded as something that is internal to language or its use, but "as a feature of the language games within which we talk about and treat language normatively [...].” (Ibidem) Likewise, the conditions of understanding cannot be provided by any "decontextualized" grammar, but must necessarily involve the communicational situation. (Taylor, 1997, p. 89) Once in an actual situation of use, the interplay of contingent/necessary in each language-game provides at least a semblance of the coerciveness that Taylor writer about.

\section{The danger of metalanguage}

Wittgenstein's defense of ordinary language should not mitigate his warnings against the fact that the use of familiar words may give us the impression that we know what a word refers to (that we seem to know its (Augustinian) meaning), and may also gives us the inadequate impression of knowing about the concept when what we actually know is about the word anger as a form of life. ${ }^{90}$ This is exactly the admonishment of writers like Taylor and Harris on how commonsensical use of metalanguage might lead us to overestimate our knowledge about the essence of things, in this case, of language.

89 "Grammar describes the use of words in the language. So it has somewhat the same relation to the language as the description of a game, the rules of a game, have to the game." (PG, p.60)

${ }^{90}$ The reader might be confused here, since above Cavell wrote that "to know how to use the word 'anger' is to know what anger is," as if suggesting that we might know the concept of anger, and thus are in principle able to know all concepts. The key term here is concept. Knowing what anger "is" does not imply that one knows the concept of anger, or whatever might be construed as its "ultimate, universal and essential nature." It means rather that one knows how to use the word anger, to accept it as a form of life, and thus be able to play the language-games with anger. 
There is a specific passage in the Philosophical Investigations about the metalinguistic term reading that illustrates very well this particular point: ${ }^{91}$

P.I. §156. Der Gebrauch dieses Worts [lesen] unter den Umständen unsres gewöhnlichen Lebens ist uns natürlich ungemein wohl bekannt. Die Rolle aber, die das Wort in unserm Leben spielt, und damit das Sprachspiel, in dem wir es verwenden, wäre schwer auch nur in groben Zügen darzustellen.

P.I. §156. The use of this word [to read] in the circumstances of our ordinary life is of course extremely familiar to us. But the part the word plays in our life, and so too the language-game in which we employ it, would be difficult to describe even in rough outline.

We could actually add, in a typical Wittgensteinian fashion, that we assume to know the essence of reading, by virtue of how clear and "extremely familiar" this activity seems to us; however, we encounter incredible difficulties when we try to confine the word in artificial boundaries, to pinpoint its exact "meaning." In other words, there are many theories of reading, but its meaning lies on the actual uses of the word. The same case could be presented for other metalinguistic terms and, ultimately, according to Wittgenstein, to all the words in language.

The interpretation of authors such as Prado Jr. and Cavell on Wittgenstein's efforts against rampant relativism must not hide their underlying risks. Once we admit the full historicity (contextuality) of the concepts and meaning as usage in ever-changing conversational contexts, the actual view that language is a form of life should in itself be contextualized and not taken as an ontological truth on the nature of language.

This inevitable conclusion is similar to the relativist critique of Wittgenstein's thought as one that is self-refuting. And likewise the strategy against it is not to deny the historicity of "language a form of life," but rather to accept that this statement is a grammatical remark that is not transcendental (nor has it ontological explaining power) but has a necessary force once we subscribe to its tenets, once we are initiated in its practices. It then becomes productive as a source upon which we can build our theoretical apparatus (like the one that is being done throughout this chapter), without the frailties of a theory that has the

\footnotetext{
${ }^{91}$ Wittgenstein's interest in this section, explains Baker \& Hacker (v. 1, part II, p. 333), is to further the study on the nature of understanding and how it relates do the activity of reading.
} 
ambitions to be the exclusive source of knowledge on language, reality and the world. The MPH produces its own statements, which should be viewed considering their own motivations and priorities and, within this context, its ideas can be employed to compare different metalinguistic practices and situations, such as the one that is the focus of the present dissertation, the book of the Lăož̃. ${ }^{92}$

\subsection{5. Etymology}

Etymological studies are hardly considered a valid source of knowledge in most of today's linguistic research, where the prevalent ideas of language as a synchronic system became the norm in contemporary linguistics. Etymological data are mostly considered as curiosities for lay readers, whose importance in academic studies is restricted to addressing specific questions of historical linguistics and the historical evolution of the different languages in the world, but theoretically incapable of saying anything valid about the actual synchronic use of words. $^{93}$

It should not be hard to notice that within the perspectivist framework presented here this damaging picture of etymology should be reassessed. Etymologies are marks of the history of words in the sense that they point to the historical distribution of the past uses of words. It has already been written here that, with the passage of time, our historically situated traditions solidify into our common sense and create truisms. The same can be said about the history of words: they point to relations and uses that may have long become archaisms or antiquated expressions, or even long forgotten relationships, but that nevertheless inform our traditions about how we, in our shared history, have been using these

\footnotetext{
${ }^{92}$ After the analyses of the metalanguage of the Laozi I intend to show that this text itself (as well as what we can interpret as Daoism) is also very amiable to perspectivism.

${ }^{93}$ Scholars who historically defended etymology as a source of knowledge of language are usually relegated to the sidelines of linguistic thought. One example is John Horne Tooke's argument defending an "etymological metaphysics," as presented in Taylor (1997, p. 123, 128ff) and Harris \& Taylor (1997, chapter 12). Very briefly, Tooke defended etymology as a dogmatically free and objective tool to describe language, however "under Tooke's institutionalism the power to determine the meanings of words rests in the hands of the linguist, as a scientific authority, possessing the technological skill to uncover the 'truths' of language." (Taylor, 1997, p. 137)
} 
words: "Etymologies are often stories [...] and are held to retain historical or culturally fundamental information in compressed form." (Hutton, 2013, p. 62)

Etymologies are often regarded as diachronic chains of semantic relations in analogy to Wittgenstein's spatial chains of "explanations" from simples to composites (P.I. §§46-59). Etymological research often seeks one distant and lost "original meaning" that, as it has often been argued, would let us know the "true" source of meaning of a word-form. Moreover, because it has dedicated most of the time to the fringes of so-called "serious" scientific research, etymology is often criticized as speculative, fanciful or lacking in scientific objectivity.

However, a perspectivist approach must consider it an epistemologically valid source of information and discard the biased hierarchy of the scientific and non-scientific:

Etymological analyses are crucially based on determinate form-meaning correlations, and even from the point of view of conventional linguistics the etymological information provided by institutional authorities such as the Oxford English Dictionary often appears on close examination to be highly speculative. (Hutton, 2013, p. 61)

The ambitious aim to identify "original meaning," however, should likewise be criticized on the same grounds, in line with Wittgenstein's' recommendation often repeated in this dissertation - that meaning is no more than the use of words and not an entity which shows an evolutionary path in time. However, once guarded against absolutistic ambitions, it remains a valid and important tool of research into the history of the use of words, often pointing at relationships and polysemies that inform our common sense, and therefore shed a light on the historicity of such commonsensical notions.

Chinese traditional etymology, as it will be seen in this dissertation, is primarily concerned with the graphic nature of the Chinese characters. Although etymology should not be restricted in this exclusivist view as limited to the written dimension of language, the graphical nature of written language offers quite amazing epistemological additions to its oral dimension and often leads us to question the traditional subservience of writing to speech that is part of traditional linguistics. This matter has been the subject of my own master's thesis 
(Barros Barreto, 2011) and is a question that has been the object of study of many authors referred to in this dissertation (in particular, Harris 2001; Auroux 2004, 2009; Taylor, 1997, chap. 2; but also Olson, 1993, and others). Their works on this subject (added to specific analysis on Chinese writing) have been of inestimable contribution to this dissertation as theoretical background that gives support to the etymological analyses that will be presented.

\subsection{6.}

\section{Translation}

As written in the introduction to this dissertation, post-structuralism and relativism have had an enormous impact in translation studies. Often considered a "theoretical impossibility" in the relativist framework, translation becomes an opportunity in metalinguistic perspectivism which dislocates often-repeated dichotomies. For instance, it is particularly relevant how we can revisit the opposition between domesticating and foreignizing translations. One could argue that these concepts also, in a way, mirror a meaning-driven philosophy of language, since they rely on the impact the translator has on the meaning of the text and its insertion in the target and original cultural contexts. ${ }^{94}$ Although this dichotomy offers efficient guidelines for the evaluation of a translator's works and the comparison between translations, within the context of perspectivism one must accept that translation is also a language activity, and, therefore, also a form of life. Consequently, translation should be regarded as sharing the problems and questions of the wider field of linguistics, and not separated from it. And, as with linguistics, one should not attempt to encircle and fully describe it through any theory, but rather to accept it as another linguistic praxis.

The adage "a translation is what we call a translation", stripped from both its ontological consequences and its relativist anarchy, turns out to be quite adequate to the present discussion. It highlights the historicity of the "concept" of

\footnotetext{
${ }^{94}$ In this dissertation I do not intend to imply that the distinction between the two hermeneutical types of translation is limited to their dependence and their distinct impact on "meaning." Naturally, there are other differences, for instance, their diverse cultural and social impacts.
} 
translation and the fact that at different times, social and cultural contexts domesticating and foreignizing translations, for instance, have been alternatively chosen as "better" translations. ${ }^{95}$ With this proviso, foreignizing translations offer to the readers a view that, in the perspectivist context, is arguably better suited to the re-visitation or experience linked to the context of production of the original text as desired in a perspectivist undertaking. It also seems to offer better chances to gauge the alterity of different contexts and reject the naïve (albeit very resilient) idea of the predilection for "transparent translations."

Therefore, in the same way, as discussed above, that one must also accept the historicity of perspectivism in order to embrace it - and then critically choose it as a theoretical stance better suited to one's own linguistic practice - the same can be sustained when discussing translation. Consequently, a particularly wellresearched translation of a famous text might acquire the status of a "standard translation," without preventing it from being revised, modified and, eventually, substituted. For a while, this one translation can be regarded as having the authority of a normative translation, however its coerciveness must be located in a time and context and, being temporal, it is also contingent and provisory. It is a trivial (common-sensical) statement to say that "translation is possible in its practice," but what is being suggested here is that it is also theoretically possible: its feasibility arises from its acceptance as a practice called translation. Therefore we might affirm that "translation presupposes an "equality of differents" without needing to assume that there must be an ontological address for the "differents." In other words, we act "as if" we could locate and define a departure point (in the original language) and an arrival point (in the target language), but these "points" exist only in our practice, in our use. They are hollow circles, or virtual points, to use the vocabulary of Deleuze and Viveiros de Castro discussed above.

Additionally, the activity of translation inevitably produces another new text, whose connection to the original solely depends on its readers acknowledging it as a translation of another text. The nature of this "connection," stripped from its

\footnotetext{
${ }^{95}$ For example, if on the one hand no one would dispute the immense impact and quality of Ezra Pound's translations of Chinese poetry in his short book Cathay (see Pound, [1915]1990 ; Wai-lim, 1969; Saussy et al, 2008), on the other hand it is clearly an extremely "domesticating" translation. This, in principle, could detract its value within the context of the post-structuralist studies of translation.
} 
purely semantic basis, is a testimony to a dialogue between two different traditions conflated into one activity. The translators are the participants who are situated in the fringes of two (potentially) drastically diverse sets of languagegames. They can experience these non-intellectual encounters and know in their practice that systematic methods of translation (automatic translators and the like), as efficient as they can be, are often fruitless - and sometimes pitiful - attempts to equalize what is not equal. Some literary authors, such as Samuel Beckett, ${ }^{96}$ had turned their efforts especially in order to

Habitar a língua do outro, a língua hostil e desacostumada, aliada à sua disposição de retornar, amiúde por tradução, à sua própria língua, [que] pode ser lida como um meio pelo qual o autor busca restituir à linguagem a sua mal disfarçada estranheza, abalar performativamente as expectativas reducionistas e uniformizantes que nela mesma se forjam e se reforçam. (Martins, 2009a, p. 12)

Inhabit the language of the other, the hostile and unfamiliar language, tied to their disposition to return, often via translation, to one's own language, [which] might be considered as a way through which the author attempts to restore to language his/her own ill-concealed astonishment, to disrupt performatically his/her reductionist and uniform expectations that are forged and reinforced in language itself.

The translators will often experience this "gap" that is only virtually bridged by their works. When faced with the practice of translation, Blanchot tells us that "every translator lives on the difference between languages; every translation is founded on the difference, even when chasing, or appearing to do so, the perverse plan of its suppression." (Blanchot, 1997 p. 58) This practice is marked by an ambiguity that enables the differentiated and exclusive regard of the foreignertranslator: while unable to obliterate the difference (and thus, in nostalgic reminiscence of its own language), they can also regard the other language, as well as their own, as foreign to them. The translator is often at odds to deal with their own native language and experiences the fleeting moments of being "more" native in the foreign language than in their own. Again, Blanchot's comments are very well apropos: "The translator is a writer of singular originality, precisely where he claims to have none." (Ibidem, p. 59)

${ }^{96}$ Beckett was a notorious self-translator and alternated freely between the English, his native tongue, and the French languages. See Martins (2009a, 2009b) for a perspectivist approach of his work. 
This perspective invites us to be open to the idea that a new language involves new worlds and new symbolic apparatuses (Weltbilder). Moreover, we benefit from our position of privileged spectators of the foreign (in this case, Chinese) text as non-native speakers. As such, we are concurrently given the opportunity to face the strangeness of a new language, whose translation is required as a prerequisite for its analysis, while in constant struggle with our own difficulty to deal with these contexts of praxis, thereby causing the imperative of self-questioning our most-entrenched practices and metalinguistic reflections. 


\section{2 \\ The metalinguistic terms}

In the first chapter of this dissertation, I have presented the theoretical affiliations that support what I have christened the Metalinguistic Perspectivism Hypothesis, or $M P H$. In very general terms, as per the $M P H$, metalinguistic repertoires are historically, contextually and culturally determined - they cannot be abstracted from the forms of life of which they are an integral part; they do not get to form autonomous systems of signifiers representing supposedly universal linguistic concepts. Under this view, metalinguistic discourse is, however, of a coercive and normative nature, which means to say that the way we talk about language guides and informs how we perceive and live what is the "nature" of language. This opens the opportunity to envision many distinctive perspectives on language, each of them viable and of equal importance. Being non-intellectual convictions deeply entrenched in our practices, rather than neatly and discernible ideologies, these different perspectives, as we have seen in the previous chapter, allow a reassessment of priorities and necessities without validating or cancelling their alternative viewpoints; or rather the opposite, the perspectives are given increased visibility when brought in productive friction between each other.

This chapter compares and contrasts the histories of a number of metalinguistic terms within the Western and Chinese contexts. Primary focus will be given to terms that appear in the translations of the Lăož̆, the main object of this study. Thus, the present chapter has a double ambition: on the one hand, it is meant to pave the way for the comparative analysis of translations to be given ahead; on the other, it is meant to be, in itself, a first source of evidence to support the MPH.

Within the theoretical framework defended in this dissertation, as we have seen, etymology, as a praxis oriented to recount the history of the use of words, is an epistemologically valid tool that provides valuable information, helping us to gauge the distinctions of metalinguistic repertoires diachronically employed between different traditions. With respect to the specific case of Chinese, one 
must consider an additional layer of complexity arising from the sheer singularity of the Chinese script.

Chinese writing has an undeniable comparative graphic richness and complexity; its characters are recognized as having both semantic as well as phonetic import. It is no wonder then that, while in the West etymology is often prone to arise suspicion ${ }^{97}$ - as a science where, as Voltaire is reputed to have said, "vowels count for nothing and consonants for very little" - the scene should be somewhat different within the Chinese linguistic tradition. The latter considers the grapho-etymological exploration of characters (hànzì 漢字) as a key contributor to the discussion on the semantics of the Chinese words/characters. A source like the Shuōwén, in spite of its age, keeps the patina of the authority of the Chinese canon, and even today it still informs studies on Chinese linguistics and semantics (Wang Li, 2005; Wang Jianjun, 2009), fueling heated debates among Chinese and Western studies alike about the semantic/phonetic nature of the Chinese script. ${ }^{98}$

Thus, grapho-etymological analysis is expected to shed light on the usage of metalinguistic terms in the Chinese tradition and, more specifically, in the Lăož́. The methodological adequacy of grapho-etymology is further reinforced in face of the intimate relationship between metalinguistic practices and the advent of writing systems. (Sylvain Auroux [1992]2009, 2004, 2007) The sheer fact that the linguistic meta-activity of grapho-etymology presents (as we will see in this chapter) a stark contrast to the meta-activity of etymology is in itself evidence that provides support to the MPH. Although they are activities that often share a name (the grapho in grapho-etymology is not part of a standard metalinguistic nomenclature), their methodology and motivations are completely distinct.

\footnotetext{
${ }^{97}$ Taylor (1997, p. 220) and Harris \& Taylor (1997, chapter 1) note that Plato used the hypothesis of a natural connection between words and reality via etymology as a way to insulate language (lógos) from rhetoric and opinion (dóxa). Once this connection proved to be untenable - as suggested in the discussion of the Cratylus - Plato refused to choose between a conventional and a mimetic language, preferring to resort to his doctrine of perfect forms or ideas. Thereafter, etymology lost its epistemological power for the majority of the Greeks.

See also Hutton (In: Love, [2006]2013) for the specifics of the Western etymological survey applied to the attempts to understand the Chinese script.

${ }^{98}$ For reference on this debate, see Gelb (1952), Cohen (1958), Diringer (1962), DeFrancis (1984), Kennedy (1964), Unger (2003) e Allenton (2008), as supporters of the "phoneticist view of writing," and Kratochvíl (1968), French (1971), Hass (1976), Sampson (1985), Ping (1999), Li \& Thompson (1982) e Fischer (2009) for a "semanticist view."
} 
In this chapter I will present the (grapho)etymological histories of a selection of metalinguistic terms from the Western and Chinese traditions. The first part of this chapter will be dedicated to exploring relevant sections of the Western metalinguistic lexicon, from an etymological point of view. The second part establishes a comparison with the Chinese case, addressing pertinent instances of grapho-etymology.

\section{1. \\ Language as a system of representation: etymological drifts in Western metalanguage}

As said above, the metalinguistic terms introduced and etymologically analyzed in this section are those that appear in (or are directly relevant to) the English, French and Portuguese translations of the excerpts from the Lăozl̆ under scrutiny in this study. Before going into these terms, however, it is important to account for some general aspects of linguistic thought in Ancient Greece. Given its foundational stance in the West, this is needed to provide a background for the analyses which will follow in this and in the next chapter.

\subsection{1.}

\section{Aspects of linguistic thought in the Western Classical World}

The linguistic speculations of the Western traditions have been, as per the $\mathrm{MPH}$ presented in the previous chapter of this dissertation, orbiting around the same patterns of questions and major preoccupations. According to the MPH, these patterns have emerged from the background of the evident (selbstverständlich) ideas that became a priori truths for the most part of the linguistic speculation in Europe and the Americas. When paying close attention to Greek metalinguistic words (as well as to their subsequent etymologically-related terms) one finds these patterns etched in their inter-relations and their networks of allusions and connotations. 
Greek metalanguage has evolved and consolidated in the fertile soil of the Greeks' philosophical speculations. Although, as Jean-Luc Nancy (1998, p. 6) has pointed out, it is far from 'easy to define the confines of the 'Occident' (for it did not simply begin in the seventh century BC in Greece)," from the times of Homer and Hesiod, Ancient Greece did provide a crucial historical and influential basis for our Western (metalinguistic) tradition. From around 500 B.C. with the Presocratics and the Sophists, Greek words steadily began to acquire new - some may call more "technical" - uses associated with the dawn of Greek philosophy, the most influential and enduring first attested speculations in the West on the nature of the world, humankind, reality and language. For that reason, Cassin (2014, p. 415) calls Greek the "mother tongue of philosophy." 99 Although a fully developed metalanguage in the ancient World had long been born elsewhere, ${ }^{100}$ it was from archaic and classical Greece that we received a more enduring heritage as well as the guidelines to the inquiries of philosophy of language in the centuries to come. After the groundbreaking works of Aristotle and Plato, by the time of the Stoics we find the first explicit foundational distinction between form and meaning, in addition to a thorough study on "parts of speech" (mérē lógou $\mu \varepsilon ́ \rho \eta \lambda$ ófov) and the first attested use of the term "etymology" (etymologiká

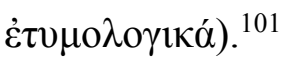

Nevertheless, when discussing the roots of Western philosophy of language, besides the fertile primordial soil of Greece, we must not forget that the longlasting influence of the Greeks was inevitably shaped by its reassessment in the Roman world. As argues Desbordes (In: Auroux, 1995), the Romans borrowed directly and practically unidirectionally from the Greek. The author writes:

\footnotetext{
${ }^{99}$ One needs to be wary of an exaggerated "inaugural" aspect of Greek thought and language. The Greeks themselves were influenced by their own forefathers and by languages and cultures which predated them. However, Greek texts constitute the first historically attested sources in the West of a comprehensive body of speculations on a multitude of aspects related to man, nature and reality that had a direct impact in the formation of what we (hesitantly, in a reductionist manner) call "Western thought."

${ }^{100}$ Metalanguage arguably has origins with the first attempts at writing and with the contact between different civilizations and languages (see Olson, 1994; Harris, 2001; and Auroux, 1995, 2009).

${ }^{101}$ See Bakker (2010, p.494-5)
} 
It is convenient not to treat separately Greeks and Latins in a study of the evolution of the ideas on language, although it is legitimate to establish a distinct assessment of the "heritage," of what is finally latinized in the moment of the rupture. (Ibidem, p. 151)

In the context of the MPH, we should not underestimate the impact of the adaptation of the Greek ideas to the Roman social milieu and of Greek-Latin bilingualism, the need to "translate" the Greek words into Latin discourse. For our purposes here, it will be particularly relevant to consider the "revolution" in the lexicon related to sense and meaning, which consisted of an incredibly heterogeneous vocabulary in Greece, compared to the multi-faceted Latin sensus. (Cassin, 2014, p. 949)

Language plays an important role in Greek philosophical speculations, and their metalinguistic reflections were likewise crucial, not only in the development of the Greeks' thoughts about language, speech and meaning - among other terms - but also in setting a panorama which will prioritize some questions and terms and relegate others. It is nevertheless a consensus that the Greeks were aware of the importance of language to all spheres of human knowledge.

However, the Greeks themselves did not develop either "a full-fledged philosophy of language in general or an explicit account of what was distinctive about their native tongue.” (Bakker, 2010, p. 485) Their major concern was directed towards the world and the "external reality," and language was seen as the necessary, albeit problematic, tool to bridge the gap between reality and the human mind. Language, in this sense, soon became perceived as an echo of other domains:

Significantly, there is no single word in Ancient Greek with more or less the same reference as our term "language." What we do find are nouns for speech "sounds and voice" ( $\varphi \omega \vee \eta ́)$, for "tongue and tongues" $(\gamma \lambda \tilde{\omega} \sigma \sigma \alpha)$, and for what is typically alleged to be the most distinctively human capacity: the capacity for articulate speech as the stating of accounts, which is the natural expression and indeed the inseparable companion of discursive reason ( $\lambda$ ó $\left.\gamma_{0} \varsigma\right)$, the obverse of one and the same coin. (Bakker, 2010, p. 485)

Therefore, Greek terms relating to language will, in different times and contexts, privilege dimensions or domains of language that are the most adequate to make it a reliable tool in the exploration of specific philosophical concerns. The 
articulation of these "aspects" of language will slowly surface from the multifaceted network of terms such as lógos, ónoma, and phoné.

We should not underestimate the impact of these articulations and developments in shaping and informing our future Western metalinguistic reflections. I turn now to these three terms by way of introduction. More of the Greek legacy will be addressed in section II.1.2 below, where I proceed to the etymological analysis of English, Portuguese and French words employed in translations of the Lăož̀.

We begin with lógos (גóyos); the all-important Greek word should be prominently addressed in any discussion of the Western metalinguistic repertoires. In spite of its common association with articulate speech as the natural expression of discursive reason, as quoted from Bakker (2010) above, lógos is likely to be one of the most polysemic of the Greek words analyzed here. Cassin (2014), differently from Bakker, prefers to write that it

\begin{abstract}
has such a wide range of meanings and so many different usages that it is difficult to see it from the perspective of another language except as multivocal, and in any case, impossible to translate it except by using a multiplicity of distinct words. (Cassin, 2014, p. 581)
\end{abstract}

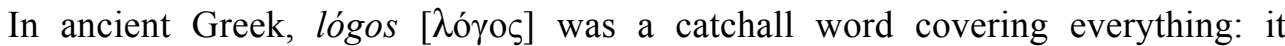
referred to a particular language or tongue, language in general, speech, and more generally discourse, but also the faculty of thinking and of speaking [...] everything, that is, except for the tongue as an organ, for which the term used was glôssa $[\gamma \lambda \tilde{\omega} \sigma \sigma \alpha]$. (Cassin, 2014, p. 544)

Ferrater Mora observes further that the origin of the term has been the object of intense discussions:

El verbo $\lambda \dot{\varepsilon} \gamma \varepsilon ı v$ se traduce por "hablar", "decir," "contar [una historia]." A este facto se ha indicado que ele sentido primario de $\lambda \dot{\varepsilon} \gamma \varepsilon \omega v$ es "recoger" o "reunir": se "recogen" o "unem" las palabras como se hace al leer (legere, lessen) y se obtiene entonces la "razón," "la significación," "el discurso," "lo dicho." (Ferrater Mora, 2009, p. 2202)

The verb légein $\lambda \dot{\varepsilon} \gamma \varepsilon \mathrm{v}$ is translated by 'to talk', 'to say', 'to tell [a story]. To this effect, it has been indicated that the primary meaning of légein $\lambda \dot{\varepsilon} \gamma \varepsilon ı v$ [present active infinitive of légo $\lambda \dot{\varepsilon} \gamma \omega]$ is to collect, to gather or to unite: one collects or unites the words as one reads (legere, lesen) thereupon obtaining reason, meaning, discourse, what has been spoken. 
Chantraine (2009, p. 600) also sees lógos as derived from légō $(\lambda \dot{\varepsilon} \gamma \omega)$, which has, according to the author, the already mentioned original senses of to gather, to collect (rassembler, cueillir), but also to choose (choisir), in the Iliad, whence to count, to number (compter, dénombrer), sometimes to enumerate (énumérer) and to produce insults or offenses (débiter des injures); and, from that, to chatter, to discourse (bavarder, discourir). Afterwards, still according to Chantraine, the word started to be used in the sense of to give an account, to say (raconteur, dire). A derived composite word in this sense is dialégomai $(\delta 1 \alpha \lambda \varepsilon \dot{\gamma} \gamma \mu \alpha 1)$, translated by the author as to converse, to dialogue, to practice dialectics (converser, dialoguer, pratiquer la dialetique). The derived form with $\mathbf{0}$

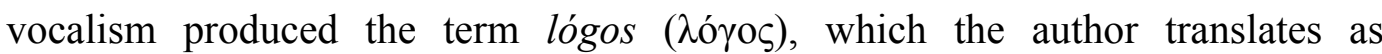
proposition, word (propos, parole).

Légō's etymological roots, according to De Vann (2008, p. 332) are the Proto-Italic *leg-e and Proto-Indo-European *leg'-e/o-, to collect. This author lists many derivatives in both semantic fields: on the one hand, legulus, a picker, or colligere, to gather, to collect; on the other hand, intelligere, to understand; trānslegere, to read out to somebody else. Apparently related to the notions of selection or choosing (with care) are: dīligere, to love, to hold dear; dīligentia, carefulness; and èlegantia, choosiness, refinement, among others.

Peters (1967, p. 110-2) glosses lógos as speech, account, reason, definition, rational faculty and proportion and offers a short history of lógos's uses, the structure of which I follow now, with some complements.

Heraclitus, "in whom it [lógos] first plays a major role," 102 used it in a technical sense as an "underlying organizational principle of the universe" (Ibidem, p. 110) related to the common meaning as proportion, or the rule of change. Both terms, frequently associated with the Greek author, presuppose a harmony guaranteed by a tension of opposites, a stable tension. ${ }^{103}$ Although hidden and only perceptible to the intelligence, in Heraclitus lógos is still a material principle, as seen in its identification with the cosmic fire.

\footnotetext{
${ }^{102}$ For Waterfield (2000, p. 32) lógos is one of the recurring themes in Heraclitus' fragments. ${ }^{103}$ However "not to be understood in the sense of cyclic return."(Waterfield, 2000, p. 111) This is an important point that will be brought in contrast with the Chinese ideas related to dào 道.
} 
Waterfield (2000, p. 32) writes that logos in Heraclitus is something that one can hear ${ }^{104}$ but, that at the same time, it is not any on particular spoken account and, actually, predates any account. Lógos as principle dictates that:

The whole world is intelligent and alive, and speaks to the wise man subtly, communicating its inner nature and enabling him to model himself on it. (Ibidem)

For De Jonge \& Ophuijsen (In: Bakker, 2010), lógos, as early as Heraclitus,

Does indeed conceptualize the conviction that the universe of our experience displays an order which we may hope and attempt to express in terms of proportions and, more generally, relations between components into which it could be analyzed [...]. (Ibidem, p. 486)

In this view, language/thought is a mirror of the (rational) harmony of the kósmos and, even more, lógos does not only represent to us this essence, but also it $i$ s the same essence.

De Jonge \& Ophuijsen emphasize the fact that it is impossible to determine an unambiguous and unitary concept for logos and that since the earliest uses in Heraclitus (as we have seen above) widely differing interpretations have been offered. Heraclitus' texts of the earliest phase of the Greek language already employ the term in a variety of ways, and such polysemies will mark Greek philosophy throughout its tension between logos-bounded reason and the seemingly arbitrariness of language. In Plato's Parmenides, the term stating

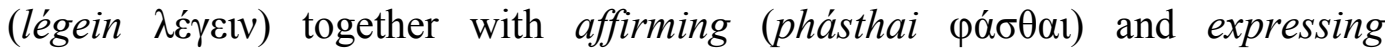
(phráxein $\varphi \rho \alpha ́ \zeta \varepsilon ı v)$ are the bearers of truth in opposition to naming (onomáxein

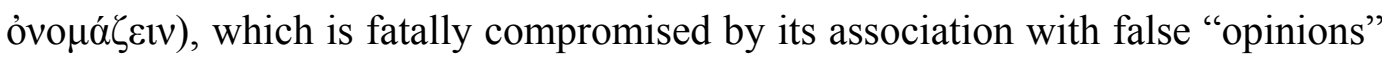
(dóxai $\delta$ ógal). Here lie some of the motivations for the long investigation on the

${ }^{104}$ Waterfield (2000, p. 37) (DK 22B1):

But of this principle [lógos] which holds forever people prove ignorant, not only before they hear it, but also once they have heard it.

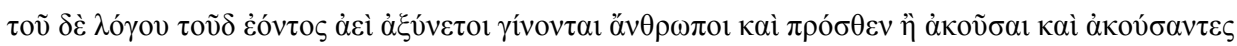

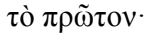


nature of names and the particular interest in etymology that is characteristic of the Greek philosophical texts. ${ }^{105}$

Plato also (Phaedo 76b) famously used lógos in opposition with mýthos $(\mu \tilde{v} \theta 0 \varsigma)$, where the former represents a true and analytical account capable of producing true knowledge. In Thaetetus 201c-d, Plato incorporated lógos to his

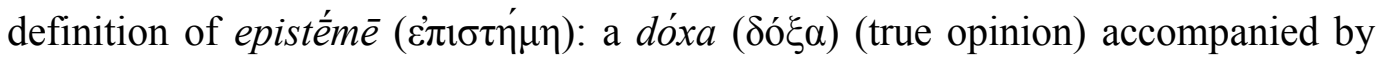
an account. From this context, Socrates used lógos as a statement to distinguish the characteristic of a thing. This account enables a description of the true being

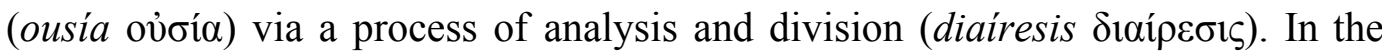
discussion of the Cratylus, Plato also showed that lógos cannot be based on an infeasible "natural connection" between names and reality, thus requiring language to reach beyond the imperfections of the sensual world, and lógos being motivated by the perfect quasi-mythological realm of forms and ideas. This is the only way, according to Plato, that it could produce true knowledge, and thus vindicate Socrates' wrongful death.

Aristotle frequently used lógos as a synonym for hóros (őpos), horismós (ópı $\mu$ ós), that is, definition. ${ }^{106}$ The Aristotelian use of lógos as reason, rationality is, according to Peters (1967), frequently employed in an ethical context - as in

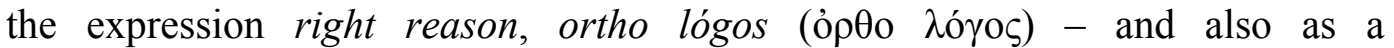
mathematical proportion, ratio. Cassin (2009, p. 584-5) proposes four networks of uses and allusions: 1) lógos as linked to eídos (see below) ("form" as opposed to "matter") and to entelécheia ("act" as opposed to "power"); 2) lógos as voice, discursiveness, rationality, proper to humans (as opposed to animals); 3) lógos as the mathematical ratio (or sense in the actual coincidence between human senses and the objects sensed); and 4) lógos as statement. In this last sense, we see lógos translated as sentence, ${ }^{107}$ related to the central importance for the declarative

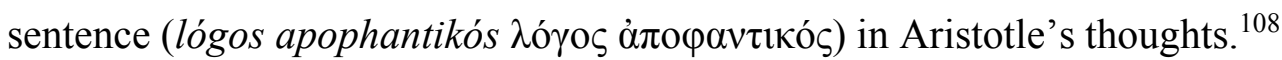

\footnotetext{
${ }^{105}$ More details about the Greek's speculation on names are presented below.

106 The Greek hóros (ópós) is usually glossed as boundary, landmark. Aristotle borrowed these "non-technical" uses for his discussion on logic, using the word to connote definition, species and also a ratio, a proportion.

107 "A sentence is a significant spoken sound some part of which is significant in separation - as an expression, not as an affirmation." (De Interpretatione, 16 26 , translated by Ackrill, 1963)

108 "The first single statement-making sentence is the affirmation, next is the negation. The others are single in virtue of a connective." (De Interpretatione, 17 b, translated by Ackrill, 1963)
} 
The Stoics brought the additional connotation of lógos as an active force in the universe, identified with nature/natural law and Zeus as a pervasive presence. The Stoics proposed the crucial distinction between inner lógos (as thought) and outer lógos (as speech), and this inner/outer distinction was appropriated by Philo of Alexandria for his discussions on the Jewish tradition of the "Word of God." The philosopher used lógos as the transcendent Divine Reason, the instrumental cause of the Universe that is externalized in the intelligible universe (kósmos

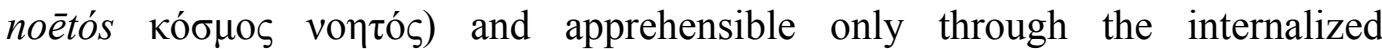
intelligence.

Lógos has entered the Western languages in expressions such as logic or logistic and the morphemes logo-, -logue and -logy. Beyond being something that is said (discourse), it points to the intelligible principle of saying, the reason as universal reason, as well as the rational rule behind all things. Its network of allusions and usages in ancient Greek has had an immeasurable impact on how the Western world's common sense came to apprehend language, thought, logic and, eventually, reality.

In the Greek discussion about language as a system of representation, the relation of names and things named played a crucial role. Gambara (In: Auroux, 1995, p. 79-92) explains that there has never been in Greece an original ancient myth or god associated with the invention of language (or writing), and that the first question that the Greek asked themselves was related to the origin of names, ónoma (óvopa). The names were initially exclusively used in connection with anthropomorphic beings and their creation was not considered a valid question since they were understood as being given, rather than created. Thus, names appeared in a "sociomorphic model," related to a baptism, from the act of bestowing a name. This is the reason why in the beginning all Greek names were perceived as proper names, while the distinction between name and the person named (or god and deity) still did not exist.

Chantraine (2009, p. 775) agrees with Gambara that ónoma was originally the term was used to refer to a personal name ("nom", d'abord de personne) and

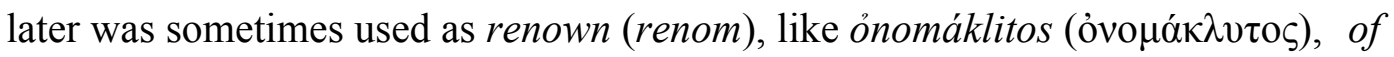


famous name (au nom illustre); or as word, calling name (mot, appellatif) in the opposition of rhèma (see below).

Once more quoting from the Cratylus (423b), there is the famous definition of ónoma, in the dialogue's attempt to find a natural predisposition for the names:

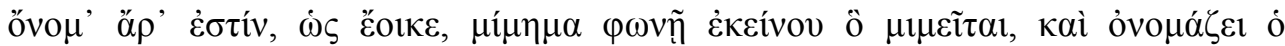

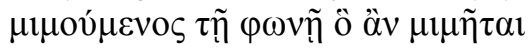

A name, then, it appears, is a vocal imitation of that which is imitated, and he who imitates with his voice names that which he imitates. (translated by Harold N. Fowler, Plato in Twelve Volumes, v. 12, Harvard University Press, 1921)

Onoma in the Platonist/Aristotelian traditions are "names" in the sense that has been discussed above, fitting the Western view of language as a system of representation. The question of the arbitrariness of ónoma has been noticed since the Presocratics and the Sophists and has been a mark of the inconveniences and dangers of language, when referring to the things in the world, due to the lack of a more precise and logical ("mathematical") language. Since Aristotle introduced the "affections of the soul" (thought, mind), name became also the fragile connection between the inner lógos (thought) and the outer lógos (language).

Although the translation of ónoma as word is also common, the Greek word was frequently used in opposition to another Greek term, rhemma ( $\boldsymbol{\rho} \tilde{\eta} \boldsymbol{\mu \alpha})$, translated as that which is said or spoken, word, saying by Liddell \& Scott (1996), and any verbal expression exceeding a word (ónoma) by Urmson (1990). In Cratylus (399b), ónoma and rhèma are opposed to each other in what we might translate as name/phrase or even word/phrase:

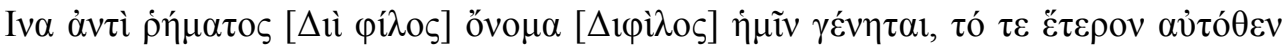

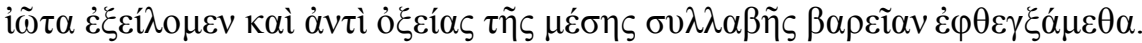

Take, for instance, $\Delta \mathrm{ì̀} \varphi$ í $\mathrm{\lambda o \zeta}$ [Diì philus]; to change this from a phrase to a name, we took out the second iota [1] and pronounced the middle syllable with the grave instead of the acute accent (Diphilus). (translated by Fowler, 1921)

However, this distinction is somewhat flexible, and rhèma also appears in its verbal nature opposing nominal ónoma, for instance in Cratylus (425a) or in Aristotle's De Interpretatione $\left(16^{\mathrm{b}} 6\right)$. In Aristotle, both ónoma and rhèma are subsumed in what might be called word, as the constituents of lógos. 
Cassin argues that both ónoma and rhèma predate these specifications, which are ultimately based on their opposition. The author writes that ónoma is "intimately associated with the oldest and most elementary awareness of the referential function of language" (Cassin, 2014, p. 1243), the idea that language is a nomenclature. In this context, language is representing things in the world, elements that basically are substantives, exactly because they are nominal types of words applied to concrete objects. These "words" initially would be names of particular or proper "things" and "people" and then would gradually refer to categories that are more general. Ónoma is the first entity of language that is recognized as "signifying" and this generic use and meaning will endure in the Greek language.

The last term from the classical Greek lexicon analyzed here, which will provide us with a more comprehensive view of the Greeks' language as a system of representation, is phoné ( 1192) from Homer as sound of the voice, voice, shriek of animals (son de la voix, voix, cri des animaux); to sound in general (son en général) in the Sophists discourse; language (langage) in Herodotus; and phrase, parole in Plato, Plutarch and others. Its many derived names indicate that phoné eventually became restricted to sound of the human speech and human voice. The related verbs are translated variously as talk out loud, to say, to reverberate, to declare (parler haut, parler, résonner, déclarer), etc. Etymologically, this word group has been attached to the one of phemi (see below) with its similar connotations. Chantraine underscores the importance of the semantic values of force and burst and the purely physical aspect of sound in the early origins of the word phèmí.

Liddell \& Scott (1996) gloss phoné by quoting Aristotle in De Anima as the "sound of the voice, whether of men or animals with lungs and throat" in

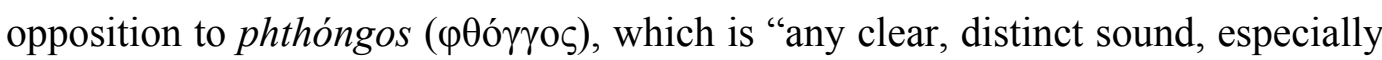
voice of men," but which sometimes appears also to connote speech, sounds in general or musical sounds. This opposition brings phoné closer to the "loudness" of the battle cries of the heroes in the Iliad and the Odyssey and, occasionally, the cry of animals, like swine, dogs and oxen. However, in its other uses, it seemed also to refer to speech and even language (in its oral aspect). 
The relevance of phoné in Aristotle was heightened in his canonical text De Interpretatione. Its famous passage $16^{3} 3$ reads:

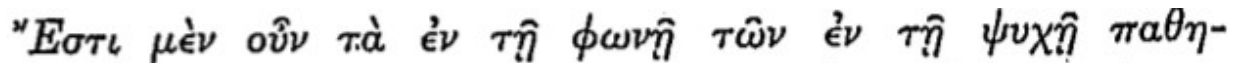

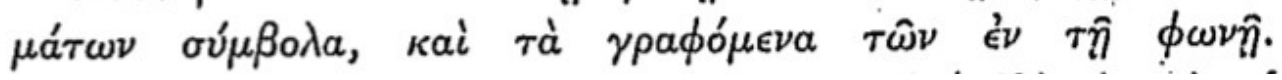

Now spoken sounds are symbols [sýmbola] of affections in the soul [psyche pathēmátōn], and written marks [graphómena] symbols of spoken sounds [phonē]. (translated by Ackrill, 1963)

What Aristotle meant in this cryptic and incredibly influential passage is the subject matter for an uncountable number of books and treatises, a thorough comprehension of which lies far beyond the scope of this dissertation. It is clear, however, that Aristotle's use of the word is proposing an "engagement" between the affections of the soul (psychē pathēmátōn $\psi v \chi \eta \pi \alpha \theta \eta \mu \alpha ́ \tau \omega v)$ and the spoken sounds (phoné $\varphi \omega v \eta ்)$, and likewise between the spoken sounds and written marks (graphómena $\gamma \rho \alpha \varphi o ́ \mu \varepsilon v \alpha)$. This hierarchy gives first prominence to the psychē pathèmátōn, thoughts; of which phoné is a mere secondary symbol, ${ }^{109}$ with graphómena its tertiary symbols. This hierarchy will motivate an incredibly enduring picture of language, which, according to the MPH, has crystallized as the common-sensical picture of language. The subservient position of writing in relation to speech in the West provides a striking contrast to what we shall see in the Chinese tradition.

The Aristotelian semiotic triangle above is intimately related to the problem of meaning and, more specifically, to the question: How are the symbolic representations between thought, sounds and written graphs meaningful? As commented above, we will skip the Greek heterogeneous lexicon - words like

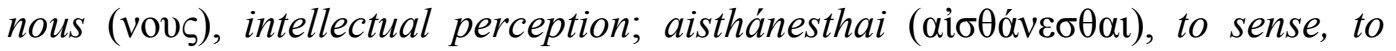
perceive; semainein ( thought - and focus on its reassessment in the Latin tongue with the word sensus.

Meaning and sense, in the Western tradition emerging from the polysemy of the Latin sensus, are projected along the physiological level ("sense organs"), the psychological level (faculty of the senses), the gnoseological level (sense as

${ }^{109}$ For the discussion on sýmbolon, see below. 
intellectual perception, thought, opinion, judgment, mind and intellect) and the logico-linguistic level (idea, concept and mental concept). ${ }^{110}$ With this,

Every sense perception that involves the intellect entails an interpretation of sense data as well as the attribution of mental concepts to data furnished by sensation and expressed through the mediation of linguistic signs. (Cassin, 2014, p. 952)

This polysemy, according to Cassin, did not exist in the Greek language and it was only under latter derivations from the Greek term nous, whose use was restricted to intellectual perception that sensus later unified in Latin. Sensus' polysemy also reflects an ambiguity in the expression common sense, which is very important to its understanding. Its technical sense (Cassin, 2015, p. 948) originates in, on the one hand, Aristotle's sensibility and the convergence of sensations, and, on the other, the more common "good sense," a sense which is shared in the community. This polysemy adds to the "force" of common sense, not only as the product of judgment in a community, but also as the common product of natural bodily perceptions.

\subsection{2. \\ Etymological analysis of Western metalinguistic terms}

Here I address the etymology of a relevant selection of Western metalinguistic terms in four brief sections: 1) terms indicating the general phenomenon or faculty; 2) action terms; 3) terms referring to units or parts; 4) terms related to the graphic dimension. ${ }^{111}$

\footnotetext{
${ }^{110}$ Eng. sense and its correlates in Western languages are directly related to the polysemy of Latin sensus, and are "articulated [as] three major meanings: 1) sensation, sense perception; 2) understanding, intellectual perception; 3) signification." (Cassin, 2014, p. 949)

111 The selection of the metalinguistic terms included here was motivated by the wish to show an overview of the Western linguistics tradition, as illustrated by the metalinguistic terms of English, French and Portuguese, translated from the seven hànzì that are analyzed in the second part of this chapter. Additional semantically related relevant words in the Western tradition are listed in the glossary in Appendix II.
} 


\subsubsection{1. \\ On the general phenomenon or faculty of language}

As we shall see in Chapter III of this dissertation, translators of the Lăož at times employed the Latin-originated words language (Eng.), linguagem (Port.), langage (Fr.). As said before, there seems to be no specific Greek word etymologically related to the modern forms language or lingua/langue:

The first attested meaning of lingua, linguae (ca. 980) was an "organ situated in the mouth" from the Latin lingua [...] the meaning of a "system of expression particular to a group," is attested at the same period [...]. (Cassin, 2014, p. 541)

However, De Vaan (2008, p. 343) writes that the term possibly has poorly

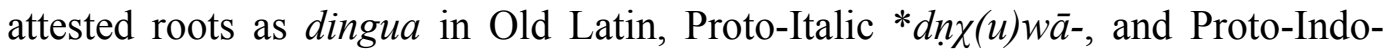
European $* d n g^{h}-u h_{2}$, tongue. Derivative forms include li(n)gula, which connotes short sword, tongue-shaped object.

Cassin (2014, p. 541) writes that in French, the form lentguage was attested to have emerged around the same time as the first attested uses of lingua, designating the human faculty of expressing oneself and communicating, with the metonymical use in expressions that related to lingua as an organ of the mouth (such as mauvaise langue, malicious gossip). ${ }^{112}$ This metonymic extension was also seen in the Greek glōssa (see Appendix II) and pointed to the use as an organ common to humans and animals as well as the faculty of speech, which was limited to humans.

Then, from the Vulgar Latin *linguaticum (twelfth century ca.), the word was used as speaking or speech. The accumulation of many related meanings and confusion between langue and langage, technical and lay, led Diderot's 1765 Encyclopédie to criticize the use of langue to designate vocabulary rather than

\footnotetext{
Moreover, it is worth mentioning that, according to the MPH, any choice of categorization and selection necessarily reflects some amount of arbitrariness and idiosyncrasy. The division of the words into these four sections reflects approximately "our" common-sensical view of the faculty of language: the "general phenomenon" of language is the main object of study, composed of "actions" (verbs), which are articulated with "units" (names, words, signs). Finally, language has an additional "graphic dimension," which is writing.

112 This is the same polysemy of the Eng. tongue or Port. lingua.
} 
language. The author would try to oppose langue to the terms idiome (particularities to a nation and the way it speaks) and parole (language in general), where langue was defined as the totality of the usages of the voice belonging to a nation, insofar as "the expression and communication of thoughts according to the most universal views of mind, and the views most common to all men." (Ibidem)

Another term that appeared in the translations to refer to language as a general phenomenon is discurso (Port.); discourse (Eng.). Discourse - and cognates in Western languages - is "a transposition of discursus from the Latin discürrěre (to run here and there, run through all directions)." (Cassin, 2014 p. 223) At the base of the Latin word we have cürrěre, to run, related to current, both words stemming from the supine curs-(um), connected to cursus, a running, a course. (Klein, 1971, p. 172) Port. curso was originally used as current, flux, direction. (Cunha, 1982, p. 196: corrente, fluxo, direção) Latin cŭrrĕre, to run, had a long list of derivatives (cursor, runner; concursāre, to run together; intrōcurrere, run inside; incursus, attack; cursāre, to rush to and fro, etc.) and is supposed to have the Proto-Indo-European *krs-e/o-, to run, as its etymological root. (De Vann, 2008, p. 157) De Vann writes further about a cognate Greek word,

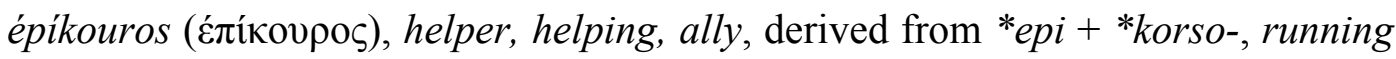
towards. For épíkouros, Chantraine (2009, p. 342) writes the gloss troupes that come to the aid, allies (troupes qui secourent, alliés), and from that, a more general sense of one who helps, who brings help, who protects (qui aide, qui porte secours, qui protège).

Discursus acquired the sense of “"conversation, dialogue' rather late, following a metaphor that highlights the hazardous nature of verbal exchange." (Cassin, 2014 p. 223) With this connotation of correct reasoning and even "rationality", discursus becomes one of the received translations of lógos. The confrontational/argumentative and logical natures of discourse seem to be both influential in the history of the word. However, these are not senses that became prominent in later uses of language, as it seems clear from the first entry on the word respectively in the Oxford English Dictionary and the Merriam-Webster: ${ }^{113}$

${ }^{113}$ Source: <http://www.merriam-webster.com/>. Accessed February, 2015. 
The method of human communication, either spoken or written, consisting of the use of words in a structured and conventional way: a study of the way children learn language / [as modifiers] language development.

a: the words, their pronunciation, and the methods of combining them used and understood by a community

b (1): audible, articulate, meaningful sound as produced by the action of the vocal organs (2): a systematic means of communicating ideas or feelings by the use of conventionalized signs, sounds, gestures, or marks having understood meanings (3): the suggestion by objects, actions, or conditions of associated ideas or feelings [...] (4): the means by which animals communicate (5): a formal system of signs and symbols $[\ldots](6)$ : machine language.

According to the view of language as a system of representation, it is symptomatic that among the senses that survive more prominently in Western languages, we should not find notions relating to the hazardous, but quite the contrary, to order, calculus and articulation.

\subsubsection{2. Action terms}

Metalinguistic terms related to linguistic action include to speak/speech, (Eng.), falar (Port.); dire (Fr.)/dizer (Port.); to say (Eng.); to call (Eng.); appeller (Fr.); chamar (Port.); and to style (Eng.). ${ }^{114}$

With respect to speak, it relates back to the Old Norse spraki, rumor, report, a cognate with the Welsh ffraeth, eloquent, both derived from the base *sprek-, to speak that "originally" meant to make a noise, shout, cry, crackle. (Klein, 1971, p. 702) It has the Indo-European base *sper(e)g- or *spher(e)g-, to strew, sprinkle, to sprout and burst, whence the Greek spharageĩn ( $\sigma \varphi \alpha \rho \alpha \gamma \varepsilon \tilde{v})$, to crackle, and Latin spargere, to scatter, to sprinkle.

Although Partridge (2006, p. 3152) follows a different line of derivation as to the network of allusions regarding speak and cognates, his conclusions are similar to Klein's. The author departs from the past principle of Latin spargere,

\footnotetext{
${ }^{114}$ Although style has a more opaque metalinguistic use than the other words in this section, it is used as a verb in English referring to the act of giving an inaugural name.
} 
sparsus, to present its rich list of derivatives in English: sparse, disperse, dispersion and also spark, sparkle, asperge, asperse, etc. Partridge writes that the

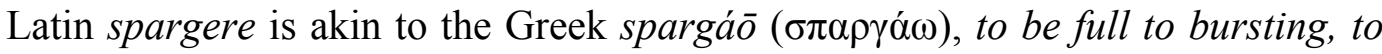
swell, be ripe, to teem or abound, and proposes the Indo-European root *spar-, as a variant of *sper-, with an extension and variant *sphereg- (as Klein), whence the Greek spéirō ( $\sigma \pi \varepsilon i ́ p \omega)$, to sow, especially by broadcasting them (whence the Eng. sperm).

From these etymologies, one notices an Indo-European base that was used to refer to "bursting-like acts" where something is scattered or sprinkled, with a loud noise and explosion involved (crackle, sparkle, sparse). Afterwards, there was a development limited to the Germanic languages, via the base *sprek-, that led to the emphasis on sound (such as the Old Norse spraka, crackle) and to sounds of language, to the point that nowadays there seems to be no remnants of the ideas related to scatter or burst in recent uses of speak.

Port. falar is glossed by Cunha (1982, p. 284) as to speak, to express using [spoken] words (dizer, exprimir por palavras). ${ }^{115}$ The author links the word etymologically with the Latin fabŭlārī, which, writes De Vann (2008, p. 231), is derived from for, fārī, to speak, to say, with a multitude of cognate words, such as fātum, prophecy, destiny; fāma, news, rumor, public opinion, reputation, fame; fābŭla, talk, rumor, story, tale; fateor, to confess, to admit; etc. Its etymological roots, according to the author, lie in the Proto-Italic *fa-a-, to speak, and ProtoIndo-European $* b^{h} e h_{2^{-}} /^{*} b^{h} h_{2^{-}}$, to speak, or $* b^{h} e h_{2}-m o / h_{2^{-}}$, speech. From these roots, De Vann also points out the derived Greek word phēmi $(\varphi \eta \mu)^{116}$ and its

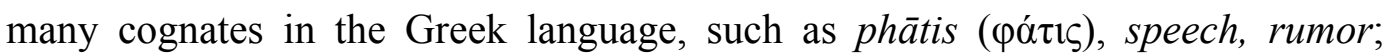

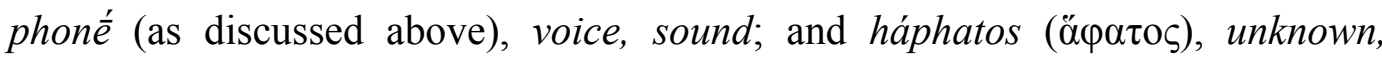
ineffable.

Chantraine (2009, p. 1151) glosses phèmí as to declare, to affirm, to claim, to assert frequently with emphasis (déclarer, affirmer, prétendre, dire, souvent

\footnotetext{
${ }^{115}$ While the Port. falar and the Fr. parler are extremely important and common verbs, there is no direct etymologically related word of importance in English. The words in English are related only via the Latin fäbŭla, story, tale, as well as in the words fable, fabulist, fabulosity, fabulous; confabulate, confabulation; and, from cognate Latin färi, affable, ineffable. (Partridge, 2006, p. 1038)

${ }^{116}$ For the etymological roots of phēmí (a cognate of phoné, see above), see next paragraph.
} 
avec emphase), as well as to say yes (dire oui), and also to believe, to think, to imagine (croire, penser, s'imaginer). Etymologically, Chantraine links the athematic radical verbal present form phèmi stemming from the Indo-European

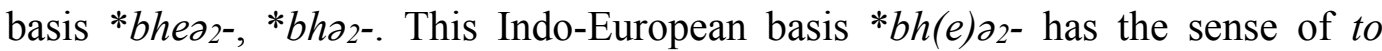
shine, to light up, as well as to declare, to expose, to say. The semantic connections between speech, the act of speaking and shedding light, enlightening are unmistakable in the Western tradition.

Dire (Fr.) and dizer (Port.) share the same etymological root, the Latin dìcēre - De Vaan (2008, p. 169) glosses the Latin dīcō, dìcēre as to talk, to speak, to declare. There are also derivative terms that allude to different types of engagement: addictus, enslaved person; condīcere, to engage oneself in, fix by contract; condīcio, contract, term; from indicium, disclosure, sign, we find legal terms, such as iüdex, judge; iüdicium, legal process, trial, etc. De Vaan notes that the Oscan cognates meddiss, meddis, judge (Chantraine, 2009: the one who states the rights, celui qui dit le droit), stems from the Indo-European root *med-, whence the Greek médō ( $\mu \varepsilon ́ \delta \omega)$. Chantraine $(2009$, p. 650) observes that the root *med- has a wide array of uses: a more general sense in Latin modus, meditor, but also in terms related to medicine and medication (Latin medeor, medicus); in German terms related to measure (messen); in the Armenian mit, thought (pensée); etc. These are all terms that in general "express the notion of a thought which regulates, orders and moderates" (experiment la notion d'une pensée qui règle, ordonne, modère)." (Chantraine, 2009, p. 650)

For Latin dīcō, dīcēre, De Vaan (2008) suggests the Proto-Italic root *deik$e / o-$, to say and the Proto-Indo-European root $* d e i k-e / o-$, to show, which has a Greek derived word deiknȳmi ( $\delta \varepsilon 1 \kappa v \bar{\nu} \mu)$, to show, to demonstrate, to indicate, attested in Homer by Chantraine (2009, p. 246). Deiknȳmi has the verbal present form deíxo $(\delta \varepsilon i \xi \omega)$, whence the very important term in Aristotle - and in Greek philosophy in general - deīxis $(\delta \varepsilon \tilde{\varepsilon} \xi 1 \varsigma)$, mode of proof with many cognate and

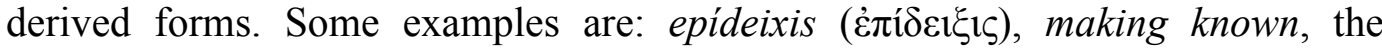
Sophist term for rhetorical effectiveness, the performative aspect of the speech

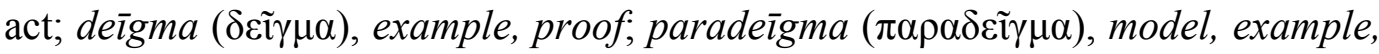

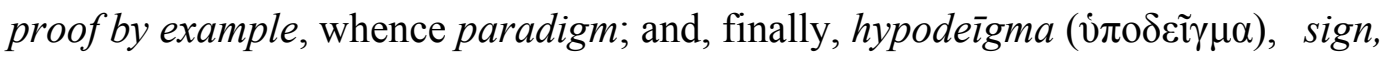


token, model, indication. In this group of cognates, proof is articulated with what is shown, becoming thereafter a model or example or even a sign.

Chantraine (2009, p. 272) also writes that there is a clear etymological

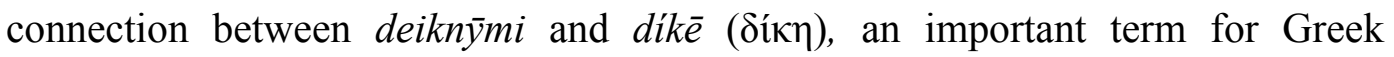
philosophy that has been variously translated as custom, manner, fashion, order, law, justice, punishment, trial, penalty, vengeance, righteous, equal, even, balanced, lawful, just, real, genuine, observant of customs and civilized. Cassin (2014, p. 1124) writes that dikè's etymological relation with deiknymi (to show) and Latin dīceere (to say) offers two - possibly complimentary - interpretations: 1) if one starts from deiknȳmi, dike would consist of designating a straight line, a dividing line between two properties, "judging" what belongs to whom; 2) if one starts from dīceere, the passing of judgment will be more "fundamentally" a speech act. Whatever the preferred interpretation, dike's etymological networks are arguably seen as testimonies to the power of language to pass judgment and assign rights and justice.

Partridge (2006, p. 2894) writes that the say has the Germanic *sagja- and Indo-European *sek- (*seqw-, after Klein, 1971, p. 658), speak, speech, to say. From the Indo-European, words have been derived in Hittite shakiya-, to declare (Klein, Ibidem), Old Norse segia (whence saga, a story), Latin inquam, I say, and

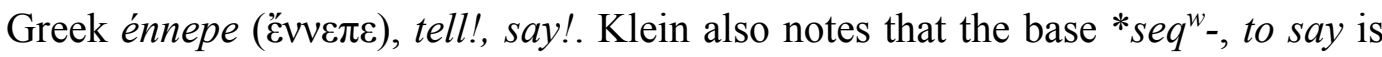
originally identical with the base ${ }^{*} \operatorname{seq}^{w}$-, to see, the latter having developed the allusions of to show, point out, remark, say. This etymological proximity of say and see is remarkable and seems to reflect the observation above about the affinity of speech, the act of speaking and shedding light, enlightening.

Call has roots in Old High German kallōn, to call, cognate with Middle Irish gall, glory, swan and Old Slav glasŭ, voice; glasiti, to cry, announce; glagolü, word; and glagolati, to speak. (Klein, 1971, p. 107) Partridge (2006, p. 390) notes that there is an obscure, albeit extremely probable, relationship to the Latin calāre, to announce, to summon and clamāre, to shout. From the Latin word, Klein $(1971$, p. 85$)$ suggests the Proto-Indo-European root $* k e h l_{1^{-}} / k h l_{l^{-}}$, to call,

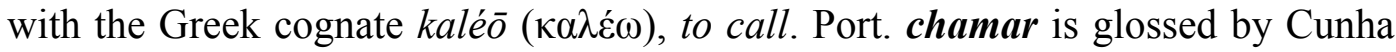
(1982, p. 145) as to call out loud someone's name, to convene, to name, to 
denominate (dizer em voz alta o nome de alguém, convocar; nomear, denominar). Cunha writes that its etymological origins stem from the Latin clamāre, thus it is a probable cognate with the Eng. call.

Fr. appeler is derived from the Latin appelāre, to speak to, to appeal, which Klein (1971, p. 456) explains as a derivate from pelāre, pellōo, to beat against, to push, strike. From the Latin we have the Eng. pulse, pulsate, push, and compounds in appeal, compel, compulsion, expel, expulse, impulse, impel, repel, propel and many others. In French, we find appeler in the tenth-century as to address someone (s'addresser (⿳亠丷)), and later uses weakened, rendered as to name, to designate (puis, par affaiblissement, 'nommer', 'dé signer'). (Ernout \& Meillet, 2001, p. 40) The Latin origins of appeler point to a more "enforced" mode of addressing someone.

Partridge (2006, p. 4179) and Klein (1971, p. 724) writes that style is derived from the element -stylar, as in peristyle, a row of columns forming an enclosure or any area so formed. The element has its origins in an Indo-European

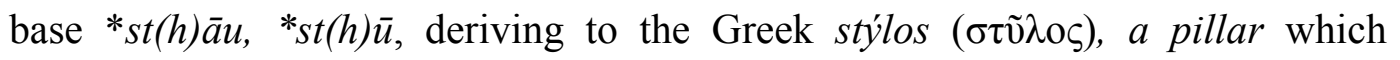
eventually became an abstract form to describe a room, a space and subsequently had even more abstract uses.

Partridge (2006, p. 3240) and Klein (Ibidem) write that style has another etymological origin, as derived from Latin stilus, with the Indo-European root *sti- or *stei-, to pierce, whence stemmed a large collection of cognate words in many languages, such as Greek stígma $(\sigma \tau i ́ \gamma \mu \alpha)$, tatoo mark, a brand and derived stigmatize and Latin stimulus; instigator, instigator; distinguere, to distinguish; and instinguere, to goad, to incite and even instinctus. More directly related to style, as a noun glossed by Klein (Ibidem) as pointed instrument for writing, whence way of writing, of speaking; akin to stiletto, stimulant and, without s-, even ticket, etiquette and tiger.

More often used as a noun, as a verb style is commonly employed as an inaugural name or a new title, given to someone (or something) due to some feat or achievement. In the Oxford English Dictionary, to style has seven major acceptations: 1) Of a person: To give a name or style to; to call by a name or style / Of a thing: To invest with a right to be called; 2) To name or address with 
honorific titles; 3) To relate or express in literary form; 4) To order, direct to a purpose; 5) To pierce with a stylet; 6) To execute (a design) with a stylus on a prepared ground; and 7) To design, arrange, make, etc., in a particular (esp. fashionable) style.

For the words from the three languages above, Eng. call, to style, Port. chamar and Fr. appeler, the usage today is such that, as a past participle (called, chamada/o and appeléle), the word becomes another property of the object thus named. The performative act of the verbs and the process of "assigning (a new) a name" have been obscured by the illusion that the object's name is another one of its (fixed) properties. Thus, for instance, when we have the habit of saying "the portable telephone is called cellphone," the object under reference increasingly becomes known as having the property of being a cellphone. Although this "ontologization" of names is a characteristic of the representational view of language, we will also revisit it in the context of the Lăož̀ in chapter III of this dissertation.

\subsubsection{3. \\ Units or parts}

We now turn to terms that are usually regarded as relating to countable units or parts of language: name (Eng.) / nome (port.) / nom (Fr.); word (Eng.); and sign (Eng.).

Name comes from the Indo-European bases *enomen, *onomen, *nōmen, and is cognate with Greek ónoma and Latin nomen. (Klein, 1971, p.486) Cognate words in different Indo-European languages refer to name, to name, be named by name, to call, nominative, etc. ${ }^{117}$ The Oxford English Dictionary shows glosses that are much in line with the previous discussion on ónoma, above, and the representational view of language:

\footnotetext{
${ }^{117}$ For the analysis of the Greek ónoma, see above.
} 
n. 1 a word or set of words by which a person or thing is known, addressed, or referred to $[\ldots]$

2 a famous person $[\ldots]$ a reputation, especially a good one $[\ldots]$

3 (in the UK) an insurance underwriter belonging to a Lloyd's syndicate.

v. [with obj.] 1 give a name to [...]

identify correctly by name $[\ldots]$

call someone or something by the same name as [...]

give a particular title or epithet to [...]

mention by name $[\ldots]$

BRITISH (of the Speaker) mention (a Member of Parliament) by name as disobedient to the chair and thereby subject to a ban from the House.

2 specify (a sum, time, or place) as something desired, suggested, or decided on $[\ldots]$

As for the etymology of word, let us first note that, among the Greeks, there is an unclear boundary between two of the most central metalinguistic terms in English: name and word. Cassin (2014) writes that

\begin{abstract}
In Greek and Latin, everyday language did not contain a term devoted specifically and monosemically to a linguistic entity that correspond to the word and that was endowed with its general properties. [...] As for the designation "word," which since Plato had been confused with that of "name," onoma [óvo $\mu \alpha]$, from the Hellenistic period onward it was expressed by the term lexis $[\lambda \dot{\varepsilon} \xi 1 \zeta]$ : "word" was understood at that time to mean "part of speech." (Ibidem, p. 1243)
\end{abstract}

Therefore, only after the Alexandrine tradition was léxis $(\lambda \varepsilon \dot{\varepsilon} \xi 1 \varsigma)$ recognized as an autonomous segment of language, with both sound and meaning, although its status within the Greeks' philosophy of language will vary widely with time and author.

Word shares its etymological roots with the Latin verbum, both being derived from the Indo-European *werdh (Klein, 1971, p. 831; Partridge, 2006, p. 3670), a word, which is an enlarged base from *wer-/*were-, to speak, spoken word. Partridge presents a long list of cognate terms, all deriving from Latin, such as verbum, the word of God; verbatim, word by word; verbōsus, verbose; as well as more opaque connections, such as Old French verve, fantasy, lively imagination.

From the Indo-European root stemmed the Greek erō ( $\dot{\varepsilon} \rho \omega)$, to say, to speak and the substantive eirōn (Eì̄ $\omega v)$, a dissembler, one who says less than he thinks, 


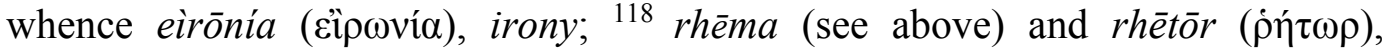
speaker, public speaker. There are many cognates with related semantic notions in Indo-European languages, for example: Old Indian vratám, command, order; Old Slav rota, oath and vračl, physician, magician; Sanskrit vratá-, vow, religious observance, commandment; and even Ossetic irod/orwoe, bride-money (!).

The Oxford English Dictionary presents us a fraction of the plethora of modern uses for word in English. The dictionary highlights five major acceptations: 1) a single distinct meaningful element of speech or writing; 2) a command, password or signal; (short) communication, news; 3) one's account of truth; promise or assurance; 4) text or spoken part of play, opera, etc; 5) basic unit of data in a computer.

The analyses above should not prevent us from recalling that word (and related Port. palavra or Fr. mot) has had an exceedingly problematic definition along the history of the language ideas. The fact that it is more easily recognized in written than in spoken language might have contributed to the difficulties in putting word into the precise demarcations required by the scientific discourse. This will have a relevant impact in the comparative study between word and the related Chinese metalanguage.

Sign is derived from the Latin signum, a distinguishing mark, a sign, a signal. (Partridge, 2006, p. 3037) The Latin word, according to the author, has obscure origins, but is probably akin to the root sec-, to cut. Its etymological roots lie in the Proto-Italic *sekno-, statue, sign and Proto Indo-European *sek $\left(h_{2}\right)-n o-$, cut. This "etymological appurtenance" to Latin secō, cut, as writes De Vann (2008), implies what the author calls a semantic shift from what is cut out, carved out $\left({ }^{*}\right.$ sek-no) to sign, to make a sign. Sïgnum is cognate with the Latin significāre, which was likely to have followed the same semantic shift, towards to make a distinguishing mark, hence to show by marks or signs, to mean. De Vann (Ibidem, p. 563) lists other cognate words of signum in Latin, such as sigillum, statuette, relief; insīgnis, clearly visible, remarkable; sīgnāre, to mark with a sign, to

\footnotetext{
${ }^{118}$ Its seems to be ironic that in the etymological roots of one of the Greek verbs related to "to say" is also the source of the word used for irony, perhaps a sign of the lower status of language in comparison to the mind, the affections of the soul. However, the fact that this verb, eiro is never used in the present form, being substituted by légo, among other options, may counterbalance this supposition.
} 
indicate, to seal; dēsīgnāre, to mark out, to plan; significāre, to indicate by signs, to mean; and significātio, meaning, sense. The connection between a (physical) mark and meaning, sense, is another indication that the meaning of an object, in the common-sensical Western view of language, is a (fixed) mark, a property, of the object, which thus becomes "signified."

The Oxford English Dictionary attempts to convey in its three glosses the semiotic functions of sign: 1) an object, quality, or event whose presence or occurrence indicates the probable presence or occurrence of something else; 2) a gesture or action used to convey information or an instruction; and 3) a notice on public display that gives information or instructions in a written or symbolic form. ${ }^{119}$

\subsubsection{4.}

\section{The visual dimension}

The terms pertaining to writing or the graphic dimension of language which will appear in the analyzed translations and deserve our attention here are grafia

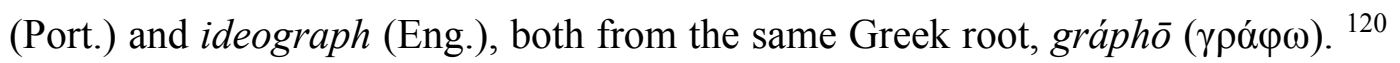
Additionally, I will present a brief discussion of image, which in the Western vocabulary has the metalinguistic function as simile or metaphor ${ }^{121}$ and which is particularly important in the discussion of the Chinese metalinguistic lexicon. These terms will later be altogether relevant in the interplay between language and its visual dimension (centered on writing) in the Greek and Chinese traditions.

Graph is glossed by Klein (1971) as a diagram, and the element-graph as "combining form, meaning either something written or something that writes." (Ibidem, p. 320) The author brings the Greek verb gráphein ( $\gamma \rho \alpha \dot{\varphi} \varphi \varepsilon v)$ ), to scratch, engrave, draw, together with other non-Indo-European cognates in order to give

\footnotetext{
${ }^{119}$ The dictionary also presents two extra glosses, for the use as zodiacal sign and as mathematical sign.

${ }^{120}$ Chantraine (2009, p. 226) glosses gráphō as to scratch/scrape, to trace, to draw, to write, whence to write a decree (érafler, tracer, déssiner, écrire, d'où rédiger un décret).

${ }^{121}$ The Oxford English Dictionary has the following example to illustrate this use: "he uses the image of a hole to describe emotional emptiness."
} 
an idea of the semantic amplitude of the history of the term, as in Hebrew $k^{e}$ thöbeth, tattooing (related to kätábh, he wrote), or the original sense of Arabic kátaba, he sewed together (later, also he wrote). The newborn activity of writing was therefore closely identified with other similar activities, such as drawing, making figures, or even making patterns.

First found in the Iliad, the notion of to scratch, to scrape is considered by Liddell and Scott (1996) the "original sense" of the word. Chantraine (2009, p.227), on the other hand, chooses the alternative to trace a line (tracer une ligne), from a moment when the boundaries between drawing and writing were much less clear than considered later on. The nominal form graphés ( $\gamma \rho \alpha \varphi \eta ́ s)$ is translated by Chantraine as drawing, painting, writing, catalogue (dessin, peinture, écrit, catalogue), but also criminal pursuit (poursuite criminelle), in its opposition to dike (see above). There is a long list of post-Homeric cognate forms with an array of prefixes and suffixes, designating, for instance, painter, scribe, copyist, paintbrush, portraitist, secretary, historian, and what is written, among the substantives; and to copy, to answer, to translate, to transcribe and others, among the verbal forms. The judicial use of gráphō is noted by Liddell \& Scott (1996), as

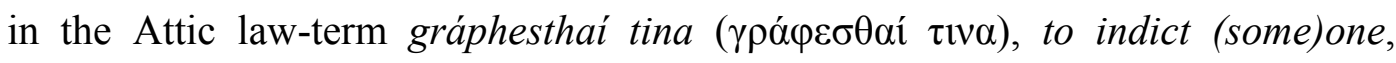

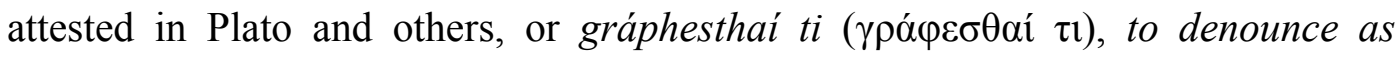
criminal, used by Democritus.

Chantraine (2009) evaluates as uncertain the etymological origins of gráphō, offering a speculative theme *gerbh-, which gave the Anglo-Saxon ceorfan, to cut, to engrave (couper, faire un entaille).

Latin also had a seemingly etymologically unrelated term to refer to the activity of writing, scrībere (whence Port. escrever and Fr. écrire). De Vaan (2008, p. 546) writes of possible roots in the Proto-Italic *skreif-e/o-, and ProtoIndo European $*_{s k r e i b}{ }^{h}-e / o$, both glossed as to carve. There is an unclear connection with the Greek gráphikos ( $\gamma \rho \alpha \varphi \iota \kappa o ́ \varsigma)$.

In English, the word writing is also not etymologically related to gráphō and Partridge (2006, p. 3828) proposes that it stems from the Indo-European * wreid-, to tear or to scratch, to carve, to incise, whence, to write. Klein (1971, p. 833 ) writes that the etymological roots of write - for instance, in the Old English 
wrìtan, write and the Old High German ri3, stroke, letter - are possible cognates

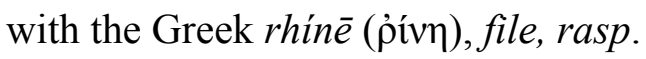

Later on, Indo-European languages developed a strong differentiation in their lexicons between words used to indicate writing and words to indicate activities like drawing or carving, thus conceding a differentiated status to writing. Although from apparently distinct etymological sources, grapho, scrībere and writing all share old connotations related to scratching, or carving and are therefore testimonies of a time when "writing" had a much more ample semantic latitude.

Regarding image, Partridge (2006, p. 1502) writes of the Latin root imāginem, the accusative form of imāgō. This last word would be a composite of *im-, to picture, and -āgo (substantive particle). This obscure root *im- might occur in the Latin imitārī, to seek to reproduce the image of, to imitate.

De Vann (2008, p. 298) suggests the Proto-Italic root*imā(je-) and the Proto-Indo-European root $* h_{2} i-m-h_{2^{-}}$, image, a cognate with Hittite himma-, imitation, substitute. The author writes that both imāgō and imitārī are derived from an earlier verb *imā-je/o-, but the Proto Indo-European roots are poorly attested, some suppositions pointing to words indicating (to) copy and twin. Klein (1971, p. 367) also considers both image and imitate as cognates, the first being derived from the stem of the second, and the author also adds a third cognate in emulate, from Latin aemulārī, to strive to equal.

In these sources there is no mention of a metalinguistic function of image, which however becomes evident in the word's third gloss in the Oxford English Dictionary: 1) a representation of the external form of a person or thing, in sculpture, painting, etc; 2) the general impression that a person, organization, or product presents to the public; 3 ) a simile or metaphor.

The metalinguistic divagations above showed us how, in the mists of time, countless uses of words were apparently forgotten by their present speakers. Examples are numerous: to scratch, to draw while writing; signs as carvings; the compulsion and impulsion in the Fr. appel; the inaugural force of naming; the force of calling which creates a new, apparently indelible, characteristic of the object called; Port. dizer as a mode of proof; to spread out and disperse the words 
in Eng. to speak, etc. However, these past uses have, unbeknownst to us, influenced - and still influence - the crystallization of prototypical images and allusions which lead us to perceive as commonsensical and obvious the representational view of language with all that it entails: the literal, compositional, universal, rational and declarative nucleus of language; the strict separation between subject and object in our scientific investigations, etc. The etymologies presented are likewise testimonies to the development of the crystallization process, to the "construction of common sense" (as per MPH), thus providing evidence of a historically and contextually situated process - the intrusion in our "daily language" of past speculations on the philosophy language and vice-versa.

\section{2. \\ The case of Chinese}

I have selected seven metalinguistic characters from the Lăož̆ - characters that the authors here under scrutiny had to translate, and for which some of the words discussed in the first part of this chapter were deemed satisfactory renderings in English, French or Portuguese. These characters are presented here, and their grapho-etymological histories and networks of allusions are compared with the semantically related Western terms. Some of the character-words included here may not seem to fit the usual definition of metalanguage as lexical terms that have language as their own reference. I will argue that the issues related to such a categorization - whether these terms "are" metalinguistic terms or not directly pertain to the objectives and purposes of the present dissertation.

First, and foremost, is dào 道, the extremely important character that lends its name to the philosophy - and later also to the religious practice - associated with the Lăožr. Though not usually recognized as a metalinguistic term per se, its translations and glosses in dictionaries uncover the reflexive aspect of its use, with remarkable implications for the Lăož̀s (and the Chinese's) conception of language. 
When reading the Lăož́, one often realizes that one of the central issues in the text concerns the question of names. What can be conceived of as a naming function - and often translated as such - appears prominently in the first lines of the Lăož̆, where its writer is faced with the problem of trying to refer to a dào 道 - an "entity" that seems elusive to definition or reference. We may ourselves interrogate whether this is really an attempt to create name labels in the sense of representational practices (a signifier / signified pair), or whether we are facing another way to use and experience language. The characters yán 言 and míng 名 are intimately pertinent to this matter and they will be analyzed in some detail.

The question of the materiality of language resonates, in the Chinese tradition, in wén 文, one of the central characters in Chinese literary thought. Although in the Lăož̀ wén 文 appears only twice, it is impossible to think of culture, language and knowledge in Chinese without a careful study of this character, especially in its opposition to $z \boldsymbol{i}$ 字, another key term in the Chinese metalinguistic lexicon. The problem of writing and speech and their relationship to knowledge will also emerge from the analysis of these two characters.

Nowadays the character $\boldsymbol{y} \boldsymbol{\imath}$ 義 is often translated as meaning, giving it a protagonistic role in the study of semantics in Chinese and the question of the meaning of language. The fact that such an important term appears in only three chapters in a text like the Lăož seems to be an indication of the different status of (our) meaning in this book and deserves closer scrutiny. ${ }^{122}$

Finally, the series of metalinguistic characters closes off with xiàng 象, which plays a leading role in the discussion of image representation in the Chinese tradition. Due to the blatantly graphical nature of Chinese writing, this character is also very closely associated with the question of representation in the language and the Chinese script.

The seven characters are followed by their gloss(es) in the Shuōwén and their discussion in the secondary sources. Afterwards, I will present the analyses

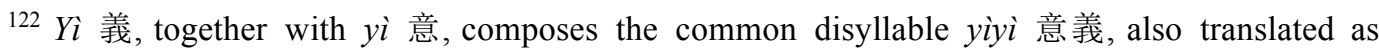
meaning. $Y i$ 意is completely absent from the Lăož̆. 
of the glosses, when available and relevant, from the other major ancient etymological sources, the Ěryă, the Shiming and the Fāngyán, followed by other major glosses from Chinese canonical texts, whenever deemed applicable. The original glosses themselves with my own translations are available for further consultation in Appendix I. Additionally, in Appendix I are some samples of each character in the writing styles predating the Shuōwén besides supplementary glosses from modern and contemporary sources.

Further discussions on the impact and importance of the seven characters in Chinese traditional thought and writing will be restricted as much as possible, for reasons of scope and space. This is particularly true about dào 道, which has been the subject in innumerous treatises and scholarly works.

In the end of each section, the analyses will be contrasted with the information from the Western metalinguistic repertoire to provide the necessary background to conjecture a comparative study of the networks of allusions gravitating around the key terms from both traditions (Chinese and Western). As already said, their comparison will offer support for the MPH and provide background information to the critical readings of the passages and translations from the Lăož̆, in chapter III of the dissertation.

\subsection{1.}

\section{Dào 道: to say, to speak, speakable, to guide}

Dào 道 is a key term in understanding, not only the Chinese thoughts on language, but also the Chinese philosophical tradition. Although the Lăož is not a book that specifically focuses on the question of language, the fact that its most important character, dào 道, also has metalinguistic uses is a sign of how its linguistic and philosophical aspects are inextricably connected.

Whole books have been written about dào 道, and the present work does not intend to provide new insights into its importance to Chinese traditional thought and the philosophical and religious implications developed around it. 
Contrariwise, I will focus on the (grapho)etymological origins of the term and on what has been written in regard to its reflexive and metalinguistic impact.

The character dào 道 has its origins linked to the cognate character dăo 導, in an almost perfect example of the traditional shēngxùn 聲訓 method. ${ }^{123}$ We will start with the graphical analysis of both characters in the Shuōwén:

for dào 道:

道: 所行道也。从定从息。一達謂之道。

dào: suǒ xíng dào yě. cóng chuò cóng shǒu. ȳ dá ${ }^{124}$ wèi zhĩ dào ${ }^{125}$

dào: The path that is walked/traveled [xing 行]. From [the radical] 定 chuò [walking], from shǒu 首[head, first]. Whoever arrives [dá 達] is called dào 道.

And 崖 for dăo 導: 導: 導, 引也。从寸道[

題]聲。

dăo: dăo, y̌̆n ${ }^{126}$ yé. cóng cùn ${ }^{127}$ dào shēng.

dăo 導: [From] guiding/leading [y̌n 引]. From the [radical] cùn 寸, and [from] the sound [of] dào 道.

123 The so-called paronomastic method, shēngxùn 聲訓, consisted of explaining a character by means of another one of close pronunciation, and consequently in supplying an etymology that is motivated both graphically as well as phonologically (See Bottéro \& Djamouri (2006)).

${ }^{124}$ dá 達: to reach, unimpeded, to be versed in, universal/general/common, to publish/say a word, etc. Rouzer (2007, p. 218) translates it as: to reach, to get in contact with, to be successful.

${ }^{125}$ In the Ëryă, chapter shìgōng 釋宮, "Explaining Dwellings," one finds the similar phrase: $y \bar{\imath} d a ́$ wèi zhì dào lù 一達謂之道路. HU (p. 213) explains dá 達 as leading to [a road], suggesting a possible translation for this phrase as follows: "The road that leads to the first direction is called dàolù 道路."

${ }^{126}$ Y̌n 引 is part of a dissyllable y̌ndăo 引導 that meant to lead, to guide, officer opening a way to go out, as well as, on its own, with the meanings of pull/draw a bow, lengthen, extend, recruit, recommend, quote, etc.

${ }^{127}$ Cùn 寸 was usually associated with an old measurement unit. GU indicates its origins directly linked to the hand (shǒu 手), thus a possible etymology as the hand that leads. See also a similar (but more complex) analysis in Boodberg (1957, p. 598-601). 
It does not seem too farfetched to visually consider dào 道 as a semantic compound (huiyi 會意 ${ }^{128}$ ): a person (here represented by its head shǒu 篔), walking, chuò 灵, which is similar to the analysis in the Shuōwén. Another straightforward interpretation is related to "movement": (people) walking, chuò 羍, forward, shǒu 临(the head being metonymically used for what is "above" or "forward"), thus indicating a "path" treaded by people.

It should be emphasized that graphically the character is drawn around what seems to have been certain idealized "images", which carry an iconic baggage ${ }^{129}$ but must be perceived as symbolic, since it is not possible to draw a direct interpretation of the character without some prior knowledge or outside guidance.

The Shuōwén also includes, besides the regular graphical analysis of the character, a comment about the type of "path" that is the dào 道. In YL it is written that the "the complete path with no deviations is one to which we can refer to as dào 道." 130

Dào 道 appears glossed in the other three major grapho-etymological sources of the Chinese tradition, Ěryă, Fāngyán and Shiming. ${ }^{131}$ In the Ěryă, dào 道 is glossed as honesty, straight, honest (zhi 直); ${ }^{132}$ laws, standards or principles

${ }^{128}$ The term huìy is used to denote one of the six categories of characters suggested by Xǔ Shèn in the Shuōwén, the one where the character is a composition of elements that bring only semantic import in the final character.

129 "Iconic" is loosely based on Peirce's terms, as explained in the following text on semiotic typology:

every sign is determined by its object, either first, by partaking in the characters of the object, when I call the sign an Icon; secondly, by being really and in its individual existence connected with the individual object, when I call the sign an Index; thirdly, by more or less approximate certainty that it will be interpreted as denoting the object, in consequence of a habit (which term I use as including a natural disposition), when I call the sign a Symbol. (Peirce (1931-58), volume 4, paragraph 521. In Sebeok (1978).)

Although I recognize that the compatibility between Peirce's semiotics and Wittgenstein's language as a form of life is not trivial, Peirce's iconicity is used here as a starting point for discussions to be found later in this dissertation.

${ }^{130}$ In Chinese: wánquán tōngdá wú qi lù jiàozuò dào 完全通达无歧路叫做道.

${ }^{131}$ As commented above, samples of relevant passages from each book are reproduced, translated and commented in the Appendix I.

${ }^{132}$ The hànzi zhi 直is usually translated as straight or direct. We should make a point here that these geometric connotations might remind us of the connection between ratio and logos, and of the Greek's concern to relate language and mathematics, particularly by the Pythagoreans. However, there is no allusion to any numerical ratio or geometric construction associated with dào 道's "straightness." As Wittgenstein taught us, we use these words for the lack of other better ones! 
(di 迪, yóu 由); travel, road, frontier (lü 旅, lù 路and yi 场); while dăo 導 usually appears referring to guidance or teaching. In the Fāngyán dào 道 is "described" as abundant/afluent and plan/scheme (respectively, yù 裕 and yóu 猷) and in the Shiming, both dào 道 and dăo 導 are recognized as the "source of the myriad things."

In the contemporary references, GH lists no fewer than fifteen different meanings for the character dào 道. Following are brief glosses in English edited from the acceptations from this dictionary:

1. Way, passage, road (path in the concrete sense);

2. law, rules. It also refers to the materiality of the chemical-physical process of changing from/into the gaseous state;

3. the source of all things in the universe. For this gloss the source is the Lăož̀ itself, chapter (XXV); ${ }^{133}$

4. worldview, a fixed/defined point of view on life;

5. method, mode (fāngfă 方法in modern Chinese);

6. from (starting from), via, through;

7. a ceremony for the spirits of the road, sung at the time the Emperor and his entourage departed on a journey;

8. name of administrative subdivisions in various dynasties: Hàn 漢, Táng 唐and Míng \& Qìng 明清;

9. $\quad$ to manage, to govern (zhilı 治理in modern Chinese); ${ }^{134}$

\footnotetext{
${ }^{133}$ This is an example of the "meaning inaugurator" role of the Lăož̆, and this gloss certainly owns its motivation not only from the Lăož́, but also from its commentaries.

${ }^{134}$ As the original source for the gloss to manage, to govern, GH has taken a passage from the Analects, chapter xué ér 學而, which is partly reproduced here:

子曰:「道千乘之國: 敬事而信。

zì yuē: "dào qiān chéng zhī guǒ: jìng shì ér xìn...

Which Legge translates as:

The Master said, "To rule a country of a thousand chariots, there must be reverent attention to business, and sincerity [...]"

Thus, validating the gloss. However, Ames \& Rosemont $(1998$, p.72) propose a very different translation:

The Master said: "The way (dao 道) to lead a thousand chariot state is to carry out your official duties respectfully and male good on your words (xin 信) $[\ldots]$ ”
} 
10. relative to dăo 導, precursor, guide, "the one who removes obstacles";

11. to talk, to explain;

12. to think, to anticipate, to expect;

13. related to tiáo 條, classifier used for something long and thin, comparable chóng 重 and $c i$ 次, which themselves are classifiers of time, sects;

14. related to dé 得 or dào 到: get to, obtain, to get. Hence the expression zhìdào 知道, now used in modern Mandarin as "to know," that would have been derived from "obtain (get to the) knowledge ( $z h i$ 知).”

From this extensive list, one begins to get the general idea of the incredible semantic latitude of dào 道. Other contemporary grapho-etymological sources are also presented in Appendix I and basically verse on the matter of the relationship between dào 道 and dăo 導, with most of the dictionaries proposing their own version of the "original meaning” (běnyì 本義, in modern Chinese) of dào 道.

Old and contemporary dictionaries differ widely regarding the "original meaning” of dào 道 and the direction of derivation between dào 道 and dăo 導. Most studies are emphatic when suggesting their own "original meaning," but undoubtedly behind this variety of interpretations of the canonical texts and their (past and present) commentaries, there is a good deal of speculation and rhetoric. It also seems possible to suggest from the exposition shown above, that even in a semantic array of allusions as wide as that of dào 道 and dăo 導, their glosses appear to be (mostly) motivated and connected, thus being more adequately described as a case of polysemy rather than homonymy. ${ }^{135}$

Therefore, in Ames \& Hall translation, this gloss would be obviouslyunnecessary.

135 The contrast between polysemy and homonymy is rather complex and even the validity of the terms themselves merits a more detailed study that I will undertake in this dissertation. In the context of the MPH, there is no absolute category as homonymy or polysemy. However, as for the characteristics usually attributed by our Western common sense to these words, in perspectivism 
Therefore, arguably, the different allusions and nuances all contribute to the metalinguistic effect of dào 道, as in its verbal and nominal roles. We will see, for instance, in the next chapter discussing the translations of the Lăož́, how these roles are very much superposed. Chad Hansen (In: Bo, 2003), claims that when dealing with the acceptations of the "verbal" dào 道, one should take into account the normative nature of dào 道, as well as the complex relationship between speech and language:

Against the prevailing practice of translating the verb as "to speak" I argued that it (a) should incorporate the normative force of the noun, i.e., something like "to guide" and (b) that the range of denotation should include both speech and writing - as well as gesturing and so forth. I suggest treating the verbal use as "to express as guidance." (Hansen, In: Bo, 2000, p. 209)

However, bearing in mind the MPH, we should, as Hansen later calls attention to in his text, be cautious about the careless association of terms such as coercive or normative with dào 道. He writes:

[...] dao signals an important difference in the conception of normativity. Ancient Chinese did not make talk of sententials, such as "laws", "rules", "principles" or "norms", central to their metadiscussion of normativity. (Ibidem, p. 211) ${ }^{136}$

We should therefore be wary of the idea that dào 道 imposes "rules" or dictates (arbitrary) "principles." These labels are themselves loaded with Western commonsensical preconceptions, reminding us of some sort of imposition of guidelines that delineate a realm separated from nature and naturalness with rigid man-made limits. On the contrary, the normativity of dào 道 should not be taken in opposition to nature: "a dao is some aspect of the natural context that invites us to perform or 'implement as guidance' our action.” (Ibidem)

there is a trend towards the acceptance of a wider latitude of polysemy, rather than a stricter homonymy.

${ }^{136}$ For a critical analysis of Hansen's view, see Harbsmeier (In: Allinson, 1989). 
Marcel Granet's (1968, p. 197) study of dào 道 is, in turn, embedded within a profound analysis of the Chinese cultural tradition, thus following what we could call a "cultural-grapho-etymological" route. The author argues that both

Tao [道] and Hsing ${ }^{137}$ [行] evoke the image of a way that should be followed, a way to inform the right conduct, a conduct that is better and more stable to the sovereign or the wise men.

The author explains how, in the story of $Y \check{u}$ the Great (Dà Y̌̌ 大禹, the legendary founder of the quasi-mythological Xià 夏 dynasty, ca.1900-1350 BC), dào 道 was specifically used in the sense of mapping the world, "to build the entire universe" in its mythical language. It was said that the sky "opened the way" (kāi dào 開道 ) to $Y \breve{u}$, i.e., it authorized him to reestablish the right practices. ${ }^{138}$ The word dào 道 was employed in its very concrete sense, as in taming the floods and "tracing the path of the rivers," and at the same time carried unavoidable connotations of observing the "right practices." Granet wrote:

We should see the formula employed by $\mathrm{Yu}$ as a manifestation of his accession to power. [This formula] honors the work in that the mythical Virtue [dé 德] of the Hero was spent tracing pathways [dào 道]. (Ibidem, p. 198)

In addition, he conjectures about the emergence of the term dào 道:

Maybe [this line of thinking] justifies the hypothesis that the word Tao [道] began by evoking the image of a movement of the king, which was intended to limit, by the tracing of the paths [xíng 行, dào 道], the portions of reality (inheritance, names, emblems, insignia) that should be divided among the faithful of the Four Cardinal Points, and for which the Five Elements were used as rubrics. (Ibidem, p.198)

This relationship between the limiting function of dào 道 as a "border delineator" poses a striking contrast to the "non-human" coerciveness of dào 道

\footnotetext{
${ }^{137}$ Granet, like other authors of his time, employed the Wade-Giles transliteration standard instead of pinyin, thus writing "tao" (and not "dao") and "hsing" (and not "xing").

${ }^{138}$ See also Kaltenmark (1965, p. 23).
} 
from Hansen's analysis and will refer directly to the function of naming of ming 名, as we shall see in the next section.

\section{$* * *$}

Dào 道's network of allusions are summarized in the next box:

Box 1- Dà o 道's network of allusions

\begin{tabular}{|c|c|}
\hline Metalinguistic & Other senses: \\
\hline senses: & $\begin{array}{l}\text { 1. Way, passage, road (path in the concrete sense); to go along, } \\
\text { bring along; tracing the path of the rivers; the movement of the } \\
\text { king (who delineates the kingdom and creates the map of the } \\
\text { World); travel, frontier; }\end{array}$ \\
\hline to explain; & $\begin{array}{l}\text { 2. law, rules, principle, worldview, a fixed, defined point of view on } \\
\text { life, method, manner, mode; }\end{array}$ \\
\hline $\begin{array}{l}\text { to say; } \\
\text { sayable; } \\
\text { spoken; }\end{array}$ & $\begin{array}{l}\text { 3. precursor, the source of all things in the universe, the way } \\
\text { whence came all things; thus: from (starting from), via, through but } \\
\text { also: (to reach), thus: get to, obtain, to get (dé 得 or dào 到); }\end{array}$ \\
\hline $\begin{array}{l}\text { enunciate; } \\
\text { discourse }\end{array}$ & 4. (to) guide, to conduct, to express as guidance (dăo 導); \\
\hline & 5. a ceremony for the spirits of the road; \\
\hline & 6. to manage, to govern; \\
\hline & 7. to think, to anticipate, to expect \\
\hline
\end{tabular}

Dào 道 has a clear metalinguistic aspect, often interpreted in what we translate in English as to say, spoken and discourse, along with other nuances, most notably, the Way of Daoism and the Chinese tradition. Its vast network of allusions in many ways departs drastically from our Western traditions, as expected under the MPH: dào 道as the delineator of frontiers, as the source of the myriad things, as the guide who conducts effortlessly, etc.

However, there are also some apparent similarities. Course is etymologically related to discourse, thus establishing a (weak) link between way (course) and language (discourse), at least in English and in other Indo-European languages. 
We have seen that the Latin discursus is a probable transposition of discürrěre (to run here and there, run through all directions), thus calling attention to the "hazardous nature of verbal exchange." However, philosophers, unaware of the historicity of the term they use, are likely to accept as a matter of course the connotations of correct reasoning and rationality of lógos, and to subtract the allusions which collide with its "common sense."

Some of the translated terms above for dào 道, such as law, rule and principle, also remind us of the polysemy of lógos as discourse/logic or reason. However, they should be understood in the context of Chinese thought, where, in general, physical patterns (see wén 文) were observed as the "principles" of

Nature, instead of the Greeks' recognition of physical realities as pale and imperfect reflections of the idealized principles of the realms of the Platonic forms.

Heraclitus used lógos as an "underlying organizational principle of the universe," which might also possibly be compared with dào 道's "principle" and "source of all things in the universe." ${ }^{139}$ However, a more careful observation of the table above shows us that the Western network of allusions built around language as lógos is, in many respects, profoundly different from what has been discussed on the grapho-etymology of dào 道. Lógos has its etymological sources in words such as proportion, analysis, the possibility to ascertain what is true, the rational faculty, and invites us to use the human intellectual capacity (human mind) in order to understand reality. On the other hand, dào 道 tells us about paths and frontiers, to guide and conduct, and the invitation is to learn from nature in order to understand how humans must properly conduct themselves. Although dào 道 might be unfathomable in its totality, it has been variously “described" as honest and straight (zhi 直), magical and abstruse (yóu 猷), abundant and affluent (yù 裕). Could one begin describe lógos with the Western

\footnotetext{
${ }^{139}$ Zhang Longxi wrote a book in 1992 entitled The Tao and the Logos: literary hermeneutics, east and west. In this book, the author suggests a comparative approach to the Chinese and Western heritages that focuses on their common traits, as what enable these traditions to engage in a productive dialogue. The author's postulated similarities between dào 道 and lógos are the centerpiece of his argumentation. Zhang's point of view follows completely different paths than those of the present dissertation, however, as per the tenets of perspectivism and the MPH, his views are worth considering as a productive counterpoint. Some ideas from this book will be revisited in the conclusion of this dissertation.
} 
counterparts of such Chinese hànzì? Contrariwise, we could recall lógos' fundamental opposition to mýthos, with its "pre-logical," thus magical, apprehension of reality. ${ }^{140}$ While both terms are testimonies to the central position of language to the human, they cannot be further apart.

Dào 道 also traces the limits of the world, nature and man, and is intimately tied to the mythologies of creation in early China, not only as the source of all things (Nature), but also as the man-made frontiers and tracing of rivers done by mythological emperors (Empire). Dào 道 is not only the multiplicity of points of view, but also the testimony that there is no stable, eternal or absolute point of view. It has a clear "coercive" nature, however its normativity is not coercive in the sense that it imposes restrictions or "artificial" (man-made) laws, but rather it suggests its "natural” guidance (in accordance to Nature, zìrán 自然) that effortlessly directs us. We perhaps might hear here to echoes of the necessary/contingent relationship in Wittgenstein that has been discussed in chapter I of this dissertation. We recall that in the later Wittgenstein, the necessary is not supported by any absolutist ground situated beyond our control, but rather by our acceptance of it as such, because of our context and history. Contrastively, although dào 道's necessary guidance likewise does not rely on absolute eternal truths, it is the necessary which is altogether different - fueled by this fuzzy notion of human and world in harmony, which "imposes" the necessary in a way that it is subtle and hardly felt. If the human realm challenged in direct opposition the natural realm, such imposition could have never being enforced. The effortless guidance of dào 道 might remind us of Wittgenstein's necessary conventions, however they stem from necessarily different (yet equally valid) points of view.

\footnotetext{
${ }^{140}$ The Lăož is a text which is often dismissed as a valid source of knowledge particularly due to the perception of its abstruse and mystic nature. In a way, Chinese philosophy has often been criticized as not being worthy of the name (philosophy) for its lack of (philosophical) precision and its esoteric nature. Hansen (1992, chapter 1) presents that what he calls "the ruling stereotype of Chinese thought," a common mainstream vision which treats analytical and Chinese thought as virtual opposites, along a reason/mystical intuition ("spontaneity") dychotomic axis, thus downplaying in most Sinological works the importance of its linguistic analysis.

As per the MPH, we should abstain from considering words such as philosophy or mystic, as fixed categories of universally valid criteria. It is, however, worthy to note that yóu 猷, translated as magical and abstruse, is used as a valid reference to dào 道, and thus it offers a direct contrast with the allusions commonly associated with lógos.
} 
Dào 道's character, as we have seen, is arguably a semantic construction of shǒu 首 (head) + chuò 定 (walking), “a person/head walking” or a “movement forward," whence the notions of (following a) road, path. However, it seems to me that the moment cùn 寸 is added into the character dăo 導 and brings to possibility interpretation as "the hand (that leads)," it also alludes to a spoken/written exhortation. The addition of a linguistic dimension will coalesce all these nuances into a 道 -discourse, a speak-guide which (unobtrusively) determines how and what the world is, as well as how we should conduct ourselves in it. The language is thus born as guidance, as a way to trace our paths and as a manner to create the world. One would certainly find parallels in the MPH when it postulates how one's (historically motivated) metalanguage surreptitiously guides our linguistic inquiry in the ever-reproducing cycle of questioning.

The texts make clear however that these paths in the world are never stable, but rather always in performative motion; never as a fixed set of unchanging rules, they are forever changing without ever changing. One could even attempt to call it the oxymoron "the ultimate true paradox," if only one could refrain from paying too much attention to what true and paradox tell us in our Western tradition! The idea of a guiding discourse which is not guided by us, but rather which guides us, has close affinities to the Wittgensteinian concept of language as a form of life, leading us through new and wondrous paths without any stable set of metaphysical rules.

As further indication of support to the MPH, throughout the many "definitions" of dào 道 in the classical sources, there is no affirmation that the discourse-dào 道 is centrally a declarative discourse or that it is necessarily tied to any kind of subject + predicate structure (or to the more syntactically correct topic + comment of Chinese). This further distances us from the lógos-discourse from metalinguistic practices that place the predicative language of affirmation and truth-values at the core of the linguistic phenomenon.

Finally, a last symptom of the MPH lies in the variety of interpretations over what constitutes dào 道's “original meaning." The sheer fact that dào 道 has "originally" been considered to be: tracing the path of the rivers; to express as 
guidance; way in the concrete sense; to guide, to lead; etc. - and that all these uses are equally valid and important to dào 道's network of allusion - is at least a strong hint that there actually is no "original meaning." This will be a recursive pattern observed in the grapho-etymology of all hànzì chosen for this dissertation.

\subsection{2.}

\section{Míng 名: name, (to be) called}

The Shuōwén's entry for ming 名reads:
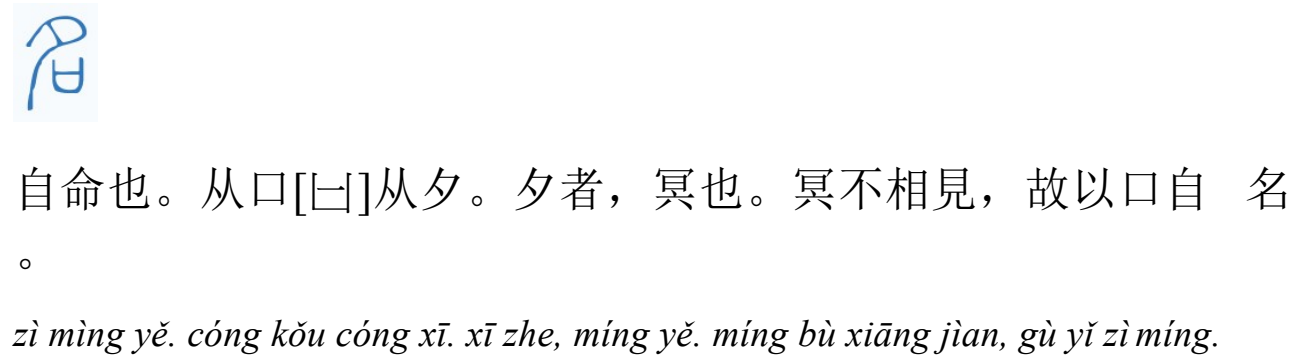
[mouth] and $x \bar{l}$ 夕 [evening, night]. $x \bar{l}$ 夕 refers to ming 冥 [dark, ignorant]. In the darkness [ming 冥] one does not see the other, so through the mouth [rises] the word [ming 名]. ${ }^{141}$

In ming 名 's seal script in the Shuōwén, we can identify the stylized characters for mouth (kǒu 口) and for night, darkness ( $x \bar{\imath}$ 夕). In Appendix I there are some examples predating the Shuōwén, where the graphic relationship is even more evident.

${ }^{141}$ Halliday ([1981]2005, p. 279) specifically quotes this gloss in the Shuōwén as an example of a "fanciful" explanation that, according to his judgment, is common throughout the dictionary. However, even if many Sinologists may agree with Halliday's observation regarding some glosses in the Shuōwén, most would not deny the enormous influence of the dictionary in the Chinese tradition. 
From the Shuōwén one immediately notices a close relationship between three phonologically related terms ming 名, ming 命 and ming 冥. ${ }^{142}$ This will be extremely relevant to ming 名's grapho-etymology.

Some authors see the graphic interpretation of the Shuōwén as a sign of a representational view of language. For example, in Chen (no date): "thus, if we want to talk about objects in the dark (i.e., use our mouths to refer to them), we must give them names. Thus, names represent objects in our speech and thought. $\mathrm{Xu}$ Shen was, therefore, concerned with the cognitive function of names".

However, one must first understand that the Shuowwén is a dictionary that is primarily concerned with the graphic dimension of Chinese characters. ${ }^{143}$ Due to the weight of its authority, many of its "definitions" were used almost indiscriminately, as if they were the product of an omniscient gaze over language and the world, and then criticized in modern studies for what was considered an exaggerated ambition. While Chen (no date) appropriates this definition as justification for an instrumentalist view of language as a nomenclature, it is likewise possible to observe in it the versatility of Chinese writing and the richness of its graphical allusions. A "mouth in the dark" could refer to the idea of a primordial darkness, where nothing stood out, where reality was nothing but an amorphous mass. The moment the mouth (the metaphor or metonym for the ability of language) appears, the darkness subsides and thus reality is "created" through language. Unlike the interpretation of Chen (no date) above, before language shone its light there were no objects to be nominated and then cognitively recognized, but rather the objects themselves were shaped through language's capacity to create. This is very much like Saussure's criticism of language as nomenclature and the picture of the dual-sided semantic and phonological planes of language cutting across the amorphous reality. While Chen (no date) uses the Shuōwén to support a nomenclature view of language, we take Saussure's inspiration on this matter. ${ }^{144}$

\footnotetext{
${ }^{142} \mathrm{~A}$ fourth one, ling 令, will also be discussed below.

${ }^{143}$ For more details, see Bottéro (no date).

144 There is an obvious caveat in supporting Saussure's side here. His position has been criticized by its potential relativism, once language is deprived of its exterior grounding in reality. Some previous discussion of the natural motivation of dào 道 guiding our practices might have hinted at
} 
In the same way that dào 道 was glossed by the shēngxùn 聲訓 method as dăo 導, for ming 名 the Shuōwén uses mìng 命 (in modern Mandarin: life, destination, order, command), a second term with which it is both semantically and phonetically similar.

The Shuōwén itself glosses ming 命 as shř 使 (to send, to cause, to have someone do something) and graphically reads ming 命 as a semantic compound of kŏu 口 and ling 令. ${ }^{145}$ The character ling 令 has the connotations of order or command ${ }^{146}$ as well as convene, provoke, cause (among other more "exotic" meanings ${ }^{147}$ ) and therefore it is reasonable to read ming 命as verbal order. Arthur Waley is one author who explicitly compares ming 命and ming 名:

For all Chinese philosophy is essentially the study of how men can best be helped to live together in harmony and good order. It is only through language (ming [名]), through “orders" (ming [命]), written differently but etymologically the same word, that this help can be given. (Waley, 1958, p. 64, my emphasis)

Visually one can easily notice the similarity between the three characters as, for example, in these examples from the seal script:

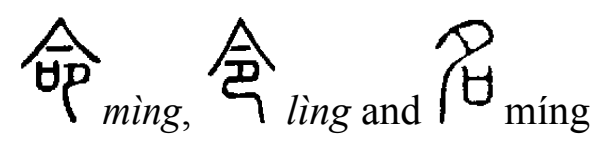

An expression in classical Chinese that helps to associate name and life is wángming 亡命, which can literally be read as lose life and lose the name, and that is traditionally associated with people who, after committing some type of

what we could call here a "Chinese line of perspectivism." From the discussion below on the "risks" of ming 名, it should be clear that the Chinese where acutely aware of the relativist trap. ${ }^{145}$ The original line in Chinese in the Shuōwén is: ming: shì yě. cóng kǒu cóng lìng. 命: 使也。从 口从令。

${ }^{146}$ In modern Mandarin, one finds the dissyllable mingling 命令, as order or command.

${ }^{147}$ Other than the glosses above, GH offers five further acceptations for ling 令: 1) a formal name of address (usually indicating an honorific position); 2) seasonal sickness (as for example in xiàling 夏令, “summer's disease"); 3) good, virtuous; 4) a formal way of addressing someone; and 5) a method of systematization of songs during the Tang dynasty. Finally, besides these glosses, 令also has variant readings of ling e lián with corresponding acceptations. 
crime, as punishment are forced to change their name and surname and to live in exile.

However, the explanations above do not justify ming 命's polysemy also as life or destiny. Is there a motivation for the connection between order and command on the one hand and life and destiny on the other?

Although for reasons of space and focus we will not discuss here the uses of ming 命 in the Lăož̆, the close relationship between ming 命and míng 名 compels us to examine it, albeit briefly. We should note that while ming 命 also designates life, destiny and order, in the Lăož̀ it appears in a clear opposition to zìrán 自然, a crucially important dissyllable in the book that is associated with nature, natural way or natural propensity. In the chapter (LI) of the Lăož̆ one reads:

\footnotetext{
道之尊，德之貴，夫莫之命常自然。 dào zhī zūn, dé zhī guì, fū mò zhī mìng cháng zìrán.
}

Yet the way is revered and virtue honored not because this is decreed by any authority [ming 命] but because it is natural [zirán 自然] for them to be treated so. (translated by Lau.)

This contrast reinforces the coercive role of ming 命 and, indirectly, of ming 名. But it is indeed a coerciveness that is fundamentally different from what we found in dào 道's analysis, where coercive meant, approximately, the natural tendency that (one) should follow. Contrariwise, ming 名's coerciveness is the unavoidable effect language/names have when they partition the world into categories and hierarchies. That is, coercive needs to be properly problematized when applied to different instances in the Lăož̆ (as well as to other texts from the Chinese tradition).

Additionally, the relationship between ming 命 and ming 名 can be analyzed along the problem of whether life and name are metaphorically related (in the Western sense) in the expression wángming 亡命. This analysis (detailed in Appendix I, Is wángming 亡命 a metaphor?), provides further evidence against 
the dangers of applying a Western metalinguistic toolkit to answer questions regarding classical Chinese.

Clearly having a reflexive metalinguistic nature, ming 名 expectedly appears in numerous passages in the $\check{E} r y a ̆$ and the Shiming (although only twice in the Fāngyán). However, there is no specific entry for the term itself, which is always used to convey the idea of expressing a name or naming something else. Therefore, the ancient grapho-etymological dictionaries of China offer no significant contribution to this analysis.

As for the contemporary sources, YL (p. 149) interprets that initially ming 名 was used as a verb, as the act of declaring a name, to name, and only later came to be used as a noun, as name. Eventually, name was used to stand for the reputation of the one being named, for their fame (mingshēng 名聲 in modern Mandarin, literally sounding name) and for one who is recognized among one's peers (yǒuming 有名 in modern Mandarin, literally have a name). ${ }^{148}$ The identification of name with the post or office one has, brought to its limits, led to GH's gloss of ming 名 as a reference for the self or I (poetically, the region on the forehead between the eyes and eyebrows, or the area just above the eyes).

Additionally, GH also glosses ming 名 as logic, a contentious term that is linked to the debate on the rectification (and "correctness") of names among the different philosophical schools in classical China. ${ }^{149}$

Another debatable translation is ming 名 as the name of the Chinese written characters. This reference is a sign of the particularities of the relationship between speech and writing in Chinese. Geaney (2010) offers a detailed

\footnotetext{
${ }^{148}$ One could speculate that the name exists only through the act performed between the namer and the named, thus not having an independent existence, which would then reflect on the Chinese language's privilege on state of being rather than to be (in Portuguese: estar vs ser) and its predominantly verbal quality. It is along these lines of thought that Ernest Fenollosa wrote in his polemical article "The Chinese written character as a medium for poetry," from which an excerpt is presented here:

A true noun, an isolated thing, does not exist in nature. Things are only terminal points, or rather the meeting points of actions, cross-sections cut through actions, snap-shots. Neither can a pure verb, an abstract motion, be possible in nature. (Fenollosa, In: Saussy et al, 2008, p.46)

This performative nature of the Chinese language will be substantiated in the presentation of the metalanguage discussed throughout this dissertation.

${ }^{149}$ More about the question of logic and the Rectification of Names in ancient China in the concluding remarks of this section.
} 
discussion on the nature of ming 名 and this author's hypothesis states that the usual translation of ming 名 as word(s) misleads the Western reader, who takes for granted that this term crosses with the same weight the oral and the written dimensions of language. In Geaney's words:

[...] my argument is that, at a time when the need to refer to writing in terms of individual units was acute, and before $z i$ 字 fully occupied this role, ming [名] appeared as "written units" [...] But I argue that the adaptation of ming was unsuccessful, because multiple associations of ming with sound and reputation worked against the use of ming to include the visual realm of writing. (p. 253)

The Chinese tendency towards harmony and balance initially might have pushed the use of ming 名 into the two realms, but eventually ming 名 became associated only with the oral aspect of word. This fracture emphasized the prominent discontinuity between the two realms of language, oral and written, that is crucial to understand the traditional Chinese view on language. This use of ming 名 and its relationship with the written dimension of the Chinese language will influence one of the commentaries in Chinese on the passage of Lăozl̆ under study here, as we shall see in chapter III of this dissertation.

Finally, I would like to finish this exploration of the histories of ming 名 with an observation from Herrlee Creel (1983). The Sinologist writes:

\begin{abstract}
The Chinese character ming [名] has been, for the past two thousand years perhaps as common as the word "name" is in English. It was, however, very rare in the earliest Chinese literature, where we find it used to mean "proper name," "to name," "famous," and "reputation." But it was rarely if ever used in the sense of what A. C. Graham calls "classifying names": names that refer to all of the members of a class, such a "man," "house," etc. Even literature that can be assigned with confidence to the Spring and Autumn period gives little presage that ming was to become an important philosophical term in the Warring States times that were to follow. (p. 315-6) $)^{150}$
\end{abstract}

${ }^{150}$ This interpretation of Creel reminds us of the way the earliest testimony we have from the Greeks considers all names are proper names, including in the later works, as far as Plato's Cratylus - as we have seen above. Later, especially with the Stoics, the distinction between proper and common name would be born. For more details, see Gambara (In: Auroux, 1995) and Desbordes (In: Auroux, 1995). 
However, well before $300 \mathrm{BC}$, continues Creel, ming 名 became “a much used philosophical term," a word used to categorize, a central term for the Legalists and an even more prominent one for the School of Names. That, however, would be many years after the Lăož̆ was first compiled. ${ }^{151}$

These comments seem to be in contradiction to the idea that ming 名 takes a leading role side by side with dào 道 in the opening lines of the Lăož (as we will see in chapter III of this dissertation). However, I see no contradiction if we would accept that to use the expression "philosophical term" - with its Western connotations - as a category of reference to Chinese names is quite controversial in the context of the Chinese traditional thought. With its apparently tortuous language and complex structure, the Lăož̀ does not seem to be aiming at generalizations, at least not rational (Western? Philosophical?) generalizations. Thus ming 名 does not seem to have a categorizing effect in terms of imposing rational classifications. If the character does appear in direct contrast with dào 道, it is because its "Daoist-naming" action can be as powerful as dào 道 and was responsible for the break of the oneness of reality that was a "pre-linguistic" dào 道. They are the mark of civilization, that the Daoists certainly may abhor, but that is nevertheless present our world, a necessary yīn 陰to dào 道's yáng 陽. ${ }^{152}$

$* * *$

In the next box, ming 名's main acceptations are schematized:

151 There is an important remark to be made here: Creel appears to be considering that the Lăož́ was written either around the times of Confucius (551-479 BC) or only some years later. It is for this reason that he treats "well before 300 BC" as "many years after the Lăož was first compiled." If we consider recent scholarship dating the text as early to mid $4^{\text {th }}$ century $\mathrm{BC}$, that means only approximately 40-70 years before $300 \mathrm{BC}$ and therefore very near Creel's date when ming 名 became a "philosophical term."

${ }^{152}$ These relationships will be made clearer along the translations of chapter III of this dissertation. 
Box 2- Ming 名's network of allusions

\begin{tabular}{|c|c|}
\hline Metalinguistic senses: & Other senses: \\
\hline $\begin{array}{l}\text { 1. act of naming, name, } \\
\text { (be) named; } \\
\text { naming, nameable; } \\
\text { to call; to tell; } \\
\text { designating/referring } \\
\text { 2. Chinese written } \\
\text { characters }\end{array}$ & $\begin{array}{l}\text { 1. fame, reputation, post or title } \\
\text { 2. nominally/on behalf of } \\
\text { 3. region on the forehead between the eyes (the "I"), } \\
\text { classifier for people } \\
\text { 4. logic/concept }\end{array}$ \\
\hline
\end{tabular}

Source: the author.

Chinese ming 名 has an uncontroversial metalinguistic function, translated as name, to name, to tell, to designate, etc. In this aspect, it finds an apparently clear counterpart in the Greek's ónoma.

The Western tradition has built on ónoma the allusion of names as marks of the named object, or labels in a system of representation. The polysemic hints of renown and reputation are present both in Chinese and the Western languages. However, ming 名 starts to distance itself from ónoma when we consider the Greek word's intimate articulation with rhēma. As we have seen, the opposition of ónoma and rhēma in the lógos-discourse is related to "the oldest and most elementary awareness of the referential function of language." (Cassin, 2014) As in the above case of dào 道, the earliest "definitions" and uses of ming 名 are not related to the idea of name as a part of discourse. In a way this should be expected, since dào 道 is not regarded as a declarative discourse which articulates names and predicates. ${ }^{153}$ There is not, in any moment, any implication that ming 名 is passively referring to things (or ideas) in the world or that ming 名, as name, should be taken in its opposition to verbs. ${ }^{154}$ The name, as end product and as

\footnotetext{
${ }^{153}$ When we analyze the translations in chapter III of this dissertation we will have a chance to see how ming 名and dào 道relate quite differently from the West's name and discourse.

${ }^{154}$ As Pellin (2008, p.535) writes:

The main branches of Chinese traditional linguistics included: xunguxue 訓詁學 (exegesis, referring to the exegesis of the Classics of Chinese ancient literature, including the works on Confucian morals), yinyunxue 音韻學(phonology), cishuxue 辭書學 (lexicography) and wenzixue 文字學 (study of Chinese graphs). The ultimate aim of linguistic research in traditional China was,
} 
action, is conflated in the character-emblem ming 名, as suggested by Fenollosa (see note 148). The name/predicate articulation is therefore absent in the Chinese tradition, which results in strikingly different contexts of use for each term, particularly when we consider that lógos was primordially composed of ónoma and rhèma as articulated into sentences, while dào 道 as discourse was solely composed of ming 名. Thus we have a stricter separation of names/verbs in the Western lógos which fits the representational function of language, while in Chinese ming 名is action and state, a performative (guidance) view of language.

There is another point of contact/friction between the Western and Chinese traditions worth considering. The translation of ming 名 as logic or concept, as we have seen, is directly related to the question of the rectification of name in ancient China, and to Xúnzľs discourse ("Names are the means by which one attempts to distinguish different realities"). This affirmation could easily fit within the Greek arguments about the referential nature of language, which led some authors to gloss ming 名as logic or concept. I argue that:

1) to read Xúnzlı's name as logic betrays later interpretations which suppose that the Chinese had a view of reality as organized by the principles of logic, something that is very controversial and not supported by our analysis in the present dissertation;

2) the Rectification of Names is a discussion in ancient China which is deeply political and ideological, tied to the establishment of Confucian "names" (or "concepts") at the heart of the State philosophy of the Chinese empire. Such motivations are very far off the abstract discussion in Greek philosophy about the arbitrariness of names and the fit between names and reality; ${ }^{155}$ and

firstly, to preserve and to develop the orthodox interpretation of the Classics, which constituted the ideological spine of Chinese society.

The branch of syntax/grammar is conspicuously absent from this list.

${ }^{155}$ However, it would be naïve to ground the Greek's explorations on the nature of names as being solely motivated by a "neutral scientific inquiry." As per the MPH, we must consider that there is no such thing as a "neutral scientific inquiry," and Plato's writings, for instance, were much driven by his personal reaction against the wrongdoing in Socrate's judgment. What I claim here is that the Greek's development of an objectively oriented science based on the dualism of empirism and 
3) the Xúnzl must be compared with Plato's or Aristotle's discourses through the intervention of a third intermediate language - in this case, English. Once the Chinese and the Greek texts are translated into English, thus employing the same lexicon, some of the most radical differences between ancient Greek and ancient China are unavoidably leveled off.

Graphically, the character ming 名 is quaintly interpreted as a "mouth (kǒu 口) which cries in the night, darkness ( $x \bar{\imath}$ 夕).” Besides that, as we have seen, its early graphs are closely related to ming 命and ling 令. Respectively we have: ${ }^{156}$

$$
\text { ming 名: }
$$

This intimate affiliation points to a definitively coercive action of ming 名, a man-made force acting through man-made language. If dào 道 - as we have already seen - is a promise of harmony of language as language of Man and language of Nature, in ming 名 the artificiality of language appears more evident and the violence of the man-made categories more menacing. This situation also calls the attention to the risk of taking Western labels into completely different contexts. As we have also seen, dào 道's coerciveness is effortless, not the result of a forced action. In this case, it seems that ming 名 's coerciveness is a completely different matter and we should be wary of referring to both actions with the same label. ${ }^{157}$

rationalism has no counterpart in the Chinese's own traditional scientific inquiries. See Bodde (1991) for more details.

156 Their graphic relationship has been already analyzed elsewhere, and the sinographs in seal script are shown here exclusively to recall their visual similarities. We might also recall the usual glosses for ming 命: life, destination, order, command and ling 令: order or command; convene, provoke, cause.

${ }^{157}$ The dào 道 of Nature is effortless, while ming 名, when acting in (possible) disharmony against the natural dào 道, becomes forced, imposed. Dào 道 is only effortless because, in principle, there is a tendency and a drive to the harmony between Man and Nature in Chinese traditional thought. They are both coercive in a way that they drive and orient the proper behavior and rites, however the way their coerciveness is felt and applied differs radically between them. 
However, ming 命's allusions are not limited to order, command (such uses are perhaps even clearer in ling 令), and the character has a strong sense of destiny and life as well. In this way, “through" ming 命we find a much closer relationship between ming 名 and life and the manner in which ming 名 as a name ends up determining the life and destiny of the person or object being named in a much stronger sense than name does in the Western tradition. The intimate relationship between order, life (ming 命) and name (ming 名), made explicit in the graphoetymological analysis above, also indicates a viewpoint that delegates an enormous power to language, which through its naming capacity, can determine the fate of the things in the world.

There is a final important point to be made. The specific translation of ming 名 as “Chinese written characters" seems to me a typical product of the confusion between speech and writing that is so prevalent in the West. The Chinese tradition - as we will see below in the discussion of wén 文 and zi 字 - establishes much clearer boundaries between these two linguistic practices and it seems controversial to use ming 名, the naming activity born in spoken Chinese, to refer to the written characters. What I argue here is that the oral nature of ming 名, which is strongly supported by this grapho-etymological analysis, is another sign of the differences in the metalinguistic repertoire referring to speech and writing between both traditions, thus providing further evidence of support to the MPH.

\subsection{3.}

\section{Yán 言: speech, word, to say, talk, language, phrase, sentence}

The character yán 言 is also a prominent character in the Lăož̀ and plays a central role in the discussions on language in the Chinese classical texts. It is usually translated as word, speech, to say, (to) talk, language, character, to express, to mean.

In the Shuōwén: 


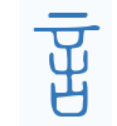

\section{直言曰言, 論難曰語。从口辛聲。凡言之屬皆从言}

zhí yán yuē yán, lùn nán yuē yŭ, cóng koǔ qiān shēng. fán yán zhi shǔ jiē cóng yán

Directly/honestly [zhí 直] yán 言is called yán 言, speech [lùn 論] [that is] difficult/ complicated/complex [nán 難 ] is called y̌̌ 語 [tongue/language/word]. From mouth [kǒu 口] and the sound [shēng 聲] from qiān 辛 [crime $\left.{ }^{158}\right]$. All [characters that belong to the] category [of] yán 言point to [semantic affinity with] yán 言.

The Shuōwén explains that yán 言 is recognized as a character as well as a radical (a semantic component of other characters) and, besides, that it is also a phonetic-semantic compound (xingshēng 形聲) rather than a purely semantic composite character (huiyi 會意).

YL (p. 467) interprets the older, pre-standardization, forms of yán 言 as a mouth blowing through a bamboo flute, ${ }^{159}$ to which an extra line was added above the "flute" in the Shuōwén. For this author, the first four characters in the Shuōwén's gloss (zhí yán yuē yán 直言曰言) mean that yán 言 is the word that presents an explanation or discourse in a straight manner, while the related character $y \check{u}$ 語, from the subsequent clause, stands for commentaries and

\footnotetext{
${ }^{158}$ 辛 qiān is an old character that is glossed as crime by the Shuōwén itself (qiān, zuì yě. 辛, 辠也 。; zui 辠 being a variant form for crime, fault, blame) and is seldom used (for instance, it does not appear at all in the Ěryă, the Shiming or the Fängyán). Harbaugh (1998, p. 192) and Wieger (1927, p. 249) interpret it as an offense (gān 干) directed towards [the law] above (上 shang). Karlgren (1923, p. 94) interprets 辛 qiān as battering rams. Some analyses (for instance, Morel, 2005, p. 329) show it in a modified graph as a phonetic indicator. There is a very close relationship between qiān 辛 and xin 辛 (to toil, grieved, pungent (taste), pungency and also one of the Ten Heavenly Stems (天干)). This relationship, as well as its influence on the analysis of yán 言 will be discussed below.

In any case, its interpretation is controversial.

${ }^{159}$ In Chinese: kǒu chū xiāo guăn yuèqì zhī xíng 口吹箫管乐器之形. Therefore, YL argues that the "original meaning" of yán 言 would be a wind instrument and, by semantic extension, to the sounds from it, then speech and, eventually, to written records, writing, etc. With the passage of time, a closer semantic relationship with $z i$ 字(see below) was developed.
} 
discussions (about yán 言). ${ }^{160}$ The “odd" graphic component (qiān 辛) is viewed by YL as a degraded form (corruption) of ping 平 (as in pingshēng 平聲, neutral or level tone).

To gain a further insight into the grapho-etymological analysis of yán 言 it is worthwhile bringing into discussion three other intimately related characters: shé 舌 (usually glossed as tongue), qiān 辛 and xīn 辛 (see footnote 158 above). First, some examples are shown in OB characters:

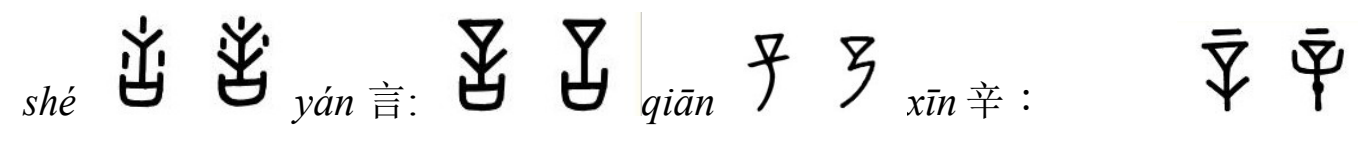

Then in the SS characters:

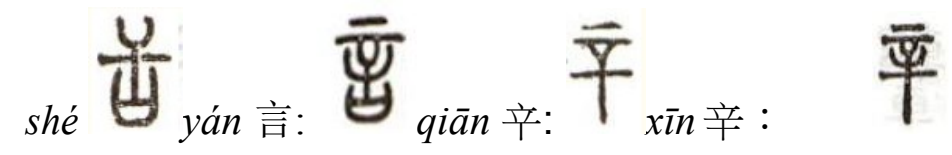

One can notice the striking visual similarities between the different characters. In CUHK's etymological study, qiān 辛 had its first attested uses as a toponym or as a personal name. Later, in the time of the BS characters, it was not seen any more as an individual character, being limited to functioning as a character component (for instance, in zăi 宰, imperial officer, personal name, sovereign slaughter). CUHK disagrees with the Shuōwén on the meaning for qiān 立, reading its $\mathrm{OB}$ form as "sickle-like" instruments and considering it a "protoform" (chūwén 初文 is the technical term in contemporary Chinese etymological studies) of $y i$ X, which in itself is an old form of yi XIJ, cut apart, sever, sickle.

The very similar character, $x \bar{i} n$ 辛 is much more common but one finds it hard to connect its usual allusions (to toil, grieved, pungent (taste), pungency, one of the Ten Heavenly Stems (tiāngān 天干)) with any act related to the production

\footnotetext{
160 The character $y \check{u}$ 語 which is nowadays most closely associated with language, had earlier uses more directly related to speech, talk, chat or idioms, therefore limited to the oral aspect of language. This character does not appear at all in the Lăož́.
} 
of words or speech. CUHK writes that in its oldest forms it resembled a cutting instrument, used to bore holes, fell trees, apply torture, etc. The Chinese linguist Guó Mòruò (郭沫若 1892-1978) considered that xīn 辛 referred to an instrument to brand and punish prisoners and criminals. This connection to punishment and crime was perhaps relevant to the general frame of mind of suffering and sorrowful of the more commonly attested uses of the character. The other related allusions would then be easily explained (such as to toil, laborious, endure hardship, bitter or miserable) and its use as one of the Ten Heavenly Stems seems posterior. The early use of $x \bar{i}$ 辛 as crime are undoubtedly related to the gloss of the similar qiān 立 in the Shuōwén. However, the relationship binding these allusions and yán 言(words and language) is still not satisfactorily explained.

The visual similarities between yán 言 and shé 舌 are also somewhat puzzling. While we can easily assume, from the graphic interpretation of the SS characters, that yán 言is shé 舌with an added horizontal line at the top, in the OB characters this relationship is much less clear. In shé 舌 there appears to be “flowing" lines from the "mouth" (and maybe the tongue ${ }^{161}$ ), while in yán 言 the "tongue" that leaves the mouth is "shut" with a horizontal line.

There is an interesting four-character expression in Chinese that also links yán 言 as word and shé 舌: shé jiàn chún qiāng 舌劍唇槍. The characters might be glossed tongue $\bullet$ sword $\bullet$ lip $\bullet$ rifle/gun, and the expression read as something like "the tongue is [like] a sword, the lips are [like] guns", or, in a more fluent English, "to exchange sharp words." There is an unmistakable connection between shé 舌, tongue, and the production of words, that is, language.

To add further evidence to the grapho-etymological analysis above, yán 言 is also glossed in the Ěryă and it appears in an important passage of the Shijìng (both passages are shown in Appendix I). Yán 言 has been glossed in these sources as large flute; language (huà 話), plan, scheme (yóu 猷, which also

\footnotetext{
${ }^{161}$ CUHK evaluates the OB shé 舌's “flowing lines" as resembling saliva and spittle coming out of the mouth. The "forked tongue" leaving the mouth, still according to CUHK, resembles a snake's tongue and that representation would be justified because the snake tongue's format is very recognizable.
} 
glosses dào 道); interval, lacunae (jiān 間); and to ask, to inquire (xùn 訊). In one of the most relevant excerpts, yán 言is also translated as $I$, me. Matthews (1943, p. 1057) also refers to this use of yán 言 with the following gloss: an initial particle, not translatable, some define it as the pronoun, I. ${ }^{162}$ The author almost humbly excuses his translation with the proviso that yán 言 is “(sometimes) not translatable." This reflects the precise difficulty of setting the Chinese character into English categories and the inevitable risks involved. If we treat yán 言 as the speaker, that is, the first person of the discourse, we are inevitably led to the identification of the speaker with their words, the view where one's words are the embodiment of the $I$, the self. However, we must be very careful when using words such as self in the context of classical Chinese thought. ${ }^{163}$

Finally, the more recent grapho-etymological sources (in Appendix I) basically add further evidence to the discussion above, offering glosses such as to speak, to talk; to discuss, to talk about; phrase, sentence, character and word.

$$
* * *
$$

The network of allusions of yán 言can be summarized in the next box:

\footnotetext{
${ }^{162}$ For instance: yán mò qi mă 言秝其馬, I would feed their/his horse(s).

${ }^{163}$ For an extensive discussion on the comparative views on the Chinese traditional ideas on the self, see Ames \& Hall (1998).
} 
Box 3- Yán 言's network of allusions

\begin{tabular}{|c|c|}
\hline Metalinguistic senses: & Other senses: \\
\hline $\begin{array}{l}\text { 1. speech, to say, to speak } \\
\text { (to) talk, to express, to mean; } \\
\text { discuss, to talk about, to let know, to tell; } \\
\text { opinion, expression of one's opinions } \\
\text { 2. word, phrase, sentence (yìyán 一 言), character, } \\
\text { language } \\
\text { 3. proverbs, established sayings, conventional sayings } \\
\text { 4. written records, writing }{ }^{164}\end{array}$ & $\begin{array}{l}\text { 1. blowing instrument, } \\
\text { large flute, } \\
\text { "mouth blowing through a } \\
\text { bamboo flute" } \\
\text { 2. an adverb marker } 165 \\
\text { 3. high, lofty } \\
\text { 4. "an initial particle, not } \\
\text { translatable, some define it as } \\
\text { the pronoun, I" }\end{array}$ \\
\hline
\end{tabular}

Source: the author.

From the table above it is clear that yán 言 has a much wider latitude of metalinguistic uses than dào 道or ming 名, being variously used to refer to speech, to speak, to tell an opinion, as proverbs, and also to what seems to be various parts of speech.

Yán 言 's graphically related characters are also numerous and highly relevant to its network of allusions, thus justifying recapitulation with a brief list of the three associated hànzì which have appeared in this grapho-etymological survey and which are graphically very similar in the Shuōwén's and previous scripts:

- shé 舌: tongue, forked tongue, “"flowing' lines from the "mouth”

- qiān 立 : crime, fault, blame (older: toponym and personal name.); sickle-like, sickle, cut apart, sever, sickle; degraded form (corruption) of ping 平 (level, even, plane, smooth, peaceful, common, ordinary, impartial); battering ram

\footnotetext{
${ }^{164}$ For this interpretation of yán 言, see the analysis of ming 名. As the grapho-etymological and philological data have provided with ample justification, both míng 名 and yán 言 have their origins and uses in the oral realm of the Chinese language and there seems to be a confusion in translating them as written records, writing.

${ }^{165}$ This is a gloss from Matthews (1943), presented in Appendix I. In this example from Matthews, yán 言 can arguably also be translated as $I$.
} 
- xīn 辛: to toil, grieved, pungent (taste), pungency, one of the Ten Heavenly Stems; cutting instrument, instrument to brand and punish prisoners and criminals.

Yán 言's grapho-etymology is much more complex and controversial than dào 道's and ming 名's, particularly due to the Shuōwén's interpretation that the graphic component on the upper part of the character is qiān 辛, a rather obscure character, diversely interpreted as crime, sickle(-like), battering rams or a degraded form of ping 平. From these various interpretations, what "leaves" the "mouth" in yán 言 is perhaps some kind of punishment (perhaps related to the coercive nature of language mentioned above?), or, maybe, the "level words of impartiality"? To add another level of complexity, qiān 辛 and xīn 辛 are also closely related, creating the possibility of extra puzzling nuances to yán 言, as: to toil, grieved, laborious, endure hardship, bitter. The lack of an "original meaning" or a "definitive interpretation" is again a strong hint that there is no firm and definitive foundation upon which language's lexicon was built: there are just words, graphic recollections of their many-faceted usages.

Once we revisit the rich etymologies of the Western words related to speech and Fr. parler / Port. falar, we see that their early allusions gravitated around notions such as noise, cry, outburst, swell, sow, the "'loudness' of the battle cries of the heroes." These words imply that the early physical sounds of language were just another noise among the many "cries" of nature. On the other hand, from the Latin diceere (Fr. dire, Port. dizer), there is the important relationship with the Greek deiknȳmi, whence the related allusions of deixis, mode of proof; deìgma, example, proof; and paradeigma, model, example. Such connotations are not found in the uses of yán 言 or other speech related characters in classical Chinese, providing support for the MPH.

There is however an interesting parallel between the graphic interpretation of yán 言 and shé 舌as stylized depictions of tongue $e^{166}$ and the Greek glōssa, also translated as tongue, both referring to the organ in the mouth and language. As

\footnotetext{
${ }^{166}$ Remember that yán 言 and shé 舌 are put together as components of the extremely common character huà 話, speech, discourse, language, communication; guide, plan.
} 
seen in the first part of this chapter, glōssa was used by Hesiod to refer to fringes of the ear of corns and, since Homer, started to be used as tongue in the physical sense, because of its similar shape - "the tongue being point-like." In spite of these parallels, while it makes sense to conjecture whether the graphs 言or 舌 might also be recognized as "point-like," one cannot imagine that the word tongue or $\gamma \lambda \tilde{\omega} \sigma \sigma \alpha$ might be recognized as such. Quite simply, when an expression such as "due to its similar shape" is used to explain the semantic drift of a word, the Western and the Chinese contexts differ significantly - for Chinese characters the similar shape can also be applied to the hànzì. ${ }^{167}$ This is another blatant example emanating from the difference between etymology and grapho-etymology, as referred in the beginning of this chapter.

For some authors, the graph yán 言 is viewed as the graph shé 舌with a dot or a line on top. This could be read as a "closed mouth," with some speculative allusion to a "complete speech," offering an enticing contrast between guttural noises and articulated language. Even if this construal was not undisputed, which is not the case, it is important to notice that, in the context of the MPH, whether or not an interpretation is the object of academic consensus, this has no epistemological priority over the multiplicity and volatility of the metalinguistic practices, which, in themselves, respond for the "truth of the facts." The fact that such construal is, once more, based on the graphic nature of the characters is another sign of the radical effects of the alterity of the Chinese script.

The productivity and visual creativity of Chinese writing is quite evident in yán 言's rich network of related characters, all adding to its dense cloud of nuances and allusions. Thus in $y \breve{u}$ 語, speech, talk, words, idiom, sign, to admonish, to exhort, we have yán 言+ wú 吾, the second character (吾) being one of the possible references to the first person of the discourse in classical Chinese. Yán 言 here arguably mirrors the proximity of ming 名 and the self, as in both characters the discourse is sometimes identified with the speaker. However, the view that yán 言 is "not translatable," having only a "faint" sense of I (used to give cadence to the text/speech), might complicate this interpretation by

${ }^{167}$ See also Campos (1997), particularly chapters 1 and 2. 
suggesting that both speech and $I$ are translations unworthy of the semantic latitude of yán 言. As we have seen in the Shuōwén, the contrast between yán 言 and $y \breve{u}$ 語 is one that compares respectively direct/honest vs. difficult/complicated speech. This leads us to speculate that the addition of the self (the speaker) brings potentially distorting effects to the discourse. ${ }^{168}$

In this aspect, from the relation between yán 言 and zhi 直 (direct, honest, vertical, straight, impartial, stretch, intentional) in the Shuōwén, we learn that yán 言 is the word that presents an explanation or discourse in a straight manner. ${ }^{169}$ This ultimately means that the discourse is only recognized as such as long as it is straight, direct and just. The importance of the (truthful) discourse is even further highlighted as yán 言 is glossed elsewhere as the same yóu 猷 guide, plan which also refers to dào 道. This fact also brings yán 言closer to the realm of nature-dào 道and thus in contrast to the more overtly artificial nature of ming 名.

Yán 言, from the long list of acceptations above, is highly polysemic, especially regarding its metalinguistic functions, and in this way it may be “nearer" lógos than dào 道. However, it remains quite uncontroversial that yán 言 has basically an oral nature, due to its close relation to kǒu $\square$ and shé 舌. Once it is clear that these metalinguistic terms are all oral, English terms such as word or sentence become very problematic translations of yán 言 since they do not specify this strict separation. This acts as evidence of the MPH, further supported by the contrast with the written nature of $z i$ 字 and wén 文, which will be analyzed in the next two sections.

\footnotetext{
${ }^{168}$ In a Daoist perspective, we can say that yán 言 still offers us the possibility of correctly following dào 道, however in order to do so, one must be aware of the natural and effortless ways of dào 道, and thus manage to avoid $y \breve{u}$ 語.

${ }^{169} \mathrm{We}$ are reminded the dào 道 has also been glossed as $z h i$ 直. See footnote 132 for the comment on $z h i$ 直's "straight" and "direct."
} 


\subsection{4.}

\section{Zi 字: writing, (Chinese) character, letter, word, courtesy name}

$Z i$ 字 is one of the most important metalinguistic characters in the Chinese tradition and it is intimately related to the Chinese's reflections on their writing. It is also, along with dào 道 and míng 名, another hànzì whose graphic history perfectly illustrates the Chinese shēngxùn 聲訓 method of interpretation by semantic as well as phonetic import of another character.

In the Shuōwén we read:

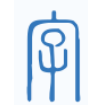

乳也。从子在它下, 子亦聲。

rǔ yě. cóng zǐ zài mián xià, ž̌ yì shēng.

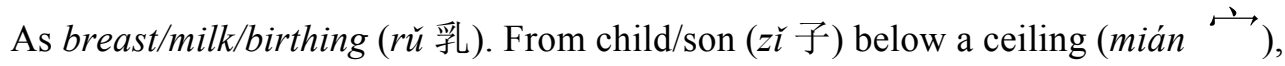
$z \check{l}$ 子also is a phonetic indication. ${ }^{170}$

Therefore $z i$ 字 has a clear graphic component which is also used as a standalone character: $z \check{l}$ 子, a highly polysemic hànzì, used as son, child, master (a polite suffix, as in Lăož̀ 老子), you (pronoun), a feudal title, etc.

In his analysis of the Shuōwén, GU (p. 226) argues, as per the shēngxùn 聲 訓 method, that the component $z \check{l}$ 子 brings not only phonetic, but also semantic, import. The author points to the idea of home and family, a house where one can raise a child. The OB, BS and LS versions (in Appendix I) appear to be quite clear graphic symbols of these notions and, eventually, the clearly pictographic character of the son/child ( 导, 夺踪) became $z \grave{\imath}$ 子. Because of the Shuōwén, GU writes that the "original meaning" of the character was to give birth to a child,

\footnotetext{
${ }^{170}$ Besides this specific gloss of 字, the Shuōwén also discusses the character at length in its postface, where it presents the (mythological) history and classification of the Chinese script. This influential account is examined in some detail below.
} 
which then was used, still according to this source, as to give birth, to bear in a more general meaning; and subsequently to get married, to raise, to rear, to bring up.

The connection of these earlier allusions with the use of $z i$ 字 to refer to writing and sinograph (hànzi), and in its opposition to wén 文 - which we will examine in detail below - is not indisputably clear and many authors offer it almost as two non-related facts. However, borrowing from the Shuōwén's influential postface, many scholars employ its mythological account of the birth of Chinese writing to explain the "involvement" of zi 字 and writing. In this account, the overall pictographic structure of the (original, primordial) Chinese characters was referred to as wén 文 (see below). As the need for a wider variety of characters and a richer script arose in a more complex society, extra "components" of the characters were added to the older pictographic forms, thus creating the "multiple component characters” (hétǐzi 合體字 in modern Mandarin, lit. coming together-body/style-character). The "birthing" of thousands of new characters would have been the metaphorical reason to call this components $z i \grave{\text { 字 }}$ 171

As per the Shuōwén's account of the mythological creator of the Chinese script, Cāng Jié 倉頴 ${ }^{172}$, the "pictographic nature" of the characters is referred to as wén 文, while the phonetic indication (which was added latter, to lessen ambiguities and distinguish between characters) is called $z i$ 字. This inaugural use led subsequent scholars to gloss zi 字 as writing, character, Chinese script (in contemporary Mandarin, also called wénzì 文字), or a style of writing/calligraphy

\footnotetext{
171 The metaphor of the birth of language (and writing) is clear in an important passage in the Shuōwén's postface:

倉頡之初作書也, 蓋依類象形, 故謂之文。其後形聲相益, 即謂之字。

Cāngjié zhī chū zuò shū yě, gài yà lèi xiàng xíng, gù wèi zhī wén. qí 後xíng shēng xiāng yì jí wèi zhī $z i$

When Cang Jie first invented writing, he created graphic forms (xiangxing) according to categories; therefore these were called wen (patterns). After that, forms and sounds (xingsheng) mutually augmented each other; these were called zi. (In: Galambos, 2006 p. 59)

${ }^{172}$ The name of Cāng Jié 倉頡 as the mythical creator of the Chinese writing appeared for the first time in the Xúnzľ (see Bottéro, 2006a, p.135).
} 
(today called ziť̌ 字體， lit. “style/body of zì 字”; or shūfă 書法， lit. "method/standard of book [letters]") and other related terms.

Another important aspect of $z i$ 字 is related to the period when the Chinese boy reaches adulthood at age of twenty and acquires a new "adult name" (or a courtesy name, biăozi 表字 in contemporary Mandarin) that shows his evolution as a human being. Karlgren (p. 310), and others, argue that at the age of twenty the boy becomes a brought up person, thus meriting a "name of style" that adequately acknowledges his adulthood.

The character zì 字 is not found in the Ěryă or in the Fāngyán, however it appears in a few passages in the Shiming. Samples of relevant passages are reproduced, translated and commented on in Appendix I. All these passages corroborate its close connection with birthing, to nurture, to cherish, foster.

GH glosses six acceptations for $z i$ 字 which might summarize the network of allusions sketched above:

1. Characters, script, writing, written language, derived directly from the Shuōwén;

2. a "short text written in characters," a letter, a brief note, etc.;

3. the pronunciation of a character; ${ }^{173}$

4. the courtesy name of a person and the act of getting/receiving a courtesy name;

5. to be pregnant ${ }^{174}$ and to bring up/to rear (a child);

6. to comfort, nurture and love. ${ }^{175}$ This interpretation is intimately connected to the bi-directional relationship of love/filial duty between parents and children.

\footnotetext{
${ }^{173}$ As in the modern expression zizhèngqiānyuán 字正腔圓, lit. “zì • correct/straight• tune/accent • shapely/agreeable/round," usually translated as speak/sing with clear and rich tones. ${ }^{174}$ As glossed in the Yú Fān zhù 虞翻注: 字, 妊娠也。$$
z i \text {, rènshēn yĕ }
$$$$
z i \text { 字, [from] be pregnant. }
$$

${ }^{175}$ For this gloss, the dictionary quotes a passage from the Shüjīng chapter kāng gào 康誥, "Announcement to [Prince] Kāng":
} 
This brief etymological survey of $z i$ 字 introduced its complex relationship with the Chinese script. There appears to be some notion of "organicity" in the script, where the addition of components was considered to be (like) giving birth to new characters in an ever-growing process. We will see in the different translations of the relevant excerpts from the Lăož̀ below how the translators decided to deal with this "inaugural naming" function of Chinese writing.

\subsubsection{1}

\section{Yán 言, zì 字and writing}

Since the nature of the Chinese language appears markedly "fractured" along its dual-sided dimensions, oral and written, it is worthwhile to recapitulate the oral connotations of yán 言and compare with $z \grave{l}$ 字's written connotations.

There are some important classical references that clearly underscore the spoken nature of yán 言 and give support to its grapho-etymological analysis presented in the previous section. We return to Geaney's (2010) discussion on early Chinese metalanguage:

The contrast of sound and sight in early Chinese texts is evident in parallels of speech - which is audible, with action - which is visible. In making this claim, I am taking the graph yan 言, often translated as "language," to mean "speech." In pre-Qin texts, metaphors of yan - coming out of the mouth, being emitted, being heard, and being listened to - all imply that yan is specifically speech. (Ibidem, p. 257)

Geaney quotes some classical texts as evidence for the oral nature of yán 言:

言為可聞行為可見 (Xúnž̌, chapter 27, dà lüè 大略, “The Great Compendium").

yán wèi kě wén xíng wèi kě jiàn

于父不能字厥子, 乃疾厥子。

yú fù bùnéng zì jué zĭ, năi jí jué zĭ.

And the father who can no longer love [zi 字] his son [ž̀ 子], but hates him. (translated by

Waltham) 
[The filial son's] speech [yán 言] can be heard and actions [xíng 行] can beseen.

言，心聲也，書，心畫也 (Fǎyán 法言, chapter wén shén juăn dìwǔ 問神卷第五, “Asking About Shen”)

yán, xīn shēng yě, shū, xīn huà yě.

Speech [yán 言] is the sound of the heartmind and writing [sh $\bar{u}$ 書] the paintings of the heartmind.

On the other hand, we have seen that the character $z i$ 字 is a very important character-emblem in the Chinese's reflections on their own language and, specifically, on the Chinese script. Pellin (2008, p. 536), for instance, writes that $z \check{l}$ 字 is “the basic term of Chinese linguistics, [...] 'word', which incorporates the graphic unit and the semantic unit all at once [...]."

$Z i$ 字 is part of the title of the Shuōwén, shuōwén jiězi 說文解字, where its relationship with another key character of the Chinese traditional metalinguistic repertoire, wén 文(see below), is discussed in detail by Bottéro (2006a, 2011) and other authors. Traditionally, as we have briefly seen above, $z \check{l}$ 字 is considered to refer to the compound characters in opposition to the simple characters (pictographic), which are denoted by wén 文. Bottéro (2011) examines the polysemy of both characters in texts that predate the Shuōwén. Regarding zi 字, the author has identified three main glosses: 1) to breast-feed, no nourish, to raise/bring up; 2) to love (ài 愛); 3) public personal name, to confer a name, to call (as 名字 mingzì, name, first name). This list is very much in accordance with the analyses we have seen above. $Z i$ 字 used in the sense of Chinese characters would only appear after the reform of the Qin dynasty. ${ }^{176}$

[C]'est dans la célèbre phrase attribuée à Qín Shǐ huá ngdì 秦始皇帝 tó ng shū wén $z i$ 同 書文字 ou shū tó ng wén zì 書同文字 (Sh Shíjijì 史記 6 239, 245) «écrire de manière unifiée les caractères (wénzi)» ou : «unifier les graphies (wén) et les caractères (zì) (c'est-à-dire aussi les mots) dans les documents», que wén et zì sont associés pour la première fois. (Bottéro, 2011, p. 27)

${ }^{176}$ Before the Qin, the terms to designate the Chinese characters would be, according to Morel (2005, p. 105), wén 文 or $s h \bar{u}$ 書. 
[I]n the famous sentence attributed to Qín Shì huá ngdì 秦始皇帝 tóng shū wén zì 同書文字 or shū tó ng wén zì 書同文字 (Shijì 史記 6 239, 245) “write in a unified way the characters (wénnzi)," or: "unify the written forms (wén) and the characters (zi) (that is the words as well) in the documents", that wén and $z i$ were associated for the first time.

According to the French Sinologist, we have "graphic form (figure/drawing) for wén and written word for zì." (Ibidem, p. 28) Therefore $z i$ 字 should refer to the Chinese characters themselves, in its graphic and concrete aspect, the visual dimension of the Chinese script. There is no mention of any connection between $z i$ 字and spoken Chinese.

In spite of these passages and analyses, the confusion between yán 言 and $z \grave{i}$ 字, as to whether they refer only to the oral or the written realm of language, remains. This misunderstanding, in my opinion, is reflected in the on-going discussion about what "exactly" is the classical Chinese equivalent of the term word in English (as seen above in the first part of this chapter). Most of the recent academic works, although accepting that the answer must be historically contextualized, still seek to "fit" the Chinese language into the Western conceptualizations of word. For instance, in Packard (2000) we see an example of an author who departs from the "clear and intuitive" notion of word in English and then tries to apply these characteristics to Chinese:

The 'word' is a clear and intuitive notion in English, because in the culture of English speakers the concept of the 'word' is particularly salient and robust [...] In Chinese, however, the word is by no means a clear and intuitive notion. In Chinese language and culture, the clear and intuitive notion - the sociological word - is the $z i$ 字. The term $z i$ actually has two distinct meanings in popular usage: it can mean either a morpheme in the spoken language, or it can mean a written Chinese character [...] But most speakers of Chinese do not distinguish between these two meanings of $z i$ when they use the term [...]. (Packard, 2000, p. 14)

Packard, albeit in what appears to be universalist motivations, recognizes the difficulty of using the translated term in Chinese:

The possibility that the 'word' is merely an artificial construct or epiphenomenon certainly occurs to the speakers of Chinese, since - metalinguistically speaking the 'word' in Chinese does not appear to be a particularly intuitive notion. 
Knowledge of the Chinese language, along with the 'culture of language' that accompanies that knowledge, suggests to Chinese speakers that the notion 'word' is a concept that comes from the West and so is based on the structure of westerntype languages. (Ibidem, p. 16-7)

What Packard's analysis lacks, in my reading, is the possibility of "another" word, one that assumes different sets of connotations in the Chinese tradition. This opens the possibility that even if word ("our," English, word) is an epiphenomenon in Chinese, certainly neither yán 言 nor $z i$ 字 are epiphenomena.

These characters (words?) are certainly central to the metalinguistic reflections of the Chinese tradition, as shown throughout this dissertation. Packard, however, proposes a "western style" morphological analysis of Chinese, and in order to do so, he must find a point of departure. In a passage that clearly betrays his Gerativist affiliations, the author states simply:

In this work, the syntactic definition of word will be used as the basis for analyzing Chinese words [...] The assumption of the existence of the syntactic word follows a universalist argument, which assumes that the word is biologically hard-wired and psychologically real [...]. (p. 18-9, my emphasis)

Packard's research is an example of the introduction of Western concepts to study linguistics that have been so current in China today since the groundbreaking work of Sinologist Bernard Karlgren (1889-1978), who laid the foundations not only of the modern thinking about historical Chinese, but also Chinese phonology and Chinese writing. The Chinese language has suffered an immense change particularly since the beginning of the $20^{\text {th }}$ century, to the point that we read that

More than 40 percent of the Chinese we use today is actually an interpolated 'foreign language' - Western vocabulary was first translated into Chinese characters by the Japanese, then borrowed into written Chinese. (Lin, In: Sze, 2010, p. 284)

However, the discussions brought in this dissertation are signs of the uncertain grounds that Western and contemporary Chinese scholars are treading when attempting to build up semantic connections between word/speech/writing 
on the one side and yán 言/zì 字/huà 話 on the other. I claim that, according to the $\mathrm{MPH}$, such semantic connections cannot be taken at face value, lest they ignore the fundamental differences between the linguistic objects and objectives of both traditions.

\section{$* * *$}

In the next box $z i$ 字's main acceptations are schematized:

Box 4- $z i$ 字's network of allusions

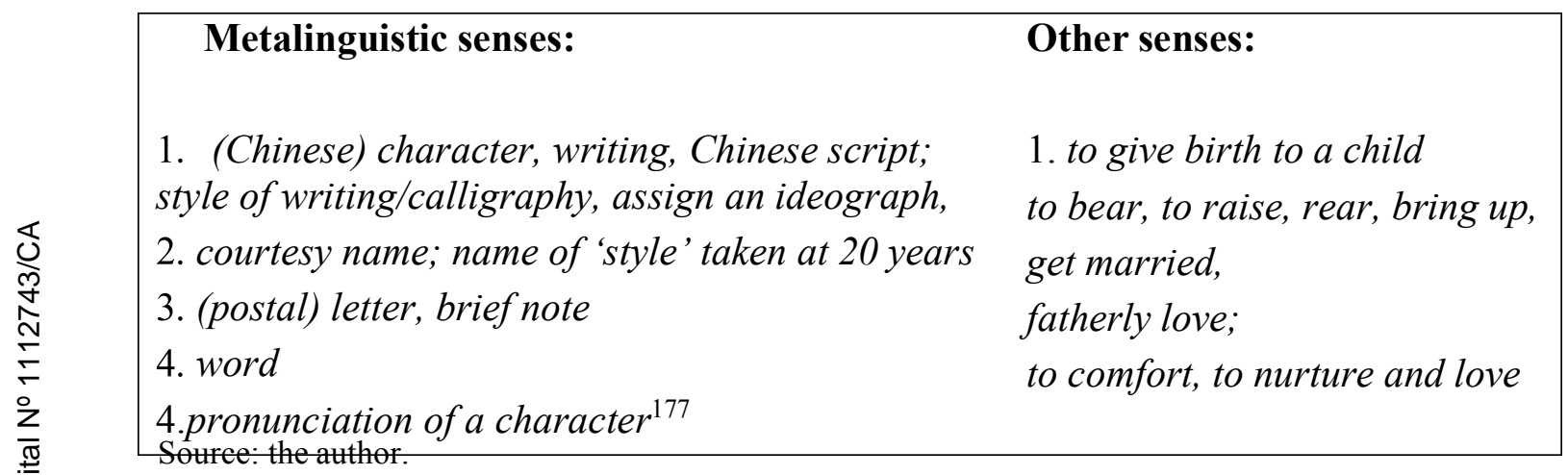

We have seen that $z i$ 字 is one of the most important Chinese metalinguistic terms, and that it is the character most often associated with the Chinese script "the basic term of Chinese linguistics." (Pellin, 2008)

There are two Chinese characters that, for completely different reasons, are crucial in the interpretation of $z i$ 字:

$z \check{l}$ 子: son, child, master, you (pronoun), a feudal title wén 文: pictography, writing, tattoo, patterns, culture, books

${ }^{177}$ As it happened before with yán 言 and ming 名, to gloss zi 字 as pronunciation of a character seems again the result of the confusion between writing and speech, the result of a context alien to the more ancient Chinese traditions. There is an additional potential problem regarding $z i$ 字: because the Shuōwén refers to it as the composite characters, which are likely to have received components to indicate mostly a phonetic import, zi 字 became sometimes associated with this "addition of phonetic import," thus the ensuing heightened confusion. 
The first, $z \grave{l}$ 子, is a graphic component of $z \grave{l}$ 字, and it is the semantic motivation for the interpretation of the earlier uses of the character. Thus we have

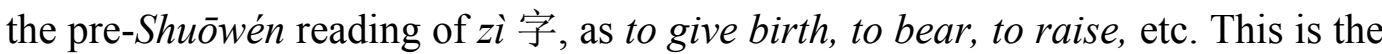
"original” use of $z i$ 字, one that is, for once, quite uncontroversial: the child/son (ž̋ 子) remains safe below a ceiling (mián や).

The second, wén 文, is part of $z \grave{i}$ 字's “post-Shuōwén period” and its history as a metalinguistic term, undoubtedly the most important regarding Chinese writing. After the Shuōwén almost all sources would point to its use as character, writing, script, calligraphy, etc. ${ }^{178}$ The gap between these two "lives" is baffling and the way to bridge it remains the object of many speculations. These speculations, to some extent, coalesced around the idea that $z i$ 字 was metaphorically seen as responsible for the birthing (or more precisely, the multiplication) of the large majority of the Chinese characters.

$Z i$ 字's almost "dual nature" seems motivated by its use to refer to the courtesy name that a young man accepts once he reaches the age of 20. Although obviously a metalinguistic usage, it is arguably motivated by the more ancient use of $z i$ 字, related to bear, raise, bring up (a "brought up person", Karlgren). This use is testimony that the pre-Shuōwén period of $z \grave{i}$ 字 continued to drive and influence the character's metalinguistic role.

Therefore, in $z i$ 字 we have a network of allusions that finds no counterpart in the Western tradition. In this tradition, the major metalinguistic terms related to writing, such as writing, to scribe (Port. escrever) or graph, have origins as tears, scratches and traces on a surface which left some sort of markings. As we have seen, there are apparently very similar hypothetical etymologies, respectively Indo-European *wreid-, to tear or scratch; Greek gráphein, to scratch, engrave, draw; and Proto-Indo European *skreib ${ }^{h}-e / o$, to carve. The boundaries between drawing and the first attempts at (proto-)writing were unclear and writing seems

${ }^{178}$ The Shuōwén was used in the Hàn dynasty to promote the idea that the Chinese history, language and script had been born in the revolution of the reformer $L \grave{l} S \bar{l}$ in the previous Qín dynasty. Its postface offers an account of the mythological birth of Chinese writing. It is no wonder that $z i$ 字, a character intimately related to birthing and nurturing, played such a pivotal role in this story. 
to have appeared, at least in the point of view of the metalanguage, as a specialization of drawing. In the Oxford English Dictionary, write is glossed as activities which involve written (alphabetic) letters, but also other markings, and which are frequently related to communication and literary production. ${ }^{179}$ The related Eng. writ is a "form of written command," an enforcement of authority. These are themes that one does not encounter as protagonist in $z i$ 字's own history.

Chinese writing, as referred by zi 字, has a completely different mythological account of its origin when compared to Western "alphabetic" writing, and it has remained marked by the cleft which divided it into two major group of characters: $z \grave{l}$ 字 and wén 文, respectively the compound characters and the simple, pictographic characters. ${ }^{180}$ This division is solely dependent on the graphic nature of the Chinese characters and also finds no counterpart in Western metalanguage. The analyses here point to remarkable differences between the activity of writing and its metalanguage, which provides support for the MPH. In the next section on the character wén 文 there will be an opportunity to further examine this issue.

\subsection{5.}

\section{Wén 文: writing, language, literature, culture}

The character wén 文 has played a prominent role in traditional Chinese studies on language, as well as cultural and literary studies. It is usually translated as culture, but it also has the metalinguistic acceptations of writing and language, besides being also used in the adjectival form as formal and literary, as well as, although less frequently, educated and refined. Some of these uses are found in suffixed forms in contemporary Mandarin, for example, púwén 葡文，Portuguese

\footnotetext{
179 1) mark (letters, words, or other symbols) on a surface, typically paper, with a pen, pencil, or similar implement; 2) compose, write, and send (a letter) to someone; 3) compose (a text or a work) for written or printed reproduction or publication; put into literary form and set down in writing; and 4) underwrite.

180 This traditional division is also not free of controversy. For instance, as seen above, Bottéro interprets that wén 文 stands for graphic form (figure/drawing) while zì 字 was used more specifically for the written word.
} 
(language) or făwén 法文, French (language) or in other dissyllables such as wéntán 文壇, literary circles/world; wénxué 文學, literature; wényán 文言, Classical Chinese writing /language; as well as wényă 文雅, refined, withculture.

Graphically, one considers that wén 文 was, at least originally, a pictogram of a tattooed human breast, which would refer to related uses as tattoo and, eventually, written character. In another interpretation, Harbaugh (1998) and other authors base their analyses on the Shuōwén (see below) and consider that the character is simply a stylized drawing of lines that intersect, a symbolic or iconic representation of all written Chinese characters. The OB and BS versions of wén 文 were likely to have been pictograms resembling a person with what seems to have been U- or V-shaped object inside the chest (Lindqvist, 2008): ${ }^{181}$

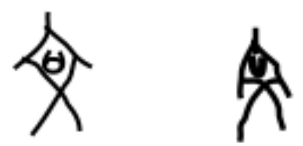

Such graphemes show a pictography that motivates the interpretations of tattoo or man with intersecting lines.

In the Shuōwén, we find the following entry for wén 文:

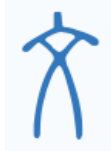

錯畫也。象交文。凡文之屬皆从文。 cuò huà yě. xiàng jiāo wén. fán wén zhī shǔ jiē cóng wén.

[From] to portrait/to depict [huà 畫]. ${ }^{182}$ Appears as intersecting lines [jiāo 交], as 文. All [characters that belong to the] category [of] 文 wén point to [semantic affinity with] 文 wén.

\footnotetext{
${ }^{181}$ See also Appendix I for other samples of wén 文pre-Qin dynasty reform.

${ }^{182} \mathrm{CT}$ (p.350) reads 錯畫as kèhuà 刻畫, lit. “to carve/to engrave a painting/a portrait"
} 
Jullien (2003, p. 22) translates the first part of the gloss: "drawing of lines, representing the figure of an intertwining." The second part, as we have seen before, is the formulaic construction used often in the Shuōwén, saying that characters with the radical 文 point to a semantic "derivation" (or relation) from wén 文.

The use of wén 文 as an act of depiction or portraiture is one that many authors and commentators will deem as being derivative of more ancient and "concrete" uses of wén 文 as the patterns of nature. It is in this acceptation that wén 文 appears in the Ëryă, the Fāngyán and in other pre-Shuōwén texts. After the reformation of the Qin dynasty, the character started to refer to pictographs, to Chinese characters in general, to calligraphy, etc. Samples of relevant passages from each book are reproduced, translated and commented on in Appendix I, and an in-depth analysis of the relation of wén 文 with patterns, culture and writing is presented in the next section.

As for the modern and contemporary authors, Bottéro (2011, pp. 26-7) surveyed the uses of the character wén 文 in the ancient texts that predated the Shuōwén, and listed her preferred uses of the hànzì:

1. Excellent, admirable, accomplished, perfect, illustrious;

2. civil, arts, belles-lettres, by opposition in wŭ 武 (military, arts of the war), whence the sense of educated, cultivated, well-read;

3. ornament, decoration, culture, by opposition in zhi 質 (substance, nature), or brilliant, elegant, colored (wén cai 文采, huáli 華麗, caisè jiaocuò 彩色交錯), by opposition of sù 素 (simple, raw, natural, white);

4. drawing, stripes, veins in the marble, veins (huawén 花紋, wénlǐ文理);

5. figure, mark, graph; 
6. wén sometimes noted the sense of the word wén 紊, disorder, confusion, chaos (wénluàn 紊亂). ${ }^{183}$

Number 4 reminds us of the physical graphic patterns briefly discussed above. They are interpreted by Owen (1992, p. 594) as alluding to patterns in a jade stone, which was from a very early time used to refer to patterns in general (e.g., the "wén 文 of the Earth" is topography). The author also points out that wén 文 is a term used for culture, refinement and study ( 1 and 3 above), and the civilian side of a State (in opposition to its military aspect) (3 above). ${ }^{184}$ And, of particular interest to this study, Owen calls attention to what he considers to be a common metaphor of the "organic tree as literature." In this metaphor wén 文 as the visible patterns on the surfaces of the leaves, which, when carefully observed, reveal the hidden form of the trunk and branches, and as such takes the role of the organic and external manifestation of some substance (質 zhi ${ }^{185}$ ) or natural principle (lǐ 理). ${ }^{186}$

${ }^{183}$ This is a potentially problematic gloss. Wén 紊 has the same components as wén 紋, seen above (to recall: wrinkles, stripes, line), but in a different arrangement. In the Shuōwén we find wén 紊 glossed as:

紊, 亂也。从系, 文聲。《尚書》曰:“若網在鋼, 有條而不紊。”

luàn yě. cóng jì, wén shēng. "shàng shū" yuē: ruò wăng zài gang, yǒu tiáo ér bù wěn."

As for [wén 紊], disorder, confusion [luàn 亂]. [Semantic import] from 系 [silk], sound [from] wén 文. The Shāngshū said: When the net has its line, there is order [tiáo 條] and not confusion [wén 紊]. (partial translation by Legge)

Therefore the Shuōwén opposes wén 紊 and tiáo 條, which is glossed in GH as long branches of trees; long, slender; statutes, laws, proper arrangement, orderliness; to understand, measure of length, enumerated list, etc. The idea seems to oppose the orderliness of a net with the disorderly arrangement of entangled lines. It might reflect the "disarrangement" of the character wén 紊, with the different layout of its components.

${ }^{184}$ This role of wén 文 in the opposition civil/military may seem at odds with the other allusions discussed so far. A look at some expressions with this use in Matthews (p. 1059) shows that civil might be related to the cultured aspect of the Chinese imperial bureaucracy, for example: wénguān 文官, civil official or wénwǔ 文武, civil \& military, which GH glosses as the sum of the dual accomplishments of the civil administration and the military conquests, as well as the composition of the literary talent and skill in the martial arts. This very old opposition is attested to in the dual name of the legendary founder of the Zhōu dynasty, known in life as King Wén (wén wáng 文王) with a posthumous name of King $W \check{u}$ (wǔ wáng 武王).

185 For Owen (1992, p. 585) zhi 質 is not substance or content in the sense of some matter that is located "inside" an external shape, but rather in opposition to 文 wén, in its simplicity and lack of ornamentation. Note that this is the same interpretation in Bottéro's gloss number (3)above.

${ }^{186}$ In continuing along the metaphor of the tree, such a "natural principle" or "substance" is the act of growing or "to tree" (to be tree), in consonance with Nature. Wén 文 is the marks that are testimonies of this "growing principle." 
This brief review of classical and contemporary authorship hints at three major "semantic hubs" that motivate the uses of wén 文: figurative patterns, writing, and culture and literature. How wén 文 articulates these three semantic realms is the subject of the next section.

\subsubsection{1.}

\section{Wén 文as the patterns of the world, culture and writing}

Wén 文 is frequently interpreted as having a usage that emanates from its older graphical form, as patterns, or lines that cross that appears primarily in nature, but also in the human's world. This crucial connection will be the source of its prominent role in the history of Chinese culture and will have a huge influence in informing the ideas pertaining the notion of culture in China. Obviously there is an extensive material on this subject and, due to reasons of space, I could only present here a small sample of the available scholarship, while aiming to establish on firmer grounds the network of allusions between culture, patterns, nature, writing and ornament.

Jullien (2003, p. 22) conjectures a relation of wén 文 with a combination of old forms of the numeral six (liù 六, OB:, 个, $\Uparrow, \lambda$ ) and the numeral five

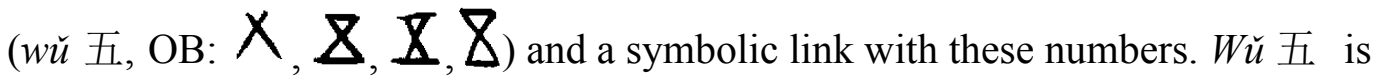
the first number whose graphical written representation implies a break with the iconic representation of the numbers directly from the visual appearance of the character. ${ }^{187}$ Another possible analogy, still according to Jullien (2003), springs from the relationship between wén 文 and yáo 爻, which designates the "mutating line in the interior to the Yijing trigram" and plays an essential role in the

\footnotetext{
${ }^{187}$ The numerals up to four were represented in OB as: - , 三 ${ }_{\text {and }} \equiv$, although four, in the small seal script already had a form similar to the modern character, $s i$ 四.
} 
symbolism of the ancient divination methods. ${ }^{188}$ Finally the author claims that there are graphical links between wén 文 and terms such as jiào 教 and xué 學, respectively to teach and to learn, implying a semantic relationship as well.

This network of relationships, according to the French Sinologist, suggests an intimate connection between wén 文and the "world order": 189

[This is] the idea that wen is naturally at work in the world and that it is through it that the reality of the universe (tian 天) and that of man (ren 人) correspond and communicate. (Jullien, 2003, p. 23)

Ames \& Hall also agree with this notion, which is shared among most of the Sinologists:

Just as the firmament displays its elegance as celestial pattern (tianwen 天文), so the human world as "the heart-mind of heaven and earth" expresses its accomplished patterns as culture (wenhua 文化). Wen is "pattern" where aesthetic value and meaning are co-present. ${ }^{191}$ (Ames \& Hall, 1988, p. 33)

The authors make reference to many compounds which highlight wén 文's complex interplay between nature and the human: literature (wénxué 文學, lit. 文study), elegance (wéntǐ 文體 lit. 文-style/body) and style (wénfēng 文風, lit. 文airs/wind), education in the humanities (wénjiào 文教, lit. 文-teach) and

${ }^{188}$ Yáo 爻 was also used to refer to various marks on animal furs, as presented in the character bó 駁, which was formerly used to designate a spotted horse (bó 駁 is composed of yáo 爻 and $m a \check{a}$ 馬, horse).

For further information of the roles of yáo 爻 and wén 文 in the Yijingng, see Wilhelm \& Baynes, [1950] 1997.

${ }^{189}$ To put an order in Nature by the imposition of wén 文, should not be interpreted as an order over some chaotic situation, but rather the identification and acceptance of the patterns in Nature caused by the intertwining of focus and field in dào 道. For this, see Ames \& Hall (1998, p. 65-6).

${ }^{190}$ In the original: “[...] l'idée que le wen est naturellement à l'oeuvre dans le Monde et qu'à travers lui la realité de l'Univers (le tian 天) et celle de l'homme (ren 人) se correspondent et communiquent."

${ }^{191}$ The polysemy of wén 文 is present, according to Major et al. (2010,p. 109), in the discussion on the title of the third chapter of the Huáinánzǐ, which is exactly tiānwén 天文. Major writes that the chapter might be either translated as Heaven Adorned or as Celestial Patterns, both acceptations "would have been present in the mind of the Han-dynasty reader." (Ibidem) 
civilization (wénmíng 文明, lit. 文-enlightnment/bright) and wén 紋, wrinkle, stripe, line (lit. 文-silk). ${ }^{192}$

Therefore, as a result of these analyses, we have on the one hand a more "graphic" sense of wén 文 as mark, pattern, figuration and on the other, an extremely symbolic use, which connotes participation in the world order and is directly connected to the notions of culture and civilization. These are values which appeared very early in Chinese history, as evidenced by the name of the mythical founder of the Zhōu dynasty, Wén Wáng 文王 (lit. “king Wén”), the civilizing ruler par excellence (see also note 184). In another example, this is testified by an old formula that appeared in Zuǒzhuàn, chapter zhāo gōng ér shí bā nián 昭公二十八年, “Duke Zhāo, $18^{\text {th }}$ year”:

\section{經緯天地曰文}

jūng wěi tiān dì yuē wén

[...] recourant au Ciel et à la Terre comme la chaîne et la trame [de son caractère], c'est ce qu'on appele l'aspect wen (accompli) [de sa nature individuelle]. (translated by Jullien, 2003, p. 23)

[It is] appealing to Heaven and Earth, as well as to the chain and weft [of its character], this is what one calls wen (accomplished) [of one's individual nature].

Within this context, wén 文is the last of the nine virtues of King Wén. Thus, to "be" wén 文 means to properly conduct oneself in a manner that is adequate to the inherent order of the universe (or, as we see in the Lăož̆, "to act in accordance with dào 道”). Moreover, to make such representation possible, and in order for the king to receive the Mandate of Heaven, the reality of man must be considered as homogeneous (in harmony) with the world. ${ }^{193}$

\footnotetext{
${ }^{192}$ The character wén 紋 is poetically translated by Ames \& Hall (1988, p. 33) as wrinkles on an older person's face that reflects character and experience.

${ }^{193}$ The man's civilizing mission is embedded within the natural order, which leads directly to the

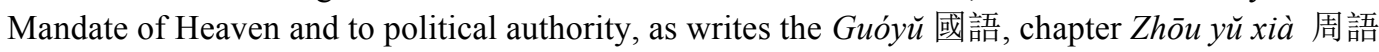
下, “Language of $Z h \bar{o} u$, second part":

能文則得天地

néng wén zé děi tiāndi
} 
As an empire built over an immense and highly literate bureaucracy, it is no wonder that civilization - actually, the Chinese civilization - meant books and culture. There seems to have been, in effect, a specific metaphorical/metonymical link between writing and culture, which was possibly motivated by the fact that, along the centuries of China's imperial period, the entrance exams to the huge administrative machine of the Empire basically dealt with the knowledge of classical texts. One's success in the exams brought enormous reputation to the candidate and was a sign of power, wealth and culture. It is arguably true to say that the Shuōwén seized wén 文as one of the key terms to refer to the Chinese characters and writing to borrow from its immense prestige among the ancient canonical texts and the Chinese society as a whole.

\section{* * *}

In the next box, wén 文's main acceptations are outlined:

Box 5-Wén 文's network of allusions

\begin{tabular}{|c|c|}
\hline Metalinguistic & Other senses: \\
\hline \multirow{10}{*}{$\begin{array}{l}\text { 1. writing, } \\
\text { pictography } \\
\text { 2. language }\end{array}$} & $\begin{array}{l}\text { 1. tattoo; drawing of lines, representing the figure of an intertwining; } \\
\text { decorative pattern; figure (carved) on the human body }\end{array}$ \\
\hline & $\begin{array}{l}\text { 2. drawing, stripes, veins in the marble, lines that intercross, veins, } \\
\text { wrinkles, ripples }\end{array}$ \\
\hline & 3. culture, literary, book; civilization; to teach, to learn \\
\hline & $\begin{array}{l}\text { 4. genteel, elegant formal, educated, refined; style, education in the } \\
\text { humanities; the civilian side of a State }\end{array}$ \\
\hline & 5. participation in the world order \\
\hline & 6. adornments, ornaments, slogans \\
\hline & 7. grain in wood or ripples on water \\
\hline & 8. "possibly a scholar sitting cross-legged" \\
\hline & $\begin{array}{l}\text { 9. "wrinkles on an older person's face that reflects character and } \\
\text { experience." }\end{array}$ \\
\hline & 10. disorder, entangle $(d)$ \\
\hline
\end{tabular}

Source: the author.

Qui incarne le wen est en mesure de "gagner" le Monde. (translated by Jullien, 2008,p.24)

Whoever can wén 文should win (děi 得) Heaven and Earth. 
At first one might be astonished by the semantic variety of glosses for wén 文. It is a metalinguistic term whose sense is primarily involved with writing and, in a more general way, also with language. However, wén 文's nuances extend far beyond the general associations with writing in the Western metalanguage, as we have seen briefly discussed in the analysis of $z \grave{l}$ 字in the previous section.

Wén 文 is a pure pictograph which refers to pictography. Its graphic interpretation has generally revolved around the ideas of a stylized figure of a human being with some sort of drawing inside their chest (repeated here for illustration):

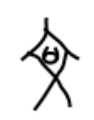

As in the case of $z i$ 字, the history of wén 文 is divided by the myth of the creation of writing in the Shuōwén. However, the break between its first and second "lives" is not as dramatic as in the case of $z \grave{l}$ 字. Before the Shuōwén, wén 文 was recognized as a pictography of a drawing, of lines intercrossing, or some kind of tattoo. In this way, one can claim that it already had a metalinguistic use (a "drawing of a drawing"). However, the early character's use was much broader, widening along metonymical derivations from lines, to the reference of the patterns of nature (and man), to their physical beauty, ornamented and elegant. Wén 文was also likely to have been regarded as a mark of the harmony of Man in Nature, the "participation in the world order" (Ames \& Hall, 1998), or, in other words, a condition where man's civilizing mission (wén 文) is embedded within the natural order (zìrán 自然).

When the Shuōwén borrowed wén 文 to refer to writing and, more specifically, to pictographs, its past usages were naturally not only a motivation for its choice but also inspired a wide network of allusions. The beauty and harmony of the patterns of Nature's dào 道 are mirrored in the Chinese's traditional views on their characters. Thus Nature's mirroring in writing of wén 文 (and, in many ways, in $z \grave{\imath}$ 字) is not meant to be understood in a representational 
way, but with wén 文 as straddling both the realms of Nature and Human, in a sensuous rather than mimetic manner.

With the discussion so far it is possible to propose a little schema which might help us to better distinguish between the uses of the metalanguage that we have analyzed thus far.

Table 1-Selected Chinese metalanguage comparison

\begin{tabular}{l|c|c}
\hline & writing & \multicolumn{2}{|c}{ speech } \\
\hline & \multicolumn{2}{|c}{ dào 道 } \\
\hline pictography & wén 文 & \multirow{2}{*}{ yán 言, ming 名 } \\
\hline compound characters & $z \grave{\text { 字 }}$ & \\
\hline
\end{tabular}

Source: the author.

It is important to bear in mind that, although with different levels of focus, all five characters (perhaps with the exception of dào 道) can, in a way, be translated as name or word. Their relationship suggests a striking contrast with the Western metalinguistic lexicon, and thus it indicates that the mere setting of these Chinese hànzì into Western categories poses bigger problems than might have been anticipated. As per perspectivism and the MPH, these differences are symptoms of distinct forms of life, of an entirely different way to relate to the written language which presupposes a much more intimate relationship between Chinese writing and harmony in the World, into a whole that is epistemologically coherent, albeit radically foreign to us.

Additionally, the fact that wén 文 was also used to connote the uses associated to graphically (and phonetically) similar hànzì, such as wén 紋, veins, grains, patterns (in clothing) and, particularly, wén 紊, disorder, confusion, chaos, is potentially enigmatic. While wén 紋is a perfect example of the Chinese method of glossing of characters called shēngxùn 聲訓, the same could no be said about wén 紊, with its opposite allusion. In this case, I argue that there was a possible graphic "contamination" between characters, which influenced their uses and 
allusions in a way that would have been impossible in a phonemic alphabet, thus an evidence of the MPH. ${ }^{194}$

\subsection{6.}

\section{Yi 義: meaning, sense, significance}

The character $y i$ 義 (义 in the simplified script of mainland China) has the established allusions of justice and righteousness in the canonical texts of ancient China, but it also referred to meaning and sense. If we consider the term under the magnifying glasses of Western linguistics, this polysemy could be examined in the light of the multiple meanings of the Greek lógos, word and literal / logical sense, and thus binding, as we have seen, the correct with the true meaning of a word. On the other hand, this dissertation's MPH invites us to examine in detail the autochthonous roots of $y \grave{\imath}$ 義, in which case the polysemy of the hànzì should be articulated with the prescriptive vision that underlies Chinese philosophy: only what is endorsed and "correct" would be of some significance. (Granet, 1934, p. 19, 27) As we will see below, in the survey of the diachronic roots of $y i$ 義, there is no clear and definitive indication of a single, indisputable origin, a result which reinforces the complexity of the issue. The fact that the grapho-etymology of $y i$ 義 frequently points to terms translatable in English as righteousness, justice or rectitude - clearly not considered "metalinguistic" per se in the Western languages' repertoire - is a sign of the difficulty in asserting Western standards and defining universal categories.

A common term in contemporary Mandarin is yìy 意義, in dictionaries usually glossed as meaning, sense, significance. The first term of the disyllable, yì 意, is also an important character in the Chinese canon, especially in literary studies and appearing in modern dictionaries often translated also as a concept,

\footnotetext{
${ }^{194}$ Scholars who uphold the primary phoneticist nature of the Chinese script would likely explain wén 紋 and wén 紊 as being phonetical-semantic composed hànzì, with the component wén 文 used only for its phonetic import. Phoneticism, however, fails to explain how it happened that wén 文 “borrowed” wén 紊's sense.
} 
idea, meaning. ${ }^{195}$ However, these English words refer to concepts that some authors find extraneous to classical Chinese thought. This could be the reason why Owen (1992, p. 594) calls yi 意“"perhaps the term in Chinese poetics [literary criticism] that is the most difficult to translate," after which the author suggests some fuzzy notions, such as resulting of a well-done interpretation, the result of a deduction from some observation, etc. ${ }^{196}$ It seems quite relevant that this character does not appear even once in the Lăož̆, where the preference is to use the second term of two syllables, $y i$ 義.

In the Shuōwén, yi 義is glossed as follows:

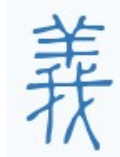

己之威儀也。从我、羊[年]。臣鉉等曰: 此與善同意, 故从 羊 [ 年卢]。

jŭ zhī weìyí yě. cóng wǒ, yáng. chén xuàn děng yuē: cǔ yǔ shàn tóngyù, gù cóng yáng

As for one ( $j \check{\imath}$ 己) [ to behave in an] impressive and dignified manner (wēiyi 威儀). From $I / m e / m y s e l f$ (我) [and from] sheep/ungulates (yáng 羊). People like Chén Xuàn 臣鉉 are saying this has the same meaning ${ }^{197}$ [yi 意] as good/virtuous/skilled (shàn 善), therefore from sheep/ungulates (yáng 羊).

${ }^{195}$ Another ancient important characters that are related to idea and meaning, and usually glossed as thought, are $s \bar{\imath}$ 思 and $l \hat{u}$ 慮. For a historical approach on their use and importance in the Chinese traditional thought, see Zhang (2002, pp. 432-9). Neither $s \bar{l}$ 思, lì 慮 nor $y \grave{l}$ 意 appears in the Lăož̀.

${ }^{196}$ Owen (1992, p.31) writes that

As a unifying minimalization of some putative content that transcends the particular words of an utterance, $y i$ most closely approaches "meaning" or "concept" in the Western sense [...] However $[\ldots]$ it never quite achieves the full level of abstraction or collectivization we find in Western terms such as meaning, concept or idea. [...] [It is] "what is meant" rather than "Meaning."

${ }^{197}$ I am translating here $y i$ 意 as meaning in order for the text to be more readable. For example, a more awkward alternative would be: this has the same result of a well-done interpretation as shàn 善. See also the observations on $y i$ 意above. 
The Shuōwén notes the semantic similarity of yì 義 and shàn 善, usually glossed as good, virtuous, skilled (at something). ${ }^{198}$ And graphically, yì 義, according to the Shuōwén, is a semantic compound of wǒ 我, the first person pronoun, I and yáng 羊, sheep, ungulates.

As for wó 我, the first person pronoun, I, some authors have suggested that it has at its origin military connotations, as a semantic composite of a hand (shǒu 手) holding a halberd or a lance ( $g \bar{e}$ 戈), in some kind of defensive/offensive position which asserts the self. ${ }^{199}$ There is therefore a complex interplay among the ancient connotations related to yáng 羊 and wó 我 that have been brought into $y i$ 義and that gave to it an almost “dual nature."

In ascertaining its subtle connotations, we might posit a hypothetical link between an impressive and dignified manner (weìiyi 威儀), such as is usually applied to armed forces and military, and the qualities of $y i$ 義, such as beautiful and good (měishàn 美善) and just and righteous (zhèngyì 正義). The figure of the sheep or ungulate in the character yáng 羊 is an oft-proposed metonym for those qualities and might have lost very early on its more literal animal reference. The martial influence is evidenced by what appears to be the precedence and importance of the cognate $y i$ 儀, etiquette, protocol, rites, ceremony; law, moral standards; looks, appearance; instrument; and manners. Therefore, one finds composites linking yi 義and military terms, such as yibing 義兵, a righteous army or q亡yl 起義, uprising, raise in arms.

The character $y i$ 義 is not found in the Ěryă or the Fāngyán, however in the Shiming it appears in fourteen passages. Samples of relevant passages from the

\footnotetext{
${ }^{198}$ Shàn 善 has the same yáng 羊 element in the upper part of its character, to which yán 言 has been added (a variant of the character is written 垃).

${ }^{199}$ Kalgren (1923, p. 209) writes that the OB form of the character wo 我 shows "two lances turned in opposite directions" and that even if $g \bar{e}$ 戈 might be a phonetic, the whole interpretation is still "doubtful." Schuessler (2007, p. 518) refuses to identify any semantic interpretation for the character and just writes that "originally, the graph for wó 我 seems to have been created to write the name of a Shang period people / country, 'sheep' 羊 was later added to 義(probably signifying pastoralists) in order to distinguish the name from the pronoun." YL (p. 326) postulates the military aspect of wó 我and claims that its original meaning was bingqi 兵器, weaponry, arms.
} 
book are reproduced, translated and commented on in Appendix I. Some of the glosses in the Shiming refer to: yi 宜, right, suitable; zhèng 正, straight, correct, honest, right; or in conjunction with Confucius' rén 仁, benevolence. The articulation of these terms with yi 義is discussed below.

Throughout this brief survey of the Chinese early etymological sources, not once have we seen any definition or hànzì that might be translated as meaning or sense. The fact that these words would be commonly employed in later translations, and even in the works of Chinese modern and contemporary authors, speaks eloquently about the intertwined ideas of suitable, just and right with meaning and sense.

Turning to the modern dictionaries, of the many expressions including $y i$ 義 listed in Matthews (1943, p. 448-9), the majority are still related to the view of $y i$ 義 as a right conduct, duty, public spirit, loyalty and morality. Some examples of compound disyllables are: yifēng 義風, public spirit, integrity, personal loyalty, patriotism (lit. “winds/airs of yì 義”); yìjié 義節, etiquette, rule of conduct (lit. “virtuous/chaste $y i$ 義”); ${ }^{200}$ yìpú 義僕, a faithful servant (lit. “yi 義 servant”); etc. The notion that what is proper and ritual is inextricably linked to the society as a whole has motivated, in Matthews' glosses, the uses as public, free, open to all: yijǐng 義井, a free well (lit. “yì 義 well”); yìxué 義學, a free (gratis) school (lit. “yi 義 study"); ${ }^{201}$ etc. Matthews also obviously refers to the use as meaning, purport, but ends his glosses with a seemingly odd use, as false, adopted, in disyllables such as yifü 義父, foster/adopter father (lit. “yi 義 father,” with similar disyllables used for sons or daughters); yifà 義髮, false hair (lit. “yi 義hair”). ${ }^{202}$

Other contemporary grapho-etymological sources are also presented in Appendix I and basically defend the hypothesis that the character is a full

\footnotetext{
${ }^{200} \mathrm{GH}$ glosses it as sense of righteousness.

${ }^{201} \mathrm{GH}$ notes that this term was also used to refer to the Buddhist teaching doctrines, such use could be translated as correct/righteous learning.

202 These are more recent disyllables, not found in the classical texts, and might be related to the relationship between $y i$ 義 and $y i$ 儀 discussed above, where $y i$ 儀refers to the outside appearance of the rites and etiquette (as in the term liyi 禮儀, etiquette, rite, protocol) and where form and objective/meaning are mixed in the relation between the two cognate characters. Thus, the “ $y i$ 義 father" might not have the appearance of the real father, but he acts and behaves like one.
} 
semantic compound. It is important however to study the more specific relationship between yì 義and rén 仁.

In CUHK, one reads that, under the influence of the Confucionist School, an important Confucian term, rén 仁, usually translated as benevolence, compassionate, was added to $y i$ 義 's connotations of propriety, dignity and correct conduct. A new disyllable rényì 仁義 was created, translated as benevolence and righteousness; kindness, justice and love for humanity, with the

progressive loss of its more explicit "military" nature. In the disyllable, rén 仁 brought in the "softer" side of Confucian ethics, while $y i$ 義motivated its “firmer" former side. This movement caused CUHK to focus the network of "original meanings" for $y i$ 義 in three disyllables: the above-mentioned rényì 仁義, as well as dàoyi 道義(morality and justice) and zhèngyì 正義(justice and righteousness).

However, after these grapho-etymological surveys, we are still unsatisfactorily left without a plausible explanation for the semantic gap between suitable, just and meaning, sense.

William Boltz wrote a very influential book in 1994 where the famous Sinologist defended the strict impossibility of a purely semantic Chinese character (the traditional huiyi 會意 category). Whether we agree or not with his views, he presents an interesting and clear-headed discussion on yi 義. (Boltz, 1994, p. 174) The author begins by glossing $y i$ 義 as ethical and fitting in moral, social, and “grammatonomic" contexts. According to Boltz, yi 義 should be seen in relation to another character, $y i$ 宜, ${ }^{203}$ appropriate in bureaucratic or administrative situations, as something that must be undertaken in accordance with the agent's title or social status. Boltz continues by writing that, in our Western prejudices, we tend to see $y i$ 義 as some ill-defined sense of “rectitude" (righteousness), but fail to see that it merely points to what is ethically appropriate, fitting or suitable in its particular contexts (as he listed above). It is not, still according to the author, an absolute morality or righteousness; and furthermore, its relativeness is not restricted to changes in a bureaucratic context - that is, depending on each role

203 This relation is also found in the Shiming. 
and position of the people involved - but rather it is also contingent on shifting broader moral and social contexts. Boltz then comments that $y i$ 義, in a linguistic context, translated as sense or meaning, should also respect this pattern, being the semantic fit of the word [to a context]. He quotes a line from Xú Kăi 徐鍇 (pp. 920-74):

\section{義者事之宜也.}

yì zhě shì zhī yí yě.

As for $y i$ 義, it is the fact that it is suitable for one thing. (translated by Boltz)

That is, for each "thing" (point of view?) there is a particular and appropriate meaning that is $y i$ 義, which might not be appropriate for another situation. Although Peter Boodberg (quoted by Boltz) understood suitable as the (right) congruency between sound, graphic and meaning, this interpretation might fail to see the most radical possibilities of $y i$ 義, which are most likely not intended by Boltz himself. That is, that the "correct meaning" often attributed to $y i$ 義 is context-dependable, perceived as just contingently upon the historically and culturally situated "ever-changing broader moral and social context." $Y i$ 義 here is far from referring to any "essential" or "intrinsic" meaning of things.

$$
* * *
$$

The box below lists the major acceptations of $y i$ 義: 
Box 6- yi 義's network of allusions

\begin{tabular}{|ll|}
\hline $\begin{array}{l}\text { Metalinguistic } \\
\text { senses: }\end{array}$ & \multicolumn{1}{c|}{ Other senses: } \\
& 1. wise, wisdom \\
1. meaning, & 2. right, righteousness, justice or rectitude \\
sense, & 3. appropriateness \\
significance, & 4. duty (towards others), loyal, purport, patriotic \\
idea & 5. common, free, adopted \\
& 6. etiquette, protocol, rites, ceremony, appearance, moral \\
& standards (yi 儀) \\
& 7. "the slaughter of cattle and sheep in sacrificial ceremonies" \\
& ( $x \bar{i}$ 犧). \\
\hline
\end{tabular}

Source: the author.

Similarly to $z i$ 字 and wén 文, $y i$ 義’s metalinguistic allusions of meaning, sense and idea are arguably restricted to its later uses. The metalinguistic function of $y i$ 義 has a close rapport with the senses related to wisdom, righteousness and appropriateness, as we have seen in this section. This presents a striking contrast with the Western polysemy of sense and sensation, as well as the intimacy between sensorial perception and intellectual perception that lies at the heart of the epistemological debate since the Greeks. From this polysemy, sensorial data gathered by the sense organs and the faculty of the senses, are processed by the intellect to make sense in the form of concepts and ideas. Nowhere in the Chinese language is there anything similar to this network of allusions; an indication that early Chinese metalinguistic practices were fundamentally distinct from the Greeks', which, as per the MPH is a sign of a radical alterity in the Chinese's views on language.

$Y i$ 義 is also considered a character with a problematic grapho-etymological history. It is a consensus that the character is a compound of wǒ 我 $(I)+$ yáng 羊 (sheep, ungulates), however some scholars would say that wó 我 only has phonetic import, while others would claim that it has a semantic contribution. The fact that the tension between such strong images (I, man vs. sheep) motivates most grapho-etymological readings of $y i$ 義 is immensely important for its network of allusions. We have the image of man, wo 我, sometimes interpreted as a "hand (shǒu 手) holding a halberd or a lance (ge $\mathbf{e})$," the strength and 
aggressiveness that is balanced against the innocence of sheep (yáng 羊), thus attaining a balance, an impartiality, justice, and so forth. This impartiality and justice are at the heart of the moral dimension of $y i$ 義, where (correct) meaning must be just and impartial. This is why $y i$ 義 has been often glossed in the ancient books with terms such as shàn 善, good, virtuous; yi 宜, right, suitable, what ought to be; and zhèng 正, straight, correct, honest, right. The moral dimension is further strengthened with the "addition" of the Confucian rén 仁, benevolence, compassionate.

Furthermore, in the Chinese $y i$ 義, meaning is inextricably linked to the attendance to the appropriate rites and to proper conduct, thus the allegiance to the State, performing one's duty in harmony in the community. The graphoetymology of the character shows a double-sided aspect of $y i$ 義: a martial side, related to etiquette, rites and the "outside appearance" (dignified and impressive); and a "softer" (more emotional) side, from the Confucian rén 仁, as compassionate and shàn 善, good, virtuous.

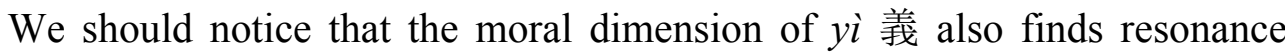
with the English use of truth. Following Cassin (2014) discussion about its etymological roots, a "true discourse" is also often considered to be just, stable, besides being truthful or veridical. ${ }^{204}$ Therefore, we would have to resort to other semantic drifts in order to assess the contrast between the two traditions: the lack of polysemy of $y i$ 義 regarding the intellectual and sensorial perceptions; the ideas of benevolence as a Confucian contribution to $y i$ 義; and $y i$ 義's ritual and martial aspects, which play a far more important role in the Chinese tradition.

It results that the moral dimension in the West is downplayed when compared to the rational and sensorial criteria of meaning. It also makes it dangerous to find in $y i$ 義 any "absolute" measure of righteousness, because what is right must be ethical and fitting, in other words, it must be suitable (yi 宜) to the

\footnotetext{
${ }^{204}$ Cassin (2014, p. 1159) writes that the polysemy of truth in English follows what Cassin calls three paradigms: 1) the Hebrew paradigm èmèt אמת is mainly theological/judicial, signifying solid, durable, stable; 2) the Greek paradigm, alétheia $\dot{\alpha} \lambda \hat{\eta} \theta \varepsilon 1 \alpha$ which "constructs truth as an elimination of what is hidden or forgotten"; and 3) the Latin paradigm of veritas, which has a normative force, instituting the "correct and proper foundation of a rule."
} 
contextual circumstance. Such a view of $y i$ 義 might be considered relativistic, if taken in Western terms. However, under the point of view of the MPH, it offers the possibility of a correct, albeit not absolute, meaning.

\subsection{7.}

\section{Xiàng 象: image, figure}

The graphic nature of the Chinese script is the obvious major motivation of the grapho-etymological analysis that was undertaken throughout the present chapter of this dissertation. It is also a key factor in the discussions on the Chinese tradition about sound and meaning and their metalinguistic reflections.

In this context, the character xiàng 象 is crucial to the semantic studies of the Chinese tradition and in its literary theory, being the hànzì that is most often associated with connotations related to the English words picture, to portray, as physical drawing or depiction. The question of pictorial depiction and the role of image in the figurative language in China are closely associated with the term xiàng 象, particularly in its relationship to other terms of Chinese imagery, impacting the relations between abstract and concrete, general and specific, etc.

Etymologically, the character of xiàng 象 is consensually thought to have been developed from stylized pictograms of the elephant. This motivation is quite clear when we take some of the more obvious examples from pre-Hàn scripts (more examples in Appendix I):

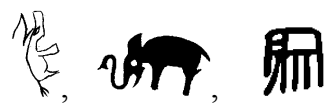

The Shuowwén offers us this gloss of xiàng 象: 


\begin{abstract}
羊
象, 長鼻牙, 南越大獸, 三季一乳, 象耳牙四足之形。凡象 之屬皆从象。

xiàng, zhăng bí yá, nányuè dà shòu, sān nián yī rǔ, xiàng ěr yá sìzú zhī xíng. fán xiàng zhī shǔ jiè cóng xiàng.

xiàng 象, long nose and teeth, big beast found in southern Vietnam, begets a son every three years, xiàng 象 has the shape of "ear and teeth" [ěr yá 耳耳牙] and four legs. All characters with radical xiàng 象indicate a semantic relationship with it.
\end{abstract}

This gloss is mostly a description of an elephant, mirrored in the Chinese character's pictography.

There are many references to this interpretation in texts from the Chinese canon (for the reproduction, translation and commentary on the relevant passages, see Appendix I). The character, which is not found in the Fāngyán, appears twice in the $\check{E} r y \check{a}$, where it refers more specifically to the processing of the elephant's tusk, implying that this was an important activity in ancient China. In the text of the Shiming, compiled more than 400 hundred years after the Ěryă, we also find xiàng 象; however, in the later text it is commonly used in its metalinguistic functions, referring to form and image or the more abstract likeness (of images). In the passages from the Shiming, there are some excerpts that mention the complex relationship between xiàng 象 and xíng 形, which are sometimes used in an interchangeable and erratic way.

The xing 形 gloss in the Shuōwén does not help us much, and probably even contributed to the inconsistent use between the characters:

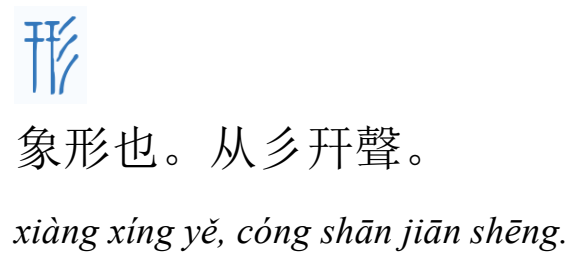


[As] xing 形, [from] xiàng 象. [Semantic import] from hair [shān $\left.{ }^{205}\right]$, sound from jiān [raise both hands]

Besides glossing xing 形 as xiàng 象, the rest of the information in this line of the Shuōwén offers little help in understanding either hànzì, besides pointing to the semantic allusion of drawing, from the character shān $乡$. Therefore, YL (p. 190) writes that xing 形 refers to the "depiction of the appearance/form of the body of things," and that xing 形's “original meaning” was form and structure (xingť̌ 形體in modern Mandarin, lit. “body/style and 形”).

Both characters (xiàng 象 and xíng 形) were so important to the early Chinese metalanguage that as the disyllable xiàngxing 象形, they named of one

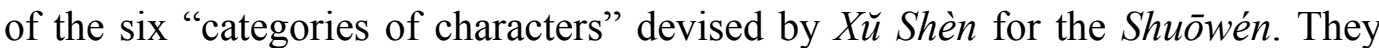
referred to what today is usually translated as pictographs (lit. "appearing/image in the form"). This complex relation, which one finds in very early periods of the Chinese language and writing, will contribute to the rich nuances of the figurative patterns in Chinese.

In the modern and contemporary grapho-etymological sources, Matthews (1943, p. 380) presents eighteen multi-character words that include xiàng 象, and that refer to aspects of elephant and/or ivory. There are seven "secondary" acceptations of the character. The first is to resemble, an image, a representation, inter, next, and it will be further discussed below. The second is stars, constellations, omens and portents. ${ }^{206}$ The third stands for Chinese chess (xiàngqi 象棋). A fourth is an odd acting, playing, ancient music. ${ }^{207}$ The fifth use was as an official interpreter, ${ }^{208}$ as in the term xiàngxu 象胥 (lit. "the figure/appearance

\footnotetext{
${ }^{205}$ The gloss of xíng 形 as "hair" might be clarified by the entry in the Shuōwén of shān 尖 itself, which reads: máo shì huà wén yě 毛飾畫文也, and can be translated as: “[As for shān 彤], that is painting brush adorning paintings and writings." The "hair" in question is the one used in painting brushes, which will draw likeness of things on paper, bamboo and silk.

${ }^{206}$ One possible interpretation of this connection arises from the fact that the heavenly bodies are phenomenologically nothing but "figures" one sees in the sky. Thus the disyllable tiānxiàng 天象, celestial phenomena, the heavenly bodies.

${ }^{207}$ The character xiàng 象was used to "christen" some specific kinds of music, plays or dances.

${ }^{208} \mathrm{GD}$ (p. 1715) quotes passages from the Lĭji and the Hànsh $\bar{u}$ which explain how some southern ethnicities in China employed xiàng 象 to refer to official interpreters.
} 
of aid/assistance). The sixth was as figures of a diagram (the classical Yijing diagrams) and the seventh, and last, a law or ordinance.

\subsubsection{1.}

\section{Xiàng 象 and Chinese representation}

Xiàng 象, as we have seen, is a central character in the history of the Chinese traditional ideas on representation and figuration. As with other characters such as wén 文 and $z i$ 字 that were also intrinsically embedded in the history of Chinese writing, this short etymological presentation cannot aim to present even a brief philosophical discussion on xiàng 象. However, due to its importance for understanding the metalanguage of the early Chinese, it is worth discussing the matter a little further.

In the Hánfêizlı's passages on xiàng 象 found in Appendix I, there is a suggestion that the rarity of the occasions on which an elephant was seen motivated the use of its pictographic character as image. We can only speculate as to whether the sighting of such an amazing animal really caused such a shock on the early Chinese, and the scribes, to the point that it eventually became the signifier (character) used to connote appearance and image. Zhang (2002, p. 213) writes about how, in the continuation of this passage in the Hánfêižr, the author uses this analogy to refer to dào 道: ${ }^{209}$

209 Zhang's book is laden with terms borrowed from the Western philosophical tradition and adopts a theoretical point of view that is strikingly different from that of this dissertation. His representationalist view on language is clear from these quotes in the introduction of his book:

"Name' and 'term' are both based on grammatical function, whereas 'concept' and 'category' refer to the content of the terms. (Ibidem, p. xix)

And his universalist bias:

$[\ldots]$ they are fundamental concepts with a necessary and universal nature. [However] ancient Chinese philosophy lacks a system of categories such as that of Aristotle. (Ibidem, p. xxv).

And from later in the book:

Languages differ, so the names they use differ, but the concept they express may be the same.

'Concept' has a more profound meaning than does 'name.' (Ibidem, p. 475).

However, the text is a scholarly edition that offers a good counterpoint to the presentresearch. 


\section{今道雖不可得聞見，聖人執其見功以處見其形，故曰：「無 狀之狀,無物之象。」}

jīn dào suĩ bù kě děi wén jiàn, shèng rén zhí qí jiàn gōng y̌̀ chǔ jiàn qí xíng, gù yuē: "wú zhuàng zhī zhuàng, wú wù zhī xiàng."

Now even though the Way cannot be acquired, heard or seen, the sages grasped the effects of its appearance in order to make its form visible; thus it is said: "the shape without a shape; the image of what is not a thing." (translated by Zhang) ${ }^{210}$

The strategy of the Hánfêiž̌ seems clear: (living) elephants were very rarely seen, the old Chinese would likely only have seen their remnants and then imagined the beasts in their glory, to the point that elephant and image - as a product of the imagination - became almost identified in xiàng 象. Likewise, writes Hánfēiž̀, dào 道 underwent a similar process: one could experience its (comparatively) pale effects, but not its full magnificent reality, therefore one could only have "imagined" it. However, one may ask, "How is imagination and figuration entangled in the character xiàng 象?”

Owen (1992, p. 587) first refers to xiàng 象as the

normative visual schematization of a thing, or of the embodiment of an idea [...] in such schematization; [...] neither the particular thing [...] nor an "idea" of a thing, but rather a sensuous schematization of the normative thing. (Owen, 1992, p. 587)

The scholar quotes the Lăozìs commentator Wáng Bì, who has used xiàng 象 as the mediator between what he calls concepts (yi 意) and language. In this context, xiàng 象 seems to be operating on the borderline, neither entirely a particularization of an object or an idea, nor a full idealization thereof. It is conceivable (albeit controversial, see also footnote 262) that Wáng Bì was already influenced by Buddhist representationalist ideas when he used xiàng 象 as an intermediation between concept and language. As the influences from India were progressively "sinicized" and integrated into the Chinese tradition, the use of xiàng 象 as appearance and image would be profoundly influenced by the new

${ }^{210}$ This is the standard translation of the same passage by W.K. Liao (1959):

Though Tao cannot be heard and seen, the saintly man imagines its real features in the light of its present effects. Hence the saying: "It is the form of the formless, the image of the imageless." 
ideas coming from the south. In this context, xiàng 象 would be increasingly associated with the mere sensorial appearance (image) of the things in the world, and the visualization, which was referred by the term xingxiàng 形象, was restricted to the phenomenal world.

In Zhang's (2002, p. 210) study of xiàng 象, the author highlights the importance of many crucial passages from the Great Commentary of the Yijing, from which I here have selected two short excerpts. In the second part of the Great Commentary, the text starts by presenting the eight trigrams and ends their very brief description by using the following expression:

\section{「。。」爻也者, 效此者也。象也者, 像此者也。}

[...] The lines [yáo 爻] imitate [xiào 效] this. The images [xiàng 像] reproduce [xiàng 像] this. (translated by Wilhelm and Baynes)

And two chapters ahead in the same Great Commentary:

是故, 易者, 象也, 象也者像也。

Thus the Book of Changes consists of images [xiàng 象]. The images [xiàng 象] are reproductions [xiàng 像]. (translated by Wilhelm and Baynes) $)^{211}$

In Wilhelm \& Baynes's commentaries on these excerpts, we find that these chapters are about the "definitions" of terms that in English are translated as lines, images and reproduction. The images are the reproductions, and the changing lines of the hexagrams are the imitations of the changes of good fortune and misfortune in this world.

Zhang writes that some commentators refer to xiàng 象 not as symbols but as referring to actual heavenly bodies, whose image is represented by xiàng 象. It is also interesting how xiàng 象 is contrasted in the context of the Yijing with xing

${ }^{211}$ Legge's translation of this passage offers an interesting counterpoint:

Therefore what we call the Yi is (a collection of) emblematic lines. They are styled emblematic as being resemblances. (translated by James Legge) 
形 (as we have seen in the Shiming). However, in his conclusion, Zhang (Ibidem, p. 211-2) takes the operations in the Yijing as symbolic, where symbols are representations, images (xiàng 象) that belong to heaven while forms (xing 形) pertain to earth. Could we fail to notice Platonic echoes in Zhang's words?

As seen in the many passages above where xiàng 象 is present, the question of representation and form seems to have played an important role in early Chinese thought and contemporary scholars have repeatedly attempted to apply the inevitable Western categories and Western metalanguage to their analyses of the Chinese canon. As xiàng 象 is translated by “our" Western “concept-laden” words such as symbol, representation or image, it often becomes difficult to disconnect the two different traditions. The contrast of xiàng 象 and xing 形 is without doubt a rich point of discussion in the study of Chinese literary thought. There is, however, a specific question which particularly interests us at this point: how much is the image (xiàng 象) considered as an intellectual abstraction of the representatum (xing 形?)? Put in a different perspective, the question is related to how "Western" metaphorical/metonymical operations function when symbolic representations are used to multiply the uses of the Chinese characters/words. Or, alternatively, can we call the figurative extension of the hànzì a "Western" tropological operation?

Chantal Chen-Andro (In: Sakai \& Struve, 2008, p. 131-153) starts her analysis from the literary criticism in China in the first half of the twentieth century, to seek a better understanding of how the Chinese in classical times (and today) conceive of what we usually call "metaphorical operations," image and symbol in Indo-European languages. The author discusses the metalinguistic terms that were used at that time in China, a crucial moment in the history of Chinese literary and linguistic thought, which faced the challenges of a new and abrupt openness to the ideas "imported" from the West. At the same time, its discussion reflects the tensions that have marked the Chinese tradition and, ultimately, the interplay of its autochthonous origins with the Western influences which began with Buddhism's arrival to China in the first century AD. 
The technical terms used in the Chinese literary criticism of that time gravitated around the character xiàng 象. Chen-Andro (Ibidem, p. 131) writes that the scholars of the early twentieth century preferred to translate what was perceived as metaphor in the West by terms linked to the idea of "image," such as the disyllable xingxiàng 形象 rather than use what is currently the preferred term, y̌nyǔ 隐喻 (lit. concealed/hidden explanation/simile). Hence, expressions like: xíng xiàng sī wéi 形象思维, “thinking [in terms of] images and forms."

There are four related expressions, all containing the character xiàng 象 that were important in the figurative thinking of the time:

- Xingxiàng 形象, image, shape, figure, which combines xiàng 象 with the character xing 形, way, shape, external appearance (see also above)

- Yixiàng 意象, image, concept, idea, xiàng 象 with the character yi 意 for meaning, idea, intention, etc. Chen-Andro notes that in traditional Chinese poetics this term indicated the "relationship between the aesthetic consciousness of the subject and the qualities of the object, in order to describe the image in the broadest sense."

- Xiăngxiàng 想象, imagine, imagination, imaginary. Xiăng 想 has allusions of (to) think, (to) reflect, (to) remember, (to) consider, etc. According to Chen-Andro, at the time the expression would have a more concrete sense of image. François Julien (In: Sakai \& Struve, 2008, p. 142) says it is a term in the Chinese tradition that never "received an accurate notional content."

- Xiàngzhēng 象征, which was the subject of many studies at the time, with its connotations of symbolize, symbol, symbolic and emblem, ended up being often used to refer to "modernist" poetry from Europe. Zheng 征 is a quite polysemic term, generally used today in the sense of “going on a journey or expedition” (zhēngtú 征途, chūzhēng 出证), in the past related to cognate zhèng 正 as aim at the target, march in 
campaign, request and receive taxes (Schuessler, 2007, p. 612) and later as evidence, proof, signal, etc. (nowadays zhēngxiàng 征象 is translated as sign, symptom).

Chen-Andro's remark about the "unstable and imprecise content" of these expressions, which showed evidence of the great difficulty of dealing with new ideas coming from Europe, is precisely what interests us in this dissertation.

As briefly alluded above, upon the entry of Buddhism to China, the representation (xingxiàng 形象 ) was devalued by the Indian-influenced aspirations to seek the principle (lǐ 理) beyond representation (象外 xiàngwài, lit. "outside of figuration/image"), or even to search for the "figuration beyond figuration" ( 象外之象 xiàngwài zhī xiàng). The term xíngxiàng 形象 lost prominence in the classical epoch, only to be completely "overhauled" in the twentieth century.

As for the disyllable yixiàng 意象, in the Chinese tradition it was, not only an aesthetic category related to representation, but also it connoted the poetic expression. (Sakai \& Struve, Ibidem, p. 135) We find side by side configuration (xiàng 象) and intention (yi 意), ${ }^{212}$ not restricted to an intellectual operation, but rather also emotionally-laden - and moreover not only an aesthetic idea, or an artistic image, but what Chen-Andro calls "intentionality- configuration" (intentionnalité-configuration). The deliberate lack of a clear focus or definition at least up to the point that one could unambiguously sort the Chinese expressions into Western categories - is, according to Owen (1992, p. 205), favored in the expression of yixiàng 意象, which ultimately becomes a "sketchy outline of what one intends." The author judges that the indeterminacy and lack of details beget the opportunity to seek particular beauty and richness.

The crisis of Chinese poetics in the early twentieth century is intimately linked to the challenge and problem of how new forms of poetry and expression would tackle the question of mimesis and image inherited from Chinese

\footnotetext{
${ }^{212}$ We should be reminded that, as briefly noted in the discussion above on $y i$ 義, the translation of $y i$ 意 as intention is one of many possibilities and obviously fails to convey the full range of uses and applications of the term. See, for instance, the discussion on the Chinese non-willing self in Ames \& Hall. (1998, p. 37-38.)
} 
traditional thought, in confrontation with the new issues of symbolism and abstraction.

Zongdai Liang 梁宗岱 (1903-1983, In: Sakai \& Struve, 2008, p. 141) discusses the function of the symbol in the new twentieth-century China, which would be used to "replace something concrete by an abstract notion," or, in the language of classical poetry, to "harbor principle in figuration” (yù lǐ yú xiàng 寓 理于象), whence we recognize the process of abstraction through symbolic figuration (xiàngzhēng 象征). The symbol therefore remains bound to the image (xiàng 象), as evidenced in the binomial itself, but also to the emotional/affective/subjective (qíng 情). Moreover, it can be hidden (y̌nyù 隐喻, eventually the standard term to translate metaphor) or be explicitly shown (xiănyù 显喻), in a relationship of overt analogy.

However, we must not forget that terms such as xiàngzhēng 象征 were foreign to the Chinese classical tradition. The operation of a concrete figuration has been little explored in the Chinese tradition and "all opposition between 'abstract' and 'concrete' lost its sense, just as between 'sensible' and 'intelligible." (Julien, In: Sakai \& Struve, 2008, p.145) If the poetic symbols representing something concrete and particular (from which could mature abstract and general concepts) were extraneous to Chinese literary thought, it is "exactly the function of representation that is itself underdeveloped (peu déployée) and why [...] there has been little development in China [of] an autonomous plane of generality." (Ibidem)

What is of interest to this dissertation is less the details of the impact of "generality" in the China of the first half of the twentieth century than the question of image and symbol in Chinese classical thought, due to its intimate connection with figurative language and metaphor, and, therefore, the question of representation.

M. Marouzeau wrote his definition of metaphor in 1943: "Procedure of expression considered as a transfer into the order of the concrete from an abstract notion.” (In: Sakai \& Struve, 2008, p. 146) For this reason some critics say there 
is no "real metaphor" in classical Chinese poetry. ${ }^{213}$ Figurative language in the Chinese tradition profited immensely from the graphical dimension of the Chinese script and was predominantly considered in its allusive value and emotional impact. This is what Chen-Andro (Ibidem, p. 148) calls the "appreciation of the implicit and the hidden (y̌n 隐)" in clear detriment of abstract and generalizing.

As discussed in the first part of this chapter, the question of representation (mimesis) is directly linked to Western binomials image / representatum, signifier / signified (meaning). We are reminded that, in the Aristotelian tradition, the signifier in the declarative sentence emerges as a conventional representation of the fixed external meaning, given by the logically determined relationship between the affections of the soul and things in the world. In the lógos apophantikós, the central issue in this epistemological frame-of-mind is whether the representation is faithful to the representatum, that is, whether it denotes its "true meaning." 214 In Chinese literary thought, the motives and the conditions of the production of meaning are central epistemological objects:

\begin{abstract}
This problem of knowledge is predicated on multiple levels of concealment, and it leads to a hermeneutics that promises to reveal the complex conditions that inform human actions and utterances. [In Confucian-based thinking] what is manifest is not an idea or a thing but a situation, a human disposition and an active relation between the two. What is manifest is ongoing and belongs entirely to the realm of Becoming. (Owen, 1992, p. 20)
\end{abstract}

Thus the appearance, in the Chinese tradition, is not something transient and contingent against the background of an invariable and transcendent shape that can be measured (as in Plato), but something that is influenced by the quality of the (concealed) interior, with which it has a necessary relationship. However, the quality is immanent to the particular observed object (not to its generalization or its "idealized form"), provided that it is observed in a certain way. The observational conditions are central to this mode of thinking, therefore causing the

\footnotetext{
213 See Liu (1962).

${ }^{214}$ We should however be careful in order not to trivialize Aristotle's thought. In his Poetics, Aristotle praised a discourse that did not aim at the establishment of truth. However, roughly speaking, we can consider that the lógos apophantikós remains firmly in the nucleus of Aristotelian language.
} 
activities of allusion and concealment to have a direct bearing on the epistemological question. Once again, we resort to Owen's words:

In the Confucian version a complicated confluence of circumstance may veil any particular inner truth; but if one but knows how to look, that inner truth is immanent in the outer phenomenon. (Ibidem, p. 21)

It seems that we are very far from the Greek alétheia, the conception of truth as a disclosure of a true reality. "Truth," in this sense, can be found in the image (xiàng 象), in how it is perceived, in the subtleties of what is hinted, in the relationship between what is hidden and what, at that moment, can (or cannot) be shown.

The question of representation (mímèsis) in Platonic-Aristotelian thought becomes something in Chinese thought that we should perhaps more appropriately call manifestation, that is, this movement from the interior to the exterior, ${ }^{215}$ which appears in expressions like xuān 宣 and ming 明. This manifestation, however, is never imposed on the poet or the writer by an omnipotent external divine force, but it is rather the result of patterns (wén 文) of nature that are mediated by the human mind, or, as writes Owen:

manifestation should be the organic "outcome" of what lies within, that is, $h \sin$ [心 ], "mind"/"heart" ("expression" as in the sense of the "expression on someone's face," a condition that may reveal, but does not "imitate" inner life as an act of voluntary self-expression). (Owen, 1992, p. 94)

This expression, which Chen-Andro calls evocation, might be an interpretation of xiàng 象 that stands in stark contrast and alterity with the much more commonly used translations of representation or image.

$$
\text { * * * }
$$

${ }^{215}$ The boundless interior and exterior, perhaps like Deleuze's interior/exterior that was discussed in the first part of this dissertation. 
Xiàng 象's network of allusions are summarized in the next box:

Box 7- xiàng 象's network of allusions

\begin{tabular}{|ll|}
\hline $\begin{array}{l}\text { Metalinguistic } \\
\text { senses: }\end{array}$ & \multicolumn{1}{c|}{ Other senses: } \\
image, & 1. elephant, "pig with large ears" \\
sign & 2. ivory, figure cut in ivory \\
figure & 3. form, similar, to resemble, comparison, model, to portray \\
symbol & 4. stars, constellations, omens and portents \\
& 5. Chinese chess \\
& 6. name used for some ancient dance, music and plays. \\
& 7. an official interpreter (in southern dialects); \\
& 8. figures of the diagram (the classical Yijing diagrams); \\
& 9. a law or ordinance.
\end{tabular}

Source: the author.

Throughout this chapter we saw the various consequences of the profound differences between Chinese semantic-biased and Western phonetic-biased scripts. This disparity, which justifies the existence of grapho-etymology, finds its most relevant character in xiàng 象, usually translated as image, sign, symbol, among other words. The fact that a term like image is considered here as metalinguistic is overtly based on the graphic nature of the Chinese script. Although, as we have seen in the first part of this chapter, image in English has a metalinguistic function as figure of speech, one might argue that it lacks an obvious reflexive aspect: the word image is not an image, it is a word which is used to refer to (an) image. However, this is not the case in Chinese: the character 象 is, in itself, an image, a figure, and it also is used to refer to image(s). Therefore, xiàng 象 as image or figure presents a metalinguistic reflexive aspect when it is - in our commonsensical view - used literally. In such a situation, we should ask ourselves whether "our" terms metaphorical or literal make any sense at all, and this is the line of questioning - with its profound consequences - that is predicted and encouraged by the MPH.

In the Western tradition, there is a complex network of words and allusions gravitating around each other and building our common-sensical notions of image, mimesis, sign and graphic representation. The etymological analysis shown in 
this first part of this chapter pointed to the notion of imitation, mimicry, portrait or faithful reproduction. For the Greeks, in the history of terms like eikón and mimesis, ${ }^{216}$ the image was a sensuous sign of the object, a measure of reality, which however could never reach its (desired) ultimate perfection - "what we see as if it were the thing itself, but which is in fact a double (eídōlon)." "True and perfect" form lies in the world of idéa. In Plato, the art of the copying of the world by poets, writers, sculptors and actors, known as mimesis, has as its product an entity whose ontological status is inferior relative to that of its original model. The functions and ultimate limitation of image in the West find only an indirect point of contact with xiàng 象.

Xiàng 象 's grapho-etymological “origins” are very uncontroversial and remind us, in some ways, of the "origins" of wén 文, both characters apparently being first used as pictography (in Chinese, as 象形 xiàngxing). In xiàng 象's older scripts it is often easy to recognize hardly stylized drawings of an elephant. In older texts, such as the Ěryă and even the Shuōwén, the character appears only in reference to the animal. However, in newer texts, like the Shiming, the situation changes drastically and it starts to appear only glossed as image, resembles, likeness: there was a "cut," which seems to have happened after the Shuōwén. This seemingly abrupt change from elephant to likeness, image is another one which defies even the most creative imagination. From this riddle emerges an at least double-sided speculative answer: 1) the remains (signs) of the elephants alluded to the seldom seen animals and provoked the imagination of the ancient Chinese; and/or 2) the use of the elephants' tusk to fabricate treasured statues portrayed physical images of objects. There is obviously no correct answer: both are present in the Chinese grapho-etymological studies; both cannot be verified or falsified. Xiàng 象 is therefore a sign and an imitation, the (stylized) pictography, the quintessential Chinese character.

Xiàng 象's network of allusions also cannot be fully grasped without this character comparison with xing 形, form, drawing of likeness, depiction of the appearancelform of the body of things. Xing 形 would refer to the physical form 
of the objects, while xiàng 象, to its appearance. Together in the Shuōwén they named Chinese pictography: xiàngxing 象形. The fact that their use and difference has always been erratic is a sign of the Chinese's lack of clear differentiation, when regarded from the point of view of the Western categories, of form and image

Xiàng 象's image-function is considered a "normative visual schematization of a thing, or of the embodiment of an idea." (Owen, 1992) Being a sensuous representation rather than a faithful copy it operates on the borderline, neither being entirely a particularization of an object or an idea, nor a full idealization of either. From the discussion in this section it is clear that xiàng 象 points not to the abstraction of the general, but rather offers a concrete figuration that values the implicit and the hidden, is contextually dependent, and offers an "organic outcome" rich in subtleties and in no way ontologically inferior to the representatum. Xiàng 象's image is an evocation, not a Platonic mimetic image.

\section{3. \\ Overview of the chapter}

One of the main objectives of this chapter lies in providing comparative data from sets of Western and Chinese metalanguage to support the MPH. As we have seen, each hànzì chosen from the Lăož̀ offers a network of allusions that stands in remarkable contrast to what we call the "Western tradition." The particular distinctions that arise from the comparison of the seven Chinese characters with the four clusters of Western metalinguistic themes have already been presented in each of the sections above. However, one can also find some patterns that are, to a certain extent, repeated through each analysis.

There seems to be a crucial difference between the two traditions in the way that they treat the relationship between writing and speech. The boundaries between writing and speech are much better marked in the Chinese script 
compared to the Western (semi) phonographic scripts. ${ }^{217}$ Actually, these realms appear so distinct from each other that we might suggest that language - as the word is used in the West - might be an epiphenomenon in ancient China, an artificial construct that puts together in the same basket the immense graphical richness of the hànzì and the more banal daily communicative spoken Chinese. The Chinese script is treasured by the ancient Chinese, not only in its graphic aspect, its aesthetic impact and the visual possibilities of its allusions, but also, and perhaps more importantly, as the wén 文 bridge that harmoniously fasten Nature's patterns and organizational principles with Human's civilizing action and culture.

As a consequence, the uncertain frontiers between name and word, that are more markedly present in the Western tradition, have drifted in the Chinese metalanguage, biased towards the rift between writing and speech. Thus, we find two completely distinct motivations for the uncomfortable problem of word in the history of language ideas: in the phonetic-biased scripts of the West, word is only clearly discernible in writing and to posit it as a "biologically hard-wired and psychologically real" entity might be a too ambitious hypothesis. Whereas in the semantically informed Chinese writing, word might be the ambiguous translation for hànzì such as yán 言, zì 字or wén 文which masks the distinctions discussed in this dissertation.

As for language, there are nowadays four individual characters that are usually translated as such: yán 言, yü 語, huà 話 and wén 文. The first three are related to the spoken dimension of language and all are obviously related to the character-radical yán 言, while the last is related to the graphic-written language. The fact that in modern Mandarin language is almost always mentioned by the use of the three yán 言-related hànzì, is arguably a sign of the changing fortunes of the written language in the context of the study of language in China (and of Chinese).

\footnotetext{
${ }^{217}$ For further information on the singular characteristics of the Chinese writing, see my own master's thesis (Barros Barreto, 2011). Some modern authors who defend a semanticist view of the Chinese writing are: Granet (1934), Kratóchvil (1968), Li \& Thompson (1982), Sampson (1985), Hansen (In: Allinson, 1989), Ping (1999), Vandeermersch (2013), and others.
} 
The question of the "original meaning" of characters in Chinese, as well as of words in the West, is subject to fierce disagreements. However, although both are speculations that attempt to recuperate ultimately untestable diachronic sources of meaning of words or characters, there are fundamental differences between the two etymological traditions. Western etymology among the Greeks was motivated by the - ultimately unsuccessful - attempt to prove that language was an unbiased medium to convey the truth. Much later, in the time of the Comparative Philologists, its inspiration was centered on finding common ancestries for the world's languages and their issues were focused on phonetic changing "laws." 218 The Chinese speculations were driven by drastically different motivations and employed an altogether distinct methodology. They were intended to organize the chaotic multiplication of the hànzì, providing firmer bases for the Chinese script and dealing with the inter-communication between the Sinitic language-dialects. The often used shēngxùn 聲訓 method of paronomastic interpretation could not even be conceived in the context of a phonetically based script, and it put in evidence a network of relationships between sound, meaning (use) and graphic that would likely seem preposterous to the "serious" linguistic researcher in the West.

Therefore, most of the grapho-etymological constructions regarding Chinese hànzì can be seen as "imaginative" or excessively "naïve," but it is indeed impossible to avoid a minimum amount of speculation, since such is the art of etymology. The fact that the interpretations show a variety of improvable (and also un-disprovable) "conclusions" that surpasses the speculation of Western etymology adds further support to the deep impact of the graphic-semantic aspect of the Chinese script on the development and self-awareness of its own spoken and written language.

Finally, the grapho-etymological histories of the Chinese characters have been marked by important disruptions that are not easily perceived in the Western metalinguistic lexicon. Despite the conservative aspect of Imperial China's society and culture, the inaugural function of the Shuōwén has had an impact in

\footnotetext{
${ }^{218}$ For the question of historicity of the phonetic laws and the role of Comparative Philology, see Harris (In: Love, 2006).
} 
the Chinese script that perhaps has no other parallel in other languages. ${ }^{219}$ However, what strikes us is that the identity of the Chinese script has endured all these centuries and so has the identity of the hànzì. One would rarely accept that $\gamma \lambda \tilde{\omega} \sigma \sigma \alpha, *$ dingua or tongue are the "same word," but no educated Chinese with a knowledge of the history of its script would deny that "same hànzì." These are speculations that reach much further than the objectives of the present dissertation, but that are somewhat hinted by the explorations and analyses of this chapter.

${ }^{219}$ Western scripts have also suffered profound changes throughout their histories. The political and ideological unity of the Chinese script as well as its strict and intimate relationship with Chinese culture, history and self-image finds no other parallel in the West in terms of longevity. Thus, the radical changes in the history of the alphabetic script since the Phoenicians is in no way related to only one cultural milieu, but crossed over dozens of culturaltraditions. 


\section{3. \\ Metalanguage in translations in the Lăozi}

The Lăož́ 老子 is a text compiled in China probably in the early to midfourth century $\mathrm{BC}$, belonging to the core of the Chinese literary canon and arguably one of the most important and influential works of this tradition. Although conventionally considered to have been written by a historical man called Lăož 老子 (lit. old master), nowadays scholars think that "[i]n all probability Lao Tzu was not a historical figure at all." (Lau, 2001, p. xii) It is a document that offers a particularly wide range of reading possibilities and knowingly lends itself to virtually contradictory interpretations. As writes Ryden (2008, p. iix): "[...] the text itself can be read in a multiplicity of ways, both in the strict grammatical sense, and in terms of its content." Furthermore, its relevance seems heightened since it is an authorless text:

\footnotetext{
There is no writer to express individual thoughts [...] The 'I' that we sometimes find in the text is not the ego of an individual who speaks to us and wants to convey some observations. It is rather a marker for the space that the potential reader - or better: listener - is supposed to occupy. (Moeller, 2006, p. 2)
}

I have selected eight passages, from the same number of chapters, from the Lăož̆. These passages should give evidence of the variety of uses and translations of the seven metalinguistic terms that were grapho-etymologically analyzed in chapter II of this dissertation. The Lăozl̆'s chapters will not be presented in their entirety, just the passages directly related to the metalinguistic terms in question. In some of the chapters, a longer excerpt will be presented with a selected translation in order to provide the reader with some background for a more comprehensive idea of the chapter. However, the comparison of the seven (or more) translations will usually be restricted to the observations around the metalinguistic terms.

In these translations, we shall see the seven Chinese metalinguistic characters analyzed in chapter II of this dissertation in the context of short 
passages extracted from the Lăozĭ. Furthermore, due to the frequent use of parallel structures in classical Chinese, some characters will be shown in direct contrast/comparison to others, providing further depth to the network of allusions presented in the past chapter and strengthening this dissertation's claim for the MPH. The translators' diverse strategies when dealing with the passages and characters will also give further evidence that we are dealing with a variety of viewpoints, each one justified by the author's own background. More importantly, the translators should, as per the MPH, use distinct sets of metalinguistic terms that result from their own propensities and the productive encounter with the original Lăož̆ that will be translated. Finally, we can gauge each translation's adequacy within the frame of perspectivism.

\section{1. The selection of translations}

There are hundreds of translations and commentaries on the Lăož̆. Apart from the translations into other languages and the contemporary studies written in Mandarin, Chinese tradition mentions what some authors estimate as around 700 known commentaries on the text, starting with Hánféiž (韓非子) ${ }^{220}$ in the third century BC. ${ }^{221}$ Translations into European languages probably began with a version in Latin presented to the British Royal Society in 1788. (Kohn \& LaFargue, 1998, p. 165-6) Creel (1983, p. 300) writes of "at least seventy translations into English" by 1975 (and, obviously, many more since). The author wrote a comparative study of a selection of twenty-three works with translations or comments of the exact first excerpt analyzed in this dissertation. Creel affirms that his selection of translations is in part arbitrary, but, he then continues, "I have included every early explication of which I could learn, and have tried to list representatives of the more important different interpretations." (Ibidem) Contrariwise, this is not a comprehensive survey, but rather an in-depth

${ }^{220}$ Hán Fẽiž 韓非子 is a classic of the so-called Legalist school in ancient China, totaling twenty books divided into fifty-five chapters. Chapters 20 and 21 are directly concerned with commentaries on some chapters of the Lăož̀. See also Watson (2003c) and Liao (1959).

${ }^{221}$ See Kohn \& LaFargue 1998, p. 119; Creel 1983, p. 300. 
exploration of a deliberately partial selection of authors, conceived to serve as favorable occasions to promote support for the MPH. However, to add further information on the possibilities of dealing with the passages in question, whenever deemed relevant, I will supplement information from a compilation of 56 different translations of the Lăož̆, mostly into English, available in the internet. $^{222}$

Before presenting the translations of the excerpts of the $L a \check{a} o z \check{l}$, it is useful to sketch a brief introduction to each translation/translator:

1. DC LAU (Liú Diànjué 劉殿爵) ([1982] 2001).

Lau is one of the best-known scholars and translators of the Chinese classics, as well as one of the key people responsible for the progress of the London University's School of Oriental and African Studies in becoming a worldrenowned reference for research in this area. While it is extremely well informed, this translation remains deeply embedded in the tradition of sinological studies published in the West.

\section{Mario Bruno SPROVIERO (2007).}

Sproviero is a professor of oriental languages at USP (Universidade de São Paulo) and his translation of the Lăozl̆ can be considered, to my knowledge, the best in Brazil, where a thorough academic-level research of Chinese and international sources was conducted in earnest, in the line of the works produced elsewhere by the sinological academia.

\section{Stanislas JULIEN (1842).}

Julien (ca. 1797-1873) was a scholar of classical Greek who attended the lectures of the famous sinologist Jean-Pierre Abel-Rémusat (1788-1832), the first holder of the chair of sinology at the Collège de France. Kohn \& Lafargue (1998, p. 166) explain that this is the first complete translation of the Lăož̀ into French and, as far as we know, the oldest extant translation into a European language.

\footnotetext{
$222 \mathrm{http}: / /$ www.sanmayce.com, accessed in 2014-2015. Henceforth referred as the compilation of 56 translations, accessed in 2014-2015. The selection of translation covers scholarly and lay works alike, providing a wide variety of interpretations of the Lăož́. Lynn's and Lau's translations are the only ones from my own selection who are included in this compilation. Some of the best known authors are designated by name in my own selections of passages. I have examined a sample of translations in the original books and e-books and there seems to be no incompatibilities.
} 
Julien's also stands out, unlike most subsequent translations of the period, for not trying to find compatible grounds between Taoist and Christian worldviews. ${ }^{223}$

\section{Roger T. AMES and David HALL (2003)}

Roger T. Ames is a prominent Sinologist affiliated with the University of Hawaii and the editor of the journal Philosophy East and West, while David L Hall (1937-2001) was a philosophy professor who specialized in Whithead and Rorty.

\section{Chad HANSEN (2009)}

Chad Hansen is a professor at the Chinese University of Hong Kong and a scholar who has proposed a radically non-universalist approach to Chinese philosophy in works such as A Daoist theory of Chinese thought for Oxford Press in 1992 and has collaborated on a number of articles about ancient Chinese philosophy.

6. WÁNG Bİ (王崸) (commentary on the Lăož̀ Dàodéjīng, 226 - 249

$\mathrm{AD})$

The text and commentaries of Wáng Bì are considered by Lau ([1982]2001) (introductory note) as the best copy of the Lăož and the one used most often by its scholars (see also Ryden, 2008, viii), until the discovery in 1973 of the silk texts of Măwángdū 馬王堆. During the Hàn dynasty and the period of the Six Dynasties (ca. $200 \mathrm{BC}$-600 AD), the Lăož̆ and its homonymous mythological author underwent a process of divinization and veneration. The text came to be increasingly read (and glossed) as if possessing an almost religious authority and the book was progressively perceived as abstruse and mystical. Wáng Bi’s commentary was written as a reaction to this cosmological point of view, and its authority and prestige rapidly grew, bearing the canonical status it has today (see Kohn \& LaFargue, 1998, p. 9). The chronological antiquity and importance of the

223 There is here an important remark about the edition that Julien used as the basis for his translation. Although he mentions Wáng Bì, Héshàng Gōng and other known editions/commentaries of the Lăož that the French author had access to, his main source is what he calls "Édition E" (p. XL), entitled Lao-tseu-tsi-kiaï, and published in 1530 by Sie-hoeï, also called Khao-kong-sien-sing or Ta-ning-kiu-sse. Whenever there are differences in the Chinese text (Julien's text is bilingual), I will make a note of it in my analysis. 
Wáng $B \grave{i}$ commentary also validate its inclusion as one of the seven translations (or rather, re-writings) of the Lăož discussed in this work.

Wáng Bì, as is common practice in other commentaries in the Chinese tradition, interspersed the original text with his own commentaries and explanations. I also made use of the translated version of Wáng Bìs Lăož̀ into English by Richard John Lynn (1999), with additional comments (when deemed relevant) from Ariane Rump's (1979) translation.

\section{CHÉN Güyìng (陈鼓应) ([1970]2006)}

Chén is a reputed scholar of Chinese philosophy, since 1949 living in Taiwan and affiliated with the National Taiwan University, a professor whose area of expertise is Taoist philosophy and history, and who has written several books about Western philosophy, especially on Nietzsche. His work is a modern translation into Mandarin, rich in references and philological research. The translation of Chén's text and commentaries into English is my own.

As argued in the introduction to this work, I do not intend to present a comprehensive panel of different translations of the Lăozí. The selection of authors obviously cannot escape my own affinities and idiosyncrasies; however, all translations, as will become clear along this dissertation, present interpretations that are valid in their own merit and are a result of their historical and cultural contexts. Their scholarly background and motivation must not deceive us, however, into thinking that the academic discourse has the monopoly over the production of knowledge about language matters, as we have already seen in chapter I of this dissertation.

We should consider the prescriptive effect of both the academic discourse and lay uses of language and their interactions, in what Taylor (1997, chapter 9) calls the "rhetoric source of linguistic theory." He argues that it is in the context of our daily dialogic discussions on language that are born the main questions guiding philosophy and language, and where the "synchronic origin of the Western linguistic tradition can be found.” It is upon this non-intellectual preconceptual basis that our "common-sense" develops into truisms and worldviews. In other words, common daily discussions and arguments about how we talk, address ourselves, make references, correct each other's speech and writing, etc., 
will ultimately guide our commonsensical views about languages and deeply affect academic inquiries about linguistics, which in turn will influence the lay discourses in a feedback mechanism.

Therefore, in trying to assess the question of the potentially different metalinguistic practices, I have included translations from different backgrounds and traditions, while attempting to maintain a reasonable level of "quality."224 However, there is an obvious caveat here, in asking how exactly one could gauge the "quality" of the texts within the framework of perspectivism, where no fixed transcendental value is present, be it ethical, logical, aesthetical or any other kind of absolute value. One can look into internal coherence and cohesion as examples of textual modes of measurement, and indeed objective methods have been developed to comparatively gauge different translations. These methods have the same normative and coercive force, as per the MPH, as other metalinguistic practices, consisting of valid epistemological tools of analysis. However, still observing the tenets of perspectivism, one must always be aware of the claims of transcendental object or a completely neutral epistemology. As for the specific case regarding the choice of translations, I must confess that in the end it becomes much more a matter of personal affinity and interest in the text and therefore inextricably linked to one's own motivations and theoretical affiliations. However, this is a difficulty that spreads over any production of knowledge (markedly, albeit not exclusively, in the Social Sciences), where scholarly works reviewed by their peers are usually biasedly evaluated by personal affinities, at least to one's own program of research. To acknowledge this influence and keep in mind its potentially distorting effects is a good academic practice that ultimately recognizes its own limitations and moderates its ambitions.

Since this is a dissertation produced in Brazil, it was relevant to include among the translations a well-researched translation done in Brazil (Sproviero's book is the best one, as far as I know). I used Ames \& Hall and Hansen's work as

${ }^{224}$ In footnote 58, I remarked that we should be aware of the reification power of words such as West, Occident, China and East. In the specific case of the different backgrounds of the Western translators, the irreducible heterogeneity of the "West" also calls our attention not to ignore the alterity between Indo-European languages and, of course, their many intra-language traditions. We shall proceed as Cassin (2014, p. xix) writes:

Neither a logical universalism indifferent to languages nor an ontological nationalism essentializing the spirit of languages $[\ldots]$ we began with the many $[\ldots]$ and we remain with the many $[\ldots]$ 
their theoretical viewpoints, which I am very much in accordance with, offer a striking contrast to the other translations. Julien was used since it is the oldest known extant translation into a European language. D.C Lau's was chosen as the translator is very authoritative and well cherished among his peers; and, finally, Chén Güying's translation into contemporary Mandarin as the scholar is well known and respected in China.

In choosing an old Chinese commentary, Wáng Bìs seemed the most relevant due to its influence in the history of the study of the Lăož and because the textual version being used in this research is the one commented on by Wáng $B i$ himself. Furthermore, as Alan Chan (1991, p. 180) writes, "the theme of language $[\ldots]$ is central to Wang Pi's understanding of the Lao-tzu."

There are earlier and supposedly less biased commentaries (such as the Hánfêizlı); however, without disregarding the immense value of these earlier works, I chose Wáng Bì's as the one that has arguably been the most influential on how the Chinese read the Lăozi throughout most of its history.

Because there are many versions of the text, the translators are not always translating exactly the same passages, and sometimes the differences might be of relevance. Lau translates both Wáng Bì and Măwángdul̆s version, but the one I use is Wáng Bì's. Julien, Sproviero, Hansen and Chén are all based on Wáng Bì, although all but Julien were aware of Măwángdū and even Guōdiàn and other recently found manuscripts. Ames \& Hall are the only ones who selected the Măwángdū text as their source and whenever that fact has had relevant impact on their translation, I will make note of it.

As a matter of organization, at the head of each section of this chapter I will present a table containing a list of the translated excerpts. After some remarks about the chapter, I will show the original passage with my own approximate character-by-character translation. Subsequently, the order or the presentation of the chosen translators will always be the same: Lau, Sproviero, Julien, Ames \& Hall, Hansen, Wáng Bì and Chén. The first three are more "traditional" translations across three different languages and contexts; the next two are more inquisitive and critical of the usual readings of the Lăozĭ; and finally, the last two are the studies in Chinese. I translated Sproviero, Julien and Chén's translations 
into English. Whenever I find that a secondary translation merits special attention, I will specifically refer to it. Wáng Bìs, as commented above, is primarily translated by Richard John Lynn, with additional commentaries (when relevant) from Ariane Rump (1979). The “original” text, which Wáng Bì presumably extracted from a previous version of the Lăož̆, is presented in characters interspersed by Wáng Bìs own commentaries, themselves shown between brackets. In the English translation, Wáng Bìs commentaries are indented further to the right. Except from Chén's text and commentaries in modern Mandarin which are shown in simplified characters, according to the original book, which was published in mainland China - all other Chinese characters in the text are written in traditional script. Julien and Sproviero's translations and the most relevant commentaries are shown both in their original languages and in English.

\section{2.}

\section{The unlanguaged dào 道?}

Table 2- The unlanguaged dào 道? - list of translations

\begin{tabular}{l|l}
\hline Lăož́ & dào kě dào, fëi cháng dào. míng kě míng, fëi cháng míng. \\
\hline Lau & $\begin{array}{l}\text { The way that can be spoken of; Is not the constant way. The name that can be } \\
\text { named; Is not the constant name }\end{array}$ \\
\hline Sproviero & $\begin{array}{l}\text { O nome que se pode nomear ... não é o eterno nome } \\
\text { O curso que se pode discorrer ... não é o eterno curso }\end{array}$ \\
\hline Julien & $\begin{array}{l}\text { La voie qui peut être exprimée par la parole n'est pas la Voie éternelle; le nom } \\
\text { que peut être nommé n'est pas le Nom éternel. }\end{array}$ \\
\hline $\begin{array}{l}\text { Ames \& } \\
\text { Hall }\end{array}$ & $\begin{array}{l}\text { Speakable way-making - this is not really way-making; nameable naming - this } \\
\text { is not really naming. }\end{array}$ \\
\hline Hansen & $\begin{array}{l}\text { Ways can be guided; they are not fixed ways. Names can be named; they are } \\
\text { not fixed names. }\end{array}$ \\
\hline $\begin{array}{l}\text { Wáng Bì } \\
\text { (orig.) }\end{array}$ & $\begin{array}{l}\text { The Dao that can be described in language is not the constant Dao; the name } \\
\text { that can be given it is not its constant name. }\end{array}$ \\
\hline $\begin{array}{l}\text { Wáng Bì } \\
\text { (comntry) }\end{array}$ & $\begin{array}{l}\text { The Dao that can be rendered in language and the name that can be given it } \\
\text { point to a thing/matter or reproduce a form, neither of which is it in its } \\
\text { constancy. This is why it can neither be rendered in language nor given a name. }\end{array}$ \\
\hline
\end{tabular}




\begin{tabular}{l|l}
\hline Chén & $\begin{array}{l}\text { The dào 道 that can be expressed in words, [this] is not the constant dào 道; } \\
\text { The ming 名 which can be explained [by using] characters, [this] is not the } \\
\text { constant ming 名. }\end{array}$ \\
\hline $\begin{array}{l}\text { Bo (for } \\
\text { dào 道 } \\
\text { only) }\end{array}$ & $\begin{array}{l}\text { The Dao can be reached in language, but the Dao that has been characterized in } \\
\text { language is not identical with, or does not exhaust, the eternal Dao. }\end{array}$ \\
\hline Boodberg & Waying wayable: no common waying. Naming nameable: no common naming. \\
\hline Source: the author.
\end{tabular}

Here is the excerpt from the first lines of chapter I of the Lăozĭ:

道可道，非常道。名可名，非常名。

dào kě dào, fêi cháng dào. míng kě míng, fềi cháng míng.

A preliminary character-by-character translation would be:

道: dào: the "way," the central theme of the Lăož̀

可: kě: indicates possibility, ability, to be admissible (can, maybe)

非: fêi: particle of negation ${ }^{225}$

常: cháng: constant, regular, always, invariably ${ }^{226}$

名: ming: name, to name, reputation

This would give us a possible translation as:

Dào 道 [that] can/is possibly/may [be] languaged/spoken/discourse/explained, not constant/regular/always dào 道. Míng 名 [that] can/is possibly/may [be] named/ nameable/called, not constant/regular/always ming 名.

These first two "sentences" 227 of the received (Wáng Bi’s) version of the Lăož are some of the most quoted and analyzed passages in the Chinese literature.

${ }^{225}$ For an extensive analysis of negation in classical Chinese, see Harbsmeier (1991, pp. 17-30) and the comments in Boodberg (1957, p. 603).

226 The character cháng 常 appears in Wáng Bìs version but not in older manuscripts found recently, where it is substituted with héng 恆, which has similar connotations. It is a quite common term throughout the Lăož̀ with a complex network of meanings. For instance, Ames \& Hall, motivated by their non-essentialist worldview, translate the same term in the chapter XVI of the Lăož as common sense, implying that it is frequent use that makes something constant, without any other ontological basis. For further discussions see, for example, Hansen (1985, p. 507) and Boodberg (1957, pp. 603-4). 
The excerpt is of particular interest to the research objectives of this dissertation since it contains two important metalinguistic expressions, dào 道 and míng 名. Although, as we have seen, the text has not been written in a linear fashion and can be read in a multitude of different sequences, the sheer fact that the excerpt in question composes the opening lines of one of the most (if not the most) influential versions of the Lăož́ should emphasize its importance. ${ }^{228}$

This passage is also significant because it shows a rather enigmatic relationship between two central terms of the text, the abovementioned dào 道and ming 名. Although they do not appear in the same "sentence," as in other chapters of the $L \check{a} O z \grave{l} \check{l}^{229}$ there is a direct connection via parallelism that closely binds dào 道and ming 名. ${ }^{230}$

A crucial matter when (re)reading the text is the question of what to make of the three instances respectively of dào 道 and ming 名. The etymological analysis has provided a rich polysemic network associated with these characters that will, on the one hand, offer a great challenge to the translators and, on the other hand, provide great freedom in possible associations and semantic allusions.

227 The term "sentence" here is being used in a very conventional and approximate way. The received versions of the Lăož́ do not carry any punctuation, yet some sort of organization is sometimes inferred through the commentaries and works of scholars depending on the specific text in question. One of them, "text A" of Măwángdū̄, has small dots that supposedly stand for chapter boundaries: of the 15 dots appearing in the manuscript, 11 are coincidental to traditional chapter transitions. We will also see in Bo Mou's and Boodberg's translations of the excerpt that these authors parse the passage as being constituted of four somewhat more "independent" statements, rather than two, as taken by the "traditional" translations.

${ }^{228}$ Creel (1983), following his interests in the search for alterity in ancient China and the Lăož̀ in particular, writes about the importance of this passage:

In these two areas, of the nature of the universe and man's relation to it, and of the role of words in relation to reality, I believe that a huge gap yawns between Western ideas and early Taoist philosophy. And I also believe that the opening words of the Lao-tzu are concerned, precisely, with these subjects. (p. 306)

${ }^{229}$ For instance chapter XXXII of the Lăož̀, which starts with: dào cháng wú míng 道常無名, with one possible interpretation being: “dào 道 is always/constantly without aname."

${ }^{230}$ Bo (2003), for instance writes:

As a matter of fact, various interpretations of the opening message seem to reach one agreement: there is a close, coherent, and parallel connection between the first and second six-character statements. (p. 252) 


\section{Lau}

The way that can be spoken of

Is not the constant way;

The name that can be named

Is not the constant name.

In Lau's book, we read the following commentary on the relationship

between dào 道 and language:

There is no name that is applicable to the tao because language is totally inadequate for such a purpose. And yet if the tao is to be taught at all some means [...] must be found [...] This is difficult task, for even the term 'tao' is not a proper name but a name we use for want of something better. (Lau, 2001, p. xv)

Here, Lau clearly points to what he perceives as a flaw in language that engenders a difficulty: language is not appropriate to refer to dào 道, and yet, if we want to say or express something about dào 道, we can only rely on words (language). Language appears to be an inadequate and flawed instrument, thus reminding us of Locke and the Western tradition of mistrusting language. Lau's words are similar to those in many other works and thus could be considered here as a type of benchmark in the line of the more traditional exegetical studies of the Lăož́, with which to compare the other translations.

\section{Sproviero}

O curso que se pode discorrer

O nome que se pode nomear

The course [way] that can be discoursed ${ }^{231}$ não é o eterno curso não é o eterno nome is not eternal course [way]

231 The translation of discorrer in Portuguese as to discourse in English is not straightforward and begs some clarification. Discorrer being used here has a common figurative meaning with the following synonyms: to dissertate, to present, to put, to comment, to develop, to enumerate, to discourse, to display, to reason, to treat (about a subject) (In Portuguese: dissertar, apresentar, colocar, desenvolver, desfiar, discursar, exportar, razoar, tratar (sobre um assunto). (Dicionário Houaiss de Sinônimos e Antônimos, Publifolha, 2008) In these acceptations, the verb is transitive indirect and the sentence "O curso que se pode discorrer" should strictly be considered grammatically incorrect, due to the lack of the preposition. Sproviero, along his book, questions the uncertain limits between verb and noun in Chinese as well as what he calls a Chinese "median voice," "between" Portuguese's (and English's) active and passive voice. This ambiguity ("The 
Despite the immense quality and the care with which the translation was made, we can arguably question whether the "eternal" could not be considered a somewhat domesticating translation due to the strong connotations of the term in the west, especially when inserted in the cosmological view of the JudeoChristian traditions.

This same remark is also valid when we come across Sproviero's comment on the language used to refer to the dào 道:

Portanto, sempre que se menciona a inominalidade do Dao, isso indica nossa impossibilidade de nomeá-lo ou concebê-lo. Não podemos confiná-lo em nós, mas devemos abrir-nos para ele. Desse 'não podermos nomeá-lo' não decorre que ele não se nomeie eternamente. (Sproviero, 2007, p. 205)

Therefore, whenever one mentions the "unnameability" of Dao, this indicates our inability to name it or conceive it. We cannot circumscribe it in ourselves; on the contrary, we must open ourselves to it. From this "we cannot name it" it does not follow that it cannot be forever named.

And further:

Dao, um som, mero flatus vocis, não é o seu nome. Este silencia para nós. Projetar no absoluto tudo o que para nós é inominável, insondável, inconsciente, imanifesto, vazio, etc., é a tendência hermenêutica das doutrinas ocidentais, mas no caso de Laozi seria tendenciosa [...] Em Laozi, tudo retorna ao Dao que segue a si mesmo [...] Portanto, o nome eterno, manifestação absoluta do Dao, é para nós imanifesto. O Dao não é transcendente em si [...], nem sujeito nem objeto, é manifestação plena, não-dual. (Ibidem, p. 206)

Dao, a sound, a mere flatus vocis, is not its name. This one is silent to us. Projecting on the absolute everything that for us is unspeakable, unfathomable, unconscious, nonmanifested, empty, etc., is the hermeneutical tendency of the Western doctrines, however in the Laozi's case that would be biased [...] In Laozi, everything returns to Dao which follows itself [...] Therefore, the eternal name, absolute manifestation of Dao, is for us nonmanifested. The Dao is not transcendent in itself [...], neither subject nor object, [but rather] a full, non-dual manifestation. 
One can perceive an attempt to link dào 道 to an eternal name, however, this is a name that goes beyond us in some way (beyond our senses?) and that therefore is "nonmanifested." It is a play on words, in which dào 道, exactly by being fully complete (encompassing the concept of "completeness" itself) cannot be seen. These explanations remind us of the "mystic nature" of the Lăož̆, a heated topic of discussion among its scholars and which has been briefly touched above in this dissertation.

\section{Julien}

La voie qui peut être exprimée par la parole n'est pas la Voie éternelle; le nom que peut être nommé n'est pas le Nom éternel.

The way that can be expressed by the word is not the eternal Way, the name that can be named is not the eternal Name.

Julien's extensive commentaries shed an illuminating light on his translation. First, regarding dào 道:

Le second mot tao 道 a le sens de yen 言, 'dire, énoncer' Sou-tseu-yeou: Il y a deux voies (deux Tao), l'une ordinaire, qui est la voie de la justice, des rites, de la prudence; elle peut être énoncée par la parole et son nom peut être nommé. L'autre est la Voie (le Tao) sublime dont parle Lao-tseu. Cette Voie, qui plane au-dessus du siècle, n'a ni forme, ni couleur, ni nom. (Julien, 1842, p. 2)

The second word tao 道 has the meaning of yen 言, “to say, to announce" [...] Soutseu-yeou [said]: There are two ways (two Tao), one is ordinary, which is the path of justice, rites, prudence; it can be uttered by the word and its name can be named. The other is the sublime Way (or Tao), which is spoken by Lao-Tseu. This Way, which floats above the century, has no form, color, or name.

And then, regarding names:

Liu-kie-fou: Tous les objets sensibles ont un nom qui peut être nommé; mais il vient un temps où ce nom, dérivé de leur forme ou de leur nature, vient à disparaître. Ce n'est pas un nom éternel. (Ibidem)

Liu-kie-fou [said:] all sensible objects have a name that can be named, but there comes a time when this name, obtained from their form or their nature, will disappear. This is not an everlasting name. 
Julien "solves" the issue of dào 道 by giving an explanation that is often employed in the texts of Chinese philology: He "separates" it into two different, well-defined entities. One is the ordinary, as it refers to the rites and laws of nature and society, is changeable and can be assigned (to something in the World). The other is the "sublime" dào 道, the one that is eternal, formless, colorless and nameless. It is the one spoken of by Lăož̆ and the main object of the Lăožr. This dichotomy is mirrored in the parallel dimension of names: all sensible objects (including the "first" dào 道) can be named, defined, cataloged or put into hierarchies. Nevertheless, these names will (eventually) disappear along with the objects named by them. Julien, however, does not explain if, in his interpretation, Lăož̌ ever refers to an "everlasting name."

This strategy to identify “different” dào 道”s (and correspondingly, different ming 名's) in the text and “explain" their difference through the use of notes is a common practice in the Chinese commentarial tradition, as we will see below when examining the works from Chinese authors.

\section{Ames \& Hall}

Ames \& Hall wrote an explicitly anti-essentialist book on the Lăož̆, proposing what the authors call a "Taoist Perspectivism":

Speakable way-making - this is not really way-making,
nameable naming - this is not really naming.

To these authors, not to have the concept means not being susceptible to its differentiation and its limits. One may find echoes of this relationship between knowledge (concepts) and limits in this passage of the Zhuāngž̌ 莊子, Chapter 6 (dà zōng shī 大宗師, “The Great and Honorable Master”):

夫知有所待而後當，其所待者特未定也. fū zhī yǒu suǒ dài ér hòu dāng, qi suǒ dài zhě tè wèi dìng yĕ. 
Now understanding is dependent upon something before it can be on the mark, and yet that which it depends upon is never fixed. (Ames \& Hall, 2003, p. 205)

Consequently, the authors throughout their book prefer the term "Waymaking" to translate dào 道, thus emphasizing that theirs is not an ontological vision, but one with a focus on becoming, the act itself of becoming. With this translation for dào 道, expressions like "constant Dao" or "eternal Dao" become inadequate and are substituted with [it is] not really way-making. One can obviously argue that the adverb really implies there is a true (real) mode of "Waymaking" (with the same being valid for naming), a kind of true/false contrast that is not suggested in the text in Chinese, but that, on the other hand, avoids an overtly ontological expression.

The results on the etymological survey on dào 道 also give some support to this translation by Ames \& Hall, when they link to the graphic nature of the character an inseparable bond of action and noun, of both the boundary and the act which delineates the border.

\section{Hansen}

Hansen's translation in many ways follows Ames \& Hall's anti-essentialist view of the Lăož̆:

Ways can be guided; they are not fixed ways.

Names can be named; they are not fixed names.

Hansen's is the only translation that explicitly indicates the normativity of dào 道 through the verb to be guided. ${ }^{232}$ There is also, in a way that is similar to Sproviero's discorrer verb, a verb usage here that arguably leads to a possible ambiguity entangling syntax and semantics: one would expect dào 道's “way” to guide us. However, if the "ways" are being guided, who can guide them if not dào

${ }^{232}$ In the compilation of 56 translations, only one translator (Thomas Cleary, The Essential Tao) used guide in his translation of the first line of the Lăozí: A way can be a guide, but not a fixed path. 
道? There is a possibly ambiguous situation, where dào 道 is both subject as well as object, which provides the translation with a "foreign" flavor that, in my opinion, adds to its quality.

Nevertheless, I consider that it is the absence of any article and the use of plural substantives that has the stronger interpretative impact. Dào 道, in this passage, is often recognized as the "the" Way, the principle on which the Lăož has been written. Hansen's translation calls our attention to the non-individuality of dào 道: ways [discourses] can indeed be guided, or, can be used as guides; however, these ways [the discourses that we use as guides] are never fixed. ${ }^{233}$ Likewise, names can [be used] to name, but these names, the ones we used in our language, will always vary.

Finally, one cannot ignore that Hansen's commentaries direct us to read dào 道 as languaged-discourses, highlighting that these inconstant and inevitably contextual guides are associated with a language dimension. Thus, the dào 道 of the stars or of nature might not at first appear to be ostensibly linguistic, but it does not either need to be interpreted in ostensible language: rather, "to interpret a dao is to perform it.” (Hansen, 1992, p. 4) In typical Daoist fashion, dào 道is both anti-language, in the restricted use of "language"; and all language, in its "dào 道" use.

This viewpoint contrasts with the more metaphysical-biased interpretations of other authors, such as Lau or Chén (below). In the Lăož̆, the same “道” is written, but each translator chooses to construe it in widely different language games.

According to Hansen, Daoism is centrally erected upon a paradox: it teaches that you should not learn. ${ }^{234} \mathrm{He}$ writes: "Taking guidance from the book should teach us not to take guidance from the book." (Hansen, 1992, p. 214) It is this

\footnotetext{
${ }^{233}$ In the compilation of 56 translations, only eleven works did not use an article preceding whatever translation of “dào 道." Additionally, only three used the plural "ways": a professor of economics in Lingnan University (Hong Kong), Lok Sang Ho (Ways that can be spelled out cannot be the eternal way.); Victor Mair (The ways that can be walked are not the eternal Way); and Liu Qixuan (There are ways to follow, $\sim$ But what is followed is not the true Way).

${ }^{234}$ See more details in the section "Wordless teaching," below.
} 
paradox, according to the author, that is reflected in the opening lines of the first chapter: "No other dao is any better off. All guidance that can come from a dao will be inconstant." (Ibidem) Hansen refuses to see an "almighty and transcendental" dào 道 that would come to solve all the Chinese ethical questions about the adequacy of names and the nature of the relationship between language/names and reality.

Hansen offers an analogy to elucidate the passage under study:

Consider "the chef who breaks yolk is not the ideal cook." It neither asserts that a unique chef who breaks yolks exists, nor that one who does not break yolk exists, nor that there is an ideal cook. Logically the sentence is equivalent to "Any chef who breaks yolks is not an ideal cook." (Ibidem, p. 216)

The illustration is clear: if we accept the analogy, the first line of the Lăož́ does not imply that there would be an "ideal dào 道," but rather that the dào 道's that are "speakable" (or the mings 名's that are "nameable") are not ideal(izable). In Hansen's words: “Lăož simply notes that daos and names lack constancy [...] the constancy goal, Laozi announces, is hopeless." (Ibidem, p. 217)

For Hansen, the political motivations of the Lăož̆ are of central importance to understanding this radical position against the dogmatic discourse one can find in other Chinese thinkers. His reading

\begin{abstract}
Makes the rectifying-names point that any prescriptive system put into words gives inconstant guidance. We can understand this line as directed straight at Confucius and Mozi or as expressing the felt paradox of Shendao's or Lăož̀'s discourse daos. (Ibidem, p. 216)
\end{abstract}

For this author, it could mean that "to speak the speakable," that is not constant speaking, i.e., that is not constant guidance (dào 道 as guiding discourse); in other words, that the use of language will not give us constant guidance. Based on the non-metaphysical nature of the traditional Chinese thought, Hansen argues that this passage does not talk about some ineffable entity that is located beyond our language. 
In this context, the second line explains the first because it mirrors the partwhole relation between dào 道's and names: dào 道's are consisted of names and not sentences. Although, throughout the Lăož̆, argues Hansen, one notices that that might be reflected by some kind of constancy in the nonsocial reality of nature, what matters for this passage is the discourse-dào 道, this language-based guidance that cannot escape its inconstancy.

\section{Wáng Bì}

Here is Wáng Bìs passage, with his added commentaries, placed between brackets, following:

\section{道可道, 非常道。名可名, 非常名。「可道之道, 可名之 名, 指事造形, 非其常也。故不可道, 不可名也。」 \\ dào kě dào, fêi cháng dào. míng kě míng, fêi cháng míng. [kě dào zhĩ dào, kě míng zhī míng, zhĭ shì zào xíng, fêi qi cháng yè. gù bù kě dào, bù kě míng yě.]}

The Dao that can be described in language is not the constant ${ }^{235}$ Dao; the name that can be given it is not its constant name.

The Dao that can be rendered in language and the name [ming 名] that can be given it point to a thing/matter [shi 事] ${ }^{236}$ or reproduce a form [xíng 形], ${ }^{237}$ neither of which is it in its constancy [cháng 常]. This is why it can neither be rendered in language nor given a name.

${ }^{235}$ Lynn translates cháng 常 as constant (as Lau) and not as eternal (as do Julien and Sproviero) or really (Ames \& Hall). This is obviously Lynn's choice, not Wáng Bìs.

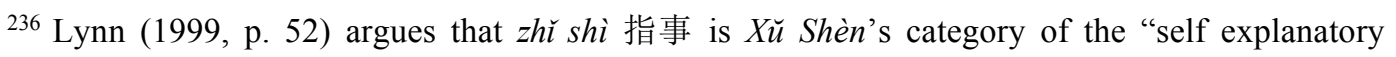
characters” (such as 上 e 下), as zàoxing 造形 is probably a variant of xiàngxing 象形 (image and form), Xŭ Shèn's second principle, pictography. Lynn wrote:

Wang Bi here reminds his reader of the limited way language functions, too limited to capture the entirety of the Dao because it always has to refer to things in the specific. [...] Wang Bi probably [thought that] not only is language limited to naming specific things, it consists of names that at best only approximate the real nature of specific things and, as such, are inevitably false or counterfeit.

237 Xing 形, as we have seen, is a character with allusions to form/shape, appearance, demonstration, imitation (of the appearance). Its prominent role in X̌̌ Shèn's work (Shuōwén) is due to its association with the pictorial form of characters. Here it seems to connote the transient physical appearance of "all things," which contrasts with the "eternal aspect" of dào 道 (see the following translation into English). 
Although the motivations and context of Wáng Bìs commentary are certainly relevant for this study, for methodological purposes I have decided to focus on a direct back-to-back comparison of its "translation" with the others shown here.

As one of the inaugurators of the Chinese commentarial tradition, Wáng $B i$ 's "commentaries" that intersperse the original text are our primary interest. The author explicitly uses dào 道 in verbal form (to tell, in the expression the Tao that can be told), doing the same for ming 名(to name, in the expression the name that can be given it). The spoken dào 道 and the named ming 名 both "point" to a particular or specific "thing," thereby building a “form" (xing 形, also glossed as image, figure, appearance, shape) but these are not "in its constance." Wáng Bi seems to stress the opposition along the lines of what can be said and named (which refers to particular forms and affairs) and the dào 道. Therefore, in Lynn's reading of Wáng $B \grave{\imath}$, we are led to a representational view of language: discourse and names point (refer) to things and reproduce (as semantic informed hànzi) the forms.

However, one must not forget that we are reading Wáng Bì through the intervention (translation) of Lynn. I repeat a partial excerpt of Wáng Bìs comment, but this time it is followed by Rump's (1979) translation:

\section{可道之道，可名之名，指事造形，非其常也。 kè dào zhī dào, kè míng zhī míng, zhĭ shì zào xíng, fêi qí cháng yě.}

The Tao that can be told and the name that can be named point to a particular affair [shi 事] and construct [zào 造] a form [xíng 形] but not their eternal aspect.

The translation of shi 事 as affair is quite common in classical Chinese, ${ }^{238}$ and translating zào 造 as construct is likewise a usual interpretation. We could therefore read Wáng Bìs comment as saying: "the dào 道 of discourse and its names point to actions and affairs and, based on them, they construe forms - that

${ }^{238}$ For instance, Rouzer (2007, p. 27) glosses it as: thing, matter, affair, occupation, job (names); to serve, to work for, to employ, to have as servant (verbs). 
is, they create categories - thus giving the appearance of a discourse; however, this discourse is not constant." ${ }^{239}$ In a way, this interpretation reminds us of Hansen's and is very distinct from Lynn's own translation and commentaries.

\section{Chén}

The second Chinese translation is from Chén, into modern Mandarin:

可以用言词表达的道, 就不是常道; 可以用文字表述的名, 就 不是常名。

kěy̌̀ yòng yán cí biăodá de dào, jiù bùshì cháng dào; kěyľ yòng wénzì biăo shù de míng, jiù bùshì cháng míng o

The dào 道 that can be expressed [biăodá 表达] in words [yáncí 言词], [this] is not the constant [cháng 常] dào 道; The míng 名 which can be explained [biăoshù 表 述] [by using] characters [wénzì 文字], [this] is not the constant ming 名.

The perfect parallelism of the original passage is approximately repeated in the expression in modern Mandarin. There are two important contrasts: first, the author of the Lăozl̆ still attempts to reach both dào 道and ming 名with some kind of reference, the only distinction being in the use of a different verb for each, to express, to convey [biăodá 表达] for dào 道 and to explain, to formulate [biǎoshù 表述] for ming 名. The different verbs are a consequence of what the scholar (and the exegetical tradition of the Lăož̀) explains as the respective verbal roles of dào 道(the “second" dào 道 in the passage) and of ming 名(the "second" ming 名 in the passage). The subtle nuances seem to indicate that there is a semantic affinity of the “verbal forms" of dào 道and ming 名.

The second contrast is also interesting and has a close connection with the first. The verbal dào 道 is translated as a verb that carries its complement with it,

${ }^{239}$ Although Rump has included a eternal aspect in the end to her translation, the Chinese text uses a single character, cháng 常, fixed, regular, constant. It is possible to borrow from Lynn to rewrite the translation as:

The Tao that can be told and the name that can be named point to a particular affair and construct a form, but neither of which is constant. 
as in: to express [itself] in words. The term used as object of the verb, yánci 言词, is usually associated with the spoken word, the oral language. As for the verbal ming 名, the expression used is to explain [by using] characters, since the object, wénzì 文字，is associated with the written language. ${ }^{240}$ The oral/writing relationship emerges here, in Chén's translation, as a shadow of the relationship dào 道 / míng 名, a perspective that could be interpreted as mirroring a subservient view of writing. ${ }^{241}$ It is important to note, however, that this interpretation arose from the translation of Chén, a contemporary work, at a time when the studies on the nature of the relationship between speech and writing in Chinese, especially in academic circles, have been strongly influenced by Western phoneticism. ${ }^{242}$

The author makes the following comment on the dào 道's of this passage:

\begin{abstract}
道可道, 非常道: 第一个 "道" 字是人们习称之道, 即今人 所谓 "道理"。第二个 "道" 字, 是指言说的意思。第三个 "道" 字, 是老子哲学上的专有名词, 在本章它意指掏成宇 宙的实体与 动力。(Chén, 2006, p. 73)

dào kě dào, fêicháng dào: dìy gè "dào" zì shì rénmen xí chèn zhī dào , jí jīn rén suówèi "dàoli." dì̀r gè "dào" zì shì zhì yán shuō de yìsi. dìsān gè "dào" zì shì lăozĭ zhéxuéshàng de zhuānyǒumíngcí, zài běn zhāng tā yì zhĭ tāo chéng yǔzhòu de shitǐ yŭ dòngli.
\end{abstract}

道可道,非常道: The first dào 道 is the one we have the habit of calling “dào 道," and which we now call reason / principle [dàoli 道理 $\left.{ }^{243}\right]$. The second dào 道 indicates the meaning [yisi 意思] of to put into words, to say [yánshuō 言说]. The third dào 道 is that of Lăož̀'s philosophy, which is a specialized name [zhuāngyòng míngci 专用名词], and in the core / basic chapters [of the Lăozí]

${ }^{240}$ See for instance the difference between a "dictionary of words [of the spoken language]," cídiăn 詞典, and a “dictionary of [written] characters," zidiăn 字典. For more details of the relation of wén 文, $z i$ 字and the Chinese written language, see chapter II of this dissertation.

241 Under this view, dào 道is the "thing," the signified, while ming 名 is the "name," the signifier - while at the same time the spoken language, yáncí 言词, carries a meaning that will be represented in writing, wénzi 文字. For a brief discussion and reference on the relationship between Chinese speech and writing, see elsewhere in this dissertation.

${ }^{242}$ As seen in chapter II of this dissertation, the term "Western phoneticism" is being used to indicate the academic tendency in the West (and China) to make the assumption that writing is merely a representation of the sounds of each language and not "true language."

${ }^{243}$ Also glossed as rationality, truth, argument. 
points to the formation of the universal substance / entity [yǔzhòude shit ǐ 宇宙的实 体] and its driving force [dòngli 动力].

In this passage one follows a path often trod by the Chinese exegetical tradition and one could almost see therein a systematic "procedure" of interpreting the three dào 道's in the passage of the Lăozĭ. Although Chén defines separately the first and third (the second being the theoretically least troublesome one, the verbal dào 道), both are "metaphysical” in their natures, respectively "reason" and the "specialized name of Lăož̆'s," which is the source and driving force of the universe.

The Chinese author presents a similar analysis for ming 名:

名可名,非常名:第一个 "名"字是指具体事物的名称。第二个 "名" 字是称谓的意思, 作动词使用。第三个 "名" 字为 老子 特用术语, 是称 "道" 之名。(Ibidem, p. 73)

míng kě míng, fêicháng míng: dìȳ gè "míng" zì shì zhǐ jùtǐ shìwù de míngchēng. dièr gè "míng" zì shì chèn wèi de yisi, zuò dòngcí shy̆yòng. dìsān gè "míng" zì wèi lăozì té yòng shùyŭ, shì chèn dào zhī míng.

名可名,非常名: first ming 名 is one that points to the name of the concrete things [jùtǐshìwù 具体事物]. The second ming 名 is that in the sense of to call [chèngwèi 称谓], [and] is used as a verb. The third ming 名 takes in Lăozĭ a special predicate usage, is the name to refer/call [chēng 称] the dào 道.

Chén's comment seems to denote a strong wish to limit and delineate the meanings of the text, and the author even finds that ming 名 could be a "special name" to refer to dào 道, which seems to be in clear contradiction with the text. This drive to "dissect" every character of the text is a common trait of the exegetical texts in the Chinese philological tradition. Chén's notes, however, do not appear to be open to the contributions from the hundreds of past commentaries, but rather seem to attempt to "contain" each ming 名 into very definite and definitive glosses.

Therefore, even though it is quite apparent in the Chinese author's analyses that there are signs of the great difficulty of language to deal with dào 道, he 
seems to adopt the strategy to resort to a "metaphysical substance" of dào 道, a "something" that is positioned at a higher level than "mere" concepts as well as the language itself. As a result, even dào 道 seems to be "dissected" with the help of metaphysical terms borrowed from the Western philosophical tradition. On the other hand, Chén recognizes the inaugural nature of this usage of dào 道 by referring to it as a "specialized name and in the core chapters" of the Lăož̀. 244

\section{Additional translations}

The seven translators above are those who will be analyzed throughout the present dissertation. This particular excerpt, however, has been put under so much scrutiny from many different scholars that it proves useful to add comments on some additional translations. Therefore, I have included an overview of two more studies that are focused on this specific passage.

The first is written by Bo Mou, a Chinese philosopher currently (2014) working in the United States in the San José State University. Although much of Bo's theoretical viewpoints depart from the ideas defended in this work, his translation and commentaries of the passage offer a contrast with the other translations that suits very well my aims here.

The second is a brief paper that the famous Sinologist Peter Boodberg (1903-1972) wrote in 1957, entitled "Philological Notes on Chapter One of The Lao Tzu," which deserves a short overview on the grounds of its immense scholarship and quite contrastive interpretations.

As said, Bo Mou's article is not a full translation of the Lăož̆, but an analysis of the exact excerpt that is the object of the present study. It suffices to examine in detail only his conclusion on the passage regarding the dào 道 (the

\footnotetext{
${ }^{244}$ To identify this dào 道as a "specialized use of the Lăož̀," Chén is doing what Hansen (1992, p. 13) criticizes as a common strategy of Confucian orthodoxy to isolate the criticism of concurring schools of thought, such as Daoism or Mohism. Hansen calls it the "Meaning Change Hypothesis," where the key terms of each school supposedly had their meanings "changed" in order to insulate the prevailing orthodoxy from being questioned in its own terms. Thus, for example, it was considered that Daoism simply "changed" dào 道 from a (Confucian) moral doctrine to a "metaphysical monistic absolute." See more details in Hansen (1992).
} 
second passage, ming 名's, follows a similar line of thought for our purposes here $\left.^{245}\right)$. His preferred translation/paraphrase is:

The Dao can be reached in language, but the Dao that has been characterized in language is not identical with, or does not exhaust, the eternal Dao. (Bo, 2003, p. 248)

Bo's argument led him to conclude that the dào 道's six character passage ( 道可道非常道) actually consists of two claims, one which is positive (we can and we do talk about the - genuine - dào 道) and another which is negative (in its “full" or "eternal" aspect, the dào 道 cannot be exhausted or fully described by language). This happens because in Bo's view chángdào 常道 (the eternal Dao, in Bo's words) is a particular dimension or layer of dào 道 in its infinite/eternal aspect that transcends any finite manifestation of dào 道 in wánwù 萬物 (“the 10,000 things in the world"). It is not, however, the only relevant aspect of dào 道, all aspects of dào 道being equally genuine.

It is outside the scope of this dissertation to discuss Bo's intricate (and somewhat tortuous) arguments about whichever dào 道 can be reached by language and what can be (at least partially) described by it. What is relevant here is that Bo's reading and conclusions of this excerpt suggests a different perspective on how to take the role of language in the opening characters of the Lăož̀. In Bo’s own words,

\begin{abstract}
The term 'dao' as a verb means a variety of ways of reaching the Dao in language that includes rigid designation through direct reference but is not limited to descriptive characterization in (partially) finite ways, at least the Dao that can be rigidly designated through direct reference can be, or be identical with, the eternal Dao. (Ibidem, p. 250)
\end{abstract}

Bo seems to be of the opinion that language does indeed capture dào 道, but, as the Lăož̀ shows, dào 道 offers different aspects to us, and, likewise, the language-dào 道 offers different ways to deal with these different aspects.

\footnotetext{
${ }^{245}$ Bo himself writes: "I consider the second six-character statement [...] to deliver essentially the same message as that delivered by the first six-character statement in a certain philosophically interesting way." (Bo, 2003, p. 252)
} 
Therefore, the language-dào 道 reflects the many-sided dào 道 and the passage is not intended to indicate the limits of our understanding of dào 道, but rather the different ways we can access (via language) the multifaceted dào 道. The author's conclusion is thus:

There is no part or dimension of the Dao that cannot be reached through language; or any part or dimension of the Dao, or even its eternal dimension, can be somehow talked about or reached in language. (Ibidem, p. 251)

Despite its somewhat awkward wording, I believe that the author is stressing the capacity of language to reach dào 道, even if this capacity (and its action and results) is as many-sided as dào 道 itself. There remains a limitation however: in all its fullness dào 道cannot be exhaustively described.

Bo's analysis is relevant for our purposes here in the way that it focuses on the linguistic engagement in the Lăož̆, offering a fresh perspective on the extent that dào 道is effectively languaged (or not).

The final translation was written in 1957 by Peter Boodberg. With the support of his extensive knowledge of the syntactical features of classical Chinese and an etymological analysis that mixes phonetic as well as semantic features of the characters, Boodberg dismissed the possibility that the second part of each line could be modifying the first part. ${ }^{246}$ In other words, he doubted that fêi cháng dào 非常道 could modify dào kě dào 道可道 or that fëi cháng míng 非常名 could modify ming kě ming 名可名. That would be, in Boodberg's words, an

Injudicious violation of the fundamental axiom of Chinese grammar: modifier precedes principal. Indo-European relative clauses are expressed in Chinese by adjectival ones. (Boodberg, 1957, p. 605)

246 Boodberg's etymologies are quite complex and, due to his unconditional support for the primacy of phonetic indication in the Chinese characters, may appear a bit far-fetched in terms of his phonological indications. However, my intention here is not to criticize his analyses, but, as per the $\mathrm{MPH}$, investigate in them possible traces of an alternate metalinguistic repertoire in Boodberg's interaction with the text of the Lăož̀. 
These lines might lead us to believe that Boodberg's view is analogous to Bo's in separating each line into two coordinated (instead of subordinated) components. However, Boodberg's conclusions are quite different from Bo's.

To his syntactic parsing the author added an extensive analysis of all the characters in these two lines. For instance, regarding dào 道:

To sum up, we feel that the traditional translation of Tao as "the Way" does little justice to the wealth of the Chinese term's semantic connotations. What word should be substituted for "way" is a matter of choice and taste. Personally, I am partial to "lodehead" in clearly metaphysical contexts, and to "headlead" (nominal and verbal) in mixed or commonplace discourse. (Ibidem, p. 602)

Boodberg considered the first dào 道 and míng 名as verbs, in disagreement to all the translations we have read above (a possible exception might be Ames \& Hall). He also treated fề 非 as a transitive verb (to negate, deny, gainsay) instead of an adverb. Moreover, even if he recognizes the difficulties in translating the wealth of the "semantic connotations" of the Chinese characters, his intentions are bold: "It is not impossible moreover to construct a crude English replica of the original text reproducing all of its ambiguities." (Ibidem, p. 607) This results in the following translation:

Waying wayable: no common waying

Naming nameable: no common naming.

The end result is remarkably modern and, one can say, even "perspectivist," reminding us of Ames \& Hall's "way-making," with his coinage of neologisms, adherence to the strict parallelism of the original and prevention from using articles and metaphysical terms ("eternal," "universal"). The strangeness one feels when reading these brief lines is testimony to the shock emanating from attempts to engage a "foreignizing" translation, which sends its ripples through a grammar that clearly rejects its new, forced, ways. As per the MPH, these are hints of the potency of the interaction of two (or more) different perspectives.

Led by his linguistic interests, Boodberg fully accepted the contribution of the grapho(etymological) analysis to the better understanding of old Chinese texts 
and intended to "establish a solider philological foundation upon which a firmer interpretation of the incipit of Taoist philosophy might be built." (Ibidem, p. 618)

To summarize the treatment that the nine scholars and translators gave to the three instances of both dào 道 and ming 名 in this short passage, I present a table highlighting the differences and parallels between the translations, including the supplemental two: 247

Table 3- The unlanguaged dào 道? - summary of the metalanguage's translations (A)

\begin{tabular}{l|c|c|c}
\hline $1^{\text {st 道 }}$ & Lau & Ames \& Hall & Julien \\
\hline $2^{\text {nd } \text { 道 }}$ & the common way & way-making & $\begin{array}{c}\text { the ordinary Way } \\
\text { (la Voie ordinaire) }\end{array}$ \\
\hline $3^{\text {rd (常)道 }}$ & $\begin{array}{c}\text { the way with authority } \\
\text { (the constant way) }\end{array}$ & $\begin{array}{c}\text { really way- } \\
\text { making } \\
\text { (dire, énnoncer) }\end{array}$ & $\begin{array}{c}\text { the eternal Way } \\
\text { (la Voie éternelle) }\end{array}$ \\
\hline $1^{\text {st 名 }}$ & $\begin{array}{c}\text { the common name } \\
\text { name of the sensible } \\
\text { objects } \\
\text { (nom des objets } \\
\text { sensibles) }\end{array}$ \\
\hline $2^{\text {nd 名 }}$ & named & nameable & $\begin{array}{c}\text { be appointed (être } \\
\text { nommé) }\end{array}$ \\
\hline $3^{\text {rd (常)名 }}$ & $\begin{array}{c}\text { the "special" name } \\
\text { (the constant name) }\end{array}$ & really naming & $\begin{array}{c}\text { everlasting name } \\
\text { (nom éternel) }\end{array}$ \\
\hline
\end{tabular}

Source: the author.

${ }^{247}$ Besides the translations of the characters, the commentaries of the translators themselves were added for further clarification. 
Table 4- The unlanguaged dào 道? - summary of the metalanguage's translations (B)

\begin{tabular}{|c|c|c|c|}
\hline & Sproviero $^{248}$ & Bo & Boodberg \\
\hline $1^{\text {st 道 }}$ & $\begin{array}{l}\text { the course } \\
\text { (o curso) }\end{array}$ & the Dao & waying \\
\hline $2^{\text {nd }}$ 道 & $\begin{array}{c}\text { discourse }(\mathrm{d}) \\
(\text { discorrer})\end{array}$ & $\begin{array}{l}\text { reached in } \\
\text { language }\end{array}$ & wayable \\
\hline $3^{\text {rd (常)道 }}$ & $\begin{array}{l}\text { the eternal course } \\
\text { (o eterno curso) }\end{array}$ & $\begin{array}{c}\text { the (eternal) } \\
\text { Dao }\end{array}$ & common waying \\
\hline $1^{\text {st }}$ 名 & $\begin{array}{l}\text { the name } \\
\text { (o nome) }\end{array}$ & & naming \\
\hline $2^{\text {nd }}$ 名 & to name (nomear) & & nameable \\
\hline 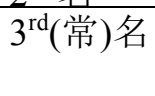 & $\begin{array}{l}\text { the eternal name } \\
\text { (o eterno nome) }\end{array}$ & & common naming \\
\hline
\end{tabular}

Source: the author.

Table 5- The unlanguaged dào 道? - summary of the metalanguage's translations (C)

\begin{tabular}{|c|c|c|c|c|c|}
\hline & Hansen & \multicolumn{2}{|c|}{ Wáng $B i^{249}$} & \multicolumn{2}{|r|}{ Chén } \\
\hline 1st 道 & ways & shi, xíng & $\begin{array}{l}\text { particular } \\
\text { case, a } \\
\text { form }\end{array}$ & dàoli & reason / principle \\
\hline 2nd 道 & be guided & dào & be said & yánshuō & to say \\
\hline 3rd(常)道 & $\begin{array}{l}\text { fixed } \\
\text { ways }\end{array}$ & cháng & eternal & $\begin{array}{c}\text { zhuāngyòng } \\
\text { míngcí }\end{array}$ & $\begin{array}{c}\text { (Lăozl’s) specialized } \\
\text { name }\end{array}$ \\
\hline $1 \mathrm{st}$ 名 & names & shi, xíng & $\begin{array}{l}\text { particular } \\
\text { case, a } \\
\text { form }\end{array}$ & $\begin{array}{l}\text { jùtǐshìwùde } \\
\text { míngchēng }\end{array}$ & $\begin{array}{c}\text { name of concrete } \\
\text { things }\end{array}$ \\
\hline 2nd 名 & be named & ming & be spoken & chēngwèi & to call \\
\hline 3rd(常)名 & $\begin{array}{c}\text { fixed } \\
\text { names }\end{array}$ & cháng & eternal & chēng dào & to call the dào \\
\hline
\end{tabular}

Source: the author.

All translations of this brief excerpt point to a double-sided trait of both dào 道 and ming 名 that can be construed as nominal and verbal natures, a problematic distinction in classical Chinese language; and one that appeared as

${ }^{248}$ Sproviero in his notes does not explicitly cite "differences" between one dào and another, between one ming and the others. It is clear, however, that the third dào is unspeakable, unfathomable, etc., while the third ming is the "absolute manifestation of Dao, [however it] is for us nonmanifested."

${ }^{249}$ As it has been already noticed, even though Wáng Bìs commentary dates from the Hàn dynasty, the translations presented here in English are from Lynn. 
somewhat "imposed" by the translators. ${ }^{250}$ It is more likely, according to the tenets of the $\mathrm{MPH}$, that, once the passage is translated into Indo-European languages and/or commented according to Indo-European standards of analysis, we are (usually) “led" to interpret the "second” dào 道 and ming 名 as “verbs," this being the most common way to make sense of the sentences. Despite the almost complete consensus on this verbal nature, we have seen how Boodberg's translation and analysis came to question even that, contributing to the erasing of any hope to have at least a minimum starting point to analyze the passage. Furthermore, we can see from Wáng Bìs notes that there is nothing that “explains” or instantiates a difference among the three occurrences of dào 道 and ming 名. We are indeed in the realm of perspectivism, where one is exhorted to embrace the inevitability of the relative, and the translators must come to terms with the differences between metalinguistic practices.

It also seems clear that dào 道 and míng 名 are intimately related in a parallel structure in this passage. In their active-performative aspects, they are basic actors in the production of language; roughly the equivalent respectively of the English verbs to say and to name. It is even more striking that they are explicitly presented in a way that seems to emphasize their reflexivity by repeatedly employing the same characters in the clauses.

In their "functions" as verbs, both dào 道 and ming 名 appear to fail their metalinguistic task: they do not seem to reach the objects of their action - the only exception might arguably be Bo's translation, where all aspects of dào 道 are ultimately reached in language, as long as one does not attempt to reach it in its entirety. We can see, in typical Daoist fashion, how language is both all-powerful (the discourse is nothing less than dào 道) as well as a deceptive failure: dào 道 in the end stays non-languaged, and while ming 名 names normatively the "myriad things" (wànwù 萬物), dào 道remains unnamed.

\footnotetext{
${ }^{250}$ It must be clear by now that the term verb itself is under interrogation by the MPH. The crux of the matter goes beyond to merely say that Boodberg argues that the "second" dào 道 and ming 名 might not "act" as verbs, or that in Hansen and Sproviero's translations their quality as active or passive verbs are also questioned. It means that the meta-term verb itself is being questioned in its universality. The use of the term in the phrase is therefore approximate and in conformity with "our usual" uses of it.
} 
The discomfort with the limits of language in the different readings of this passage is arguably a consequence of the difficulty to delimit the boundaries that are inextricably connected: between literal and metaphorical, verb and noun, language and world, the named and the non-named, and the languaged and the non-languaged. It might, indeed, arise from the difficulties that result from the coercive force that language-life exerts upon us, exhorting us to construe artificial boundaries and limits as if they were natural, eternal and ontological. ${ }^{251}$ The fluidity of the metalinguistic barriers points to different directions of coercion and, consequently, to different visions of language, as per the MPH.

Some authors present their analyses as ways to "solve" the problems of the text. However, within the framework of the $\mathrm{MPH}$, there is no definitive way to solve the ambiguities of the text without resorting to favoring one point of view or interpretation over another. In a book such as the Lăož̆, where the ambiguities are an explicit mark of the text, we should accept and be comfortable with them. The Lăož̆, in this way, might be perspectively encouraging us to moderate our ambitions regarding the complete dissolution of ambiguities in any text.

Among the seven main translators, with the exceptions of Ames \& Hall and Hansen, there is a tendency that seems to drive us to a representational view of language. According to the MPH, we should expect that authors who are fully embedded in the Western traditions would unknowingly adopt such "commonsensical" views. However, the Lăož tests these convictions, due to the interpretative latitude and diversity of its text and the richness of the graphoetymological connections in the Chinese language. Hansen's might be the most radical in his ideas, but his text is slightly different from the "mainstream." $\mathrm{He}$ argues that dào 道's are all a multiplicity of discourse-dào 道's, without any metaphysical nature outside language. This is subtly reflected in his translation, where he employs the "standard" term way, but in the plural with no article whatsoever. Hansen's seems to me to be the best translation within the framework of the MPH. His text and notes, although it would be excessive to call them perspectivist (in the way discussed in this dissertation), certainly are open to

\footnotetext{
${ }^{251}$ We will see below how the Lăož treats the "emergence of names" and postulate similarities with the MPH's coercive drive of words to create categories.
} 
considering a Chinese alterity, not only in contrast to the Western practices, but also by being profoundly anti-essentialist - which shall become clearer along this chapter of the dissertation.

The inclusion of Bo's and Boodberg's translations increased the complexity of this evaluation, both being translations that explicitly had the objective of subverting the most common readings of this passage. Bo brings an alternative, (partially) positive reading of the first line: we can reach dào 道 through language, that is, dào 道 is, at least partially, languaged. Boodberg's is perhaps the one translation where our feeling of foreignness is at its highest, to a point that it is almost incomprehensible. Departing from syntactic considerations, Boodberg's innovative translation is not only another sign of the lack of one "correct" reading but also, most importantly, it is an innovative attempt to enlarge the syntactical and lexical limits of the English language, as if showing its efforts in an attempt to reach the dào 道of the Lăož̀.

Hansen wrote in his A Daoist theory of Chinese thought:

Daoism is a dao about dao: it discourses about discourse, prescribes about prescription. It is a series of theories about daos. Laozi, like Shendao, wants to escape the socializing effects of language [...] The striking new insight of Daoism is that our discourse is the real authority, not nature. Nature was a universal shield behind which philosophers hid what they were really doing. Nature is neutral in the dispute between moral philosophers. (Hansen, 1992, p. 210)

This text reflects the author's preference in explicitly referring to the metalinguistic characteristic of dào 道, while, at the same time, calling our attention to the key unsolvable dilemma of Daoism: how can we dào 道about dào 道 and at the same time identify whether this one dào 道 we are using is or is not recognized as the "one" (correct, ideal, constant) dào 道? However, this is exactly the strength of discourse: its real authority lies in what it does without any support or justification from outside. Language is not gauged in any background, but rather it is a form of life. 
It is common to translate the "verbal" dào 道 and ming 名 in the passage under analysis respectively as to say and to name. ${ }^{252}$ I believe this happens because these are the common metalinguistic terms that we have in English (and Western languages) that seem to be the most compatible with the way we usually read the passage. However, in the similar way that we also read in the Lăož́, "I do not know its name, so I style it 道," 253 we also do not know their (dào 道's and ming 名's) names, so we style them to say and to name. Once translated, the signifiers become the same as ours, but, and this is what I propose that we should consider here, they are part of a completely different metalinguistic repertoire.

\section{3. \\ Wordless teaching}

Table 6- Wordless teaching - list of translations

\begin{tabular}{|c|c|}
\hline Lăož̃ & shìyı̌ shèngrén chù wúwéi zhī shì, xíng bù yán zhī jiào. \\
\hline Lau & $\begin{array}{l}\text { Therefore the sage keeps to the deed that consists in taking no action and } \\
\text { practices the teaching that uses no words. }\end{array}$ \\
\hline Sproviero & por isso o homem santo .. cumpre os atos sem atuar ... pratica a doutrina sem fal \\
\hline Julien & $\begin{array}{l}\text { De là vient que le saint homme fait son occupation du non-agir. } \\
\text { Il fait consister ses instructions dans le silence. }\end{array}$ \\
\hline $\begin{array}{l}\text { Ames \& } \\
\text { Hall }\end{array}$ & $\begin{array}{l}\text { It is for this reason that sages keep to service that does not entail coercion (wuwe } \\
\text { And disseminate teachings that go beyond what can be said. }\end{array}$ \\
\hline Hansen & $\begin{array}{l}\text { Using this: sages don't act on constructs in addressing affairs; } \\
\text { They practice a "don't-use-language" teaching }\end{array}$ \\
\hline $\begin{array}{l}\text { Wáng Bì } \\
\text { (orig.) }\end{array}$ & $\begin{array}{l}\text { Therefore the sage [sheng 聖] tends to matters without conscious effort. }[\ldots] \\
\text { And practices the teaching that is not expressed in words. }\end{array}$ \\
\hline $\begin{array}{l}\text { Wáng Bì } \\
\text { (comment) }\end{array}$ & $\begin{array}{l}\text { That which by nature is already sufficient unto itself will only end in defeat if } \\
\text { one applies conscious effort to it. }\end{array}$ \\
\hline
\end{tabular}

${ }^{252}$ Boodberg's translation made us question even the suitability of the label verbal for the $2^{\text {nd }} d a ̀ o$ 道 and ming 名 in the excerpt in question. In the context of the MPH we could not have done otherwise!

${ }^{253}$ From chapter XXV of the Lăož̀. Translated by Lau. This passage is analyzed below, in section III.7. 


\begin{tabular}{l|l}
\hline Chén & $\begin{array}{l}\text { Therefore people who have [follow] Dao employ an inactive attitude/stance to } \\
\text { deal with the affairs of human life, implement teaching "without words." }\end{array}$ \\
\hline Source: the author
\end{tabular}

Source: the author.

This passage comes from chapter II, which is important since it introduces the idea of the articulation of distinctions and the production of opposites. Furthermore, it presents the Daoist central idea of the complementarity of opposites (what Waley (1958, p. 51ff) calls the relativity of all attributes). The chapter begins with a famous Lăož̀ "paradox": "As soon as everyone in the world knows that the beautiful are beautiful, / There is already ugliness." ${ }^{254}$ These opposite pairs (beautiful / ugly, in this case) are abundant throughout the text and their purpose seems to be the building up of insurmountable contrasts, only to dismiss them in the next line. These contrasts are summed up later in this chapter with the key pair yǒu 有 / wú 無, which might be translated as something(ness)/nothing(ness), have/have not, etc. The character yǒu 有 is usually used as an existential marker in classical Chinese, while wú 無 is its opposite. When this pair is compared alongside other, more mundane contrasts, such as beautiful/ugly, long/short, high/low, our attention is brought to the elusive division line between these extremes and the lack of a clear-cut contrast, where boundaries are artificial constructs and opposites are always in constant interchange. These contradictions are not to be "solved" in a Western dialectical process. As writes Chang Chung-Yuan ([1977]2014):

In the self-identity of contradiction, the opposites of being and non-being, or beauty and ugliness, are mutually identified within themselves and not in any higher synthesis. Thus, there is no progression toward an absolute beyond all contradictions. (Chang Chung-Yuan, [1977]2014, p. 9-10)

Hansen claims that names in pairs would show that one name entails its opposite.

${ }^{254}$ Translation by Ames \& Hall. The original text is: tiānxià jiēzhī měi zhī wèi měi, sì è y̌̀. 天下皆 知 美之為美, 斯惡已。 
Knowing any term is knowing how to distinguish. Thus we learn each word and its opposite together. [...]. Laozi sees a distinction giving rise to a name pair: the opposites. Knowledge is mastery of a vocabulary, not definitions but spontaneous, conditioned inclinations to discriminate. [...] The focus is still on practical guidance, but he [Laozi] adds an affective mechanism. Socialization produces behavior-influencing desires. They are not innate. (Hansen, 1992, p. 211)

There are other different viewpoints on this matter, such as the interpretation by Harbsmeier (In: Allinson, 1989), where the juxtaposition of the contrastive characters is a sign of the abstraction of the idea of dimension in the Chinese language. ${ }^{255}$

The same coexistence of opposites is found in the yǒu 有 / wú 無 pair: they belong to a continuum; a "Nothing' is conceived [...] as a positive complement to Something, not its mere absence." (Graham [1960]1990, p. 6) To emphasize this contrast, instead of the clear-cut difference between something/nothing in English, Ames \& Hall prefer to translate the pair as determinate/indeterminate, which "are not ontological categories at all, but are rather [overtly] conventional distinctions that have explanatory force in giving account of how things hang together." (Ames \& Hall, p. 81)

For the specific purposes of this dissertation, we are concerned with the proposed opposition of teaching/words, which, from the start, might seem odd compared with other more obvious pairs (such as ugly/beautiful or tall/short). It is evident that there are types of teaching that can abstain from using words, however, as will be shown below, the parallelism in the lines of the Lăož́ favors this "oppositional" interpretation. This is the excerpt under analysis here:

\author{
是以聖人處無為之事, 行不言之教 \\ shìy shèngrén chù wúwéi zhī shì, xíng bù yán zhī jiào
}

\footnotetext{
${ }^{255}$ See for instance: "We note that duan chang literally: 'being short or being long', or 'length', cannot here refer to short and long things [...] Duan cháng indicates a dimension." (Harbsmeier, In: Allinson, 1989, p. 138). The famous Sinologist has a strong conviction on the use by the ancient Chinese of abstract terms, such as length, or truth. In another quote: "Calling words 'not empty' [wú xūci 無虛詞] is a classical Chinese way of calling them true.” (Ibidem, p. 132)
} 
Therefore the sage [shèngrén 聖人] handles [chù 處256] his affairs [shì 事] without action [wúwéi 無為], proceeds [xíng 行] with no-words [bù yán 不言] teaching [jiào 教].

The character that is most relevant to our objectives is yán 言, usually translated as words, speak, speech, and its relationship with jiào 教, usually translated as teaching(s), to teach ${ }^{257}$ From the compilation of 56 translations there is a sample of the variety of alternative translations of the Chinese expression from the excerpt above, bù yán zhī jiào 不言之教:

Wordless teaching (Henricks); teaching without talking (Wilhelm); practice their philosophy without words; teaches by "saying nothing" (Ren Jiyu); teaching notalking; teaches the unspoken teaching; teaches without verbosity; conveys his instructions without the use of speech (Legge); speechless instruction; avoid making speeches (through using tantalizing rhetoric); teaches without preaching; carries out the doctrine without words (Mair); provides wordless instructions; teaches by the precept of silence; teach well by teaching nothing; carries on his teaching done without talking (LaFargue); teaches without utterance; guides people by living in accord with the essence of life; teaches through no-words (Chang Chung-yuan); carried out education by non-preaching; teach without undue words; teaches by quiet example; teach by one's own proper behavior and manners, rather than just offering empty words and gestures; conveys by silence his instruction (Carus); practices a doctrine which cannot be imparted by speech.

The character jiào 教, different from other linguistic activities, does not posses a yán 言 radical. The character appears in the following gloss from the Shuōwén:

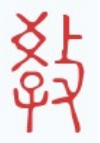

${ }^{256}$ Chŭ 處, to dwell in a place, to manage, to deal with / place, location (Rouzer, 2007, p. 173). Măwángdu $\vec{\imath}$ s text uses $j \bar{u}$ 居, which is a partial synonym, clearly designating to reside, to dwell (Ibidem, p. 81). This act of "dwelling" might be regarded in a metaphorical way, in how to "handle" the "affairs" and the passage could be read as: "therefore the affairs reside in nonaction."

${ }^{257}$ There are also a few prominent terms of the Lăož̀ in this passage - such as shèngrén 聖人, sage and, particularly, wúwèi 無為, usually translated as non-action or inaction. Ames \& Hall (1998, p. 49) write about wúwè $i$ 無為that: “The notion of jing 靜, “stillness, tranquility” that is often used to characterize this posture, is not passivity, but an ongoing, dynamic achievement of equilibrium." 


\section{教，上所施下所效也。从支从孝[李]。凡教之屬皆从教。}

jiào, shăng suǒ shī xià suǒ xiào yě. cóng pū cóng xiào [㸚]. fán jiāo zhī shŭ jiē cóng jiào.

教, above [part of the character, it's] executing/implementing [shī 施], below [part of the character, it's] the effect/imitation [xiào 效]. From tap/knock lightly [pū 支], from filial piety [xiào 孝]. All [characters that belong to the] category [of] jiào 教 point to [semantic affinity with] jiào 教.

In the LS character in the Shuōwén and in older scripts, YL (p. 352) claims it is possible to imagine in the lefthand side of the character a child $\&$ ) learning arithmetic by writing two small "x's," while at the righthand side there would be a hand holding a teacher's pointer.

This briefest excursion in jiào 教's grapho-etymology shows us that there is no overtly linguistic activity involved, but rather a teaching by example and by showing the correct ways. ${ }^{258}$ However, the parallel construction in the Lăož seems to imply a stronger and more direct relationship between speech and teaching. ${ }^{259}$

As in the excerpt The unlanguaged dào? above, there is another clear parallelism in this chapter, which can be highlighted by juxtaposing two parts of the excerpt where the semantic as well as the grammatical parallelism becomes clearer:

(1) 是以聖人 [shìyı̌ shèngrén] - Therefore the sage

(2) 處無為之事, [chù wúwéi zhī shi] - handles his affairs without action

(3) 行不言之教[xíng bù yán zhījiào] - proceeds with no-words teaching

${ }^{258}$ The Zhuāngzĭ did make direct references linking the teaching activities with words, such as this passage from chapter 4, 人間世, "In the World of Men":

其言雖教, 謫之實也。古之有也, 非吾有也。

qí yán suī jiào, zhé zhī shí yě. gǔ zhī yǒu yĕ, fềi wú yǒu yĕ.

Though my words [yán 言] may in fact be lessons [jiào 教] and reproaches, they belong to ancient times and not to me. (Watson, 1968, p.57)

${ }^{259}$ However, we might remember that the relation between wén 文 and jiào 教 postulated by Jullien, and mentioned in the previous chapter of this dissertation, also questions the notion of teaching limited as an oral activity. 
The sub-excerpt (1) introduces what the sage should do. The parallel constructions are the sub-excerpts (2) and (3). In these, one notices that non-action (wúwéi 無為) is to the conduction of (his) affairs (shì 事) as non-words (bù yán 不 言) are to teaching (jiào 教). Once we accept the parallelism, which indicates that teaching is supposed to be accompanied by words, the compared paradoxes become clear: as the "conduction of the affairs (to act) without action," 260 is the "teaching without words." Without this parallel, the phrase "teach without words" could be understood in a simpler and more straightforward way: in order to teach one does not necessarily need words; one can convey teaching by one's actions, by providing examples, etc. However, with the parallel construction the paradox is as much as "forced" upon us: to teach (jiào 教) is viewed here as an exclusively spoken activity, however, it must be performed "without words."

Having gained this background information, we can proceed to the translations themselves.

\title{
Lau
}

Therefore the sage keeps to the deed that consists in taking no action and practices the teaching that uses no words.

Lau's translation is almost identical with my own brief, "rough characterby-character" translation above. We may argue that to "practice a teaching that uses no words" might give clearer allusion to unconventional manners of teaching that employ no language than alternatives - such as shown above - such as "wordless teaching."

\section{Sproviero}

\author{
por isso \\ o homem santo cumpre os atos sem atuar \\ therefore \\ pratica a doutrina sem falar \\ the holy man accomplishes [his] acts without acting \\ ${ }^{260}$ Waley (1996) translated Therefore the Sage relies on actionless activity.
}


practices [his] doctrine without speaking

Sproviero's reading of the Lăozı̀'s oppositions is quite different from what has been argued so far. He claims that there is always a hierarchy along the text that implies a preference for one side of the dichotomies over the other, and that one should only avoid the absolutist vision on what stands on the sides of these dichotomies. For Sproviero, reality in the Lăozľ is not contradictory per se, "there is no contradictory principle [... and] one must exclude the contradictory from thought." (Sproviero, 2007, p. 211) Therefore, according to the Brazilian author, abstract thought should discriminate the knowledge of reality and "consider the oppositions in thought as dependent on a sensible subject." (Ibidem, p. 213) The subject must always be considered in the context of their world, and that is how we should "act without acting, practice the doctrine without speaking." The sheer impact of the contradiction seems lost, because to accomplish something without acting and to practice something without speaking are perfectly logical possibilities. Speaking (yán 言), our main point of interest here, loses its force and stands as a distortion of the doctrine that must be avoided. Locke's mistrust of language, as the archetypical case of suspicion on language in the West, and seen in chapter one of this dissertation, might find resonance in these words.

\author{
Julien \\ De là vient que le saint homme fait son occupation du non-agir. \\ Il fait consister ses instructions dans le silence. \\ From there it results that the holy man makes as his occupation that of non-acting. \\ He consists his instructions in silence.
}

Julien writes a note to explain what he understood about non-acting action and non-wording teaching:

Le saint homme se sert du Tao pour convertir le monde. Ses occupations, il les fait consister dans le non-agir; ses instructions, il les fait consister dans le non-parler, le silence (c'est-à-dire qu'il instruit par son exemple et non par des parole). Il cultive le principal et ne s'appuie point sur l'accessoire. Le monde se convertit et l'imite. Ceux qui ne sont pas vertueux réforment leurs habitudes, et la vertu éminente passe dans les moeurs. (Julien, 1842, p. 9) 
The sage uses the Tao to convert the world. His occupations, he makes them consist of non-acting; his instructions, he makes them consist in the non-talking, the silence (that is to say that he instructs by example and not by words). $\mathrm{He}$ cultivates the principal and does not seek support in the accessory. The world [is thus] converted and imitates him. Those who are not virtuous reform their habits, and the eminent virtue is passed in the customs.

It seems clear that Julien has not interpreted the parallelism as an indication that teaching without speaking is one of the Lăozl̆'s paradoxes, and instead chose a more trivial solution, that is, teaching by example. In the French scholar's notes there is also an emphasis on the sage's (saint homme) task of the conversion of people to the cause of Daoism that seems foreign to the text, or at least not emphasized at this point. Finally, from his explanations Julien notes that the word (la parole) is "accessory" and that it is by following the Tao that the sage cultivates the "principal."

\section{Ames \& Hall \\ It is for this reason that sages keep to service that does not entail coercion (wuwei) And disseminate teachings that go beyond what can be said.}

Once again, Ames \& Hall's translation is quite contrastive with the more "traditional" translations above. Their "acting with no-action" becomes an "action that does not entail coercion." In this way, it distances itself from the idea of inaction and supports the Lăož̀ s suggestion that the sage must not be just passive in their actions.

More relevant to the present discussion is the translation of the second line, "disseminate teachings that go beyond what can be said." Although Ames \& Hall defend an explicitly anti-metaphysical view of the Lăož̀, the term "beyond" used in the translation invites us to imagine a "meta-space" that is unreachable by language, an un-languaged space, that is related to an un-languaged dào 道 (as seen in the discussion of Chapter I). There is the possibility of an implicit devaluation of language in these lines. 


\section{Hansen}

Using this: sages don't act on constructs in addressing affairs;

They practice a "don't-use-language" teaching

Hansen is perhaps even more explicitly anti-metaphysical than Ames \& Hall. In the translator's comment on the chapter, he writes that names come in conventional pairs and that it is only through our customs and contexts that we chose one over the other. But the Lăož̆, argues Hansen, suggests that the sages are not limited to these conventional constructs and that is the natural way of dào 道. These social conventions are explicitly avoided by the sage in the first line of Hansen's translation, who considers that wúwéi 無為 is “acting on constructs," that is, acting according to social and conventional constructs. It does not mean that the sages are above conventions or that their words are to be taken irrespective on context. Quite the contrary, the sages recognize conventions as such, and not as eternal and unchangeable laws and concepts.

The second line might appear to be a more orthodox reading and similar to other translations and would not add much to the analysis here lest we do not situate it within Hansen's general viewpoint on Daoism and the Lăož̆. The author seems to interpret that this line is a direct criticism of what "we" conventionally call teaching; that is, conveying information with the use of language. A “don'tuse-language teaching" might be construed as an apparent contradiction, but it only serves to show that teaching should not be restricted to "use-language teaching," which is also a social construct, a virtual prison and an aggression against the natural ways of dào 道. There is no eternal and definitive teaching, even though we are clouded by its constant and common use as "use-language teaching." The consequence of Hansen's translation and analysis is apparently quite the opposite of Ames \& Hall's depreciation of language, even though we might recognize the affinities between these scholars. 


\section{Wáng Bì}

\section{是以聖人處無為之事, 「自然已足, 為則敗也。」行不言 之教。}

shìy̌ shèngrén chù wúwéi zhī shì, [zìrán yǐ zú, wéi zé bài yě.] xíng bù yán zhījiào

Therefore the sage [sheng 聖] tends to matters without conscious effort.

That which by nature [ziràn 自然] is already sufficient unto itself will only end in defeat if one applies conscious effort [wéi 為] to it.

And practices the teaching that is not expressed in words.

Wáng $B \grave{\imath}$ explains in the beginning of the chapter why one opposite must not be chosen over the other with the following commentary:

\section{喜怒同根，是非同門，故不可得偏舉也，此六者皆陳自然不 可偏舉之明數也。 \\ xǐ nù tóng gēe, shifêi tong mé, gù bùkě děi piān jŭ yě, cǐ liù zhě jiē chén zìrán bùkě piān jŭ zhī ming shŭ yĕ.}

Delight and anger have the same root, and approval and disapproval come from the same gate, thus they cannot be used with bias [piān 偏]. These six [existence or absence, difficulty or ease, long or short, instrumental sounds or voice tones, highs and lows, and before and after $^{261}$ ] are all terms that express what is natural [ziràn 自然] and cannot be used with bias.

The key expression here is what Lynn translates as bias, in Chinese, piān 偏. This polysemic character carries the allusions of crooked, devious, dishonest, tilt(ed), partial, unfair; an antonym of zhèng 正, right, straight, correct, etc. That is, Wáng Bì finds that there is no way to decide whichever pole of the opposition (be it beauty/ugly, high/low, etc.) could be impartially chosen over the other,

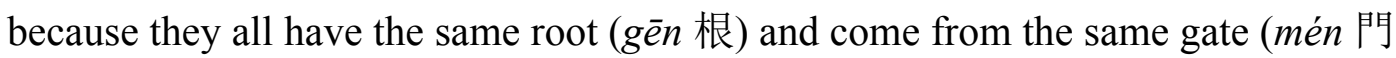
) .

The sage's way must, in Lynn's translation, “tend to matters without conscious effort" and practice a "teaching that is not expressed in words." Wáng ${ }^{261}$ These are the six oppositions presented in the beginning of the chapter. 
$B \grave{\imath}$ writes in his additional comment that the natural way (zìrán 自然) is already (y̌̌ 已) sufficient (zú 足) in itself and that any action (wè $i$ 為) would end in defeat (bài 敗). Lynn translates wèi 為 as "conscious effort" and in that manner opposes the "natural way" with a way that is guided by conscious reflection, by any "artificial" (non-natural, non-spontaneous) planning or thought. Wáng Bì makes no direct comment on the specific passage "practices the teaching that is not expressed in words." However, the close parallelism between the two excerpts allows us to argue that what is valid for action (wèi 為), must be likewise valid for the words (yán 言). The natural way, the effortless and natural way of teaching is also "already" in itself. Words would taint it, would bring man-made divisions that are anathema to dào 道. Language would end in defeat.

\section{Chén}

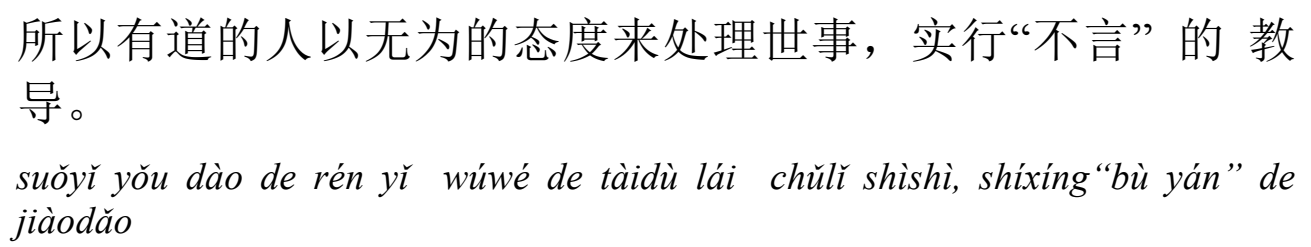
jiàodăo

Therefore people who have [follow] Dao employ an inactive attitude/stance to deal with the affairs of human life (shishì 世事), implement teaching “without words."

This author also comments on the expression he wrote between quotes, bù yán 不言, which I have translated as without words/speech:

不言：不发号施令，不用政令。“言”，指政教号令。“不言 之 教”, 意指非形式条规的督教, 而为潜移默化的引 导 。叶梦得说: “号令教戒, 无非“言”也。” (<<老子解

$>>)($ Chén, 2006, p. 83)

bù yán: bù fā háo shī lìng, bùyòng zhèng lìng. "yán”, zhì zhèng jiào háo lìng. "bù yán zhì jiào, "yì zhǐ fềi xíngshì tiáo guĩ de dū jiào, ér wèi qián yí mò huà de yìndăo. Yè Mèngdé shuō: "háo lìng jiào jiè, wúfêi 'yán' yě." ("lăo zĭjiě")

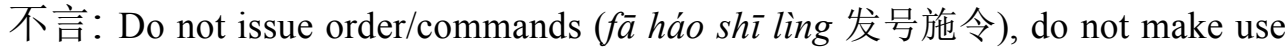
of government decrees (zhèngling 政令). “言”, points to a verbal order of political and educational nature. “bù yán zhì jiào 不言之教”, means not the kind of directive 
learning which takes the form of rules and regulations but [one] that guides through an unobtrusively influence and unnoticed transformations. Ye Mengde [10771148] (in the Lăož̀ jiě 老子解 ) said: "verbal orders teaching [one] to admonish/exhort, that is nothing but 言.”

The connection between yán 言 and coercive orders is very clear in Chén's translation and commentary. There is also an institutional dimension to these “orders" when Chén uses the character zhèng 政 (government/politics). The character ling 令 -already analyzed in conjunction with ming 名 and ming 命- is also prominent and reinforces the idea discussed in the previous chapter between language (míng 名 and yán 言) and a coerciveness - and this intimate relationship appears in expressions in Chén's text, such as: $d \bar{u}$ 督, superintend and direct; hàolìng 号令, verbal order, mark of command; and jiè 戒, to guard against, exhort, admonish.

As for wúwéi 無為, Chén glosses it with the modern Mandarin words, bù gānrăo 不干扰, do not disturb/interfere and bù wàngwéi 不妄为, do not take rash action, and stresses that non-action act does not mean no action or no movement at all, but rather to avoid an action that has an intentionally violent/aggressive nature (măn díyide qīn bă xìngde xíngdòng 满敌意的侵把性的行动), an action that is reckless, unscrupulous (ziyi 恣意), or that diligently seeks private gain (zīzi yingsī 孜孜营私), etc. In conclusion, Chén's analysis on this specific point seems to be reduced to a series of moral lessons and loses the more profound impact that one can find in the translations and commentaries of authors such as Hansen or Ames \& Hall.

The short passage that includes yán 言 has its translations summarized in the table in the following page: 
Table 7- Wordless teaching - summary of the metalanguage's translations

\begin{tabular}{|c|c|c|}
\hline Source & Original text & English text \\
\hline Lăož̀ & xíng bù yán zhī jiào & proceeds with no-words teaching \\
\hline Lau & & $\begin{array}{l}\text { practices the teaching that uses } \\
\text { no words }\end{array}$ \\
\hline Sproviero & pratica a doutrina sem falar & $\begin{array}{l}\text { practices [his] doctrine without } \\
\text { speaking }\end{array}$ \\
\hline Julien & $\begin{array}{l}\text { fait consister ses instructions } \\
\text { dans le silence }\end{array}$ & $\begin{array}{l}\text { He consists his instructions in } \\
\text { silence. }\end{array}$ \\
\hline Ames \& Hall & & $\begin{array}{l}\text { disseminate teachings that go } \\
\text { beyond what can be said. }\end{array}$ \\
\hline Hansen & & $\begin{array}{l}\text { practice a "don't-use-language" } \\
\text { teaching }\end{array}$ \\
\hline $\begin{array}{l}\text { Wáng Bì / } \\
\text { Lynn }\end{array}$ & xíng bù yán zhījiào & $\begin{array}{l}\text { practices the teaching that is not } \\
\text { expressed in words. }\end{array}$ \\
\hline Chén & shíxíng bù yánde jiàodăo. & $\begin{array}{l}\text { implement teaching "without } \\
\text { words." }\end{array}$ \\
\hline
\end{tabular}

Source: the author.

In this passage yán 言, word, and jiào 教, to teach, are construed as opposites in the same way as beautiful/ugly, long/short and something/nothing. It is the parallel construction which "forces" the paradox upon us: to teach (jiào 教) is viewed here as an exclusively spoken activity; however, it must be performed "without words."

The translators again employed many strategies to highlight their own preferences. Lau, Sproviero and Julien apparently saw no real contradiction in "teaching without words" other than the statement that language is unfit to transmit "true knowledge." Ames \& Hall, in a different way, also imply the inadequacy of language as the vehicle of teaching, not in silence, but in a space that is "beyond (language)." Their notes, however, show that the authors themselves must have been out of words to translate this line. From the parallelism of the previous line, it is reasonable to say that Ames \& Hall might have interpreted that, since the sage's service does not entail coercion, teachings should likewise not be coercive; and thus we must avoid the potential abuse of language's created categories if we consider them as eternal and unchanging. This is a sign of Ames \& Hall's perspectivist view of language. Hansen is more explicit about how he sees teaching and language: language creates conventional meanings ("constructs") which are (wrongly) perceived as natural categories. When the sages, who recognize that languages works on constructs, use a “don't- 
use-language" teaching, they are admonishing against this potential misuse of language. Therefore, in a paraphrase that emphasizes the paradox, they are teaching not to teach, that is, not to impose one's construct as unquestionable teachings onto other people.

Wáng Bì seems more negative about language. In the author's possibly Buddhist-influenced interpretation of the Lăož́, ${ }^{262}$ the effortless way of teaching is "already" in itself and it is only tainted by language and its "artificial" modes. From Wáng Bìs commentaries, it seems to point to an altogether different, alternative "kind" of teaching, known and practiced by the sages, who can do without language. However, we might also interpret that language is a possible evil only as long as its words are considered as fixed categories, therefore, leading us away from dào 道. This version is compatible with a perspectivist reading of the Lăož̀.

Finally, Chén is very specific about this "teaching without words": they are orders or decrees of a political and educational nature. It is possible, in Chén's interpretation, to unobtrusively influence someone with a teaching that does not resort to words. Therefore Chén is acknowledging the coercive nature of yán 言, as shown in the previous chapter. However, in suggesting alternatives to a "coercive teaching," the author seems to resort to a series of moral lessons.

In summary, yán 言 has been acknowledged by all authors as a potential source of worries and distortions and, in that manner, possibly disruptive to dào 道. It might even remind us of the qiān 辛 and xīn 辛 nuances of to toil, grieved, endure hardship or bitter from the previous chapter of this dissertation; however, it certainly departs from its allusions as a direct and honest speech.

${ }^{262}$ This is a controversial matter. For instance, Alan Chan's (1991) comparative study of Wáng Bì and Héshàng Gōng's Lăož̀ downplays the Buddhist effect in the former. Contrastingly, Hansen (1992, p. 28) argues that as a whole in the exegesis of the works of Chinese philosophy there is usually an underestimated Buddhist influence. Li (In: Luo \& He, 2009, p.17) explains that the "translation of Buddhist scriptures started on a large scale towards the end of the late Hàn dynasty [206 bC-220 AD]," therefore exactly by the time Wáng Bi was starting his writing. Although the coincidence in time complicates the matter, it also hints to a restricted availability of the Buddhist ideas when Wáng Bì was alive. It is undeniable, however, that the "negative" concepts of the Lăož provided fertile ground for the adaptation of the incoming Indian Buddhist texts that were arriving in China from the $1^{\text {st }}$ century AD. 
Yán 言 seems to differ profoundly from its Western metalinguistic translated counterparts, such as language, word or speech. Although mistrust of language is a theme in both ancient China and the West, they are completely different questions. Lau, Sproviero and Julien might have seen otherwise, and postulated that wordless teaching is necessary because words are accessory, rhetorical instruments in the hands of the ruling class. However, in the other translators' texts, yán 言 is seen under quasi-perspectivist eyes: it construes contextual and conventional categories, but the danger lies in considering these constructs as eternal and fixed. This is what should not be taught.

The similarity between Chinese and Western traditions appears in the character jiào 教 and the activity of teaching in their relation to words. Teach, according to Partridge (2006, p. 3384), stems from Old English tāēcan, show, guide, hence to guide educationally, to show to (someone) by way of instruction; a cognate of German zeichen, to provide with means of recognition or knowing; and also related (according to Klein, 1971, p. 748) to Old English taken, sign, token. The vernacular words are derived from an Indo-European base *deik-e/o-, to say, the same base - as we have seen in chapter II of this dissertation - of Latin $d \bar{\imath} c \bar{c}$, dīcêre, Fr. dire, and Port. dizer, to say. This "spoken" dimension of teach, however, does not seem to restrict the perception that the activity of "educational guidance" is confined to the linguistic realm. ${ }^{263}$ Therefore, "wordless teaching" is not necessarily considered a paradox per se.

The grapho-etymological exploration of jiào 教 also suggested the possibility of alternative acts of teaching by showing and by example. Therefore the construal of a paradoxical relationship between jiào 教and yán 言in the Lăož́ implies significant contrast, not only with the Western tradition, but also with other Chinese discourses. The parallel construction of the Lăož̀ insists that the relationship between jiào 教 and yán 言 are similar to those between wúwéi 無為 and shi 事: wordless teaching is an action-less act or activity. That similarity stands in direct contrast to the Western metalinguistic vocabulary and might provide further evidence for the MPH.

${ }^{263}$ As further evidence, Port. ensinar and Fr. ensigner, to teach, are derived from composed forms of the Latin signum, with no direct mention of it as a spoken activity. 


\section{4 . \\ Creating Words for dào 道}

Table 8-Creating Words for dào 道 - list of translations

\begin{tabular}{|c|c|}
\hline Lăozĭ & $\begin{array}{l}\text { shì zhì bù jiàn, ming yue yí; tīng zhì bù wén, míng yuē xī; bó zhì bù dé, míng yuē } \\
\text { wēi. cǐ sān zhě bùkè zhì jié, gù hún ér wéi yī. }\end{array}$ \\
\hline Lau & $\begin{array}{l}\text { What cannot be seen is called evanescent; What cannot be heard is called rarefied; } \\
\text { What cannot be touched is called minute; These three cannot be fathomed; And so } \\
\text { they are confused and looked upon as one. }\end{array}$ \\
\hline $\begin{array}{l}\text { Sprovier } \\
\mathrm{o}\end{array}$ & $\begin{array}{l}\text { ao olhá-lo ... não se vê ... o nome soa yi; ao escutá-lo ... não se ouve ... o nome soa } \\
\text { xi; ao tocá-lo ... não se obtém ... o nome soa wei; este trino não se pode decompor; } \\
\text { portanto confundido é uno }\end{array}$ \\
\hline Julien & $\begin{array}{l}\text { Vous le regardez (le Tao) et vous ne le voyez pas: on le dit incolore; Vous l'écoutez } \\
\text { et vous ne l'entendez pas: on le dit aphone; Vous voulez le toucher et vous ne } \\
\text { l'atteignez pas: on le dit incorporel; Ces trois qualités ne peuvent être scrutées à } \\
\text { l'aide de la parole. C'est pourquoi on les confond en une seule. }\end{array}$ \\
\hline $\begin{array}{l}\text { Ames \& } \\
\text { Hall }\end{array}$ & $\begin{array}{l}\text { hearing it; We thus call it "inaudible."; Groping and yet not getting it; We thus call } \\
\text { it "intangible"; Because in sight, sound, and touch it is beyond determination; We } \\
\text { construe it as inseparably one. }\end{array}$ \\
\hline Hansen & $\begin{array}{l}\text { If you look and fail to see: Its name is "remote"; If you listen and fail to hear: Its } \\
\text { name is "rarefied"; If you touch and fail to feel anything: Its name is "subtle"; } \\
\text { These three cannot give us warning signs; Hence blending, we treat them as one. }\end{array}$ \\
\hline $\begin{array}{l}\text { Wáng Bì } \\
\text { (orig.) }\end{array}$ & $\begin{array}{l}\text { hear it not, we call it the inaudible. When we try to touch it but find it not, we call it } \\
\text { the imperceptible. Because these three aspects of it are impossible to probe, it } \\
\text { remains a single amorphous unity. }\end{array}$ \\
\hline $\begin{array}{l}\text { Wáng Bi } \\
\text { (com.) }\end{array}$ & $\begin{array}{l}\text { It is shapeless, leaving no image, and soundless, leaving no reverberation. Thus it } \\
\text { can permeate [tong] absolutely everywhere and reach absolutely everywhere. We } \\
\text { cannot get to know it and even less know how to give it a name derived from how it } \\
\text { looks, sounds or feels. Thus, because it is impossible to probe, it remains a single } \\
\text { amorphous unity [hun er wei yi] }\end{array}$ \\
\hline Chén & $\begin{array}{l}\text { Seeing it and not seeing [it], [its] name is called “ý 夷”; hearing it and not hearing } \\
\text { it, [its] name is called "xī 希”; touching and not touching it, [its] name is called “wēi } \\
\text { 微 ." The image/form of these three does not [come] from careful study and } \\
\text { knowing [it] well, it has a muddy and submerged whole. }\end{array}$ \\
\hline
\end{tabular}

Source: the author. 
This chapter (XIV in the Lăož) probes deeper into what might be called the "characteristics" of dào 道 and the ill-fated attempts do "describe" it along three axes of human perception: sight, hearing and touching. ${ }^{264}$ The text clearly shows us the difficulty to reach dào 道 using our physical senses. ${ }^{265}$ Furthermore, it admonishes that when one uses the sensory axes, the perception of dào 道 becomes confused and it is (mistakenly?) perceived as one. However, we only have our senses to reach out for the world, and therefore we must be aware of how our senses may confuse us.

Let us first present this excerpt in Chinese traditional characters followed by the pinyin transcription and my preliminary character-by-character translation:

\section{視之不見，名曰夷；聽之不聞，名曰希；搏之不得，名曰 微。此三者不可致詰, 故混而為一。 \\ shì zhī bù jiàn, míng yuē yí; tīng zhì bù wén, míng yuē xī; bó zhī bù dé, míng yuē wēi. cì sān zhě bùkě zhì jié, gù hún ér wéi yī.}

No-seeing look, name called yi 夷; no-listening hear, name called $\mathrm{x} \bar{l}$ 希; nograbbing touch, name called wēi 微. These three [č̃ sān 此三] cannot reach investigation [jié 詰], hence confusedly [hún 混] treated/becoming one.

This character-by-character translation might give us some hints about the difficulty of expressing the unsayable. The chapter somehow transmits the frustration with the eternal (continuous and ongoing...) attempts to "embrace" the dào 道 and eventually being unable to do so. Ames \& Hall (2003, p. 97) write:

The continuous flow of experience within which a life is lived teases our sensual and cultural sensoria by seeming to allow for discrimination only to defy any predication we might propose to assign it.

${ }^{264}$ Because the chapter writes about a "trinity" that is perceived as one, it became an extremely important passage in the earlier Western studies of the Lăož̆ that saw an underlying universal Christian trinity in its lines.

${ }^{265}$ One should be careful when using the word sense in this context, due to the high polysemy of the word, as it has been shown in chapter II of this dissertation. The sense of sense in the passage from the Lăož is related to what Cassin describes as the psychological level of sense, as in the faculty of the senses. 
This difficulty in predicating dào 道 seems justified within a Chinese worldview in which language itself does not focus on predication. Therefore the Lăož̌ (as well as other classical Chinese texts) profits from a sequence and rhythm of emblem-images, characters that are placed side-by-side invoking images, sensations and intuitions. Sproviero argues that such sentiments cannot be “decomposed/analyzed” (jié 詰), ${ }^{266}$ and that we become “confused” (hùn 混) when we view it as One. However, this is not the interpretation of other authors, as we will see below.

It is a complex excerpt involving several metalinguistic terms. First, it calls our attention to the question of the Lăož̀ as one of the founding texts of the Chinese language, since it presents a list of formulaic expressions such as " $\mathrm{X}$ 謂 X” or “X 名曰 X," which are used as "lists of definition" or taxonomies. Wáng Li 王力(2005, p. 2-3) offers the following explanation for this passage:

\section{《老子》说，看不见的叫“夷”，听不见的叫“希”，抓不住的 叫“微”。

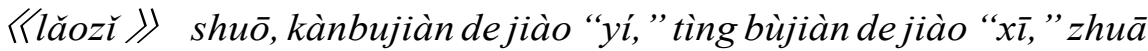 bùzhù de jiào "wēi."}

Lăož says: to see without looking is called “夷," to hear without listening called “ 希,” to touch without grabbing called “微."

Wáng 王 often quotes these formulaic expressions when he writes about the first linguistic reflections in texts from the classical Pre-Qin era - besides the obvious dictionaries such as the Shuōwén, Ëryă and Fāngyán - where in several passages the authors list taxonomies. These authors are thus creating a technical vocabulary geared towards the non-specialist, in an attempt to resolve ambiguities,

${ }^{266} \mathrm{Jie}$ 詰 is another metalinguistic term with a yán 言 radical. In GH, it has the glosses of 1) inquire after, examine (wèn 問); 2) investigate and ascertain cause/ responsibility (chájiū 查究); 3) tortuous and complicated (as in the expression jiéqu 詰屈, where qū 屈 means crooked, wrong);) and 4) bright, as the - next - morning/day (as in the term yi 翌 or the expression jiézhāo 詰朝).

In the Shuōwén, the semantic allusion is present in the radical yán 言 while the component $j i$ 吉 (lucky, auspicious, good, beautiful) stands as a phonetic indicator. There is nevertheless overall positive connotations in the results of this inquiry and investigation, even though its ways are frequently tortuous and complicated. 
usually highlighting synonyms and antonyms. In this way, they are consolidating the foundations of spoken and written Chinese language, in an era where the language was still not under the stricter control of the state and the creativity and liberty of the Chinese writers were at their peak. ${ }^{267}$

In giving names to what was heretofore unknown and unnamed, the Chinese were creating their language, in a process that - as could be interpreted from this passage for the Lăož́ - was potentially very dangerous and bound to cause confusion. This is a sign of how powerful language was considered to be.

We can now proceed to examine how the translators dealt specifically with this passage from the Lăož̀.

\section{Lau}

What cannot be seen is called evanescent;

What cannot be heard is called rarefied;

What cannot be touched is called minute.

These three cannot be fathomed

And so they are confused and looked upon as one.

The chapter first assigns “names" (ming 名) to call (yue 曰) the impossible effects caused by dào 道 on the senses. As we have seen in the previous analysis of ming 名, names coercively categorize the world creating hierarchies, and through language we shape our "artificial" realities. This seems ultimately impossible with dào 道. Therefore these new “categories” ( $y i$ 夷, $x \bar{l}$ 希, wēe 微) are “muddled" and indiscernible and eventually cannot be "fathomed" (jié 詰 ) because they are confused with each other.

${ }^{267}$ One example that pre-dates the Lăož̆ comes from the Zuǒzhuàn 左传:

《左传》庄公三年说, 军队驻扎一夜叫“舍”, 驻扎两夜叫“信”, 驻扎超过三夜叫“次”。

[In] Zuǒzhuàn, book 3 of duke Zhuāng [it was] said, an army stationed for one night, [that is] called “舍,” stationed for two nights, [that is] called “信," stationed for three or more nights, [that is] called “次."

Wáng 王 argues that this classification meant to elucidate the details of the "art of war," while the Lăož̆'s taxonomies were geared towards the "art of philosophy." 


\section{Sproviero}

Sproviero wrote:

\author{
ao olhá-lo \\ ao escutá-lo \\ ao tocá-lo \\ este trino não se pode decompor \\ portanto confundido é uno \\ To look at it \\ To listen to it \\ To touch it \\ This triad cannot be decomposed \\ Therefore, confused, it is one
}

$\begin{array}{ll}\begin{array}{l}\text { não se vêe } \\ \text { não se ouve } \\ \text { não se obtém }\end{array} & \begin{array}{l}\text { o nome soa yi } \\ \text { o nome soa xi }\end{array} \\ \text { not see it } & \text { the name sounds } y i \\ \text { not hear it } & \text { the name sounds } x i \\ \text { not keep it } & \text { the name sounds wei }\end{array}$

It is clearly a quite innovative translation. Sproviero decided to leave three terms untranslated: $y i$ 夷, $\mathrm{x} \bar{\imath}$ 希, wēi 微, although they are not especially rare in classical Chinese. Or rather, Sproviero "translated" them with their phonetic transcriptions in the Latin alphabet. In his notes he leaves a hint of the motivations for his choice: they refer to the Western speculations, begun by Abel Rémusat in the nineteenth century, which believed they had found a hidden allusion to the name of the Christian God YHVH (Yahveh) in the Lăož̀, more specifically in these three characters. Although recognizing that this hypothesis has been discredited as totally unfounded by the Chinese sources and traditions, and directly motivated by the French author's Christian influences, Sproviero writes that:

[E]ssa tese que já faz parte da história do Dao De Jing, e por isso, as primeiras três sentenças [do capítulo XIV] podem ser lidas quer pelo som quer pelo sentido. O fundamental é que essa polêmica não altera a questão da importância do nome eterno, mas pelo contrário, a reforça. (Sproviero, 2007, p. 229)

[T] his thesis, already part of the history of the Dao De Jing, remains and therefore, the three first sentences [of chapter XIV] can be read either by sound or by meaning. What is fundamental is that this polemic does not alter the importance of the eternal name, but, quite on the contrary, reinforces it.

Sproviero's interpretation is likely to be the result of Western confusions about name and sound, written word and spoken sound, as discussed briefly in the first part of this thesis and which seems at odds with the taxonomic attempts of 
the Chinese classics discussed above. Nevertheless, the fact that he recognizes that the "Yahveh" hypothesis is not historically sound and, at the same time, uses it to reinforce the "importance of the eternal name" is a tacit acceptance of the underlying influences of past histories that remain with us. In a way, a view that is entirely compatible with perspectivism.

\section{Julien}

Julien wrote this passage as:

Vous le regardez (le Tao) et vous ne le voyez pas: on le dit incolore.

Vous l'écoutez et vous ne l'entendez pas: on le dit aphone.

Vous voulez le toucher et vous ne l'atteignez pas: on le dit incorporel.

Ces trois qualités ne peuvent être scrutées à l'aide de la parole. C'est pourquoi on

les confond en une seule.

You look at it (Tao) and you do not see it: we say it colorless.

You hear to it and you do not listen-understand it: we say it voiceless.

You want to touch it and you do not reach it: we say it bodiless.

These three qualities cannot be scrutinized by means of the word. This is why we confuse them as only one.

Here Julien also brings the reader's attention to the three "characteristics" of dào 道, by highlighting them in italics and employing the usual vocabulary that emphasizes the negativity so often associated with dào 道: colorless, soundless ${ }^{268}$ and bodiless. For his translations, the French author specifically states that he is indebted to Héshàng Gōng's glosses. For example, in the Chinese commentator's gloss of the first adjective (colorless, $y i$ 夷) we have:

\section{視之不見名曰夷，無色曰夷。言一無采色，不可得視而見 之。}

shì zhī bù jiàn míng yue yí,wú sè yuē yí. yán yī wú căi sè, bù kě děi shì ér jiàn zhī.

When looking at it one does not behold it. Its name is $I^{269}$

\footnotetext{
268 The French word aphone has different connotations in regard to English voiceless, which is more neutral. Aphone is usually applied to living beings, particularly to humans. It also connotes a person that is taciturn (although not necessarily).

${ }^{269}$ Erkes' transliteration of Chinese was the Wade-Giles method, which used $i$ instead of $y i$. The author also preferred to leave the phonetic transcription in upper-case typeface.
} 
What is without colour is called I. This means: An invisible colour can neither be perceived not seen. (translated by Erkes)

The fact that Héshàng Gōng had to specifically present a gloss for yí 夷 seems necessary due to the high polysemy of the term. As per GH, yi 夷 has been variously used as: a reference to non-Han people (especially in the East of China); level, plain; people of the same generation; to arrange, to place; to uproot, to kill, to suppress; to sit, to squat; happy, joyful; conventional practices; etc. The dictionary uses the reference of this exact passage of the Lăož̀ in its gloss of yí 夷 as having no form [and] no image (无形象). For Julien, since dào 道 is not reachable by the physical senses, they become naturally confused and we mistake them as the one aspect that seems to be ubiquitous of dào 道, its emptiness and non-corporeality.

Julien translates zhi jié 致詰 as to scrutinize, which is, he explains, "the process of searching for the answers by asking other people for it." This is not possible for dào 道, says the author, which can only be known by "renouncing the light and stripping from one's body."

\author{
Ames \& Hall \\ Ames \& Hall presented the following translation: \\ Looking and yet no seeing it \\ We thus call it "elusive." \\ Listening and yet not hearing it \\ We thus call it "inaudible." \\ Groping and yet not getting it \\ We thus call it "intangible." \\ Because in sight, sound, and touch it is beyond determination \\ We construe it as inseparably one.
}

This is an important passage to underscore Ames \& Hall's "Daoist perspectivism," as can be noticed by the translation of some of its key terms. The authors" translation of the three "characteristics" of dào 道 calls our attention (much in line with Julien, above) to the misapprehension of dào 道: we look, yet do not see it, we need to use our vocabulary for it, thus we call it "elusive." But it 
is clear from Ames \& Hall's translation that dào 道 is neither elusive, inaudible nor intangible. These are words we use, for lack of better ones, thus we end up “painting” an artificial picture of dào 道. To further emphasize the contrast with Nature's dào 道, construe is how Ames \& Hall chose to translate zhì jié 致詰, when they write "we construe it as inseparably one." Further along the text (not included in the excerpt under analysis), the authors say that the "inseparably one" picture of dào 道 that we construe defies discrimination (in the original text, míng 名). The English verb discriminate ${ }^{270}$ comes from Latin discrīmināre, to divide up, in itself a derivate from cernēre, to sift, distinguish, decide, with important cognates such as dēcernere, to separate, distinguish; sēcrētus, separate, withdrawn, secret; and even crimen, indictment, accusation. These terms all allude to some discriminatory choice, a separation or distinction that is somewhat arbitrary, thus perhaps needing some secrecy or being liable to an accusation. It is not natural, not an investigation on nature, but a human and artificial categorization. And that is what stands in disagreement with dào 道, the human constructs. Finally, it is also worth noting the translation of wúwù 無物 (the "nonbeing") as indeterminacy, a metalinguistic term which refers to what cannot be determined, cannot be circumscribed. English determine has its roots ${ }^{271}$ in Latin dēstināre, to arrange the purchase of, to determine, to settle, itself a derivative of stāre, to stand, to halt and related to praestināre, to bargain for, buy. The allusions seem clear: a bargain, a negotiation, implying that dào 道's form is not liable to be negotiated, to be construed, exactly because dào 道 is the image of the non-negotiable, of what stands beyond the reach of human constructs.

\section{Hansen}

Chad Hansen wrote:

If you look and fail to see:

Its name is "remote."

If you listen and fail to hear:

Its name is "rarefied."

\footnotetext{
${ }^{270}$ This etymology is based on Partridge (2006, p. 826) and De Vann (2008, p. 110).

${ }^{271}$ As per Partridge (2006, p. 782) and De Vann (2008, p. 589).
} 
If you touch and fail to feel anything:

Its name is "subtle."

These three cannot give us warning signs.

Hence blending, we treat them as one.

Hansen also preferred to avoid the more elegant choice of Sproviero and used English counterparts as translations of the three "characteristics" of dào 道, but he is careful to argue that these "three" cannot ultimately explain dào 道for us nor give us "warning signs" (Hansen uses sign as the translation for both jié 詰 and for xiàng 象 in the chapter XXI of the Lăož ${ }^{272}$ ). The three English words (remote, rarefied and subtle) are not necessarily paradoxes in themselves; they emphasize the difficulty in accessing dào 道 through the use of our physical senses. It is exactly because dào 道 is not invisible, mute or incorporeal that we are confused, and we end up construing it "as one."

Hansen translates wúwù 無物(void/empty, non-thing, nothing) as no natural kind, again in the attempt to contrast the Nature-like quality of dào 道, at the same time avoiding transcendental allusions related to terms like void or emptiness. Thus dào 道's image (sign) is the "sign of no natural kind," not an image (because it has no form, no shape attainable by human senses), but a trace which points to its own negation, to "non-Nature."

\section{Wáng Bì}

視之不見名曰夷，聽之不聞名曰希，搏之不得名曰微。此三 者，不可致詰，故混而為一。「 無狀無象，無聲無響，故 能無所不通，無所不往，不得而知，更以我耳目體，不知為 名, 故不可致詰, 混而為一也。」

shì zhī bù jiàn míng yuē yí, tīng zhī bù wén míng yuē xī, bó zhī bù dé míng yuē wēi. cì sān zhě, bù kě zhì jié, gù hùn ér wéi yī. [wú zhuàng wú xiàng, wú shēng wú xiăng, gù néng wú suǒ bù tong, wú suǒ bù wăng;wàng, bù dé ér zhī, gēng y̌̃ wǒ ěr mù ť̆, bù zhī wéi míng, gù bù kě zhì jié, hùn ér wéi ȳi yẻ]

When we look for it but see it not, we call it the invisible. When we listen for it but hear it not, we call it the inaudible. When we try to touch it but find it not, we call it

${ }^{272}$ This choice of translation by Hansen will be discussed in more detail in the passage from chapter XXI of the Lăož́, section III.6. 
the imperceptible. Because these three aspects of it are impossible to probe, it remains a single amorphous unity.

It is shapeless, leaving no image, and soundless, leaving no reverberation. Thus it can permeate [tong] absolutely everywhere and reach absolutely everywhere. We cannot get to know it and even less know how to give it a name derived from how it looks, sounds or feels. Thus, because it is impossible to probe, it remains a single amorphous unity [hun er wei yi]

Wáng Bì starts his commentary with the so-called "negative description" of dào 道: no format/shape (zhuàng 狀), therefore no image (xiàng 象); no sound (shēng 聲), therefore no reverberation/noise (xiăng 響). Dào 道 is unreachable by not only our physical senses, but also our knowledge (zh̄ 知), ${ }^{273}$ and its name cannot be deduced by the use of our senses ("we cannot get to know it and even less know how to give it a name derived from how it looks, sounds or feels"). It is of particular interest to this dissertation how Wáng Bì articulates the similar xiàng 象 and zhuàng 狀: the shape (zhuàng 狀) seems to have some sort of ontological precedence over the image (xiàng 象), which is secondary, as much as noise and reverberation (xiăng 響) are caused by sound (shēng聲).

When he writes "without knowing it we cannot give it a name," Wáng $B i$ brings the question of the natural (or here, perhaps, logical) motivation of names -

\footnotetext{
${ }^{273}$ The hànzì zhī 知is key to understand Wáng Bìs commentary here. In the Shuōwén we read: 詞也。从口[甘]从矢[命]。 cíyè. cóngkǒu[ [甘] cóngshr [命].

[As for $z h \bar{l}$ 知], word/diction/literary form \& genre. From mouth (kǒu口), from arrow (shı̌ 矢).
}

In the Mòž̌ (jīng shàng 經上, Canon I) we have:

知, 聞、說、親, 名、實、合、為。

zhī, wén, shuǒ, qīn, míng, shí, hé, wèi.

Zhi (know). by hearsay, by explanation, by personal experience. The name, the object, how to relate, how to act. (translation by A.C.Graham)

Wilder \& Ingram (1974, p. 38) write that $z h \bar{l}$ 知 is “[Arrow] united with mouth, we have the knowledge possessed by one who can give his word, opinion, with the precision and speed of an arrow." CUHK (and others) claim that this is a naïve interpretation, and that $s h \check{\imath}$ 矢 is just a phonetic indicator.

In its many instances in the Lăož́, zhi 知 is commonly translated as to know. It is also often translated as knowledge or wisdom. However, as the passage above from the Mòzı implies, and if we support Hansen's view that the ancient Chinese did not have a theory of mind, zhi 知 appears to be more pragmatically used as to know, without reference to the epistemological processes involved.

As for an alternative view which supports the mind/language dichotomy in the Chinese tradition, see Zhang (1992). 
similar to the discussion in the Cratylus - or the question of the identification of name with the designatum. It leaves open to question whether Lynn recognizes the naming function as being predominately passive from the point of view of the subject, that is, motivated by the identification of traits and characteristics of the named entity - an arguably more "Western" point of view - or with a viewpoint that is more in accordance with the coercive force of naming of the Chinese tradition.

Lynn translates zhì jié 致詰 as to probe. Partridge (2006, p. 2566) explains that Eng. probe is cognate with the verb to prove, via the Latin probāre, to prove, to taste and Late Latin proba, a test, a proof (eventually, a surgical probe). The etymological basis, according to Partridge is Latin probus, upright, honest, good (hence the English cognate, probity). From this brief analysis, zhi jié 致詰 in Lynn's reading of Wáng Bì is used in the acceptation of attempting to prove, to verify its righteousness, its honesty. Therefore, dào 道 cannot be ascertained in its righteousness, cannot be measured by the human senses, it remains impervious to human probes.

\section{Chén}

看它看不见，名叫“夷”;听它听不到,名叫“希”;摸它摸 不着 , 名叫“微”。这三者的形象无从究谙, 它是浑沦一体 的。 kàn tā kànbujiàn, míngjiào "yí"; tìng tā tìng bù dào, míngjiào "xî"; mō tā mō bùzhāo, míngjiào "wēi." zhè sān zhè de xíngxiàng wúcóng jiū ān, tā shì hún lún ȳ̄ tĭ de.

Seeing it and not seeing [it], [its] name is called “ $y i$ 夷”; hearing it and not hearing it, [its] name is called " $x \bar{\imath}$ 希"; touching and not touching it, [its] name is called "wēi 微." The image/form [xíngxiàng 形象] of these three does not [come] from careful study and knowing [it] well, it has a muddy (hún 浑) and submerged (lún 沦) whole.

Some of Chén's translated terms are quite conventional and remind us of previous translations. For instance, zhì jié 致詰 is translated by jiū'ān 究諳, to study carefully/investigate and know [it] well. However, one can notice different 
motivations from other passages. For example, Chén says that dào 道's shape “defies description” when he writes: bù kě míng zhuàng 不可名状, lit. “cannot name [the] shape.” In this interpretation, one might read that dào 道 does have a shape (zhuàng 狀) and that only its description (or name) is unknown to us.

Chén (2006, p. 126) also explains the "mysterious" three names of the nonaction actions:

“夷”、“希”、“微”：这三个名词都是用来形容感官所不能把 捉的“道”。

"yí," "xī," "wēi": zhè sāngè míngcí dōu shì yòng lái xíngróng gănguān suǒ bùnéng bă zhuō de "dào."

“夷”,“希”,“微”: these three words are all sensorial adjectives [xíngróng gănguān 形容感官] used for the “dào 道” which cannot be grasped/held/touched.

The short text above is simply a definition for the three "unknown" characters, an acknowledgment of the inaugural dimension of the Lăož̀. In other words, these are "artificial words" to denote the senses related to what cannot be sensed.

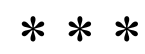

The main interest of this passage refers not exactly to a metalinguistic term, but rather to a metalinguistic operation. It regards the strategies used by the translators to deal with the inaugurational use by the Lăož of three existing characters to designate the three "non-action actions" that are distinctive of dào 道. In the following table these strategies are summarized: 
Table 9- Creating Words for dào 道 - summary of the metalanguage's translations

\begin{tabular}{|c|c|c|}
\hline Source & & the names \\
\hline & Original text & English text \\
\hline Lăozĭ & $y i^{\prime}$ 夷, $\mathrm{x} \bar{l}$ 希, $w \bar{e} i$ 微 & $y i$ 夷, $\mathrm{x} \bar{l}$ 希, $w \bar{e} i$ 微 \\
\hline Lau & & evanescent, rarified, minute \\
\hline Sproviero & soa yi, xi e wei & sounds yi, xi and wei \\
\hline Julien & $\begin{array}{l}\text { incolore, aphone, } \\
\text { incorporel }\end{array}$ & colorless, voiceless, bodiless \\
\hline $\begin{array}{l}\text { Ames \& } \\
\text { Hall }\end{array}$ & & $\begin{array}{l}\text { "elusive," "inaudible," } \\
\text { "intangible" }\end{array}$ \\
\hline Hansen & & "remote," "rarefied," "subtle" \\
\hline $\begin{array}{l}\text { Wáng Bì / } \\
\text { Lynn }\end{array}$ & $y i^{\prime}$ 夷, $\mathrm{x} \bar{l}$ 希, $w \bar{e} i$ 微 & invisible, imperceptible, inaudible \\
\hline Chén & 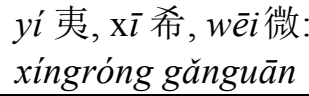 & $\begin{array}{l}y i \text { 夷, } \mathrm{x} \bar{l} \text { 希, wēi 微: sensorial } \\
\text { adjectives }\end{array}$ \\
\hline
\end{tabular}

Source: the author.

In this passage, the Lăozı̌s capacity of creating new names for hitherto impossible contradictions has a reflexive action: it is a text that creates itself (in a way, similar to a dictionary). The way the Lăozl̆ creates this new "technical vocabulary" is not entirely different from the inaugural uses of metalinguistic vocabulary in the Greek philosophical texts. However, such improbable association of hànzì (names) and definitions, where motivations are lost in time and new uses differ radically from previous ones, is in direct contrast with the more reflected and deliberate adaptation of the ancient Greeks, thus providing evidence that supports the MPH.

The fact that a) other texts from the Chinese canon also often created names using a similar formulaic syntax; b) the Shuōwén, and other dictionaries, were extremely important of for the linguistic tradition in China; and c) out of the four areas of classical Chinese linguistic enquiry, two were directly related to the lexicon (císhūxué 辭書學, lexicography, and wénzìxué 文字學, study of Chinese graphs); points to the importance of the creation and study of names in the Chinese tradition, a metalinguistic activity that was broached very differently in ancient Greece, thus providing further support for the MPH.

However, it is important to notice that the result of what the Lăož is unwittingly doing appears to be exactly what it is admonishing against: creating names, which could be, in the future, mistakenly considered as fixed categories 
due to the sheer weight of the text's authority. Such is the same conundrum we have seen in Wittgenstein's texts, with his creation of new vocabulary uses. Undoubtedly, in order to prevent us from making this mistake, the Lăož̆ quickly warns its readers: these three (uses of hànzi) will confuse us!

The only translation that left explicit the traces of this inaugural force is Sproviero's. Whatever his explicit motivations, when he left the three terms (only) transliterated he was, unknowingly, reacting to the text in a way that has subverted his own metalinguistic practices, more specifically, the practice of translation, which coerced the translators to use terms in their native language as "translations" of the object language. Sproviero's "untranslated" yi, xi and wei are signs of a dislocated practice of translation, as expected by the MPH.

Julien, Ames \& Hall and Hansen are less bold than Sproviero, but also hint at the metalinguistic role of the Lăož by leaving the English translated word between inverted commas or italics, thus showing that this is not the commonly accepted use of the words. Chén also writes a note explaining why the Lăozl̆ has used these hànzì, looking for sensorial adjectives for what cannot be sensed.

\section{5. \\ Righteousness and Ornaments}

Table 10-Righteousness and Ornaments - list of translations

\begin{tabular}{|c|c|}
\hline$\overline{L a ̆ o z \check{l}}$ & $\begin{array}{l}\text { jué shèng qì zhì, min lì băibèi; jué rén qì yì, mín fù xiàocí; [...] č̌ sān zhě y̌̌wéi } \\
\text { wén bùzú. }\end{array}$ \\
\hline Lau & $\begin{array}{l}\text { Exterminate the sage, discard the wise; And the people will benefit a hundred fold; } \\
\text { Exterminate benevolence, discard rectitude; And the people will again be filial; } \\
{[\ldots] \text { These three, being false adornments, are not enough [...] }}\end{array}$ \\
\hline Sproviero & $\begin{array}{l}\text { não à santidade } \ldots \text { fora a sabedoria } \ldots \text { o povo é cem vezes favorecido; não ao } \\
\text { amor humano ... fora a justice ... o povo volta a ser filial e paternal }[\ldots] \text { essas três } \\
\text { sentenças são ornamentos; ornamentos não suficientes }[\ldots]\end{array}$ \\
\hline Julien & $\begin{array}{l}\text { Si vous renoncez à la sagesse et quittez la prudence, le peuple sera cent fois plus } \\
\text { heureux; Si vous renoncez à l'humanité et quittez la justice, le peuple reviendra à } \\
\text { la piété filiale et à l'affection paternelle. [...] Renoncez à ces trois choses et } \\
\text { persuadez-vous que l'apparence ne suffit pas. [...] }\end{array}$ \\
\hline Ames \& & Cut off the sagacity (sheng) and get rid of wisdom (zhi); And the benefit to the \\
\hline
\end{tabular}




\begin{tabular}{|c|c|}
\hline Hall & $\begin{array}{l}\text { common people will be a hundredfold; Cut off authoritative conduct (ren) and get } \\
\text { rid of appropriateness (yi); And the common people will return to filiallity (xiao) } \\
\text { and parental affection (ci) [...] But these sayings as they stand are still lacking } \\
{[\ldots]}\end{array}$ \\
\hline Hansen & $\begin{array}{l}\text { Terminate "sageliness," junk "wisdom," Your subjects will benefit a hundredfold; } \\
\text { Terminate "humanity," junk "morality," Your subjects will respond with filiality } \\
\text { and affection. }[\ldots] \text { These three, treated as slogans are not enough. }[\ldots]\end{array}$ \\
\hline $\begin{array}{l}\text { Wáng Bì } \\
\text { (orig.) }\end{array}$ & $\begin{array}{l}\text { Repudiate sagehood and discard wisdom, and the people would benefit a } \\
\text { hundredfold. Repudiate benevolence and discard righteousness, and the people } \\
\text { would again be obedient and kind to each other. [...] As for these three pair of } \\
\text { terms: Because they serve as mere decoration }[\ldots]\end{array}$ \\
\hline $\begin{array}{l}\text { Wáng Bì } \\
\text { (com.) }\end{array}$ & $\begin{array}{l}\text { Sagehood [sheng] and intelligence [zhi] designate the best of human talent [cai]; } \\
\text { benevolence [ren] and righteousness [yi] designate the best of human behavior } \\
\text { [xing]; and cleverness [qiao] and sharpness [li], designate the best of human } \\
\text { resources [yong]. However, the text directly says that these should be repudiated. } \\
\text { Because such "decoration" [wen] is utterly inadequate, one does not give people } \\
\text { the chance to identify with these expressions and so never does anything that } \\
\text { exemplifies what they mean. Thus the text says: Because these three pairs of terms } \\
\text { serve as mere decoration, they are never adequate. }\end{array}$ \\
\hline Chén & $\begin{array}{l}\text { Forsake skillful arguments [and] people can receive a hundred times benefits; } \\
\text { abandon false pretentions, [and] people can resume [their] natural/instinctive filial } \\
\text { piety [skillful argument, false pretenses, ingenious profits], these three are all } \\
\text { [clever/cunning] decorations/ornaments, [they] are not enough to } \\
\text { govern/administer all under heaven. }\end{array}$ \\
\hline
\end{tabular}

Source: the author.

This passage was selected from chapter XIX of the Lăož̀.

Lăozl’s philosophy is frequently interpreted as defending praise for the natural, at the prejudice of the civilized and the artificial. When reading its lines, one often feels that once we leave the radical liberty of nature and language starts to create categories and constructs that will guide our behavior, the effortless way of dào 道 is inevitably lost. Civilization and social norms are inextricably tied to culture, writing and, ultimately, to language. ${ }^{274}$ The rise of a class of "wise men" gives space to jargon and exoteric knowledge, to authority and coercion, to new artificial desires and a rule maintained by force. Chapter XIX deals with these social (as opposed to natural) values and the reaction to what Sproviero refers to as the "decadence of the customs (mores)," in a movement back to purity. In the undercurrent, the chapter is also a thinly disguised attack on some of the most

\footnotetext{
${ }^{274}$ The connection between culture, writing and language in ancient China has been previously discussed in chapter II of this dissertation in the section on the grapho-etymology of wén 文.
} 
cherished Confucian values, rén 仁 or $y i$ 義, which give way to the preferred xiào 孝and $c i$ 慈.

There are two terms in this chapter of the Lăož̀ that are particularly important to this dissertation and have already been grapho-etymologically analyzed here: $y i$ 義 and wén 文. They can be located in the reproduction of the full chapter, which follows:

\begin{abstract}
絕聖棄智, 民利百倍; 絕仁棄義, 民復孝慈; 絕巧棄利, 盜 賊無有。此三者以為文不足。故令有所屬：見素抱樸，少私 寡欲。

jué shèng qì zhì, mín lì băibèi; jué rén qì yì, mín fù xiàocí; jué qiăo qì lì, dào zéi wúyǒu. č̆ sān zhě y̌̌wéi wén bùzú. gù líng yǒu suǒshŭ: jiàn sù bào pŭ, shăo sī guă yù .

Cut off sagacity [shèng 聖], discard wisdom/knowledge [zhi 智 $]^{275}$, people benefit a hundredfold; cut off benevolence [rén 仁], discard righteous(ness) [yi 義], people return [to] filial piety and compassion [xiàocí 孝慈]; cut off cleverness [qiăo 巧], discard profit [ $l i$ 利], robbers and thieves are no more. These three taken as adornments [wén 文] are not enough. Therefore [this] will cause that there is something to be subordinated to: see the plain and simple [sù 素], embrace the uncarved block [pú 樸], lessen the private [sī私] [and] diminish desires [yù 欲].
\end{abstract}

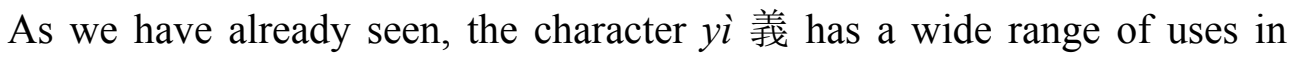
classical Chinese, which today could variously be translated as justice and literal sense, meaning of a character, talking, etc. In this passage yi 義 is listed among other important Chinese values that the Lăozl̆ identifies as undesired side-effects from civilization: shèng 聖, sagacity; zhì 智, wisdom/knowledge; rén 仁, benevolence; qiăo 巧, cleverness; and li 利, profit. The passage might be summarized by the identification of the qualities to be avoided and those that should be sought:

\footnotetext{
${ }^{275}$ The reaction against the Daoists' efforts to undermine the power of the ruling elite and the grip of the government is reflected in the subsequent use of the first four characters of this passage, juéshèngqizhi 絕聖棄智, which became part of the language as a fixed expression that $\mathrm{GH}$ translates as resort to obscurantism.
} 
Table 11-Righteousness and Ornaments - qualities to be avoided and to be sought

\begin{tabular}{|c|c|}
\hline \multirow{3}{*}{$\begin{array}{c}\text { sān 三 } \\
\text { wén 文 } \\
\text { The three } \\
\text { "adorments" }\end{array}$} & $\begin{array}{l}\text { shèng 聖, sagacity \& zhi 智, } \\
\text { wisdom/knowledge }\end{array}$ \\
\hline & rén 仁, benevolence \& yi 義, righteousness \\
\hline & qiăo 巧, cleverness \& li 利, profit \\
\hline $\begin{array}{l}\text { lessen and } \\
\text { diminish }\end{array}$ & $s \bar{\imath}$ 私private \& yù 欲 desires \\
\hline return to & xiào 孝, filial piety \& cí 慈, compassion \\
\hline see and embrace & sù 素, plain \& pú 樸uncarved block \\
\hline
\end{tabular}

If the undesirability of virtues such as benevolence or wisdom might defy explanation, it is even more baffling with a term like shèng 聖, the hànzì that the Lăozl̆ itself often employs to refer to the sage (shèngrén 聖人, lit. shèng-person). In this list, rén 仁 and yi 義are directly opposed to xiàoci 孝慈, respectively, filial piety and compassion. The relevance of $y i$ 義 to the connotations of justice, (true) meaning, is particularly important here, because it shows that these concepts cannot be considered in their universality, otherwise, how could the Lăož be pledging against formidable truth and justice? We recall from our previous discussion in chapter II of this dissertation that yi 義 has the allusions of suitable (yi 宜), appropriate rites and proper conduct, which have informed the judgment of correct meaning in ancient China. We have also seen how yì 義 was appropriated by the Confucian establishment, forming the disyllable rényì 義仁, rectitude and benevolence. It is no wonder that the Lăozl̆ exhorts us to discard these fossilized Confucian emblems.

The "three adornments" (the three that are considered as "wén 文”) that the text refers to are listed in the table above. The text's interpretation of wén 文 is very likely informed by these terms. The Lăož̌ appears to use wén 文 as a metaphor for civilization and for everything that opposes the "naturalness" of nature; therefore, its role in the text is apparently as something to be avoided and not desired. In this passage, the two other undesired characteristics directly related to wén 文 are: $s \bar{l}$ 私, private, personal, selfish, as opposed to the public, shared and selflessness; and yù 欲, wish, desire, craving, as opposed to being content, 
satisfied. It is also possible to interpret wén 文 as a character that points to old texts and canonical works that are respected only due to their age and tradition among old scholars, thus referring to the Confucionist ritualistic basis criticized by the Lăozì. This is the reading of Duyvendack (1954):

It seems to me that wen "ornament, written character, literature, culture" here suggests the idea of a "dead letter" of an edict. It is not enough merely to forbid the practice of these virtues as a negative way; one should counter them with something positive. What is needed is the active promotion of a state of simplicity without culture. (Ibidem, p. 54)

On the opposite side of wén 文, stands the image that in the Lăož̀ is most commonly used as a metaphor for the natural and the simple, pú 樸, usually translated as the uncarved block, but also with connotations of honest/sincere, bark of a tree, growth of trees and even the bizarre rat meat not yet dried by

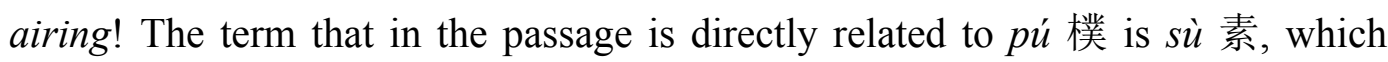
beside its use as plain and simple also refers to white raw silk. This last interpretation is the one that informs Sproviero's translation, and would emphasize a raw material, in direct parallelism with the concrete image of the uncarved block. However, in the compilation of 56 translations, only three other translators also used silk. The discussion on the uncarved block will be resumed later (in The emergence of names, section III.8).

In the presentation of the translations, I will examine only two short excerpts containing the two metalinguistic terms here under analysis, yi 義 and wén 文:

絕聖棄智，民利百倍; 絕仁棄義，民復孝慈；「。。」此三 者以為文不足。

jué shèng qì zhì, mín lì băibèi; jué rén qì yì, mín fù xiàocí; [...] cĭ sān zhě y̌̌wéi wén bùzú 。 [...] 


\section{Lau}

Exterminate the sage, discard the wise,

And the people will benefit a hundred fold;

Exterminate benevolence, discard rectitude;

And the people will again be filial; [...]

These three, being false adornments, are not enough.

Lau translated yi 義 as rectitude and wén 文 as false adornments, two quite conventional translations. The additional choice of wise instead of wisdom leaves the translated text less metaphysically oriented. In using rectitude and other terms that have a positive connotation in English, such as benevolence or wise, Lau's translation retains the sense of shock one experiences when reading this very unconventional chapter. Rectitude is a cognate in English of right and righteousness, etymologically related with the notions of stretch, straighten, lead, conduct, and therefore also related to government (see also appendix II). The criticism against a "righteous form of government" fits quite well in the social and historical context of the foundation of Daoism and the Lăož́.

For his translation of wén 文, Lau inserted "false" (ornaments) instead of the more common "regarded as" (ornaments), thus transposing the Lăozĭ's attack against civilization (as opposed to nature) to an iconoclastic attack against the Confucionist establishment, which had created these "false ornaments" (false idols).

\section{Sproviero}

não à santidade

o povo é cem vezes favorecido

não ao amor humano

o povo volta a ser filial e paternal [...]

essas três sentenças são ornamentos

ornamentos não suficientes.

no to sanctity

the people is a hundred times favored

no to human love

the people is again filial and paternal [...]

those three sentences are ornaments

ornaments not enough. fora a sabedoria

fora a justiça

out with the wisdom

out with the justice 
Sproviero (2007, p. 232) comments on the possible translations of wén 文as tattoo, adornment, ornament, culture, written text and literature. Sproviero's text, although as a whole very different in style and choice of words from Lau, has similarly conventional translations for yi 義 and wén 文, respectively justice and ornaments. Obviously rectitude differs from justice, however, both have etymological roots in a righteous and lawful form of government.

\section{Julien}

Si vous renoncez à la sagesse et quittez la prudence, le peuple sera cent fois plus heureux.

Si vous renoncez à l'humanité et quittez la justice, le peuple reviendra à la piété filiale et à l'affection paternelle. [...]

Renoncez à ces trois choses et persuadez-vous que l'apparence ne suffit pas.

If you give up the wisdom and leave the caution, the people will be hundred times happier

If you give up humanity and leave justice, the people will return to filial piety and paternal affection $[\ldots]$

Give up these three things and be persuaded that the appearance is not enough.

Julien's translation of $y i$ 義 as justice is the same as Sproviero's; however, his translation of wén 文 as l'apparence (the appearance) is conversely quite rare. In the compilation of 56 translations, only one, by the famous German Sinologist Richard Wilhelm, used the term (he translated beautiful appearance).

Julien explains in his notes that the Lăož̆'s attack on such seemingly virtuous qualities is derived from the abuse of the early sages who, initially guided by these admirable qualities, distorted them for their own benefit and moreover used them as a mask that hid their unwholesome motives. Once let to themselves, the people will return to these qualities of old, the same yi 義 or rén 仁 that the Lăož̀ now asks to be discarded, but the same only in name, and completely different in use and implications. As for the translation of wén 文 as the appearance, one can speculate that the French author borrowed the graphical aspect of wén 文 as patterns, marks and writings, as a general allusion to physical appearance in the Western tradition in contrast to essence (see chapter I of this dissertation). From Julien's notes, we can conjecture about his view that the essence that was related to the meaning of these hànzì in ancient and wiser times 
is being perceived as long lost, thus remaining only the "empty shell" of the apparent characters themselves.

\section{Ames \& Hall}

Cut off the sagacity (sheng) and get rid of wisdom (zhi)

And the benefit to the common people will be a hundredfold.

Cut off authoritative conduct (ren) and get rid of appropriateness (yi)

And the common people will return to filiality (xiao) and parental affection (ci)

$[\ldots]$

But these sayings as they stand are still lacking.

In Ames \& Hall we find contrast in both yì 義, appropriateness, and in wén 文, these sayings as they stand. This last expression is a bit cumbersome, but appears to call the attention to the passing/transitory nature of sayings and their meanings (their use). Furthermore, it highlights that we are dealing here with a linguistic matter: the ornaments, as a term used in other translations, are not mere graphic embellishments, they rather refer to the products of a culture that has subverted the use of the words, which referred to ancient virtues, for its own profit. Culture, as proxy for civilization, says the Lăož̆, is bounded to language that inevitably must be seen in its context, lest people gradually begin to think that words and categories are eternal and unchanging and lose contact with dào 道.

As for $y i$ 義's translation as appropriateness, it stands in stark contrast with righteousness and justice, words that in English carry an extremely positive sense, and in that way, maybe appropriateness lessens somewhat the initial impact and strangeness of the other translations. However, impact apart, appropriateness which has been analyzed in some depth in the first chapter of this dissertation carries strong connotations of a private matter, of peculiar to oneself or one's own. Therefore Ames \& Hall construe $y i$ 義as what is particular to each one, thus, what is correct to each one. For another Confucian virtue, rén 仁, which is translated by these authors as authoritative conduct, this expression is constituted by English terms that both have a negative connotation: authoritative conduct as a coercion of power. The parallel is unmistakable: appropriateness as the appropriation of meaning for one's own interest. If we take all six English expressions used by 
Ames \& Hall, sagacity, wisdom, authoritative conduct, appropriateness, cleverness and personal profit, only wisdom carries a clear positive connotation in English, while sagacity and cleverness could also be regarded as positive qualities, in spite of some adverse undertones. One thing is clear: if some of these were virtues of old, they are clearly being misused, and that effect has been very well achieved in Ames \& Hall's translation.

\author{
Hansen \\ Terminate "sageliness," junk "wisdom," \\ Your subjects will benefit a hundredfold. \\ Terminate "humanity," junk "morality," \\ Your subjects will respond with filiality and affection. [...] \\ These three, \\ Treated as slogans are not enough.
}

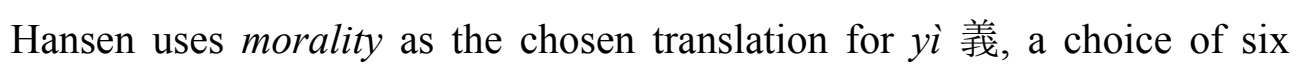
translators in the compilation of 56 translations. Morality is derived from Latin mōs, mōris, "custom, usage," with possible origins in Indo-European roots connoting manner and measure. The question of moral and justice involves a complex debate with many-faceted philosophical consequences and cannot be approached satisfactorily in the present dissertation. It suffices to note that etymologically morality has more relativistic overtones than justice and in that way might be more compatible or nearer in effect with Ames \& Hall's appropriateness.

As for wén 文, the choice as slogan is quite bold (and unique, to my knowledge) and carries a negative connotation but maybe not the "antiquity" and "traditionalism" of the characteristics that are usually related to wén 文. The term slogan also carries strong political tints that might be adequate to what Hansen is wanting to convey. Slogan's etymological origins, according to Partridge (2006, p. 3087), are as a contraction of Gaelic battle-cry sluagh-ghairm, literally an army's war-cry. 


\section{Wáng Bì}

絕聖棄智, 民利百倍; 絕仁棄義, 民複孝慈; 「。。」此三 者以為文不足, 「聖智, 才之善也。仁義, 人之善也。巧 利, 用之善也。而直雲絕, 文甚不足, 不令之有所屬, 無以 見其指，故曰，此三者以為文而未足」

jué shèng qì zhì, mín lì băi bèi; jué rén qì yì, mín fù xiào cí, [...] cǐ sān zhě y̌̀ wéi wén bù zú, [shèng zhì, cái zhī shàn yě. rén yì, rén zhī shàn yĕ. qiăo lì, yòng zhī shàn yè. ér zhí yún jué, wén shèn bù zú, bù lìng zhĩ yǒu suǒ shŭ, wú yò jiàn qí zhĭ, gù yuē, cĭ sān zhě y̌̀ wéi wén ér wèi zú]

Repudiate sagehood and discard wisdom, and the people would benefit a hundredfold. Repudiate benevolence and discard righteousness, and the people would again be obedient and kind to each other. [...] As for these three pair of terms: Because they serve as mere decoration.

Sagehood [sheng] and intelligence [zhi] designate the best of human talent [cai]; benevolence [ren] and righteousness [yi] designate the best of human behavior [xing]; and cleverness [qiao] and sharpness [li], designate the best of human resources [yong]. However, the text directly says that these should be repudiated. Because such "decoration" [wen] is utterly inadequate, one does not give people the chance to identify with these expressions and so never does anything that exemplifies what they mean. Thus the text says: Because these three pairs of terms serve as mere decoration, they are never adequate.

Wáng Bìs comments overtly explain that the six characteristics (the "three decorations") are usually taken as being the "best" in human talent, behavior and resources, even though Lynn himself comments that "“cleverness' and ‘sharpness' strongly imply deceit.” (Lynn, 1999, p. 83) Thus, for Wáng Bì, yi 義is explicitly considered one of the best traits of human behavior, righteousness. For both yi 義 and rén 仁, Lynn writes that they are "the best of humanbehavior" (rén yì, rén zhī shan yě 仁義，人之善也, lit. “rén 仁 and yì 義, the good of human, rén 人”).

The translation of wén 文as decorations is not uncommon, as we have seen, but in this case it might possibly be referring to sayings or words, in that they are expressions, and one should not limit oneself to merely emulating or imitating them and then expect that this would be “enough" (zú 足). Wáng Bi is also 
meticulous in his explanations as to why these decorations are not enough: the expressions in themselves do not cause people (who read or hear them) to identify their affiliation, or the way they can be categorized (suǒsh ŭ 所屬), and neither show (the people) what they are pointing to (that is, make people see their

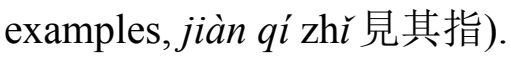

\section{Chén}

抛弃巧辩，人民可以得到吉倍的好处；弃绝伪诈，人民可以 恢复孝慈的天性; 「。。」〔智辩、伪诈、巧和) 这三者全 是巧饰的, 不足以治理天下。

pāoqì qiăo biàn, rénmín kěyl̆ dédào jí bèide hăochu; qì jué wěi zhà, rénmín kěyl̆ huîfú xiào cíde tiānxìng; [...] (zhì biàn, wěi zhà, qiăo hé) zhè sānzhě quán shì qiăo shìde, bùzú y̌̌ zhilì tiānxià.

Forsake skillful arguments [qiăobiàn 巧辩], [and] people can receive a hundred times benefits; abandon false pretentions [wěizhà 伪诈], [and] people can resume [their] natural/instinctive [tiānxìng 天性] filial piety [xiàoci 孝慈] [...] (skilfull argument, false pretenses, ingenious profits), these three are all clever/cunning [qiăo 巧 ] decorations/ornaments (shi 饰), [they] are not enough to govern/administer [zhill 治理] all under heaven.

There is a textual question that needs to be addressed before we can start to analyze Chén's version of the Lăož̀ in modern Mandarin. The Chinese scholar accepts that the commonly used textual version of the Lăož̆ refers to jué rén qì yí 絕仁棄義, the same “discard benevolence, abandon righteousness” of all other translators. Chén, however, argues that in the older bamboo version of the Guōdiàn Lăož̀ the line read jué wěi qì zhà 絕偽棄詐 (in the simplified script: 弃 绝伪诈 ), which could be translated as "discard [the] false, abandon pretentions/cheating." ${ }^{276}$ Whichever version is used, the result is what mostly interests our analysis here: the two Confucian cardinal virtues, rén 仁 and $y i$ 義,

${ }^{276}$ The Guōdiàn "corrected version" is supported by some more textual arguments, including other passages from the Lăož̆ and a passage from the Zhuāngž̆ that might have corrupted the received (Wáng Bì) version of the Lăož̀. 
are eliminated from Chén's original text and the obviously negative false pretentions (wěizhà 偽詐) are put in their place.

In a way, the whole impact of the contradictions from the Lăozl is lost in quite direct and sensible instructions; for instance, "abandon false pretentions" is a very commonsensical recommendation for anyone. These "three" also become quite plain "false ornaments," cunning deceptions, intended to convey falsity and to hide truthfulness. As one final note, Chén translated wén 文 for the character that is usually employed nowadays to refer to ornaments, shi 饰 - an almost "literal" translation.

\section{$* * *$}

The passage of this section includes two metalinguistic terms summarized in the following table:

Table 12-Righteousness and Ornaments - summary of the metalanguage's translations

\begin{tabular}{|c|c|c|c|c|}
\hline & \multicolumn{2}{|c|}{ discard $y i$ 義 } & \multicolumn{2}{|r|}{ wén 文 } \\
\hline Source & Original text & English text & Original text & English text \\
\hline Lăož̀ & $q i y i$ 茟義 & $\begin{array}{l}\text { discard } \\
\text { righteous(ness) }\end{array}$ & wén 文 & adornments \\
\hline Lau & & discard rectitude & & adornments \\
\hline Sproviero & fora a justiça & out with justice & ornamentos & ornaments \\
\hline Julien & quittez la justice & leave justice & l'apparence & the appearance \\
\hline Ames \& Hall & & $\begin{array}{l}\text { get rid of } \\
\text { appropriateness }\end{array}$ & & sayings \\
\hline Hansen & & junk "morality" & & slogans \\
\hline Wáng Bì / Lynn & & $\begin{array}{l}\text { discard } \\
\text { righteousness }\end{array}$ & & "decoration" \\
\hline Chén & wěizhà 伪许 & false pretentions & qiǎoshi 巧饰 & cunning ornaments \\
\hline
\end{tabular}

Source: the author.

The relevance of the translated excerpt from chapter XIX of the Lăož lies in two metalinguistic terms that have been discussed in chapter II of this dissertation: yì 義, meaning, justice, rectitude; and wén 文, writing, culture, ornaments. Since the Lăož̀ predates the Qín reform mirrored in the Shuōwén, we should not expect any reference to the "overtly metalinguistic" wén 文; however, 
the translations are products of their times and, written many centuries after the Lăož̆, were certainly influenced by later uses of the character.

This chapter of the Lăož is one which is most likely to surprise the reader. From what we have seen of the usual translations and the grapho-etymological history of $y i$ 義 and wén 文, it may indeed be hard to understand why the text launches such vituperative attacks on these virtues. According to the graphoetymological data in chapter II of this dissertation, the Lăož̆ seems to suggest to the reader to renounce, first, appropriate meaning, writing and culture, and second, wisdom, benevolence and the sage! This is a text that, as per the MPH, lets us see the strangeness of its practice of language and of metalanguage.

The hànzì that refer to qualities that are refuted in the text are called sān wén 三文, three adornments, ${ }^{277}$ and it is possible to interpret their nature with a representational bias. See, for instance, Rump's (1979) translation of an excerpt of Wáng Bi’s commentaries:

Ornaments are greatly inadequate. If people are not enabled to hold on to something, there is nothing by which they will perceive the fundamentals. (Ibidem, p. 58 , my emphasis)

One can read that the "old qualities" referred to in the text are laudable virtues represented by hànzi that exist outside of language, and that it has been the posterior political action of humans that subverted their fundamentals, that is, their "original meanings." The character that the text used to denote this misuse is wén 文, “empty slogans," words (characters) that had been distorted in order to disguise the imposition of authority by the ruling elite. Indeed, in many commentaries, including Julien's or Wáng Bì's, the misuse of the "old qualities," such as yì 義, righteousness, rén 仁, benevolence, or shēng 聖, sage(hood) was a sign of how words (hànzi) created categories that could be changed to suit one's political or ideological agendas. Julien's lone choice of appearance as the translation of wén 文 might have been motivated by the character's graphic aspect

${ }^{277}$ See the second table in this section. 
of the hànzì as patterns or marks, but also reflects the "empty shells" of hànzì, once deprived of their correct meanings. This interpretation fits perfectly the representational view of language. As Alan K. Chan (1991) wrote in his exegesis of Wáng Bi:

Sageliness as such is therefore not an "ornament" (wen) to be discarded, as the Lao-tzu seems to imply; rather, as "expressions" (wen) such words as "segeliness" and "benevolence" are inadequate and should be improved. (Ibidem, p. 85) (my emphasis)

However, as per the MPH, the Lăož can be a testimony to the mistake to think it possible to fix or improve expression, an advice that resonates with Wittgenstein's warning against taking “words on holiday” (P.I. §38). As we have seen, the expressions (hànzi) are not enough to identify (create) affiliations and categories. We can read Wáng Bìs words in an opposite way as compared to the interpretation above, as almost a type of prototypical perspectivist affirmation, where words have no "power" (meaning, life) outside of their uses in different contexts:

Because such "decoration" [wen] is utterly inadequate, one does not give people the chance to identify with these expressions and so never does anything that exemplifies what they mean. (Lynn, 1999, p. 82)

As for the translation of $y i$ 義, the character is traditionally translated as rectitude, righteousness or morality, and these are the choices of Lau, Sproviero, Julien and Lynn's Wáng Bì. In the compilation of 56 translations, these are the chosen words in the vast majority of the works. ${ }^{278}$ Hansen's translation of $y \grave{\text { 義 }}$ (and of wén 文, for that matter) mirrors the interpretation that the Lăož̀ was basically attacking Confucionism, while Chén's exchange of the Confucian yì 義, righteousness and rén 仁, benevolence, by wěizhà 偽詐, false pretentions, muddled any purported attack. Thus, for these authors, the two hànzi are translated to reflect the more or the less pronounced political and ideological

${ }^{278}$ Some of the alternative terms are: fairness, duty, moral judgments and justice. 
motivation of the whole passage. There is no reference, direct or indirect, to the posterior use of $y i$ 義as metalanguage.

A remarkable exception is Ames \& Hall's translation of yi 義 as appropriateness, which is clearly in line with the two authors' perspectivist reading of the Lăož and the results of the grapho-etymological analysis in chapter II of this dissertation. Once we are affected by the use of $y i$ 義 as significance or meaning, we might interpret that Ames \& Hall are implicitly defending that meaning is contextually appropriate, that it is related to proper conduct, and the idea of suitability to the context (yi 宜, suitable). However, the metalinguistic reference is only indirect.

From the summary table above, there is an apparent greater latitude of translations of $y i$ 義 than of wén 文, on which there is a virtual complete agreement on the almost synonymous adornments, ornaments and decoration. However, there is an enormous variety in the translation of wén 文, as surveyed from the compilation of 56 translations:

Three sayings; three passages; three (negative principles) (Ren Jiyu); these three [not specified]; three things; three methods (of government) (Legge); three refinements; three pairs [which] adorn; three issues; three external adornments; three pairs [which] serve as mere decoration; three statements (Mair); three false adornments; three are inadequate formulation; four [!] principles [which] form the foundation of human culture; these points; three [...] as superficial forms; three epigrams; four, if we consider them as culture; three [which] are superficial and inadequate (Paul Lin); taking these three lines as your text (LaFargue); three [which] are based on artifice; attributes [which] are mere superficialities; things based on artifice; outward refinements (Chang Chung-yuan); three steps [which] are inadequate for culture; three maxims; three remedies for artificial civilization; three fundamentals [!]; external matters; three things for which culture is insufficient (Carus); mere words (Duyvendak); three artificial categories (Wieger, from French); three beautiful appearances (Wilhelm, from German). ${ }^{279}$

This is, to my knowledge, the character from the Lăožr that has the largest variety of translations. ${ }^{280}$ This is evidence of the high polysemy of wén 文 and its

\footnotetext{
${ }^{279}$ Please note that the English translation by the owner of the website from German and French has not been verified or examined by myself.

${ }^{280}$ Rump (1979, p. 59) seems to concur. She writes that the polysemy of wén 文 "has led to various translations, perhaps more diverse that any other word."
} 
ultimately contradictory role in the Lăož̆: on the one hand, refinements, adornments, fundamentals, culture; on the other, superficialities, false, outward, inadequacy, external. It is no wonder that in Ames \& Hall's choice of translation as sayings one finds a more neutral term to refer to wén 文. These authors, together with Hansen, selected a metalinguistic term to translate wén 文, a telltale of the influence of the Shuōwén and the posterior Chinese tradition on their choice. The contrast of the authors' choice between translations of wén 文 as metalanguage and non-metalanguage is again testimony to the MPH.

\section{6.}

\section{The "true essence" and image}

Table 13-The "true essence" and image - list of translations

\begin{tabular}{|c|c|}
\hline Original & 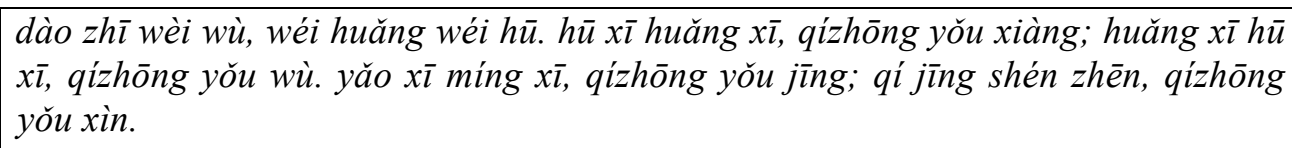 \\
\hline Lau & $\begin{array}{l}\text { As a thing the way is; Shadowy and indistinct. Indistinct and shadowy; Yet within } \\
\text { it is an image. Shadowy and indistinct; Yet within it is a substance. Dim and dark; } \\
\text { Yet within it is an essence. This essence is quite genuine. And within it is } \\
\text { something that can be tested. }\end{array}$ \\
\hline Sproviero & $\begin{array}{l}\text { o curso feito coisa... tão ofuscante que eclipsa; eclipsado! ofuscante! ... em seu } \\
\text { interior há imagem; ofuscante! eclipsado! ... em seu interior há coisa; isolado! } \\
\text { abscôndito! ... em seu interior há essência; essa essência... pura verdade. em seu } \\
\text { interior há fidelidade. }\end{array}$ \\
\hline Julien & $\begin{array}{l}\text { Voici quelle est la nature do Tao. Il est vague, il est confus. Qu'il est confus, qu'il } \\
\text { est vague! Au dedans de lui, il y a des images. Qu'il est vague, qu'il est confus! } \\
\text { Au dedans de lui, il y a des êtres Qu'il est profond, qu'il est obscur! Au dedans de } \\
\text { lui il y a une essence spirituelle. Cette essence spirituelle est profondément vraie. } \\
\text { Au dedans de lui, réside le témoignage infaillible (de ce qu'il est). }\end{array}$ \\
\hline $\begin{array}{l}\text { Ames \& } \\
\text { Hall }\end{array}$ & $\begin{array}{l}\text { As for the process of way-making; It is ever so indefinite and vague. Though } \\
\text { vague and indefinite; There are images within it. Though indefinite and vague; } \\
\text { There are events within it. Though nebulous and dark; There are seminal } \\
\text { concentrations of qi within it. These concentrations of qi are authentic. And have } \\
\text { within them true credibility. }\end{array}$ \\
\hline Hansen & $\begin{array}{l}\text { Treating ways as a natural kind is; Simply confused! Simply superficial! } \\
\text { Superficial - Mmm! Confused - Mmm! Within them, signs are present. Confused } \\
\text { - Mmm! Superficial - Mmm! Within them, natural kinds are present. Yawning - } \\
\text { Mmm! Murky - Mmm! Within them, germination is present. Their germination is }\end{array}$ \\
\hline
\end{tabular}




\begin{tabular}{|c|c|}
\hline & superlatively authentic. Within it reliability is present. \\
\hline $\begin{array}{l}\text { Wáng Bì } \\
\text { (orig.) }\end{array}$ & $\begin{array}{l}\text { The Dao as such is but dim, is but dark. [...] Dark, oh, dim, oh, but within it some } \\
\text { image is there. Dim, oh, dark, oh, but within it something is there. [...] Abstruse, } \\
\text { oh, indistinct, oh, but within it the essence of things is there. [...] The essence is } \\
\text { most authentic, for within it the authentication occurs. }\end{array}$ \\
\hline $\begin{array}{l}\text { Wáng Bi } \\
\text { (com.) }\end{array}$ & $\begin{array}{l}\text { "Dim" and "dark" refer to the appearance of that which is formless and not } \\
\text { attached to anything. [...] It [the Dao] originates things thanks to its formlessness } \\
\text { and brings things to completion thanks to its freedom from attachments. The } \\
\text { myriad things are originated and completed in this way yet do not know how it } \\
\text { happens. Thus the text says: "Dark, oh, dim, oh, but within it some image is there. } \\
\text { Dim, oh, dark, oh, but within it something is there." [...]"Abstruse" and } \\
\text { "indistinct" refer to an appearance of unfathomable profundity [shenyuan]. It [the } \\
\text { Dao] is so unfathomably profound that we cannot treat is as something seen, yet } \\
\text { the myriad things all proceed from it. Because we cannot see it and so fix what its } \\
\text { authentic existence [zhen] is, the text says: "Abstruse, oh, indistinct, oh, but within } \\
\text { it the essence of things [jing] is there. [...] Xin [trust] means xinyan } \\
\text { [authentication]. When things revert to the unfathomably profound, the ultimate } \\
\text { state of authentic essence [zhenjing zhi ji] is attained and the nature [xing] of all } \\
\text { the myriad things are fixed. Thus the text says: "The essence is most authentic, for } \\
\text { within it the authentication occurs." }\end{array}$ \\
\hline Chén & $\begin{array}{l}\text { Dào, this thing, is dim and faint. Such dimness and faintness, but inside it there } \\
\text { is/are sign(s)/indication(s); such dimness and faintness, but inside it there are } \\
\text { material objects; such profound and far reaching obscurity, but inside it there is } \\
\text { essential quality; such obscure profundity, but inside it is [what] is liable to be } \\
\text { examined/proved. }\end{array}$ \\
\hline
\end{tabular}

Source: the author.

Chapter XXI of the Lăož̀ is entitled by Hansen "The Nature of Dao." It calls our attention to the ultimate importance of following dào 道, but also attempts to further elucidate "what" dào 道is.

The passage extracted from the chapter reads:

[...] 道之為物, 惟恍惟惚。忽兮恍兮，其中有象; 恍兮忽 兮, 其中有物。窈兮冥兮, 其中有精; 其精甚真, 其中有 信。 $[\ldots]$

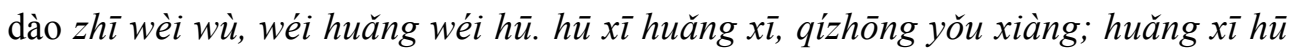

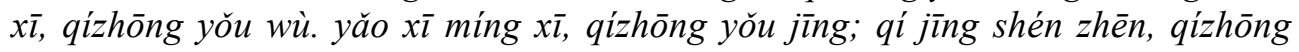
yǒu xìn.

dào as thing [wù 物], indistinct/shadowy [huănghū 恍惚]. Shadowy/indistinct [hūhuăng 忽恍], in its middle there is image [xiàng 象 ]; Indistinct/shadowy [huănghū 恍忽], in its middle there is thing [wù 物]. Obscure/secluded [yăo míng 窈冥], in its middle there is jīng 精; its jīng 精 deeply genuine/authentic [zhēn 真], in its middle there is trust/fidelity [xin 信]. 
This is another deeply enigmatic passage of the Lăož̆, where the text does not spare characters to show how "shadowy, unclear and indistinct" dào 道 is, while at the same time leading the reader in a movement that gradually progresses towards its center, its core: first, the image (xiàng 象), then the thing (wù 物), then essence (jīng 精), which, as the text goes, is genuine (zhēn 真), therefore trustworthy and true (xin 信).

Although the two more ostensibly metalinguistic characters here are xiàng 象 and $x i n$ 信, ${ }^{281}$ this is a passage of particular relevance to this dissertation since it provides an important contrast between the triad translated as image / substance / essence (in Lau's words) and between the pair truth and what can be tested (also in Lau's translation). All of these are terms that are loaded with a heavy historical "baggage," and one must be cautious to translate jīng 精as essence and zhēn 真 as truth without careful provisos. As we will see, the position of these two characters in parallelism with xiàng 象, image, offers an opportunity to examine a character that, as studied in more detail in chapter II of the dissertation, is central in the studies on figurativity in classical Chinese thought.

The character jing 精, although frequently translated as essence, is particularly polysemic. ${ }^{282}$ A brief grapho-etymological exploration suggests that its earlier uses point to the opposite of the term yăo ming 窈冥 (obscure and secluded), which has been used to describe dào 道; therefore, maybe instead of essence, it should be more adequately translated as light, clear, distinct and pure.

The chapter starts by presenting a picture of a shadowy dào 道, without an outward boundary or even a physical body that, presumably, could be reached by

${ }^{281}$ The metalinguistic function of xin 信 is very clear from its grapho-etymological history. The Shuōwén calls it a semantic compound of person (rén 人) and word (yán 言); the Ěryă relates it to honesty, confidence, reliable or with the "result of words." The Shiming recognizes that only through xin 信-words is there mutual understanding and no disagreements between people. Thus, xin 信 is identified as a desired quality of language, a sort of reliability, and therefore has been metonymically used to refer to message, (written) letter or instructions.

${ }^{282} \mathrm{GH}$ has twelve acceptations for it, among them, refined white grain of rice (for example, in the Analects, 10.8, Zhuāngžl, Men of the World) quintessence, semen, vigor, ghost, clever/sharp. Rouzer (2007, p. 218) glosses it as essence, pure, to purify, to be skilled or well versed in. In most of its uses, its primary allusion seems to be good, kind, correct, straight, clear, and distinct. The Shuōwén glosses it as zé 擇, to choose, to select, to differentiate, and to distinguish. 
the senses, and therefore described as invisible, silent, odorless and immaterial (see also the section above, Creating words for dào 道). However, according to this passage, dào 道 is at the same time full of images, things and "clearness." What is in dào 道is genuine (zhèn 真) and besides, it is trustworthy (xin 信).

In the compilation of 56 translations, some characters discussed here have quite standard translations: xiàng 象 is almost always translated either as image or as form; zhèn 真 as (very/entirely) real, genuine or true (but also pure, spirit or concrete); jīng 精 is frequently translated as essence, but also as force, life-force, quintessence, life seed, particles, semen-like essence, spirit, vital energy, seed; and finally xin 信 as true, truthful, confirmable, credible, true (genuineness), evidence, valid, faith, sign, infallibility, sincerity, reliability.

\title{
Lau
}

\author{
As a thing the way is \\ Shadowy and indistinct. \\ Indistinct and shadowy, \\ Yet within it is an image; \\ Shadowy and indistinct \\ Yet within it is a substance. \\ Dim and dark, \\ Yet within it is an essence. \\ This essence is quite genuine \\ And within it is something that can be tested.
}

Lau's translation is quite standard, with the common translations of xiàng 象 as image, wù 物 as substance, jīng 精 as essence and zhèn 真 as genuine. It perhaps departs from the norm in its translation of xin 信, to be tested. The scholar has used other English words to translate xin 信 in different chapters, and in his chosen term for this passage the author is implicitly assuming that that which merits trust must be capable of being tested. Despite the originality of his chosen translation for xin 信, Lau's interpretation is actually not that far removed from many others, which have used (as listed above) terms such as evidence, confirmable, credible or valid. It seems quite incongruous, however, in the context of the Lăozl̆, how one could be asked to find a way to test or to prove the “essence” (jīng 精) of dào 道. One possible way of explaining this proof requisite 
is via the act - an act of faith, almost - that would be required from someone willing to accept dào 道 as it is, with no physical evidence to be tested and no theistic motivation. ${ }^{283}$ This "leap of faith" has led to what some have called, as we have seen, a "mystical way" of the Lăož̆, an often misleading label that connotes non-intelectual adherence. ${ }^{284}$ If, on the one hand, it has been used to criticize the Lăož̀s lack of rigor, on the other hand, it might also be recognized as the nonintellectual acceptance and support of a Wittgensteinian disposition, enabling a proof without the epistemological support of reason.

\section{Sproviero}

$\begin{array}{ll}\text { o curso feito coisa... } & \text { tão ofuscante que eclipsa } \\ \text { eclipsado! ofuscante! } & \text { em seu interior há imagem } \\ \text { ofuscante! eclipsado! } & \text { em seu interior há coisa } \\ \text { isolado! abscôndito! } & \\ \text { essa essên interior há essência } & \text { pura verdade } \\ \text { em seu interior há fidelidade } & \\ \text { the course made thing } & \text { so dazzling that it eclipses } \\ \text { eclipsed! dazzling! } & \text { in its interior there is image } \\ \text { dazzling! eclipsed! } & \text { in its interior there is thing } \\ \text { isolated! covert! } & \text { in its interior there is essence }\end{array}$

this essence.... pure truth in its interior there is fidelity

Sproviero's translation seems even more standard than Lau's, although the Brazilian author prefers to describe dào 道with images of intense light that dazzle and thus prevent us from actually "seeing" dào 道. Sproviero also explains what he understands by the dào 道's image (xiàng 象):

\footnotetext{
${ }^{283}$ In his analysis of Chinese religious philosophy, Neville (In: Allinson, 1989, pp. 48-74) wrote that:

Chinese religions express and can develop a spirituality of ontological creativity devoid of the difficulties of the Western theism/mysticism split. (Ibidem, p. 48)

Never in China did the idea of creation ex nihilo develop in ways comparable to its theistic use in Europe. (Ibidem, p. 59).

The Christian myths of creation of the world presupposed a transcendent creator, independent outside - of the World. Such theistic vision contrasts to with Western mysticism, which conceives of a creator who is not an entity, but the "formless abyss" out of which the world was created. Neville argues that the "main burden of Chinese thought is immanent," (Ibidem, p.60) however, not mystic in the Western manner, but rather in what the author calls "the way of incipience." (Ibidem, p.62)

${ }^{284}$ See also footnote 140.
} 
Não há dualidade entre o Dao e sua imagem. Sendo total a transparência, a imagem não aparece como um reflexo, mas é a própria visibilidade absoluta do curso. (Sproviero, 2007, p. 233)

There is no duality between Dao and its image. The transparency being complete, the image is not shown as any reflection, but rather it is the absolute visibility of the course [Dao].

The author takes image in its commonsensical Western acceptation as a reflection and representation of a thing and argues that dào 道's image is a different one: it is totally transparent as well as absolutely visible. The clashes of these contradictions seem to be quite in consonance with the spirit of the Lăož̀.

\section{Julien}

Voici quelle est la nature du Tao.

Il est vague, il est confus.

Qu'il est confus, qu'il est vague!

Au dedans de lui, il y a des images

Qu'il est vague, qu'il est confus!

Au dedans de lui, il y a des êtres

Qu'il est profond, qu'il est obscur!

Au dedans de lui il y a une essence spirituelle. Cette essence spirituelle est

profondément vraie.

Au dedans de lui, réside le témoignage infaillible (de ce qu'il est);

Here is what is the nature of Tao

It is vague, it is unclear.

That it is unclear, that it is vague!

Within it, there are images

That it is vague! That it is unclear!

Within it, there are beings

That it is deep, that it is obscure!

Within it, there is a spiritual essence. This spiritual essence is profoundly true.

Within it, lives the infallible testimony (of what it is);

Julien's translation is not far from the two others above; however, in some of the French author's commentaries lie his more particular views. For example, regarding image he writes: "It [dào 道] is itself the model and image of all beings" (Julien, 1842, p. 76-7), which might remind us of the Platonic images and forms and apparently betrays Julien's own Western heritage. The French Sinologist continues by writing that, although dào 道 has no body or visible form, all Beings are contained inside it. Afterwards, he explicitly describes how yǒuxin 有信(there 
is/to have trust/fidelity) should be understood: "to have or to contain inside itself a true testimony, which does not fail." (Ibidem, p. 77) Thus one can interpret his translation of xin 信 as true (vraie in French) as something that is reliable, upon which one can trust it will not fail. ${ }^{285}$

\section{Ames \& Hall}

As for the process of way-making, It is ever so indefinite and vague. Though vague and indefinite, There are images within it. Though indefinite and vague, There are events within it. Though nebulous and dark, There are seminal concentrations of qi within it. These concentrations of qi are authentic, And have within them true credibility.

Ames \& Hall's translation differs from the ones analyzed before in many aspects, although I will focus here only on those that have a direct bearing on the terms whose metalinguistic functions are the subject of this dissertation. The authors translate jing 精 as seminal concentrations of qi, this "qi" being the important Chinese notion of $q i$ 氣 which, being a term that has entered Western vocabulary with the growing presence of Chinese ideas in the West (especially from Chinese medicine), is left as Western calque of the Chinese character. As we have often seen throughout this dissertation, the graphic dimension of the hànzi has direct import to their network of allusions: the component m̌ 米, rice, skin, infinitesimal, present in both jing 精 and qi 氣, inexorably influences their uses. What is of further importance for us here is that these "concentrations of qi" are authentic, the translated term from zhen 真. In the compilation of 56 translations, the word authentic was only found in Lynn's translation (as we will see below). Its etymological origins lie in Greek "authentikos, adj[ective form] of authentēs,

\footnotetext{
${ }^{285}$ However, one must be very careful with the identification of French vraie with English true. As discussed in the first chapter of this dissertation, truth (and true) is an incredibly polysemic word that works almost as an umbrella term in English, covering ontological, gnosiological, logical and moral dimensions. Here, it is important to note that French vraie belongs to the Latin paradigm, which has a more normative force than English true, in itself belonging to the Hebrew paradigm. See that discussion for more details.
} 
one who acts on his own authority, a chief" (Partridge, 2006, p. 183), thus, someone or something (in this case, the "concentrations of qi") that imposes an authority, something that does not rely on others for its power. Thus emanates from dào 道 its "true credibility" (xìn 信), not due to some ontological reality, but "on its own authority," due to its effects and actions.

\author{
Hansen \\ Treating ways as a natural kind is \\ Simply confused! Simply superficial! \\ Superficial-Mmm! Confused-Mmm! \\ Within them, signs are present. \\ Confused-Mmm! Superficial-Mmm! \\ Within them, natural kinds are present. \\ Yawning - Mmm! Murky-Mmm! \\ Within them, germination is present. \\ Their germination is superlatively authentic. \\ Within it reliability is present.
}

What is most remarkable about Hansen's translation is his use of signs as the English term for xiàng 象. ${ }^{286}$ As we have seen in chapter II of this dissertation, there is a striking difference between image and sign. The first is an attempt at reproducing the outward appearance of a concrete "thing," while the second points to a hint, to a mark (or a signal) left or produced by the "thing" that allows us to infer its presence (former or actual). As seen in the Western etymology chapter, sign is derived from Latin sīgnum, which has obscure origins, but that might have originated from Proto Indo-European *sek(h2)-no-, (to) cut, which gives us the idea of a signal as "part" or a trace that was left of the "original thing." Back to the excerpt in question, that would mean that Hansen might be wishing to avoid the term image as perfect (Platonic) copies inside dào 道, favoring the more indirect signs or signals, which also alludes to a process of change and movement, as well as a measure of uncertainty in terms of physical image. As Hansen might have had it, the mention of images inside dào 道 could easily provoke the imagination to focus excessively on the visual phenomena; while signs would have more indirect ways of raising emotions and allusions.

\footnotetext{
${ }^{286}$ See also the discussion of chapter XIV of the Lăož̆, Creating words for dào 道.
} 
The uncommon choice of authentic as the translation for zhèn 真 - also made by Ames \& Hall - reaffirms the theoretical affinities between Hansen and these scholars. And although not directly pertinent to the dissertation, Hansen's choice to translate jing 精 as germination is also highly original, pointing to the etymological roots of the character (recall the radical mi 米, rice, skin, infinitesimal) and its performative view of dào 道. By calling attention to these semantic allusions related to the history of the hànzì, Hansen reiterates the high polysemy of the character and its fundamental difference with the universalizing essence.

\section{Wáng Bì}

道之為物, 惟恍惟惚。「恍惚無形, 不系之歎。」惚兮恍 兮，其中有象; 恍兮惚兮，其中有物。「以無形始物，不 系成物，萬物以始以成，而不知其所以然，故曰，恍兮惚 兮，其中有象也。」窈兮冥兮，其中有精; 「窈、冥, 深 遠之歎，深遠不可得而見。然而萬物由之，其可得見，以定 其真。故曰，窈兮冥兮，其中有精也。」其精甚真，其中 有信。「 信, 信驗也。物反窈冥, 則真精之極得，萬物之 性定。故曰，其精甚真，其中有信也。」

dào zhī wéi wù, wéi huăng wéi hū. [huăng hū wú xíng, bù xì zhī tàn.] hū xī huăng

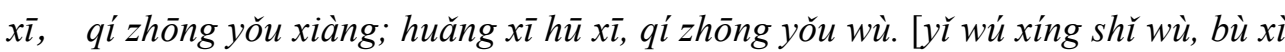

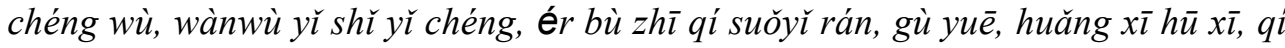
zhōng yǒu xiàng yě.] yăo xī míng xī, qi zhōng yŏu jīng; [yăo, míng, shēn yuăn zhī tàn, shên yuăn bù kě děi ér jiàn. rán ér wàn wù yóu zhī, qi kě děi jiàn, yì dìng qi zhēn. gù yuē, yăo xī míng xī, qi zhōng yǒu jīng yè.] qí jīng shèn zhēn, qí zhōng yŏu xìn. [xìn, xìn yàn yě. wù făn yăo míng, zé zhên jīng zhī jí děi wànwù zhì xìng ding. gù yuē, qí jīng shèn zhèn, qí zhōng yǒu xìn yě.]

The Dao as such is but dim, is but dark.

'Dim" and "dark" refer to the appearance of that which is formless and not attached to anything.

Dark, oh, dim, oh, but within it some image is there. Dim, oh, dark, oh, but within it something is there.

It [the Dao] originates things thanks to its formlessness and brings things to completion thanks to its freedom from attachments. The myriad things are originated and completed in this way yet do not know how it happens. Thus the text says: "Dark, oh, dim, oh, but within it some image is there. Dim, oh, dark, oh, but within it something is there." 
Abstruse, oh, indistinct, oh, but within it the essence of things is there.

"Abstruse" and "indistinct" refer to an appearance of unfathomable profundity [shenyuan]. It [the Dao] is so unfathomably profound that we cannot treat is as something seen, yet the myriad things all proceed from it. Because we cannot see it and so fix what its authentic existence [zhen] is, the text says: "Abstruse, oh, indistinct, oh, but within it the essence of things [jing] is there.

The essence is most authentic, for within it the authentication occurs.

Xin [trust] means xinyan [authentication]. When things revert to the unfathomably profound, the ultimate state of authentic essence [zhenjing zhi ji] is attained and the nature [xing] of all the myriad things are fixed. Thus the text says: "The essence is most authentic, for within it the authentication occurs."

As with the previous analysis, I will restrict myself to what is pertinent to the present dissertation, that is, the Chinese characters xiàng 象, zhēn 真 and xìn 信. In Lynn's translation, they are respectively image, authentic (as Hansen and Ames \& Hall) and trust. However, Wáng Bi’s comments help us speculate as to what the Chinese commentator expected from the use of such characters. Thus the "image" of the things inside dào 道 is possible due to its own formlessness and freedom from attachments. And because dào 道 is absolutely without form (or image), the myriad things, which all have forms, cannot fathom their origins, no more than they could comprehend dào 道itself.

As for zhēn 真 and xin 信, both characters are intimately related. From Wáng Bìs text it seems that it is exactly because we fail to see or perceive dào 道 through our senses that it has its authenticity guaranteed (Lynn translates it as authentic existence, however, the text reads only zhēn 真). Wáng Bì explicitly conveys how this authenticity is guaranteed: by its "own authentication," that is, by xinyàn 信驗. The addition of the second term in the disyllable makes all the difference: yàn 驗 is related to what can be verified, proved, tested, which generates a result or an effect. The disyllable therefore points to a trust that is not blind, that is justified, thus authenticated. This authentication occurs when the 
myriad things return to the "unfathomably profound," that is, dào 道. That is when their true jing 精is attained and their “nature” (xing 性) ${ }^{287}$ is fixed.

For further clarifications on Wáng Bì's thoughts specifically on xiàng 象, we might take a little detour to the author's text ming xiàng 明象, Elucidation of the Image. As Owen (1992, p. 32-3) explains to us, Wáng Bì was attempting to explicate the triad yì 意, concept, yán 言, language and xiàng 象, image, fundamental to the understanding of the Yijjing. Very roughly, Wáng Bì suggested the mediation of image between proto-concepts (we are reminded from the commentaries above that $y i$ 意 never reaches a full process of abstraction) and language. Thus: "Language was born of the Image [...] Image was born of the concept." (Wáng Bì, míng xiàng translated by Owen, 1992, p. 33) This importance of image is certainly motivated by the graphic dimension of Chinese writing and, if we consider $y i$ 意 as a "mental phenomenon" (something that is debatable in early Chinese thought), the graphic (written) realm of language will be the one that is the intermediary, not in a hierarchical projection of representation, but rather synedochal partial manifestations of $y i$ 意.

\section{Chén}

道这个东西，是恍恍惚惚的。那样的惚惚恍恍，其中却有迹 象;那样的恍恍惚惚, 其中却有实物; 那样的深远暗昧, 其 中却有精质; 那样的暗昧深远，其中却是可信验的。

dào zhège dōngxi, shì huănghuăng hūhū de. nàyàngde hūhū huănghuăng, qízhōng què yǒu jìxiàng; nàyàngde huănghuăng hūhū, qizhōng què yǒu shíwù; nàyàngde shēnyuăn àn mèi, qizhōng què yŏu jīng zhì; nàyàngde àn mèi shēnyuăn, qizhōng què shì kě xìnyàn de.

Dào, this thing, is dim and faint. Such dimness and faintness, but inside it there is/are sign(s)/indication(s) [jìxiàng 迹象]; such dimness and faintness, but inside it there are material objects [shiwù 实物]; such profound and far reaching obscurity, but inside it there is essential quality [jingzhi 精质]; such obscure profundity, but inside it is [what] is liable to be examined/proved [xinyàn 信验].

${ }^{287}$ I will not extend an analysis on this complex character. It suffices to say that it is also translated as quality, (inherent) disposition, temperament and even life. Owen (1992, p. 587) calls it individuating nature, the innate characteristics that distinguish an individual or class of individuals from others. The author however warns us not to consider it as an ontologically motivated individuation. 
We must resort to Chén's notes for further clarification on the specific terms that interest us here. As for xiàng 象, the author is explicit: he reads it as the modern disyllable jìxiàng 迹象, which can be translated as sign, mark, indication. Chén quotes another commentator, whom sheds some light on the matter: "a form that can be seen, it accomplishes a thing; a form that cannot be seen, it accomplishes a sign [xiàng 象].” (Chén, 2006, p. 157) Thus, there can be no image from what cannot be seen, but only a mark, a sign (this is also Hansen's preferred translation).

Although not directly our main concern here, it is worth seeing how Chén explains jīng 精: zuì wêixiăo de yuánzhì 最微小的原质,that is: “the most minute element(s)," or "the most basic elementary particles." (Ibidem) The Chinese author also quotes many passages, including some from other contemporary scholars who used English terms to gloss jing 精, such as essence, intelligence, spirit and life-force, terms that were often present in the translations of this passage of the Lăožr. It is these "most minute elements" that are, in Chén's view, inherently true in the sense of real, authentic, actual (modern Mandarin zhēnshi 真實), and they are what can be tested, what can be authenticated via proof and inquiry, thus the same term xinyàn 信驗 (in simplified characters, 信验) used by Wáng Bi.

\section{$* * *$}

Table 14- The "true essence" and image - summary of the metalanguage's translations

\begin{tabular}{|l|l|l|l|l|}
\hline Source & \multicolumn{2}{|c|}{$\begin{array}{c}\text { 象, 物and 精 } \\
\text { English text }\end{array}$} \\
\hline & Original text & English text & Original text & End 信 \\
\hline Lăož́ & xiàng, wù, jìng & $\begin{array}{l}\text { image, thing, distinct \& } \\
\text { clear }\end{array}$ & zhēn, xìn & authentic, trust \\
\hline Lau & & image, substance, essence & & genuine, (can be) tested \\
\hline Sproviero & $\begin{array}{l}\text { imagem, coisa, } \\
\text { essência }\end{array}$ & image, thing, essence & $\begin{array}{l}\text { (pura) verdade, } \\
\text { fidelidade }\end{array}$ & (pure) truth, fidelity \\
\hline Julien & $\begin{array}{l}\text { image, être, } \\
\text { essence spirituelle }\end{array}$ & $\begin{array}{l}\text { image, being, spiritual } \\
\text { essence }\end{array}$ & vraie, infaillible & true, infallible \\
\hline $\begin{array}{l}\text { Ames \& } \\
\text { Hall }\end{array}$ & & $\begin{array}{l}\text { images,events,seminal } \\
\text { concentrations of qi }\end{array}$ & & $\begin{array}{l}\text { authentic, true } \\
\text { credibility }\end{array}$ \\
\hline Hansen & & signs, natural kinds, & & superlatively authentic, \\
\hline
\end{tabular}




\begin{tabular}{|l|l|l|l|l|}
\hline & & germination & reliability \\
\hline $\begin{array}{l}\text { Wáng Bì } \\
\text { Lynn }\end{array}$ & xiàng, wù, jīng & $\begin{array}{l}\text { image, something, } \\
\text { essence of things, }\end{array}$ & zhēn, xìnyan & $\begin{array}{l}\text { authentic, } \\
\text { authentication }\end{array}$ \\
\hline Chén & $\begin{array}{l}\text { jìxiàng, shíwù, } \\
\text { jīngzhì }\end{array}$ & $\begin{array}{l}\text { signs, material objects, } \\
\text { essential quality }\end{array}$ & $\begin{array}{l}\text { àn mèi shēnyuăn, } \\
\text { xìnyàn }\end{array}$ & $\begin{array}{l}\text { obscure profundity, be } \\
\text { examined/proved }\end{array}$ \\
\hline
\end{tabular}

Source: the author.

As we have seen, there are two important metalinguistic terms in this passage: xiàng 象 and xin 信. The first is frequently translated as image, while the second is a polysemic character, translated as fidelity, trustworthiness, trust, but also as word and letter. ${ }^{288}$ These two hànzì are shown in parallel constructions respectively with wù 物 and jīng 精, and with zhèn 真. The parallelism becomes more evident if we break the excerpt into eight and four character lines in the next page (the hànzì of interest are underlined).

道之為物, 惟恍惟惚。(line 1)

忽兮恍兮，其中有象； (line 2)

恍兮忽兮，其中有物。(line 3)

窈兮冥兮，其中有精；(line 4)

其精甚真，(line 5)

其中有信。(line 6)

Line 1 introduces to us the "shadowy and indistinct" dào 道, "as a thing, wù 物” (“as a natural kind," in Hansen's words). While reaffirming that it remains obscure, shadowy, lines 2-4 give us some hints about its nature: “inside it” (其中) there are images, things, essences (or clearness, distinctness). A "movement," as I have claimed above, seems clear: distinctness makes up things, which, in turn, provide us with images. However, it is no clear statement of an ontological hierarchy. Finally, in lines 5-6 the parallels are less clear, albeit present still, between zhèn 真 and xin 信: in its (jīng 精) clearness, one finds the extreme, the

${ }^{288}$ For the grapho-etymological details of word, see chapter II of this dissertation, and for letter, see appendix II. 
utmost authenticity (zhèn 真); in its (zhēn 真) midst there is what is trustworthy (xin 信).

The importance of lines 2-4 in the passage are related to how the translators perceived the metalinguistic xiàng 象. Lau, Sproviero, Julien, Chén, and Lynn's reading of Wáng Bì all betray a close attachment to the idea of an ultimate essence or reality, in a representational chain that starts with the image, continues with the thing (representatum) and ends in the essence. This could surface, for instance, in Julien's use of "spiritual essence," with its Christian inspiration, or in Chén's rationalist "the most basic elementary particles." ${ }^{289}$ It is worth noticing that, although the translation of jīng 精 as essence gives credible evidence of an ontological disposition by these authors, the word itself, essence, as per the MPH, does not necessarily imply that we must subscribe to such metaphysical views. We need only to recall Wittgenstein's Wesen as that which is called by grammar essence. ${ }^{290}$ Nevertheless, xiàng 象 might still be construed in a subservient position in the chain towards essence. In Wáng Bì's observation in the míng xiàng 明象 it is clear that xiàng 象 has a much more prominent position in Chinese thought, especially with regard to language.

Ames \& Hall's translation also stands in profound contrast to those of Lau, Sproviero, Julien and Chén. It explicitly rejects the possibility of interpreting a representationalist hierarchical chain: images are followed by events and those by (authentic) seminal concentrations of qi (qi 氣). The use of events underlines the performative character of Ames \& Hall's reading of the Lăož̆, while qi 氣 is what "cannot be resolved into any kind of spiritual-material dichotomy. $Q i$ is both the animating energy and that which is animated." (Ames \& Hall, 2003, p. 63) This is therefore the opposite of Julien's spiritual essence. In this context, images are empowered, the visual counterpart (rather than subsidiary) of events and the concentrations of qi.

${ }^{289}$ Chén seems to be developing an almost scientific theory of the nature of dào 道: it remains obscure, formless, unreachable by the senses, however it is composed of traces of the very basic elements that make up reality and can eventually be attested and proved. It is hard not to read traces of the modern mind in these lines that interpret a text over 2000 years old.

${ }^{290}$ See chapter I of this dissertation. 
In many ways, Hansen follows Ames \& Hall's strategy: a highly original translation of jing 精 - in close accordance to its grapho-etymological roots - as germination, the seeds that put in movement the eternal circulation of signs (xiàng 象) and natural kinds (wù 物, as opposed to human's artificial kinds), and which indicate dào 道 as the source of the myriad things. This network of allusions particularly the author's choice of signs for xiàng 象 - is completely foreign to a chain of representations "inside" dào 道 and asserts the possibilities of forms of life.

As for xin 信, following are some of its translated terms from the compilation of 56 translations, all (except for Mair's neutral tokens) frankly positive:

Proof (Henricks), unfailing Sincerity, truth, real, faith, harbors the sincerity of facts, truthfulness, growth power, yields trustworthy results, believable, efficacious (Waley), tokens (Mair), can be relied upon, belief, tested as true, true genuineness (LaFargue), its validity can be proven, evidence of reality, creditable, invariably vital, evidence, unquestionably genuine, truth is ever sure, reliability (Wilhelm).

It is remarkable that a hànzì that clearly has the components of man and speech side by side (人+言 $=$ 信) is translated to such assertive, but mostly not metalinguistic, words as proof, real, sincerity of the facts, true genuineness, evidence of reality or truth is ever sure. This "non-metalinguistic" function of xin 信 in the translations is likely what enabled this positive vision in a text that has been read so ambiguously about language. Xin 信 appears not to belong to the metalanguage of the Lăozi - further evidence of its dislocation. The way to credibility and authentication seems to be of a non linguistic nature.

Wáng $B \grave{\imath}$ offers a theory on xìn 信 : "Xin [trust] means xinyan [authentication]," related to what can be verified and tested, and, in the case of dào 道, such authentication occurs when the myriad things return to the (original) unfathomably profound (yăomíng 窈冥) ${ }^{291}$ and their “nature” (xìng 性) is fixed.

\footnotetext{
${ }^{291}$ The reader might recall the brief discussion above, where yăomíng 窈冥 was shown as a term that is often taken in its opposition to as jing 精.
} 
Wáng $B \grave{\imath}$ appears to reinforce his essentialist reading of the Lăož̆: things have an inherent quality or disposition, which is individualized when they are coherent with dào 道. From Wáng Bìs lines, the ultimate desired objective is to "fix" the authentic and the qualities/nature. There is, however, another possible interpretation that brings Wáng Bì closer to a more transgressive view, such as Hansen's or Ames \& Hall's. As we have briefly discussed above, xin 信's mode of authentication happens, according to Wáng $B \grave{i}$, when the myriad things return to dào 道, which, in Wáng Bì's own words, can be characterized as yăomíng 窈冥, obscure and secluded. However, it is “inside dào 道” where one finds jīng 精, which is the opposite of yăoming 窈冥! Therefore, this return to the sources cannot be the result of any kind of intellectual accomplishment, and neither can xin 信's authentication or proof. Other translations such as Ames \& Hall and Hansen also seem to concur with a non-essentialist basis for authentication or proof.

It should be clear to the reader that we have ample reasons to insist on the non-intellectual nature of such trust and certainty. The dislocation of the Western metalinguistic term proof and its significant contrast with the modes of proof in the Chinese tradition are evidence of support for the MPH.

\section{7.}

\section{"I style it 'Dao"”}

Table 15- "I style it 'Dao"” - list of translations

\begin{tabular}{l|l}
\hline Original & wú bù zhī qí míng, zì zhī yuē dào, qiăng wèi zhī míng yuē dà. \\
\hline Lau & $\begin{array}{l}\text { I know not its name; So I style it 'the way'. I give it the makeshift name of 'the } \\
\text { great'. }\end{array}$ \\
\hline Sproviero & eu não sei seu nome; dou-lhe a grafia: 道Dao; forçado a nomeá-lo digo: grande. \\
\hline Julien & $\begin{array}{l}\text { Moi, je ne sais pas son nom. Pour lui donner un titre, je l'appelle Voie (Tao). En } \\
\text { m'efforçant de lui faire un nom, je l'appelle grand. }\end{array}$ \\
\hline $\begin{array}{l}\text { Ames \& } \\
\text { Hall }\end{array}$ & $\begin{array}{l}\text { I do not yet know its name (ming). If I were to style it, I would call it way- } \\
\text { making (dao). And if forced to give it a name, I would call it grand. }\end{array}$ \\
\hline
\end{tabular}




\begin{tabular}{|c|c|}
\hline Hansen & $\begin{array}{l}\text { I don't know its name. To assign an ideograph to it, we say "way." Forced to } \\
\text { construct a name for it, we say "great" }\end{array}$ \\
\hline $\begin{array}{l}\text { Wáng Bì } \\
\text { (orig.) }\end{array}$ & We do not know its name; [...] So I style it "Dao" [Way] (partial) \\
\hline $\begin{array}{l}\text { Wáng Bì } \\
\text { (com.) }\end{array}$ & $\begin{array}{l}\text { Names [ming] are used to determine forms [xing], but, amorphous and complete, } \\
\text { it has no form, so we cannot make any such determination. Thus the text says } \\
\text { "we do not know its name." [...] Names [ming] are used to determine forms, and } \\
\text { style names [zi] are used to designate [cheng] attributes [ke]. To speak of "Dao" } \\
\text { [Way] is derived from the fact that absolutely nothing fails to follow it and } \\
\text { because, of all the terms that might be used to address the "amorphous and } \\
\text { complete," this one has the broadest meaning. }\end{array}$ \\
\hline Chén & $\begin{array}{l}\text { I do not know its name, reluctantly I call it “道," and reluctantly I am forced to } \\
\text { give it a created/raised name [thus, I] call it "great" }\end{array}$ \\
\hline
\end{tabular}

Source: the author.

Chapter XXV of the Lăož́ also deals with the investigations on the nature of dào 道and thus is called by Hansen "Origins and Foundations."

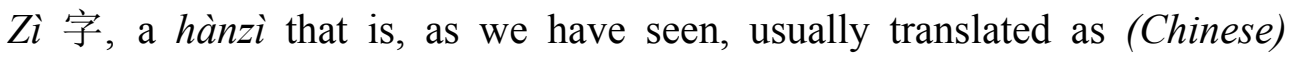
character and that later became intimately linked with, and fundamental to, understanding the Chinese language and writing, appears only once in the Lăož̆. The passage in question is a crucial one in the text's numerous attempts to refer to the unnameable and unfathomable dào 道. It also provides a striking contrast between $z i$ 字 and ming 名, a term that has already been analyzed elsewhere in this dissertation.

This is a chapter that begins with a speculation on the origins of dào 道. However, the passage that interests us here regards another (ultimately unfruitful) attempt to give it a "name." As we have already seen in the previous chapters analyzed here, dào 道's unchanging name is unknowable to us. This passage proposes that we circumvent this limitation by assigning to it a "courtesy name," a $z i$ 字. $Z i$ 字's role in the passage under scrutiny is controversial and the translators dealt with it in an array of different ways. The opposition and balance between $z i$ 字 and wén 文 in the Chinese literary thought is also relevant to appreciate how later scholars and commentators understood the Lăozľs strategies to use “alternative" ways of referring to dào 道. 
Following the same scheme of presentation as above, I now present the excerpt in question:

\footnotetext{
吾不知其名, 字之曰道, 強為之名曰大。

wú bù zhī qí míng, zì zhī yuē dào, qiăng wèi zhì míng yuē dà.

I do not know its name (míng 名), [I] zì 字-ly call [it] “dào 道,” forced to create [to it] a name [ming 名], [I] call it “dà大” (big/great).
}

In this passage, instead of attempting to find a name (míng 名) for dào 道, the writer bestows upon it a $z i$ 字. In the grammatical structure of Classical Chinese, $z i$ 字is positioned as the modifier of the verb yue $\boxminus$, to call, thus the odd translation “I 字-ly call it 道."

The text continues, as if this solution is not sufficient; and it appears that we remain still “forced" to provide a name for dào 道. One first calls dào 道 "great," then (in the continuation of the text, not shown here), "passing away" (shi 逝, understood as physically leaving the presence of someone or just plainly dying) and, finally, "returning" (făn 反). This richness of images can evoke theistic interpretations and has added to the variability of readings of the Lăož́

\section{Lau}

\section{I know not its name}

So I style it 'the way'.

I give it the makeshift name of 'the great'.

Lau used style as the translation of $z i$ 字. As we have seen, to style, as a verb, is commonly employed as an inaugurating name or a new title due to some feat or achievement.

In a further attempt to refer to dào 道, the Lăož gives, in Lau's translation, a "makeshift" name as "the great." Makeshift (in the Oxford English Dictionary) has the connotations of temporary, a "temporary substitute," but it can also especially refer to of an inferior kind; improvised; formed haphazardly. 
Consequently, this can be interpreted as claiming that great is not "enough" to call dào 道; it does not do justice to it; it is but temporary (as is its style-name), serving the Lăozl’'s need for this passage. Thus, dào 道 is never-ending, while at the same time it cannot be pinpointed, it cannot be reduced to anything.

\section{Sproviero}

$\begin{array}{ll}\text { eu não sei seu nome } & \\ \text { dou-lhe a grafia: } & \text { 道Dao } \\ \text { forçado a nomeá-lo digo: } & \text { grande } \\ \text { I don't know its name } & \\ \text { [I] give it the orthography: } & \text { 道Dao } \\ \text { Forced to name it I say: } & \text { big }\end{array}$

Sproviero, in his commentaries writes that "not knowing its eternal name, we give it a surname: way. Needing to evoke/summon it, it is called big." ${ }^{292}$ (Sproviero, 2007, p. 235) In his translation, Sproviero decides to translate $z i$ 字 as "to give it the orthography," that is, to give it a written character in order to refer to it in the written medium. The Lăož̀ is a written text, and albeit from a more ancient spoken tradition, it had for long been identified primarily as a text. Writing is the way to "fix" the spoken words in stable written signs. However, dào 道 cannot be fixed and the Lăož̀ decided to make clear that this is not its "name," but rather only a (precarious) way to refer to it. We attempt to describe it or to explain it incorrectly with the words that we are forced to use.

This interpretation, inferred from Sproviero's translation, has some quite conventional views on writing and speech as well as the "nature" of dào 道. I believe this is the path taken by many translators of the Lăož̀. For the purposes of this dissertation, it suffices to say that such interpretation is likely to result in a subservient view of writing that certainly is not congruent with the Chinese tradition.

\footnotetext{
${ }^{292}$ In the original: "Não sabendo seu nome eterno, dá-se-lhe um sobrenome: curso. Necessitando evocá-lo, chama-se grande."
} 


\section{Julien}

Moi, je ne sais pas son nom.

Pour lui donner un titre, je l'appelle Voie (Tao).

En m'efforçant de lui faire un nom, je l'appelle grand.

Me, I do not know its name.

To give it a title, I call it Way (Tao).

By trying hard to create a name for it, I call it big.

Julien writes of a title (un titre) for dào 道, but the author, in his notes, contrary to Sproviero and others, explains that this title "Voie" (Way) is justified and not the product of a simple volitional act: we call it Way because "all beings arrive to life through it." (Julien, 1842, p. 93) This interpretation finds a justification to "fix" dào 道's qualities that is perhaps not in accordance with the Daoist tradition of the Lăož̀.

Therefore, as per Julien's translation and note, it seems that, if one would try hard to find a name for it, one would eventually succeed, gathering the characteristics of dào 道, which can then be listed and explained: it is incredibly high and enormous; it is always in movement and escaping from our grasp; it is always distant and unreachable; etc. However, more than anything, it is the Way by which all things under heaven originated. Thus, its "name" is "correct."

\footnotetext{
Ames \& Hall

I do not yet know its name (ming).

If I were to style it,

I would call it way-making (dao).

And if forced to give it a name,

I would call it grand.
}

Ames and Hall's selection of English words is not very different from the other translators, and actually resembles a mix of Lau and Julien. It is in their notes that the authors state the sheer difficulties of apprehending dào 道, resorting to direct assistance from Wittgenstein: 
According to Wittgenstein, one cannot predicate the whole. That is, one cannot say that the totality of things is either large or small if there is nothing beyond it to compare. (Ames \& Hall, 2003, p. 116)

Therefore, according to Ames \& Hall, this is what makes dào 道 so special and at the same time so utterly common: it pervades all, however, it is not reduced to anything. In other words, it is the ultimate universal and the ultimate relative as well, having no common ground to be compared to, no background on which to fix its name, its identity. One's ambitions must then be naturally limited: I do not style it “道," IF I were to style it, I would call it “way-making." At the same time, it appears that Ames \& Hall preferred to keep the "pre-Shuōwén" connotations of zì 字, and therefore did not allude to the possible interpretation of the graphic aspect of the 字-name.

\section{Hansen}

I don't know its name.

To assign an ideograph to it, we say "way."

Forced to construct a name for it, we say "great"

Hansen's use of ideograph to refer to $z i$ 字 is also an audacious move and in perfect accordance with the semanticist view held by the author on Chinese writing, although arguably incongruous with the historical context of the Lăož́. In Hansen's own notes, the alternative of an ideograph avoids a name that is

Tied to that of a natural kind, attribute or social matter. If we must name the natural structural feature of paths, we can say that they are "extensive, everywhere, through all times and reversible." (we can walk them either way.) (Hansen, 2009, p. 224)

The mere possibility to name dào 道, in Hansen's analysis, would give us an enormous power over it, an authority to fix some kind of "natural kind, attribute or social matter." The author is here true to his view on Daoist thought that name and language are how we coercively describe and artificially hierarchize the things in nature, therefore distancing ourselves from dào 道. Although Hansen 
here fails to explain how exactly, through writing, one can avoid this "essentialist trap," it seems that the fact that writing and speech are not linked in a relationship of dependence (see Hansen (1992); or Hansen (In: Allinson, 1989)) enables one to call the character 道, but not to call dào 道 itself. The written character assumes an independence that would be unthinkable in a more phonetic system of writing, which has a vast impact on how we think about the Chinese script.

\section{Wáng Bì}

Wáng Bì writes a long commentary after each line of the passage in question. Because we are primarily interested in the metalinguistic terms, specifically $z i$ 字, I will not show the whole excerpt, but rather reduce it to its first two “lines" (吾不 知其名, 字之曰道), thus focusing on the commentaries that are more pertinent to the analysis here:

吾不知其名, 「名以定形, 混成無形, 不可得而定, 故 曰，不知其名也。」字之曰道，「夫名以定形，字以稱 可, 言道取於無物而不由也。是混成之中, 可言之稱最大 也。」

wú bù zhī qí míng, [míng yĭ dìng xíng, hùn chéng wú xíng, bù kě děi ér dìng,

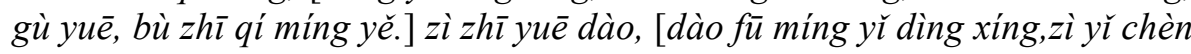
ké, yán dào qŭ yū wú wù ér bù yóu yě. shì hùn chéng zhĩ zhōng,kě yán zhī chèn zuì dà yĕ.]

We do not know its name;

Names [ming] are used to determine forms [xing], but, amorphous and complete, it has no form, so we cannot make any such determination. Thus the text says "we do not know its name."

So I style it "Dao" [Way]

Names [ming] are used to determine forms, and style names [zi] are used to designate [cheng] attributes [ke]. To speak of "Dao" [Way] is derived from the fact that absolutely nothing fails to follow it and because, of all the terms that might be used to address the "amorphous and complete," this one has the broadest meaning. ${ }^{293}$

${ }^{293}$ Lynn's English term meaning is not associated with the hànzì used to connote what is regularly translated as such. The last excerpt in Wáng Bì's commentaries can also be thus translated:

可言之稱最大也 
In his commentary, Wáng Bì seems very direct in how he conveys what names are: “Names are used to determine forms" (ming y̌ ding xíng 名以定形). What Lynn is translating as determine, ding 定, has also the acceptations of to stabilize, to suppress, certainly, surely. In using dìng 定, it seems that Wáng Bì is giving to language a power to settle down what he calls a "form" (xing 形), but what might as well be interpreted in Western terms as an identity, a meaning. Names are ways to stabilize nature in human terms, to put things into conventional straightjackets. Because dào 道 is amorphous and indistinct, there can be no "form" (characteristic) associated with it, therefore names, ming 名, are useless.

On the other hand, zi 字, style names (in Lynn's translation), are used to designate (chēng 稱) what Lynn calls attributes, the Chinese character kě 可. This is a very common character in modern Chinese that has quite different uses in the classical language, as we briefly saw in the first excerpt from the Lăož̀. To recapitulate, Rouzer (2007, p. 37) glosses it as to be feasible, to be allowable, to be permissible, to which GH adds a few other readings, as probably, likely and to merit, to deserve, along with some other less common uses. Harbsmeier (In: Allinson, 1989, pp. 130, 136) construes a ké 可 that is somehow linked with other "Chinese notions of semantic truth," and the famous Sinologist translates it as be able to, be admissible, be logically acceptable. Harbsmeier also writes that "acceptability $(k e)$ is not the same as fitting the facts (dang). Something is ke 'acceptable, admissible' because it conforms to rules of debate." (Ibidem) Therefore, in Harbsmeier's view, one finds a rhetorical dimension to kě 可. Nonetheless, one sees in kě 可connotations of possibility and potentiality.

Writing after the Shuōwén, Wáng Bì must have been influenced by the connection of $z i$ 字 and writing. However, the Chinese author made no comment about it. One hypothesis is that $z i$ 字 became so obviously related to writing after the Shuōwén that he did not need to make any further comments. Thus, a possible paraphrase of the passage 夫名以定形, 字以稱可 is: “spoken names are used to 
fix qualities and characteristics, while hànzì are uses to designate potentialities, possibilities." The fact that $z \grave{l}$ 字are also "style names" that indicate a phase when maturity has been reached, might also allude to these new "potentialities."

\section{Chén}

我不知道它的名字, 勉强叫它作“道”, 再勉强给它起个名字 叫做“大”。

wǒ bù zhìdào tā de míngzi, miănqiăng jiào tā zuò "dào," zài miănqiăng gěi tā qŭ gè míngzi jiàozuò "dà."

I do not know its name [míng 名], reluctantly I call [jiào 叫] it “道,” and reluctantly I am forced to give it a created/raised [q̌ 起] name [mingzi 名字] [thus, I] call it "great" [dà 大].

Chén's translation does not add to the analysis that has been made so far. $\mathrm{He}$ uses the common Chinese character jiào 매, to call, as a translation for zì 字 and

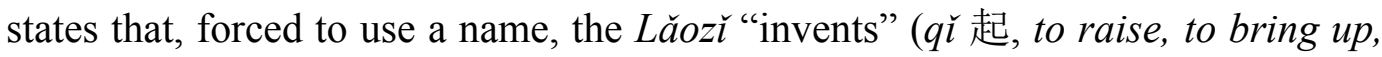
to start, to launch) the "name" (míngzi 名字) dà 大.

\section{$* * *$}

Table 16- "I style it 'Dao", - summary of the metalanguage's translations

\begin{tabular}{|c|c|c|}
\hline Source & Original text & English text \\
\hline Lăozĭ & $(w u ́)$ zì zhī yuē dào & [I] zì-ly call [it] “dào 道,” \\
\hline Lau & & I style it 'the way' \\
\hline Sproviero & dou-lhe a grafia:道Dao & [I] give it the ortography:道Dao \\
\hline Julien & $\begin{array}{l}\text { Pour lui donner un titre, je } \\
\text { l'appelle Voie (Tao). }\end{array}$ & $\begin{array}{l}\text { To give it a title, I call it Way } \\
\text { (Tao). }\end{array}$ \\
\hline Ames \& Hall & & $\begin{array}{l}\text { It I were to style it, } \\
\text { I would call it way-making (dao). }\end{array}$ \\
\hline Hansen & & $\begin{array}{l}\text { To assign an ideograph to it, we } \\
\text { say "way." }\end{array}$ \\
\hline \multirow{2}{*}{$\begin{array}{l}\text { Wáng Bì / } \\
\text { Lynn }\end{array}$} & $(w u ́) z \grave{l} z h \bar{\imath}$ yuē dào & So I style it "Dao" [Way] \\
\hline & zì yı̌ chēng kě & $\begin{array}{l}\text { style names [zi] are used to } \\
\text { designate [cheng] attributes [ke]. }\end{array}$ \\
\hline Chén & $\begin{array}{l}\text { miănqiăng jiào tā zuò } \\
\text { "dào" }\end{array}$ & reluctantly I call it “道” \\
\hline
\end{tabular}

Source: the author. 
The short excerpt translated from chapter XXV of the Lăož̀ clearly reminds us of the conundrum about the name of dào 道 from the book's first chapter. The author of the Lăozl is again faced with the impossible task of assigning a name to the unnamable dào 道. However, this chapter proposes to us a new strategy, which involves the interplay between two metalinguistic hànzì, ming 名, which we saw in chapter I, and a new one, $z i$ 字.

One is reminded that in $z \grave{l}$ 字 's grapho-etymological survey, its clear metalinguistic function was established only in the Shuōwén's postface, written some four hundred or more years after the Lăož̆ was first compiled. All its preShuōwén glosses refer to acceptations connected to birthing, breastfeeding, to raise, to rear, to bring up, etc. There are grounds to postulate that the likely derived use as style or courtesy name (of a young man reaching the age of twenty) - attested in the Shiji (between 109-91 BC), about two hundred years before the Shuōwén, but still over two hundred after the Lăož - was already an established use, or perhaps it was another use inaugurated in the Lăozl̆. One thing seems clear: at the time of the Lăož (and for a long time afterwards), zì 字 had no attested use to refer to writing or to Chinese characters.

In post-Shuōwén classical Chinese, zi 字 was both characters and birthing, as if the force behind the multiplication of the hànzì was seemingly independent of the direct control of humans. When zi 字 is bestowed upon dào 道, at first, dào 道 might appear as if it had been "tamed," but this is an illusion. “道” is pure signifier, it is the simultaneous birth of 道 (the character) and dào 道, because, as we have seen, there is no separation between them.

There are basically two ways, in my interpretation, to read this passage. First, considering $z i$ 字 a style name, a new name one gets once one has attained full maturity. This would be an interpretation contemporary with the time of the Lăož̆, and a choice of authors such as Lau, Julien, Ames \& Hall, and Chén. In a second choice, post-Shuōwén, the passage offers the contrast between the written and the spoken sphere of the Chinese language: name (ming 名, yán 言) belongs to the spoken realm, while 字-name pertains to the written sphere. This is the choice of Sproviero and Hansen. Further evidence of the MPH is given by the 
completely different ways the translators dealt with $z i$ 字's diachronic allusions. While some decided to discard the influence of the character's firm basis from the Shuōwén - given it is historically posterior to the Lăož́ - others, who were likely to be fully aware of historical distance between the Lăozl̆ and the Shuōwén, did not refrain from taking advantage of the network of allusions of the term in a free drift of signifiers. The Shuōwén and the Lăozl̆ are both formidable sources of dislocation of the metalinguistic $z i$ 字.

In the compilation of 56 translations, to style is the most often used English translation for $z i$ 字 (including authors such as Victor Mair and Paul J. Lin). Some other options are:

The word, to call (Ren Jiyu, LaFargue), to name, give it the designation (Legge); gave it the alias; use the character "Tao" to name it; attempted to designate it Tao; is the by-name that we give it (Waley); [I] label it; for the purpose here, let's call it; I have decided to call it; to label, to address it as; in a far-fetched way I name it; I call it by the by-name "Way" (Duyvendak).

It seems clear that the author of the Lăož̀ is practicing a volitional act - he apparently arbitrarily decided to call it, or to write it as, “dào 道.” As per Lăož̀ s philosophy, the name is not meant to fix or assign any semantic characteristic; it is a testimony to the arbitrariness of names, which, in this interpretation, is in quite direct opposition to the Confucian doctrine of the "Rectification of Names." To emphasize this distinction, the text chose $z i$ 字 over ming 名, the latter having been used in the Confucian discussion on names.

A name (míng 名) for the Lăož̀ has never existed (see section III.2), thus it was necessary to create one ( $z i$ 字). Similarly, in the Greeks' most ancient sources, names have always been created and never found; there were no previous names, detached from the named "things." (Gambara, In: Auroux, 1995) Later, etymology was necessary to find these lost original names. The MPH showed us the possibility to accept the radical alterity within the interstices of similarity. In the Chinese tradition characters have been created by Cāng Jié and, in accordance to dào 道's natural ways, Chinese writing gave birth (zì 字) to a multitude of characters. Chinese names, contrary to Greek names, were not proper names from 
the start, they were entirely natural. ${ }^{294}$ Grapho-etymology has, like in the Greek tradition, subsequently been used to find the "original uses" of characters. Contrastively, however, Chinese grapho-etymology is fundamentally (re)drawing a picture of the world, one where the natural patterns are harmoniously reflected in the Chinese script. Their different origins were extremely influential on how the Greeks and Chinese had each their commonsensical view on names. Proper Greek names were arguably much more strongly identified as labels ontologically fixed to the named thing. These developments provided evidence of the dissimilarity of English names as compared to zi 字 and ming 名, thus offering a support for the MPH.

Julien's notes show us how this author believed that, eventually, dào 道's characteristics might be fully described if we were to use a "correct name." The French Sinologist's words, once more, disclose his representationalist viewpoint. On the other hand, although Ames \& Hall's version used an orthodox translation, their commentaries on the impossibility of assigning a name to dào 道are signs of their alignment with a non-essentialist and performative nature of dào 道. The same could be said about Hansen's translation, which, in spite of not being compatible with the Lăozl̆'s historical context, shows the author's affiliations to the semanticist view of the Chinese language - as has been mentioned elsewhere in this dissertation.

Wáng Bìs commentaries are innovative and suggest to us a theory of names: names are used to determine forms. From what we have seen so far, names are ways through which one mistakes human-made categories for a stable nature. Whatever Wáng Bì's specific motivations may be, it is clear that dào 道 does not conform to a list of characteristics that could be fixed, but rather that it merits a designation that points to potentialities. This is perhaps motivated by the multifaceted realm of the Chinese characters, where these potentialities surpass the more limited one-dimensional realm of speech.

\footnotetext{
${ }^{294}$ Hansen (In: Allinson, 1989, p. 92; 1992, p. 46-52) argues that Chinese nouns function as "mass nouns" and therefore "do not have an intrinsic principle of individuation." (Ibidem, 1989) Thus, they function approximately as the opposite of unmodifiable propernames.
} 
The clear contrast between the metalinguistic practices of the translators is a sign that the distinct constructs of metalanguage are leading each author through different visions of language and thus provide evidence of the MPH. Although we might use our "best practices" to gauge the affinity of each author's translation in accordance to our own priorities and Weltbild, we should not value the other Weltbilder as being true or false. They are just different forms of life. Furthermore, once we accept that their different perspectives are not just signs of different and irreconcilable ideologies, they provide us with a richness of usages that arguably makes us envision a Daoist vision of language that is so paradoxically clear. $Z \grave{l}$ 字 is writing, it gives birth to language and assigns maturity: while “道” clearly cannot reduce dào 道, it is dào 道, a way whence the myriad things came, reversible, extensive and everywhere. Dào 道 is utterly common and supremely singular, since it pervades all and cannot be reduced to anything. That $z i$ 字 is used to bestow a sign of maturity to a dào 道 that is atemporal and never completed (thus, never fully mature) at the same time confounds and enlightens us, it is trivially baffling.

\section{8.}

\section{The emergence of names}

Table 17- The emergence of names - list of translations

\begin{tabular}{l|l}
\hline Lăozĭ & sȟ̀ zhì yǒu míng, míng yì jì yǒu, fú yì jiāng zhĩ zhī, zhī zhǐ suǒy̌̌ bù dài. \\
\hline Lau & $\begin{array}{l}\text { Only when it is cut are there names. As soon as there are names. One ought to know } \\
\text { that it is time to stop. Knowing when to stop one can be free from danger. }\end{array}$ \\
\hline Sproviero & $\begin{array}{l}\text { feito o corte ... logo surgem os nomes. já havendo os nomes ... aí deve-se saber } \\
\text { parar. sabendo parar ... nada periclita }\end{array}$ \\
\hline Julien & $\begin{array}{l}\text { Dès que le Tao se fut divisé, il eut un nom. Ce nom une fois établi, il faut savoir se } \\
\text { retenir. Celui qui sait se retenir ne périclite jamais. }\end{array}$ \\
\hline $\begin{array}{l}\text { Ames \& } \\
\text { Hall }\end{array}$ & $\begin{array}{l}\text { When we start to regulate the world we introduce names. But once names have been } \\
\text { assigned, We must also know when to stop. Knowing when to stop is how to avoid } \\
\text { danger. }\end{array}$ \\
\hline Hansen & As you start to institutionalize there are names. As soon as there are names, \\
\hline
\end{tabular}




\begin{tabular}{l|l}
\hline & $\begin{array}{l}\text { Generally, you really should know to stop. If you know to stop, you could avoid } \\
\text { danger. }\end{array}$ \\
\hline $\begin{array}{l}\text { Wáng Bì } \\
\text { (orig.) }\end{array}$ & $\begin{array}{l}\text { When the cutting of it starts, names come into existence. Once names exist, one } \\
\text { should know to stop. It is by knowing to stop that danger can be avoided. }\end{array}$ \\
\hline $\begin{array}{l}\text { Wáng Bì } \\
\text { (com.) }\end{array}$ & $\begin{array}{l}\text { "When the cutting of it starts" refers to when the uncarved block begins to fragment } \\
\text { and [the sage] becomes chief of officials. When he first cuts out senior officials, he } \\
\text { cannot help but set up names and ranks [mingfen] in order to establish superiors and } \\
\text { inferiors [zunbei]. Thus "when the cutting of it [the uncarved block] starts, names } \\
\text { come into existence." If he lets things go beyond this, there will be contention over } \\
\text { [issues as small as] the point of a small knife. Thus the text says "Once names exist, } \\
\text { one should know to stop." Eventually, if the names of official appointments are } \\
\text { used to address people, the mother [natural source/Dao] of government will be lost. } \\
\text { Thus "It is by knowing to stop that danger can be avoided." }\end{array}$ \\
\hline Chén & $\begin{array}{l}\text { Ten thousand thing exist, then many kinds of designations [mingchēng 名称] } \\
\text { emerge, [with] many kinds of designations, already instituted [zhiding } \text { 制定], then } \\
\text { [we] know there are limitations [xiàndù 限度], knowing there are limitations, the } \\
\text { [we] can avoid danger. }\end{array}$ \\
\hline Source: the author.
\end{tabular}

Chapter XXXII of the Lăož̀ begins with a renewal of a central statement in the Lăož́: "the way is for ever nameless" (translated by Lau). It then proceeds to one of the most original and frequently mentioned metaphors of the Lăož̆, that of the uncarved block, which was briefly mentioned in the section Righteousness and Ornaments. However, in chapter XXXII the uncarved block undergoes a dramatic change when the carving starts, driven by the formidable emergence of language.

The "cutting" (or carving) of the uncarved block is here related to the advent of names, perhaps as a precondition for their existence. The creative power of the names, however, is considered in the Lăož to be too powerful and dangerous, so much that it needs to be limited ("one should know when to stop" ${ }^{295}$ ). Wáng Bì writes that the names are associated with the development of laws and institutions and with the end of the ideal simplicity prescribed by the Lăož̆. Once there are names, preconized the Daoist doctrine, the fruitless and never-ending disputes about the correctness of names also starts, giving way as it did to bitter arguments

\footnotetext{
${ }^{295}$ We might recall Wittgentein's P.I. §133:
}

The real discovery is the one which enables me to stop doing philosophy when I want to. The one that gives philosophy peace, so that it is no longer tormented by questions which bring itself into question. 
among the many philosophical schools of classical Chinese. This chapter thus adds another layer to the reflections on names in the Lăož́.

From this chapter, I have extracted a very brief passage that describes the carving of the uncarved block, the emergence of names and a warning against its subsequent dangers:

\section{始制有名，名亦既有，夫亦將知止，知止所以不殆。 \\ shǐ zhì yǒu míng, míng yì jì yǒu, fú yì jiāng zhī zhĭ, zhī zhǐ suǒyǐ bù dài.}

Start fabricating/cutting [zhi 制], there are names [ming 名], names also then being [yǒ 有], now it is also about to know [to] stop [zȟ 止], know [to] stop, therefore not [be] defeated/harmed [dài 殆].

A brief glance over the excerpt seems to suggest a quite straightforward interpretation: once the uncarved block is cut or shaped (by human hands), nature gives way to civilization, thus names and categorization appear. But once humans have names, they also need to know how to curtail them, to keep them from distancing themselves too much from the nature-dào 道, and too much into the alluring dangers of civilization.

As seen in the table above, the authors selected for this dissertation translated míng 名 as names (Chén used modern Mandarin míngchēng 名称, which I translated as designations). Likewise, in the compilation of 56 translations, with the exception of very few authors who chose a radically different metaphorical reading of the whole Lăož́, ${ }^{296}$ almost all authors also translated ming 名as names (Han Hiong Tan used terminology; Tao Huang, rules; and Paul Carus, nameable).

One very important term for the analysis here is zhi 制. Rouzer (2007, p. 120) glosses it as to determine, to decide, to regulate, and to govern. A common added acceptation is to control (kòngzhi 控制 in modern Mandarin), to stipulate.

\footnotetext{
${ }^{296}$ Some translations, such as Lee Sun Chen Org, Thomas Z. Zhang, Shi Fu Hwang and Sum Nung Au-Young might even be called versions of the Lăozl due to the extreme latitude of interpretation they insert in their text. As we have briefly seen in the first chapter of this dissertation, in the context of the MPH, the differences between original, translation, version or re-writing is how we use each of these terms.
} 
It was also used to refer to the Emperor's commands and the observance of some ancient rites. However, the character is a cognate with another variant, zhi 製, to make, manufacture, create, initially used (according to Schuessler (2007 p. 621), and others) as "to cut out [as clothes]" and eventually to all genera of human production activities, including the production of written texts. The polysemy between to control/regulate/stipulate and to create/manufacture is relevant for this passage since it refers to the founding moment when names "appear."297 Although ming 名 is the metalinguistic term of interest to us, in this passage the key character is zhi 制, because it shows us "how" the names appear. In the compilation of 56 translations, the translators used widely distinct strategies to "explain" the metaphor:

As soon as we start to establish a system (Henricks); once the Primal Simplicity diversified; when institutions/systems begin; once there was government (Ren Jiyu); as soon as it [the directions of men] proceeds to action (Legge); when a governing blade begins carving it up; at the beginning of institution; the administration of the empire demands names; with the growth of the earliest system; in the beginning of creation (Paul J Lin); whenever a system is set up, new terminology appears; when discrimination begins (Chung-yuan); the rule must be expressed; when you organize; as soon as Reason creates order (Carus); when creation begins (Wilhelm).

The establishment of institutions, systems, regulations and laws is the most often used theme which "solves" the metaphor of cutting the uncarved block, although metaphysical interpretations are also not uncommon. A few authors, like most who will be discussed here, prefer to leave the metaphor fairly intact:

Once the whole is divided; with the final cutting; once the block is carved (Waley); as soon as one begins to divide things up (Mair); when you begin making decisions and cutting it up (LaFargue); when this simplicity is divided; start fashioning; as soon as it is carved (Duyvendack).

${ }^{297}$ A brief excursion on the etymology of English words such as control, regulate, on the one side, and manufacture, create, on the other, shows indiscernible etymological contact between these two networks of allusion. 


\section{Lau}

Only when it is cut are there names.

As soon as there are names

One ought to know that it is time to stop.

Knowing when to stop one can be free from danger.

The first sentence suggests a possible straightforward interpretation, once we admit that we are talking metaphorically about the uncarved block: once carved (or once $c u t$ ), it loses its indistinctness, its simplicity, its total homogeneity, its indeterminacy. With the translation of zhi 制 as cut, the polysemy alluded above is not apparent and we are reduced to the simple metaphor of the carved block.

\section{Sproviero}

\author{
feito o corte \\ já havendo os nomes \\ sabendo parar \\ the cut is made \\ once existing the names \\ knowing to stop
}

\author{
logo surgem os nomes \\ ai deve-se saber parar \\ nada periclita \\ soon the names appear \\ then one should know to stop \\ nothing is endangered
}

Sproviero's translation does not differ much from Lau's. It is in the author's notes that we come to understand more about his interpretation about the effect and danger of the names. Sproviero writes:

Assim que se talha o estado original, é preciso ordenar, é preciso dos nomes. Os nomes não podem perder sua referência e significado. A linguagem não deve ser excessive, antes, precisa [...] "Saber parar", além de indicar saber parar diante dos nomes, indica que se deve apartar-se do Dao, da simplicidade original, fundamento da diversidade. (Sproviero, 2007, p. 239)

As soon as the primordial state is cut, one needs to create order, one needs names. The names cannot lose their references and meaning. Language must not be excessive, but rather, [it needs to] be precise. [...] "Know to stop," besides indicating knowing to stop before the names, [it also] indicates that one should distance oneself from Dao, from the initial simplicity, [it is the] fundament of diversity. 
From his comments it is clear that Sproviero interprets the potential danger of names in their misuse, in what he calls "names without sense." His is a preoccupation shared among many Chinese thinkers who offered guidelines to the proper use of names. However, it seems that this stance is not compatible with the debate that the Lăož̆ proposes to us, that names (language) are an inevitable consequence of human life, and that once we recognize they are a human product - thus conventional and artificial - we can protect ourselves against relying too much on them. Sproviero's notes also add an odd admonishment: by writing "know to stop," the Lăož̀ is telling us that one "should distance oneself from Dao" (indica que se deve apartar-se do Dao). I have not found among other translations and studies any hint that the Lăož̀ might be suggesting keeping one's distance from dào 道 - perhaps it is the somewhat ambiguous writing in Sproviero's text that invites this interpretation.

\author{
Julien \\ Dès que le Tao se fut divisé, il eut un nom. \\ Ce nom une fois établi, il faut savoir se retenir. \\ Celui qui sait se retenir ne périclite jamais. \\ As soon as Tao was divided, it had a name. \\ This name, once established, it is necessary to know to stop. \\ The one who knows to stop is never in danger.
}

Julien equates the uncarved block with the Tao itself, which has been split, divided and carved. However, from his translation, this inaugurating moment did not trigger the appearance of names, but rather it was Tao's name that was supposedly created. Julien assumes that the "Tao without a name" was the one before the impact of life (the division). It was then forever changed, having lost is simplicity and indistinctness, becoming split, categorized, named, thus giving way to all Beings. There is here a quasi-religious moment of the birth of life, similar to some translations in the compilation of 56 translations, especially the oldest ones, such as those of Carus (1898) and Wilhelm (1910). Names (ming 名) are used to stand for life and for the sensible world. The same Christian motivation that led Julien to interpret this moment as a metaphor of the Christian Creation, also led him to judge that in order to "know how to restrain" (in the face of life) 
Il ne faut pas se laisser entraîner et séduire par des choses sensibles, il faut rester dans une quiétude parfait et se suffire à soi-même; alors on ne sera exposé à aucun danger. (Julien, 1842, p. 122)

One should not let be led and seduced by the sensible things, one should rest in perfect quietness and be sufficient in one-self; then one would not be exposed to danger.

One final translation note: the translation of se retenir as to stop is justified by Julien's own notes: “alors is faut savoir s'arrêter" (therefore one must know [when] to stop).

\section{Ames \& Hall}

When we start to regulate the world we introduce names.

But once names have been assigned,

We must also know when to stop.

Knowing when to stop is how to avoid danger.

Ames \& Hall's translation is supplemented by the authors' interpretation of the carving of the uncarved block as the inevitable regulation of the world. In their notes, the authors explain why names must be introduced and why they are potentially dangerous:

In order to function effectively in managing our environment, we need distinctions. These distinctions in themselves are functional and enabling, but once established, can take a life of their own. We quickly fall into the trap of turning names into things, so that these names identify some more real "I-know-not-what" that stands independent of the now "superficial" way in which we actually experience any particular event. (Ames \& Hall, 1993, p. 127)

Thus names are, for Ames \& Hall, the necessary artificial distinctions of nature. For these authors the danger lies in considering these distinctions as "with a life of their own," that is, as ontological, fixed categories of reality, "deeper" than the empirical reality or "more real" than our senses. 


\title{
Hansen
}

As you start to institutionalize there are names.

As soon as there are names,

Generally, you really should know to stop.

If you know to stop, you could avoid danger.

\section{For Hansen}

\begin{abstract}
'carving' in the metaphor symbolizes the social distinctions governing the uses of names [...] the uncarved block is the metaphor for the state prior to this socialization, which works by the contrast of a natural object (wood) and the utensil or implement produced by carving it. (Hansen, 2009, p. 228)
\end{abstract}

The author emphasizes that implements (such as a block of wood or a rod of iron) are originally natural substances, which are then used and shaped to serve social and artificial needs. Implements thus are relative to both the social and the natural spheres. Once carved (that is, belabored by human hands and intellect), they became artificial and named objects, whose identity relies on the uses humans have for them, they gain new potentialities and capabilities that are referred to and associated with their new names, thus they can be labeled, ranked,

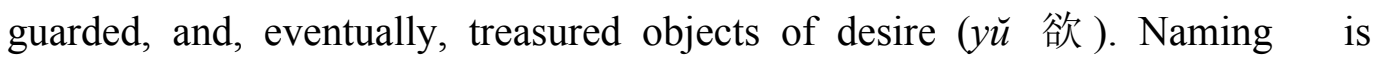
inextricably linked to the human-made artificial use of utensils, as well as to natural things categorized by humans Thus we can construe the parallel of naming and shaping and understand how Hansen translated zhi 制 as institutionalized.

\section{Wáng Bì}

始制有名，名亦既有，夫亦將知止，知止所以不殆。「始 制，謂樸散始為官長之時也。始制官長，不可不立名分以定 尊卑，故始制有名也，過此以往將爭錐刀之末，故曰，名亦 既有，夫亦將知止也，遂任名以號物，則失治之母，故知止 所以不殆也。」

shǐ zhì yǒu míng, míng yì jì yǒu, fū yì jiāng zhī zȟ̆, zhī zhǐ suǒ yǐ bù dài. [shǐ zhì, wèi pŭ săn shĭ wéi guān cháng zhī shí yě. shĭ zhì guān cháng, bù kě bù lì míng fên

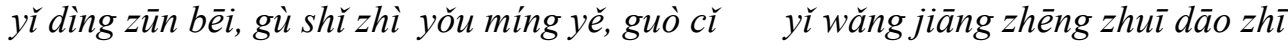


mò, gù yuē, míng yì jì yǒu, fū yì jiāng zhī zhǐ yě, suì rèn míng y̌̀ hào wù, zé shī zhì zhī mǔ, gù zhī zhǐ suǒ y̌̀ bù dài yě.]

When the cutting of it starts, names come into existence. Once names exist, one should know to stop. It is by knowing to stop that danger can be avoided.

"When the cutting of it starts" refers to when the uncarved block begins to fragment and [the sage] becomes chief of officials. When he first cuts out senior officials, he cannot help but set up names and ranks [mingfen] in order to establish superiors and inferiors [zunbei]. Thus "when the cutting of it [the uncarved block] starts, names come into existence." If he lets things go beyond this, there will be contention over [issues as small as] the point of a small knife. Thus the text says "Once names exist, one should know to stop." Eventually, if the names of official appointments are used to address people, the mother [natural source/Dao] of government will be lost. Thus "It is by knowing to stop that danger can be avoided."

The commentator Wáng Bì offers an extensive note to explain this brief passage. He explains the metaphor of the "cutting of the uncarved block" by inserting the figure of the "chief of officials" (guānzhăng 官長). It is through this military ranking process that Wáng Bì demonstrates the categorizing power of names, by creating “seniors and junior (ranks)" (zūnbēe 尊卑). As for the dangers of names and knowing when to stop, at first it seems that Wáng Bì limits them to occasional "contentions over small or petty issues" (here Wáng Bì uses what has become a “fixed expression” in the Chinese language zhui dāo zhī mò 錐刀之末, lit. the tip of a small knife). Later in his comment, it becomes clear that there lies a more threatening danger therein:

遂任名以號物

suì rèn míng yĭ hào wù

in the end, [if] names of terms of office [are used as] designation [號hào] of things [the mother of government will be lost] (my translation)

That is, with the (continuous) use of names of rank to address people, names become fixtures and eventually take the place of "things," in a turning point where names become, mistakenly, considered eternal, and not conventional and artificial designations. 


\section{Chén}

万物兴作就产生了各种名称, 各种名称已经制定了, 就知道
有个限度, 知道有所限度, 就可以避免危险。 wànwù xīng zuò jiù chănshēngle gèzhŏng míngchēng, gèzhǒng míngchēng y̌̉jīng zhìdingle, jiù zhīdào yǒu gè xiàndù, zhīdào yǒusuǒ xiàndù, jiù kěy̆ bìmiăn wēixiăn.

Ten thousand things exist, then many kinds of designations [mingchēng 名称] emerge, [with] many kinds of designations, already instituted [zhiding 制定], then [we] know there are limitations [xiàndì 限度], knowing there are limitations, the [we] can avoid danger.

Chén translates ming 名as designations, mingchēng 名称, much in line with previous translations seen above. The dangers (weixiăn 危險 ) of these “designations” appear once they become fixed or instituted (zhiding 制定) and start to present limitations (xiàndì 限度) in themselves (what Ames \& Hall called "with a life of their own"). One must acknowledge that these limitations are illusory, are a product of our civilization's institutionalization of names and categories. From his translation, we see that Chén is very much in line with the analysis of Wáng Bì, Hansen and Ames \& Hall.

\section{$* * *$}

Table 18- The emergence of names - summary of the metalanguage's translations

\begin{tabular}{|c|c|c|}
\hline Source & Original text & English text \\
\hline Lăož̆ & shǐ zhì yǒu míng & Start fabricating/cutting, there are names \\
\hline Lau & & Only when it is cut are there names. \\
\hline Sproviero & $\begin{array}{l}\text { feito o corte, logo } \\
\text { surgem os nomes }\end{array}$ & the cut is made, soon the names appear \\
\hline Julien & $\begin{array}{l}\text { Dès que le Tao se fut } \\
\text { divisé, il eut un nom. }\end{array}$ & $\begin{array}{l}\text { As soon as Tao was divided, it had a } \\
\text { name. }\end{array}$ \\
\hline $\begin{array}{l}\text { Ames \& } \\
\text { Hall }\end{array}$ & & $\begin{array}{l}\text { When we start to regulate the world we } \\
\text { introduce names. }\end{array}$ \\
\hline Hansen & & $\begin{array}{l}\text { As you start to institutionalize there are } \\
\text { names. }\end{array}$ \\
\hline \multirow{2}{*}{$\begin{array}{l}\text { Wáng Bì / } \\
\text { Lynn }\end{array}$} & shǐ zhì yǒu míng & When the cutting of it starts \\
\hline & $\begin{array}{l}\text { wèi pù săn wèi } \\
\text { guānzhăng zhī shi yě }\end{array}$ & $\begin{array}{l}\text { refers to when the uncarved block } \\
\text { begins to fragment and [the sage] } \\
\text { becomes chief of officials. }\end{array}$ \\
\hline Chén & $\begin{array}{l}\text { chănshēng le gèzhǒng } \\
\text { míngchēng }\end{array}$ & $\begin{array}{l}\text { [then] many kinds of designations } \\
\text { [mingcheng 名称] emerge }\end{array}$ \\
\hline
\end{tabular}

Source: the author. 
This very short excerpt provides a metaphorical (mythical?) account of the emergence of names in the Lăož̆ and its potentially dangerous consequences. The main focus of this dissertation lies not in what the text prescribes against the "dangers of names," but rather on how the translators approached the metalanguage of the passage and the implicit vision of language in each of their strategies.

As discussed above, in the founding moment when names “appeared” $z h i$ 制 played a particularly prominent role. The polysemy of the character involving control and regulation together with (human) creation is a sign of a Chinese Weltbild where human activity inevitably leads to control and regulation and might be a testimony to the inaugurating force of the Lăož in the Chinese language. The survey of the compilation of 56 translations showed that the translators chose to equate the emergence of names (language) with the establishment of institutions, systems and laws. As we have seen, although not a metalinguistic term, zhi 制's polysemy in Chinese differs radically from the network of allusions of its translated terms in the West. Such distinction, in the context of this passage of the Lăožl, is a symptom of the Chinese viewpoint that associates clearly coercive and guiding qualities with language, as it has been repeatedly mentioned in this dissertation.

Julien's translation and commentaries distance this inaugurating moment from the advent of names: instead of the general institution of names, it was only dào 道 which begot a name, opening the chance for the emergence of life. Furthermore, its danger is not related to the misuse of names, but rather to the seduction by the sensible things, a plausibly Christian theme. In contrast to the other authors, this is hardly a myth of the birth of language.

Sproviero's commentaries are also frankly embedded in the Western tradition, when he writes, for instance, that the danger with names arises because they "cannot lose their references and meaning" and that they "must be precise." The implicit admonition is that the meanings of the words must be fixed and agreed between all people. Sproviero's conclusion is almost the exact opposite of Ames \& Hall's, Wáng Bi’s, and even Chén's. For these three authors, what we should be aware of is the "trap of turning names into things," the peril to perceive 
names as having some sort of independent ontology, a fixed reality, to forget that names are contextual, ideological and historical. This view of language resonates strongly with the MPH and the Wittgensteinian view of language.

Hansen's notes, although in general agreement with Ames \& Hall and Wáng $B i$, have more far-reaching consequences: language is inextricably linked to the artificial use of utensils, and if one considers that utensils are a metonym for all sorts of artifacts produced by civilization and, eventually, a metaphor for civilization itself, the identity of civilization relies on the name given to its innumerous artificial categories. There is clearly a relativist interpretation possible with Hansen's translation, which is perhaps counterbalanced by the author's defense of the natural guidance of dào 道, seen elsewhere in his writings.

There is a fairly widespread consent among the translators that names are restless in their conventional confinement. The fact that "once there are names, there is danger" indicates a situation where names were born as a necessity of the drive of humans to regulate and make ( $z h i$ 制) the civilized (human) world; ${ }^{298}$ and subsequently, it became clear that humans inevitably fail in their control (zhi 制) over language and names. It is a picture in close consonance with the $\mathrm{MPH}$, Taylor's "rhetorical origin of linguistics" and Harris "myth of language," and reminds us of the Wittgensteinian language as form of life.

\footnotetext{
298 There is an implicit telos of names alluded in this passage and accepted by all authors, including Ames \& Hall and Hansen. Although names (ming 名) here might be considered as a metonym for language (yán 言, dào 道) - so that the passage would indicate the Lăož̀s argument of a telos of language - we should remember that this is a metonym motivated by the Western commonsensical view of language as a tool of representation. If we accept that dào 道 is discourse, thus language, we have seen in section III.2 that ming 名 does not "reach" dào 道. One of this dissertation's ambitions, I hope, is that its reader should be careful about juggling with metalinguistic terms.
} 


\section{9}

"Right words in reverse"

Table 19- "Right words in reverse" - list of translations

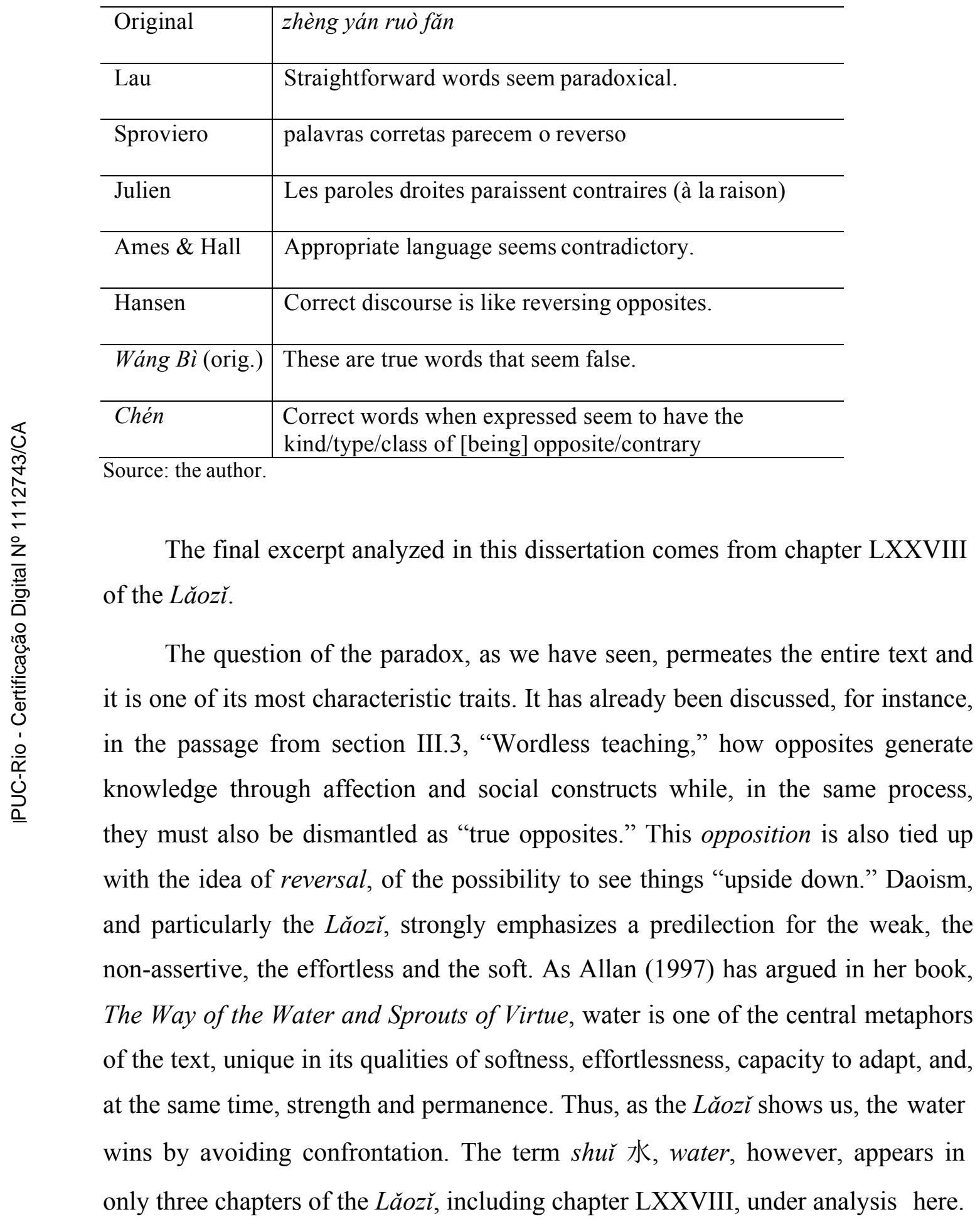


The chapter describes the appealing nature of water and then presents the image of the sage-ruler, the one who must act and teach "like water."299

It is in this context that we read how this chapter ends with the enigmatic phrase: right words seem to reverse. The short excerpt is:

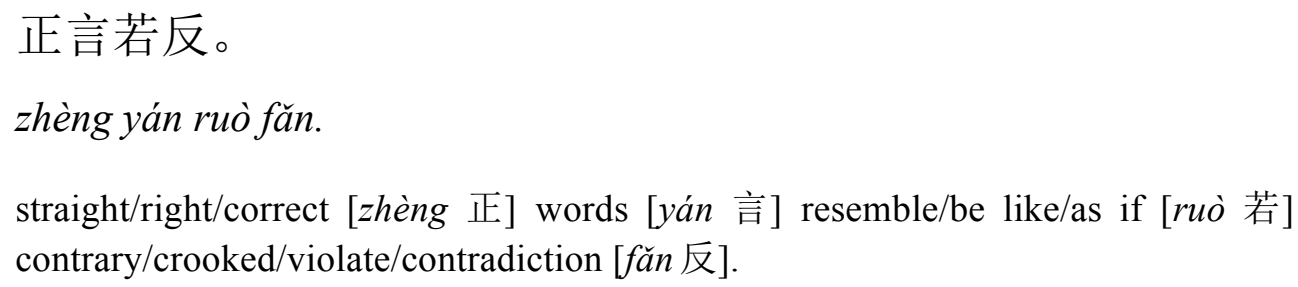

Similar to many other passages from the Lăož̆, there is a trivial interpretation to this passage, which could be paraphrased as "words could be deceiving." In another straightforward interpretation, the correct discourse, which one should adopt, is often the one that is most difficult to understand, and, therefore, appears in contradiction, appears incorrect. This could easily be a commentary on the Lăož̀ itself, which claims to be a correct and true text, though consisting of a seemingly contradictory one. It might as well be another way to characterize language through the lenses of the MPH.

In the last chapter (LXXXI) of the Lăožl, there is another passage that similarly warns us against the (potentially deceitful) appearance of words:

信言不美，美言不信。善者不辯，辯者不善。知者不博，博 者不知。

xìn yán bù mèi, měi yán bù xìn. shān zhe bù biàn, biàn zhe bù shān. zhī zhe bù bó, bó zhe bù zhī.

Truthful [xin 信] words are not beautiful [měi 美]; Beautiful words are not truthful. Good [shān 善] words are not persuasive [biān 辯]; Persuasive words are not good. He who knows [zh̄̄ 知] has no wide learning [bó 博]; He who has wide learning does not know. (translated by Lau)

\footnotetext{
${ }^{299}$ Remember also in the section "wordless teaching" how the Lăozĭ described the sage's teaching as not consisting of words.
} 
This passage could be read as an explicit attack on rhetoric, a sign of mistrust towards any text that relies on the use of the "beautiful words" for dramatic impact - in a remarkable coincidence with the Greek Platonic tradition's attacks against the Sophists and their "sophistry." In the context of the Lăož̆, however, we can identify what Hansen calls Daoism's anti-language viewpoint: a stance not against language in itself, but against the danger of the imposition of order by force, the perils of taking social constructs as if they were unquestionable realities. ${ }^{300}$ It is a crusade against the false "sage," the one who pretends to have the patina of the authority, the airs of the "learned man," which would grant him or herself the ability to teach others about the world.

As is common throughout the Lăož̆, this is not the only possible reading of this passage. ${ }^{301}$ However, this brief discussion prepares us for the arguments that follow, as we return to the analysis of the brief excerpt from chapter LXXVIII of the Lăož̀.

The characters of zhèng 正and făn 反 themselves deserve some study, being here directly related to the reflections of the Lăož̆ on language. I will present a very short grapho-etymological analysis which focuses on the relation between făn 反and zhèng 正.

In the Shuōwén we read:

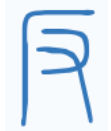

覆也。从又, 厂反形。

fù yě. cóng yòu, cháng făn xìng

${ }^{300}$ See this discussion in the previous section on the "emergence of names."

${ }^{301}$ Harbsmeier (In: Allinson, 1989, p. 132) analyzed an excerpt of the Héshàng Gōng (and many commentaries) defending the "Chinese concept of truth." Héshàng Gōng’s passage reads:

信言者如其實也

xìn yán zhè rú qi shí yĕ

Which the Sinologist translates as: "Truthful words' correspond to the reality concerned." This passage, according to him, "leaves little doubt as to how he understands Laozi at this point." [that is, truth is the correspondence of words and reality]."(Ibidem) 
[As for făn 反], to return, to answer, to turn over, to ruin, to reverse [fü 覆]. From repeat, again, moreover [yò 又] and from cliff, shed, workshop [chăng 厂], a form [which appears] inverted [făn 反].

Many scholars interpret the LS character as a stylized pictogram of a hand throwing a rock over a cliff. The allusion of what is "turned over" becoming lost or ruined is inextricably linked to earlier uses of the character, thus its direct and frequent opposition to zhèng 正, complete, right and correct. The subsequent translations to English as contradictory involve a strong logical allusion that seems absent in the Chinese tradition. ${ }^{302}$ Zhèng 正, as we have seen before, carries the force of prescriptive action, of how one must behave in accordance to customs (sú 俗) and ritual (li 禮), and therefore has a strong import in Confucian ethics. At the opposite pole, făn 反 became an expected Daoist reaction: the rejection of the ritual and of authority as non-natural imposed coercion, thus a "return" to what has been discarded and forgotten by the Confucian tradition. This interpretation has a deep impact on the reading of the short passage under scrutiny.

Furthermore, făn 反 appears prominently in another passage in the beginning of the Lăozl̆'s chapter XL:

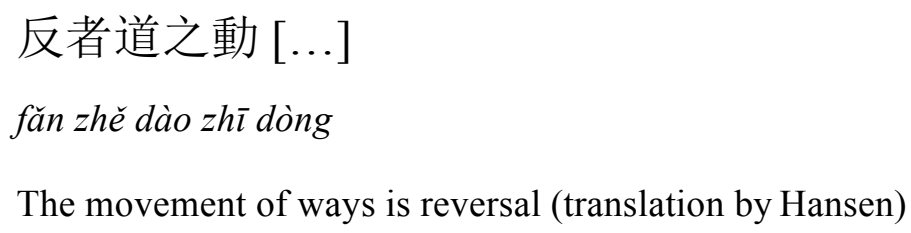

This "reversal" is often also translated as returning, contrary, turning back and some authors connect it with a cycle movement (a reference to the Yijing). ${ }^{303}$ It can be read as one returning on dào 道's path, or the reversal of the path itself. In any case, it provides us with another indirect connection between yán 言 and dào 道.

\footnotetext{
${ }^{302}$ For the question of logic in ancient China, see the end remarks on ming 名 in chapter II of this dissertation.

${ }^{303}$ Ames \& Hall (2003, p. 215) remember that in the Guōdiàn the hànzì used is fán 返, thus "reinforcing the choice of 'returning' over 'reversing' in describing the movement of dao." (Ibidem)
} 
Once again, we resort to the compilation of 56 translations for the many choices of the translation of ruò făn 若反 (be like/appear făn 反) in chapter LXXVIII of the Lăož̆, where the predominance of appear/seem paradoxical and reverse does not hinder many alternative expressions:

\begin{abstract}
Seem to say the reverse (Henricks); sounds like/seems its opposite (LaFargue, Wang-tsit Chan); appear to reverse themselves; [positive words] seem to be negative (Jiyu); often sounds paradoxical; seems to be wrong; sound like nonsense to present-day people; [words of clarity] sound confused; appear antithetical [to the established belief]; appear to be controversial; seem false; seem crooked (Waley); seem contradictory (Mair); seems often paradoxical and against common sense; [factual words] seem ironical; seem the most absurd; are as if contrary(Wilhelm).
\end{abstract}

The negative allusions (wrong, false, confused, crooked, absurd, ironical), although not exactly motivated in the context of the Lăož̆, find arguable support in the brief grapho-etymological exposition above, and are prominent in this list.

\title{
Lau
}

Straightforward words seem paradoxical.

Lau's translation does not add to the analysis above. Both English words straightforward and paradoxical do not have the connotations of prescription that was commented above, but are acceptable and common translations of the Chinese characters. It is perhaps the most common standard of translation of the passage and does not carry strong negative overtones against the "Straightforward words."

\section{Sproviero}

palavras corretas parecem o reverso.

correct words seem the reverse.

Sproviero's translation seems more adequate than Lau's in his choice of words: while correct has a stronger nuance of prescription, reverse has a weaker logical connotation. A paraphrase of Sproviero's passage could be "correct words seem incorrect," that is, the words and rituals that the State prescribe as correct 
are quite the opposite, and in that blatant opposition, the idea of "correctness" itself breaks apart: correct is what one calls correct.

\begin{abstract}
Julien
Les paroles droites paraissent contraires (à la raison).

The right words seem contrary (to reason).
\end{abstract}

The addition of "to reason" between parentheses is immensely relevant for the interpretation of Julien's translation. In his commentary, the author claims that the seemingly absurd nature of the words is apparent only from the point of view of the masses (point de vue de la foule), but not from the point of view of the sages (whom Jullien calls le Saint). Although this interpretation appears amicable to some sort of perspectivism, such would be a superficial reading, since, on Julien's commentary, the sages are the ones who have the monopoly of the correct words and the masses only misinterpret them.

One could argue that Julien is defending the validity of the Lăož̆, which has often been criticized for its "mysticism" and lack of rigorousness of logic. Julien is claiming that this is a misreading from the "point of view of the masses," and the sages, the ones who have been enlightened by dào 道, know its true meaning. However, from what we have seen of the Lăozl̆ so far, if it were the case that some kind of "correct" meaning could be established, the whole purpose of the book would perhaps be defeated.

\title{
Ames \& Hall
}

Appropriate language seems contradictory.

Ames \& Hall suggested appropriate as the term translated from zhèng 正, which gives perhaps a better sense of the use of the term in the context of Confucian thought. The Lăož̀ stands in reaction to what is "appropriate" when its appropriateness becomes state enforced dogma, a sort of Orwellian Newspeak. ${ }^{304}$

${ }^{304}$ Remember that in section III.5, Righteousness and Ornament, Ames \& Hall translated yi 義 as appropriateness. In that passage, the Lăož̆ suggested that $y \grave{\imath}$ 義ought to be discarded. 
As for the translation of its opposite, făn 反, the authors chose contradictory, which also carries a logical overtone and somewhat weakens the explicit paradox.

In their commentary on this chapter, Ames \& Hall (2003, p. 198) argue that this passage also refers to the inseparability of opposites (see section III.2, the unlanguaged dào 道?) and the impossibility of a true, literal and universally specific language, thus reinforcing what has been analyzed above in the opposition of zhèng 正 and făn 反.

\section{Hansen}

Correct discourse is like reversing opposites.

Once again, Hansen's translation is clearly subversive, particularly regarding the second part of the excerpt. The scholar translates zhèng 正 as correct (like Sproviero), which has some prescriptive overtones, but it is in the translation of făn 反 that the author innovates with a "double" reversion: "reversing opposites." Again, there is a quite trivial reading of Hansen's line: in dào 道-discourse (that is, the correct discourse), the common-sensical opposites are reversed (for instance: the weak prevails over the strong, the low is chosen over the high, etc.). This reading is much in accordance with what has already been noticed of the predilection of the Lăozl̆ for the weaker, softer and feminine side against the stronger, harder and masculine. However, a much more radical reading would imply that the prescribed discourse (the one of the rulers who do follow dào 道) is inherently reversed/reversible, that is, language's opposites (what we can contextually recognize as wrong) are immediately reversed in their quality, thus being (also contextually) recognized as right. In this theoretical viewpoint, there is no absolute right or wrong, no clear distinction between zhèng 正and $f a ̆ n$ 反. ${ }^{305}$

${ }^{305}$ However, Hansen's analysis of făn 反 in chapter XL of the Lăozĭ reinforces the author's interpretation that "a natural (and prescient) guide can value the opposites of these constructs. Good advice frequently tells us to reverse conventional wisdom." (Hansen, 2009, p. 233) 


\section{Wáng Bì}

Wáng Bì did not append any commentary to this short passage, therefore this translation says more on Lynn's interpretation than on Wáng Bi:

\section{正言若反。}

These are true words that seem false.

In Lynn's translation, the force of the paradox is obviously lost and the passage becomes a simple declarative sentence, which could be paraphrased, for instance, as, "Lăozl̆'s words, although appearing to be incorrect or false, are nevertheless true." Lynn also makes a commentary quoting a well-known Chinese scholar, Qián Zhōngshū 錢鍾書 (1910-1998), who is critical of the Lăož̆ and considers this passage an example of the "mystic's tendency to use the rhetoric figures of paradox and oxymoron." The widespread predisposition to read the Lăož̆ as a mystical book, with all its implications, is much criticized by other scholars who read in it a coherent and logical (with its implications) text, such as Hansen (1992, p. 225), for example.

Looking for the voice of Wáng Bì which might helps us in assessing his reading of the passage in question, we turn to the chapter XL of the Lăož́, where Wáng $B \grave{i}$ wrote the following commentary on $f a ̆ n$ 反:

\section{有以無為用，此其反也。 \\ yǒu y̌̃ wú wéi yòng, cĭ qí făn yě.}

What exists becomes useful by making use from what does not exist. This is what is meant here by "reversion." (translated by Lynn)

It is indeed a seemingly paradoxical way to refer to făn 反, a bridge between yǒu 有 (be, to have, being) and wú 無 (not to be, not to have, beingless). Using both passages above together it is possible to create a hypothetical observation based on Wáng Bìs commentaries: "Words that are zhèng 正 (straight, correct, honest, right) seem to be words that make useful what we have (what exists) by 
using what we do not have (what does not exist)." In a possible interpretation, words are the space where contradictions thrive.

\title{
Chén
}

\author{
正道说出来就好像是相反的一样。 \\ zhèng dào shuōchūlái jiù hăoxiàng shì xiāngfăn de yīyàng. \\ Correct words [zhèngyán 正言] when expressed seem [hăoxiàng 好像] to have the \\ kind/type/class/appearance [ȳ̄yàng 一样] of [being] opposite/contrary [xiāngfăn 相 \\ 反].
}

Chén (2006, p. 339) explains that the right words (zhèngyán 正言) are the words associated with dào 道 and that its language is such that they appear to be contrary to the discourse, that is, they seem to be contradictory, paradoxical. The author also mentions the Héshàng Gōng commentaries of the Lăož̆,

\section{此乃正直之言，世人不知，以为反言。 \\ č̌ năi zhèngzhí zhī yán, shìrén bùzhī, y̌̌wéi făn yán.}

These are the correct words. The men of the world do not know this. Therefore they think them perverted. (translated by Erkes)

Erkes translated făn 反 as perverted, which at his time of writing (1945) might not have had the same strong moral connotations as today. ${ }^{306}$ As we have seen in the previous translations, it appears to be more sensible to translate făn 反 as opposite/contrary. If we substitute Erkes' perverted by contrary, Héshàng Gōng's commentary gives support to Julien's own notes (just exchange Julien's "point of view of the masses" by Héshàng Gōng's "men of the world"). In any case, the monopoly of the "correct words" supposedly belongs to a class of enlightened sages.

\footnotetext{
${ }^{306}$ Partridge (2006, p. 3676) notes that pervert has its etymological roots in Latin uersāri, to be situated or occupied, which has the compound conuersāri, to associate with, then conversation. The addition of the prefix per- implies to turn (thoroughly), whence to cause to turn outbad.
} 
Another commentator quoted by Chén (Ibidem, p. 339) wrote that the “suitable correct words of dào 道 appear distorted/contrary ( $f a ̆ n$ 反) to the human ears"; and another wrote that these "contrary words" refer exactly to the long list of contradictions and paradoxes that are spread throughout the Lăož̆, and part of the "meaning of the profound and abstruse words" of the text. I would take it that these commentaries are less than willing to accept that paradoxical words might be perfectly correct ones.

Table 20- "Right words in reverse" - summary of the metalanguage's translations

\begin{tabular}{|c|c|c|}
\hline Source & Original text & English text \\
\hline Lăož̆ & zhèng yán ruò făn & $\begin{array}{l}\text { right/correct words resemble/be like } \\
\text { contrary/crooked/contradictory }\end{array}$ \\
\hline Lau & & Straightforward words seem paradoxical. \\
\hline Sproviero & $\begin{array}{l}\text { palavras corretas parecem o } \\
\text { reverso }\end{array}$ & correct words seem the reverse \\
\hline Julien & $\begin{array}{l}\text { Les paroles droites paraissent } \\
\text { contraires (à la raison) }\end{array}$ & The right words seem contrary (to reason) \\
\hline $\begin{array}{l}\text { Ames \& } \\
\text { Hall }\end{array}$ & & $\begin{array}{l}\text { Appropriate language seems } \\
\text { contradictory. }\end{array}$ \\
\hline Hansen & & $\begin{array}{l}\text { Correct discourse is like reversing } \\
\text { opposites. }\end{array}$ \\
\hline $\begin{array}{l}\text { Wáng Bi / } \\
\text { Lynn }\end{array}$ & zhèng yán ruò făn & These are true words that seem false. \\
\hline Chén & $\begin{array}{l}\text { zhèng dào shuōchūlái jiù } \\
\text { hăoxiàng shì xiāngfăn de } \\
\text { yīyàng. }\end{array}$ & $\begin{array}{l}\text { Correct words when expressed seem to } \\
\text { have the kind/type/class of [being] } \\
\text { opposite/contrary. }\end{array}$ \\
\hline
\end{tabular}

Source: the author.

This small excerpt has at its centerpiece the question of language and words. One can read many subtexts in the passage: literal vs. metaphorical, truthful vs. deceitful, right vs. wrong. Once again, the Chinese metalinguistic hànzì is yán 言, usually translated as words.

The direct parallelism of two important characters zhèng 正 and făn 反, prepares the reader for what can be read as a metaphor of the Confucionist/Daoist debate, a controversy which involves the established discourse and the proposal of an alternative way. It gives evidence that this is a political and ideological passage. Făn 反 opens the possibility to "turn things over," to menace the status quo. The 
translators' metalinguistic use of yán 言 was particularly rich and varied in this short passage, which provided further evidence supporting the MPH.

Chén's and Julien's translations are the ones which clearly assume that there is indeed a "correct" meaning for words, and that it is limited to the sages and not accessible to the "point of view of the masses" or the "men of the world." Language, in this view, is likely to be considered a system of representation, in which "unfathomable" truth lies in the hands of the enlightened elite. As for Wáng $B i$, he does not insert a commentary after this short passage, therefore we had more to say about Lynn's point of view. The translator's comments and English text based on this short excerpt imply a truth-oriented view of language, where the paradox of truth and falsity has been used as a rhetorical device. Wáng Bìs commentary from chapter XL of the Lăož presents us with an eloquent and poetic line that can be interpreted much in a perspectivist manner: the encounter of not have and have are incredibly productive and are indeed a source of the correct words.

For Ames \& Hall, the alleged essentialist foundations of language are more explicitly denounced when zhèng 正 is translated as appropriate. A paraphrase of their translation of the passage, language is appropriately contradictory, or, contradiction is part of language, points to the impossibility of a truly literal language. This reversal of representationalist expectations on language is even more pronounced in Hansen's translation and commentaries.

We have seen how this passage of four characters is at the same time very trivial and profoundly impenetrable, in a way mirroring the writings of Wittgenstein and the perception that the boundaries between the trivial and the profound are, in accordance with perspectivism, as hard to pinpoint as those between ugly and beautiful, right and wrong, true and false. Even the more "conventional" translations, such as Lau's and Sproviero's, offer to us the possibility of two quite opposite readings: 1) words, although conceivably correct and meaningful, can be deceiving; and/or 2) there is no such thing as a "correct" word, because even words that seem correct, might not be. In reading (1) we find clear parallels with the Western mistrust of language, from the Greeks to Locke. On the other hand, in reading (2) meaning as a concept seems to fall apart. There 
is an obvious risk of relativism and of sophistry (in its negative connotation); however, the fact that, in the translators' words and commentaries, we are able to envision tendencies to one or the other direction and different reactions to the metalanguage of the Lăož̆, shows us their metalanguage repertoire is fundamentally diverse, as expected per the MPH.

3.10.

\section{Overview of this chapter}

The translations selected in this chapter have shown a contrast that was certainly expected in a text with such latitude of interpretation. However, the objective of this chapter was not limited to such a trivial observation. The analyses have also succeeded in showing that the way the translators dealt with the metalanguage within the context of the Lăožr - that is, in situations of actual use - provided sufficient evidence of (radical) differences in their metalinguistic practices, as expected per the MPH. Furthermore, as I have argued, such differences not only resulted from distinctive ideological contexts or motivations, but also, when read through the magnifying glasses of each other, have acted as evidence of the incredible capacity of such encounters to dislocate such entrenched ideologies, as well as to reveal their own limits and inadequacies.

The text's great succinctness and insoluble ambiguities, shown through its own language and textual structure, acts as an admonishment to moderate our ambitions. The Lăož appears to be a text that is not to be solved. This reflects Cavell's opinion that language's ambiguities are perhaps what provide it its power of illumination and of enriching perception.

Starting in the first passage, we read that verbal and nominal are clearly construed categories. That, in itself, might not be a novelty for those who study classical Chinese, but it has been given tremendous emphasis in the sequences of the three dào 道's (language, the way, ways) and three ming 名's (names, to call). There is nothing in the text that marks their difference, and we, as readers, are led by the text to assign categories in order to make the text intelligible for us. 
Although the coercive force of the text led us to consider the "2 $2^{\text {nd" }}$ dào 道's and ming 名's as (Western) verbs, we have seen how Boodberg's convoluted translation is testimony to the struggle of the author to reject such categorization.

One of the key issues regarding dào 道's languaged nature is whether to considered it a metaphysical eternal and constant entity or, on the contrary, to argue that the existence of such entity is simply not sustained in the Lăož́. Although the passages analyzed here seem to point to the latter, what is most relevant in terms of support for the MPH is that such contrasting views are possible, the result of the incredibly productive encounters of different traditions and histories.

The paradox of wordless teaching (bù yán zhī jiào 不言之教), seen in section III.3, emerges in the parallel construction of chapter II of the Lăož̀ as an unlikely paradox. The fact that "wordless teaching" can be considered in a trivial way (compare, for instance with "teach by example"), but also in this more profound way, makes us think about dào 道: if dào 道 is language and it is the ultimate teacher (guidance), how can one teach without words? This is why Hansen writes that Daoism is a dào 道 about dào 道, which ultimately teaches us not to teach (or not to learn). That in these lines teaching is equated with words, and because the prescriptive nature of language is so ominous in the Chinese tradition, builds up a complex network of allusions that is foreign to the Western tradition. Finally, the mere fact that it can be perceived as a paradox in Chinese, but not necessarily in an Indo-European language such as English, stands for further evidence of the MPH.

In Creating words for dào 道 (III.4) we are tricked by our own physical senses in attempting to assess dào 道. Why then, would the Chinese not employ logical reasoning and thus develop a "true" philosophical inquiry? It happens that the "physical senses" could not be disentangled from the intellect in ancient China and no rational thought was devoid of feelings. The ways to reach dào 道 cannot be divided into empirical and rational categories, lest we risk the danger of perceiving names as ontologies. The fact that the Lăož̀ creates idiosyncratic names as marks of the incongruity of the senses when dealing with dào 道 is a 
strong indication of an affinity with the Wittgensteinian notion that words are what we call them.

Names, in the context of the Lăož̆, are not just manipulated to fit one's purposes. In the passage The emergence of names (III.8), the names emerged from the necessity of humanity to control and to make (zhi 制) the world civilized, however, once existing, humans were not in control (zhi 制) anymore.

The reader in China must feel shocked by the opening lines of the section Righteousness and ornaments (III.5): Discard wisdom! Cut off benevolence and the sage! The text is not only moving against Confucian values, but is also explicitly encouraging us not to confuse names with eternal categories, and in doing so uses no less a hànzì than the venerable wén 文 of Chinese culture and patterns of nature. One would feel hard-pressed to imagine examples that are more striking to show the radical view of the Lăož against considering anything at its face value. Moreover, we see again how the translators have different approaches to wén 文, on some occasions accepting its open metalinguistic appurtenance, and on others using a Western metalinguistic term that serves a clearly different function as expected in the passage of the Lăož̆.

We can also recall how, in the section The true sense and image (III.6), ding 定 was used refer to the "fixing” of nature (xing 性) in consonance with dào 道: in this context to fix is not to fix, but rather tie up with dào 道's "fixlessness" discourse. However, in the section I style it 'Dao' (III.7), Wáng Bì wrote that words were used to fix (ding 定) forms (xíng 形). The Lăozl̆ seems, then, to be constantly constructing a dual-sided lexicon that is ultimately faulty, because it cannot fix any character's nature: ding 定 is conventionally fixing forms and creating categories that eventually cannot be fixed. It is in dào 道's darkness (yăoming 窈冥) where one finds light (jing 精) and fixes one's disposition in tandem with the never-fixed dào 道; but that is where, according to the text, one also finds authentication (zhèn 真) - or, in a more essentialist reading, "ultimate truth.” The paradox of yăoming 窈冥 and jīng 精 is the ultimate truth, as are others in this paradoxical text; the paradox is what is most clear, most obvious, 
and even trivial. Actually, there is no paradox, outside of what we call paradox. This is the MPH.

Nowhere is the question of the paradox clearer (is this not a paradox in itself?) than in the passage Right words in reverse (III.9), where, paraphrasing Ames \& Hall, language is appropriately contradictory. However, once other translators such as Chén and Julien consider that there is a correct meaning - it is just not available to the common people - we see a radical difference in the reading of the passage, and in the use of the metalinguistic term paradox.

It is an altogether too complex matter to speak about paradox in English without referring to words such as concept, meaning or thought. As we have seen, there are three major characters in classical Chinese related to this cluster of allusions: $s \bar{l}$ 思, for thought, thinking - Zhang (2002, p.436) adds lì 慮as a similar

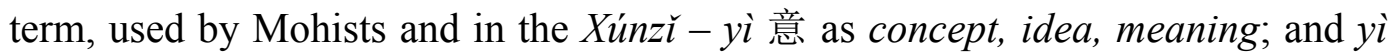
義 as truth, significance, meaning. While the first three are absent from the Lăož̆, $y i$ 義's use, as we have seen in Righteousness and ornaments (III.5) is arguably non-metalinguistic (righteousness, justice, rectitude). It is no coincidence, in my opinion, that there are no metalinguistic terms in the Lăož to refer to what is usually translated in English as meaning or concept. Despite its central position in the history of the Chinese ideas, it is a book which, apparently, does not speak about meaning or, even, ideas! It, however, certainly manages to convey its ideas and it is a meaningful text. How the Lăož succeeds in that is a clear demonstration of a radically different use of metalanguage e an important support for the MPH.

The power of zi 字, style name, Chinese character, to create Chinese language is anachronistically present in the section I style it "Dao" (III.7). Once again, we are hard pressed to make sense of a passage that can be translated "I don't know its name, reluctantly I called it “道'.” Writing was created, in Chinese myth, by Cāng Jié, however, the Lăož̃ does not seem to suggest the there was any ancient name for dào 道 that had been forgotten. Wáng Bì is clear when he writes that since names are to designate possibilities / potentialities (kě 可) and because dào 道 is boundless in possibilities, certainly no name (míng 名) could aspire to 
reach it. In any case, there is always the tension between zi 字 and ming 名 that mirrors the tension between writing and speech. That $z i$ 字 was chosen to style (inaugurate) dào 道 as well as to be responsible for the multiplication of the hànzi is a blatant testimony to the importance of writing for the Chinese language, even if this is historically incorrect!

The translations are each a product of their time and it is clear that some of the chosen translated terms were influenced by uses of characters that only emerged sometimes long after the Lăož̀ was first compiled. Examples of such translations are wén 文 as sayings or slogans and zì 字 as orthography. The fact that wén 文 is one of terms in the Lăož̆ with the most varied translations is a sign of its complexity and the influence of the history and usage over time in the network of allusions of the characters, very much in consonance with the MPH.

The parallel constructions on many of the passages have proven to be particularly essential to their exegesis (see sections III.3 and III.6). As we have seen in some of the layouts, that fact that Chinese hànzi are all aesthetically constructed in a way to occupy the same virtual space in the written media highlights the graphical nature of the parallel, only made possible due to the characteristics of the Chinese script, and only in the written language. It is another sign, as per the MPH, that Chinese writing has direct bearing on the possibilities of interpretation of the language. The parallel structure of the Chinese written language is a striking example of alterity.

Adding to these contrasts, I have found several points of contact between what the passages show us through their translations and commentaries and the tenets of the MPH. While understanding that one must be cautious when presenting summaries of two perspectives that are not reducible to mere lists of categories, I propose a brief summary of these commonalities:

- language is not apprehensible as a whole, cannot the reduced to a telos, it is a non-intellectual activity that shows its ever-changing patterns;

- metalanguage can be regarded as a failure as a tool since it cannot abstract language from itself. Without a background onto which to project language's categories and names, we are often in danger of being misled 
by our own tendency to construe these as if they were themselves providers of such background. These are the reasons why metalanguage terms should be considered not as tools, but rather as forms of life, in their use.

- Language-dào 道 is not composed of articulations of name-míng 名, words-yán 言 or characters-zi 字. It is not primarily aimed at representation and description, but in its use it has a coercive force - via metalanguage - on how we construe our visions of language.

- Oppositions are likewise (at least partially) conventional. Paradoxes are not only constitutive of language, but also the notion of paradox itself is profoundly (and trivially) paradoxical.

In a text that has clear political tints, the translations themselves are shown to be political. This was particularly clear in the Righteousness and ornaments (III.5) excerpt, where the choice of Hansen emphasized Lăozı̌’s attack on Confucionism, while Chén's seemed to have toned it down. The political use of words is, in itself, not a novelty (once again we are reminded of Orwellian Newspeak); it is the fact that the Lăozl chose such key terms from Confucian and Chinese dogma as examples of the misuse of words that highlights that, simply, there is no dogma. The Lăož̆, considered as strictly non-dogmatic bears witness to the productive encounters between different perspectives and has arguably unsettled the Chinese contemporary reader, and made them see the strangeness of their own situation. This is expected from the tenets of the MPH.

As for the translators, as a whole it is possible - while acknowledging the risk of being unfair and too reductionist - to classify the seven translators into two main groups. In the first group, Lau, Julien, Sproviero, Lynn's translation of Wáng Bì and Chén have showed in their translations the mark of a predominantly representationalist view on language. The rule of meaning was disguised in accepting that the correct words were the province of the sage, in the existence of a metaphysical dào 道 beyond the reach of language, in the misuse of our language as the misapprehension of its true meaning. In Julien, for instance, the 
role of words is accessory. Words and language cannot explain dào 道, cannot teach (jiào 教), and wén 文are just empty vessels, or just appearances.

Hansen and Ames \& Hall are the authors who espouse ideas that are explicitly in consonance to the ideas presented in chapter I of this dissertation. However, even with these authors we sometimes find residues of a "hidden" representationalism in their words, as when Ames \& Hall (Wordless teaching, III.3) write that the sage's teaching should go beyond words, into a supposedly meta-space unreachable by language.

Hansen is vocal in defending the problem of essentializing language:

We ought to appreciate that a particular culture's common-sense theory of language might differ from ours. Philosophers from a particular culture tend to take their own language's traits as essential characteristics of all languages (Hansen, In: Allinson, 1989, p. 76)

For these authors, despite their differences, in general, dào 道 is a coercive guidance that is all-pervasive, in everything; language (and language-teaching) becomes dangerous when it leads humans to take constructs as if they were ontological categories; words are not used for their metaphysical meanings, but rather for their appropriateness.

Finally, the work of Wáng Bì is certainly the most difficult to evaluate within the context of the MPH, since it involves the interference of another translator, Richard Lynn. I have shown, in the few selected passages, my own evaluation of Lynn's reading of Wáng Bì and I have found that the American translator has imposed his representational view of language onto Wáng Bìs characters. In almost all the passages (such as III.2, 3, 5, 6, 8 and 9), we have seen Wáng Bìs words as signs of a perspectivist view which shows many affinities with Ames \& Hall and Hansen. 


\section{4. \\ Conclusion}

This dissertation has explored conceptions of language and metalanguage informed by the later Wittgenstein's perspectivism. It has set out to show possible resonances and transformations of this philosophical view in a dual-sided exploration of metalinguistic terms and passages from the Lăož̆. The findings presented in the past two chapters, focusing on the metalinguistic practices of etymology and translation, are consistent with the theoretical and practical questions that have been introduced in the beginning of this dissertation. These questions might be (re)grouped into three major lines of inquiry: 1) what is the relevance of perspectivism and the MPH for the Lăož̆? Could we call the Lăož̆ perspectivist?; 2) what does the grapho(etymology) of Western and Chinese terms inform us regarding the MPH?; and 3) what do the translations of the Lăož tell us about each author's metalinguistic practices?: How do they add support for the $\mathrm{MPH}$ ?

\section{Daoist and Greek Wanderings}

Contrary to the alleged incommunicability of relativist encounters, with perspectivism the clashes of different perspectives might provide us with opportunities to face the instability of our own subterranean propensities - and to wonder at how the seemingly paradoxical may at the same time be so trivial and incomprehensible.

Daoist teachings have been marked by the form of parables, and probably have as their opera major the thirty-three tale-chapters of the Zhuāngzĭ. These tales, apparently aimlessly drifting, find deep resonance in the wanderings of the later Wittgenstein; for, the Zhuāngž̌ is a text that is not aimed at presenting a structured thesis, but whose force resides in the same rich encounters one expects to see in the context of perspectivism. These encounters are usually marked by surprise and astonishment, unexpected meetings, colorful characters and masters like Lăo Dān (the "historical” Lăož̀) and Confucius. 
The encounters I now partially recount here may indeed cause a feeling of strangeness, perhaps even perplexity, and are prone to make one interrogate one's own tacit partialities.

- Is there order in no order? Wén 文, culture, patterns; wén 紊, disorder, confusion; and wén 紋, patterns (in clothing), lines: the thread that is lost from the net, thus reversing patterns and order into confusion, entanglement. Wén 文 's common use as patterns contrasts with its alternative gloss as confusion, entanglement. (section 2.2.5)

- How is wordless teaching a paradox? Teaching without words [bù yán zhī jiào 不言之教], a non-paradox in the West (or even in the Chinese tradition outside the Lăozl̆), takes side along non-acting action and other opposite pairs that are much clearer paradoxes to us. (3.3)

- How to coin new words for dào? Yi 夷, elusive; $x \bar{l}$ 希, inaudible; and wēi 微, intangible: the Lăozl̆ creates of an absolutely idiosyncratic vocabulary. For instance, yi 夷, elusive, no-listening hear, had been used to refer to the following: some non-Han people; level, plain; people of the same generation; to arrange, to place; to uproot, to kill, to suppress; to sit, to squat; happy, joyful; conventional practices. (3.4)

- Discard wisdom! Cut off benevolence and the sage! These slogans (wén 文) reinforce the political and rhetorical nature of the Lăož̆, but they also allude to the creative power of language, the misuses of language and the error of taking words "on-holiday." (3.5)

- What fixes the never-fixed discourse-dào 道? Yăomíng 窈冥, obscure and jing 精, clearness: the paradoxical used in order to emphasize the transitory nature of words. In dào 道's inner darkness one finds light, and fixes one's disposition in tandem with the never-fixed discourse-dào 道. This is where one finds authentication (zhēn 真) or, in a more essentialist reading, ultimate truth. The paradox is itself the ultimate truth; the paradox is what is most clear, most obvious. (3.6) 
- $\quad$ Correct discourse is like reversing opposites! The language prescribed by the Lăož̀ is one that is appropriately contradictory and, as a form of life, does not follow the script of logic. If right (zhèng 正) seems crooked (făn 反), it is because in the ramblings of language, once opposites are reversed, they become straight and we lose track of where we started. (3.9)

The encounters are enriched by the surprising semantic possibilities of the hànzìs, which sometimes challenge our metalinguistic repertoires:

- $\quad Z i$ 字, as that which (literally?) gave birth to the multiplicity of Chinese characters, becomes arguably one of the most important metalinguistic terms in the Chinese tradition. (2.2.4)

- $\quad Y i$ 義, the metalinguistic meaning, sense and idea; but also wise, righteousness, appropriateness, duty, patriotic, common, free, adopted, etiquette, rites, appearance, moral standard and... the slaughter of cattle and sheep in sacrificial ceremonies. What is the meaning of meaning? $(2.2 .6)$

- Xiàng 象, the elephant that became the image. As image or figure, xiàng 象 presents a metalinguistic reflexive aspect when it is - in our commonsensical view - used literally as figure? However, in the Chinese script there is no letter! (2.2.7)

- Jing 精: essence, clear, distinctiveness; germination; concentrations of qi 氣. Is the seed (m̌ 米, rice, skin, infinitesimal) a metaphor or literal graphic motivation? The space of the graphical contamination dislocates our metalanguage, such as metaphor and literal.(3.6)

However, one has to acknowledge that the chance of perplexity is not confined to the ways of the Chinese language and of Cāng Jié, the mythical creator of the Chinese script. Greek etymology may also be a source of awe. In the mists of time, countless ancient uses of words have been forgotten by their present speakers. Examples are numerous: style, a case of homonymy or polysemy? From a row of columns forming an enclosure to the cognates tattoo mark, a brand, stimulus, to distinguish, to incite, instinct, stylet and to 
metalinguistic style (of writing) and to style (a name); ornament, does ôrdō, order, pattern, puts in order language with an ornate rhetoric?; Greek glōssa has the sense of language, but also a rare and dialectal word; is it not ironic that meaning stemmed from IE *main- or *mein-, to be of opinion?; symbol in Greek as contract, engagements and even intercourse, is akin to bállō, to reach, to affect, to throw and has an unlikely cognate in diábolos, enemy, slanderer; Port dizer (to say) derived from Greek cognate deiknȳmi, to show, to demonstrate, whence deìxis, mode of proof, deìgma, example, and paradeìgma, model, paradigm; how does the compulsion and impulsion in the Fr. appel compare to call?; slogan is derived from a contraction of Gaelic battle-cry sluagh-ghairm!; from the IE *wer/*were-, to speak, stemmed some of the most central metalinguistic terms in the West: word, verb, (via Greek erō) eirōnía, irony, rhēma, that which is said, and rhētōr, rhetoric, but some more unlikely cognates in other languages: Old Slav vrač̆ , physician, magician, Sanskrit vratá-, vow and Ossetic irøed/orwoed, bridemoney, etc.

Unbeknownst to us, these past uses have, nevertheless, influenced - and still influence - the crystallization of prototypical images and allusions that we take for granted as common-sensical and obvious: language as a tool of representation; the literal, compositional, universal, rational and declarative as the core of language; the strict separation between subject and object as mirroring ónoma and rhemma... The etymologies presented are likewise testimonies to the development of the crystallization process, to the "construction of common sense," thus providing evidence of a historically and contextually situated process that has been guiding our linguistic inquiries - the intrusion of "daily language" in our speculations on the philosophy of language and vice-versa. We must not forget that this is not an intellectual process where clearly delineated etymological factors all added to future networks of allusions. Some past uses are less "compatible" with the representational picture of language, for instance, discürrěre's allusion of the "hazardous nature of verbal exchange." These uses were "forgotten" and, in a way, suppressed by the growingly predominant common-sense picture of language.

We are all Greeks, as the Classists sometimes say, but furthermore, the (meta) language that we use is firmly built upon Greco-Roman foundations. 


\section{Daoism encounters Wittgenstein}

To take language as a form of life presupposes that language is contextual and historical and exhorts us to embrace the inevitability of the relative: not the background (metaphysical truth), but the relation; not a variation of truth according to the subject, but the conditions under which the truth of a variation appears to the subject. This view entails many consequences, which, being shared by Wittgensteinian perspectivism and Daoism's Lăož̆, suggest their close affinities.

First, we notice their shared seemingly paradoxical (dis)comfort with language. Wittgenstein shows a predilection for ordinary (gewöhnlichen) language, but if he, on the one hand, insists that everything is fine with ordinary language (B.B., p.28), on the other hand, he also warns us against its "mystifying power" (B.B., p.6, P.I. §109), its tendency to mislead us into its reification. Taylor and Harris more explicitly detected in the reflexive nature of language and in metalanguage the center of this reifying propensity.

In the Lăož̆, one is likewise warned against the dangers of reifying language; we are alerted that languaged-dào 道 is never constant, and exhorted to discard the ornaments of language - not ornaments as in the expression "ornate language," but as reified hànzì.

Whatever the case, mistrust for language in the Chinese tradition happens in a way that hardly matches that of the Western tradition. In the latter, suspicion was related to the overblown role of logic and the imperatives of rhetorical selfdiscipline that are characteristic of Western representationalist theories of language and mind. Indeed, in the Chinese tradition, the danger of names was likely not linked to any notion of abstract meaning, as classical Chinese philosophers did not formulate a representationalist theory of language that aimed at creating faithful meaning/form pairs linking language and reality. In an arguably Wittgensteinian spirit, they understood that the danger lay in the possibility that the reification of language might misguide the proper conduct of dào 道. 
It is evident, however, that the reflexive uses of language tend to drive it towards reification - words about words are prone to be "taken on holiday." This drive was manifested not only when the Greeks started to think of names as entities separated from the named objects, but also when the Chinese carved the uncarved block ( $p u^{\prime}$ 樸) of nature, thus creating names. These are historical accounts that, once metalinguistic practices were instituted together with language, reification gave way to entities perceived as fixed and universal, such as meaning and logic.

The tacit picture of an essentially precise, objectified, modeled and circumscribable language that was born under the aegis of an implicit transcendental reified logic finds formidable nemeses in the Lăož and in perspectivism. The Chinese book taught us to rejoice in the apparent contradictions of its text, as if attempting to show that without "straightness," there would be no contradiction: "straight words seem to turn themselves." Contradiction, thus, considered in its common uses, cannot be of an inherent and absolute order of language, which is itself irreducible and alive; a space where the impossible may suddenly seem possible, while shrouded by a veil of regularities (Regelmäßigkeiten), affinities (Verwandtschaften), similarities and family resemblances (Ähnlichkeiten and Familienähnlichkeiten), blurred edges (unscharfe Bilder) and reasonable men (vernünftige Menschen). Better still, contradiction is a self-defeating term, since language-dào 道 is nothing but use, and use is neither true, nor untrue; neither reasonable, nor unreasonable.

In the space of language, the Lăož is an almost perfect example of where the trivial encounters the unfathomable: wordless teaching; way wayable; image of no form; voiceless sound; wisdom in discarding wisdom; the essence of dào 道, appropriate language seems contradictory... If Daoist wisdom is the site of the trivialized, its infinite wisdom is the counterpart that shows us that the limits between the most familiar and the utterly foreign are like yán 言's very faint sense of the $I$. It can be summarized in an oxymoron like uncommon-sense.

The intense and productive dialogue between Lăož̀ and the type of Wittgensteinian metalinguistic perspectivism that has been evidenced throughout this dissertation supports the claim that they are both traditions that reject 
metaphysical-oriented theories of (meta)language and are amiable to the view of language as a form of life.

\section{Lăozi as the other (language)}

But how is the (meta)language we read in the Lăozí "other" to us? It seems that the Lăozl̆'s (meta)linguistic alterity can be heuristically approached on two levels, or seen from at least two (mutually inclusive) angles:

1) The Chinese language level: metalinguistic alterity testifies to the particularities of Chinese language and forms of life, where metalinguistic practices offer a striking contrast to those that are tied to Weterns representational tradition. This "commonsensical perspectivism" - as compared to Western "commonsensical representationalism" - finds special resonance in a text like the Lăož̆;

2) The Lăož̀-Daoist level: metalinguistic alterity is in some aspects tied to the ideas expressed in this singular text, which can be read as favoring a theoretical perspectivist stance on language, knowledge and the world. From this angle, the Lăož̀ is striving to think "otherwise," as much as are Wittgenstein, Nietzsche, Deleuze, Viveiros de Castro, Taylor or Harris.

Broadly speaking, the "Chinese language level" has a more direct articulation with chapter II of this dissertation, since it refers to a more general use of (meta)language in ancient China - offering a glimpse at sketches of a Chinese Weltbild. The "Lăož̀ level” pertains, of course, more directly to chapter III of this dissertation. However, since the Lăož is obviously a text written in classical Chinese, it too gives testimony to the coercive nature of metalanguage in that language, thus making chapter III of this dissertation also relevant for the "Chinese language level." 


\section{Chinese language's Weltbild as the space of the other}

Along the research for this dissertation, some themes have repeatedly surfaced and are very briefly summarized here, as a space to conjecture glimpses of linguistic alterity, as predicted by the MPH. I have arranged them into two major foci of discussion: the question of writing and speech, and the question of language and nature.

\section{Writing}

The Chinese script profoundly influenced the emergence and use of Chinese metalanguage. Among the more relevant aspects of this alterity are:

- The central importance, for the study of the hànzì, of the Shuōwén and the myth of the creation of Chinese writing by Cāng Jié. This creational myth compares to the myths of Toth and Seshat and the hieroglyphic writing; Itzamná for the Mayas; and Nidaba in Sumer (all examples of scripts that had semantic import).

In Greece, however, there was originally no myth of the creation of language or of writing; there was no dictionary (lexicon) as influential as the Shuōwén or the Éryă. In Western metalanguage - Indo-European *wreid-, to tear or scratch; Greek gráphein, to scratch, engrave, draw; and Proto-Indo European $*_{s k r e i b}{ }^{h}-e / o$, to carve - writing appeared typically as a specialized use of drawing, with no defining moment, no birth.

- The dào 道 of Nature and the importance of its harmony with Chinese culture and writing. The fact that the hànzi were so vital in the Chinese tradition is mirrored in that the beauty of the patterns of Nature's dào 道 and the way the Chinese traditionally viewed their characters. The written language was the graphic space that witnessed the intermingling of Human and Nature.

- Writing as the space of translation between the languages of China. With the lack of "foreign" languages until the advent of Buddhism in the $1^{\text {st }}$ century $\mathrm{AD}$, Chinese writing was viewed as the universal space of written language. While the Western tradition tends to assume that meaning is shared between languages while words are not, in pre-Buddhist China the written word was 
also shared between the Sinitic languages, thus eliminating the need for a meaning-oriented translation.

- Grapho-etymology as a space of graphic alterity. It is clear from the grapho-etymological explorations of chapter II how the graphical dimension of the Chinese script interferes with the hànzì's uses and allusions. As examples already mentioned here: $\dot{7}$, patterns and confusion 突); yì 获, righteousness, meaning, rites, rectitude 我, I, myself; shān

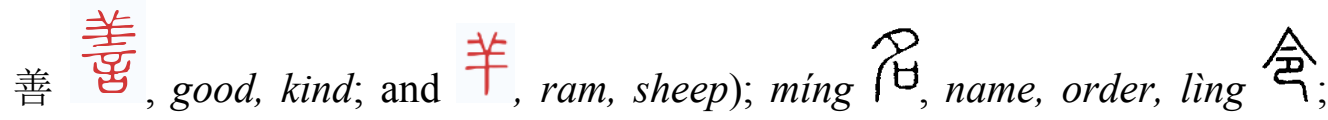
life, ming 创; rites; 旁, image, elephant; etc.

\section{Language and Nature}

The perception of harmony between Human and Nature, in rough lines, circumvented existentialist crises in the Chinese traditional thought, and made the search for the fundamental nature of the world and of reality relatively irrelevant. There was arguably no clear separation between what we know in the West as lógos and mythos, and no devaluation of the sensual and empirical world, as well as a lesser need for abstraction and the rational.

Therefore, language and dào 道 were considered as coercive forces that suggested a "natural" guidance effortlessly directing us. This compares with Cavell's apprehension of Wittgenstein's thought as pointing to the notion of rules that are volatile but "not merely conventional" and to the a view of necessity that is "anthropological or contingent necessity." Although the "natural" in Wittgenstein may compare to the "natural" in dào 道, the latter seemed to emerge from the predominant vision of harmony between Human and Nature. In other words, the necessary in dào 道 stemmed from the propensity of human and world realms to be in harmony, which "imposes" the necessity in a way that it is hardly felt: for humans to maintain their harmony with Nature, they must follow Nature's dào 道. Since they were originally in total harmony, to do so requires minimum effort. 
The harmony with Nature can be explored through the grapho-etymology of wén 文, as patterns of Nature and patterns of Human (culture, writing). Such patterns are traces or signs of the natural principles ( $l i$ 理) of Nature and, at the same time, they are seen as the source of Chinese culture. This "transitional" space between Human and Nature is indicated in François Jullien's interpretation that the graphic for wén 文 is a cognate of the graphic forms of numerals five and six, the first numbers whose hànzis show a break with the iconic (natural) representation. Therefore, to "be" wén 文 is to properly conduct oneself in consonance to the inherent, ever-changing patterns of Nature. Language naturally follows this prescription.

The abhorrence against generalizations and abstraction; and the inevitable tendency that, once we are disconnected from the world due to the reification of language, we are drawn to our own constructs and forget their history, psychology and prejudices: Chinese thought (particularly Daoism) is in close accordance with these perspectivist views, although motivated by an altogether different historical background.

Chinese (meta)language is not centered on description and representation nowhere does one find the affirmation that the discourse-dào 道 is at its core a declarative discourse - but on guidance to the proper manner of acting in accordance to nature-dào 道. The close relationship between ming 命, míng 名 and ling 令 is a testimony to the proximity (in Chinese) of what is translated in English as order/command with life/destiny and name/naming. It is a mark of the focus of Chinese thought and language on order, harmony and proper guidance.

While the Greek tradition felt the need to secure a reliable tool to investigate the World and our relations with it, and predominantly valued the descriptive and representative function of language, the Chinese also felt this need for a reliable tool, only not to represent, but to guide, regulate and co-ordinate proper behavior.

\section{The Lăozi’s perspectivism and the translations}

The central subject of the Tao-te-ching, the Tao or absolute, is by nature inaccessible through language, as Lao-tzu says. The language used to speak about it, full of enigmas, breakups, incoherencies, may have this precise function, which 
is that it tries to speak of that which no human speech can ever expose, to transmit a certain truth - or The Truth - with the help of riddles, symbols, allusions, and metaphors. (Robinet, In: Kohn \& LaFargue, 1998, p. 123)

We can now proceed to approach the question of perspectivism in the text and philosophy of the Lăož̀.

The Lăož̆ can be seen as a profoundly metalinguistic text. Hansen (1992, p.120) claims that Daoism is a dào 道 about dào 道, a discourse that prescribes about discourses. In one way, it is telling us mainly about itself, about how there is nothing beyond itself. In another, it is telling us not to follow its prescriptions.

What I propose here is that we consider the (meta)language of the Lăož̆ as a (meta)language that does not seek to name or to represent. If that had been the case, it could only fail, exactly because it presupposes the existence of this "unlanguaged" sphere. This is where I think we can find a connection between the notion of the Lăož̀ as both a text without "original" meaning and a source of epistemological knowledge. It is, perhaps, language as depicted by Robinet: full of enigmas, breakups, incoherencies, as it manages to speak of "that which no human speech can ever expose (...) with the help of riddles, symbols, allusions, and metaphors" (words like symbol and metaphor may be cause for hesitation here, but we use them for lack of better ones!).

Somehow, when we read the Lăož̆ and "feel" that there is something "empty" in the interstices of its lines, that is when we learn something about dào 道. It does not happen through any definitions or through logical or inferential thought, but rather as some kind of initiation, a leap of faith, a sensation of wonderment. In spite of the wording, sometimes associated by some authors affiliated with both universalist or relativist viewpoints with derogatory terms such as "mystical mumbo jumbo," this is meant as deserving our serious consideration.

The enigmatic language of the Lăozl is one where no background can be found or established; and, because of that, it germinates, it inaugurates new meanings, not only through its further interpretations (the translations, readings, re-writings), but more radically, it seems, with the book's innovative and almost 
reckless uses of language. It has the fluency of something that escapes grasping, escapes the coercive control of naming and, in that, it reflects the unnamed nature of dào 道. The Lăož̀ "speaks" through a language that struggles not to be language, not to present statements, but rather to fuse language and languaged, verb and noun, action and result. Through its nature, it invites us to think about a language - after all, it is composed by characters that are written and sounds are pronounced when read - that is nameless, and that therefore has somehow forsaken its natural predisposition to name and to impose meaning.

It is a trivial conclusion that the translators discussed here brought their world-pictures (Weltbilder) with them and, in their interaction with the context and the text of the Lăož̆, each interpreted the text differently with distinct choices of words and metalanguage. Their contrast could be construed because of different incommunicable ideologies, or, in other words, of relativism. As per perspectivism, we should postulate that each author was driven by their different perceptions of what was commonsensical metalanguage, accepting (and also rejecting) the practices they see in the original text. The evidence of dislocation of their metalinguistic propensities, which affects their metalinguistic repertoire, reinforces the $\mathrm{MPH}$.

We have seen in chapter III how some of the translators' motivations and backgrounds were arguably identified as conditioned by representational views of language, while others, even if unable to completely renounce their own tacit and rational-less convictions, showed more affinity with a perspectivist view of language, and arguably also with the MPH. These differences are reflected in the metalinguistic repertoire they construed (or decide not to).

Roughly speaking, Lau, Julien and Sproviero were identified with the representational view of language, spanning three Indo-European languages and one hundred and fifty years. Additionally, Chén represented what we might call a "modern Chinese representationalism." Even though his book is heavily laden with philological quotations from the classics, and he offers a fresh and enticing view on the Lăož̆, his implicit views on language, in a way, reflect a trend in modern Sinology: employing Western linguistic tools of enquiry to assert the 
similarities between both languages in order to construe a shared universal background.

Hansen and Ames \& Hall are outspoken defenders of views that could, in many ways, be identified as Daoist perspectivism. Daoism, Ames \& Hall say, "expresses acosmotic thinking in its most consistent form": with "no Being behind the beings of the world," they add, "the way of things is both continuous and radically perspectival." (1998, p.65) Their practices are thus dually perspectivist: by accepting the possibility the alterity of Daoist (Lăož) thought; and also by identifying in such ideas a picture that they call perspectivist-like. Perspectivist thinkers, such as Ames \& Hall, writing about the texts of more universalist oriented Sinologists, such as Harbsmeier or Boltz, bring their perspectivist-oriented world-picture to examine their colleagues' representationalist-oriented (meta)linguistic practices. This situation is not different from the analyses of this dissertation on the writings of authors such as Lau and Julien.

Wáng Bìs translation is one of the most emblematic as a case for the MPH. Although sometimes he seems to convey a representationalist view of language, in many instances he is better aligned with the visions from Ames \& Hall or Hansen. However, being translated into English by Lynn, we have seen how his metalinguistic repertoire has also been dislocated and translated with a more representationalist bias.

In attempting to assess the seven translations, I have resorted not only to the translated texts, but also to the copious notes of these scholars. The analyses presented in chapter III showed how far the translations dislocated the ancient Chinese metalinguistic contexts, as they were outlined in chapter II, and also expounded their affinities and incompatibilities with the metalinguistic views presented in chapter I.

For instance, in translating the "2 $2^{\text {nd” }}$ dào 道 from dào kě dào 道可道 (as seen in section 3.2) as be guided, Hansen has appropriated more than the other authors from the practices illustrated by the grapho-etymology of dào 道. As for

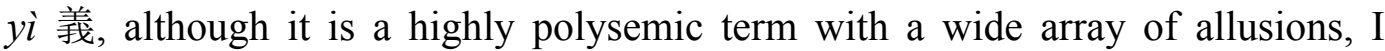
believe Ames \& Hall were more sensible to its history as the balance of wǒ 我, I, 
myself and shān 善, good, kind, and its suitableness (yí 宜, right, suitable) in its translation as appropriateness. The adequacy of the translations of zi 字, character, in the Lăož̆, is a more complicated matter since it involves, as we have seen, a network of allusions that had changed dramatically with its foundational use in the Shuōwén. Sproviero and Hansen correctly called attention to the crucial written dimension of $z i$ 字, while on the other hand failed to attend to its inaugural force as a "style name" (from the allusions of giving birth, raising). As seen in section 3.4 (Creating words for dào 道), it is undisputable that Sproviero's choice of keeping the three "new names" untranslated reflected, perhaps unwillingly but with originality, a parallel creation of a new vocabulary in Portuguese. Finally, when Julien wrote that the sages know the correct meanings of the words, the French author is attesting his affiliations to a representational view of language.

The fluid boundaries of what might be considered metalanguage are highlighted in the choice of translated terms by the translators. Between Western languages, generally metalanguage is translated by metalanguage - word translates palavra, palavra translates parole, Bedeutung translates meaning, etc. Contrariwise, in this dissertation there were few instances when that did not happen. For example, xiàng 象, as image and sign, serves two completely different metalinguistic functions between the Western and the Chinese traditions: respectively, one that is connected with the hànzi being the image of a thing and an image itself; the other as a word referring to a metaphorical extension, a trope.

In another case, Hansen translated the " 2 nd" dào 道 from dào kè dào 道可道 as be guided, whereas the usual preference would be for terms such as say, spoken, discourse: although arguably be guided has a reflexive function in the Lăož̆, it cannot be recognized as such, say, in the English metalinguistic lexicon. Boodberg's translation of the " $2^{\text {nd" }}$ dào 道 as wayable is even more contrastive, nothing even close to what we may consider metalanguage in English, certainly a word which stretches the usual grammatical norms! Boodberg's choice distorts usual English syntactical configurations to emphasize the performative nature of dào 道as way, while at the same time avoids its discursive aspect. 
Additionally, wén 文 has been translated not only as metalinguistic sayings and slogans, but also as ornament. Although the latter would perform a metalinguistic function in Western languages as rhetorical devices, the English word has a network of allusions that as drastically disconnected to wén 文's own acceptations.

Finally, xìn 信, arguably a hànzì which is graphically metalinguistic (rén 人, man + yán 言, speech $=$ xìn 信, words by which we stand $)$ is translated as credibility, trust, reliability, authentication or testimony.

From this brief and partial recollection of the analyses from chapters II and III, we see that there is evidence for the MPH not only in the compared analyses of the translations, but also in the contrast and relations that can be established between translations and grapho-etymologies. The Lăož and its movements of thought show affinities with perspectivist ideas as explored in chapter I, and with the MPH.

There is one final note to remark upon. As said, Lau, Julien and Sproviero, in general, do not seem sensible, in their translations, to the tradition of Chinese metalinguistic practices addressed in Chapter II, since their Weltbilder, as stated above, tend to reflect a representational view of language. Consequently, if one is unknowledgeable in the Chinese language and chose only the translation of Lau, Julien or Lynn, for example, the translated text would certainly provide no, or very weak, support for the MPH or for perspectivism. The cross-referencing and use of different translations are particularly relevant in a text that is so utterly pol(ys)emic as the Lăož̀.

\section{Dào 道 and Lógos}

We return to the question in the title of the second section of chapter III: The unlanguaged dào 道?, or, paraphrased: Is dào 道 languaged? In other words, does language reach "it"? Although different authors have different answers for this ancient question, I argue that, within the context of MPH, the answer itself is not of the utmost importance. We should listen to Wittgenstein's suggestion and revisit the question, by proposing other questions. If dào 道 is also understood as 
language, does it make sense to ask whether "dào 道 is languaged" or not? Does the question become: is language languaged? This cluster of questions seems at the heart of the metalinguistic conundrum that infiltrated all interstices of this dissertation, since it asks whether language can (or cannot) totally encompass/explain itself; or whether a purely objective science of linguistics is theoretically possible.

Since the Lăož poses the question using dào 道, it is also a question about the nature of dào 道. To approach the problem through the perspective of dào 道 might shed some light on the problem concerning language and linguistics. For that I invite the reader to contemplate the following two descriptions of dào 道:

Dào 道 is an irreducible, unbounded and non-intellectual activity that has no telos. It is a collection of uncountable dào 道-discourses that contextually determine the world, creating meaning in every such situation. These dào 道-discourses have never-ending patterns of regularity, which might mislead us into thinking we know its nature, and at the same time enable us to write about it and to follow it. In short, dào 道-discourses are life.

And:

the Chinese word tao, which also represents the foremost Chinese philosophical concept, contains in one word the same duality of thinking and speaking $[\ldots]$ there is no reason why Plato should not be considered as in harmonious company with Laozi in the contemplation of logos or the tao, given that for both philosophers and the traditions they represent, the relationship between thinking and language is so antithetical that it may be indicated in terms of conceptual opposites like inner / outer, intuition / expression, and signified / signifier. (Zhang, 1992, pos. 914 \& 958)

The first "description" of dào 道 is my own: I have construed it by adapting the Wittgensteinian characterizations of language that have been presented and used in this dissertation. The second text is an excerpt from a book written by the Chinese scholar Zhang Longxi, entitled The Tao and the Logos: literary hermeneutics, east and west. I imagine their contrast is eloquent.

This disparity, in itself, might not be a great novelty, given that dào 道 and the Lăož are a notoriously fluid concept and text, respectively. What might strike 
the reader is the incredible chasm that separates these two interpretations. I suggest that both readings of dào 道 may be taken as collaborative, in a way that their dialogue is possibly conducive to the sort of dislocation of subterranean predispositions that is so dear to perspectivism. When considered together, each text gives the reader the chance to rethink what they might have understood from the other; each passage offers options of intelligibility when in contact with the other, while at the same time might become absolutely opaque and resilient.

As one embraces the Wittgensteinian reading of dào 道, one is offered the possibility of accepting and valuing the text of Zhang as testimony of a historical force, but probably not the other way around. If dào 道 and lógos are related in so harmonious way to the point of erasing an enormous distance in time and space, our ambition to build a "theory of everything" might not seem so far-fetched.

I believe, however, that a healthy growth of human knowledge should be grounded upon a maturity that increasingly becomes more necessary, due to the crucial coexistence of relentless and mindboggling technological progress with the limitation of philosophical speculations. Taking side with one against the other, would cause an imbalance that might lead either to immoderate universal ambitions, or to the most shallow and innocuous paralyzing relativism.

To these two passages, I finally add a third one, from Wáng Bi’s wonderful insight from the epigraph of this dissertation. It echoes perhaps the great Brazilian writer João Guimarães Rosa, who once described his own "metalanguage" by saying: "in every word lies a poem" (Rosa and Lorenz, 2009, p. 1xvii). So, for a last characterization of the Lăož́: 


\section{5 \\ Bibliographic References}

\section{Philological Sources}

The present thesis is not strictly a work of Sinology and, for reasons of scope and space, I will refrain from citing a large array of philological sources, including only a few quotes that are most relevant. Following are the texts from the Chinese classical canon quoted in the dissertation, with their main translations.

Shijinng 詩經, the Book of Odes, one of the "Chinese Five Classics," made up of 305 poems, compiled around $600 \mathrm{BC}$ and one of the major and most authoritative sources of the Chinese language. Translation by Arthur Waley (1937) Shijing: the ancient Chinese classic of poetry. New York: Grove Press, 1996.

Yijing 已經, the Book of Changes, another of the "Chinese Five Classics" which described the theory of the eight trigrams and is one of the main sources of the Chinese philosophical thought. Translation by Richard Wilhelm and Cary Baynes (1950) The I Ching, or Book of Changes. Princeton University Press, 1997.

L $\dddot{j} j$ 禮記, the Book of Rites, one of the Three Rites Canon (also one of the "Chinese Five Classics"), a description in 49 chapters of the rites and costumes of the Zhōu dynasty.

Zuŏzhuàn 左傳 is Commentary of Zuo, the most important report on the chünqiū 春秋, the Annals of Spring and Summer, a chronogical account of the State of $L \breve{u}$ 魯, in the time of the Zhōu dynasty (also one of the "Chinese Five Classics") ${ }^{307}$

Shüjing 書經, the Book of History, one of the "Chinese Five Classics" a collection of historical documents and speeches, it contains examples of the earliest Chinese prose and was compiled between 6th and 4th centure BC. Translation by James Legge and Clae Waltham Shu Ching: Book of History. Gateway Edition, 1971.

Zhuāngž̀ 莊子, together with the Lăož̆ and the Hánfêiž̀, a major foundational work of Daoism, written (at least partially) by the famous Chinese master of the same name around $4^{\text {th }}$ century BC. Translation by Burton Watson (1968) The Complete Works of Chuang Tzu. Columbia University Press.

${ }^{307}$ For further information on the Shìjing, the Yìjing and the Lĭjì, besides the translations noted here, please see also Michael Nyman, The Five "Confucian" Classics. Yale University Press, 2001. 
Analects, lúnyŭ 論語, a twenty-chapter work of dialogues between Confucius and his disciples, recorded by later Confucian scholars. Translation by Roger Ames \& Henry Rosemont (1998) The Analects of Confucius: a philosophical translation. Ballantine Books, 1998.

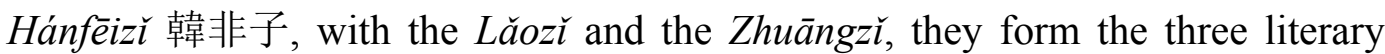
basis of Daoism and was written in the $3^{\text {rd }}$ century BC. Translation by W. K. Liao (1959), from http://www2.iath.virginia.edu "Traditions of Exemplary Women", accessed in 2013-2015.

Additional translations of various Chinese books into English by James LEGGE (1815-1897), from this author vast pioneering translation work on the Chinese classics, mostly from The Chinese Classics: with a Translation, Critical and Exegetical Notes, Prolegomena, and Copious Indexes, 5 vols., (Hong Kong: Legge; London: Trubner, 1861-1872) and his many additional translations published The Sacred Books of the East, edited by Max Müller and published by the Oxford University Press between 1879 and 1910.

WANG BI 王㢶 (226-249 A D) Laozi Daodejing Wangbizhu 老子道德經王㢶 注.

\section{Bibliography}

ALEXANDRE, G. G. Lao Tsze: the great thinker... London: K. Paul, Trench, Trubner \& Co, 1895.

ALLAN, Keith. Linguistic Metatheory. Language Sciences, n.25, 2003. p. 533560 .

The Western Classical Tradition in Linguistics - Equinox. London: Oakville, [2007] 2010.

ALLAN, Sarah. The Way of Water and Sprouts of Virtue (Suny Series, Chinese Philosophy \& Culture). State University of New York Press, 1997.

ALLETON, Viviane. (Org.). Paroles à dire, parole à écrire. Paris: Édition de l'école des hautes études en sciences sociales, 1997. Paris, 2008.

L’écriture chinoise: le défi de la modernité. Éditions Albin Michel:

L'oubli de la langue e l''invention' de l'écriture chinoise en Europe. Études Chinoises, v. XIII, n. 1-2, printemps-automne, 1994. 
ALLETON, Viviane. Traduction et conceptions chinoises du texte écrit. Etudes chinoises, v. XXIII, 2004.

ALLINSON, Robert. (Ed.). Understanding the Chinese Mind: the philosophical roots. Oxford University Press, Hong Kong, 1989.

ALMEIDA, João J. R. L. (trad \& coment). Observações sobre "o ramo de ouro" de Frazer. Ludwig Wittgenstein. Revista Adverbum, n.2, v.2, 2007.

AMES, Roger T.; HALL, David. Dao De Jing: "making this life significant". New York: Ballantines Books, 2003.

AMES, Roger; HALL, David. Thinking from the Han. State University of New York Press. 1998.

AMES, Roger; ROSEMONT, Henry. The Analects of Confucius: a philosophical translation. Ballantine Books, 1998.

ARISTOTLE. Categories and De Interpretatione. Trad. J. L. Ackrill. Clarendon Press, Oxford, [1963] 2002.

AUROUX, Sylvain, KOERNER, E. F. K, NIEDEREHE, Hans-Josef and VERSTEEGH, Kees. Handbooks of Linguistics and Communication Science: band 18.1, History of the Language Sciences. Berlin: Walter de Gruyter, 2000.

A Revolução Tecnológica da Gramatização. Trad. Eni Puccinelli Orlandi. Ed. Unicamp. Campinas, [1992] 2009.

Histoire des Idées Linguistiques (tome 1, 2 and 3). Pierre Mardaga Editeur: Liège, [1992, 1995] 2000.

La Philosophie du langage. Ed. Presses Universitaires de France. Paris, 2004.

La question de l'origine des langues suivi de L'historicité des sciences. Presses Universitaires de France: Paris, 2007. Paris, 1998.

La raison, le langage et les normes. Presses Universitaires de France:

BAKER, G. P.; HACKER P. M. Wittgenstein: understanding and meaning: part I - Essays. v. 1. Wiley-Blackwell $-2^{\text {nd }} \mathrm{ed}, 2009$. . Part II - Exegesis, v. 1 Wiley-Blackwell, 2005.

Wittgenstein: rules, grammar \& necessity: part I - Essays \& Exegesis, v.2. Wiley-Blackwell - $2^{\text {nd }}$ ed, 2014. 
BAKKER, Egbert (Ed.). A companion to the ancient Greek language. WileyBlackwell, 2010.

BALfour, F. Henry. Taoist Texts, Ethical, Political and Speculative. Shanghai: Kelly and Walsh, 1884.

BARROS BARRETO, Cristiano. Pensares sobre a escrita chinesa. Dissertação de Mestrado, Departamento de Letras, PUC-Rio, 2011.

BARTHES, Roland. "A morte do Autor”. In: O Rumor da Língua. São Paulo: Martins Fontes, 2004.

BASSETI, Benedetta. Orthographic input and phonological representations in learners of Chinese as a Foreign Language. Written Language and Literacy, 9 (1) 2006, p. 95-114.

BASSNET, Susan. When is a Translation not a Translation apud BASSNET, Susan; LEFEVERE André. Contructing Cultures: Essays in Literary Translation. Clevendon/Philadelphia: Multilingual Matters, 1998.

BAUER, Robert S. Written Cantonese of Hong Kong. Cahiers de Linguistique Asie Orientale, 17, 1998, p.245-93.

BAXTER, William. A Handbook of Old Chinese Phonology. Berlin: Mouton de Gruyter, 1992.

BAXTER, William; SAGART Laurent. Baxter-Sagart Old Chinese reconstruction, version of 20 February 2011: order by Grammatica Recensa number, 2011.

BLACKNEY, Raymond Bernard. A Course in the Analysis of Chinese Characters. The College of Chinese Studies. Toronto: Global Language Press, [1948] 2007.

BLANCHOT, Maurice. Friendship. Transl. by Elizabeth Rottenberg. Stanford, Stanford University Press, [1971]1997.

BO, Mou. Comparative approaches to Chinese philosophy. Aldershot, Burlington: Ashgate Publishing Ltd., 2003.

BODDE, Derk. Chinese Thought, Society and Science. University of Hawaii, 1991.

BODMAN, Nicholas C. A linguistic study of the Shih Ming: initials and consonant clusters. Harvard University Press, 1954.

BOLTZ, William. Origin and Early Development of the Chinese Writing System. New Haven, American Oriental Series, v.78, [1994]2003. 
BOODBERG, Peter. Philological Notes on Chapter One of The Lao Tzu, Harvard Journal of Asiatic Studies. v. 20, n. 3/4, Dec., 1957. p. 598-618.

Some Proleptical Remarks on The Evolution of Archaic Chinese. Harvard Journal of Asiatic Studies, v. 2, n. 3/4, Dec., 1937, p. 329-372.

BORGES, Jorge Luis. Pierre Menard, autor do Quixote. In: Ficções. Transl. by Carlos Nejar. São Paulo: Abril Cultural, 1972.

BOTTÉRO, Françoise. Revisiting the wén 文 and zì 字: The Great Chinese Characters Hoax, [s.d.].

Cang Jie and the Invention of Writing. In: ANDERL C.; EIFRING. H. (Eds.). Studies in Chinese Language and Culture. Oslo: Hermes Academic Publishing, 2006a. p. 135-155.

- Chinese writing: ancient autochthonous perspective. Mémoire d'Habilitation à diriger des recherches sous la direction d'Alain Peyraube, 2011.

. Écriture et Linguistique Autochtone en Chine, 2011. Disponível em: $<$ http://crlao.ehess.fr/docannexe/file/1515/francoise_bottero_hdr_1_me_moire_20 11.pdf $>$. Acessed in 10 fev. 2012.

Review of The Origin and Early Development of the Chinese Writing System, by William Boltz. Journal of the American Oriental Society, 116.3, 1996.

BOTTÉRO, Françoise; DJAMOURI, Redouane. Écriture chinoise: données, usages et répresentations. EHESS, Paris, 2006.

BOTTÉRO, Françoise; HARBSMEIER, Christoph. The Shuowen Jiezi Dictionary and the Human Sciences in China, [s.d.].

BRITTO, Paulo H. Lícidas: diálogo mais ou menos platônico em torno de "como reconhecer um poema ao vê-lo", de Stanley Fish. Revista Palavra, 3. Rio de Janeiro, 1996.

CAMPOS, Haroldo. (Org.). Ideograma: Lógica Poesia Linguagem. Ed. Cultrix. São Paulo, 1977.

CARUS, Paulo. (Trad.). Lao Tze's Tao Teh King. Chicago: The Open Court Publishing Co, 1898.

CASSIN, Barbara. Dictionary of Untranslatables: a philosophical lexicon. Princeton University Press, 2014.

CAVELL, Stanley. The Claim of Reason. Oxford University Press, 1979. 
CHAN, Alan K. L. Two visions of the way. (Suny Series, Chinese Philosophy \& Culture). State University of New York Press, 1991.

CHANG, Chung-yuan. Tao: a new way of thinking. London \& Philadelphia, Singing Dragon. (kindle version), [1977] 2014.

CHANG, H-L. Hallucinating the Other: Derridean Fantasies of Chinese Script. revised version of a paper presented at the conference on Representations of Otherness: Cultural Hermeneutics, East and West, organized by UWM's Vilas Research Professor Ihab Hassan and held at the Center for Twentieth Century Studies in April 1988. (downloaded in August, 2010).

CHANG, Tung-Sun 张东荪. Ren Shi Lun 认识论. 北京 : 商务印书馆出版. Beijing, Shangwuyin Shudian Chuban. [1939] 2011.a

CHANTRAINE, Pierre. Dictionnaire étymologique de la langue grecque: Histoire des mots par Pierre Chantraine. Paris, Klincksieck, [1968, 1980] 2009.

CHAO, J. R. Grammar of Spoken Chinese. Berkeley: University of California Press. 1965.

CHAO, Yuen Ren. A Note on an Early Logographic Theory of Chinese Writing. Harvard Journal of Asiatic Studies, v. 5, n. 2, Jun., 1940, p.189-191.

CHEN, Bo. Xunzi's politicized and moralized philosophy of language: an essay in comparative philosophy, [s.d.]. From $<$ http://www.phil.pku.edu.cn $>$.

CHEN Fuhua 陈复华. (Ed.). Gudai Hanyu Cidian 古代汉语词典. 北京:商务印 书店(Beijing, Shangwuyin Shudian)1998.

CHEN, Guoying 陈鼓应 Laozi jin zhu jin yi (Notes and modern translation of Laozi). 老子今注今译. 北京: 商务印书馆 Beijing: Shangwuyin Shuguan, [1970] 2006

CHEN, Lee-Sun. Laozi's Daodejing: from philosophical and hermeneutical perspectives. Bloomington, In: iUniverse (kindle version), 2011.

Laozi's Daodejing: the English \& Chinese translations based on Laozi’s original Daoism. Blomington: iUniverse. (kindle version), 2011.

CHEN, Tao 陈涛 (ed.). Laozi 老子. 昆明：云南人民出版社(Yunnan Renmin Chubanshe, Kunming), 2011.

CHEN, Tao 陈涛. Changyong hanzi qianshi. 常用汉字浅释。北京: 新界出 版社(Beijing, New World Press), 2011. 
CHENG, Anne. Histoire de la pensée chinoise. Paris: Éd. du Seuil, 1997.

CHICHARRO, Gladys. Devenir Chinois en apprenant à lire et écrire. Ateliers, 24, 2001, p. 87-124.

CHINESE UNIVERSITY of Hong Kong - CUHK. Multi-function Chinese

Character Database. Disponível em:

$<$ http://humanum.arts.cuhk.edu.hk/Lexis/lexi-mf/> Acessed in 12 jan. 2015.

COBLIN, W. South; LEVI Joseph A. Francisco Varo's Grammar of the Mandarin Language (1703): an English Translation of 'Arte de la Lengua Mandarina'. Amsterdam: John Benjamins. 2000.

COUTINHO, Steven. The Abduction of Vagueness: Interpreting the "Laozi." Philosophy East and West, v. 52, n. 4, Oct., 2002. p. 409-425.

CREEL, Howard. On the Ideographic Element in Ancient Chinese. T'oung Pao, Second Series, v. 34, Livr. 4, [1939]1940, p. 265-294.

Chinese Writing. Asiatic Studies in American Education, 2. Washington: American Council on Education, 1943.

On the Nature of Chinese Ideography. T'oung Pao Second Series, v. 32, Livr. 2/3, 1936, p. 85-161

CREEL, Herrlee G. On the Opening Words of the Lao-Tzu. Journal of Chinese Philosophy, 10, 1983. p. 299-329.

Shen Pu-hia: a Chinese Political Philosopher of the Fourth Century BC. University of Chicago Press, 1974.

. What is Taoism? Journal of the American Oriental Society, v. 76, n. 3, Jul. - Sep., 1956. p. 139- 152.

CUNHA, Antônio Geraldo da. Dicionário Etimológico da Língua Portuguesa. Rio de Janeiro: Lexikon Editora Digital, 4a edição, [1982] 2010.

De VAAN, Michiel. Etymological Dictionary of Latin and the Other Italic Languages (Leiden Indo-European Etymological Dictionary). Leiden: Brill Academic Pub, 2008.

DeFRANCIS, John. The Chinese Language: fact and fantasy. Honolulu: University of Hawai'i Press, 1984.

DELEUZE, Giles. Critique et Clinique. Paris: Éd. du Minuit, 1993.

Le Pli: Leibniz et le baroque. Paris Éd. du Minuit, 1988. 
DELEUZE, Giles. Nietzsche e a Filosofia. Electronic version transl. by Ruth Jofilly Dias and Edmundo Fernandes Dias. Rio de Janeiro: Ed. Rio, [1962]1976.

DEWEY, John. Experience and Nature. London: George Allen \& Unwin, Ltd., 1929.

DUPONCEAU, Peter S. A dissertation on the nature and character of the Chinese system of writing: in a letter to John Vaughan, Esq. Philadelphia, 1838.

DUYVENDAK, J. J. L. Tao Te Ching: the book of the way and its virtue. London: John Murray (Publishers) Ltd., 1954.

ECO, Umberto. Quase a Mesma Coisa. Transl. by Eliana Aguiar. Rio de Janeiro/São Paulo: Editora Record, 2007.

ELMAN, Benjamin. From Value to Fact: The Emergence of Phonology as a Precise Discipline in Late Imperial China. Journal of the American Oriental Society, v. 102, n. 3, Jul. - Oct., 1982. p. 493-500.

ERKES, Eduard. Ho-Shang-Kung's commentary on Lao-tse. Artibus Asiae, v. 8, n. 2/4, 1945. p. 121-196; v. 9, n. 1/3, 1946. p. 197-220; v. 12, n. 3, [1945]. 1949. p. 221-261.

ERNOUT, Alfred; MEILLET, Antoine. Dictionnaire de la Langue Latine Histoire des Mots. Paris, Klincksieck, [1932] 2001.

FAZZIOLI, Edoardo; MEI LING, Eileen Chan. Caratteri Cinesi. Ed. Mondadori. Roma, 1986.

FERRATER MORA, José. Dicionário de Filosofía (in 4 volumes, 1994), $2^{\text {a }}$ edition of Ariel Filosofia, Madrid, 2009.

FISH, Stanley. Is there a text in this class? The authority of interpretive communities. Cambridge, Ma./Londres: Harvard University Press, 1980.

FONSECA, Angela F. A tradução das escrituras budistas na China: a primeira onda. Master's thesis - Language Department, PUC-Rio. Rio de Janeiro, 2008.

GALAMBOS, Imre. Orthography of Early Chinese Writing: Evidence from Newly Excavated Manuscripts. Budapest Monographs in East Asian Studies, 2006.

GAO Ming 高. Zhongguo Gu Wenzixue Tonglun 中国古文字学通论. 北京 : 北京大学出版社Beijing, Beijing Daxue Chubanshe), 1996. 
GEANEY, Jane. Grounding "Language" in the senses" what the eyes and ears reveal about ming 名(names) in early Chinese texts. Philosophy East and West, v. 60 , n. 2, April 2010. p. 251-293.

GILES, Herbert. Synoptical Studies in Chinese Character. Shanghai: A. H de Carvalho, Kelly \& Co, 1874.

GLOCK, Hans-Johann. A Wittgenstein Dictionary. Wiley-Blackwell, 1996.

GRAHAM, A. C. (transl). The Book of Lieh-tzu: a classic of Tao. New York: Columbia University Press, 1960.

Disputers of the Tao: Philosophical Arguments in Ancient China. Chicago: Open Court Publishing Company, 1989.

GRANET, Marcel O Pensamento Chinês. Trad. Vera Ribeiro. Contraponto Editora. Rio de Janeiro, [1934,1968] 1997.

Gu Hanyu Da Cidian (古汉语大辞典) (electronic version, ABC software, original by 上海辞书出版社 Shanghai Cishu Chubanshe) [s.d.].

GU Yankui 谷衍奎. (Ed). Hanzi Yuanliu Zidian 汉字源流字典. 北京：华夏 出 版社. Beijing, Huaxia Chubanshe, 2003.

HACKER P. M. Wittgenstein: Meaning \& Mind, v. 3, parts I \& II. WileyBlackwell, 1990.

HALLIDAY, M. A. K. Studies in Chinese Language. London, NY: Continuum Press, 2005.

HAN-LIANG, Chan. Semiographemics: A Peircean trichotomy of classical Chinese script. Semiotica, 108-1/2, [1996] 1998, p.31-43.

HANNAS, William C. Asia's Orthographic Dilemma (Asian Interactions and Comparisons). Honolulu: University of Hawai'I Press, 1997.

HANSEN, Chad. A Daoist theory of Chinese thought. Oxford University Press, 1992.

Chinese Ideographs and Western Ideas. The Journal of Asian Studies, v. 52, n. 2, May, 1993, p. 373-399.

HANSEN, Chad. Chinese Language, Chinese Philosophy, and "Truth". Journal of Asian Studies, v. XLIV, n.3. 1985.

Philosophy of Language in Classical China. From the internet, 01/June/13 [s.d.]. 
HANSEN, Chad. Tao Te Ching: on the Art of Harmony. London: Duncan Baird Publishers, 2009.

HARBAUGH, Rick. Chinese Characters: A Genealogy and Dictionary. Taipei: Han Lu Book \& Publishing Co, 1998.

HARBSMEIER, Christoph. Aspects of Classical Chinese Syntax. Scandinavian Institut of Asian Studies: Monograph Series n. 45, 1991.

HARRIS, Roy. Integrational linguistics and the structuralist legacy. Language \& Communication, n. 19, 1999, p. 45-68.

. Integrationism, language, mind and world. Language Sciences, 26, 2004. p. $727-739$.

Language, Saussure and Wittgenstein: How to play games with words. London: Routledge, 1988.

The Language Myth. London: Duckworth, 1981.

HE Jiusheng 何九盈. Gu Hanyu Yinyun Xueshuyao 古汉语音韵学述要(修订 本), 2010.

HENRICKS, Robert. G. Lao-tzu Te-tao Ching: a new translation based on the recently discovered Ma-wang-tui texts. New York: Ballantine Books, 1989.

HU Qiguang \& FANG Huanhai 胡奇光, 方环海. Erya Yizhu 尔雅译注. 上 海 : 上海书籍出版社(Shanghai, Shanghai Shuji Chubanshe) [2004] 2007.

HUTTON, Christopher. Human diversity and the genealogy of languages: Noah as the founding ancestor of the Chinese. Language Sciences 30, 2008. p. $512-$ 528

IDOEDA, Iñaki Preciado. (Trad.) Tao Te Ching: los libros del Tao. Madrid: Editorial Trotta. 2006.

JACQUES, Guillaume. Introduction to Chinese Historical Phonology. Online version, Leiden, March 2006, p. 27-31.

JIE Dong. The enregisterment of Putonghua in practice. Language \& Communication, n. 30, 2010. p. 265-275.

JOSEPH, John. Harris's Saussure - Harris as Saussure: the translations of the Cours and the third course. Language Sciences, 33, 2011, p. 524-530.

JOSEPH, John; LOVE, Nigel; HARRIS, Roy \& TAYLOR, Talbot. Landmarks in Linguistic Thought, vols 1 \& 2, Routledge: London and New York, [1997] 2001. 
JULLIEN, François. La Valeur Allusive. Paris: Presses Universitaires de France. 2003.

Le détour et l'accès. Paris: Éd. Bernard Grasset, 1995.

O diálogo entre as culturas: do universal ao multiculturalismo. Trad. André Telles. Rio de Janeiro: Ed. Zahar, 2008.

JULIEN, Stanislas. (Trad.). Lao Tseu Tao Te King: le Livre de la Voie et de la Vertu. Paris: Imprimerie Royale, 1842.

KALTENMARK, Max. Lao Tzu and Taoism. Stanford: SUP, 1965.

KANE, Daniel. The Chinese Language: Its History and Current Usage. Singapore: Tuttle Publishing, 2006.

KARLGREN, Berhard. Ordet och Pennan i Mittens Rike. Sound \& Symbol in Chinese. London: Oxford University Press, [1918] 1923.

. Analytic Dictionary of Chinese and Sino-japanese, 1923.

Grammata Serica Recensa. Reprinted from The Museum of Far Eastern Antiquities, bulletin 29, Stockholm, 1957.

KATO, Joken. Chinese Characters. Monumenta Nipponica, v. 8, n. 1/2, 1952, p 192-229.

KEELER, Lauren. Linguistic reconstruction and the construction of nationalistera Chinese linguistics. Language \& Communication, n. 28, 2008. p. 344-362.

KENNEDY, George. A minimum vocabulary in Modern Chinese. The Modern Language Journal, v. 21, n. 8, May, 1937, p. 587-592.

. The Monosyllabic Myth. Journal of the American Oriental Society, v. 71, n. 3, Jul. - Sep., 1951, p. 161- 166.

KLEIN, Ernest. A Comprehensive Etymological Dictionary of the English Language. Elsevier, [1971] 2003.

KNOBLOCK, John (trad). Xunzi, a translation and study of the complete works. Stanford University Press. [s.d.].

KOHN, Livia; LAFARGUE, Michael. Lao-tzu and the Tao-te-ching. Albany: SUNY,1998.

KRATOCHVIL, Paul. Chinese Language Today: Features of an Emerging Standard. London: Hutchinson University Library, 1968. 
KWONG Ki Chu. An English and Chinese Dictionary. Shanghai, San Francisco, London (Trubner \& Co), 1887.

LAU, D. C. Tao te ching: a bilingual edition. Hong Kong: Chinese University Press, [1982] 2001.

LEIBNIZ, Gottfried. La Monadologie, 1714.

LEPSCHY, Giulio. History of Linguistics vol1: the eastern traditions of linguistics. New York: Longman Publishing, 1994.

LI, Feng; BRANNER, David. (Eds.). Writing and Literacy in Early China. Seattle: University of Washington Press, 2011.

LIAO, W. K. The Complete Works of Han Fei Tzu: a classic of Chinese political science. London: ARTHUR PROBSTHAIN. Internet: $<$ http://archive.is/YbXO>, University of Virginia Library. 1959.

LIDDELL, Henry George; SCOTT, Robert. A Greek-English Lexicon (with revised supplement). Clarendon Press, Oxford, 1996.

LIN, Alvin. Writing Taiwanese: The Development of Modern Written Taiwanese. Sino-Platonic Papers, 89. 1999.

LINDQVIST, Cecilia. China: Empire of Living Symbols. Da Capo Press, 2008.

LIU, Guangbi 刘光弜. Laozi Shidu. 老子试读. 合肥: 安徽人民出版社 (Hefei, Anhui Renmin Chubanshe). 2012.

LIU, James J. Y. The Art of Chinese Poetry. Chicago: University of Chicago Press, 1962.

LIU, Lydia H. (Ed.). Tokens of Exchange: the problem of translation in global circulations. Durham: Duke University Press, 1999.

LIU, Xiaogan 刘笑敢. Laozi Gujin 老子古今. 2009.

LOVE, Nigel. (Ed.). Language and History: Intregrationist perspectives. London: Routledge, [2006] 2013. Are languages digital codes? Language Sciences, v.29, 2007, p.690709. 2004. . Cognition and the language myth. Language Sciences, v.26, p. 525-544, 
LOVE, Nigel. Ideal Linguistics. Language \& Communication, v. 8, n. 1, 1988, p 69-84.

. Integrating Austin. Language Sciences, v. 19, n. I, 1997, p. 57-65.

. Searle on language. Language \& Communication, v.19, 1999, p. 9-25.

p 1-17.

. The Fixed-code Theory. Language \& Communication, v. 5, n. 1, 1985,

LOVE, Nigel; ALSALDO, Umberto. The native speaker and the mother tongue. Language Sciences, 32, 2010, p. 589-593.

LUO Xuanmin. Translating Modernity Towards Translating China. In: Luo Xuamin; He Yuanjian. (Org.). Translating China. Multilingual Matters Press. Bristol, 2009.

LURIE, David. Language, writing, and disciplinarity in the Critique of the "Ideographic Myth": Some proleptical remarks. Language \& Communication, n. 26, 2006, p.250-269.

Language, writing, and disciplinarity in the Critique of the "Ideographic Myth": Some proleptical remarks. Language \& Communication, 26, 2006, p. 250-268.

LYNN, Richard John. The Classic of the Way and Virtue: Tao-te ching. Columbia University Press, 1999.

MA, Rusen 马如森. Jiagu Jinwen Taben 甲骨金文拓本. 上海: 上海大学出 版 社(Shanghai, Shanghai Daxue Chubanshe), 2010.

MAIR, Victor. A hypothesis concerning the origin of the term fanqie (“countertomy"). Sino-Platonic Papers, number 34, Oct 1992.

Buddhism and the Rise of the Written Vernacular in East Asia: The Making of National Languages. The Journal of Asian Studies, v. 53, n. 3, Aug., 1994, p. 707-751.

Sound and Meaning in the History of Characters: views of China's Earliest Script Reformers. From: Mary Erbaugh éd: Difficult characters. Interdisciplinary studies of Chinese and Japanese writing, 2002.

MAJOR, John S; QUEEN, Sarah A.; MEYER, Andrew Seth; ROTH, Harold D. The Huainanzi: Liu An, king of Huainan. New York: Columbia University Press, 2010 . 
MARGULIĖS, George. La Langue et l'écriture chinoises. Éditions Payot: Paris, 1943.

MARTINS, Helena.A Linguagem como Forma de Vida e o Perspectivismo. Projeto Inédito Submetido ao CNPQ, 2012a. $2012 b$. . Tradução e Perspectivismo. Revista Letras de Coritiba, n. 9 (no prelo), Beckett e a Língua dos Outros - que outros? Tradução em Revista, n.7, 2009a, p. 01-14.

O chapéu de Beckett. Revista Gragoatá, 26, 2009b, p. 135-154.

MATHEWS, R. H. Matthews' Chinese-English Dictionary. Harvard University Press, [1931]1943.

MATHIEU, Rémi. Lao tseu: le Daode jing. Paris: Éd. Médicis-Entrelacs, 2008.

McDONOUGH, Richard. Reflections on reflexivity. Language Sciences, v. 22, 2000, p.203-222.

MILLER, Richard. Wittgenstein in Transition: A Review of the Philosophical Grammar. The Philosophical Review, n. 4, 1977, Jstor, acessed Nov'14.

MOELLER, Hans-Georg. Before and after representation. Semiotica, n. 143 - 1/4, 2003, p. 69-77.

Chinese Language Philosophy and Correlativism. In: Bulletin of the

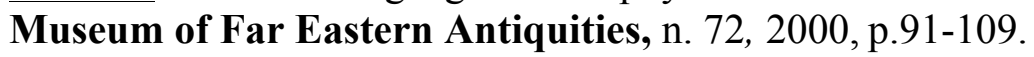

The Philosophy of the Daodejing. New York: Columbia University Press. (kindle version), 2006.

MOREL, Paul. Le Champ du Signe. Paris: Editions You Feng, 2005.

MOUNIN, Georges. Fragmentos dos caps. 1 e $3+$ caps. 4 e 5 . Os problemas teóricos da tradução. Transl. by Heloysa de Lima Dantas.São Paulo: Cultrix, [1963]1975.

NANCY, Jean-Luc. The Sense of the World. Minneapolis: University of Minnessota Press, [1993, 1997] 2003.

NIETZSCHE, Friedrich. Über Wahrheit und Lüge im außermoralischen Sinn. In: Philosophy and Truth: Selection of Nietzsche's Notebooks of the early 1870's. Ed and Tr. by Daniel Breazeale, Humanities Press, New Jersey, [1973]1993. 
NIETZSCHE, Friedrich. Da Retó rica. Trad. de Tito Cardoso e Cunha. In: Lisboa: Vega, 1995, from the original Nietzsches Gesamwelte Werke, Mü nchen, Musariou Verlag, 1922.

The Gay Science. Cambridge Texts in the History of Philosophy. Ed. Bernard Williams, transl. Josefine Nauckhoff, CUP, [1887]2001.

The Will to Power. Ed. by Walter Kaufmann, tr. by Walter Kaufmann and R.J. Hollingdale. New York: Vintage Books, 1968.

NORMAN, Jerry. Chinese. CUP, 1988.

NYMAN, Michael. The Five "Confucian” Classics. Yale University Press, 2001.

OWEN, Stephen. Readings in Chinese Literary Thought. Council on Asian Studies, Harvard, 1992.

OXFORD English Dictionary (OED), $2^{\text {nd }}$ Edition - kindle version. [s.d.].

PACKARD, Jerome L. The Morphology of Chinese. Cambridge, CUP, 2000.

PARTRIDGE, Eric. Origins: a short etymological dictionary of modern English. Routledge \& Taylor, [1958]2006.

PELLIN, Tommaso. Inventing a modern lexicon for grammar in Chinese: the experience of Wang Fengzao, Ma Jianzhong and $\mathrm{Yan} \mathrm{Fu}$. Language Sciences, $\mathrm{n}$. 30, 2008, p. 529-545.

PENG, Yushang 彭裕商. Guodian Chujian Laozi Jishi 郭店楚简老子集释, 2011.

PETERS, F. E. Greek Philosophical Terms: a historical lexicon. New York University Press, 1967.

PING Chen. Modern Chinese: history and sociolinguistics. Cambridge: Cambridge University Press, 1999.

PING Shanjiu 平山久. Hanyu Yuyinshi Tansuo 漢語語音史探索, 2012.

PLATO, Cratylus. Plato in Twelve Volumes, v. 12, translated by Harold N. Fowler. Cambridge, MA, Harvard University Press; London, William Heinemann Ltd., 1921.

PORTER, David. Ideographia: The Chinese Cipher in Early Modern Europe. Stanford University Press, 2001.

PRADO Jr, BENTO. Erro, ilusão, loucura. São Paulo: Editora 34, 2014. 
QIAN Zhongshu. Limited Views: essays on ideas and letters. Harvard Asian Center, 1998.

QIU Xigui 雸锡圭. Hanzi Xuegaiyao 汉字学概要, 2012.

RAMSEY, Rachel. China and the Ideal of Order in John Webb's. An Historical Essay.... Journal of the History of Ideas, v. 62, n. 3, 2001, p. 483-503.

REN, Jiyu 任继愈. Laozi Yidu 老子绎读. 北京: 商务印书店 (Beijing, Shangwuyin Shudian), 2009.

RICHARD, Sears. "Chinese Etimology," mantained by Richard Sears. Disponível em: <http://www.chineseetymology.org> Acessed in 12 jan. 2015.

ROBERTS, Moss. Dao De Jing: the Book of the Way. University of California Press, 2001.

ROHDEN, Huberto. (Trad.). Tao Te Ching: o livro que revela Deus. São Paulo: Editora Martin Claret, 2003.

ROHSENOW, John S. ABC Dictionary of Chinese Proverbs. University of Hawaii Press, 2002.

ROSA, João G.; LORENZ, Günter W. Diálogo com Guimarães Rosa. In: COUTINHO, Eduardo (Org.). João Guimarães Rosa: ficção completa, v. 1, Rio de Janeiro: Nova Aguilar, [1965] 2009.

ROUZER, Paul. A New Practical Primer of Literary Chinese. Cambridge: Harvard University Press, 2007.

RUMP, Ariane. Commentary on the Lao Tzu by Wang Pi. Monograph 6 of the School for Asian and Comparative Philosophy, University Press of Hawaii, 1979.

RYDEN, Edmund. Daodejing: a new translation by Edmund Ryden. Oxford World's Classics, 2008.

SAUSSURE, Ferdinand de. Curso de Linguística Geral. Transl. by Antônio Chelini, José Paulo Pires and Izidoro Blikstein. Ed. Cultrix. São Paulo, [1916]2006.

SAUSSY, Haun. Outside the Parenthesis (Those people were a Kind of Solution). MLN 115. The Johns Hopkins University Press, 2000, p.849-891.

SAUSSY, Haun; STALLING, Jonathan and KLEIN, Lucas. (Orgs.). The Chinese Written Character as a Medium for Poetry: a critical edition written by Ernest Fenollosa and Ezra Pound. New York: Fordham University Press, 2008. 
SCHALKWYCK, David. A Report to the Academy: Talbot Taylor and the rhetorical roots of contemporary language theory. Language Sciences, n. 27, 2005, p. 97-112.

SCHUESSLER, Axel. ABC Etymological Dictionary of Old Chinese. Honolulu: University of Hawai'i Press, 2007.

Minimal Old Chinese and Later Han Chinese. Honolulu: University of Hawai'i Press, 2009.

SEELEY, Christopher. History of Writing in Japan. Honolulu: University of Hawai'I Press, 2000.

SHARROCK, Wes; COULTER Jeff. After interpretation: Roy Harris on mind and knowledge. Language Sciences, n. 33, 2011, p.519-523.

SHEPHERD, Robert J. Perpetual Unease or Being at Ease? Derrida, Daoism, and the 'Metaphysics of Presence'. Philosophy East and West, v. 57, n. 2, Apr., 2007. p. 227-243.

SPROVIERO, Mario Bruno. (MBS). Laozi Dao De Jing. São Paulo: Ed Hedra, 2007.

SUAREZ, Rosana. Nietzsche e a Linguagem. Rio de Janeiro, Ed. 7 Letras, 2011.

SZCZESNIAK, Boleslaw. The Origin of the Chinese Language According to Athanasius Kircher's Theory. Journal of the American Oriental Society, v. 72, n. 1, Jan. - Mar., 1952, p. 21-29.

SZE, Arthur. (Ed.). Chinese writers on writing. San Antonio: Trinity University Press, 2010.

TANG, Han 唐汉. 汉字的奥秘. hanzide aomi 北京:新世界出版社. Beijing: Xinshijie Chubanshe, 2012.

TANG, Lanzhuan 唐兰撰. Zhongguo Wenzixue 中国文字学. 上海: 上海古籍 出 版社 (Shanghai, Shanghai Guji Chubanshe) 2004.

TAYLOR, John. Polysemy's Paradoxes. Language Sciences, v.25, 2003, p. 637655.

TAYLOR, Talbot. Calibrating the child for language: Meredith Williams on a Wittgensteinian approach to language socialization. Language Sciences, v. 40, 2013, p.308-320.

Language constructing language: the implications of reflexivity for linguistic theory. Language Sciences, v.22, 2000, p. 483-499. 
TAYLOR, Talbot. Language development and the integrationist. Language Sciences, v.33, 2011, p. 579-583. 1997. p.1-5.

Roy Harris and the Philosophy of Linguistics. Language Sciences, v.19, Theorizing Language. Emerald Press, 1997.

Understanding others and understanding language: how do children do it? Language Sciences, v. 34, 2012. p. 1-12.

Where does language come from? The role of reflexive enculturation in language development. Language Sciences, v.32, 2010, p. 14-27.

TONG, Q. S. Between knowledge and 'plagiarism,' or, how the Chinese language was studied in the West. Language Sciences, v. 30, 2008, p. 499-511.

UNGER, J Marshall. The Very Idea. The Notion of Ideogram in China and Japan. Monumenta Nipponica, v. 45, n. 4, Winter, 1990, p. 391-411

URMSON, J. O. The Greek Philosophical Vocabulary. Duckworth, 1990.

VANDERMEERSCH, Léon. Les deux raison de la pensée chinoise: divinations et idéographie. Paris: Éd. Gallimard, 2013.

VENUTI, Lawrence. A Invisibilidade do Tradutor. Transl. by Carolina Alfaro. Revista Palavra, n. 3. Rio de Janeiro, 1996.

VIVEIROS DE CASTRO, Eduardo. Perspectivismo e multinaturalismo na América indígena. O que nos faz pensar n. 18, setembro de $2004^{\mathrm{a}}$.

Exchanging Perspectives: The Transformation of Objects into Subjects in Amerindian Ontologies. Common Knowledge, v. 10, issue 3, Duke University Press, 2004b.

VIVEIROS DE CASTRO, Eduardo.. A Inconstância da Alma Selvagem. São Paulo: Ed. Cosac Naify, 2011.

Filiação Intensa e Aliança Demoníaca. Novos Estudos 77 - Mar., 2007.

No Brasil todo mundo é índio, exceto quem não é. Originally published in Povos Indígenas do Brasil: 2001-2005, de Beto e Fany Ricardo. [s.d.].

. O Nativo Relativo. Mana [online] 8(1), 2002. p. 113-148.

. The Nazis and the Amazonians, but then again, Zeno. "Comparative Relativism" Seminar - Copenhagen, Set., 2009. 
VOLPICELLI, Z. Chinese Phonology. Shanghai: China Gazette Office, 1896.

WAI-LIM Yip. Ezra Pound's Cathay. Princeton University Press, 1969.

WALEY, Arthur. The Way and Its Power. New York: Grove Press,[1934]1958.

WANG, Jianjun 王键军. Zhongxi Yuyanxueshi Zhibijiao 中西方语言学史之比, 2009.

WANG, Li 王力. Zhongguo Yuyan Xueshi 中国语言学史. 上海: 复旦大学出 版社. Shanghai: Fudan Daxue Chubanshe, 2005.

WANG, Jian; INHOFF, Albrecht W.; CHEN Hsuan-Chih. (Eds.). Reading Chinese Script: a cognitive analysis. New Jersey: Lawrence Erlbaum Associates, Inc, 1999.

WATERFIELD, Robin. The First Philosophers: The Presocratics and Sophists. Oxford University Press, 2000.

WATSON, Burton (Trad.). Zhuangzi: basic writings. Columbia University Press, 2003 b.

. (Trad.). Hanfeizi: basic writings. Columbia University Press, 2003c.

. (Trad.). Mozi: basic writings. Columbia University Press, 2003c.

. (Trad.). Xunzi: basic writings. Columbia University Press, 2003a.

WATTERS, Thomas. (Trad.). Lao Tzu: a study in Chinese philosophy. London: Williams \& Norgate, 1870.

WERRY, Chris. Rhetoric and reflexivity in cognitive theories of language. Language \& Communication, v. 25, 2005. p. 377-397.

WIEGER, L. Chinese Characters: their origins, etymology, history, classification and signification: a thorough study from Chinese documents. Hokien Fu: Catholic Mission Press. 1927.

WILDER, G. D; INGRAM, J. H. Analysis of Chinese Characters. New York: Dover Publications, [1922]1974.

WILHELM, Richard. (Trad.). Tao-te King. Lao-tzu. São Paulo: Ed. Pensamento, [1978]2004.

WILliamS, C. A. S. A Manual of Chinese Metaphor. University of Michigan Library (edição digitalizada). 1920. 
WITTGENSTEIN, Ludwig:

Remarks on Frazer's “The Golden Bough”. from Wittgenstein's Nachlass, The Bergem Electronic Edition. Oxford University Press, 2000.

Philosophische Untersuchung - Philosophical Investigations. Translated by ANSCOMBE, G. E. M.; HACKER, P. M. S. and SCHULTE, Joachin. WileyBlackwell, 2009.

The Collected Works of Wittgenstein. Edited by WRIGHT, G. H. von and ANSCOMBE, G. E. M. Blackwell, 1998.

Philosophical Remarks (P.R.),

Philosophical Grammar (P.G.),

Blue \& Brown Books (B.B.),

Remarks on the Foundations of Mathematics (R.F.M.),

Culture \& Value (C.V.),

Philosophical Investigations (P.I.)

Preliminary Studies for Part II of Philosophical Investigations MSS 137138 (P.S.),

On Certainty (O.C.).

WOHLFART, Günter. Philosophical Taoism - Zhuangzi Lectures, [2005] 2012.

WOLF, George; LOVE, Nigel. Linguistics Inside Out: Roy Harris and His Critics. John Benjamins, 1997.

WU, Juh Cherng. Tao Te Ching: O Livro do Caminho e da Virtude (ano?) Rio de Janeiro: Ed. Mauad (electronic edition). [s.d.]

XU, Shen (Han) 許慎（漢）/ Xu Xuan (Song) 徐鉉（宋）Shuowen Jiezi 說文 解字. 上海: 上海古籍出版社 (Shanghai, Shanghai Guji Chubanshe) 2004.

YANG, Liu (Ed.) 杨柳. Xinbian Shuowen Jiezi Daquanji 新编说文解字大全 集. 北京: 中国华侨出版社(Beijing, Zhongguo Huaqiao Chubanshe) 2011.

YU, Pauline; BOL, Peter; OWEN, Stephen; PETERSON, Willard. Ways with words. University of California Press, 2000. 
ZHANG, Dainian. Key Concepts in Chinese Philosophy. Transl. by Edmund Ryden. Yale University and Foreign Language Press. 2002.

ZHANG, Longxi. Mighty Opposites. Stanford University Press, 1998.

The Tao and the Logos: literary hermeneutics, east and west. Duke University Press. 1992.

ZHENGZHANG, Shangfang. The Phonological System of Old Chinese: Collection des Cahiers de Linguistique Asie Orientale. Paris: EHESS: CRLAO, 2000 .

ZHIQUN Chen. Ideographic versus Phonetic: A Debate over the Nature of Chinese writing in the 1930s. Chinese Studies Review, n. 1, v. 3, May 2008.

ZOURABICHVILI, François. O Vocabulário de Deleuze. 2003. Electronic version, transl. by André Telles, 2004). 


\section{6 \\ Appendix}

6.1.

Appendix 1 - Timeline (until $3^{\text {rd }}$ century AD)

In this section I present a chronological table with the approximate dates of the most relevant milestones regarding the historical context of the Lăož̆, together with its its different versions, manuscripts, and commentaries, ${ }^{308}$ etc., until the Three Kingdoms Period.

\section{Eastern Zhou dynasty 東周 dōngzhōu, 770-256 BC:}

Spring and Autumn period 春秋時代 chūnqiū shídài (771-481 BC)

- Lăož̀ 老子, 571-480 BC - traditional dates (Ryden 2008, xxxv) $)^{309}$

- Kŏngzĭ(Confucius) 孔子, 551-479 BC

Warring States period 張國時代 zhàngguó shídài (481-221 BC):

- Mòzl 墨子, $\left(470-c .391 \mathrm{BC}, f l .5^{\text {th }}\right.$ cent. BC $)$

- Lièž 列子 ( $f l$. ca. 400 BC): Lăozl̆ is mentioned as “Lao Dan”.

- Mèngzì (Mencius) 孟子 $\left(f l .4^{\text {th }}\right.$ cent. BC)

- Zhuāng $Z \check{l}$ 莊子, (mid- $4^{\text {th }}$ cent. BC - beginning $3^{\text {rd }}$ cent. BC): several passages discussing "Laozi" and hypothetical meetings between Lăož̆ and Confucius.

- Guōdiàn 郭店, (ca. 300 BC) manuscript on bamboo of the Lăož́

- Xún Zĩ 荀子(ca. 312-230 BC)

- Eryă 爾雅dictionary $\left(3^{\text {rd }}\right.$ century $\left.\mathrm{BC}\right)$

- Lüshi Chūnqiū 呂氏春秋(postface dated 240 BC)

\footnotetext{
${ }^{308}$ For an extensive table of the commentaries of the Lăož̆, see Robinet (In: Kohn \& LaFargue, 2008, p. 120-1)

309 There is no consensus even about the approximate dates of the writing of the Lăožl. Current scholarship dates it around the second half of the $4^{\text {th }}$ century BC. For more details, see Idoeda (2006, p. 22-29), Baxter (In: Kohn \& LaFargue, 1998, p. 232-3), Kaltenmark (p. 13-5) and others.
} 
- Hánfēiž̀, attributed to Hánfēi ( 韓非 ) †233 aC: the oldest surviving commentary of chapters of the Lăož̀.

\section{Qin Dynasty 秦朝 qíncháo, 221-206 BC}

\section{Western Han Dynasty 西漢代xihàndài, 206 BC- AD 8}

- Măwángdū 馬王堆 silk manuscript of the Laozi: version A, 206-195 BC; version B, 194-180 BC.

- Huáinánzĭ, compiled ca. $140 \mathrm{BC}$

- Shǐji 史記, Annals of History, between 109-91 BC

- L L $\dddot{j} i$ 禮記, Classic of Rites, compiled by Tai Sheng (fl. $1^{\text {st }}$ cent. BC)

- Yán Zūn 巖尊, commentary dào dé zhī guĭ lún (end $1^{\text {st }}$ cent. BC)

- Fāngyán 方言dictionary, attributed to Yáng Xióng 揚雄(53 BC-18 AD)

\section{Eastern Han Dinasty 東漢代 dōnghàndài, 25-220 AD}

- Hànshū, 漢書, Book of Han, finished AD 111.

- Shuōwén jiězi 說文解字dictionary, traditional date $123 \mathrm{AD}$

- Héshàng Gōng 河上公, commentary of the Lăož̀

- Foundation of the Celestial Masters of Dao, tiān shī dào 天師道, $142 \mathrm{AD}$, religious Daoism

- Shiming 釋名dictionary, around 200 AD.

\section{Three Kingdoms Period 三國時代sānguó shǐdài, 220-280 AD}

- Hé Yàn 何晏, ca.195-249 AD, commentary on the Lăozl̆ (dào dé lùn 道德論).

- Wáng Bì 王矶, 226-249 AD, first dated commentary of the Lăozĭ.

- Xiăng ěr (想爾), ca. 190-220 AD, manuscript commentary of the Lăož́.

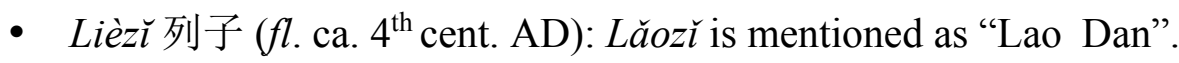




\section{2.}

\section{Appendix 2}

This appendix includes additional information that provides further support to the comparative analyses of the seven Chinese characters selected in the second part of chapter II. Presented here, where relevant, are: 1) a brief exhibition showing samples of each character in the writing styles predating the Shuōwén; 2) passages translated and briefly discussed from the Chinese canonical sources; and 3) glosses of the characters from the modern and contemporary graphoetymological sources. A complementary analysis regarding míng 名 is also included in this appendix.

The palaeographological sources are taken from the Multi-function Chinese Character Database, kept by the Chinese University of Hong Kong (http://humanum.arts.cuhk.edu.hk/Lexis/), henceforth CUHK, and, if not otherwise noted, from the website http://www.chineseetymology.org/, accessed in 2012-2014, kept by Richard Sears. The CUHK's primary sources, indicated where possible, are as follows: 1) For the Oracle Bone characters, the standard source is the jiăgŭwén héji 甲骨文合集, a 13 volume compilation of 41.956 characters published by Zhōnghuá shūjú 中化書局, edited between 1978 and 1982. 2) For bamboo characters, the Guōdiàn jí 郭店集 (from which the Guodiàn Lăož̀ is a part); the Măwángdū 馬王堆; the Tsinghua Bamboo Slips (Qìnghuá jiăn 清華簡) - a collection of texts dating to the Warring States period and acquired in 2008 by Tsinghua University; the Shànbó zhúshū 上博竹書, the collection of slips from the Shanghai Museum; and the Shuihǔdì Qín jiăn 睡虎地秦简, a collection of slips unearthed in Hubei dating from the Qin dynasty. 3) For the Bronze Script, there are many sources indicated in the CUHK, among them Zhòngjíyimü yí 仲姞 義母匝, from the later Western Zhou dynasty; Xiàngqiěxīn dǐng 象且辛鼎, from the Shāng dynasty; and the Shìtāngfù dǐng 師湯父鼎 and Kuāng yǒu 匡面, both from the Middle Western Zhōu dynasty. 
道 dào.

\section{Samples predating the Shuōwén}

BS:
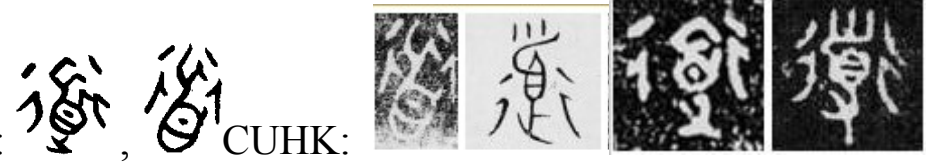

Guōdiàn Lăož̃:

LS:

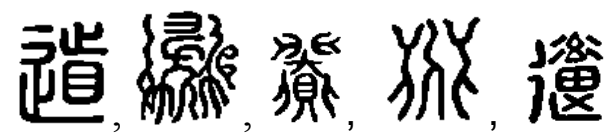

And in Bamboo: ${ }^{310}$ CUHK (Qīnghuá jiăn 清華簡二•繫年70)

\section{Passages from canonical traditional sources}

Dào 道 appears twice in the first chapter of the $\check{E} r y \check{a}$ (shiğ̌ 釋詁， "Explaining the old reading"). The first gloss is:

釋詁: 梏, 梗，較，延，庭，道，直也。311

shìgǔ: jué, gěng, jiào, tǐng, tíng, dào, zhí yěrl2

The tradition interprets the characters of this line with their meanings relating to honesty, straight, honest (glossed here as $z h i$ 直). ${ }^{313}$ Thus we have, for example, jué 梏, honest; gěng 梗, straight, honest; ť̌ng 颛, which should be read as ting 挺 of tingzhi 挺直, which means straight, standing, etc. Later in the same chapter one sees three other characters glossed by dào 道:

\footnotetext{
${ }^{310}$ Some old Chinese script styles, such as "Bronze script," refer to the media of writing, although the style cannot be confined to any one particular media since the media itself has a big impact on the general appearance of the character, and therefore this has led to some confusion. For these reasons, the bamboo writing examples might also be considered as portraying "Bronze" script characters.

${ }^{311}$ The character for dào 道 is shown here in a larger typeface only for visual contrast for this analysis.

${ }^{312}$ The semantic relations among the characters in the Ëryă are sometimes speculative and laden with philological justifications. In order to simplify and to help with legibility, instead of presenting the translation of all the characters in the Ëryă lists I have selected some characters that are explained in the text immediately after the lines in Chinese and pinyin.

${ }^{313}$ For these interpretations, most of my analyses are indebted to HU.
} 
釋詁: 迪, 繇, 訓, 道也。

shigǔ: dí, yóu, xùn, dào yě.

A modern reading of these characters orbits around meanings related to laws, standards or principles (in modern Mandarin: dàoli 道理 ${ }^{314}$ ). Thus: dí 迪, as principle, according to, argument, to enlighten; yó 繇 as a correlate of yóu 由 and translated as cause, reason; finally xùn 訓to teach, (to give) rules, laws, to explain. Because the term in the end of the series is dào 道 itself, one can arguably assume that this suggests more important (direct?) connotations of dào 道than those of the first series that ended in $z h i$ 直.

It should be clear by now that once these glosses are translated into contemporary English all the connotations of the English words become explicit and are potentially misleading. For instance, in translating di 迪 as principle or xùn 訓 as laws and then using the English words as glosses for dào 道, one would inevitably connote strong implications of a natural order organized under strict laws and principles. The connotations of to enlighten, argument, to teach and to explain, seem more reasonable, although to restrict our glosses to them would only show a bias towards another worldview with other motivations. As per the methodological principles at work here, I intend to show a broad gamut of glosses in order to articulate the many connotations involved.

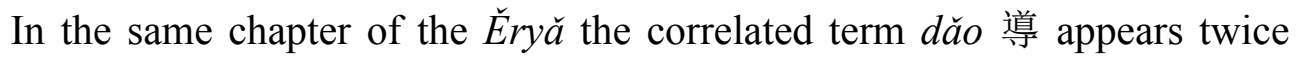
(but, unlike the Shuōwén, never in the same line with dào 道):

釋詁: 詔, 亮, 左右, 相, 導也。詔, 相, 導, 左, 右, 助, 勴也。亮, 介, 尚, 右也, 左, 右, 亮也。

shìgǔ: zhào, liàng, zuǒyòu, xiāng, dăo yě. zhào, xiāng, dăo, zuǒ, yòu, zhù, lü yě. liàng, jiè, shàng, yòu yě, zuǒ, yòu, liàng yĕ.

${ }^{314} \mathrm{Ll}$ 理 is "the Chinese term most often associated with reason and reasoning." (Ames \& Hall, 1998, p.29) This translation is highly problematic, as these authors notice, and potentially misleading. Ames \& Hall argue that in the absence of an ontological tradition, the act of understanding the dynamics of dào 道 (hence the term dàoľ 道理) cannot have ontological reference, that is, it cannot objectify the subject of its study, dào 道. 
With regard to the first group of characters, ${ }^{315}$ all refer to some kind of guidance or teaching. For example, we see zhào 诏 as notification, (imperial) edict, which eventually takes the meaning of order, orientation, teaching (such as jiàodăo 教導 in modern Mandarin). Liàng 亮 connotes clear, to reveal, to show, honest, etc., but also takes the acceptation of teaching (such as fŭdăo 辅導 in modern Mandarin). Zuǒyòu 左右 literally means left-right, and HU (p. 36-7) reads this as zuóyòu 佐佑 assist the regent in ruling the country. Dăo 導 also reappears in the second group of characters ${ }^{316}$ with the connotations of helping or assisting. One notices the repetition of characters between the two series, but with different interpretations (emphases) according to the series in question. For example, liàng 亮 is glossed in the second group as honest and sincere, believe, to be creditworthy. ${ }^{317}$

Dào 道 likewise appears in the fifth chapter of the Ěryă, shigōng 釋宮, "Explaining the dwellings," where it closes off another series of characters:

釋宮: 路, 旅, 途也, 路, 場, 猷, 行, 道也。 shìgōng: lù, lü, tú yě, lù, yì, yóu, xíng, dăo yě.

In this chapter dào 道 is positioned among terms that in general refer to a physical space, as in travel / to travel (lü 旅), road (lù 路) to walk, to go (xíng 行), frontier (yi场), plans, schemes (yóu 猷 $^{318}$ ) and others.

And later in the same chapter:

釋宮：一達，謂之道路，二達，謂之歧旁，三達，謂之劇 旁, 四達, 謂之矆, 五達, 謂之康, 六達, 謂之莊, 七達, 謂之劇驂, 八達, 謂之崇期, 九達, 謂之迬。

\footnotetext{
${ }^{315}$ Zhào, liàng, zuǒyòu, xiāng, dăo yě 詔, 亮, 左右, 相, 導也。

${ }^{316}$ Zhào, xiāng, dăo, zuŏ, yòu, zhù, lü yě 詔, 相, 導, 左, 右, 助, 勴也。

317 See HU (p. 17 \& 37).

${ }^{318}$ Curiously, yó $u$ 猷 is glossed in GH also as magic, witchcraft, specifically in a comment written by Zhèng Xuán 鄭玄(127-200 AD) about Taoism! See also the gloss from the Fāngyán, below.
} 
shìgōng: yī dá, wèi zhī dào lù, èr dá, wèi zhī qū páng, sān dá, wèi zhī jù páng, sì dá, wèi zhī qù páng, wǔ dá, wèi zhī kāng, liù dá, wèi zhī zhuāng, qũ dá, wèi zhī jù cān, bā dá, wèi zhì suí qī, jiǔ dá, wèi zhī kuí.

Unlike the other glosses shown before, this is not a mere list of characters, but a specific list of the "Nine directions/destinations," jiǔdá 九達, considered as different "types of paths." I will not go into detail here about the interpretation of these different "paths," only calling attention again to the "concrete" aspect of dào 道.

In the Fāngyán, dào 道 appears as the object of a gloss only once, in book three:

$$
\begin{aligned}
& \text { 裕、猷, 道也。東齊曰裕, 或曰猷。 } \\
& \text { yù 、 yóu, dào yě. dōng qí yuē yù, huò yuē yóu. }
\end{aligned}
$$

Abundant/affluent [yù 裕], (magical/abstruse) plan/scheme [yó $u$ 猷], [these glosses are for ] dào 道. In the Eastern State of Qí [dōng qi $i$ 東齊] [dào 道] was called $y \grave{u}$ 裕 or yóu 猷.

Once more we perceive the intricate network of related meanings and sounds of ancient Chinese. The Fāngyán presents alternative forms of dào 道 that were presumably spoken in what was, during the Zhōu dynasty, the Eastern State of Qi (in present Shāndōng). It seems unlikely that a term as omnipresent in ancient China as dào 道would have completely different forms in Qí. Therefore it could be argued that these two new characters, yù 裕 and yóu 猷, had a semantic import to the uses of dào 道. GH even has one of the glosses of yù 裕 as dào 道: the connotations of abundant, opulent and luxurious eventually "merged" in the use of yù 裕as the richness of Dao, the plentiful Way, etc. A similar movement happened to yóu 䣭, as the scholar Zhèng Xuán (127-200) wrote: yóu dào yě 䣭, 道也, “[as for] yóu 猷, [it is glossed by] dào 道.”

The Shiming refers to this gloss in the beginning of its "explaining speech/words" chapter (shì yányǔ 釋言語): 
道, 導也, 所以通導萬物也。

dào, dăo yĕ, suǒy̆ tōng dăo wànwù yĕ.

dào 道, [From] dăo 導, the reason why [suǒyı̆ 所以] [is] through dăo 導[came] the myriad things [wànwù 萬物]

We have seen that modern analyses will also identify parallels between the two characters, both semantically as well as phonetically. Ames \& Hall (2003, p. 57), for instance, write that the Shuōwén's etymological analysis of dào 道 is a conjugation of to pass over, to go over, to lead through (on foot) (alluded by the character for feet) with foremost (alluded by the character for head). The close relationship between dào 道 and dăo 導 shows, for these authors, their "primarily gerundive, processional and dynamic" character. The oldest instance of dào 道, still according to these authors, would have been in the Liji, in the context of "cutting a channel, thus 'leading' a river to prevent the overflowing of its banks." (Ibidem)

\section{Additional contemporary sources}

GU starts its analysis of the character dào 道 with a graphical evaluation of dăo 導 (both are considered semantic compounds, huìyi 會意), a graphic representation of a hand in front of a head showing the way. ${ }^{319} \mathrm{GU}$ states that the “original meaning” of dào 道 was to guide, to lead (y̌ndăo 引導), and then lists nine derivative meanings, usually in the same line as the GH. It is worthwhile to note that GU indicates that the character associated with the "original meaning" of this "word family" is dào 道- and not dăo 導. According to this source, only later would there have been a “semantic separation” (fênhuà zìỳ 分化字義) between the two characters, with the addition of the radical cùn 寸 used to differentiate between the meanings of dăo 導 (lead, teach, etc.) and dào 道 (with a derived meaning to be guided by the way and, later, way, the way). The dictionary concludes: "all meanings derived from dào 道 are related to the meanings of to

${ }^{319}$ In the original Chinese text: shǒu zài tóu qián yú lùshang yǐndăo xíng zhī yì 手在头前于路上引 导行之意. 
guide, to lead." ${ }^{320}$ In this sense, when it favors the chronological semantic derivations associated with dăo 導 (instead of dào 道), GU's analysis differs from the Shuōwén's.

YL, on the other hand, prefers to identify the "original meaning" of dào 道 as the way in the concrete sense (dàolù 道路), thereafter evolving to process and then on to other more abstract uses, such as method, manner, etc.

The relationship between dào 道 and dăo 導 is also prominent in the phonetic-motivated etymological study of Schuessler (2007). This author writes that the meanings of "road, way, method" are suggested by dào 道 in the bronze inscriptions and in the Shijīng. Schuessler considers dào 道as a cognate of dăo 導, which in turn is glossed as "to go along, bring along, conduct" and was written dào 道 in the Zuǒzhuàn 左傳 and dăo 導 in the Mencius (Mèngž̀ 孟子), with the semantic derivation as to explain in the Lĭjì and talk about in the Lăož̀ and also again in the Mèngž̀.

\section{Míng 名}

\section{Samples predating the Shuōwén}

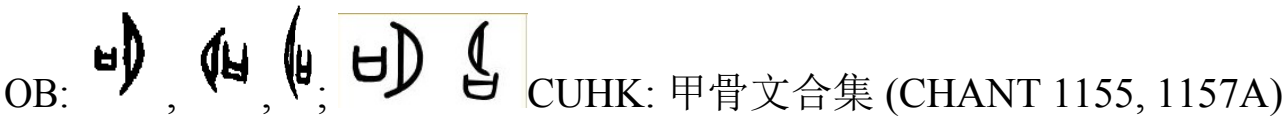

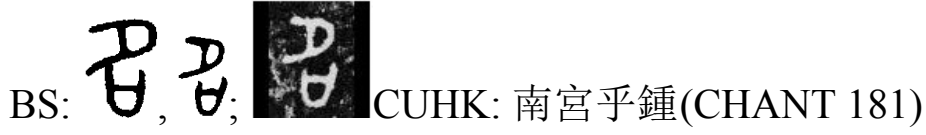

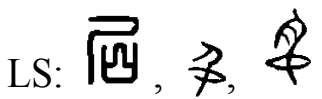

\section{Is wángmìng 亡命a metaphor?}

The character ming 命's relationship to ming 名 can also be analyzed from the point of view which affects what we might call its literal and metaphoric meaning.

${ }^{320}$ In the original Chinese text: fán cōng dào qŭ yì de zì jiē yŭ yǐndăo děng yì yǒnguān 凡从道取义 的字皆与引导等义有关. 
We have seen in the grapho-etymological exploration of ming 名, ming 命 and ling 令 in the main text, that there is an intimate relationship between the act of naming, which has a coercive force, and what we might think of as a metaphor for the entire life of the one being named. However, I suggest that we ponder whether this could actually be called a metaphor. In English in an expression like "The political scandal ruined his good name," it makes sense in principle to say that "ruined his (good) name" is a vehicle (in the sense of IAL Richards ${ }^{321}$ ) being used in lieu of the assertion "ruined his reputation," or, taken to the ultimate consequences, "ruined his life." The abstract noun "name" or "reputation" should not be predicated with the verb to ruin, which "usually" (literally?) should be applied only to predicates that have a more concrete reference, so we find ourselves in a situation of linguistic unfamiliarity, of a feeling of oddness. ${ }^{322}$ It is undoubtedly difficult to specify exactly what this kind of strangeness is, hence, for example, the use above of the adverb usually between quotation marks to refer to the typical usage of the verb to ruin. This feeling of oddness thus became one of the central subjects in the studies of the metaphor, examined in their motivations, originality, illocutionary and perlocutionary effects, etc. For our purposes, without going into too much detail, it seems enough to think that there is a "mismatch" between parts of speech and an expectation that a term A would "naturally" (again the quotation marks show us a clear situation of discomfort!) never be used before a term B following in the discourse, but with another, better matched, term $\mathrm{C}$ that is absent, the one referred by IAL Richards as tenor.

How is this analysis relevant for this example in Chinese? First, we have terms that are "related" (cognates) in both their phonetic and graphic forms, ming 名 and ming 命, one being used (in the Shuōwén) as a gloss for the other. Even if today one of the terms is characteristically used to refer to what we would translate in English as name (ming 名) and the other as life and order (ming 命), the etymological analysis seems to show that this distinction is relatively recent. Second, there is no clear distinction made whereby a term was actually replaced in

\footnotetext{
321 The Philosophy of Rhetoric, 1936.

322 Quoting another important author in the Western studies on metaphor, "be ruined" is the modifier (the unreal, the "metaphoric") while "life" is the modified (the real, the "literal"), as per Beardsley (Aesthetics, 1958).
} 
the discourse by the other, as in the case above in English (life by name/reputation). An expression like wángming 亡命 could be read both in the sense of losing life (not in the sense of dying, but to lose all the benefits of life), as well as losing the name and reputation. There is no grammatical or linguistic feeling of oddness and therefore it does not seem that we are dealing here with a metaphor, at least not in the "usual" (Western?) sense of the word. If the metaphor necessarily implies that there must be a literal sense (as shown by the analysis of vehicle / tenor proposed by I.A.L. Richards or the relationship between modified and modifier by Monroe Beardsley), from the moment one side is questioned, the other is naturally impaired. The metaphor is a phenomenon that is necessarily related (by opposition) to a literal sense, one that is somehow nearer to the reality, to "the world outside of language." By this connection to reality (or the perception thereof), literal expressions would not cause the unfamiliarity that occurs in the case of a metaphorical expression. In the example of the Chinese character the literal and metaphoric merge into the polysemy of the character ming 命, both life as well as name/reputation. One can counter-argue that in the Western use of an expression such as "lose or finish (with) their name," the word name is polysemous and could also denote life. However, we tend to consider that name primarily (or usually) does not designate life, only in certain special secondary situations. This hierarchy is lacking in classical Chinese's ming 命 and it is this absence that opens the possibility to ask ourselves whether there is truly a primary or main literal sense.

\section{Additional contemporary sources}

In GH there are eight entries for ming 名:

The first refers to the act of naming (命名mingming, as noted above).

The second refers to logic in traditional China. ${ }^{323}$

\footnotetext{
${ }^{323}$ The relation between name and logic in the West, as seen in the first part of chapter II of this dissertation, would be one that is directly related to the correctness of naming things in the world. The question of the adequacy of names in China was from quite early times an important subject of heated debate among the different schools of Chinese traditional thought. Two main axes of reasoning were developed along the question of conventionality of names and the validity (and danger) of the "rhetorical usage" of language. An often-used term of the tradition is zhèngming 正
} 
The third use is usually translated as fame, reputation.

The fourth uses the expression mingyi 名義 (lit. name-justice/righteousness, translated as on behalf of, nominally), an act that metonymically identifies the name of a position or an office with the status, capacities and qualities usually related to that position or office. The example used in GH is: "[If] the name is not correct/fair, the speech will be adverse/unfavorable." 324 From this one can infer a close and interchangeable relationship between the appointment (the act of naming) and the designatum (the appointee), exactly in accordance with what was discussed in the main body of the text between ming 名and ming 命.

The fifth refers to the act of designating, or referring to something or someone.

The sixth sense denotes a term used to indicate the name of the Chinese written characters, which is usually called $z i$ 字. ${ }^{325}$

The seventh is a classifier for number of people (e.g., three performers or executioners $\left.{ }^{326}\right)$. It is not unreasonable to link the meaning associated with duty and professions (the fourth item above) with this more specific usage as a classifier of the people associated with such an office.

The eighth and last refers to the region on the forehead between the eyes and eyebrows, or the area just above the eyes (this reference shows up in the $\check{E} r y a ̆$

名, correct names, or the correction of names, as well as another expression used to address this debate, mingshi wènti 名实问题 (“the question of the [relationship between] names and reality"). Without going into much detail, GH mentions a passage in the Xúnž̌, from a chapter zhèngming 正 名 (here usually translated "Rectification of the Names") that resumes some thoughts of Confucius and became very influential for the Chinese tradition. The passage reads: "Names are the means by which one attempts to distinguish different realities" (translation of Watson, 2003, p. 151, in Chinese: ming yě zhě, suǒyl qĩ léi shí yě 名也者, 所以期累實也). It is this “cognitive" function of the name that was glossed above as logic.

${ }^{324}$ In Chinese (GH): míng bù zhèng zé yán bù shùn 名不正则言不顺。

${ }^{325}$ This example comes from the works of Zhèng Xuán 郑玄 (127-200 AD): “In the past [it was] called name (名), today [it is] called character (字),” in Chinese: gǔ yue ming jīn yuē zì 古曰名,今 曰字.

${ }^{326}$ In Chinese: sān ming dāo fŭ shǒu 三名刀斧手。 
with the gloss of the disyllable yijie 猗嗟 as an interjection of admiration ${ }^{327}$ ). This use, although seemingly disconnected from the others, could be considered in a different perspective if we remember the Chinese gesture of pointing to oneself while indicating the self. Although one usually would point to one's own nose, ${ }^{328}$ it does not seem absurd to think that the gesture of pointing to one's forehead fulfilled a similar function. This reflexive function is easily applicable to the idea of naming and name and a reference for the self or $I$.

\title{
Yán 言
}

\section{Samples predating the Shuōwén}

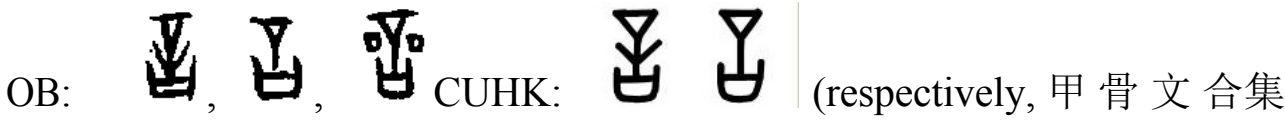

CHANT:0722 e 0722A)

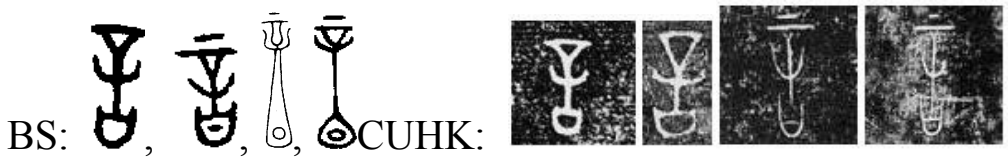

Bamboo: CUHK:

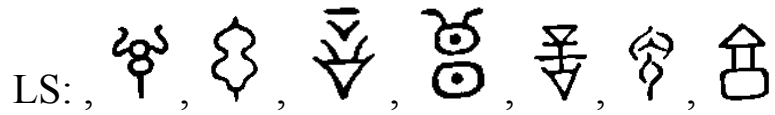

\section{Passages from canonical traditional sources}

The view that yán 言 was originally a graph for a blowing instrument is supported in the glosses from the $\check{E} r y$ ă chapter shìuè 釋樂, "Explaining music":

\author{
大簫謂之言，小者謂之筊。 \\ dà xiāo wèi zhī yán, xiăo zhě wèi zhī jiăo.
}

\footnotetext{
${ }^{327}$ This meaning's locus classicus is a phrase from the poem yijizie 猗嗟 of the Shijing translated by James Legge as: "Alas for him, so famous! His beautiful eyes how clear!" (in Chinese: yijjiē ming $x \bar{i}$, měi mù qīng $x \bar{i}$. 猗嗟名兮、美目清兮。). The disyllable that names the poem, $y \bar{i} j i \bar{e}$ 猗嗟, is here translated as an interjection indicating admiration: Alas! It is from Mr. Mao's commentary on the Shìjīng (máo shī zhuàn 毛詩傳), which became the received (standard) version of the famous book and was written in the second century BC that we see this interpretation of ming 名: “above the eyes, that is míng” (in Chinese: mù shăng wéi ming 目上為名。).

${ }^{328}$ This is reflected in the polysemy of the term $z \grave{i}$ 自, traditionally considered a former pictogram for nose, which then became used as the reflexive pronoun self.
} 
The large flute [大籃] is called yán 言, the small one is called jiăo笠329

This quite cryptic use of yán 言 is explained by HU (p. 231) who refers to an exceedingly rare character cognate that is written exactly like yán 言 with the added radical for "bamboo" (zhú 竹, Kangxi radical n. 118) on top of it. In contrast to this "large flute" character, the "small vertical flute" is referred to as jiăo 筊. This whole reference seems very much out of context in comparison to the other uses of yán 言 and might be the product of the exceedingly unregulated use and liberty of the scribes in creating new characters before the standardization of the Qin dynasty.

As expected, however, yán 言 is quite commonly found in other passages in the $\check{E} r y a \check{a}$, and it has a large array of interpretations. The first chapter of the book, shig ǔ 釋詁, “Explaining the old reading," for instance, shows the following glosses for wŏ 我( $I, m e$, in modern Mandarin):

印，吾，台，予，朕，身，甫，余，言，我也。 áng, wú, tái, yú, zhèn, shēn, fŭ, yú, yán, wǒ yě.

According to HU (p. 34), all characters in this list besides yán 言, indicate what we call in English grammar the first-person singular pronoun. What would be the justification for the inclusion of yán 言in the list?

We can refer, as HU (p. 34) does, to the following passages from a poem in the Shìjing - xiăo yă - tóng gōng (詩經・小雅・娅弓) for justification:

\section{䑣弓弨兮、受言藏之。 \\ tóng gōng chāoxī 、 shòu yán cáng zhī.}

The red bow [乍弓] is unstrung, when one is given it, one puts it away [藏]. ${ }^{330}$

\footnotetext{
${ }^{329}$ My translation

${ }^{330}$ Translated by Arthur Waley. James Legge's translation reads: “The red arches, unbent, were received and deposited."
} 
The act of "receiving" or "being given" is stated in the verse as "shò yán 受言,” literally “receiving/received • yán 言.” This is what might have suggested to the commentators to read yán 言 as $I, m e$; and what Waley translates as a more impersonal one.

A similar situation from another poem of the Shìjing - dà yă - yì (詩經•大 雅・抑):

\section{罒面命之、言提其耳。}

fěi miàn mìng zhī, yán tí qie ěr.

What I not [féi 罒] face to face [miàn 面] declared [ming 命] to you, I have not hoarsely whispered in your ear. ${ }^{331}$

In the Zhèngjiān 郑笺 commentary on the Shijinng we again see the reading of yán 言 as $I$, me, reaffirming the translations above made by Waley and Legge.

Further along the Ěryă, in the same chapter shigǔ 釋詁, “Explaining the old reading," there is a line of characters which are listed as candidates for glosses for yán 言:

話, 猷, 載, 行, 訛, 言也。

huà, yóu, zăi, xíng, é, yán yĕ.

HU (p. 59) treats this series as if all its characters connote the meaning of speech or spoken [language]. The first character huà 話, for instance, is a hànzì composed of yán 言, the radical, with shé 舌, tongue, and it is used as speech, discourse, language, communication. ${ }^{333}$ The second term, yóu 猷, is usually

\footnotetext{
${ }^{331}$ Translated by Waley. Legge: "Not [only] did I charge you face to face, But I held you by the ears."

332 The oldest complete extant commentary of the Shijingn, written in the Later Hàn period by scholar Zhèng Xuán 鄭玄(127-200).

${ }^{333}$ Both characters are closely related. Schuessler (2007, p. 588), for instance, writes that both are cognates (alofams) belonging to the same linguistic "family," which is also evidenced by the reconstruction of their pronunciation in Archaic Chinese: $\left(\mathrm{njwo}^{\mathrm{B}}\right)$ for huà 話and (njen) for yán 言. From a very different viewpoint, Morel (2005, p. 329), when discussing the relationship of yán 言 and yǔ 語 writes: "Dire, discourir, c'est Yan [言].. Le dialogue s'appelle Yu [語]." (To say, discourse, that is Yan [言].. [as for the] dialogue is called $\mathrm{Yu}$ [語])
} 
translated as plan, scheme, but it could also be seen as a particle that introduces a speech. HU (p. 59) quotes an important commentary on the Ěryă, called Guōzhù 郭注 (written by the scholar Guōpú 郭璞，276-324 CE), where yóu 猷 is considered a “synonym” of 道: yóu, dào yě, dào yì yán yě 猷, 道也; 道亦言也 。“[As for] yóu 猷, that is dào 道, dào 道 is the same as yán 言." ${ }^{334}$ The other characters have similar connections: zài 載 is considered by HU as words, text of alliance; $e$ 訛as words of gossip, and so forth.

In the same chapter of the Ěryă, "Explaining the old reading," HU (p. 61) shows that yán 言 is present in a series that glosses the term jiān 間, a seemingly unrelated term which HU interprets with the connotations of interval, lacunae. ${ }^{335}$ Yán 言 indicates what the Ěryă would like to show as instances of discontinuities, spatial as well as temporal and discursive.

And finally, in chapter shìyán 釋言, “Explaining Words,” we find the very short gloss:

$$
\begin{aligned}
& \text { 訊, 言也。 } \\
& \text { xùn, yán yě. }
\end{aligned}
$$

Which is simply attempting to explain the character xùn 訊, to ask, to inquire, by the character yán 言.

The huà 話 grapheme is then taken as "words" (yán 言) on their way out of the mouth (shé 舌 would point to a generic "object", qiān 千, coming out of the mouth, ”, kǒu 口. The character shé 舌, when alone, is nowadays translated as tongue, the human organ). This etymology would indicate a more "physical" bias on the side of the production of words, as compared to the character $y \check{u}$ 语. In the highly disyllabic modern Mandarin, huàyǔ 話語 is used, among other options, to refer to speech, discourse, words, locution (almost always as substantive and not as verbs). The four-time incidence of the pictogram kŏu $\square$ in the digraph reinforces the allusion to the spoken word, and seems to facilitate the polysemy in $\operatorname{word}(s)$, discourse.

${ }^{334}$ See also above the close relationship between yóu 猷and dào 道in the Fāngyán.

${ }^{335} \mathrm{I}$ have not included here an analysis on the different interpretations of the character $j i \bar{a} n$ 间/間, which today is generally translated as between, but also with an allusion of an interval, as in the modern Mandarin expression shijiān 時間, time. 


\section{Additional contemporary sources}

In GU's (p. 299) reading of the Shuōwén, the author concludes that qiān立 had been analysed erroneously. The close relationship of yán 言 and yinn 音(sound, tone, phone) is stressed when GU affirms that both characters have the "same origin." GU "reads" the form of a "double flute musical instrument" (xiāoguăn yuèq $i$ 箫管乐器) on top of the OB character, with the "mouth" (kǒu 口) blowing through it. Therefore, for GU, yán 言's “original meaning” was as a musical instrument. ${ }^{336}$

CT (p. 387) also follows YL and considers yán 言 a pictogram (xiàngxíng 象形), quoting, for instance, a passage from the Analects chapter xiāngdàng 鄉黨, "Home Village":

食不語，寢不言

shí bù yŭ, qĭn bù yán

While eating he would not converse, and having retired for the night he would not talk.

This passage bears witness to the close relationship between yán 言 and y̌u 語. The “original meaning” of yán 言 for the author would be to speak, to talk (shuōhuà 說話 in modern Mandarin), which then developed as to discuss, to talk about (tánlùn 談論) and also to state (one's views) (chénshù 陳述) and to let know, to tell (gàosu 告訴). CT argued that the usages as verbs related to speech activities also led to more abstract uses, such as opinion, expression of one's opinions (yánlùn 言論) and to parts of the discourse, such as phrase, sentence (yīyán一言) and character, word (zi 字). Another direction of semantic extension was found in its use as theory, doctrine (xuéshuō 學說), in the sense of "his

${ }^{336}$ Lindqvist (2008, p. 310) shares this view:

This character [言] is primarily used in the sense of speech, word, but its basic meaning is large flute, and it is generally considered that the character was originally a picture of a flute with a mouth blowing into it.

Wieger (1927, p. 186), on the other hand, proposes a similar, but more poetic, and ambiguous, gloss: yán, xīn shēng yě 言，心聲也。, “Yán 言, the sound from the heart-mind [xìn 心].” 
words" ${ }^{337}$ and finally, the books and writings themselves (zhuòzuò 着作). Finally, CT wrote that yán 言 was borrowed for use as an auxiliary word, for the rhythm and cadence of the text. ${ }^{338}$ This "faint" or "thin" nature of yán 言 calls our attention to the difficulty to pinpoint its exact "meaning" or purpose in these instances, apart from its mere presence or use in the text.

Wieger (1927, p. 186) and Wilder \& Ingram (1974, p. 5) would simply interpret the graphic component qiān 辛as a stylized expression for $\operatorname{word}(s)$ when they analyze yán 言 as being a semantic composite meaning "words coming out of the mouth." This type of analysis could be identified as the "naive" view so often criticized by later authors, such as William Boltz. As a striking counter-example of more scholarly etymology, Karlgren's (1923, p. 94) analysis involves the phonetic reconstructions from ancient and old Chinese, which identifies the character as words, speech, language, speak. However, the famous Sinologist also offers his own study of the character, where the graphic components on top indicate the symbol of a battering ram (Kalgren does not offer an explanation for his interpretation). Besides this, the author also argues that the possibility that qiān 产 (offense, crime) might act as a phonetic indicator is very remote and farfetched.

TH (p. 53) analyzes yán 言 as a dot (diăn 點) that is added above shé 舌, a mouth/tongue (as we have seen), with the iconicity of the "speech coming out of the mouth.” The close relationship between shé 舌 and yán 言 is again explicit in the construction of the character $y \check{u}$ 話, already discussed above. Morel (p. 329) also argues against the Shuōwén's classification of yán 言 as a semantic-phonetic compound and reaches similar conclusions as TH: the older graphic forms are said

\footnotetext{
${ }^{337}$ As in this example from the Mèngž̌, chapter téng wén gōng shāng 滕文公上, “Duke Téng Wén 1 ":

有為神農之言者許行, 自楚之滕。

There came from Chu (楚) to Teng (滕) one Xu Xing (許行), who gave out that he acted according to the words of Shen Nong (神農). (translated by James Legge)

${ }^{338}$ In this usage, GH refers to yán 言 as an "empty” character (yŭzhù 語助, lit. "helping expression"), a character which is set in the text for reasons of meter or to give the necessary rhythm to a specific line or verse.
} 
to indicate some kind of pictogram showing the word (here symbolized as a trace) coming out of the mouth through the tongue.

Matthews (1943, p. 1097) notes two other infrequent uses of yán 言, not yet referred to here: 1) as an adverb marker (similar to rán 然), ex. yú yán chū sù 與言 出宿 “I rise and pass the night outside” (or rising(ly) [I] go out [to] overnight); ${ }^{339}$ and 2) in the sense of high, lofty. In this sense, the character would have a secondary reading of yin in the expression yinyin 言言 used in the Shijīng(詩經一 大雅 -241 皇矣):

\section{臨衝閑閑，崇墉言言。 \\ lín chōng xián xián, chóng yōng yín yín.}

The siege platforms trembled, The walls of Chong towered high

As a final phonological note on yán 言, Schuessler (2007, p. 588) treats yán

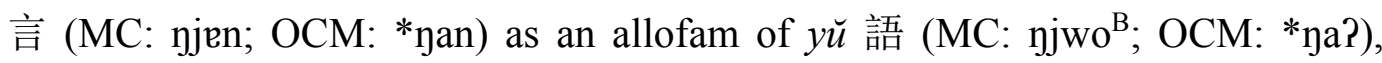
which meant speak, speech, to talk in passages from the Shijing, with possible cognates in yàn 唁, to console, to express condolences and yàn 諺 (both $\mathrm{MC}$ : njän ${ }^{\mathrm{C}}$ ), proverb, saying, adage, respectively from the Shìjing and from the Zuǒzhuàn.

字zì

\section{Samples predating the Shuōwén}

OB: $\hat{f} \hat{f} \hat{8}$

Bamboo (CUHK): 宇 审 (Măwángduĩ Lăož̀)

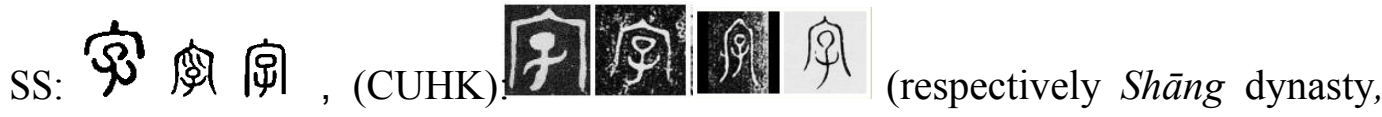
late Eastern $Z h \bar{o} u$, later Spring \& Autumn period - the last two samples)

${ }^{339}$ In this particular phrase it also seems possible to translate yán 言 as I (Rising I go out [to] overnight). 


\title{
Passages from canonical traditional sources
}

The character $z i$ 字 appears in a few passages in the Shiming, more specifically in the important chapter shì yányと̌ 釋 言 語, “explaining speech/words":

\author{
慈, 字也; 字, 愛物也。 \\ cí, zì yě; zì, ài wù yě \\ Kind/loving ( $c i$ 慈), [from] $z i$ 字; $z i$ 字, [from] loving [all] things.
}

This seems to substantiate the idea of the close connection between birthing and the parent/child relationship based on love [from parents to children] and filial piety [from children to parents] as in this passage of the Zuŏzhuàn chapter y̌̆ gōng sān nían 隐公三年, “Duke Y̌n, third year”:

\author{
父慈子孝 \\ fù cí ž̌ xiào \\ Father [has] love/compassion, children [have] filial piety.
}

The "semantic extension" from birthing to nurture, cherish, foster is also supported by CT (p. 469), who refers to a passage in the Shijing, The Major Odes, 245 shèng min 生民, “birth to the people”:

\author{
誕真之险巷，牛羊腓字之。 \\ dàn zhì zhì ài xiàng, niú yáng féi zì zhī. \\ Indeed, they put it [Jiang Yuan's child] in a narrow lane; but oxen and sheep \\ tenderly cherished it. (Waley)
}

\section{Additional contemporary sources}

There is considerable agreement in the modern and contemporary studies on $z i$ 字. Here are only some examples.

Karlgren (1923, p. 310) glosses zi 字 as to breed, nourish, bring up, fatherly love; then a "brought up person"; thus, name of 'style' taken at 20 years; name, appellation; word, written character, letter. Other Western studies follow similar 
routes. For instance, Wilder $\&$ Ingram (1974) chose $z \grave{l}$ 字 as the first character of their Chinese character Primer and wrote:

[zì 字 means] to have children under one's roof [...] [The character is a] logical composition, to shelter, to nurse, to bear. By extension it refers to the characters produced or born by combining the simple 文 wén, into compound characters, 字 $[\ldots]$

Schuessler (2007, p. 633) treats $z i$ 字 as belonging to the same word family as $z \check{l}$ 子, thus the close relationship between both characters.

\section{文wén}

\section{Samples predating the Shuōwén}

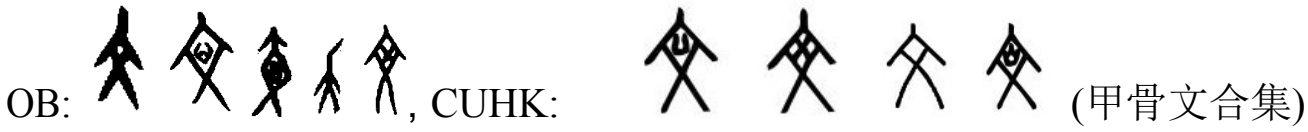

BS: (8)

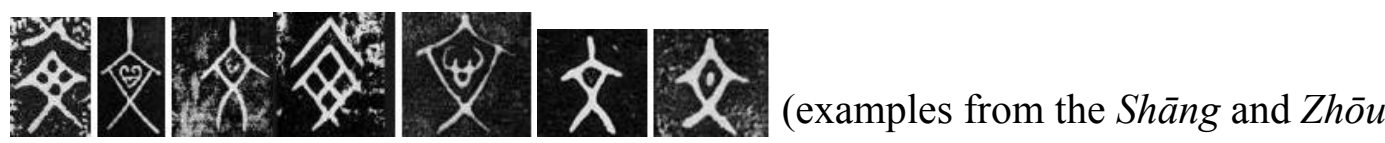

dynasties)

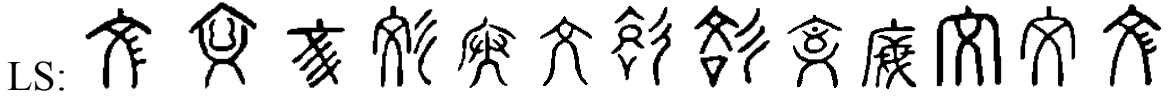

\section{Passages from canonical traditional sources}

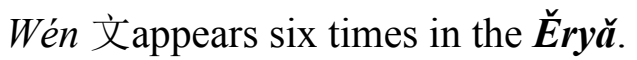

Its first instance is in the chapter shidi 釋地, “Explaining Earth”:

東北之美者，有斥山之文皮焉。

dōngběi zhī měi zhě, yǒu chì shān zhī wén pí yān.

In the beautiful east, in the Chi mountain [斥山] [there are tigers whose] skin [皮] [shows] decorative patterns [文] (according to HU, p. 255) 
Then it appears three times in the chapter shiyú 釋魚, “Explaining fishes,” which basically deals with the description of the different categories of fishes (and related marine and lacustrine animals) and the vocabulary to describe them. For example:

\section{餘貾，黃白文。 \\ yú chí, huáng bái wén.}

[the] Yú frog, [whose skin has] yellow and white patterns. (according to HU, p. 255)

A similar use is found where wén 文appears twice in the chapter shishòu 釋 獸, “Explaining beasts.” In conclusion, all uses in the Ěryă allude to the specific decorative and patterned reference of wén 文, in very concrete instances in Nature.

However, one reads what appears to be a more allusive gloss in the Shiming chapter shì yányǔ 釋言語“Explaining speech/words”:

\section{文者，會集眾綵以成錦繡，會集眾字以成辭義如文繡然也。 \\ wén zhe, huì jí zhòng căi yĭ chéng jǐnxiù, huì jí zhòng zì y̌̀ chéng cíyì rú wénxiù rán $y \check{e}$. \\ wén 文, the collection of a multitude of colored silk (căi 綵) becoming beautiful brocades (jinnxiù 錦紼), collection of a multitude of characters (zì 字) becoming meaningful expressions [cíyi 辭義 ] like [it is] from/of embroidered silk dresses/clothes (wénxiù 文繡, lit. embroidery-wén 文).}

Here the metaphorical (or maybe metonymical?) connection between the visual patterns in the silk - which, as we have seen above, reflect similar patterns in nature - are directly reflected in the "meaningful expressions" (ciyi 辭義) of writing. ${ }^{340}$ It seems quite telling that as they are laid out along these patterns, the written characters ( $z i$ 字) are now endowed with some form of signification, a meaning (use?) that appears to be a consequence of this reflection in nature.

\footnotetext{
${ }^{340}$ This early use of $y i$ 義 associated with $c i$ 辭, word in this context appears also relevant and contrasts with the differentiated uses that will be analyzed in the section on the grapho-etymology of $y i$ 義.
} 
In the Fängyán there are two glosses relating to wén 文, respectively in chapters twelve and thirteen:

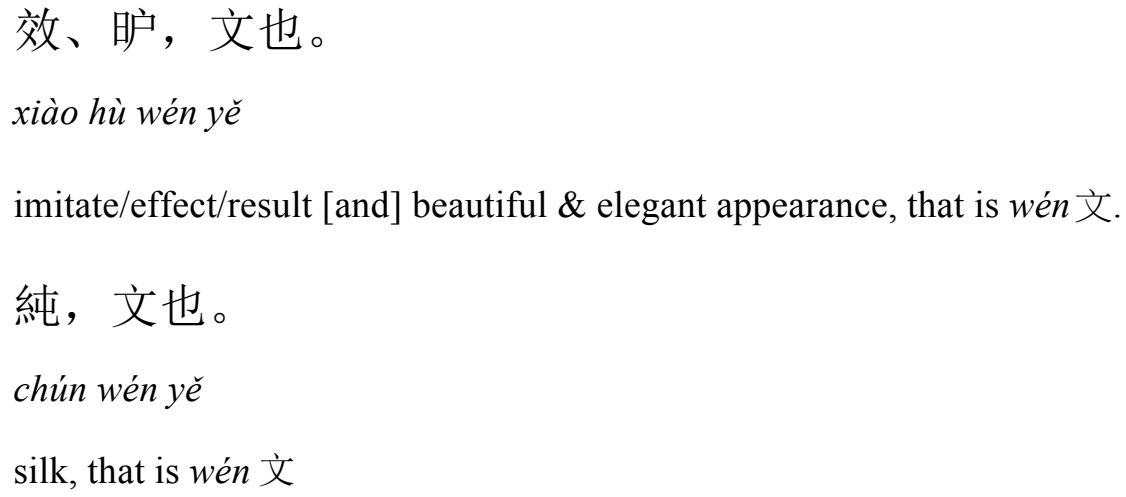

These very brief translations do not do justice to the complexity of these glosses. For instance, chún 純 is an incredibly polysemic character, with five different readings and over ten acceptations in GH. However, if we focus on the translations here suggested, they are both allusions to the concrete aspect of wén 文, its appearance as "beautiful patterns," possibly in brocades and silk clothing, imitating Nature's own patterns. This interpretation is not far from what we have seen in the glosses from the Ëryă.

As shown in many glosses above, there is ample evidence of a close connection between wén 文 and the patterns in Nature. As seen above, a common type of pattern refers to marks and bands that were seen on the skin of animals. This is also evidenced by expressions like wényīn 文茵, “elegant mat made of a tiger's skin" (lit. "mattress of patterns"), which was also written with the homophone disyllable wényīn 文鞇, “armchair made of tiger skin used in small carriages," attested from examples in the Shijing and the Shiming. Another expression with the same allusions is wénmă 文馬 for piebald horse, a horse which is covered in "patches or spots of two colors, esp. with white and black" (Collins American Dictionary) and wénhàn 文翰, which connotes a pheasant explained in the Yì Zhōu shī 逸周書, The Lost Book of Zhōu, as a "bird with multicolored patterned feathers which lives in the marshes." This same expression 
is however glossed completely differently in the xīn Táng shu 新唐書, The New Book of Táng, and others, as referring to a literary article! $!^{341}$

CT (p. 350) states that the "original meaning" of wén 文 is a "decorative pattern/figure (carved) on the human body." The author takes an example from the Lijjì chapter wángzhi 王制, “Royal Regulations”:

\author{
東方曰夷，被髮文身。 \\ dōngfāng yuē yí, bèi fā wén shēn. \\ In the East [they] were called $y i$ 夷, [their] hair was disheveled and their body

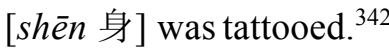

For this author, subsequent uses of wén 文 were more abstract, referring to multicolor interlocking patterns and lines in general. The notion of patterns and many colors was borrowed to point to the adjectival use as magnificent, resplendent (huáméi 華美), often in comparison and opposition to the abstract notion of "quality" (zhì 質), as in this example of the Analects, chapter Yōng yě 雍 也, "As for Yōng”:

\title{
子曰：「質勝文則野，文勝質則史。文質涁彬，然後君 子。」
}

zǐ yuēe: "zhì shèng wén zé yě, wén shèng zhì zé shĭ. wén zhì bīn bìn, ránhòu jūnž̌."

The master said, “When one's basic disposition (zhi 質) overwhelms refinement (wen 文), the person is boorish; when refinement overwhelms one's basic disposition, the person is an officious scribe. It is only when one's basic disposition and refinement are in appropriate balance that you have the exemplary person.

The traditional idea that the Chinese characters evolved from pictures and pictographs is intimately related to the polysemy of wén 文 as decorative patterns/figures and as written characters (hànzi). One example from the classics

\footnotetext{
${ }^{341}$ This is more understandable once we know that hàn 翰 was used to refer to writing brushes, which in that time were made out of bird feathers (and also the stiff part of a bird's wing), as well as "pheasant-like" birds. Some of the other connotations of the character seem to be more baffling: white horse or to assist.

${ }^{342}$ My translation. Or: "The tribes on the east were called Yi. They had their hair unbound, and tattooed their bodies" by James Legge.
} 
comes from the Hòu Hàn Shū 後漢書, History of the Eastern Han, chapter zhānghénglièzhuàn 張衡列傳:

飾以管文, 山龜, 鳥獸之形。

shì y̌̃ zhuàn wén, shān guī, niăo shòu zhī xíng.

Adorned with calligraphy (seal characters) in the shapes of a tortoise of the mountain, of birds and beasts.

The character zhuàn 管 referred to the seal style of writing and wén 文 was added exactly to specify that the text was written in a style that reminded the reader of natural landscapes.

\section{Additional contemporary sources}

Karlgren (1923, p. 370) offers the following glosses for wén 文: streaks, lines, strokes; ornament, ornated, elegant; written character; word, expression, written composition, essay, written language; literary, scholarly; civil (as opposed to $w \breve{u}$ 武, military), and writes that the OB character shows "some intertwined strokes.” Wilder \& Ingram (1974, p. 144) offer similar glosses, but include a different interpretation for the older forms of wén 文: “it is supposed to represent the grain in wood or ripples on water.” Morel (2005, p. 170) glosses wén 文as lines, writing and writes:

To paint oblique lines. Representing lines that cross [each other]. [In the] Jia Gu Wen [style of script, it] represents a man seen straight at his face, his breast decorated with painting or with tattoos.

Wieger (1927, p. 161) notes that wén 文is a primitive (character), glossed as lines that intercross, veins, wrinkles, ripples; sketch, literary, genteel, and elegant. The author writes that wén 文 is also used as the radical of "a few characters relating to ornamentation." And, finally, in a quite original "reading" of the ancient script form of wén 文, Blackney $(1948$, p. 12) provides one of the most evocative: "possibly a scholar sitting cross-legged." 
The purported origin of wén 文 as a designation of some sort of decoration is also defended by Hansen (1982, p. 45). This author highlights the importance of the wénhuà 文化, already used in classical Chinese as civilization, in the sense of a culture heritage that is transmitted between the cadres in the civil administration. For Hansen the idea that the civilizing act is equivalent to a decoration / beautification that is provided by an "accumulation" of literature is significant for Chinese thought.

Jullien (2003, p. 27) presents what he considers the four different levels of uses of wén 文: 1) the wen of Nature, in relation to the marks on the bodies of animals; 2) in relation to the principle of cosmic order (the founding trigrams); 3) according to the notions of culture and education (as a civilization); and 4) as a graphic sign.

Finally, Matthews (1943, p. 1058) offers no less than 151 expressions in current Mandarin (the first edition of this authoritative Chinese-English dictionary was published in China in 1931) that contain the character wén 文. They are testimonies to the wide array of connotations of the term and the extraordinary compositional capabilities of the Chinese language. A brief look through the list will show evidence that in that transitional period (first half of the twentieth century) in the dawn of the vernacular as a written language in China, the expressions containing wén 文 related to literary, civilized/civilization, writing/written records, surpassed by far $(127 \times 3)$ the older more "figurative" and "patterned" uses, which, as we have seen, were so prominent in the canonical texts of ancient China.

\section{義 yì}

\section{Samples predating the Shuōwén}

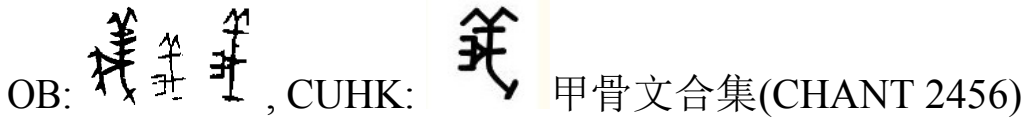




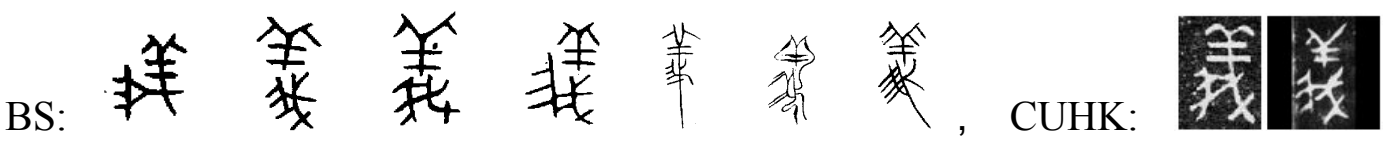

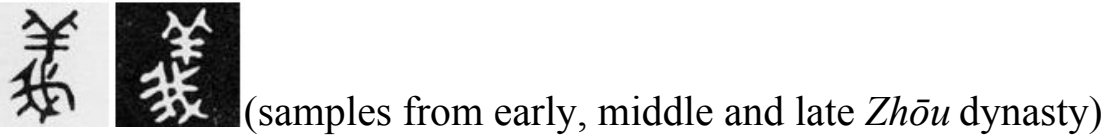

\section{LS:

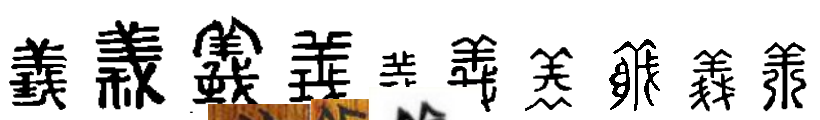 \\ SILK (CUHK): (清華簡, 上博竹書 \& 郭店簡)}

\section{Passages from canonical traditional sources}

Here are two selected passages from the Shiming glossing $y i$ 義. The first is from the chapter shi yányǔ 釋言語, “Explaining speech/words”:

義, 宜也。裁制事物, 使合宜也。

yì, yí yě. cáizhì shìwù, shǐ héyí yě.

$Y i$ 義, [from] right/suitable/approximate [yi 宜]. To restrict/control/stipulate things, [that is] enabling/ensuring suitableness.

Here is a character, yi 宜, usually glossed as right, suitable, what ought to be, etc., which will help build the network of classical references and connotations built around $y i$ 義.

In the chapter shì diăn yi 艒典藝, “Explaining dictionary skills,” we read:

《爾雅》, 爾, 昵也; 昵, 近也; 雅, 義也; 義, 正也。 $[\ldots]$

Ëryă, ěr, nì yě; nì, jìn yě; yă, yì yě; yì, zhèng yĕ. [...]

[As for the name] Éryă, ěr 爾[from] near/familiar/intimate (nì 昵); nì 昵 [from] near/close (jì 近); yă 雅, [from] yì 義; yì 義 [from] straight/correct/honest, right (zhèng 正) [...]

This gloss is an explanation of the name of the dictionary $\check{E} r y a ̆$, which can be interpreted as a "list of near/approximate correct [meanings]." What is relevant 
to this dissertation is the early connection between $y i$ 義 and the important and polysemic term zhèng 正, straight, correct, honest, right.

\section{Additional contemporary sources}

$Y i$ 義 is glossed by Karlgren (1923, p. 85) as just(ice), righteous(ness), duty towards others, good, patriotic, common to all, public, (right) sense and signification, and reconstructed in Archaic Chinese as ngjie. The character is presented as a compound of yáng 羊, sheep/ungulates, that would point to the characteristics of being good-natured, kind, while wǒ 我, I, me, being reconstructed in Archaic Chinese as $n g \hat{a}$, acts as the phonetic element. ${ }^{343}$

Wilder \& Ingram (1974) also call the term a semantic-phonetic compound, however they concoct a semantic justification for both of its parts. In these authors' analysis, the wó 我component of the character brings its

Original meaning, namely, a conflict - two spears attacking each other. With the addition of 羊 yang $^{2}$, the two combatants have changed and become lamblike: neither one is aggressive, concord is restored. (p. 160)

Blackney (1948, p. 96) glosses yi 義 as righteousness and, as is typical of older manuals of Chinese etymology, opts for the fully semantic graphic motivation of the character: "To take to 我, myself, the virtues of 羊, the sheep. [Therefore,] kindly words." Wieger (1927, p. 761) presents an unjustified list of acceptations for the character: duty, right, loyal, idea, meaning, purport, common, free, adopted and justice. TH (p. 124) also considers yi 義 a purely semantic compound, a stylized pictogram of two rams facing each other and, in the bottom, clashing at each other. For the author, the meaning is related to the balance between both animals, bringing the idea of impartiality, fairness and justice, and also of etiquette, rite.

Schuessler (2007, p. 566), in his speech-oriented etymological analysis, brings two characters from the Shuōwén and the Shiming, yi 儀 and yi 宜 (both pronounced as *yai in Schuessler's "minimal old Chinese, OCM") as supposed

\footnotetext{
${ }^{343}$ Note that in the Shuowwén the wó 我 part of the character has a semantic import.
} 
cognates of $y i$ 義. While $y i$ 宜 and $y i$ 儀 are translated as to be right, righteous, proper, yí 儀 alone accounts for proper conduct, demeanor, manner and dignity. The author then describes the character $y i$ 義 itself, together with another cognate, $y i$ 議 (*yaih in OCM), as to be right, righteous, proper (attested in BS as well as the Shijing); and as true sense, meaning in the Lijji. However, Schuessler concedes the difficulty of translating a term that has so many philosophical implications, preferring to offer a list created by a translator of the Mòzi: notion, idea, view, purpose, standard.

For GU (p. 33), yi 義 should be considered a semantic compound (huiyì 會 意). The author is in agreement with the Shuōwén when he writes that in its $\mathrm{OB}$ and BS forms, yì 義 was derived from yáng 羊 and wǒ 我, however the author offers another interpretation: the wǒ 我 component stands as a knife-like instrument ( $\bar{a}$ ojù 刀锯), used to slaughter cattle and sheep in sacrificial ceremonies, therefore the author's hypothetical "original meaning" of the character. This interpretation would be supported by the purported relationship between $y \grave{i}$ 義 and $x \bar{\imath}$ 犧, this last character used to connote the sacrifice of animals for ceremonial purposes. ${ }^{344} \mathrm{GU}$ then offers a semantic synchronic derivation timeline: from the act of the sacrifices of animals to the name of the sacrificial ceremonies themselves and a more comprehensive name for ceremonies in general; the characteristic that such ceremonies are guided by suitable and impartial (correct) principles, to conform or act according to protocols and correct principles; up to a point that these "right practices" were seen as correct principles, the right way, the true way, dàolì 道理.

\footnotetext{
${ }^{344}$ See for instance the passage in the Shāng Shū 尚書chapter Wēiž 微子, “Count of Wei”: jīn yān mín năi răng qiè shén qí zhī xī quán shēng 今殷民乃攘篙神祇之爔特牲, “The people of Yin will now steal even the pure and perfect victims [xī quán shēng 犧牷牲] devoted to the spirits of heaven and earth." (translated by Legge)
} 


\section{象 xiàng}

Samples predating the Shuōwén

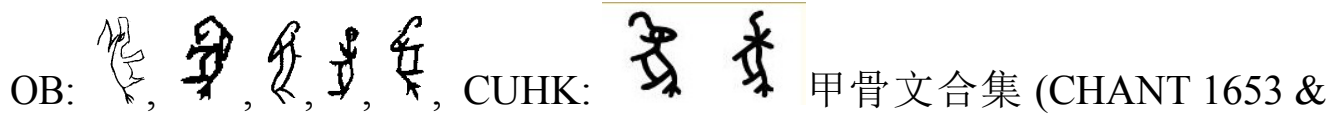
$\left.1653^{\mathrm{A}}\right)$

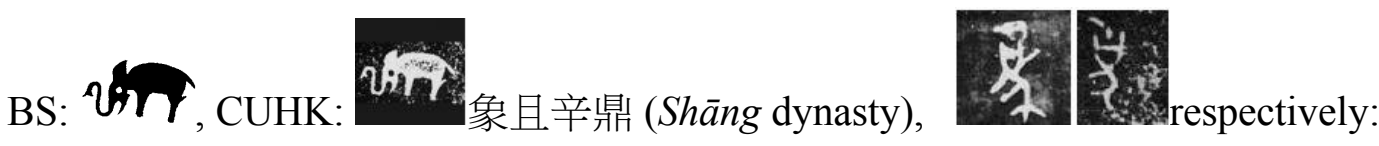
師湯父鼎2780 and 匡卢5423 (Eastern Zhou, middle period).

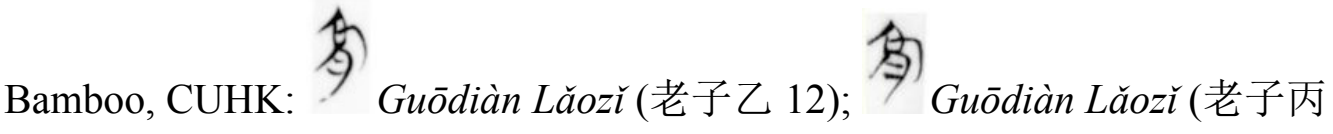
4);

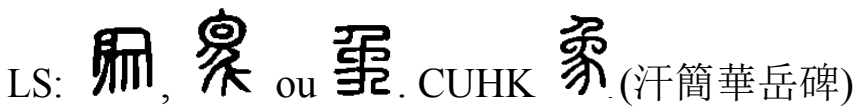

\section{Passages from canonical traditional sources}

In the $\check{\boldsymbol{E}} \boldsymbol{r y a ̆}$ the character xiàng 象 appears on two consecutive lines in the chapter shiqi 释器, “Explaining utensils":

象, 謂之鵠。角, 謂之觷。犀, 謂之剒。木, 謂之席。玉, 謂之雕。

xiàng, wèi zhī hú. jiăo, wèi zhī xué. xī, wèi zhī cuò. mù, wèi zhī duò. yù wèi zhī diāo.

Xiàng, [its processing is] called hú 鵠 (swan). Horn, [its processing is] called xué 觷 (to polish). Rhinoceros, [its processing is] called cuo 剒(to cut, to chop). Wood, [its processing is] called duò 剫 (lumbering). Jade, [its processing is] called diāo 雕 (carving, engraving).

It may be peculiar to find a gloss of xiàng 象 - used as elephant in the Shuōwén about 300 years later - in the chapter of the Ěryă that prominently deals with instruments and their uses in the processing of raw materials. A more careful examination of this line however shows that the passage in the Ëryă provides a name for the process of using the ivory from the elephant's tusk. The odd character hú 鵠, which is usually glossed as swan, may be read, according to HU 
(p. 224), as $y \check{u}$ 齠, an obscure character that is a component of the disyllable jǔy y̌ 齟䶜, which in turn indicates a dental arcade - both characters have the radical ch 齒, tooth, tooth-like - where the lower and upper teeth are in disarray, metaphorically used to connote disharmony or enmity in general (as per GH). One can speculate that $y \check{u}$ 䶣 was the name identified in the $\check{E} r y a \check{~ t o ~ r e f e r ~ t o ~ t h e ~ p r o c e s s ~}$ of carving or working on elephants' ivory tusks. Another interesting speculation hangs on the "normal difference" between the long elephant tusk and the animal's teeth, leading to the idea of comparison and some kind of image that could be a metaphorical link to subsequent uses of xiàng 象.

The following line of the $\check{E} r y a \check{~ i s ~ v e r y ~ s i m i l a r, ~ a l s o ~ c o n s i s t i n g ~ o f ~ a ~ l i s t ~ o f ~}$ names of processes related to raw materials. However, in this case all the processes that are named are directly related to some sort of carving or engraving. Some materials are repeated, such as wood and jade, but the process' names are different. This is exactly the case with xiàng 象, which is shown here:

$$
\begin{aligned}
& \text { 象, 謂之磋。 } \\
& \text { xiàng, wèi zhī cuō. } \\
& \text { xiàng, [its processing is] called cuōo 硡. }
\end{aligned}
$$

The character $c u \bar{o}$ 磋 in modern Mandarin is usually translated as to discuss, to consider, to deliberate, as, for example, in the disyllable cuōshāng 磋商, to discuss, to exchange views. However in ancient Chinese it was also read as to polish, to put a gloss on, often from an interpretation from a line in the Shijing, wèi fêng • qi ào 衛風・淇奧, “Odes of Wèi • Little bay of $Q i$ ”:

\footnotetext{
有罒君子、如切如磋、如环如磨。

yŏu fěi jun ž̌, rú qiēè rú cuō, rú zhuó rú mó.

Delicately fashioned is my lord; As thing cut [qiēe切], as thing filed [cūo 硣]; As thing chiseled [zhuó 环], as thing polished [mó 磨]. (translated by Waley)
} 
The careful and time-consuming polishing of the ivory led to the related use of cuō 磋as careful and attentive discussion or consultation.

The character xiàng 象 also appears in many sections of the Shiming. However, it is usually not glossed in itself and never refers to the animal elephant, but rather it appears used in its common metalinguistic functions, referring to form and image or likeness of images, in the glosses of other characters. For instance, in the chapter shì sàngzhi 釋喪制, “Explaining mourning rites”:

冢, 腫也, 象山頂之高腫起也。

zhŏng, zhǒng yĕ, xiàng shāndǐng zhī gāo zhŏng qŭ yě.

Grave, tomb [zhǒng 冢], as swelling [zhǒng 腫], resembles [xiàng 象] the swelling [format] of the high summit of mountains. ${ }^{345}$

In the next line, from the chapter shì xíngť̌ 釋形體, “Explaining physical bodies," xiàng 象 is however used on its own, in a relationship with another important character for Chinese traditional figurative language, xing 形:

形，有形象之異也。

xíng, yǒu xíng xiàng zhī yì yě.

[As for] xing 形, to have form, shape [xing 形] is different than to resemble [xiàng 象].

The usage of xing 形 and xiàng 象 is sometimes interchangeable and the characters have a complex relationship that - as this analysis intends to show will be instructive regarding the nuanced differences in the use of both characters. This particular line of the Shiming appears to rule out any confusion between them, plainly stating that they are "different" ( $y i$ 異). Because this chapter of the book deals with the "physical bodies," we can speculate that xing 形 would refer to the physicality of the bodies, while xiàng 象 to its appearance. This distinction

\footnotetext{
${ }^{345}$ This is a typical Shiming gloss that attempts to link both phonetic form and semantic import, in this specific case, between zhǒng 冢 and zhǒng 腫.
} 
appears somewhat clearer in another line from the chapter shì sàngzhì 釋喪制, "Explaining mourning rites":

丘, 象丘形也, 陵亦然也。 qiū, xiàng qiū xíng yě, líng yìrán yě.

[As for] mound, grave [qī̄ 丘], [it] resembles [xiàng 象] the form of mound, grave [qīu 丘], similar to hill, mound, imperial mausoleum [líng 陵].

In the cryptic language of the early Chinese texts, however, it seems odd that the "resemblance of the form" of a "thing" is used to describe the thing-initself. A similar line in English looks very much like a tautology, for instance: "as for a horse, it resembles the shape of a horse." What might be the added information here? Maybe none, but perhaps only as long as we consider xing 形 and xiàng 象 merely Chinese counterparts of the words shape/form and resemble, in English.

From its obvious iconographic quality in the early scripts, xiàng 象 is itself traditionally classified as a xiàngxíngzi 象形字, a “pictogram.” CT (2011, p. 371) states that its original meaning was the reference to the animal elephant, quoting as its source the lǘshichūnqiū 呂氏春秋, the Spring and Autumn Annals of Mr. Lü, chapter gŭyuè 古樂, “Ancient Music”:

商人服象, 為虐于東夷

shāngrén fú xiàng, wèi nüè yú dōngyí

Men of Shang [dynasty] used elephants to pull carriages against the cruel [tyrants] of eastern [China's] barbaric [lands].

And in Hánfêizǐ̀s Chapter 10 shí guò dì shí 十過第十, "the Ten Faults":

\section{昔者黃帝合鬼神於泰山之上，駕象車而六蛟龍}

In by-gone days the Yellow Emperor once called a meeting of devils and spirits at the top of the Western T'ai Mountain, he rode in a divine carriage pulled by dragons. (translated by W.K. Liao)

In this last excerpt, the translator of the Hánfêižl did not use the word elephant. However, the disyllable xiàngche 象車 (lit. “elephant-cart”) was used 
specifically to refer to carts that were pulled by elephants, although in this case the translator (maybe incongruently) wrote that the cart was pulled by (six) dragons. It is also important to note that in the GH it is written that xiàngche $\bar{e}$ 象車 was also used to refer to exquisite carts made from mountain forest wood with a precious, "rare and auspicious" appearance (ruiying 瑞應 ), in what may be already an early metaphorical use for xiàng 象.

In time, the emphasis shifted from the animal to its long tusks and the material (ivory) of the adornments made from it, as indicated by the Shiji 史記 chapter shìèr zhū hóu niánbiăo 十二諸侯年表, “Yearly Chronicle of the Feudal Lords":

\section{紂為象箸 \\ zhòu wèi xiàng zhù \\ Zhou made ivory sticks.}

Passing these very concrete meanings to more abstract connotations (imagine, visualize, resemble) is unclear and quite speculative, but Hánfêiž̀ already shows a different use in one of the chapters in which the legalistic author comments on the Lăož̀ (shì lăož̀ dì èrshí 解老第二十, “Chapter Twelve: Explaining Lăož’') and explains the use of the abstract character:

\section{人希見生象也，而得死象之骨，案其圖以想其生也，故諸人 之所以意想者皆謂之「象」也。}

Men rarely see living elephants. As they come by the skeleton of a dead elephant, they imagine its living According to its features. Therefore, it comes to pass that whatever people use for imagining the real is called "image."

Eventually, still according to CT, the character also took a nominative use (image, shape, figure), as quoted in this passage of Yìjing in the xìcí shàng 繫辭上, also known as "The Great Treatise":

在天成象, 在地成形, 變化見矣。 
In the heavens there are the (different) figures there completed, and on the earth there are the (different) bodies formed there. (Corresponding to Them) were the changes and transformations Exhibited (in the Yi). (translated by James Legge)

In the heavens phenomena take form; on earth shapes take form. In this way change and transformation become manifest. (translated by Wilhelm and Baynes)

We can observe that the assertion that there was a clear and definite semantic derivation (animal $\rightarrow$ verbs related to image $\rightarrow$ image / figure) is not proven by classical Chinese texts, since such meanings cannot be proven to appear in chronological order. For example, a more "abstract" connotation is already found in the Yijing, one of the oldest Chinese classics, whose current research dates to the end of the 2nd millennium $\mathrm{BC}$.

\section{Additional contemporary sources}

Karlgren (1923, p. 237) concurs with most authors that originally xiàng 象 was a "picture of an elephant" and glosses elephant, ivory, figure cut in ivory, figure, image, form, similar, to resemble, comparison, symbol and model. Wilder \& Ingram (1974, p. 113) concede the difficulty of justifying the character's semantic derivations: "It is difficult to explain why this symbol should have been taken for an image." Wieger (1927, p. 175) agrees with all other authors on the figurative origin of the character. The Kāngxī radical of xiàng 象 is radical n. 152, sh $\check{~}$ 豕, considered to be the pictograph of a pig. Blackney (1948, p. 98), for instance, considers that xiàng 象 stands for "an elephant, [that] is a 'pig with large ears."”

Schuessler (2007, p. 534-5) identifies three different "unrelated" versions of xiàng 象 that, in his analysis, would be homophones and homographs, a suggestion of homonymy. All separated glosses for xiàng 象 have Schuessler's

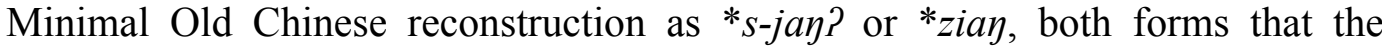
author claims as being poorly attested. The first gloss was used to designate elephant, ivory, a former pictograph (found in this oracle bones samples - as seen above - as well as the Shijing) and whose word would have been taken as a loanword, an analysis that is motivated by similar phonological forms in other languages of South and Southeast Asia. The second use of xiàng 象 has the 
meaning to interpret, to translate (a foreign language), a possible cognate of xiáng 詳, explain in detail. Finally, the third acceptation involves two interchangeable characters, xiàng 象 and xiàng 像, and the connotations indicated are: to look like, to be, from Zǔozhuàn; but also xiàng 象, to resemble, in the Xúnzĭ; image, in the Huáinánzĭ; and to outline, appearance, symbol, in the Shüjīng. Schuessler himself comments that xiàng 象, image, appearance, is usually considered "the same word" (and therefore, pertaining to a case of polysemy rather than homonymy) as xiàng 象, elephant, ivory. As an explanation for the seemingly odd relationship, Karlgren has proposed the influential interpretation that the use of ivory as a material for sculptures that mimic the image and appearance of physical things would "merge" these two meanings under xiàng 象 (or xiàng 像). Schuessler argues that ivory was obviously not the only material for sculptures and offers possible phonetic origins of the word xiàng 象 from sources of ancient Tibetan, but his arguments in this matter are highly speculative. 


\section{3.}

\section{Appendix 3}

Listed in this appendix in alphabetical order are the etymologies of the Western and Greek words which are semantically related to the terms discussed in chapter two of this dissertation, but at the same time are neither 1) etymologically related to the translated terms from the Lăož́; nor 2) metalinguistic terms in the Western lexicon.

\section{Adornment (Eng.), ornamento (Port.)}

There seems to be no one "abstract" term in ancient Greek to refer to what we might call the quality of adornment, ornament or decoration, other than specific terms which connote specific types of ornaments. Some examples are:

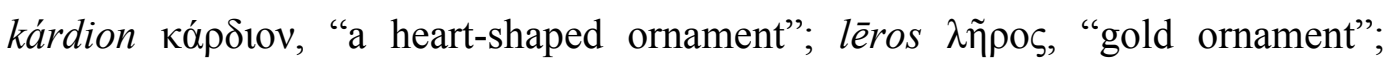
leontís $\lambda$ Eovtís, "lion-shaped ornament"; khlídōn $\chi \lambda i ́ \delta \omega v$ "ornament, bracelet, or

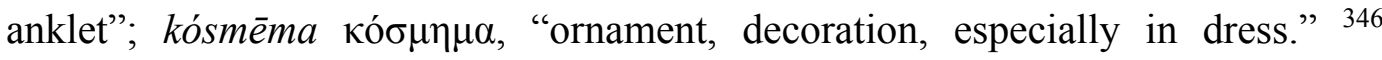
Besides these terms are the verbs connoting the act of decoration: hepikosméo

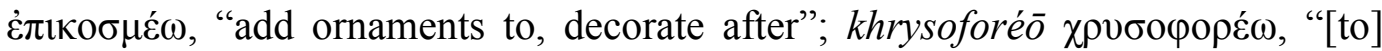
wear golden ornaments" (and also "pay gold as tax" or "carry gold"); etc.

In the context of the Greek philosophical discourses of Plato and Aristotle on language and their attacks against the Sophists it is plausible that any "adornment" in language was to be attacked or dismissed as hindrance to any "rational" use of language.

Cunha (2010, p. 464) writes that Port. ornamento (fourteenth century) is etymologically related to the Latin órnammentum and the verb ōrnāre, having the same origin as the English word adornment. De Vann (2008, p. 434) reports that the Latin terms are derivatives of $\bar{o} r d \bar{o}$, "row, line, rank; series, pattern, routine," possibly from the Proto-Indo-European $* h_{2} O r-d$-. De Vaan writes of possible original uses as to prepare, to equip, to arrange, whence the idea of an order or ordination that pleases the eye and could be taken as adornment, ornament.

\footnotetext{
${ }^{346}$ For this particular term, kósmēma, although rare, Liddell \& Scott (1996) also indicate its metaphoric use as "of the virtues."
} 
Partridge (2006, p. 2220) presents a long list of cognate words in English under the major gloss for order:

ordain, ordainer, ordainment; ordinal (adjective, hence noun); ordinary (adjective and noun); ordinance and ordnance and ordonnance; ordinand; ordinate, ordination; - ornament (whence ornamental and ornamentation), ornate, ornature.-Latin compounds: adorn, adornment; exordium; extraordinary; primordial, primordium; inordinate; subordinate (adjective, hence verb), subordination.

The author also identifies the Latin $\bar{o} r \bar{o}$ as the basis of the group, which he writes as a "tech term for the order of the threads in the woof, hence, in nontechnical language, a row, a rank, hence order in general." Partridge (2006) likewise claims that the "embellishment" use of ôrnāre derived from this ordination, to put in order.

A similarly used word in Eng. \& Fr., decoration (and Port. decoração), is identified in Partridge (2006, p. 739) as etymologically linked to decency with previous uses as seeks to please, [to be] gracious, as in the Latin decorum, decentia.

\section{Appropriateness, proper (Eng.)}

Klein (1971, p. 45) lists appropriate as derived from the Latin appropriātus, past perfect form of the verb "to make one's own," in itself derived from ad- + proprius, glossed by De Vaan (p. 493) as “one's own, peculiar, specific" and from the Proto-Indo-European *priH-o-, “own, dear.” Some Indo-European cognates are: Sanskrit préștha-, dearest, and prīnanti, to please; Middle Welsh rhydd, free; Gothic frijon, "to love," and frijons, "friend," etc.

Partridge (2006, p. 2579) writes that proper is derived via French from the Latin proprius, "private or peculiar to oneself," which the author speculates as probably from prō prīuō, prīuus being private and therefore "by private and particular right," hence the words proprietās, and the English property.

As far as this author has seen, in the sources there seems to be no cognate word in Greek with the Proto-Indo-European root *priH-o-. However, in Cassin (2014, pp. 40, 727) one finds a semantic link with the Eng. appropriation and to appropriate in the sense of "making it one's own," whose use was derived from a 
Late Latin term, appropriatio, that indicated, especially in Medicine and Chemistry, the senses of assimilation and catalysis. Appropriatio was the direct

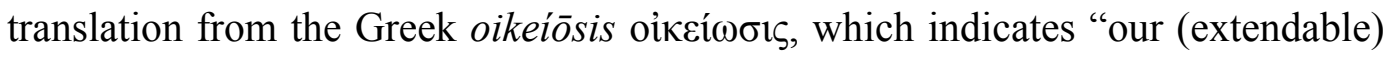
relationship to that with which nature has made us familiar and which is peculiar to us"; the affinity (by appropriation) that led to familiarity and to what is "domestic" (oikelos oikeĩos), whence the Eng. economy. Oikeiósis adds to the sense of making/turning familiar ("make one's own") to its use by the Stoics as "the purpose of founding relationships of justice between human beings" through a self-esteem, which finds love among other human beings, thus founding in nature the social bonds.

\section{Aretế ápعтń}

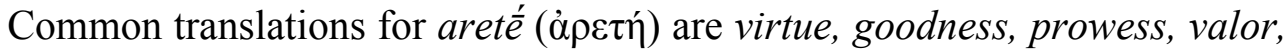
miracle, wonder; its history is related to the problematic of virtue in ancient Greece and it is an important word in the history of Greek thought (Chantraine, 2009, p.103). Its etymology, according to Chantraine is obscure and no root in Indo-European or cognate words in other languages is proposed by the author. However, he notes a possible relationship with areiōn (à $\left.\rho \varepsilon^{\prime} \omega v\right)$, those devoted to

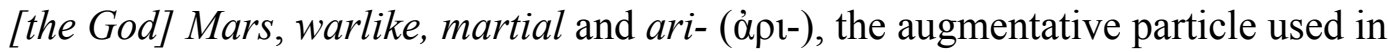
poetry. Cassin (2014, p. 1205) goes further and writes that areté is based on the

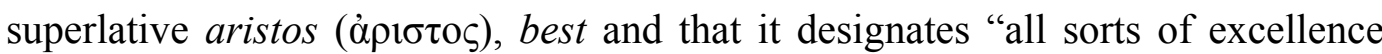
that are thus bound together [...] of the body [...] as well as of the soul [...] including the rewards of that excellence, the consideration and happiness that come with it." Cassin (2014) writes that there is an ontological dimension to areté as it applies to all spheres of human activity and nature (even physiological nature) - and its breadth of meaning is evident in Plato's Protagoras. In this text, Plato writes about the areté of technique, which pertains to a certain group of experts and can be thought; but also about the areté of politics, which is shared equally among all men and thus cannot be thought.

Scott \& Liddell (1996, p. 430) and Urmson (1990, p. 30) both gloss areté as "goodness, excellence, of any kind. In Homer they are especially of manly qualities," but also of the gods and women. Later it became more common to refer to the "glorious deeds, miracles" of the gods. Therefore, excellence becomes 
bounded with the deeds, or likewise with the fulfillment of some specific purpose or function. For Chantraine (2009), the Homeric hero lives and dies according to a certain ideal and superiority which is symbolized in the word areté.

Partridge (2006, p. 3977) writes that areté is akin to areiō $n$, better, and aristos, best and notes the rare Engl. aretalics, the "science of virtue." Urmson (1990), as Cassin (2014) above, notes that this proximity of areté and Latin virtus is misleading, because neither term was used as virtue in the common English sense, but rather as "excellences" in an abstract sense, conjoining potentialities and abilities to their utmost possibilities.

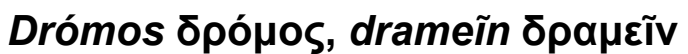

Chantraine $(2009$, p. 283$)$ glosses drameĩn $(\delta \rho \alpha \mu \varepsilon i v)$ as to run, to run a race (courir, faire un course), noticing that the verb is already used in Homer in the sense of s'étendre (to extend, to stretch). The form drómos is attested from Homer into Modern Greek with the senses: course (race, of horses, athletes, etc.), "lieu où court, piste" ("place where one races," racetrack) and, finally, rue, route (street, route, the modern usage in Greek). Etymologically, dramein belongs to an important family meaning to run (courrir), attested by the Sanskrit drávati, drámati, with the Indo-European root*der-.

Chantraine (2009) does not indicate any abstract use of the word in ancient Greek, however Liddell \& Scott (1996, p. 450) mention a "metaphoric" use as

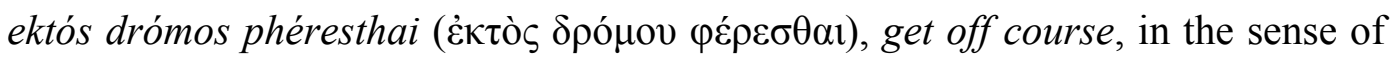
wander from a point, (Aeschylus, Prometheus Bound, line 877 or Cratylus, section $414 \mathrm{~b}$ ). However, the term does not seem to have had a typical abstract usage in ancient Greek, being more restricted to concrete situations. In the current English vocabulary we find the etymologically related common word-element drome, related to run, a (race)course and the verb to tread (Partridge, 2006, pp. $3544,4021)$.

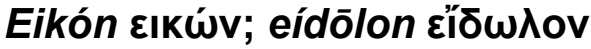

Eikón (Eıкóv), according to Cassin (2014, p. 245), is derived from *eikô, to resemble, thus the idea of similarity between the actual object and its "image," its 
icon. Chantraine (2009, p. 338) writes of the absence of plausible cognates in other Indo-European languages and declines to present any Indo-European root. Contrariwise, Partridge $(2006$, p. 1493) risks a constructed *weikōn with a possible cognate in Lithuanian paveiklas, an example, a pattern, and $i$-vykti, to hit upon, to prove right (both are also suggested by Klein (1971), who glosses eikón as likeness, image, portrait, picture, statue).

Urmson (1990) writes that the precise meaning of the cognate Greek substantive eikasma $\left(\varepsilon i{ }^{\prime} \kappa \alpha \sigma \mu \alpha\right)$ is disputed, but "it seems to be the attempt to gauge the nature of objects from awareness of their images alone." In Neoplatonism, eikón was commonly used to refer to the "doctrine that the sensible world image is an image of the intelligible." (Ibidem. p. 49) Liddell \& Scott (1996) alternatively gloss eikasma as likeness and probability, and the verb eikázō

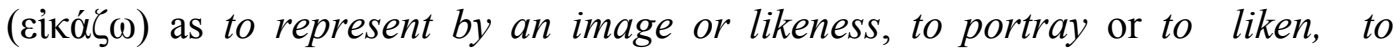
compare (also used passively, to be like, to resemble). In Chantraine (2009), eikázo, and other related verbs, are testimonies to the shift from the sense of image, resemblance, to that which can be translated as deduce from a comparison, to

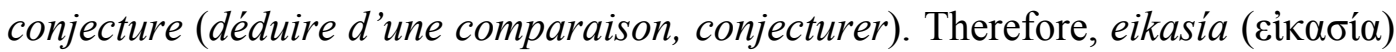
does not only indicate image, but also conjecture (both of soothsayers and doctors). The (visual) image becomes, in a way, a measure onto a reality that is liable to be copied with some degree of perfection. To "attain the best possible resemblance" begets a moral dimension, as presented in a word such as epieikeia

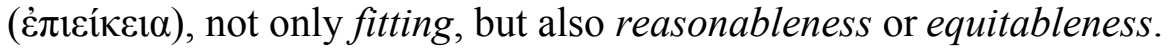

This moral dimension is also found in Plato. According to Cassin (2014, p. 245), eikón is the "faithful reproduction," the one which best resembles the object, therefore eikón is usually related to the positive side of imitation and, in that way,

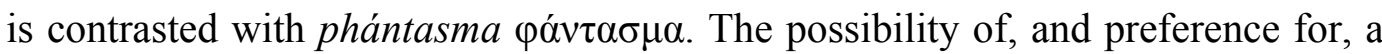
truthful and absolute depiction of reality is mirrored in the opposition of eikón and phántasma and the clear predilection for the former over the latter. However, although a "perfect" depiction of a thing is theoretically possible, the senses could be deceiving, as substantiated by another pair of terms, eídōlon and eídos.

Cassin (2014) writes that eidōlon ( $\varepsilon \hat{\imath} \delta \omega \lambda \mathrm{ov}$ ) has its roots in the verb to see and is "what we see as if it were the thing itself, but which is in fact a double." 
(Ibidem. p. 245) This interpretation calls attention to the risk of a visual illusion, of some type of (possible) deception. ${ }^{347}$ In that context, eidolon is the counterpart often pejoratively used in comparison with the more virtuous term of the same

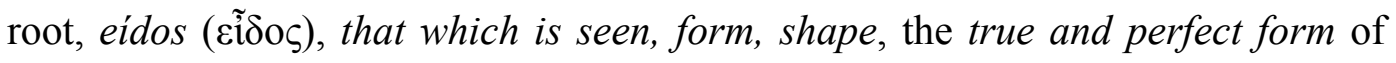
Platonism, whence the word idéa (i $\delta \varepsilon \dot{\varepsilon} \alpha$ ), form, idea. This vast and complex network of words and uses seems to indicate the feasibility to truthfully portray reality through images, thus constructing a faithful representation of the world. This truthful representation acquires a moral dimension of equitableness, of truth. However, in representing reality, there are inevitable risks involved with a degree of debasement, of degradation.

For some final remarks on the question of representation in ancient Greece and the relationship between eikón, eidōlon, sēmeīon and sýmbolon, see the entry in sýmbolon.

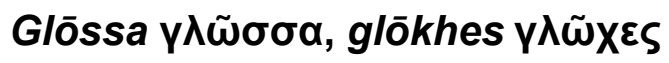

Chantraine (2009, p. 220) writes about a plural name in Hesiod, glōkhes $(\gamma \lambda \tilde{\omega} \chi \varepsilon \varsigma)$, fringes of the ear of corns (barbes de l'épi), whence important derived names were created with the general sense of point, edge (pointe), the point of an arrow and other later uses. ${ }^{348}$ The derived glossa $(\gamma \lambda \tilde{\omega} \sigma \sigma \alpha)$ came to be used as tongue (in the physical sense), from Homer into Modern Greek - "the tongue considered as point-like." From the Odyssey it was also used in the sense of language, a rare and dialectal word as well as other adapted uses, such as the reed of the flute or the clarinet, chain, shoelaces, etc. Liddell \& Scott (1996) note that glōssa was used metonymically in expressions that are translated as to please the tongue, frankness of speech, let loose one's whole tongue, speak without restraint, word of mouth, etc.

Finally, Partridge (2006, p. 1291) notes that the Latin glōssa is "a hard word needing to be made clear" and presents the derived forms in English such as gloss,

\footnotetext{
${ }^{347}$ In Cassin's words (2014, p. 247): “The image is one of those notions whose supposed obviousness is deceptive, and must be resisted."

${ }^{348}$ Chantraine writes, however, that the whole etymological justification from the word glókhes is not established and is, therefore, quite speculative.
} 
glossary and from the Attic form glotta $(\gamma \lambda \tilde{\omega} \tau \tau \alpha)$, the words glottic, glottis, epiglottis, etc.

\section{Letter (Eng.)}

Letter has its etymological roots in the Latin littera, letter of the alphabet, writing, erudition (De Vann, 2008, p.346). There is speculation (discredited by De Vaan (2008)) of a root in Indo-European *lei-to- and the derived form linō, to smear. The semantics are nevertheless enticing: smeared sign $>$ letter. From the Latin littera evolved a series of adjectives that will increase the complexity of the network of allusion of letter: litterālis, Eng, literal; litterārius, Eng. literary; and litterātus, Eng. literate.

The Oxford English Dictionary presents five acceptations to letter, which reflect the tripartite polysemy of letter (typeface), literal (meaning) and literary: 1) a character representing one or more sounds used in speech; any of the symbols of an alphabet; 2) a written, typed or printed communication; 3 ) the precise terms of a statement or requirement, the strict verbal interpretation; 4) literature; 5) a style of typeface.

It is interesting to speculate about the possible connections between the history of the word letter (and correlates in other Western languages) and the postulation of literal meaning as an inherent property of words and expressions. If, as authors such as Harris, 2001; Auroux, 2004, 2009; Taylor, 1997; and Olson 1993 have suggested, the advent of writing is decisive for the development of metalinguistic repertoires, then there is reason to believe that different types of writing systems should favor different views on language. In the case of the present study, one might think that the very notion of literal might be connected with alphabetic writing systems.

\section{Meaning (Eng.)}

The term meaning has a very poor attested etymological history in comparison to sense. Its origins are usually thought to be found in Indo-European bases reconstructed by Klein $(1971$, p. 452) as *main- or *mein-, to be of opinion 
(thus, German Meinung), to think, and not etymologically related to mean, average or mean, unkind.

As seen in the study of sense, its high polysemy in the Latin sensus has evolved etymologically into semantic differentiation in the Indo-European vernaculars. This happened, for instance, in German Sinn and Bedeutung and also in English sense and meaning. As writes Cassin (2014, p. 956), it was in medieval studies of semantics that a new array of technical terms had developed, between them, meaning.

\section{Mímēsis $\mu і 1 \mu \eta \sigma \mathrm{s}$}

Mímēsis ( $\mu$ í $\left.\mu \eta \iota_{\varsigma}\right)$, a term of central importance in Platonic thought, is glossed by Peters (1967) as mimicry, imitation and art (i.e. fine art). In Plato's philosophy, there is another kind of art besides the productive activities (such as craftsmanship), one that is shared by man and gods and which does not produce "originals", but merely copies (see eikón). The product of the mímēsis - created by poets, writers, sculptors and actors - seeks to approximate reality. In gauging its results, we should realize that "the activity known as mimēsis has as its product an entity whose ontological status is inferior relative to that of its model." (Peters, 1967, p. 118, my emphasis) This dualism will be central throughout Greek philosophy and thought, a belief that there is a "true" reality attainable by true knowledge (épistếmē), while we must use opinion (dóxa) to relate to the imitative realm. This mimetic quality of the human arts will also apply to language and will have a fundamental impact on how the Greeks perceived it.

\section{Righteousness, righteous, right, rectitude (Eng.)}

Klein (1971, p. 639) writes that Eng. right is a cognate of the Greek horégō

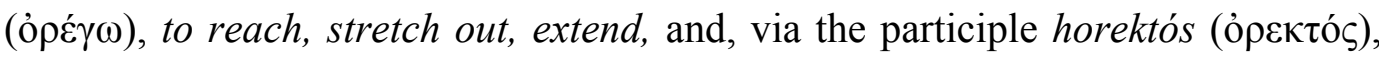
the Latin rēctum - passive past participle of regere - to keep straight, lead, conduct, direct. All words stem from an Indo-European base *reg-, to stretch, straighten; straight, right; to lead, direct, rule, related to regent and its cognates. Partridge (2006, p. 2771) concurs and speculates that "perhaps the basic sense of 
*reg- is 'a straight line' or, better, 'a movement straight from one point to another, hence a movement along a straight line."”

De Vann (2008, p. 517) presents many cognate forms which alternatively indicate notions of government, a line or a right (direction), such as: rēgillus, upright, vertical; regimen, control, steering; regiō, district; regio, direction, line; rēgula, rod, rule; rectā, directly; rector, ruler, guide; etc. De Vann's reconstructed Proto-Indo-European form is *h3reg-e/o-, to stretch, to direct, with semantically similar cognates in other Indo-European languages, for example Sanskrit raj-, to stretch, to direct (oneself); Old Persian rāsta-, straight, right, true, justice and the Greek horégō (see above). Liddell \& Scott (1996) gloss horégō as "to reach, stretch, stretch out," cognate with the Latin porrigo and the metaphorical uses in Classical texts as "to reach after, grasp at, yearn for a thing." In this Greek word it seems that the notions related to conduct, guide or govern are absent, leaving the more physical sense of spatial straightness.

Klein (1971, p. 622) glosses rectitude as righteousness, from the Latin rēctus, straight, right and having similar etymological roots as the terms above.

\section{Sabedoria (Port.)}

Usually translated in English as wisdom, Cunha (2010, p. 573) attested its form deriving from the verb to know (to have knowledge, awareness, information or news); saber (ter conhecimento, ciência, informação ou noticia); and earlier, thirteenth century, use as to have [good] flavor, to please the taste (ter sabor, agradar ao paladar). The Portuguese verbe stems from Latin săpěre, sapiǒ, to taste, be intelligent, to know. De Vaan (p. 538) writes of derivatives both in the semantic realms of flavor, taste, as well as regarding consciousness, intelligence. The proto-Indo-European root suggested is ${ }^{*} s h_{l} p-i-$, to notice. As far as this author has seen, in the sources there seems to be neither a cognate word in Greek nor an etymological connection between the Eng. wise, wisdom (see above) and sapience and sage. Sage, according to Partridge (2006, p. 2853) is derived from Vulgar Latin *sapius, which in its turn has roots in Latin sapidus, pleasant to taste (whence Eng. savour(y), Port. sabor), used in Late Latin (AD 180-600) as prudent, wise and in itself derived from săpěre. 


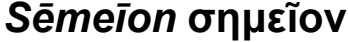

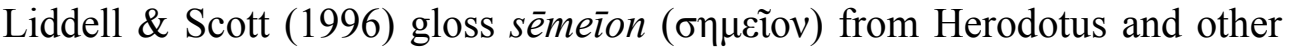
texts as mark by which a thing is known, and also, sign, token or trace. It can be a sign from the gods or a sign from the star in the heavenly abode, but also more mundane signs, as those made through flags, ensigns, standards, signals, etc. Some authors (Aristotle, Euclid) also use it as a sign from a mathematical point of view or as a point in time, an instant. Urmson (1990) notes that in later, especially Epicurean and Stoic, philosophy, semeion is "some perceptible state of affairs that is used as a sign of the imperceptible." (Ibidem. p. 149)

Chantraine (2009, p. 963) identifies sēmeīon as derived from sēma $\sigma \tilde{\eta} \mu \alpha$, everything that makes up a sign, a signal, a mark, a reconnaissance signal (tout ce que constitue un signe, un signal, une marque, un signe de reconnaissance), etc. Its etymology is considered opaque by the author, who merely repeats Brugmann's suggestion of having a possible cognate in Sanskrit dhyā-man, thought.

For some final remarks on the question of representation in ancient Greece and the relationship between eikón, eídōlon, sēmeīon and sýmbolon, see the entry in sýmbolon.

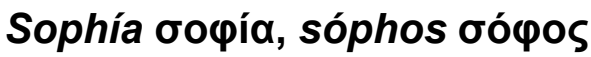

Peters (1967, p. 179) glosses sophía (бофía) as wisdom and technical wisdom, and its "original meaning" would be linked with craftsmanship as in the Iliad, 15.412. ${ }^{349}$ Scott \& Liddell (1996, p. 1621) gloss sophía as "cleverness or skill in handicraft and art, as in carpentry," and also refer to this verse of the Iliad. Thereupon sophia would be associated with the crafts (technē $\tau \varepsilon \dot{\varepsilon} \chi \vee \eta)$, like music, poetry, singing, medicine, divination and even driving, among others; a sort of a "practical wisdom," prudency in affairs or sound judgment and, as such, similar to

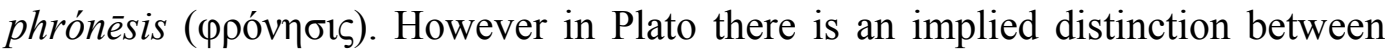

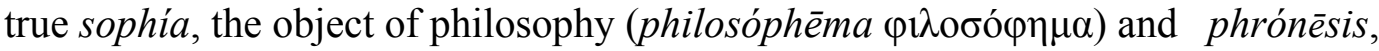

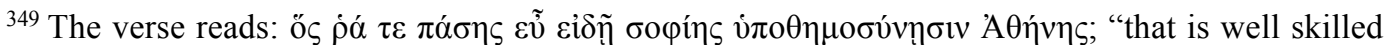
in all manner of craft [sophíes] by the promptings of Athene." (Iliad, XV.412, from http://www.perseus.tufts.edu, accessed in Dec'14)
} 


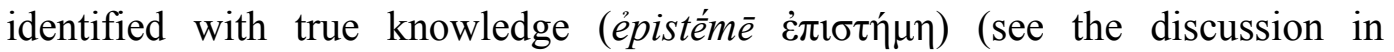
Thaeatetus 145e). Sophia became often recognized as in opposition to the search

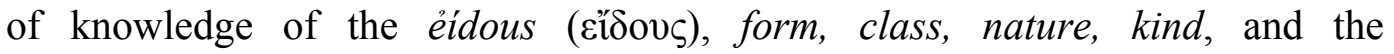
practitioners of the "false" knowledge, the sophists, who mastered the technique of speech in order to pose false claims based on a knowledge they did not possess. Cassin (2014, p. 1242) notes that the Latin sapientia derived from sophia and that it "retains the term's twofold practical and theoretical orientation: the sóphos ( $\sigma$ $\varphi$ $)$ ) is first a clever man, an expert, before he is a scientist. He is a life-model before he is a master of science." Plato's distinction split theory from practice, scientia from sapientia, and modern (Indo-European) languages generally retain wisdom in its practical-ethical meaning, as opposed to the "scientific" meaning.

However, for Aristotle, sophía became the desired intellectual virtue in comparison to its lesser-esteemed counterpart, phrónēsis.

The term phrónēsis itself is glossed by Urmson (1990, p. 132) as "basically, thought or understanding," thus alluding to the private understanding as opposed to a universal reason (lógos). Its opposition to sophía does not appear to be clear, as Urmson also writes that Aristotle and Plato normally employed the term to refer to practical wisdom, sagacity and prudence, translations that are often associated with sophia itself. Most of the examples clearly point out that the qualities of phrónēsis are used in a private manner, for one's own interest, in order to live pleasantly and to one's advantage. However sometimes phrónēsis appears side by side with lógos as qualities that are necessary to correctly grasp reality and truth. ${ }^{350}$ In the end of his article, Urmson (1990) closes adamantly: "phrónēsis is closer to the English 'wisdom' than is sophia." Cassin (2014, p. 777) notes that the vast array of possible translations of phrónēsis into vernacular Indo-European languages is testimony to the extension of its semantic field: Eng. prudence, wisdom, practical wisdom; Fr. sagesse, intelligence, sagacité; Latin prudentia, etc. This author writes that its distinction from sophia is also problematic - however, in his study of the intellectual virtues, Aristotle (Nichomachean Ethics 6.2) subdivided the rational part of knowledge into the "scientific" part (to

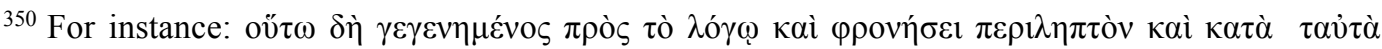

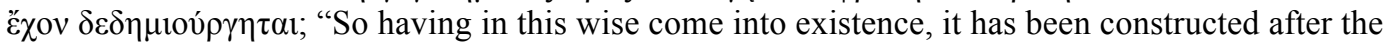
pattern of that which is apprehensible by reason (lógō) and thought (phronēsei) and is selfidentical." (Plato, Timaeus, 29a , from http://www.perseus.tufts.edu, accessed in Nov'14)
} 
epistemonikon) and the "opinionative" part (to doxastikon). The object of the truly scientific study was achieved through necessary and theoretical thinking, and excellence in this field was called sophía. Comparatively, in the study of contingent things and practical things, "things to be done," excellence was called phrónēsis.

Chantraine (2009, p. 996) has not identified a suitable etymology for sophía. However, he notes that along the history of the early Greeks in the movement from practical knowledge to a more philosophical and speculative knowledge there was an identifiable change of connotations associated with sophia, along with other related terms. Partridge (2006) also find that sophia is of "obscure origin," and writes of Brugmann's postulation of an Indo-European etymon *tuoghos, *tuoguhos.

Current derived forms in English are sophism, sophist, sophistry, sophisticate (from Greek sophistikós), and the morpheme -sophy (as in philosophy).

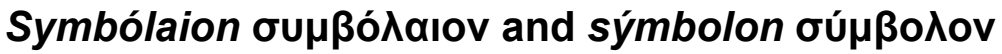

Sýmbolon ( $\sigma 0 ́ \mu \beta 0 \lambda o v)$ is glossed by Liddell \& Scott (1996) as sign, mark, token. In a specific legalist environment it connotes contract, covenant, bond, an acknowledgement of a loan, therefore the bond contracted by two (or more) parties, but also, more generally, the engagements of life, common civil rights and even intercourse. Klein (1971, p. 737) glosses the Greek word as token, sign, pledge, guarantee, symbol, properly something thrown together, which is related to the Greek verb bállo ( $\beta \alpha \dot{\lambda} \lambda \lambda \omega)$, to throw, to hit, to put for oneself, to conceive (a child), to lay the foundations (Liddell \& Scott, 1996).

Chantraine (2009, p. 154) lists the uses of bállo, to reach, to affect; to throw (a weapon); to throw oneself to (atteindre, lancer (une arme), se jeter). Its most general sense, writes the French author, is related to the Fr. verb mettre (to put), whose wide semantic field opens the opportunity for a high degree of polysemy, as well as a multitude of composed and derived words. With the vocalism o one finds, for instance, bólos (ßónos), the act of throwing, of putting (fait de lancer), 


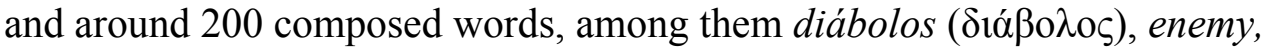
slanderer and sýmbolon, signal of reconnaissance.

Cassin (2014) writes that Homer and Hesiod did not use sēmeīon (see), but only sèma and sýmbolon, both with a pronounced concrete meaning and social usage. The first, sema, in the sense of signal (to begin a battle, for instance; or as a landmark), was a sign of recognition, which "guarantees the trustworthiness of an identity or a message." In brief, "sēma refers us to something other than itself, which it signals in a more or less constant or natural manner, thus leaving room for interpretation.” (Cassin, 2014, p. 974) As for sýmbolon, Cassin concurs with Klein (1971) and Chantraine (2009) in the etymology referred above: sým + ballo $(\sigma 0 ́ \mu+\beta \alpha ́ \lambda \lambda \omega)$, to throw together, which, albeit being also a sign of recognition, had a more precise use than sèma. Sýmbolon would refer to a part of an object divided in two, which, once reunited, would give witness to an "old relation between guests, an exposed child and his parents or all sorts of parties in a contract," that is, the relation between the whole and its parts. Therefore, it could be identified with a token, a passport, a receipt, a contract, a treaty or a guarantee.

We will appeal again to the famous passage $16^{\mathrm{a}} 3$ of De Interpretatione as a crucial insertion of sýmbolon in the study of language:

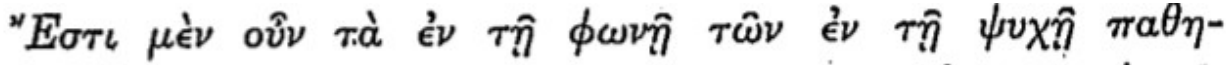

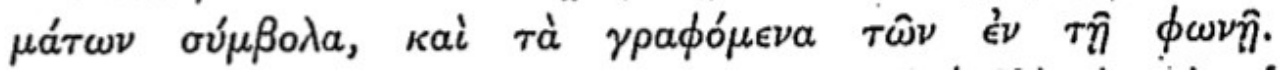

Now spoken sounds are symbols of affections in the soul, and written marks symbols of spoken sounds. (translated by Ackrill)

There is no reference to whether the sýmbola of the passage should refer to Homeric sýmbolon and sēmeìon, as it has usually been distinguished in later semantic studies in the Western tradition. It is clear, however, that Aristotle's use of the word seems to depart from its "legalist" use, in proposing a more natural "engagement" between his triad thoughts/sounds/writing.

The question of the Greeks' investigations on the nature of things lies upon the relationship between the "image" and "form" of the thing (depicted or seen) and the thing "in itself." As Cassin (2014, p. 245) summarizes, there is a rich Greek vocabulary, some of which has been glossed in this dissertation: eídolon, 


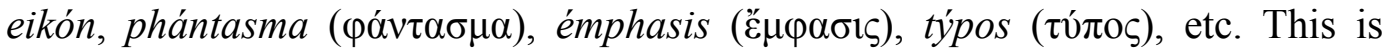
testimony to the difficulty with the multiplicity and ambiguity of a semantic field that is not directly related to any one thing or concept, but to a relationship where "a visible thing yields the vision of another." The terms which have been analyzed here should give testimony to the complexity of this matter.

In sýmbolon, the idea of a part/whole representation seems to be emphasized, as well as the movement and action - the "throwing together" - from the word's etymological roots. In sēmeīon, the symbolization is one that involves recognition, necessary to build trust and create trustworthiness. In the tripartite relationship between eikón, eidōlon and mímēsis, it is the question of visual representation that is under discussion, as if warning against the dangers of misrepresentation and concealment. At the same time, it points to the perfect reality of the pure forms (idéa) that are theoretically possible through comparison, conjecture and probability in the concept of representation in eikón, but on the other hand are menaced by the dangerous eidōlon, perhaps mere mímēsis of reality

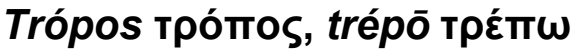

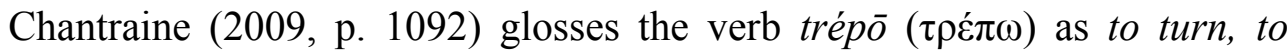
direct oneself to, to turn towards, to put yourself (somewhere) (tourner, diriger vers, se tourner vers, changer, mettre en fuite, (se) mettre quelque part). With the vocalism o the verbal form generates most of its derived forms, among them

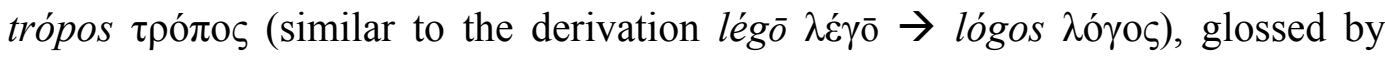
Chantraine as direction, manner, behavior's way (direction, manière, manière de se comporter) - however distinct and in contrast with éthos ( $\tilde{\hat{\eta}} \theta \mathrm{o} \varsigma)$, character, disposition (of man) - way [in music] (mode [en musique]). ${ }^{351}$ Etymologically trépo comes from the form *ter-, likely the same in Sanskrit taraláh, the one who stirs and is agitated - in every sense of the word (qui se remue en tous sens, qui s'agite), therefore from *tr-em- we find the Greek trémo $(\tau \rho \varepsilon ́ \mu \omega)$ and Latin tremō, tremble, tremor, and from the related forms *ters-, *tors-, the Latin terre $\bar{o}$, terrify,

\footnotetext{
${ }^{351}$ There is an important passage in Plato's Republic (400d) involving three key Greek metalinguistic terms which includes trópos:

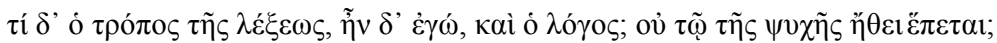
'And what of the manner [trópos] of the diction [léxeōs], and the speech [lógos]?' said I. 'Do they not follow and conform to the disposition [êthei] of the soul [psykhess]?' (translated by Paul Shorey)
} 
terror. If we are to agree with this etymology, the movement and change due to trembling and agitation caused some "turning" and (re)established a direction.

Liddell \& Scott (1996) gloss the term as turn, direction, course, way in Herodotus, but also mention the common usage as way, manner, fashion, guise, customs, ${ }^{352}$ a way of life, habit, custom; "a particular mode in music"; "manner, style in writing, especially in Rhetoric"; and "mode or mood of a syllogism" in Logic.

Despite its complex network of abstract meanings, the expression trópos does not assume a prominent role in the Greek philosophical reflections. It seems that the more concrete uses as turning [to] led to the abstract use of direction and thus to manner, fashion, way.

The modern Eng. trope is important in semantics as an indication of the use of figurative language. Partridge (2006, p. 3586) writes that trope is "a turning, a turn, especially in language, hence a figure of speech," from the Latin tropus and Greek trópos. Other derived forms include English tropic from the Greek adjective tropikós ( ( $\tau \rho о \pi ı \kappa o ́ \varsigma \kappa v ́ \kappa \lambda o \varsigma)$, a "turning circle", the solstice. The classical use as a "figure of rhetoric" associated with the term trope has given way, in English, to a variety of other usages in Philosophy and other contexts, as notes Cassin (2014, p. 1157).

\section{Way (Eng.), voie (Fr.)}

From Old English weg and Proto-Indo-European *ueg $g^{h}-e / o$ - (de Vann, 2008, p. 658), "to carry"; *weghh- (Klein, 1971, p. 822), "to move"; with the Latin cognate vehō, "to convey, carry." Derivatives in Latin connote ideas of transport, vehicles, travel and even to collect (convehere). Cognates in other Indo-European languages are also likewise related, for example, the Sanskrit váhati, also connoting "to convey, carry." The notion of distance is also clear in the word away and Partridge (2006, p. 3681) notes that the cognate form wegan in Old

\footnotetext{
${ }^{352}$ For example, in Plato, Laws (804b):

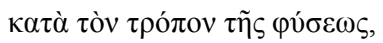

"according to customs [trópon] of [their] nature," also translated as "according to the shape [trópon] of their nature." (transl. by Bury)
} 
English is related to weghen (Middle English) and weight, a semantic relation to the notions of move, carry (a weight).

Partridge (2006) claims that way is related to the Latin via/uia, from IndoEuropean *weghya, that assumes, according to the author, more abstract uses: "a way (other than a mere path), a road, a street, hence a route (a way habitually travelled), also a march, a journey, hence also a way of life, even a method, is of Italic origin.” (Ibidem., p. 3681) These abstract uses have numerous derivatives in Eng., such as devious from dè uius (from dè uiā, "down from the way"); obvious from obuius, placed or coming in the way (ob uiam); and trivial from triuius, divided into, or shared by, three ways.

Fr. voie and Port. via are derived etymologically from Latin via/uia, which De Vann (2008, p. 673) glosses as road, with related cognates such as viāticus, of/for a journey; viātor, traveller, agent; etc. This author constructs the ProtoIndo-European *uih ${ }_{1-e h_{2}}$, pursuit, with cognates such as, for example, the Sanskrit viyánti, they pursue and the Greek hiemi (in $\mu 1)$, to strive after, to wish. Scott \& Liddell (1996) gloss the Greek word hièmi as to set a going, put in motion, but also to send from Homer on, to send forth, to utter (of sound), to throw, to hurl, to let flow (of water) and to let fall. Later, more metaphorical uses connote to be set upon doing a thing, to desire to do it, where one can see uses more directly related to (embark on a) journey and the Latin via.

Finally Chantraine (2009, p. 441) glosses the Greek word as to sent, to throw lance, to emit - a sound (envoyer, lancer, émettre (un son)). The French

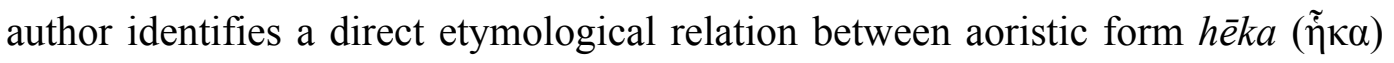
and Latin $\bar{l} e c \bar{l}$, the perfect of iacere, "to throw," and a possible root *ye-/yat-, but the relation between hèka and hiémi (ï $\mu \mathrm{i}$ ) is more uncertain.

\section{Wise, wisdom (Eng.)}

Klein (1971, p. 829) writes of two related semantic fields of the adjectival form in Eng.: 1) knowing, learned and 2) prudent. The Germanic related forms, such as German weise, wise and Gothic -weis, knowing, stem from an IndoEuropean base *weid-, to see, to know. Klein also writes that the "original meaning" of Old European wīse was knowledge. Wise's roots (especially in a verbal usage) are related to guide (see), in the sense of to show the way, to direct 
or, more literally, to make wise. Finally, in a nominal usage, Klein observes that wise is used to connote manner, fashion, as related to German Weise, way, manner, Old Norse visa, strophe, verse, and vis in the expression ödru vis, otherwise.

Klein (1971) notes that the related forms in Eng., vision and wit, also stem from the same Indo-European base *weid- mentioned above. Partridge (2006, p. 3692) also reinforces that Germanic wit and wise and other cognates are akin to Latin uidēre to see, Sanskrit veda, I know (and, maybe originally, I see), which was also used as knowledge, especially sacred knowledge.

Partridge (2006) and Chantraine (2009, pp. 438, 751) also include as

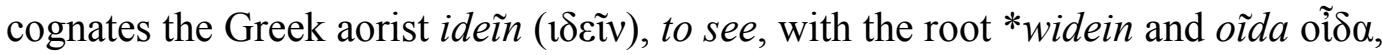
the perfective "I know," with the root *woida. Related Indo-European words are, for instance, Old Prussian waidimai, we know, Welsh gwidd, knowledge and Armenian gitem, I know, Partridge (2006) also calls for the Indo-European base *weid-, as to see (truly), therefore to know. There is a truly extensive array of cognate and derived forms in ancient Greek and Indo-European languages related to oida/idein/veda/uidere. Among their meanings are: knowledge, testimony, the one who knows, arbiter, to see, appearance, form, category, etc.

Therefore, the well-known identification of to see and to know ("to see is to know") is also reflected in the Greek cognates oida (see above); eidon (cĩ $\delta o v), ~ I$

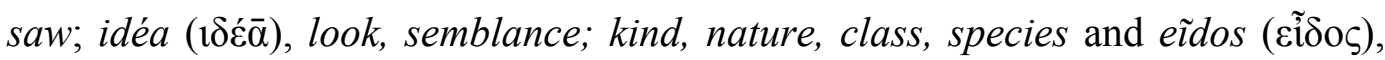
form, shape, literally "that which is seen," among other words. ${ }^{353}$ The history of these terms was immensely influenced by the Platonic doctrine of forms, as in archaic pre-philosophical usage eĩdos and idéa were polysemic and almost synonymic terms (form, appearance, category, class, structure) before Plato presented them in a more circumscribe pair of structure $\mathrm{x}$ form (see also Cassin, 2014, pp. 1031-1037). It is not necessary here to delve much deeper into this incredibly rich network of connotations and etymologies, which were so crucial in shaping the way the semantic fields of knowledge, vision and form is understood in the West. One needs only to notice the close intermingling of these notions in our tradition.

\footnotetext{
${ }^{353}$ See also above the discussion on the Greek word eidōlon cǐ $\delta \omega \lambda$ ov.
} 